
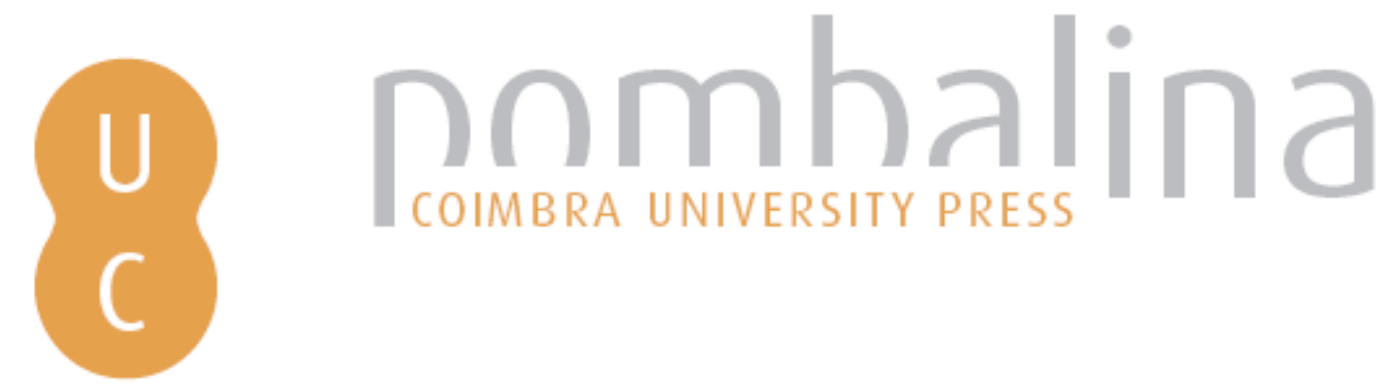

O homem de Estado Ateniense em Plutarco: o caso dos Alcméonidas

Autor(es): $\quad$ Ferreira, Ana Maria Guedes

Publicado por: Centro de Estudos Clássicos e Humanísticos da Universidade de

URL

persistente: URI:http://hdl.handle.net/10316.2/9721

DOI: DOI:http://dx.doi.org/10.14195/978-989-721-026-6

Accessed : $\quad$ 26-Apr-2023 13:44:23

A navegação consulta e descarregamento dos títulos inseridos nas Bibliotecas Digitais UC Digitalis, UC Pombalina e UC Impactum, pressupõem a aceitação plena e sem reservas dos Termos e Condições de Uso destas Bibliotecas Digitais, disponíveis em https://digitalis.uc.pt/pt-pt/termos.

Conforme exposto nos referidos Termos e Condições de Uso, o descarregamento de títulos de acesso restrito requer uma licença válida de autorização devendo o utilizador aceder ao(s) documento(s) a partir de um endereço de IP da instituição detentora da supramencionada licença.

Ao utilizador é apenas permitido o descarregamento para uso pessoal, pelo que o emprego do(s) título(s) descarregado(s) para outro fim, designadamente comercial, carece de autorização do respetivo autor ou editor da obra.

Na medida em que todas as obras da UC Digitalis se encontram protegidas pelo Código do Direito de Autor e Direitos Conexos e demais legislação aplicável, toda a cópia, parcial ou total, deste documento, nos casos em que é legalmente admitida, deverá conter ou fazer-se acompanhar por este aviso.

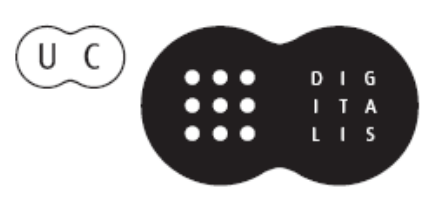




\section{O homem de Estado ateniense em Plutarco \\ O caso dos Alcméonidas}

Ana Maria Guedes Ferreira 


\section{O homem de Estado ateniense em Plutarco \\ o caso dos Alcmeónidas}

Ana Maria Guedes Ferreira 
Todos os volumes desta série são sujeitos a arbitragem científica independente.

Autor

Ana Maria Guedes Ferreira

Título

O bomem de Estado ateniense em Plutarco: o caso dos Alcmeónidas

EDITOR

Centro de Estudos Clássicos e Humanísticos da Universidade de Coimbra

EDIÇÃO:

1a/ 2012

Coordenador Científico do Plano de Edição

Maria do Céu Fialho

Conselho editorial

José Ribeiro Ferreira, Maria de Fátima Silva, Francisco de Oliveira e Nair Castro Soares

Director Técnico da Colecção:

Delfim F. Leão

Concepção Gráfica e Paginação:

Rodolfo Lopes, Nelson Ferreira

IMPRESSÃO:

Simões \& Linhares, Lda. Av. Fernando Namora, n. . 3 Loja 4. 3000 Coimbra

ISBN: 978-989-721-025-9

ISBN DigitAL: 978-989-721-026-6

Depósito LegAL: $352410 / 12$

CCentro de Estudos Clássicos e Humanísticos da Universidade de Coimbra

(C) Classica Digitalia Vniversitatis Conimbrigensis (http://classicadigitalia.uc.pt)

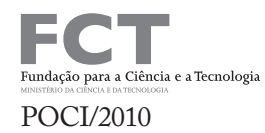

Reservados todos os direitos. Nos termos legais fica expressamente proibida a reprodução total ou parcial por qualquer meio, em papel ou em edição eletrónica, sem autorização expressa dos titulares dos direitos. É desde já excecionada a utilização em circuitos académicos fechados para apoio a lecionação ou extensão cultural por via de e-learning. 


\section{SuMÁRIO}

$\begin{array}{ll}\text { Nota INTRODUTÓRIA } & 7\end{array}$

Parte I. O triunfo da IITOPIA SObre o myeos 9

Parte II. Convenções literárias associadas À vida de Um Fundador 29

Parte III. A Vida de Teseu

1. Origem, formação e reconhecimento 51

$\begin{array}{ll}\text { 2. Aventuras } & 61\end{array}$

3. Ação política 93

3.1. O sinecismo e o funcionamento da nova Atenas 93

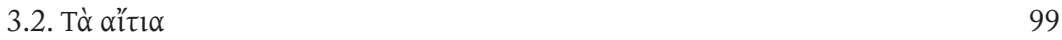

3.3. O princípio do fim 106

$\begin{array}{lr}\text { 4. Fim de vida } & 109\end{array}$

Parte IV. Atenas, o umbigo da Hélade 113

Parte V. O homem de Estado do século V 133

1. Do nascimento ao ingresso na vida ativa: a educação do político em Atenas 135

2. O caso de Péricles e Alcibíades 159

2.1. Família, principais características e formação dos Alcmeónidas $\quad 159$

$\begin{array}{ll}\text { 2.2. O ingresso na vida pública } & 191\end{array}$

2.3. A ação política $\quad 210$

2.3.1. O político $\quad 211$

2.3.2. O militar $\quad 261$

$\begin{array}{ll}\text { 2.4. Morte } & 303\end{array}$

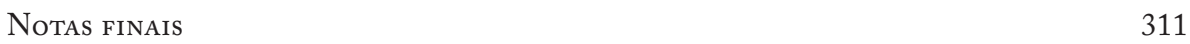

$\begin{array}{ll}\text { BibLIOGRAFIA } & 315\end{array}$

ÍNDICE DE NOMES

ÍNDICE DE AUTORES ANTIGOS E CITAÇões

$\begin{array}{ll}\text { ÍNDICE DE AUTORES MODERNOS } & 389\end{array}$ 


\section{Nota INTRODUTÓRIA}

A escolha do autor e do corpus a trabalhar no âmbito deste estudo não foi fortuita e prendeu-se sobretudo a quatro fatores: o apreço pela obra de Plutarco; o facto de já me ter debruçado sobre a Vida de Péricles anteriormente; a glória imortal de Atenas e a minha curiosidade pelo funcionamento da mente humana.

Vem de há muito o meu fascínio pela obra do Queroneu que, apesar de ter perto de dois mil anos de idade, continua a ser atual. Não é preciso grande esforço de concentração para nos depararmos amiúde com reparos feitos por Plutarco, em relação aos quais pensamos: «Mas isso ainda hoje é assim!» ou "Como pode algo semelhante ao que ainda hoje experimentamos ter também ocorrido há mais de dois mil anos?» $\mathrm{O}$ grande mérito das Vidas Paralelas de Plutarco consiste exatamente em dar a conhecer a essência do caráter humano - cujas virtudes e defeitos são tão intemporais quanto a própria humanidade - e estimular a reflexão sobre esse tema, com recurso a episódios das vidas de indivíduos (muitos dos quais por ocasião da redação das respetivas biografias já podiam ser considerados paradigmáticos) que alcançaram posições de topo nas suas comunidades. É que o Queroneu defende que cabe a cada um de nós voltar os olhos para o passado, aprender com o que outros antes de nós tiveram e fizeram de bom e mau e empregar os conhecimentos adquiridos através da experiência alheia, de modo a tentarmos não incorrer nos mesmos erros.

Embora a sugestão do nosso autor seja excelente, não se pode dizer que os homens a tenham seguido. Com efeito, torna-se difícil de compreender como é que seres dotados de inteligência insistem em cometer as mesmas faltas já protagonizadas pelos seus mais remotos ascendentes. Não obstante, o biógrafo tem o mérito de ter sabido perscrutar a alma dos seus heróis, de ter avaliado a influência das suas características sobre as ações que levaram a cabo, mas sobretudo de ter escapado à possibilidade de classificar algum deles como exclusivamente bom ou mau.

Explicado em traços gerais o meu fascínio pelo autor, impõe-se agora justificar a opção pelas biografias de Teseu, Péricles e Alcibíades. Perante uma produção de cariz quase enciclopédico como é a de Plutarco, coube-me limitar o corpus a tratar. Para essa delimitação contribuiu o facto de já anteriormente ter traduzido a Vida de Péricles. Pareceu-me, assim, incontornável rentabilizar esse trabalho prévio. E também a ideia veiculada pelo biógrafo de que nos apercebemos melhor das semelhanças e diferenças da virtude, colocando vidas ao lado de vidas, ações ao lado de ações, como grandes trabalhos de arte ${ }^{1}$.

\footnotetext{
${ }^{1}$ Plu. Moralia 243B-C.
} 
Ora, uma vez que Péricles representa o auge de Atenas (ou, sem exagerar, o apogeu da própria Hélade, pela magnificência que alcançou), pareceu-me interessante

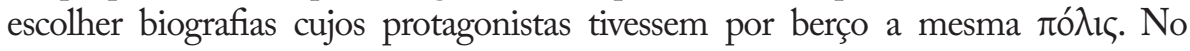
entanto, afigurou-se-me impossível tratar mais do que três Vidas que respondessem a esse critério, sob pena de me defrontar com um volume de material incomportável em uma dissertação. Por isso, ao visualizar todos os textos que correspondiam ao critério «vidas de Atenienses», optei por acrescentar ao corpus a Vida de Alcibiades, visto que este, além de ser um Alcmeónida como o filho de Xantipo ${ }^{2}$, estava para a decadência da cidade como Péricles para o seu apogeu.

Escolhidas que estavam as biografias de Péricles e Alcibíades, considerei pertinente completar o estudo com a Vida de Teseu. A ideia da integração deste terceiro exemplo surge do facto de, como a própria história antiga (Heródoto desde logo) demonstra, haver a necessidade de um modelo ou padrão ideal, que sirva como que de frontão à obra. Teseu, do seu plano mitológico, caracterizado já com elementos que vieram a tipificar o «homem de Estado ateniense» no seu melhor, cumpria naturalmente esse papel.

Definido o corpus, senti que era fundamental tratar à parte a Vida de Teseu, já que esta se encontra naquela fronteira ténue que separa o mito da história, como o próprio biógrafo afirma ${ }^{3}$. Esta mesma razão levou-me a anteceder o capítulo dedicado à análise desta biografia de dois outros, um consagrado à reflexão sobre a diferença entre mito e história; outro sobre o tratamento literário dado a personagens que, como Teseu, estiveram envolvidas na fundação de cidades ou dinastias. Quanto ao capítulo sobre Teseu propriamente dito, dividi-o, grosso modo, em quatro grandes momentos ${ }^{4}$, compatíveis com a análise que queria fazer também das vidas dos Alcmeónidas, de modo a verificar se seria possível vislumbrar uma linha de continuidade no que respeita à origem, formação e atividade entre os três exemplos selecionados. No que concerne às vidas de Péricles e Alcibíades, optei por cotejá-las em um mesmo capítulo, por razões diversas: o facto de serem personagens históricas, a pertença a uma mesma família e a possibilidade de se poder ver Alcibíades como um sucessor de Péricles, não por ter o mesmo perfil ou por defender os mesmos objetivos, mas porque subiu ao poder pouco depois da morte do filho de Xantipo.

Foi, portanto, deste modo e com base nos pressupostos explicitados que concebi um estudo cujos principais objetivos são especificar os traços de caráter que, de acordo com este corpus, definem o bom político e verificar a influência concreta dessas qualidades e defeitos na ação política de cada um.

\footnotetext{
${ }^{2} \mathrm{O}$ facto de serem parentes permite-nos refletir sobre aspetos como a influência da genética e da educação na forma de agir do político.

${ }^{3}$ Vide p. 32.

${ }^{4}$ Origem, formação e reconhecimento; Aventuras (que decorre da especificidade da Vida de Teseu); Ação política e Fim de vida. No caso concreto da parte dedicada à vida dos Alcmeónidas, antepus-lhe algumas páginas onde se reflete sobre o paradigma da educação do homem de Estado no séc. V a.C.
} 


\section{PARTe I}

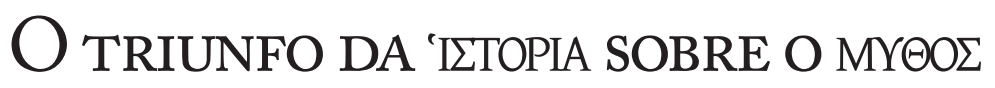


Ao contrário do que aconteceu no seio de outras civilizações, como a persa e a egípcia (nas quais existiam arquivos que só vieram a ter equivalente grego no período helenístico), poucos foram os indícios anteriores ao séc. $V$ a.C. que chegaram até nós no que concerne ao registo de informações sobre processos ou atividades do quotidiano social, que pudessem atestar um empenho profundo no registo e conservação dos factos. Não devemos, como é óbvio, asseverar que isso seja reflexo de mero desinteresse, pois temos a consciência de que muito se perdeu ao longo dos séculos e de que a tradição de transmitir oralmente a cultura e a informação também terá contribuído para isso. Ademais, sabemos que o interesse do homem grego pela preservação dos acontecimentos e informações é algo de muito antigo, que podemos fazer remontar ao período micénico, já que os textos em linear B decifrados demonstram a antiguidade do gosto pela compilação de feitos e objetos, como, por exemplo, as oferendas aos deuses ou as deslocações de gado ${ }^{1}$.

Mas tal interesse existiu, efetivamente, e manifestou-se sobretudo através do $\mu \tilde{v} \theta$ o, cujos testemunhos mais antigos remontam aos Poemas Homéricos ${ }^{2}$, nos quais, como veremos mais à frente, também existem prenúncios daquilo a

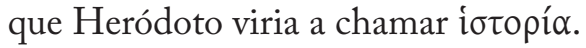

O conceito de mito não esteve desde sempre conotado com a ideia de mentira ou ficção. Segundo Liddell - Scott (1996), $\mu \tilde{0} \theta$ o começou por significar simplesmente 'palavra' (Il. 9.443), 'discurso'(Od.1.358), 'conversação' (Od. 4. 214), 'história/narrativa' (Od. 3. 94). Em Homero, essa história podia ser verdadeira ou falsa, mas, com o tempo, ao termo acabou por ficar associado

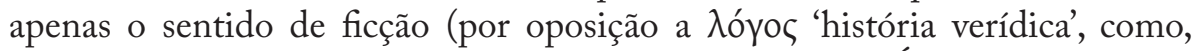
por exemplo, em Platão, Prt. 320c, ou Píndaro, O.1.29). É por isso que hoje concebemos o mito como algo fabuloso, ainda que possa estar, de algum modo, ligado a uma situação real, com particular importância para toda a comunidade. Mas, na Antiguidade, aquilo que modernamente é entendido como produto do imaginário coletivo, foi, durante muito tempo, inquestionável e aceite de

\footnotetext{
${ }^{1}$ Sobre este assunto, consulte-se, por exemplo, Chadwick (1987).

${ }^{2}$ Ainda que possa parecer um lugar-comum, devemos, como em quase tudo o que diz respeito à cultura grega, recuar aos Poemas Homéricos, porque se, por um lado, constituem o mais antigo e um dos maiores repertórios de mitos da Grécia antiga, por outro, apresentam já indícios de interesse pelo relato histórico. E, como se estes não fossem argumentos bastantes, muitas das técnicas literárias adotadas pelos historiadores, nomeadamente por Heródoto, são de origem homérica. Sobre os recursos estilísticos utilizados pelos historiadores, vide infra pp.17-18
} 
forma literal. Só com o advento do espírito científico ${ }^{3}$ foram postas em causa as histórias fantásticas (e nem sempre edificantes para a divindade) transmitidas pelos poetas. A partir de então, várias foram as correntes filosóficas que se preocuparam em interpretar o mito, partindo dos mais diversos princípios: alguns consideravam que deveria ser encarado sob uma perspetiva alegórica; para outros, a abordagem deveria ser etimológica; ou, segundo um terceiro grupo, histórica. Com o correr dos séculos e o aparecimento da mitologia enquanto ciência que estuda este fenómeno, surgiram, pelo menos, tantas definições quantas as correntes perfilhadas pelos estudiosos ${ }^{4}$.

Um deles, Rose (2003: s. v.), defende que o $\mu \tilde{v} \theta$ os mais não é do que a tentativa pré-científica e imaginativa de explicar fenómenos (reais ou não) que provocam a curiosidade de quem «faz» o mito e que apela mais à emoção do que à razão. Através dele, pretendia-se explicar o passado, se bem que, no início, não houvesse preocupações de cariz cronológico: ninguém podia, nem pode, precisar quando os acontecimentos narrados tiveram lugar ${ }^{5}$. Mesmo assim, servia para organizar o mundo e para dar segurança e sentido de identidade a um povo.

Se o mito viu algumas das suas histórias particularmente preservadas e citadas, foi porque estas funcionavam para os Gregos, de geração em geração, como mestres nas várias áreas do saber, desde a ética até à política ${ }^{6}$. Daí que Morley (1999: 34) afirme:

«a myth is a history, told and retold but retaining the same basic form, handed down from generation to generation; but a story with some deeper significance, embodying the values of the community, forming part of people's sense of identity, legitimising some practice or institution.»

E assim, o mito, sobretudo através da poesia épica, foi satisfazendo o interesse histórico dos Gregos até meados do século VI a.C., altura em que a

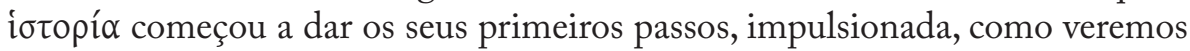
nas páginas seguintes, pelo dealbar do espírito científico e pelo efeito histórico e cultural das Guerras Pérsicas.

Não nos devemos esquecer de que a palavra ícopía é da família do verbo

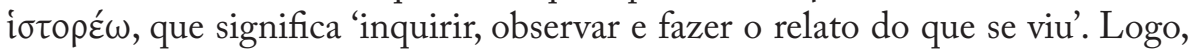

Vide p. 14.

${ }^{4}$ Sobre a problemática do mito, vide Burkert (2001); Barthes (1988); Durand (1982); Eliade (1977); Jabouille (1994) e Lévi-Strauss (1981).

${ }^{5}$ Em Hesíodo, já se verificava uma certa tendência para a organização cronológica dos factos, particularmente no relato do Mito das Idades, onde a inclusão da idade dos heróis parece ser, segundo vários estudiosos, uma prova do despertar da consciência histórica. Sobre este assunto, leia-se, por exemplo, Rosenmeyer (1957).

${ }^{6}$ Cf. Finley (1989: 6). 
o substantivo tem o sentido de 'inquérito, conhecimento obtido através da investigação - testemunho visual direto, informação' (Hdt. 1. 299) e 'relato escrito dessas inquirições' (vide Hdt. 7. 96). Da mesma família é o substantivo ǐ $\tau \omega \rho$, que, na Ilíada, designava aqueles que assumiam a função de juízes ou árbitros, encarregados de, após o inquérito, decidir qual das partes tinha razão. No século VI a.C., recebiam a denominação de ǐotopes os iónicos que, enquanto astrónomos, geógrafos ou viajantes curiosos, tentavam compreender a diversidade do mundo a nível humano e físico. Assim, um historiador, ou seja, alguém que escreve iotopía, é um investigador que dá o seu testemunho relativamente aos factos examinados ${ }^{7}$

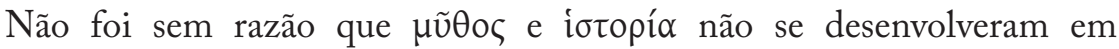
simultâneo, apesar de, no fundo, visarem ambos a descrição e compreensão do passado, bem como o seu registo e o das suas consequências no presente. Conquanto possamos afirmar que têm a mesma função, é preciso ter em conta que correspondem a fases distintas da evolução do pensamento grego: o mito corresponde à infância desta civilização, à qual faltavam formas «científicas» de justificar os acontecimentos, pelo que se recorria a episódios ou fatores sobre-humanos para explicá-los. Por isso, embora muitas vezes tenham um fundo de verdade, acabam por ganhar conotação de mentira, de ficção, sobretudo com o advento da iotopía, que, por sua vez, surge com o desenvolvimento do espírito científico e crítico e que vai pôr em causa a tradição mítica anterior.

Podemos dizer que o espírito científico, que nos leva a questionar tudo o que nos rodeia e a tentar compreender racionalmente a mudança, começou por se manifestar na Iónia e por se exercer no domínio do estudo do cosmos, mas depressa se estendeu ao campo humano e social. Foi sob o ascendente desta nova forma de pensar - responsável pela origem do raciocínio crítico e analítico, da observação e do inquérito - que aquilo que até então era incontestável passou a ser posto em causa. Podemos citar três exemplos famosos, embora não contemporâneos. $\mathrm{O}$ mais antigo pertence a Estesícoro (fr. 11 Diehl), cuja vida decorreu entre os séculos VII - VI a.C., que não acredita que Helena tenha ido para Troia e que tenha sido o móbil da guerra lendária.

Outro testemunho muito famoso pertence a Xenófanes de Cólofon (fr. 11 Diels), que, um século mais tarde, critica a forma como a tradição mitológica retrata as divindades, fazendo com que não haja qualquer relação entre religião e ética, o que para este filósofo era inaceitável - os deuses não podiam ter comportamentos criticáveis à luz da moral.

${ }^{7}$ Daqui podermos concluir que história não estava etimologicamente relacionada com o estudo do passado. Naquela altura, aquilo a que hoje chamamos história não tinha designação específica. Vide 18 sqq. 


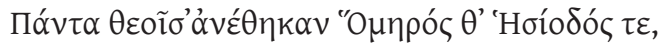

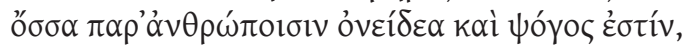

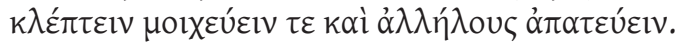

"Quanto há de vergonhoso e censurável, Tudo isso atribuíram aos deuses Homero e Hesíodo: roubos, adultérios e mentiras."

Xenófanes (fr. 14 e 15 Diels) mostra também alguma incredulidade ante a conceção antropomórfica das divindades gregas, alegando que, se os crentes fossem animais, cada espécie faria os seus deuses à respetiva imagem e semelhança, o que mostra o relativismo dos conceitos veiculados pela mitologia.

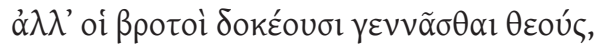

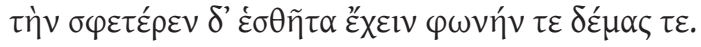

"Julgam os mortais que os deuses foram gerados, Que têm os trajes deles, e a mesma voz e corpo.”

(fr. 14 Diels)

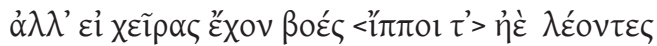

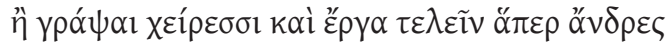

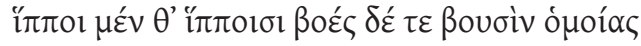

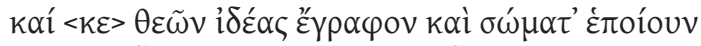

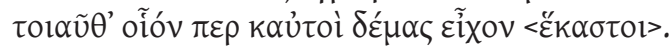

"Mas se os bois, <os cavalos> ou os leões tivessem mãos, ou pudessem pintar ou esculpir como os homens, os cavalos desenhariam imagens equinas dos deuses, e os bois, bovinas, e pintariam a forma e o corpo dos deuses como eles os têm, de modo que <cada espécie> teria o seu aspeto físico."

(fr. 15 Diels)

Podemos invocar ainda as palavras de Hecateu de Mileto ${ }^{10}$ (FgrHist 1a), contemporâneo de Xenófanes, que nos mostra que muitos Gregos, tendo a noção de que as histórias narradas pelo mito eram pouco sérias e fidedignas,

${ }^{8}$ Rocha Pereira (1998b: 132).

${ }^{9}$ Idem: 132.

${ }^{10}$ É considerado o inventor da cronologia genealógica e da explicação racional das tradições míticas, instrumentos básicos para o discurso histórico. Hecateu continuou a interessar-se pela geografia, na esteira da escola milesiana, cuja linguagem, bem como o estilo científico, também adotou. 
tentavam descrever a sua própria visão do mundo, contribuindo sobremaneira para o desenvolvimento da história, na medida em que se tornava imperativo justificar, com testemunhos, as respetivas opiniões.

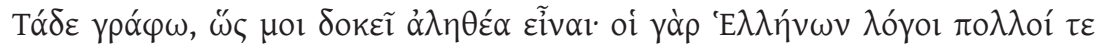

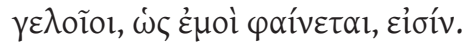

"Eu escrevo de acordo com o que me parece ser a verdade, pois as histórias dos Gregos são, em meu entender, muitas e ridículas ${ }^{11}$."

Mas esse esforço de reflexão levado a cabo por muitos nunca foi suficiente para destituir o mito da posição que ocupava na mentalidade e vida gregas. Os vestígios do mito eram omnipresentes. Quem poderia duvidar da existência de Teseu, se, em Atenas, era possível visitar o seu santuário?

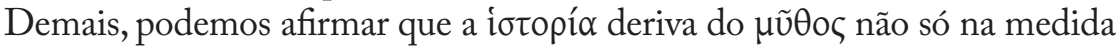
em que resulta da crítica daquele, mas também porque aproveita muitos dos elementos por ele utilizados e não despreza a ficção como símbolo antropológico de uma realidade cultural. Este aspeto é fundamental em Heródoto e conservase na historiografia posterior: de facto, certas «verdades históricas» não são mais do que ficção ou, se quisermos, são apenas «verdades ou realidades culturais».

Um dos elementos aproveitados são as genealogias, pelas quais o povo grego nutria particular apreço, pelo menos desde os Poemas Homéricos. Elas serviam para explicar a existência ou a origem de comunidades e famílias, relacionando cidades e indivíduos com fundadores que teriam vivido na idade dos heróis (séc. XIII a.C.). Eram sobretudo os nobres que se interessavam pela conservação de tal tradição, pois, ao tornarem-se descendentes das personagens em causa, viam aumentado o seu prestígio.

Por isso, podemos dizer que os genealogistas foram pioneiros da historiografia, que esteve, desde os primórdios, relacionada com a investigação etnográfica e geográfica ${ }^{12}$. Os primeiros genealogistas terão tido acesso a poemas épicos locais (nos quais se baseavam) que exaltavam determinadas linhagens de nobres. Só mais tarde, sob a influência dos Poemas Homéricos e da aspiração das linhagens locais a se ligarem à épica homérica, terá havido necessidade de desenvolver e complicar as teias da cadeia genealógica, ainda que extravasando o âmbito da região original.

Outro elemento não menos importante para o alvor da história foi o ressurgir da escrita ${ }^{13}$, que, além de permitir a criação de listas de informação diversa e a

\footnotetext{
${ }^{11}$ Idem: 138.

${ }^{12}$ Podemos pensar em Heródoto como exemplo máximo, ou pelo menos mais conhecido, da convivência entre investigação histórica, etnográfica e geográfica.

${ }^{13}$ Sobre este assunto, leiam-se, por exemplo, Woodward (1997); Powell (2002).
} 
fixação da tradição oral (com a manutenção do estilo formular e do conteúdo que lhe eram próprios), contribuiu sobremodo para o desenvolvimento do espírito crítico, na medida em que veio facilitar o confronto, até então impossível, de versões diferentes, impondo, assim, uma maior coerência aos relatos.

A opção pela prosa como novo veículo de pensamento crítico também concorreu para o aparecimento da história. Tal facto não nos deve surpreender, já que, se o verso vinha sendo, de há muito, utilizado para escrever sobre temas mitológicos, havia que recorrer a outro instrumento, não só para refutar a tradição mítica (até porque é mais fácil argumentar em prosa), mas também para expor temas relacionados com o mundo contemporâneo, como o das viagens ou da medicina.

Segundo Bertelli (2001), os textos em prosa pressupõem uma audiência distinta, certamente mais reduzida e disposta a aceitar as críticas à tradição genealógica e mítica. Além disso, de acordo com este autor, «a prosa era de longe um instrumento mais efetivo para o distanciamento da estrutura formular da poesia genealógica, para o seu questionamento e para avançar com argumentos que a refutassem.»

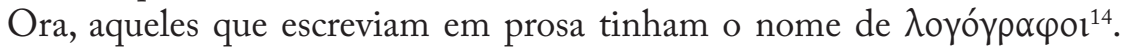
Ainda que os trabalhos dos primeiros se tenham perdido, podemos acreditar que deles fariam parte fábulas e mitos. A partir do séc. VI a.C., e na esteira dos físicos e geógrafos iónicos, tornaram-se críticos da tradição poética e mitológica. Apesar disso, Tucídides afirma que estavam mais interessados em cativar a multidão (ou seja, no efeito dramático do texto) do que em revelar a

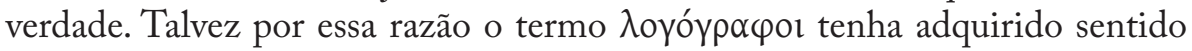
pejorativo no final do séc. $\mathrm{V}$ a.C., passando a designar, além daqueles que escrevem discursos para outros proferirem, também os que contam histórias incríveis.

O relato histórico sofreu ainda, como já foi mencionado, profundas influências da épica homérica, não obstante a forte ligação desta com o mito. Isso estará certamente relacionado com o facto de os Poemas Homéricos terem sido, durante muito tempo, aceites como registo de factos verídicos, apesar dos muitos episódios fantásticos, como o de Polifemo ou o da batalha entre Aquiles e o Escamandro. Mas não só: não nos podemos esquecer de que a memorização da Ilíada e da Odisseia era, por apologia dos melhores educadores, prática corrente, o que ajuda a explicar por que razão cada Grego tinha o seu conteúdo e estilo entranhados no espírito. Assim, e para todos os efeitos, mito e história acabaram por ser, de algum modo, sinónimos. Só com o desenvolvimento do espírito crítico (a que nos referimos atrás) e com a sua

${ }^{14} \mathrm{Cf}$. Thuc. 1.21. Hecateu é o logógrafo que melhor conhecemos. Dos restantes, praticamente só os nomes chegaram até nós, como, por exemplo, Dionísio de Mileto, Xanto da Lídia ou Cílax de Carianda. Sobre estes autores, consulte-se e. g. Lesky (1995: 247-253). 
aplicação à cultura e à tradição é que os episódios maravilhosos da epopeia começaram a ser postos em causa. Todavia não se evoluiu logo para a história, pois a primeira tendência foi ignorar e desculpabilizar as incongruências de Homero:

\section{quandoque bonus dormitat Homerus ${ }^{15}$.}

Por essa razão, só se chegou à história quando se sentiu a necessidade de comprovar aquilo que se dizia através de testemunhos dos que haviam presenciado os feitos. Mas era impossível aplicar tal método aos Poemas Homéricos, pelo que os estudiosos se debruçam, ainda hoje, sobre a historicidade dos mesmos.

Não admira, pois, que, tidos durante largo período como verosímeis e verídicos, tenham influenciado o relato histórico. Uma das marcas mais evidentes de tal ascendência é o tema: a guerra. De facto, aquelas que são conhecidas como as duas primeiras e mais importantes obras de historiografia grega centram-se, como a Ilíada, em grandes episódios bélicos: Heródoto dedicou-se às Guerras Médicas e Tucídides, à do Peloponeso. Ambos os autores consideram as «suas» guerras as maiores, logo, superiores à de Troia.

Também a Odisseia deixou o seu cunho sobretudo em Heródoto, que, por vezes, parece perder-se por entre digressões baseadas em relatos etnográficos e geográficos, também muito frequentes no poema que relata os errores de Ulisses.

Ademais do gosto pela genealogia, igualmente incutido pelos Poemas Homéricos (cf. e. g. Il. 6. 123-8 - quando Diomedes pede a Glauco que se identifique), encontramos em diversos passos destes poemas indícios da preocupação, que já então existia, em cometer feitos gloriosos que pudessem ser recordados pelas gerações vindouras, tal como naquele tempo já se recordavam os feitos dos antepassados. Neste sentido, Hornblower (1994: 7) chama a nossa atenção para trechos como Il. 3. 125-8 (passo no qual Helena surge como a primeira pessoa a, de algum modo, tentar conservar os principais acontecimentos da guerra para a posteridade, uma vez que os retrata nas suas tapeçarias) e Il. 9.189-194 (onde Heitor, às portas da morte, suplica por um fim glorioso que possa mais tarde ser recordado).

A influência dos Poemas Homéricos sobre a íotopía exerceu-se também em termos formais, já que os historiadore ${ }^{16}$ se serviram de recursos tipicamente épicos para a captatio beneuolentiae do leitor/ouvinte, tornando, assim, mais viva

\footnotetext{
${ }^{15}$ Hor. Ars 359.

${ }^{16}$ Não nos iremos alargar em exemplos nem em referências a historiadores que não Heródoto e Tucídides para não nos alongarmos demasiado, visto não ser este o objetivo principal do nosso estudo. Sobre este tema, vide e. g. Bury (1958) e Hornblower (1994).
} 
a narração. Embora Tucídides tenha sido mais comedido no emprego dessas técnicas, preferindo sobretudo os discursos, em Heródoto abundam digressões, o recurso à ring-composition (que lhe valeu duras críticas, pois narrativas anacrónicas não são consideradas muito fiáveis pelos leitores) e às fórmulas à maneira homérica, que lhe permitiam organizar e repartir a narrativa.

Podemos ainda referir que, do mesmo modo que os Poemas Homéricos deixam transparecer como viviam os Gregos de outrora, Heródoto também nos permite observar o modus vivendi dos Gregos e dos Persas do século VI e V a.C., bem como de outros povos que vai tratando: Egípcios, Citas, Etíopes...

Por tudo o que já foi dito relativamente aos elementos que confluíram dando origem, no século V a. C., com Heródoto (considerado por Cícero ${ }^{17}$ o pai

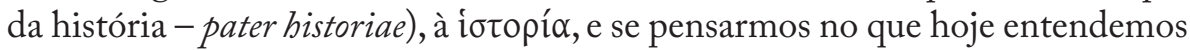
por história, facilmente verificamos que, embora aquela esteja na origem do conceito moderno, apresenta-se como uma realidade bastante diferente, quiçá mesmo nada científica.

Importa, pois, de seguida, verificar o que Heródoto de Halicarnasso

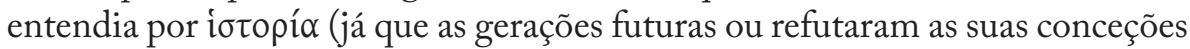
- caso de Tucídides, por exemplo - ou voltaram a defendê-las) e comparar esse entendimento com o atual.

Logo no início do Livro I das suas Histórias, Heródoto apresenta-nos os seus objetivos com a redação desta obra:

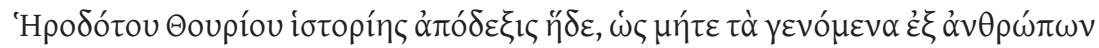

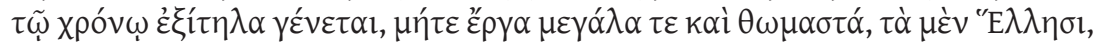

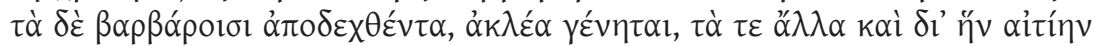

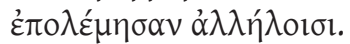

"Esta é a exposição das investigações de Heródoto de Halicarnasso, para que os feitos dos homens não se desvaneçam com o tempo, nem fiquem sem renome as grandes e maravilhosas empresas, realizadas quer pelos Helenos quer pelos Bárbaros e sobretudo a razão por que entraram em guerra uns com os outros ${ }^{18}$."

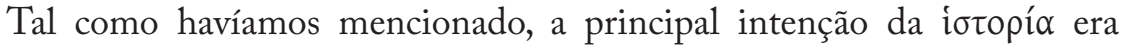
conservar determinados feitos para memória futura. Mas Heródoto acrescenta ainda a importância de que aqueles fossem explicados - só assim as gerações vindouras poderiam ter uma perceção mais profunda do sucedido.

${ }^{17}$ Leg. 1. 1.5: Marcus: Quippe cum in illa ad ueritatem, Quinte, <quaeque> referantur, in hoc ad delectationem pleraque; quamquam et apud Herodotum patrem historiae et apud Theopompum sunt innumerabiles fabulae. Assim é, Quinto, porque uma [a história] remete para a verdade, a outra [a poesia] geralmente para o prazer, ainda que em Heródoto, o pai da história, e em Teopompo haja inúmeros relatos fabulosos.

${ }^{18}$ Tradução de Ribeiro Ferreira - Silva (1994). 
É óbvio que a explicação das causas implica não só uma investigação cuidada e rigorosa, mas também - e inevitavelmente - a interpretação dos dados obtidos, já que estes não falam por si só, mas apenas quando estão relacionados entre si. E isso é tarefa do historiador... ${ }^{19}$

Nesse sentido, Heródoto preocupava-se, em primeiro lugar, com a distinção entre mito e acontecimentos reais - por exemplo, as campanhas persas que invoca de facto ocorreram; já a Guerra de Troia e outros episódios, plenos de intervenções divinas, são meros $\lambda \varepsilon \gamma o ́ \mu \varepsilon v \alpha^{20}$. É o caso dos raptos míticos de Io, Europa, Medeia e Helena (cf. Hdt. 1. 1.4 - 5.1) que, segundo Persas e Fenícios, constituíam a causa remota das Guerras Pérsicas. Ainda que não deixe de narrar a explicação defendida por aqueles povos, Heródoto (Hdt. 1. 5. 3) distancia-se dela, quando afirma que não se posiciona relativamente à veracidade dessa versão e que, quanto a ele, o agente mais antigo da desavença entre Gregos e Persas terá sido Creso, o primeiro a investir contra os Helenos. O espírito crítico, de que já falámos, manifesta-se, pois, nesta divisão. A Heródoto, não lhe parecem normais ou plausíveis as intervenções diretas e miraculosas da divindade, que não estão de acordo com a sua vivência do dia-a-dia. Só aquilo que a sua experiência comprova como verosímil o convence. Ainda assim, o nosso autor refere essa tradição ao longo da sua obra, salvaguardando sempre o facto de que mencionar tais perspetivas não significa acreditar nelas ${ }^{21}$.

No entanto, aceita a veracidade dos oráculos e o papel premonitório dos sonhos, dois elementos da tradição literária partilhados pela historiografia e pela tragédia. É, por exemplo, com um sonho que Creso (Hdt. 1.38. 1) justifica ao filho Átis os cuidados excessivos que lhe dedica. Todavia nem sempre oráculos e sonhos conseguem cumprir a sua missão. Não porque sejam enganadores, mas antes porque os que deles se servem fazem uma leitura deturpada das mensagens, o que acaba por dar origem a situações trágicas. Em Hdt. 1. 55, ficamos a saber que o excesso de confiança de Creso para atacar os Medos se deveu a uma consulta que fez à Pítia com o intuito de conhecer a duração do seu reinado. Perante a afirmação do oráculo de que aquele deveria fugir sem pejo quando um mulo fosse rei dos Medos, Creso ficou tranquilo, pois jamais os homens se sujeitariam a ser governados por outra espécie, logo, o poder nunca sairia das mãos da sua família... $\mathrm{E}$ as consequências foram as que sabemos...

Heródoto gostava de partir em busca de testemunhos (de caráter oral ou arqueológico), de observar os locais que tinham sido o palco das ações que relatava, pois dava mais valor aos dados obtidos em primeira mão do que a

${ }^{19} \mathrm{O}$ desejo de um relato rigoroso, que exclua a interpretação e juízos de valor, é uma obsessão relativamente moderna. Mas, na verdade, qualquer trabalho no âmbito da história acaba por consistir numa interpretação, mais ou menos convincente. Cf. Morley (1999: 15).

${ }^{20}$ Tucídides (1.20) também defende que não devemos confiar em tudo aquilo que a tradição apresenta como verídico.

${ }^{21}$ Vide infra p. 20. 
versões em segunda. Por isso podemos afirmar, com base nas suas próprias palavras, que o método por ele usado combina a observação (ő $\psi \iota \varsigma, \alpha u ̉ \tau o \psi i ́ \alpha)$,

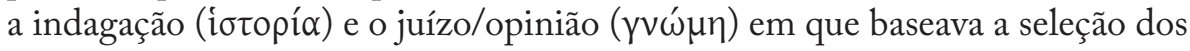
dados e a relação que estabelecia entre eles $(\sigma u \mu \beta \alpha ́ \alpha \lambda \varepsilon \varepsilon \sigma \theta \alpha \mathrm{l})$ :

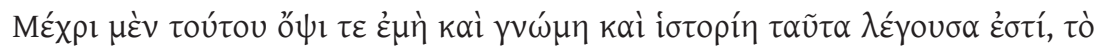

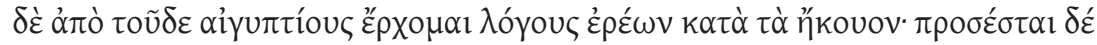

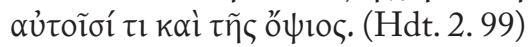

"Tudo o que disse até aqui é fruto do que observei e investiguei e da minha opinião. A partir de agora vou narrar as crónicas egípcias, segundo o que ouvi e acrescentando alguns pormenores que eu próprio constatei ${ }^{22}$."

Defendia, portanto, que, havendo mais do que uma variante sobre o mesmo acontecimento, todas as partes deveriam ser ouvidas, e, consequentemente, todas as versões deveriam ser apresentadas ao leitor/ouvinte ${ }^{23}$. No entanto, reservava-se o direito de não acreditar em tudo o que transmitia; fazia-o apenas por «obrigação científica»:

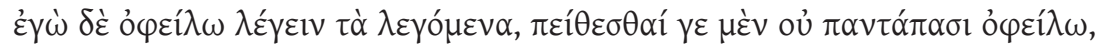

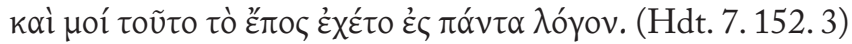

"Sou obrigado a contar relatos em que não devo acreditar; e esta advertência é válida para toda a minha narração."

É possível exemplificar um desses momentos de referência a vários pontos de vista sobre um mesmo problema, recordando Hdt. 1.5-6, no qual o autor reflete sobre a causa da inimizade entre Ocidente e Oriente. Havia versões diferentes, do lado grego e do lado dos Persas e Fenícios; Heródoto não toma partido, mas defende uma terceira versão que tem por verdadeira - tal hostilidade ficou a dever-se ao ataque de Creso contra os Helenos.

Apesar de se assumir como historiador ao longo de toda a obra, é no segundo capítulo das suas Histórias que, de acordo com Hunter (1982: 92), isso é mais evidente:

«It reveals the historian at work, choosing his material in the light of a thesis and reasoning to defend that thesis by appealing to a source that he believed to be reliable. In justifying his assertions, he made clear what he considered truth and certainty, what opinion and belief.»

${ }^{22}$ Tradução de Ribeiro Ferreira - Silva (1994).

${ }^{23}$ Já Hecateu, que preferia a coerência da narração, optava por selecionar e criticar a mais provável das diferentes versões. 
No entanto, ainda que Heródoto tenha ficado conhecido como «pai da história», foi, por razões de ordem vária, a Tucídides que, durante largos séculos, coube o estatuto de modelo a seguir. Não nos podemos esquecer, em primeiro lugar, de que este foi responsável pelo descrédito do predecessor, pois, sem mencionar nomes, criticou por diversas vezes o seu método de trabalho, fazendo, entre outras coisas, passar a ideia de que as informações de Heródoto eram pouco fidedignas, já que, entre muitos «defeitos», a presença do mito ao longo das suas Histórias era uma constante ${ }^{24}$.

Outros fatores a contribuir para tal evolução foram não só o objetivo de Tucídides ao escrever história, mas também o âmbito que abrangia: centrava-se nos acontecimentos políticos e militares do seu tempo, sem dar particular atenção a aspetos económicos, artísticos, religiosos ou etnográficos. Fazia-o por aqueles serem os temas que mais interessavam aos seus concidadãos, mas também por considerar que, se compreendesse a vida política coeva e as suas consequências militares, chegaria ao conhecimento da essência humana. A sua atração por temas contemporâneos justifica-se ainda pela convicção de que a melhor forma de conhecer os factos é assistir ao desenvolvimento dos mesmos, o que o leva a optar pelo método da observação direta e da consulta a testemunhos fidedignos ${ }^{25}$, métodos esses que não eram aplicáveis ao estudo de épocas distantes, já que para esses períodos a poesia era praticamente o único elemento disponível. E, como agravante, não estavam, como nos dias de hoje, disponíveis nem fotografias nem transcrições de discursos, quer em papel, quer em suporte magnético, ainda que existissem arquivos oficiais e entre as famílias aristocráticas.

Os historiadores helenísticos, romanos e bizantinos nunca esqueceram o modelo de Tucídides, que era particularmente cómodo para o relato de conflitos de duração limitada, sobretudo no que respeita ao estilo, como se pode verificar no uso de discursos e na coordenação entre análise política e militar. E, se a partir do séc. IV a.C., surge a tendência para a redação de uma história geral da Grécia desde os primórdios (cf. Éforo), tal resulta da influência dos capítulos iniciais de Tucídides, onde este historiador faz uma breve resenha do que se passara desde as origens até ao eclodir da Guerra do Peloponeso (Arqueologia).

Plutarco não foi exceção. Da leitura atenta da sua obra, sobressai a presença constante da História da Guerra do Peloponeso, embora as referências a ela nem sempre sejam explícitas. Como é sabido, os antigos não tinham a preocupação que temos nos nossos dias com o rigor das citações, pois, muitas

\footnotetext{
${ }^{24}$ Não que Tucídides não recorresse a relatos verbais com tanta frequência quanto Heródoto; diferia dele, no entanto, por um maior rigor dos critérios para o estudo da tradição oral, pois só transmitia o que era verosímil. É por essa razão que apresenta menos ficções do que Heródoto.

${ }^{25}$ Mas, a partir do séc. IV a.C., o relato histórico passa a apoiar-se com mais frequência na consulta de registos de instituições públicas e religiosas, jogos e competições literárias.
} 
vezes, não indicavam as suas fontes. Mas, se compararmos passos de Tucídides com alguns de Plutarco sobre o mesmo tema, ainda que o historiador não seja mencionado, a sua influência fica evidente.

Plutarco não foi exceção. Da leitura atenta da sua obra, sobressai a presença constante da História da Guerra do Peloponeso, embora as referências a ela nem sempre sejam explícitas. Como é sabido, os antigos não tinham a preocupação que temos nos nossos dias com o rigor das citações, pois, muitas vezes, não indicavam as suas fontes. Mas, se compararmos passos de Tucídides com alguns de Plutarco sobre o mesmo tema, ainda que o historiador não seja mencionado, a sua influência fica evidente.

No entanto, ao redigir as Vitae, o Queroneu não tinha por objetivo escrever uma obra de cariz historiográfico ${ }^{26}$. Isso mesmo afirma no passo (Alex.1.(1-)2) que a seguir se transcreve:

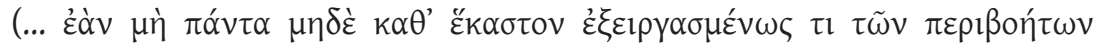

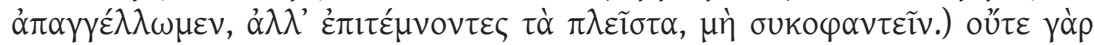

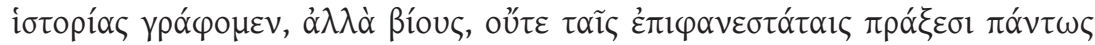

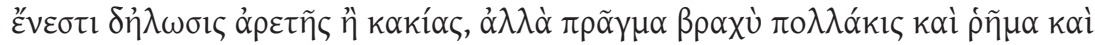

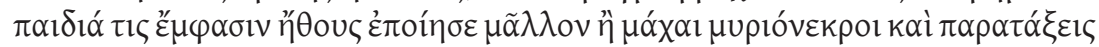

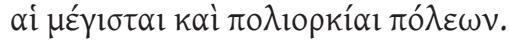

“(... se não relatarmos com grande pormenor, um por um, cada feito célebre, mas dermos apenas, para a maior parte dos casos, um resumo, que não haja reclamações). Porque não é história que nos propomos escrever, mas biografia, nem é de forma alguma nas ações mais admiráveis que está a explicação da virtude e do vício. Muitas vezes um pequeno feito, uma palavra, ou uma anedota refletem melhor a imagem do caráter do que combates mortíferos e do que as grandes batalhas e cercos das cidades."

É também um pouco essa a ideia que nos fica da leitura do proémio da Vida de Galba (2.5), onde corrobora que o relato exaustivo dos factos é da

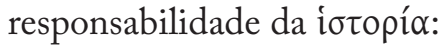

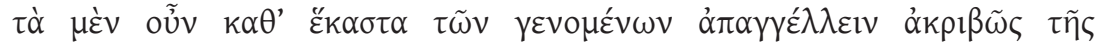

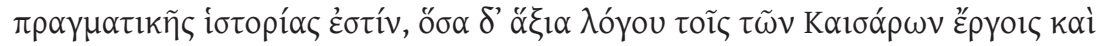

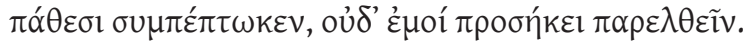

\footnotetext{
${ }^{26}$ No entanto, por vezes, como que se esquece desse seu propósito e acaba por agir como um verdadeiro historiador: em Per. 12 e 13 alarga-se em pormenores que, embora relacionados com uma das decisões mais importantes de Péricles - as obras de embelezamento de Atenas -, em nada contribuem para a descrição do protagonista: refere-se aos artistas responsáveis pelos monumentos, às profissões intervenientes nas obras e aos materiais utilizados.
} 
"Relatar exatamente cada um dos acontecimentos desse tempo é o objetivo da história, mas todas as ocorrências dignas de registo nos atos e nas experiências dos Césares, não convém que eu, da minha parte, as omita.”

A relação de Plutarco com a história não é, pois, pacífica: se, por um lado, é à história (enquanto repertório de exempla) que vai buscar elementos verídicos para ilustrar as virtudes (e, mais raramente, os defeitos) que quer realçar, quando caracteriza os protagonistas das diferentes Vidas; por outro, faz questão de demarcar a sua atividade da de um historiador ${ }^{27}$. Isso é algo que, ao leitor mais incauto, pode causar particular estranheza, pois existe a tendência - errónea - para tentar classificar os géneros literários antigos, de acordo com as nomenclaturas e conceitos atuais. Um bom exemplo para essa situação é precisamente a distinção entre biografia e história. Hoje, o relato biográfico é, de um modo geral, aceite como ramo daquela ciência humana. No entanto, entre os Gregos isso não acontecia ${ }^{28}$ : a história era vista essencialmente como um relato político-militar da existência de determinado povo; a biografia era entendida como narração dos feitos e costumes dos indivíduos ${ }^{29}$. Para nos apercebermos disso, basta recorrer aos testemunhos de alguns autores da Antiguidade, nomeadamente de Políbio (Hist. 10. 2. 1-5) e de Plutarco (cf. passo que acabámos de citar), que, segundo os dados que até nós chegaram, foram os primeiros a estabelecer formalmente essa distinção. Segundo Políbio, os historiadores apenas se devem preocupar com os vícios e as virtudes quando estes tiverem determinado o curso da ação política ${ }^{30}$ (que é o seu objeto de estudo). Tudo o que vise o elogio ou o denegrir da imagem das figuras públicas não deve fazer parte do relato histórico. Isto significa não que Políbio recuse a inclusão esporádica de dados biográficos no texto, mas antes que não aceita que se faça da história um grande encómio. No fundo, para Políbio, o historiador deve ser imparcial e rigoroso ${ }^{31}$.

Apesar da sua convicção, o Queroneu seguiu, na generalidade das Vidas, os princípios que norteavam a redação de um relato histórico. Por isso, tem particular cuidado com a seleção e análise das fontes e procura comprovar as

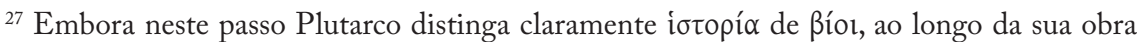
muitas vezes usa o primeiro termo para designar biografia. Para esclarecimento e exemplificação desta aparente contradição, vide Valgiglio (1987: 50-51; 1992: 3963-4051).

${ }^{28}$ A distinção helenística entre biografia e história só foi substituída pela aceitação da biografia como forma legítima de relato histórico a partir do século XVI. Cf. Momigliano (1993: 2).

${ }^{29}$ Segundo Tácito (Agricola 1), é esta a definição de biografia: clarorum uirorum facta moresque posteris tradere.

${ }^{30}$ Políbio, como fica implícito da sua afirmação, já tinha a consciência de que a formação individual e a personalidade tinham um papel determinante na conduta política.

${ }^{31}$ Esta posição demarca o relato histórico apregoado por Políbio do de Heródoto que, muitas vezes, ao contar episódios de caráter pessoal sobre as suas personagens, facilmente envereda pela ficção. 
afirmações que faz. Quanto aos acontecimentos que evoca - de forma rigorosa e quase sempre isenta -, opta apenas pelos que servem o seu propósito (o que exclui a reprodução de discursos, pormenores cronológicos, a descrição de campanhas militares ou decisões e triunfos políticos e os excursos geográficos, típicos da historiografia) e prefere aqueles que aceita como históricos e verídicos $^{32}$. Como ele próprio afirma no prólogo da Vida de Teseu, procurou sempre cingir os seus estudos a figuras cujas vidas decorreram em períodos tidos como históricos e não mitológicos ${ }^{33}$. No entanto, por vezes, como no caso do par Teseu/Rómulo, sacrifica esses princípios em prol do seu objetivo maior.

O cerne do problema é esse, precisamente. Embora biografia e história tivessem ambas um objetivo essencialmente didático, direcionavam-se para campos opostos. Logo no princípio do Livro 1 da sua História da Guerra do Peloponeso (Thuc. 1. 22. 4), Tucídides afirma categoricamente que escreve aquele texto para que as gerações vindouras possam conhecer a sucessão dos acontecimentos (logo, há necessidade de os descrever e explicar ${ }^{34} \mathrm{com}$ pormenor) e as causas da maior guerra de todos os tempos e para que, na posse de dados imparciais, possam retirar as suas conclusões e fazer os seus juízos. No fundo é esse o sonho de todo o professor ou educador: que os seus pupilos, após terem recebido os conhecimentos básicos, tenham capacidade de agir e pensar pelos seus próprios meios.

No caso da biografia - e especialmente no das Vidas Paralelas - o objetivo didático consistia em contribuir para a formação moral dos leitores e do próprio autor, através da recordação dos grandes homens do passado e da análise das suas qualidades ${ }^{35}$. Assim, podemos dizer que de alguma forma a biografia é um compromisso entre a história e a ética. Plutarco queria que

${ }^{32} \mathrm{Na}$ Vida de Címon (2. 2), por exemplo, sugere que acima de tudo importa basear o relato

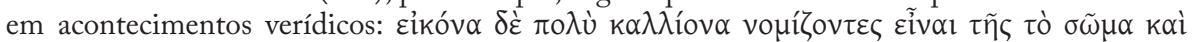

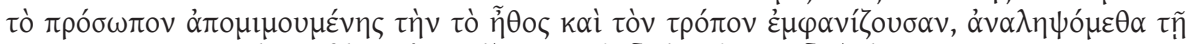

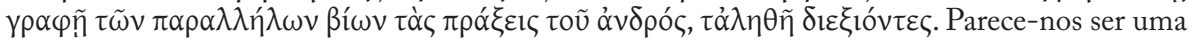
imagem mais bela aquela que reproduz o caráter e a conduta do que a que imita o corpo e o rosto; por isso iremos retratar neste tomo das Vidas Paralelas as acções deste homem, contando a verdade.

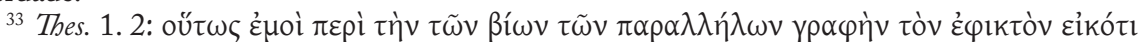

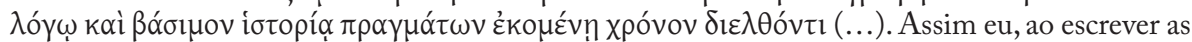
Vidas Paralelas, percorri as épocas em que as teorias se podem testar com argumentos e o relato se pode testemunhar com factos.

${ }^{34}$ Cornélio Nepos, em Pelópidas I, também aponta esta necessidade como principal diferença entre historiografia e biografia: o relato histórico procura explicar os acontecimentos (e, por isso mesmo, como já se referiu, por vezes evoca as qualidades ou defeitos dos indivíduos como justificativa de ações e opções), o biográfico não: Vereor, si res explicare incipiam, ne non uitam eius enarrare, sed historiam uidear scribere.

35 A diferença de objetivos, e consequentemente de métodos, entre historiografia e biografia - que aqui surgem representadas por Tucídides e Plutarco respetivamente - teve como consequência óbvia um produto final distinto, como nos diz Stadter (1989: liii), "Thucydides analysis is truer and deeper, but Plutarch allows us to consider the man behind the strategy." 
o seu texto funcionasse como uma espécie de espelho, refletindo as virtudes características de cada um dos heróis retratados ${ }^{36}$ - um pouco como se se tratasse de um "speculum principum" avant la lettre. Era essa imagem refletida que deveria guiar o comportamento daqueles que pudessem contemplá-la. Com a sua obra (cf. Per. 2. 2-4), pretendia incutir no leitor a necessidade de imitação das virtudes que apresenta em ação através das personagens que as incarnam ${ }^{37}$.

Plutarco acreditava que quem tem a oportunidade de contemplar o Bem ( $\tau$ ò $k \alpha \lambda o ́ v$ ), não resiste a agir em conformidade com ele. Ora este interesse filosófico-moral da biografia em geral e das Vidas Paralelas em particular é provavelmente a principal diferença entre a historiografia e o discurso biográfico. É por sua causa que o biógrafo é levado a selecionar um indivíduo e, dentre as suas ações (isto é, os factos históricos), aquelas que melhor manifestem a posse das virtudes a evidenciar. Esses feitos acabam por servir de 'ilustração', de exemplo. No caso da historiografia (e basta pensar em Tucídides), que enfatiza as decisões e ações coletivas, o valor do indivíduo, embora não seja negado, só é apreciado se este tiver um papel fundamental na vida político-militar de determinado período. No fundo, o valor do indivíduo resulta não das virtudes por ele possuídas, mas da sua contribuição para o

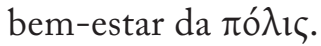

Por isso, podemos dizer com Gentili - Reni (1970: 23) que a biografia em Plutarco não pode ser definida apenas como 'descrizione dei fatti di una vita', mas antes 'comme individuazione della natura di una personalità necessariamente considerata nell'aspetto unitario delle sue azioni e dei suoi discorsi'.

De facto, os biógrafos antigos não tinham a intenção de descrever a vida dos indivíduos enquanto tal, isto é, tendo em consideração apenas os feitos e os traços de personalidade que os distinguiam das restantes pessoas; o que procuravam era salientar as características comuns a determinados tipos humanos. O facto de Plutarco agrupar os seus protagonistas em pares confirma, de certo modo, essa inclinação. Além de resultar da influência dos biógrafos latinos da época imperial, a sua opção pela redação de vidas paralelas foi favorecida (ou talvez tenha sido até suscitada) pelas circunstâncias de

${ }^{36} \mathrm{Na}$ Vida de Demétrio (1. 6), porém, Plutarco evidencia não as virtudes, mas os vícios, sempre com os mesmos objetivos pedagógicos: se a contemplação das qualidades nos incita a imitá-las, a dos vícios permite-nos fazer um autodiagnóstico e põe-nos em estado de alerta, pois já tivemos oportunidade de verificar, através dos exemplos, quão nefastos são os efeitos de qualidades negativas. Além disso, só apreciamos melhor o que é bom se tivermos um termo de comparação...

${ }^{37}$ Isso não significa que os protagonistas por ele escolhidos não possuíssem defeitos. Plutarco reconhece a existência dessas máculas e não as omite, como faziam os encómios, pois defende o rigor das suas descrições. No entanto, considera que não se deve dar demasiada importância aos aspetos menos positivos. Cf. Cim. 2. 4-5. 
vida de Plutarco: não nos podemos esquecer de que era um membro de valor reconhecido na sociedade greco-romana (era, inclusive, cidadão de Roma e de Atenas), que beneficiava ainda do filelenismo que então grassava na capital do Império. Por isso podia comparar os dois povos sem ferir suscetibilidades, já que era legítimo manifestar a sua admiração por ambas as pátrias, sem ter que negar nenhuma delas. A sua obra torna-se deste modo agente de fomento da relação entre os dois povos e da (auto)estima pelos Graeculi (diminutivo de conotações negativas), que ao serem comparados com os Romanos, se não os superavam, pelo menos não lhes ficavam atrás ${ }^{38}$... Por fim, penso que também podemos realçar o seu intuito de mostrar como constituições tão diversas e povos com temperamentos tão diferentes podem ambos dar origem a homens de virtude, dignos de imitação. Basta pensarmos no caso de Péricles e Fábio Máximo: embora o primeiro seja grego e o segundo latino e mais novo (com uma diferença de cerca de dois séculos) e as circunstâncias das suas vidas obviamente sejam também diferentes, possuem muitas virtudes semelhantes, que, logo no proémio da Vida de Péricles ${ }^{39}$, o Queroneu indica. Essa «inclusão» só é passível de ser feita devido à existência de determinados padrões de personalidade que foram fixados sobretudo com os peripatéticos ${ }^{40}$, segundo os quais a um tipo específico corresponderiam ações e maneiras de ser próprias e facilmente dedutíveis depois da sua identificação. No entanto, a descrição feita nas Vidas de Plutarco conjuga esse método indutivo, influenciado pelos peripatéticos, segundo o qual o caráter permite compreender e até antever as ações, com o dedutivo, de acordo com o qual só chegamos ao caráter pela observação dos feitos.

$\mathrm{Na}$ sequência do que foi brevemente explanado nas páginas anteriores, é fácil constatarmos que a história daquele tempo, embora seja o gérmen da atual, era entendida de forma bastante diversa. Segundo Luce (1997: 4), a historiografia clássica não era

«an account of abiding conditions and institutions, whether military, religious or political; not an analysis of social classes, economic factors or cultural achievements. Such topics did appear in histories, to be sure, but in the form of prefaces and digressions, often brief. The overall framework was narrative of events, without which those other subjects, which most people today consider central to historical writing, could find no place. When an author wished to write an extended account of topics like the constitutions of states or military tactics he sometimes composed a separate long monograph rather than making it a subordinate part of a larger history».

\footnotetext{
${ }^{38}$ Sobre este assunto, vide Russell (1966: 140-141).

${ }^{39}$ Esta breve exposição das semelhanças funciona como justificação da opção por aquele par e não por outro.

40 Invoquemos o exemplo dos Caracteres de Teofrasto.
} 
$\mathrm{Na}$ verdade, não obstante a perseguição do rigor na narração dos factos, a história continua a ser vista como um subgénero literário até ao séc. XIX, período em que passa a ser considerada ciência e a dispor de meios para estender o seu âmbito de estudo a épocas remotas. Só então este ramo do saber alarga as suas áreas de interesse: o historiador deixa de investigar apenas no campo da atividade política e militar de um povo e passa a interessar-se por outros domínios, como, por exemplo, o económico e o religioso.

Para esta mudança de estatuto contribuiu também o desenvolvimento dos métodos de investigação, nomeadamente dos estudos arqueológicos, dos documentos, e o renascimento do interesse pela tradição oral e pelas viagens.

Se hoje em dia os critérios de Heródoto - e mesmo de Tucídides - nos parecem pouco fidedignos e até a-históricos, isso deve-se à evolução do próprio conceito de história e dos instrumentos de investigação disponíveis nas diferentes épocas. Mas não é por isso que os dois pioneiros deste tipo de investigação veem reduzida a sua importância. Os passos que deram foram certamente condição sine qua non para que chegássemos à história dos nossos dias, até porque, na verdade, o que naquele tempo se acumulava em uma única narrativa, está atualmente repartido por áreas específicas, como a antropologia, a etnografia e a filosofia da história. 


\section{PARte II}

CONVENÇõES LITERÁRIAS ASSOCIADAS À VIDA DE UM FUNDADOR 
Como já foi dito ${ }^{1}$, embora se assuma como biógrafo e não como historiador, Plutarco baseia a redação das suas Vidas nos critérios normalmente observados no relato historiográfico. Esta atitude justifica o facto de a quase totalidade dos indivíduos por ele retratados serem personagens históricas, regra apenas desrespeitada no caso do par Teseu/Rómulo, segundo o autor ${ }^{2}$. No proémio da Vida de Teseu (1. 4), Plutarco explica a Sóssio Senecião ${ }^{3}$ que decidiu escrever sobre duas personagens cujas vidas não estão dentro dos limites a que se costuma cingir, porque as investigações que fez a propósito do par Licurgo/ Numa o fizeram recuar até à fronteira do período mitológico:

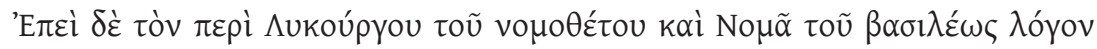

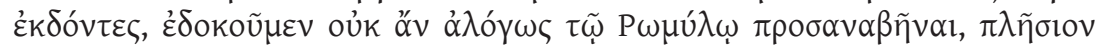

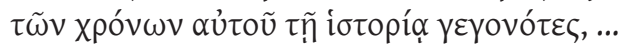

"Contudo, ao publicarmos o texto sobre o legislador Licurgo e o rei Numa, pareceu-nos que não seria despropositado recuarmos até Rómulo, pois a nossa investigação já nos havia conduzido a um período próximo do seu...”

Assim sendo, e devido à importância de Teseu e Rómulo, não se justificava não tratar as figuras daqueles que são considerados os fundadores da «bela

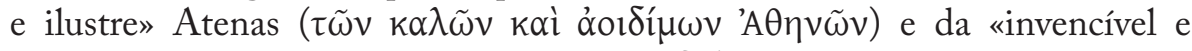

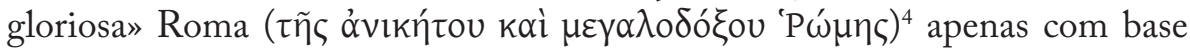
no argumento da falta de historicidade. Esse «senão», o biógrafo procurará colmatá-lo através da racionalização do mito (que consiste na escolha das versões mais credíveis e na tentativa de libertar a narrativa dos elementos mais fantasiosos ${ }^{5}$ ), algo que, ele sabe, nem sempre será possível (Thes. 1. 5).

${ }^{1}$ Vide supra p. 22.

${ }^{2}$ No entanto, somos levados a crer que Licurgo e Numa também foram uma exceção à regra. Sobre este assunto, vide Flacelière (1948: 68-69); Pérez Jiménez (2000: 139 e 153).

${ }^{3}$ Romano, amigo de Plutarco, cuja vida decorreu entre os reinados de Domiciano e Trajano. Segundo Jones (1971: 55), o Queroneu dedicou-lhe as Vitae Parallelae por considerar que ninguém simbolizava melhor a fusão cultural entre a Grécia e Roma.

${ }^{4}$ Thes. 1.5 .

${ }^{5}$ Como exemplos, podemos invocar a forma como lida com o facto de Poséidon ser frequentemente apontado como pai de Teseu (vide infra p. 54) e com a crença de que Rómulo e Remo teriam sido amamentados por uma loba (Rom. 4. 3-5), dizendo que a mesma palavra latina (lupa) servia para designar a fêmea do lobo e as mulheres que, como Aca Larência, se dedicavam à prostituição. Heródoto procedeu de modo semelhante no livro primeiro das suas Histórias, quando se refere a Cino. Sobre este assunto, vide infra p. 36 nota 19. 


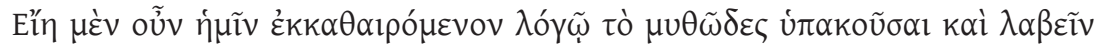

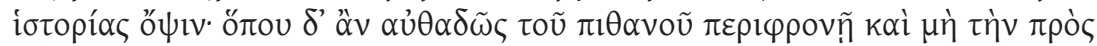

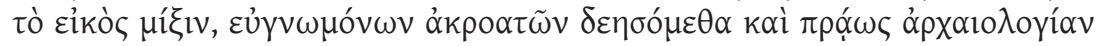
$\pi \rho \circ \sigma \delta \varepsilon \chi \rho \mu \varepsilon v \omega \nu$.

“Oxalá conseguíssemos que, expurgado pela razão, o mito se adaptasse e ganhasse forma de história; mas, se alguma vez, com audácia, desprezar a credibilidade e não admitir um acordo com o verosímil, precisaremos de leitores compreensivos e que acolham com paciência as tradições antigas.”

De facto, Plutarco tenta proceder em conformidade com estes princípios, pois, sempre que possível, indica as diferentes versões de um mesmo episódio, chamando a atenção para aquela que lhe parece ser mais plausível. Em Rom. 6. 1 , por exemplo, quando refere que os gémeos Rómulo e Remo ${ }^{6}$ foram criados por Fáustulo, porqueiro de Amúlio, afirma que o mais certo é tê-lo feito não às escondidas de todos, mas com o conhecimento e apoio de Numitor.

O texto (Thes. 1.4) parece sugerir que a formação do par Teseu/Rómulo teve por base a escolha da figura romana, já que Plutarco começa por dizer que não seria despropositado tratar a figura de Rómulo ( $\varepsilon \delta$ ¿

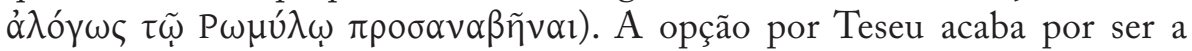
mais lógica em termos paralelos: embora não sendo o verdadeiro fundador

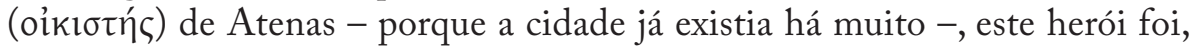
sobretudo a partir do século $\mathrm{V}$, considerado o fundador de uma civilização e de um projeto político decisivo por lhe ser atribuída a responsabilidade pela união de todas as comunidades da Ática, que deu origem à Atenas de que hoje se tem memória ${ }^{7}$.

No segundo capítulo do proémio, Plutarco continua a justificar a escolha deste par, invocando outras características que Teseu e Rómulo têm em comum: a origem ilegítima e clandestina, a fama de serem filhos de deuses, as capacidades intelectuais e militares ${ }^{8}$, os infortúnios domésticos e

${ }^{6}$ Segundo Plutarco (Rom. 4. 1 e 6.2), os nomes dos jovens ficaram a dever-se ao facto de terem sido vistos a mamar numa loba. É que, em latim, teta dizia-se ruma, de onde a deusa que tutelava a alimentação dos recém-nascidos chamar-se Rumina. Por essa mesma razão, a figueira sob a qual os gémeos foram amamentados recebeu o nome de Ruminal. Plutarco levanta igualmente a hipótese de a designação da figueira provir do nome de Rómulo. Trata-se, pois, de mais um exemplo de recurso a elementos míticos com a função de aítıov para justificar antropónimos, topónimos, tradições, festas... Voltaremos a comprová-lo mais adiante, quando nos debruçarmos especificamente sobre a Vida de Teseu. Vide infra pp. 99-105.

${ }^{7}$ Plutarco deixa transparecer esta dualidade no texto, na medida em que ora o invoca através do substantivo que designa o fundador de uma cidade - oikı бฑ́ (Thes. 1. 5), ora se lhe refere

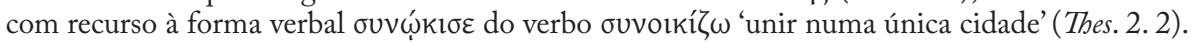
Sobre a evolução do mito de Teseu, vide infra p. 61.

${ }^{8} \mathrm{O}$ modo como o Queroneu alude a estas duas qualidades revela (como vários outros passos da sua obra) o constante recurso e o profundo conhecimento da História da Guerra do Peloponeso 
o descontentamento popular de que foram objeto em fim de vida. Podemos acrescentar que, além destas semelhanças, ambos simbolizam a unidade dos respetivos povos e o estabelecimento das suas principais instituições.

Ora, a especificidade destas duas figuras - escolhidas, como já vimos, por serem fundadoras das «capitais» do mundo de então - fez com que o retrato que o Queroneu delas traça fosse influenciado pelos tótrol que, na tradição literária da Antiguidade, estão, por norma, associados à descrição da vida de um herói, de um fundador de grandes dinastias ou civilizações. É a essa análise que procederemos em seguida.

De um modo geral, as crianças são vistas pelos pais (e avós) como um dom e como uma forma de deixarem um sinal da sua passagem pela Terra. No entanto, a relação entre pais e filhos nem sempre é pacífica e dá, não raras vezes, origem ao célebre "conflito de gerações», que resulta da tentativa que cada um faz para impor a sua vontade, a sua visão do mundo. Os filhos têm como objetivo sobretudo a emancipação; os pais, a preservação da autoridade. No fundo, uns querem conquistar poder; os outros, conservá-lo. Esta luta está documentada desde tempos imemoriais. Basta-nos recordar o mito da sucessão divina, a forma como Crono depõe Urano e como, mais tarde, Zeus sucede a Crono, que devorava os filhos para não se ver privado do cetro ${ }^{9}$. Trata-se, de certa maneira, de uma luta pela sobrevivência que, como o mito demonstra, é normalmente vencida pela fação mais jovem.

Apesar de os (futuros) pais terem consciência desta realidade (até porque foram/são, primeiro, filhos), anseiam pela chegada de descendência. De tal modo que, quando ela tarda, procuram compreender a razão da demora e superar essa dificuldade.

$\mathrm{Na}$ Antiguidade, os homens que (após sucessivas tentativas com a mesma ou com diversas mulheres) não conseguiam ter filhos costumavam consultar os oráculos para saber o que havia de errado. Curiosamente - e apesar das aparências - essa infertilidade acabava por se revelar uma espécie de bênção divina, cujo poder cessava mal eles tomavam uma atitude para tentar solucionar o problema. É que, uma vez consultado, o oráculo (segundo o qual os filhos que viessem a nascer constituiriam um perigo para a vitalidade e poder dos progenitores ${ }^{10}$ ) funcionava como instrumento - diríamos nós hoje - de fertilização artificial. Ironia das ironias - ou quiçá do destino -, no momento

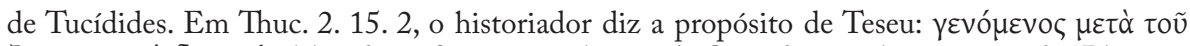

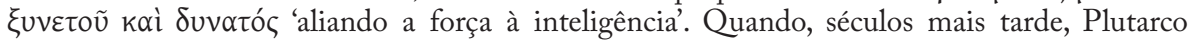
escreve sobre Teseu e Rómulo, cita (certamente de cor) Tucídides, embora altere a posição das

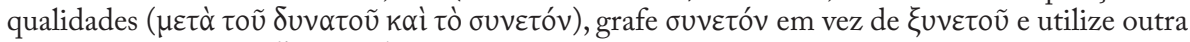

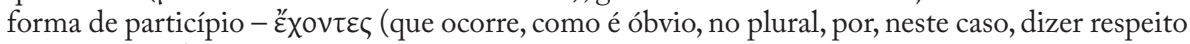
a duas pessoas).

${ }^{9}$ Cf. eg. Hes. Th. 155-211 (sobre Urano) e 454-507 (sobre Crono).

${ }^{10}$ Cf. S. OT 711-714. 
em que, alertados pelo oráculo, decidiam não ter filhos, logo eram levados a fecundar uma mulher.

Ainda que sujeito a diversas versões, o caso de Laio é paradigmático: estranhando a ausência de prole, também ele optou por interrogar Febo e pedir o seu auxílio. A resposta que obteve aconselhava-o a não contrariar os deuses e a evitar gerar um filho que seria o seu assassino e a ruína da casa real. Ironicamente, foram as diligências do Labdácida para respeitar o aviso divino que despoletaram o nascimento da criança agora indesejada: Jocasta, ferida nos seus brios pela rejeição do marido (cuja causa não conseguia compreender), embriagou-o e seduziu-o ${ }^{11}$. Podemos, pois, asseverar que Laio só indiretamente desrespeitou a advertência que lhe fora feita, porque, ébrio, não estava capaz de impor a sua vontade e, além disso, a iniciativa não foi dele, mas sim da mulher. Este tipo de situação está imbuído de sentido trágico, na medida em que, por mais que tente evitar o seu destino, o homem caminha a passos largos na sua direção. É como afirma Lesky $(1995: 133)^{12}$ :

“o homem não é vítima passiva do seu destino, intervém nos acontecimentos, mas os deuses dispuseram-no de tal modo que cada passo, com que se crê afastar da sua fatalidade, o aproxima mais dela."

Noutros casos, ademais de não ocorrer o problema da infertilidade, o elemento fantástico que transmite a ameaça é não o oráculo (que, parece-nos, pode ser conotado com a ideia de ordem ou proibição dos seres superiores a propósito de um perigo efetivo), mas o sonho, que funciona como uma premonição, uma sugestão de que há um perigo latente. Segundo Heródoto (1. 107-113), foi por causa dos sonhos que, para evitar o nascimento daquele que lhe haveria de usurpar o trono, Astíages organizou - com uma antecedência excessiva e ineficaz (porque, mais uma vez, o homem, ao tentar fugir do seu destino, só consegue contribuir para a sua realização) - o futuro da filha. O primeiro ocorreu quando Mandane, mãe de $\mathrm{Ciro}^{13}$, ainda era uma criança. Nessa altura, Astíages viu a cidade e toda a Ásia submersas pela urina dela. Este

${ }^{11}$ Cf. Apollod., Bibl. 3. 5, 7. É antigo o motivo da embriaguez e da sedução utilizados como método para se conseguir do cônjuge (ou de um qualquer homem) aquilo que se pretende. Podemos invocar o famoso episódio do Dolo de Zeus (Il.14 passim) ou mesmo o que aconteceu a Egeu (cf. Thes. 3. 5; Paus. 2.31. 12 e 33.1), que gerou um filho numa situação idêntica à de Laio. Eurípides, no monólogo de abertura das Fenícias (Ph. 13-22), confia à própria Jocasta a evocação dos acontecimentos, com abundante recurso a pormenores de natureza conjugal. Se compararmos esta versão com a do Rei Édipo de Sófocles (que se limita a aludir à existência do oráculo), fica evidente a diferença de gosto dos dois poetas.

${ }^{12} \mathrm{Na}$ verdade, a frase citada é relativa a Édipo, mas não deixa de, neste contexto, poder ser aplicada ao próprio Laio. Sobre a problemática do destino, vide infra p. 43.

${ }^{13}$ Sobre Ciro, leiam-se, e.g., Krappe (1930: 153-159); Avery, (1972: 529-546); Immerwahr (1966: 89-93 e 161-167); Vandiver (1990: 249-253). 
sonho foi tido como um indício nefasto para o poder do rei: é que, para Medos e Assírios, a urina ${ }^{14}$ era símbolo do nascimento de um filho. Assim, o sonho de Astíages constituía uma ameaça ao seu estatuto de governante supremo, pois, segundo a premonição, o poder do jovem herdeiro estender-se-ia da Média por toda a Ásia.

Por isso, para evitar dissabores, quando Mandane atingiu a idade própria, casou-a não com um medo, mas com um persa, chamado Cambises, que considerava pouco digno da filha, devido à crença de que era possível evitar os perigos relacionados com a descendência, se uma mulher fosse desposada por um homem de condição social inferior ${ }^{15}$.

O segundo sonho de Astíages, porém, revela que o estratagema não fora eficaz: desta vez, ele vê nascer do sexo da filha uma vinha - símbolo do poder e do sucesso - que cobria toda a Ásia, o que, de acordo com os intérpretes, significava que o seu neto iria substituí-lo no poder. Mas Mandane já estava grávida; portanto, a Astíages apenas restava a hipótese de tentar resolver o problema a posteriori.

Há, porém, histórias em que a ameaça representada pela figura de um descendente é de tal modo óbvia que quem detém o poder procura pôr sem demora - e sem sucesso - cobro ao perigo, sem que nenhuma divindade necessite de o alertar. É o caso de Amúlio, tio-avô de Rómulo ${ }^{16}$ e Remo. Como aquele tinha destronado o irmão Numitor, pai de uma única filha, o poder assim alcançado apenas poderia ser reivindicado pelos netos que Numitor viesse a ter. Era, pois, evidente que, para se salvaguardar, Amúlio precisava de fazer tudo o que estivesse ao seu alcance para que a sobrinha não se envolvesse com nenhum homem. Foi por isso que o usurpador fez dela uma sacerdotisa vestal. Não obstante, a jovem deu à luz dois gémeos do sexo masculino.

Contudo, apesar dos oráculos (ou das premonições) e dos esforços para evitá-lo, perante a iminência da chegada destas crianças, predestinadas a nascer e a realizar feitos ou missões de monta, aos progenitores ou outros familiares (o avô, no caso de Ciro; o tio-avô, no de Rómulo e Remo) que se sentiam em perigo, apenas restava aguardar, vigilantes, a sua chegada. Só então poderiam tentar, mais uma vez, frustrar o destino. Desta feita, a solução encontrada consistia em condenar à morte os recém-nascidos.

${ }^{14}$ Cf. Asheri (1988). Segundo Immerwahr (1966: 163, n. 40), para os Persas, que reverenciavam a pureza da água, a urina era sinónimo de poluição. Sobre este assunto, consulte-se Pelling (1996: 68-77).

${ }^{15} \mathrm{O}$ mesmo destino tiveram Labda, a mãe de Cípselo (Hdt. 5.92), e a Eletra de Eurípides (El. 34 sqq.). Quanto a Cambises, ao contrário do que Heródoto parece sugerir, tinha ascendência real. Sobre a história da casa real da Pérsia, vide Bowman et alii (2000: 4, 2-6).

${ }^{16}$ Em Rom.2.2-8, Plutarco narra diferentes versões sobre a origem dos gémeos. Aquela em que baseámos o nosso raciocínio é a que ele considera mais fidedigna (Rom.3-8). 
Este motivo - o da criança nobre condenada à morte por um rei - constituía uma ação pouco digna, pelo que a sua execução era delegada em terceiros. No caso de Ciro, a missão infame foi entregue a um nobre da confiança de Astíages, Hárpago ${ }^{17}$; também ele (embora tenha, oficialmente, aceitado a tarefa) recusou conspurcar as mãos com crime tão hediondo, alegando temer que o rei, um dia, se viesse a arrepender. Mas, como não podia contrariar a vontade daquele, mandou chamar um servo para que, este sim, abandonasse a criança indefesa à própria sorte ${ }^{18}$.

E curioso notar que, nestas histórias, existe um certo antagonismo entre os agentes: os que mandam matar fazem-no por não olharem a meios para manter o seu poder; contudo aqueles a quem ordenam a execução apiedam-se das crianças mas temem a ira dos autores morais do abandono, porque são de condição inferior e propriedade daqueles. Não obstante, o instinto de proteger uma criança pequena fala mais alto, até porque, além de não terem medo de perder o poder, os «salvadores» acreditavam que as precauções que tomariam seriam suficientes para que as crianças jamais fossem descobertas; logo não seriam punidos por não terem cumprido as ordens.

Não admira, pois, que Mitradates ${ }^{19}$, o servo escolhido por Hárpago para, em seu lugar, pôr fim à vida de Ciro, tenha ouvido o conselho da mulher: esta acabara de dar à luz um nado-morto e via naquela criança a hipótese de viver as experiências da maternidade. Bastava-lhes, por isso, para salvar o recém-nascido, colocar as suas ricas vestes reais na criança morta, de modo a que todos acreditassem tratar-se do filho de Mandane. Estamos perante outros dois motivos comuns no âmbito deste género de narrativas: as roupas (ou sinais, $\gamma v \omega \operatorname{lí} \mu \alpha \tau \alpha$ em grego ${ }^{20}$ ) que permitem o reconhecimento de uma criança nobre e a substituição, por uma criança humilde, de outra de condição social diversa.

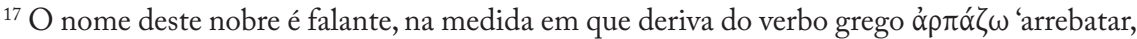
raptar', o que relaciona esta figura com o rapto e o abandono do recém-nascido.

${ }^{18} \mathrm{Na}$ verdade, estas crianças conseguiam sobreviver, apesar da tenra idade, porque estavam predestinadas a isso. Assim, ainda que não pudessem, nesta fase, ter um papel ativo na própria defesa, estavam protegidas por forças superiores, pela própria natureza, como no-lo confirmam os casos em que são alimentadas por animais (vide infra p. 42).

${ }^{19}$ Os nomes do boieiro de Astíages e da sua companheira são igualmente falantes: Mitradates está relacionado com o deus Mitra, que tutela o Sol e a Natureza; Cino é o correspondente grego do medo spaca 'cadela'. Assim, estas duas personagens recebem nomes correspondentes à função que têm na história: Mitradates desempenha o papel da Natureza protetora; Cino, o do animal que aleita o recém-nascido, outro motivo comum a este tipo de relatos. Estamos, pois, perante uma racionalização do mito efetuada por Heródoto, que tinha dificuldades em aceitar que uma criança tivesse sido alimentada por uma cadela. Segundo Vandiver (1990: 251), «this supports the contention that when Herodotus includes fabulous material, he does so consciously and therefore for a purpose». Cf. supra p. 16.

20 Segundo Aristóteles, que na Poética (1454b-1455a) teoriza sobre as cenas de reconhecimento (isto é, em que se passa da ignorância ao conhecimento), aquelas que se baseiam em sinais são as menos engenhosas e as que revelam menor capacidade imaginativa do poeta. Sobre este assunto, consulte-se Briquel (1983: 67-74). 
Este é também um dos casos em que se pode verificar claramente a atuação das forças superiores no sentido de proteger o predestinado: é que esta «coincidência» ${ }^{21}$ permitia poupar a vida do jovem Ciro, ainda que, para isso, uma criança nobre tivesse de ser criada, até ao momento da revelação da verdade e do reconhecimento, no seio de uma família que não a sua de origem, e que, por norma, é de condição social diferente (regra geral, mais humilde) ${ }^{22}$.

No caso de Édipo, os executores da ação são o pai, que tem o cuidado de lhe trespassar os tornozelos ${ }^{23}$ para assegurar que ninguém queira ficar com uma criança que tenha tal marca (isto demonstra bem o apego de Laio ao poder, já que toma todos os cuidados para que o filho se não vingue); o porqueiro tebano encarregado de expô-la (cf. S. OT 718-720); o pastor de Corinto, ao qual o porqueiro, com pena, entrega Édipo, e os reis de Corinto, Pólibo e Mérope, que acolhem a criança trazida pelo pastor, pois não podiam ter filhos (S. OT 1022-1024) ${ }^{24}$. Assim, embora a sua vida tenha sido salva por pessoas de condição humilde, Édipo acaba por ser criado no seio de uma família real. Curiosamente, na versão que Sófocles apresenta do mito, por uma questão de economia dramática, as pessoas que lhe salvaram a vida na infância são as mesmas que lha vão destruir na idade adulta, na medida em que fica a seu cargo revelar-lhe a verdade.

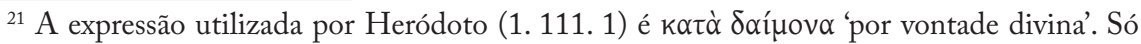
a vontade divina pode justificar a ocorrência de acontecimentos que permitem, neste caso, a salvação da criança predestinada. Segundo Immerwahr (1966: 164), a expressão utilizada pelo historiador é uma espécie de cristalização que teria o sentido de 'por coincidência'. No entanto, reconhece que tais coincidências apresentam «religious overtones, since they reveal processes of nature». Contudo, as coincidências desempenham um papel fundamental em outros momentos deste tipo de narrativas, pois é igualmente por causa delas que a verdade vem ao de cima.

${ }^{22} \mathrm{O}$ caso de Édipo constitui uma exceção. Cf. p. 45.

${ }^{23} \mathrm{Na}$ sua tradução do Rei Édipo (p. 123, nota 91), M. C. Fialho afirma que o nome do herói parece estar relacionado com o hábito de se amarrar (perfurando ou não) os tornozelos das crianças que eram expostas depois de nascer. É deste modo que justifica o comentário feito pelo

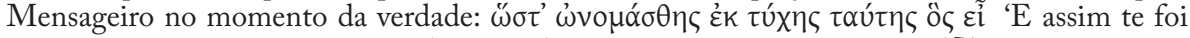
dado o nome por esta ocorrência.' (OT 1036). Consequentemente, o nome Oídírous derivaria do verbo oỉóa 'intumescer' e do substantivo roú ‘ 'pé', cujo sentido literal é 'de pés intumescidos'. Segal (2001: 36 e 111) apresenta outras duas etimologias possíveis: o nome pode provir da forma verbal oĩ $\delta \alpha$ 'eu sei' e do substantivo toúc 'pé', cujo sentido seria 'aquele que conhece o enigma dos pés', em alusão ao enigma da Esfinge; ou ser formado a partir do mesmo verbo e do advérbio de lugar пoũ 'onde', pelo que significaria 'eu sei onde'. Neste caso, realçar-se-ia a ironia trágica que envolve a figura de Édipo, que julga saber tudo (inclusive qual o seu lugar no mundo), mas que, de facto, vive enganado, levando uma vida e habitando um lugar dos quais tentava fugir a todo o custo.

${ }^{24}$ Segundo outra versão (cf. e. g. Apollod., Bibl. 3. 5-7; Paus. 10. 5. 2), Édipo teria sido colocado numa arca que foi arrastada pela corrente (como aconteceu aos gémeos romanos e a Moisés) até à costa de Sícion, onde a mulher de Pólibo se encontrava a vigiar as lavadeiras do palácio. Nessa altura, a rainha - que, de acordo com esta versão, se chamava Peribeia - conseguiu convencer as criadas de que acabara de dar à luz. Como não tinha (nem podia ter) filhos, Pólibo criou Édipo como se fosse do seu sangue. 
Segundo Plutarco (Rom.3), no caso de Rómulo e Remo, os carrascos são o tio-avô (o mandatário do crime, que ficara mais certo do risco que corria ao observar o tamanho e beleza extraordinários dos gémeos ${ }^{25}$ ) e o escravo a quem este ordenou que arrancasse os recém-nascidos à mãe e os abandonasse à sua própria sorte. Ao contrário do que temos verificado ser o padrão, este servo não se apieda da sorte das crianças, mas preocupa-se antes com a própria segurança: se as deixa junto à margem do rio, contrariando as ordens que recebera para lançá-las à água, é simplesmente com medo da força da corrente. Neste caso, é imperioso não esquecer de invocar a Natureza (e o fator "coincidência») como agente de salvação (e simultaneamente elemento fantástico da narrativa): em causa estão a força da corrente (que, além de ter impedido o cumprimento das indicações reais, fez com que o rio, galgando as margens, conduzisse os recém-nascidos para um sítio tranquilo ${ }^{26}$ ) e a loba que aí os amamentou ${ }^{27}$. Só então entra em cena o quarto agente típico deste género de história, o escravo que tem a seu cargo o tratamento dos animais, neste caso, porcos. Aqui, chama-se Fáustulo ${ }^{28}$ e trabalha para Amúlio, portanto, para o executor moral do abandono. Também ele, como é costume, vai criar no seio da sua humilde família duas crianças de ascendência nobre.

O facto de serem adotados por famílias humildes permite que, apesar de continuarem a viver na mesma comunidade que os seus carrascos, levem uma infância incógnita e tranquila até ao momento propício para o reconhecimento. Apenas Édipo, que foi levado para outra cidade e não precisava de crescer escondido, viveu no seio de uma família igualmente nobre e real.

Contudo, a verdade relativa à condição destas crianças começa, desde cedo, a ser denunciada pela sua maneira de ser e de agir. É aquilo a que Vandiver (1990: 251) chama o motivo do «blood will out»: a nobreza destes jovens era algo inato, algo que lhes estava no sangue e que não podia ser ocultado por circunstâncias exteriores, pelo facto de viverem com famílias de condição social inferior.

A história de Ciro é, quanto a este aspeto, paradigmática. Segundo Heródoto (1. 114-119), o reconhecimento do neto por parte de Astíages deu-se quando aquele tinha apenas dez anos, na sequência de uma brincadeira durante a qual o menino não conseguiu reprimir o seu caráter régio, a sua

${ }^{25}$ Cf. Rom. 3. 4-5. Naquele tempo, acreditava-se que quem estava destinado a feitos heroicos tinha beleza e estatura superiores à dos comuns mortais ou era de origem nobre. Cf. Tatum (1996: 144).

${ }^{26}$ Estes acontecimentos fazem-nos pensar na história de Moisés, narrada pelo Antigo Testamento (Ex. 2). Também ele foi deixado na margem de um rio, embora, neste caso, a criança tenha sido abandonada pela mãe que tentava poupar-lhe a vida. E, ironia das ironias, a criança de origem humilde foi criada pela filha do Faraó, o responsável pela sua exposição e abandono.

${ }^{27}$ Vide supra p. 31 , nota 5.

${ }^{28}$ Em Rom. 3. 5, Plutarco, embora discorde dela, invoca uma versão segundo a qual Fáustulo seria o mesmo servo que abandonou as crianças. 
predisposição para reinar. Mesmo sem imaginar qual era a sua verdadeira origem, desempenhou o papel de monarca de modo irrepreensível, como se tivesse nascido para isso: de entre as várias decisões que tomou, destacam-se nomeadamente a exigência de uma casa e de um corpo de guarda ${ }^{29}$, a escolha do «olho do rei», ou seja, o funcionário que, entre os Persas, tinha a cargo a vigilância, e a forma severa como puniu um jovem de boas famílias que se recusou a obedecer-lhe - é que, se os restantes companheiros o haviam julgado digno do cargo, então deveria agir em conformidade. Por causa deste último comportamento, foi chamado à presença do rei (que desconhecia ser o próprio avô), na sequência da queixa que o pai do rapaz açoitado fez junto de Astíages. A forma como reagiu diante do monarca todo-poderoso (ao qual apresentou as suas razões, falando de igual para igual, sem qualquer receio) e o ter-se mostrado recetivo a um castigo (caso Astíages visse nisso um ato de justiça) despoletaram o aparecimento da verdade. A estes elementos denunciadores, podemos acrescentar ainda as semelhanças fisionómicas que Ciro tinha com o avô e o facto de a idade que aparentava corresponder ao período de tempo decorrido desde a exposição da criança.

Estamos, pois, perante um tipo particular de $\gamma \nu \omega \rho i ́ \sigma \mu \alpha \tau \alpha$, que não consiste em objetos, como roupas ${ }^{30}$, armas ou a cesta em que as crianças foram expostas (como no caso de Rómulo e Remo ${ }^{31}$ ) e que decorre da racionalização da narrativa a que Heródoto procedeu. Neste caso, o historiador faz com que o próprio caráter e semblante do jovem sejam suficientes para a confirmação da verdade, dispensando o recurso a elementos de natureza mais fantástica, que contrariavam a ideia que ele tinha de relato histórico ${ }^{32}$.

Mas, como, apesar da forte probabilidade, tudo não passava de meras suspeitas, o rei procurou descobrir a verdade, indagando-a junto do responsável pela criança e daquele a quem havia delegado o abandono do neto. Mitradates (como, de resto, os escravos das outras narrativas que conheciam a veracidade dos factos) começou por manter a sua versão da história, pois temia pela sua sorte e pela de Ciro. Só decidiu revelar tudo, quando o rei ameaçou torturá-lo. O elemento tortura é recorrente neste contexto, já que ante a recusa do porqueiro tebano (que tinha medo da reação do rei e conhecia a dimensão da tragédia que se iria abater sobre a casa real de Tebas), também Édipo utiliza o mesmo método. Os únicos que se prontificam a contar tudo são

${ }^{29}$ Estas duas primeiras medidas trazem-nos de imediato à memória as exigências que Déjoces (trisavô de Ciro) fez quando foi escolhido para reinar sobre os Medos. Cf. Hdt. 1. 98.

${ }^{30} \mathrm{Na}$ história de Ciro, as roupas também desempenharam um papel importante enquanto $\gamma v \omega \rho i ́ \sigma \mu \alpha \tau \alpha$, mas na fase da exposição. Lembremo-nos de que o que permitiu aos eunucos da confiança de Hárpago reconhecer a criança a sepultar foram justamente as vestes reais que o filho morto do casal de boieiros envergava para ser tomado como neto de Astíages. Cf. supra p. 36.

${ }^{31}$ Cf. Plut. Rom. 8. 2-3.

32 Vide supra p. 19. 
Hárpago, o porqueiro de Corinto, e Fáustulo, que procuravam, deste modo, obter benefícios. O primeiro, ao avistar Mitradates, pensou (erradamente) que Astíages iria perdoá-lo se não lhe mentisse ${ }^{33}$. O segundo vinha em busca de uma recompensa por se ter prontificado a anunciar a morte de Pólibo a Édipo e, mais tarde, por lhe revelar que os seus medos de cometer crimes contra os «pais» eram infundados. Já Fáustulo receava pela vida de Remo, capturado após uma querela entre boieiros de Amúlio e Numitor ${ }^{34}$ e julgava conseguir salvá-lo se tudo se soubesse. Note-se, pois, que, regra geral, o medo - um sentimento que com frequência o rei/tirano desperta nos seus súbditos - é o principal móbil da confirmação da verdade.

Curiosamente, no caso das três histórias que temos vindo a analisar, a verdade é sempre divulgada (ou, pelo menos, confirmada) por pessoas de condição servil. Evidencia-se, mais uma vez, o sentido do trágico que perpassa todas estas narrativas. Elas mostram que o poder, a vida, a segurança e a felicidade dos reis não são mais do que uma aparência, do que algo transitório e efémero. Neste contexto, os reais detentores do poder são os criados que, ao desobedecerem a ordens antigas e ao revelarem a verdade, mudam, em definitivo, não só a vida dos monarcas, como a das crianças que outrora salvaram.

Mas regressemos à forma como o reconhecimento se despoleta. $\mathrm{O}$ caso de Rómulo é semelhante ao de Ciro, embora, no momento decisivo, a verdade venha ao de cima por causa do seu irmão gémeo ${ }^{35}$. Plutarco (Rom.6.3-5) refere que também a natureza de Rómulo deixara, desde muito cedo, transparecer que tinha uma origem diferente da daqueles que o criavam $^{36}$ : o porte, a

${ }^{33}$ Sobre a vingança de Astíages contra Hárpago, vide infra p. 44, nota 52.

${ }^{34}$ Cf. Rom. 8. 1-6.

${ }^{35}$ Importa refletir, de modo breve, sobre a presença de irmãos (não necessariamente gémeos) no âmbito destas narrativas que se relacionam com a problemática da sucessão. Neste caso concreto, a superioridade de Rómulo começou a manifestar-se desde cedo e veio a culminar na morte de Remo, para que os dois não tivessem que partilhar o poder. Uma situação semelhante é invocada por Heródoto (4. 8-10) nas duas versões que narra sobre a fundação da Cítia. A primeira, que atribui a esse povo, refere a existência de três irmãos, o que, segundo Corcella (1993: 232), era uma forma de justificar a tradicional tripartição da sociedade em sacerdotes, guerreiros e produtores de riqueza. Destes três, coube ao mais novo, chamado Cites, assumir o poder (cf. Hdt. 4. 5. 4, 4. 10. 2) na sequência de um prodígio (também ele tradicional), que faz do benjamim o único capaz de realizar a tarefa ou de ultrapassar, com êxito, a prova que lhe garante o acesso ao trono. Segundo os Citas, só ele terá conseguido tocar nos objetos de ouro incandescentes, que haviam caído do céu, sem que se derretessem. Segundo os Gregos do Ponto, só ele conseguiu manejar o arco como Hércules (o seu pai, de acordo com esta versão) determinara - puxando a corda na direção do ombro (cf. e. g. Pl. Lg. 795a). Sobre o arco como $\gamma \vee \omega p i ́ \sigma \mu \alpha \tau \alpha$, vide infra página seguinte. Podemos, em jeito de curiosidade, invocar ainda o episódio do rei David (nome que, na língua semita, significava 'comandante, chefe militar'), narrado no Antigo Testamento (Sam.1.16.1-13). Também este, que era o mais novo de muitos irmãos, foi escolhido por Deus para reinar sobre Israel.

${ }^{36}$ Estamos, mais uma vez, perante o motivo do «blood will out». Vide supra p. 38. 
inteligência, a coragem, a audácia, a habilidade política e o tipo de atividades a que se dedicava (como a caça, o exercício físico e a defesa dos oprimidos) eram próprias de um homem livre ${ }^{37}$.

Contudo, o reconhecimento por parte do avô fez-se por intermédio do irmão, Remo, aprisionado pelos porqueiros de Numitor na sequência de uma querela que os opôs aos de Amúlio. Na presença do neto desconhecido, a primeira coisa que chamou a atenção de Numitor foi o aspeto, bem como as restantes características de homem nobre que, embora em grau inferior, Remo partilhava com Rómulo. Além da estatura e força - visivelmente superiores às dos restantes jovens da sua idade -, parecia ser resoluto, intrépido e mostrava-se (como Ciro) tranquilo diante do perigo em que se encontrava.

É curioso notar que Plutarco (Rom. 7. 5) - embora com algumas reticências, pois introduz este pormenor com a expressão $\omega$ ఢ parece'-invoca a influência divina ( $\theta \varepsilon$ cõ $\sigma u \mu \pi \alpha \rho o ́ v \tau o \zeta ~ k \alpha i ̀ ~ \sigma u v \varepsilon \pi \varepsilon v \theta u ́ v o v \tau o \zeta$ "na presença de um deus que dirigia o começo das grandes empresas") para justificar a suspeita plantada no coração de Numitor em relação à identidade do jovem. Assim, fica, mais uma vez, claro que o fator "coincidência» ou intervenção divina é um móbil fundamental para o desenvolvimento destas histórias ${ }^{38}$.

Interrogado por Numitor, Remo revelou-lhe prontamente o pouco que sabia, inclusive a existência de $\gamma v \omega p i ́ \sigma \mu \alpha \tau \alpha$ que poderiam permitir o seu reconhecimento pelos progenitores: a cesta em que haviam sido colocados e as inscrições gravadas em bronze que ela continha. Portanto, no caso dos gémeos romanos, podemos falar em dois tipos de $\gamma v \omega p i ́ \sigma \mu \alpha \tau \alpha$ : os «inatos», como o aspeto físico e a personalidade (do mesmo modo que na narrativa sobre Ciro) ${ }^{39}$; e os que são da responsabilidade de terceiros - o cesto. A esta última categoria pertencem o cinto e o arco (símbolo da aptidão militar) que, segundo Heródoto, Hércules deixou à mãe dos três irmãos cítios para que, através deles, ela fosse capaz de reconhecer qual dos filhos deveria permanecer consigo e reinar. ${ }^{40}$

Outro pormenor a que Remo se refere é o do seu aleitamento misterioso por uma loba. O Queroneu justifica o facto de os gémeos descendentes de Eneias passarem por filhos de Marte através deste motivo, já que, segundo a lenda, eles foram alimentados por uma loba e por um picanço, dois animais

${ }^{37} \mathrm{E}$ com predisposição inata para a vida política, já que estas são algumas das características que o Queroneu considera fundamentais em alguém que pretende abraçar esta carreira.

${ }^{38}$ Sobre este assunto, vide supra pp. 37 e 38.

${ }^{39}$ A respeito de Édipo, podemos considerar que o que funciona como $\gamma v \omega p i ́ \sigma \mu \alpha \tau \alpha$ são as marcas nos pés, que, no entanto, apesar de atestarem a sua origem real, servem de argumento para que ele se veja privado do poder (ao contrário do que acontece com os outros heróis).

${ }^{40}$ Com Teseu, passa-se algo semelhante. Vide infra p. 53. 
consagrados àquela divindade ${ }^{41}$. Sempre em busca de uma versão mais racional do mito, Plutarco argumenta que esta tradição permitiu tornar mais credível a história da mãe dos gémeos, que atribuía ao deus da guerra a paternidade dos filhos. Mas o biógrafo alega que o verdadeiro pai de Rómulo e Remo era Amúlio, que, envergando trajes de guerra (daí a «confusão» da jovem), estuprara a sobrinha ${ }^{42}$.

Este elemento fantástico da alimentação de recém-nascidos por animais encontra paralelo, por exemplo, na história de Ciro: segundo Heródoto (1. 122. 3-123.1), quando Cambises e Mandane recuperaram o filho, que falava constantemente em uma mulher de nome Cino ('cão'), espalharam o boato de que o menino havia sido amamentado por uma cadela, com o intuito de que os Persas acreditassem que a salvação do seu filho resultara da intervenção divina $^{43}$.

Como facilmente se depreende do que temos vindo a dizer, a tentativa de apresentar os heróis como indivíduos particularmente protegidos pelas divindades é comum neste género de narrativa. Tal é uma estratégia que permite, ao mesmo tempo, aumentar a credibilidade daqueles e justificar a sua superioridade e poder. Não é, pois, por acaso que, muitos deles, passam por filhos de deuses ${ }^{44}$.

Retomemos a análise da forma como os reconhecimentos se processam, a propósito do que aconteceu com Édipo. No seu caso, a verdade apenas veio ao de cima depois de cumpridos os oráculos e de ter assumido o poder em Tebas. A revelação foi adiada, em parte, porque o facto de ele ter crescido no seio de uma família real permitiu que não se levantassem mais cedo suspeitas sobre a sua verdadeira identidade, pois tudo aquilo que poderia ser entendido como características inatas de uma pessoa de origem nobre estava em perfeita sintonia com a sua situação de príncipe herdeiro.

Ao contrário do que aconteceu com Ciro ou os gémeos romanos, foi Édipo quem, perante os indícios, decidiu partir em busca da própria origem e conduziu o seu autorreconhecimento, mesmo tendo que, para isso, ameaçar ${ }^{45}$

${ }^{41}$ Rom. 4. 2-3. Cf. supra p. 31, nota 5.

${ }^{42}$ A propósito desta versão, cf. D. H. 1.77 sqq.

${ }^{43}$ Vide supra p. 36 nota 19. Sobre a racionalização do mito aqui operada por Heródoto, cf. Ribeiro Ferreira - Silva (1994: 135, nota 29). Em momentos anteriores (Hdt. 1. 118. 2 e 121. 1), o historiador diz que Astíages atribuía a sobrevivência de Ciro a uma mudança da fortuna (enfatizada pelo uso recorrente da forma verbal $\pi \varepsilon \rho i ́ \varepsilon \sigma \tau \iota)$, o que mais uma vez confirma, como já dissemos antes, a importância do fator «coincidência»/destino/intervenção divina para o desenrolar deste tipo de narrativas. Cf. supra pp. 37 (nota 21) e 38.

${ }^{44} \mathrm{O}$ mesmo ocorre também em relação a Teseu, como veremos. No caso de Édipo (pelo menos na versão de Sófocles, OT 1086-1109), esta hipótese chega a ser levantada pelo Coro, mas tem uma motivação diferente. Sobre o estásimo em causa, vide Fialho (1991: 128, nota 95).

${ }^{45}$ Cf. supra p. 39. 
quer o mensageiro, quer o servo, e contrariar a vontade da esposa/mãe, que the pedia para não continuar a indagar sobre o passado ${ }^{46}$. Esta situação coaduna-se com a personalidade do herói «decifrador de enigmas», que livrara os Tebanos da maldição da Esfinge ${ }^{47}$ e que, como "prémio», casara com a rainha de Tebas, a própria mãe. De facto, enquanto «decifrador de enigmas», Édipo não podia delegar em mãos alheias a descoberta da «sua» verdade.

A história do Tebano (que temos analisado sobretudo com base na versão de Sófocles) está envolta em circunstâncias trágicas. Se, por um lado, todas as suas tentativas para contrariar o destino saem goradas e o precipitam para a concretização da realidade que procura evitar ${ }^{48}$; por outro, é dominado por uma cegueira ${ }^{49}$ (que só na parte final da tragédia se torna física) que impede o afamado «decifrador de enigmas» de descobrir sozinho a sua verdade, de saber interpretar os indícios com que se depara ${ }^{50}$. Nas palavras de C. Segal (2001: 36), Édipo é, por isso, «the most contradictory of men in his combination of intelligence and ignorance».

Regressemos ao esquema típico destas narrativas. Uma vez reconhecidos pelas famílias, além de se vingarem daqueles que os haviam abandonado à própria sorte, os heróis submetem-se, de livre vontade, a empresas que, na sua perspetiva, são uma forma de ajudar o povo oprimido, mas que, no fundo, se convertem em uma prova que os conduz diretamente ao poder.

Segundo a versão que Heródoto narra da história de Ciro, Astíages, encontrado o neto, ficara tranquilo, pois acreditava (apoiado pelos Magos) que, como aquele já havia reinado, o oráculo já se tinha cumprido (Hdt. 1.

${ }^{46}$ Cf. S. OT, episódios 3 e 4.

${ }^{47}$ S. OT 35-36. Estamos perante o motivo, também ele comum neste género de narrativa, da superação da prova de acesso ao poder. No caso de Édipo, o parricídio, que abre caminho à sua ascensão ao trono, é anterior à prova. Vide infra p. 45.

${ }^{48}$ Vide supra p. 34. Existem vários estudos que desenvolvem o tema do destino nesta tragédia. Sem querermos ser exaustivos, invocaremos apenas as obras já citadas de Fialho e de Segal, em cujas bibliografias é feita referência a outros títulos.

${ }^{49}$ Segundo Buxton (1980: 25), «blindness is a powerful verbal and visual metaphor for the limits of humanity, limits of which the dramatist wants his audience to be aware». É exatamente essa a principal questão levantada pela tragédia de Sófocles, segundo Vega (2003: 37): « el problema de lo trágico se hace, en Sófocles, problema de conocimiento o, mejor digo, de ignorancia, esto es, no de ausencia de conocimiento, sino de un conocimiento ilusorio, de aparencia que entra en tensión con la verdad. El sentimiento trágico de la existencia (que, en otros trágicos, efunde de otros contrastes: vitalidad y razón, naturaleza y cultura, etc.) surge, en Sófocles, de la conciencia de la limitación del conocimiento humano».

${ }^{50}$ Neste contexto - como no dos oráculos ou sonhos - torna-se imprescindível saber interpretar a mensagem recebida. É que os deuses até procuram prevenir os homens dos perigos que os ameaçam, estes é que nem sempre têm capacidade para compreender o que lhes é dito. Como afirma Buxton (1980: 36) «The oracle onuxível, gives signs (Herakleit. fr. $93 \mathrm{DK}$ ), but offers no guarantee that fallible humanity will interpret the signs correctly». Este elemento trágico mostra quão limitada é a condição humana. Sobre este assunto, consulte-se, também, e.g., Knox (1964); Segal (22001: 3-4 e passim); Fialho (1992) e bibliografia por eles citada. 
120). No entanto, o comportamento que teve para com Hárpago despertou neste um sentimento de vingança tão forte que o nobre, privado do filho ${ }^{51}$, dedicou o resto da sua vida a incitar no jovem o desejo de conquistar o trono do avô (Hdt. 1. 123-124). Com efeito, não fosse a insistência de Hárpago, Ciro provavelmente nada teria feito nesse sentido, pois era o herdeiro legítimo do trono da Média. No entanto, aderiu ao projeto de Hárpago e depôs o avô, punindo assim um homem que, por amor ao poder, além de tratar os súbditos com crueldade, não poupava a própria família.

Mas, apesar de quase ter morrido por causa do avô, Ciro não lhe fez mal, pelo contrário, permitiu que vivesse perto de si até ao fim dos seus dias. Este respeito para com o vencido não decorre de sentimentos provocados por laços de consanguinidade. É antes um comportamento característico do Rei persa, cuja benevolência em relação àqueles que derrotava ficou famosa. Basta-nos, para comprová-lo, recordar o que se passou com Creso e com Psaménito (Hdt. 3.14 sqq.).

No caso de Rómulo e Remo (Rom. 8.7 - 9.1), o desenvolvimento da ação foi mais célere, mais precipitado: descoberta a verdade, os gémeos tiveram de aproveitar o fator surpresa para matar Amúlio e restituir o trono a Numitor. Não podiam, como Hárpago e Ciro, planear tudo ao pormenor, porque, uma vez descoberta a sua existência, Amúlio tudo faria para neutralizá-los.

Depois de regularizada a situação em Alba, como, apesar de desejarem reinar, não quisessem fazer frente ao avô ${ }^{52}$, decidiram fundar uma nova cidade nas proximidades do local onde haviam sido amamentados pela loba. Mas, já o vimos atrás ${ }^{53}$, não era possível que dois irmãos reinassem em simultâneo. Os desentendimentos que desde cedo surgiram a propósito da escolha do sítio exato para a fixação da cidade ${ }^{54}$ confirmaram tal impossibilidade e resultaram na morte de Remo (que, consoante as versões, terá sido assassinado pelo próprio irmão ou por um companheiro chamado Célere) e de Fáustulo. A partir de então, Rómulo tornou-se o único senhor de Roma, até ao momento em que, por questões políticas e familiares, se viu obrigado a partilhar o poder com o rei dos Sabinos ${ }^{55}$.

A história de Édipo difere, nesta última fase, sobremaneira, das de Ciro e dos gémeos: é que, na de Édipo, o processo é inverso, pois, em vez de

${ }^{51}$ À semelhança do que acontecera a Tiestes, Hárpago foi convidado por Astíages para um banquete cuja principal iguaria eram as carnes do filho. $\mathrm{O}$ caráter excessivo de Astíages manifestou-se, mais uma vez, após a derrota, quando mandou empalar os Magos (Hdt. 1. 128. 2).

${ }^{52}$ Plutarco (Rom. 9. 2-3) levanta a hipótese de a criação de uma nova cidade decorrer da necessidade de alojar e proteger escravos e criminosos que se haviam juntado a eles.

${ }^{53}$ Vide supra p. 41 , nota 37.

${ }^{54}$ Cf. Rom. 9.4 -10. 2.

${ }^{55}$ Sobre o rapto das Sabinas e a guerra com este povo, vide Rom.14-19. 
ser o reconhecimento a conduzi-lo ao poder, é o reconhecimento que o leva a um afastamento voluntário do trono ${ }^{56}$. Por isso, a conquista do cetro não é, como nas outras histórias, um ato de vingança explícito e voluntário. Pelo contrário: as "provas» de acesso ao poder superadas pelo herói ilustram com requinte a temática da cegueira e do relativismo do conhecimento humano ${ }^{57}$. Ao tentar lograr o destino, Édipo afasta-se dos pais adotivos, mas aproxima-se dos verdadeiros, precipitando, assim, o cumprimento dos oráculos.

A primeira prova com que se deparou é semelhante à de outros mitos e consiste em um encontro com alguém que quer impedir o herói de prosseguir o seu caminho. Ainda que, naquele momento, Édipo e Laio ignorassem a verdade, nós sabemos que aquela era a segunda vez que o rei de Tebas tentava coartar os passos do filho. Se, a um Édipo indefeso, valera, no momento do abandono, a ajuda dos pastores, no momento do (re)encontro, ao jovem, adulto e no auge das suas forças, bastaram-lhe as próprias mãos para se livrar, sozinho, do pai e daqueles que trabalhavam às ordens dele. Édipo abria, assim, involuntariamente e sem qualquer segunda intenção, o caminho para o trono que era seu por direito ${ }^{58}$.

A derradeira prova faz dele, aos olhos do povo, o sucessor ideal para o rei assassinado. É que não só se mostrou zeloso do bem-estar dos Tebanos, mas também foi o único com perspicácia suficiente para responder com acerto à questão colocada pela Esfinge, livrando a cidade de Tebas desse monstro híbrido, meio mulher, meio leão, que devorava todos aqueles que por ele passavam sem adivinhar o enigma ${ }^{59}$. Esta prova valeu-lhe, em jeito de recompensa, o cetro e a mão da rainha viúva em casamento. Mas, na verdade, aquilo que se afigurava uma grande conquista de um homem que se destacava pela inteligência mais não foi do que o concretização dos oráculos e a verificação da falta de fiabilidade do conhecimento humano ${ }^{60}$.

Em jeito de síntese, podemos dizer, com base na análise que fizemos, que as narrativas sobre a vida de heróis/fundadores possuem uma estrutura comum (proibição do nascimento que não é respeitada; abandono do recém-nascido; crescimento do herói no seio de uma família adotiva; revelação da identidade; vingança e recuperação do poder), normalmente envolta em um espírito

${ }^{56}$ Vide supra, p. 41 , nota 40.

${ }^{57}$ Sobre este assunto, vide supra p. 44, nota 51.

${ }^{58}$ Cf. S. OT 800-813. A este propósito, leia-se, e. g., Segal (22001, 36 e 90 sqq.).

${ }^{59}$ Cf. S. OT 44-48, 507-511, 690-695. Ao contrário do oráculo, que causou em Édipo uma forte ansiedade e um sentimento de inexorabilidade, o enigma facilmente decifrado deu-lhe orgulho e confiança [falsos, ilusórios, é certo] na sua capacidade de interpretar o mundo que o rodeia. Cf. Segal (22001: 62). 186).

${ }^{60}$ Sobre a oposição entre realidade e aparência no Rei Édipo, vide Reinhardt (1976: 135- 
trágico, sem que seja forçoso que todos os pormenores referidos ocorram em cada uma das histórias ou que sejam tratados de uma mesma forma.

Se nos dedicámos à comparação das histórias de Ciro, Édipo, Cites e Rómulo foi para podermos encontrar pontos comuns que tenham reflexo na forma como Plutarco nos apresenta a vida do fundador de Atenas. É que o biógrafo não pôde, decerto, alhear-se à tradição que ao longo de séculos estabeleceu os princípios que deviam presidir a este tipo de narrativa. No próximo capítulo, poderemos, pois, verificar de que modo o Queroneu utilizou a tradição anterior na Vida de Teseu. 


\section{Parte III}

A Vida de Teseu 
«Aqui é Atenas, a antiga cidade de Teseu.» ${ }^{1}$

Quando aborda a figura mítica de Teseu, Plutarco procura seguir a estrutura de um retrato que não se distancie excessivamente daquele que seria provável obter se se tratasse de uma figura histórica. Mas, ao mesmo tempo, não consegue fugir à influência dos padrões literários comuns à descrição de outras personagens que partilham o estatuto de fundadores de cidades ou dinastias. Por isso, o Queroneu tenta - na medida do possível - manter uma estrutura semelhante à das biografias de homens de Estado cuja existência não levanta dúvidas ${ }^{2}$ : os primeiros capítulos são consagrados às origens, infância e educação do herói (3-5); segue-se-lhes um bloco dedicado aos principais acontecimentos que antecedem o início da sua vida pública e política (6-23); outro, dedicado às medidas que caracterizaram o seu governo (24-25); outro, ainda, a episódios da vida privada, que, neste caso, correspondem a algumas das mil e uma aventuras ligadas à saga de Teseu (26-34); e, por fim, um último sobre a fase final da vida, morte, funerais e tudo o que se relaciona com a forma como o biografado permanece na memória do povo (35-36).

É fácil verificar que uma boa parte da obra é dedicada à narrativa das aventuras de Teseu e compreender que isso acontece porque Plutarco não podia ignorar a tradição associada a esta figura, que se tornou o herói nacional de Atenas ${ }^{3}$.

Importa, pois, no âmbito deste capítulo, ter em conta o aproveitamento que o biógrafo faz dos dados sobre Teseu veiculados pela tradição. Não nos podemos esquecer de que, no seu tempo, Plutarco dispunha de diversas fontes (muitas das quais hoje desconhecidas e/ou perdidas), nomeadamente da memória iconográfica (preservada nas pinturas ou em vasos, esculturas e monumentos) e da memória literária (como os poemas 17 e 18 de Baquílides; o Hipólito, o Hércules e as Suplicantes, de Eurípides; o Édipo em Colono, de Sófocles; o «Elogio de Helena», de Isócrates). É também claro que Plutarco tinha por hábito selecionar e organizar criteriosamente os dados que considerava pertinentes para ilustrar o seu ideal de homem de Estado e, neste

${ }^{1}$ Inscrição do Arco de Adriano, em Atenas (séc. II d.C.).

${ }^{2}$ Ou seja, como afirma Dugas (1943:1), trata-se de um «exposé logique qui, de la naissance à la mort du héros, raconte les épisodes marquants de son existence; exposé qui les présente comme un bloc et n'essaie pas de reconstituer la formation de la légende, de distinguer l'ancienneté de ses éléments et d'en retracer l'évolution.»

${ }^{3}$ Sobre a evolução do mito de Teseu e suas diferentes versões, leiam-se, e. g., Graves (2004: 329-377); Grimal (1992: s. v.); Calame (1990). 
Parte III - A Vida de Teseu

caso particular, para tornar o relato mais verosímil. Assim se justifica que não se debruce sobre as contradições mitológicas e as manipulações políticas da figura de Teseu.

Por questões metodológicas, vamos procurar dividir a nossa análise em quatro momentos: origem, formação e reconhecimento; aventuras; plenitude da ação política; fim de vida. 


\section{ORIGEM, FormaçÃo E RECONHECIMENTO}

No que respeita à tradição sobre a origem de Teseu, importa ter presente que se coaduna com os tórol normalmente associados ao nascimento de um herói ${ }^{4}$. Deparamo-nos, por isso, em um primeiro momento, com a proibição estabelecida e comunicada ao progenitor por um oráculo, pois Egeu ${ }^{5}$ que depois de sucessivos casamentos ainda não tinha descendência, vai a Delfos consultar a Pítia, que lhe dá a seguinte resposta:

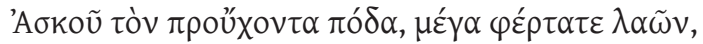

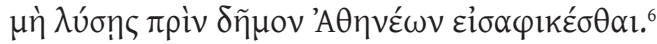

"Não soltes do odre o pé proeminente, ó grande príncipe, Antes de regressares a Atenas."

Como a mensagem divina não lhe parece clara, Egeu opta por passar por Trezena no regresso a casa para assim poder questionar $\mathrm{Piteu}^{7}$ sobre o sentido daquelas palavras. E de novo se verifica (à semelhança do que vimos anteriormente a propósito do nascimento de Ciro ou Édipo) que, quanto

${ }^{4}$ Cf. capítulo 2.

${ }^{5}$ Egeu era bisneto de Erecteu (o filho de Pandíon e Zeuxipa), neto de Cécrope, filho de Pandíon II e irmão de Palanteu (donde o seu receio de que os Palântidas pudessem vir a atentar contra a vida do filho - cf. infra p. 53).

${ }^{6}$ Thes. 3. 5. O oráculo em causa é invocado, com ligeiras variantes textuais, por outros autores como E. Med.679-681; Apollod. Bibl.3.15. 6. De um modo geral, e segundo $\Sigma$ E. Med.679, o odre é entendido como símbolo da barriga e o pé, do pénis. No entanto, Flacelière (1948: 71), chama a atenção para o facto de, em alguns oráculos (como os citados por Plutarco em (Thes. 24. 5-6), a palavra odre ser empregue simbolicamente em vez de Teseu ou de Atenas.

${ }_{7}$ Consta que este era um dos muitos filhos de Pélops e Hipodamia, irmão, de entre outros, de Tiestes e Atreu. Além de sábio e poeta, era um arguto intérprete de oráculos. Este motivo é aproveitado por Eurípides na Medeia (663-688), onde Egeu revela à heroína o oráculo divino e a sua intenção de consultar Piteu, não só o mais sábio dos homens, mas também o companheiro de armas preferido de Egeu. Teseu, que fora criado pelo avô, confiou-lhe, após o casamento com Fedra, a educação de Hipólito, fruto da sua relação com a Amazona Segundo Paus. 2. 30. 8-9, Piteu foi também responsável pela união de duas cidades - Hipereia e Anteia -, que ficaram conhecidas pelo nome de Trezena, em homenagem ao seu irmão Trézen. Por isso, podemos afirmar com Pérez Jiménez (2000: 234) que, no caso da Vida de Teseu, o үévoৎ (que, na obra de Plutarco, costuma funcionar como um referente positivo e explicar a atuação do biografado) justifica a habilidade deste herói para «fundar» Atenas. A hereditariedade deste tipo de «comportamentos políticos» é igualmente sugerida no logos de Ciro (Hdt. 1. 98). Vide supra p. 39. 
mais empenho se coloca em seguir o conselho dos deuses para evitar uma calamidade, mais se acelera o cumprimento do destino. É que, conhecedor do oráculo, o Pelópida vê nessa previsão uma excelente oportunidade para alargar o seu poder através de um futuro neto ${ }^{8}$. Por isso, como uma alcoviteira, fomenta o relacionamento entre Egeu e a própria filha, Etra, do qual resulta a gravidez que o rei de Atenas deveria ter evitado?.

No entanto, ao contrário do que aconteceu a Ciro e a Édipo, durante a infância, Teseu só é privado da companhia do pai $^{10}$, pois como era de prever, dadas as circunstâncias da sua concepção, a família materna acolheu-o de braços abertos.

Ora, desrespeitada a proibição e nascida a criança, é forçoso que, mais dia, menos dia, a verdade sobre a sua origem seja revelada. $\mathrm{O}$ reconhecimento de Teseu ${ }^{11}$ apenas é passível de comparação (de entre os exempla que analisámos anteriormente) com o que aconteceu aos três filhos que Héracles gerou de um ser híbrido, misto de mulher e de serpente ${ }^{12}$. Do mesmo modo que Héracles confiara à mãe dos seus filhos objetos que iriam mais tarde permitir saber qual deles era digno de subir ao trono da Cítia, também Egeu, desconfiando que Etra tivesse engravidado, engendra um plano que lhe permitiria confirmar a paternidade da criança. Por isso, quando esta entende que o filho - por causa

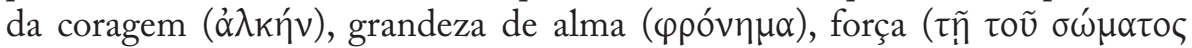

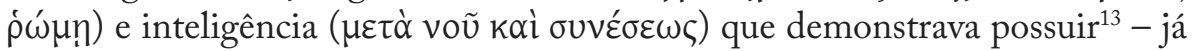

${ }^{8}$ De acordo com Flacelière (1948: 74), Piteu terá interpretado o oráculo da Pítia do seguinte modo: se, contrariando a profecia, Egeu tivesse um filho, este seria responsável pela sua morte e suceder-lhe-ia no trono de Atenas. O certo é que, ao contrário de Ciro e de Rómulo, que depõem conscientemente o avô e o tio avô, Édipo e Teseu são responsáveis involuntários pela morte dos progenitores e pela sua própria ascensão ao trono: Édipo mata o pai (cuja identidade desconhecia), quando procurava evitar o cumprimento do oráculo que predizia tal episódio; Teseu é culpado da morte do pai, na medida em que se esqueceu de hastear a bandeira branca que deveria indicar que sobrevivera ao Minotauro. O motivo do parricídio é, pois, um elemento que surge com alguma frequência no âmbito deste tipo de narrativas.

${ }^{9}$ Vide supra p. 34 , nota 11.

${ }^{10} \mathrm{O}$ crescimento longe da figura paterna é um tópico frequente na narrativa da vida dos heróis fundadores. Cf. Hdt. 4. 8-10, a propósito dos filhos de Héracles, nascidos na Cítia.

${ }^{11} \mathrm{O}$ nome de Teseu, como aliás não é raro no âmbito deste género de narrativas, é falante. Plutarco (Thes. 4.1) dá testemunho disso, ao referir duas hipóteses para justificar a sua origem e

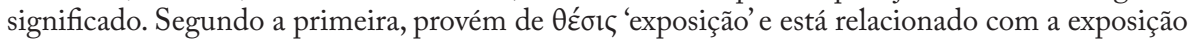
dos $\gamma v \omega \rho i ́ \sigma \mu \alpha \tau \alpha$. De acordo com a segunda, decorre do facto de ter sido reconhecido por

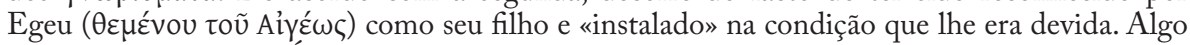
semelhante acontece a Íon, cujo nome está relacionado com o oráculo de Apolo, segundo o qual seria filho de Xuto o primeiro indivíduo com o qual ele se deparasse ao sair ( $\dot{\xi} \xi$ lov (E. Ion. 535). Sobre estas e outras hipóteses avançadas para explicar a procedência do nome do herói, vide respetivamente, Walker (1995: 89-90); Pérez Jiménez (2000: 157, n. 17).

${ }^{12}$ Hdt. 4. 8-10. Vide «Convenções literárias associadas à vida de um fundador», nota 37.

${ }^{13}$ Estas características (enumeradas em Thes. 6.2), que o biografado possui desde tenra idade, são, segundo Plutarco, fundamentais para um bom homem de Estado. Thuc. 2.15. 2 também faz

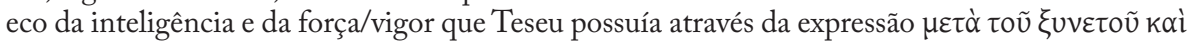


tinha atingido a idade de conhecer a sua origem, procede de acordo com as instruções de Egeu. Antes de partir, o rei de Atenas deixara tudo preparado: caso Etra estivesse grávida e desse à luz um rapaz, quando este chegasse à idade adulta, deveria conduzi-lo à rocha sob a qual escondera a própria espada e as sandálias (que funcionariam como $\gamma v \omega \rho i ́ \sigma \mu \alpha \tau \alpha^{14}$ ). Se o jovem fosse capaz de levantá-la (comprovando, assim, a sua ascendência), Etra deveria enviá-lo em segredo a Atenas para que se apresentasse ao pai. Até lá, teria de ocultar a paternidade do filho varão, pois Egeu temia que os seus sobrinhos, os Palântidas (que representavam a oposição tradicional que barra a ascensão do jovem ao poder como legítimo sucessor e herdariam o poder se Egeu não tivesse descendência), lhe fizessem algum mal.

Importa abrir aqui um parêntesis para abordar a questão da paternidade de Teseu. A tradição apresenta-o ora como filho do mortal Egeu, ora como filho do imortal Poséidon ${ }^{15}$. Plutarco, que se havia comprometido, no proémio desta vida ${ }^{16}$, a expurgar, na medida do possível, a narrativa de elementos inverosímeis, aponta uma justificação para esta dupla paternidade. Segundo o biógrafo, Piteu fizera correr rumores que atribuíam a paternidade de Teseu a Poséidon, deus particularmente adorado em Trezena por ser o protetor da

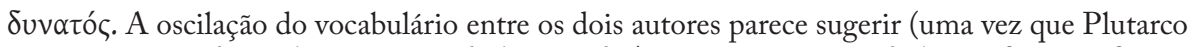
certamente não desconhecia o texto do historiador) uma preocupação do biógrafo em enfatizar esses traços de Teseu, já que não só define a inteligência do herói com recurso a duas palavras com o sentido de inteligência, como também especifica que a força em causa é física.

${ }^{14}$ São vários os testemunhos iconográficos deste episódio. Para pormenores, consulte-se, e.g., Sourvinou-Inwood (1971: 94-109). A propósito da simbologia destes $\gamma v \omega \rho i ́ \sigma \mu \alpha \tau \alpha$, citamos as palavras de García Gual (1990: 148): «Lépée est l'instrument de la gloire et les chaussures comportent un valeur symbolique. Un prince mal chaussé devient vite suspect:

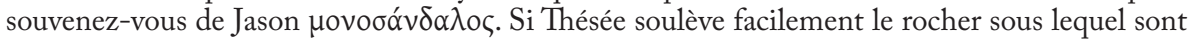
placés ces objects, ce n'est pas par sa force extraordinaire, mais parce que cette prouesse lui était magiquement réservée, comme le signe de sa legitimité. Il est l'héritier légitime, le fils du roi.» Sobre a diversidade de $\gamma v \omega \rho i ́ \sigma \mu \alpha \tau \alpha$, vide supra pp. 36 (nota 20) e 41.

${ }^{15}$ Teseu surge como filho de Poséidon, e.g., Od. 11.631; E. Hipp. 887sqq.; Isoc. 10. 18. De acordo com Paus. 2.33. 1, Etra foi induzida por Atena a dirigir-se à ilha de Esféria, onde foi possuída por Poséidon. Segundo Apollod. Bibl. 3. 15. 7 e Hyg. Fab.37, Egeu e Poséidon terão partilhado, na mesma noite, o leito de Etra. A lógica mítica permitia a existência de dois pais, um mortal e um deus (como, por exemplo, Héracles, filho de Zeus e Anfitrião, ou Helena, filha de Zeus e Tíndaro). No caso de Teseu, a preferência por Egeu decorre das necessidades propagandísticas de Atenas, que não exclui totalmente a paternidade divina e o ascendente que ela dá. Essa duplicidade está atestada nos poemas 17 e 18 de Baquílides, que ora o apresenta como filho do mortal, ora como filho do deus. Sobre a dupla paternidade de Teseu, que decorre da dualidade Trezena/Atenas, consultem-se, e.g., Pérez Jiménez (2000: 159, nota 24); Walker (1995: 84-92). Em Atenas, o interesse por esta versão manifestou-se particularmente a partir da década de 70 do século $V$, por causa do poderio marítimo que Atenas desenvolveu. De realçar ainda que, no âmbito das narrativas sobre a vida dos fundadores, é frequente apresentar-se os heróis como alguém particularmente protegido pela divindade, o que aumenta a sua credibilidade e justifica a sua superioridade e poder. Por isso, muitos passam por filhos de deuses. Vide capítulo «Convenções literárias associadas à vida de um fundador», notas 18 e 21.

${ }^{16}$ Vide supra p. 32. 
cidade $^{17}$. Assim, é como se a menção a Poséidon não fosse mais do que um estratagema para evitar perguntas sobre o verdadeiro pai, ao mesmo tempo que fazia com que o povo olhasse para o seu neto com especial deferência.

Descoberta a verdade, aquele que haveria de ser responsável pelo sinecismo de Atenas anui a ir ter com Egeu, mas decide fazê-lo por terra e não por mar, contrariando assim os conselhos da mãe e do avô, que preferiam que seguisse pelo percurso mais seguro. Contudo, não estamos perante um mero capricho de um jovem temerário e rebelde. Pelo contrário, a opção pelo caminho mais perigoso é a decisão ponderada de um mancebo com três objetivos nobilíssimos e bem definidos: por um lado, ser motivo de orgulho para o pai (algo que não conseguiria se «fugisse» por mar); por outro, igualar Héracles nas façanhas que inevitavelmente teria de cometer; e, por fim, fomentar o progresso, limpando o território da selvajaria que aí grassava e impondo uma nova ordem.

Iniciava-se, assim, a terceira fase da educação de Teseu - até então assegurada, no seio da família materna, pelo próprio avô e pelo pedagogo Cónidas ${ }^{18}$-, assente na emulação com o filho de Alcmena ${ }^{19}$.

Este momento - e a viagem em si mesma (Thes. 8-11) - é de crucial importância não só para demonstrar como o desejo de emulação pode ser um fator determinante de conduta, mas também para construir a imagem que Plutarco pretende veicular do herói. É com esse intuito que o biógrafo discorre, durante quase dois capítulos, sobre a imensa admiração que Teseu nutria por Héracles. Tal apreço, que a generalidade dos Gregos sentia pelo herói ${ }^{20}$ que levara a cabo missões tidas como impossíveis (de entre as quais

${ }^{17}$ De tal modo que Trezena recebe, por vezes, o nome de Posidónia. A influência do deus na vida local é igualmente testemunhada pelo aparecimento do tridente no verso de algumas moedas catalogadas em Poole (1873-1927, passim).

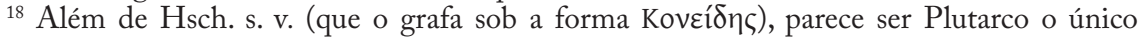
testemunho sobre o nome e intervenção desta personagem. O papel de Cónidas na formação do herói deve ter sido realmente muito importante, porque, segundo Thes. 4, ainda no séc. I d.C. era homenageado com o sacrifício de um carneiro na véspera das Teseias (festa celebrada em honra de Teseu no dia 8 de Pianépsion). O biógrafo chega a comentar que essa homenagem é mais justa do que a feita ao escultor Silânio (séc. IV a.C.) e ao pintor Parrásio (séc. V-IV a.C.), que produziram imagens de Teseu. Tal posição não surpreende, pois tem por base a distinção entre obras e artífices, que o Queroneu defende, por exemplo, em Per. 1.4 - 2. 1: o facto de admirarmos as primeiras não nos obriga a admirar e emular os seus autores. Sobre as Teseias, vide Parke (1977: 82-83); Simon (1983). De acordo com Toepffer (1889: 172, n. 1), Cónidas

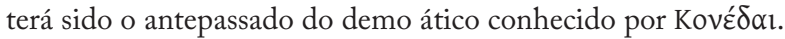

19 Sobre a importância da emulação em Plutarco, leiam-se, e.g., Pérez Jiménez (2002: 105-114); Frazier (1996).

${ }^{20}$ Esse apreço materializou-se num culto tão abrangente em termos geográficos quanto as aventuras de Héracles. Não admira, pois, que Pausânias mencione, ao longo da sua obra, diferentes templos dedicados ao filho de Zeus e de Alcmena (cf. 1. 19. 3, 2. 10. 1, 2. 11. 8, 3 . 15. 3, 4. 23. 10, 4. 30. 1, 6. 21. 3, 7. 5. 5, 8.32. 3, 9.11. 4, 9. 11. 6, 9.24. 3, 9.26. 1, 9. 27. 6-8, 9 . 32.2 e 9.32. 4, 9. 38. 6). Na verdade, mesmo em Atenas - que segundo Filócoro (FGrHist 328 F 18) era o único centro onde se prestava culto a Teseu -, Héracles era muito mais popular do que o fundador, pelo que possuía diversos locais de veneração, enquanto Teseu apenas tinha 
o extermínio de seres que molestavam as populações locais ${ }^{21}$ ), era vivido por Teseu com mais intensidade, na medida em que ambos partilhavam a mesma ascendência pelo lado materno ${ }^{22}$.

Para ilustrar melhor o sentimento que assaltava o espírito de Teseu, o biógrafo invoca uma anedota célebre, segundo a qual Temístocles costumaria dizer que o troféu de Milcíades o impedia de dormir ${ }^{23}$ e, logo a seguir, descreve como Teseu vivia atormentado pela ânsia de mostrar a si e aos outros que não era inferior ao primo. Como no-lo diz Plutarco (Thes. 6. 9):

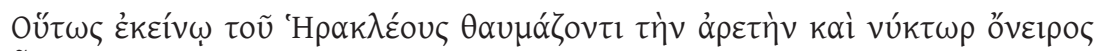

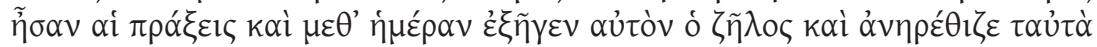

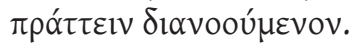

"Do mesmo modo Teseu, que admirava a virtude de Héracles, sonhava de noite com as suas ações e, de dia, a emulação tornava-o nervoso e inquieto, levando-o a pensar nos mesmos feitos."

Assim, como a oportunidade com que se deparava - de poder, à semelhança de Héracles, tornar-se um herói civilizador ${ }^{24}$, libertando as populações das

quatro. Estranhando o facto, os Atenienses procuraram justificar essa discrepância, aduzindo o argumento testemunhado por E. HF 1328-33. Cf. Plu. Thes. 35.3 (vide infra pp. 90-91). Sobre este assunto, consultem-se Woodford (1971: 211-225) e Walker (1995: 20-24), que faz uma síntese dos diferentes estudos que abordam a questão do culto de Teseu.

${ }^{21}$ Com efeito, expurgar o mundo dos perigos primitivos de modo a torná-lo habitável e a permitir uma verdadeira civilização é o sentido das aventuras destes heróis, responsáveis pelas primeiras cidades ou culturas humanas.

${ }^{22}$ Etra e Alcmena eram primas germanas, pois eram filhas dos irmãos Piteu e Lisídice, respetivamente. Sobre este parentesco, vide E. Heracl. 207-212, 224, versos nos quais Iolau recorda os laços de sangue ( $\sigma$ $\gamma \gamma \varepsilon ́ v \varepsilon l \alpha)$ existentes entre os filhos de Teseu e os de Héracles para suplicar auxílio para os últimos. É curioso notar que Plutarco prefere chamar a atenção apenas para a ascendência humana, em detrimento da divina (para escamotear mais um elemento fantástico da narrativa). Mas, na verdade, Teseu e Héracles também eram primos por parte dos pais: o primeiro era filho de Poséidon, o segundo, de Zeus (cf. Isoc. 10. 23). Ainda que nos Heraclidas se dê especial ênfase à relação de consanguinidade e de gratidão existentes entre Héracles e Teseu para justificar a forte ligação do herói pan-helénico com Atenas, sabemos que tal também se deve a outros motivos. Por um lado, corria que Héracles tivera um papel determinante na vitória de Maratona (como no-lo testemunha Paus. 1. 15. 3, ao afirmar que no Pórtico Pintado (que data de ca. 455 a.C. e terá sido mandado erigir por um parente de Címon, chamado Pisíanax) estavam representados Teseu a sair do solo, Atena e Héracles; ou Hdt. 6. 108.1, segundo o qual os Atenienses terão acampado no Heracleion de Maratona antes da refrega). Por outro, não nos podemos esquecer de que Héracles era para os jovens atenienses o paradigma de atleta e o instigador do espírito agónico necessário à vida política na ró $\lambda$ s. A propósito desta temática, consulte-se, e. g., Wilkins (1990: 329-339).

${ }_{23}$ Thes. 6. 9. Plutarco refere esta mesma anedota outras vezes, nomeadamente em Them. 3. 4, Moralia 84B, 92C, 184F, 552B e 800B. Esta vontade de fazer mais e melhor é tipicamente ateniense. Cf. capítulo «Atenas, o umbigo da Hélade», p. 121.

${ }^{24}$ Vide p. 57. 
terríveis ameaças com que se debatiam no dia-a-dia - era única, não podia nem queria abrir mão dela. Este era o momento ideal para satisfazer o seu almejo de glória ( $\varphi$ ı em prática a sua $\delta ı \kappa \alpha \iota \sigma u ́ v \eta$ e difundir a sua $\varphi \imath \lambda \alpha v \theta \rho \omega \pi i \alpha^{25}$ (Thes. 7. 3), pois tinha como objetivo só atacar os malfeitores em legítima defesa.

Do que acabámos de dizer, fica claro que esta opção ajuda a esboçar a imagem de um jovem determinado e intrépido (já que, apesar de todos os rogos e da descrição tenebrosa que o avô lhe fez dos perigos que iria encontrar ${ }^{26}$, não desistiu do seu propósito), disposto a ajudar o próximo em detrimento do seu próprio bem-estar e segurança. E estas são, como sabemos, algumas das características que o político deve possuir.

Plutarco contraria toda uma tradição literária que aposta em comparar os dois heróis - na maior parte das vezes com o intuito de valorizar a figura do herói ateniense. Prefere não enveredar por esse caminho, porque o seu objetivo era, como já vimos, concentrar-se nos efeitos pedagógicos que o desejo de emulação e o conhecimento da história podem ter sobre quem se quer dedicar à causa pública e está destinado a feitos de renome ${ }^{27}$. Nesse sentido, cinge-se a apontar pormenores decorrentes da emulação. Em Thes. 8.1, revela que Teseu, à semelhança de Héracles (que usava a pele do leão de Nemeia ${ }^{28}$ ), escolhera como insígnia a clava que usurpara a Perifetes. Em Thes. 11. 2, declara que Teseu imitava Héracles no seu comportamento para com os prevaricadores: só atacava em legítima defesa, recorrendo ao mesmo método com que era atacado (aplicava, portanto, a lei de talião).

Importa ter presente que o cotejo entre os dois primos e heróis gregos se tornou constante a partir dos séculos VI e V a.C. ${ }^{29}$ Surgiu como estratégia política da Atenas de então, nomeadamente no âmbito da política expansionista na direção do Peloponeso (cuja propaganda se baseava na viagem do herói de Trezena para Atenas $)^{30}$. Foi nessa altura que Teseu passou a ser apresentado como o espírito da Atenas idealizada e a alternativa iónia para o dório Héracles $^{31}$.

${ }^{25}$ Duas características que, como veremos no capítulo «Atenas, umbigo da Hélade», são bem atenienses...

${ }^{26}$ Cf. Thes. 6. 7.

${ }^{27}$ Cf. Pérez Jiménez (2000: 236).

${ }^{28}$ Curiosamente, Plutarco parece dividir entre os dois as insígnias - pele de leão e clava - que a tradição (cf. e.g. Ar. Ra. 496) associava a Héracles. Segundo Graves (2004: 336), «o assassínio de Perifetes [episódio considerado tardio, cujo testemunho literário mais antigo ocorre em E. Supp. 714] foi inventado para explicar a clava de punho revestido de bronze que Teseu usava, semelhante à de Héracles».

${ }^{29}$ Para uma perspetiva do tratamento deste tema ao longo da literatura grega, leiam-se, por exemplo, Mills (1997: 136-159); Walker ( I 995: 127-135).

${ }^{30}$ Sobre o uso propagandístico do mito de Teseu, vide p. 98.

${ }^{31}$ Cf. Walker (1995b: 31-33); Boer (1969: 9-10). 
Um dos elementos usados para essa comparação é o facto de ambos serem considerados heróis civilizadores. Com efeito, havia entre os antigos a noção de que a «vida civilizada» não era algo que existisse desde sempre, mas antes uma conquista para a qual contribuíram os feitos de determinados heróis, ditos «civilizadores», que se opunham à violência pela violência, à injustiça e que eram capazes de livrar o mundo de monstros, de proteger a humanidade dos seus inimigos e da ausência de valores e de normas de convívio social ${ }^{32}$. Como afirma Tucídides, que, nos primeiros doze capítulos da sua História da Guerra do Peloponeso, descreve o modus vivendi nos primórdios da Hélade, o dealbar da vida civilizada só foi possível quando se conseguiu pôr fim à selvajaria, ao domínio do mais forte sobre o mais fraco. $\mathrm{O}$ historiador insiste na noção de que o modo de vida de então se assemelhava ao «atual modo de vida dos bárbaros» (Thuc. 6. 6) e na ideia de que Atenas foi o primeiro local onde a civilização brotou na Grécia (Thuc. 6.3). De facto, o homem só consegue dedicar-se a atividades que não estejam diretamente relacionadas com a subsistência como a ciência, a filosofia e a arte - quando vive em paz e segurança.

Isócrates, por exemplo, apresenta quer Teseu quer Héracles como heróis civilizadores ( $\tau 0 \tilde{v} \tau \tilde{\omega} v \dot{\alpha} v \theta \rho \omega \hat{\pi} \omega \omega \nu \dot{\alpha} \theta \lambda \eta \tau \alpha^{\prime 3}{ }^{33}$ ), mas atribui uma importância distinta aos feitos e comportamentos de cada um. Segundo ele, apesar de os feitos de Héracles terem alcançado maior fama por serem mais difíceis

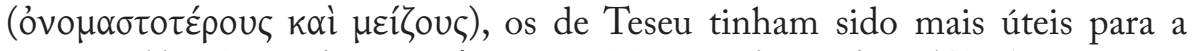

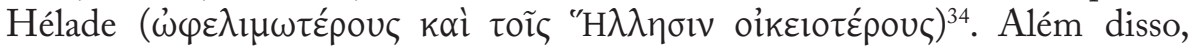
caracteriza Héracles como uma espécie de mercenário, contratado para resolver problemas alheios; ao passo que Teseu surge como um voluntário que, de livre e espontânea vontade, enfrentava perigos em prol do bem-comum (Isoc. 10. 24-25).

$\mathrm{Na}$ verdade, a maioria das façanhas de $\mathrm{Hé}$ racles ${ }^{35}$ foi cometida a serviço de Euristeu, com o objetivo de alcançar a imortalidade (D. S. 4. 9. 5). Só esporadicamente - sobretudo no decurso dos doze trabalhos e durante o cativeiro na corte de Ônfale -, quando confrontado com situações de violência gratuita e de desprezo pelos valores vigentes (como o respeito pelo estrangeiro e pela hospitalidade - por exemplo, nos episódios de Sileu ${ }^{36}$, que obrigava os estrangeiros a trabalharem nas suas vinhas, e no do rei Anteu ${ }^{37}$, que lutava

${ }^{32}$ Convém, contudo, não esquecer que até estes heróis - aos quais, como veremos adiante, também se atribui o estabelecimento de cultos e jogos - protagonizam aventuras «menos éticas» (como raptos ou parricídios) que, embora possam parecer contraditórias, também servem para ilustrar como os comportamentos desviantes levam, fatalmente, ao sofrimento.

${ }^{33}$ Isoc. 10. 23.

${ }^{34}$ Esta posição está em sintonia com a perspetiva ateniense coeva de Isócrates, segundo a qual Atenas era o berço da vida civilizada e da paz.

${ }^{35}$ Sobre este tema, consultem-se, e. g., Brommer (1972); Galinsky (1972).

${ }^{36}$ Apollod. Bibl. 2. 6. 3; D. S. 4. 31. 7.

${ }^{37}$ E. g., Pi. I. 4. 87; D. S. 4. 17. 4; Paus. 9.11.6. 
com eles até que caíssem de cansaço), agiu de modo espontâneo, punindo os prevaricadores. A defesa de tais valores é, como se sabe, partilhada por Teseu, que libertou a estrada que vai dar a Atenas de malfeitores, possibilitando assim o livre acesso à cidade que se apresentava como berço da civilização.

Como muito bem sintetiza M. P. Nilsson (1972: 55),

"while Herakles only too often represents brute force, Theseus is the Athenian youth educated in the palaestra. While the deeds of Herakles are those of an old mythical hero who slays ferocious beasts, Theseus puts down highwaymen and robbers $^{38}$, enemies of a peaceful and civilized life."

Depois de narradas as aventuras pelas quais Teseu passou até chegar a Atenas (Thes. 8-12) ${ }^{39}$, Plutarco conta-nos como foi o primeiro encontro do herói com o pai. Naquela época, Egeu vivia com Medeia ${ }^{40}$, porque esta lhe havia garantido que, com a ajuda das suas mezinhas, teria descendência (isto significa, portanto, que o rei não voltara a ter notícias de Trezena). A feiticeira pressentiu a identidade de Teseu e resolveu livrar-se dele antes que a verdade fosse revelada a Egeu. Para isso, convenceu o rei, velho e assustado ${ }^{41}$ com o descontentamento que grassava em Atenas, a recebê-lo como hóspede e a envenená-lo durante um banquete ${ }^{42}$.

${ }^{38}$ De entre as aventuras de Teseu, destaca-se a da javalina de Crómion (mencionada por B. 17. 24, E. Supp. 316-317; D. S. 4. 59. 4; Paus. 2. 1. 3; Apollod. Epit. 1. 1; Hyg. Fab. 38), a única que o mostra em confronto com uma figura não humana. Plutarco, contudo, refere-se a uma versão racionalista do mito, que faz desse ser uma mulher, mas não indica qualquer fonte. Flacelière (1948: 76) sugere que o biógrafo terá seguido uma versão de Filócoro (FGrHist 328 F 17), autor que, a propósito do Minotauro, também avança uma versão mais racional (cf. Thes. 16.1). Sobre a racionalização dos motivos, vide supra p. 32.

${ }^{39}$ Este tema encontra-se desenvolvido entre as páginas 61-67.

${ }^{40} \mathrm{Na}$ sequência de uma promessa que, segundo E. Med.708-758, teria sido feita por Egeu (não só por amizade, mas também em troca da solução para as suas dificuldades de procriar) antes de aquela ser expulsa de Corinto por Creonte. Sobre esta cena da Medeia, leia-se, por exemplo, Dunkle (1969: 97-107).

${ }^{41}$ Embora Plutarco apenas mencione a ameaça interna que preocupava Egeu, B. 18. 30 e Apollod.Epit.1.5 dão-nos testemunho de que o monarca temia perder o trono para o estrangeiro. Como sabemos, este medo não é infundado, pois Egeu morre (ainda que indiretamente) às mãos do filho, como Piteu previra ao interpretar o oráculo. Vide supra p. 51, n. 7. O motivo da sucessão por um príncipe que acaba de fazer uma viagem iniciática é, também ele, recorrente na literatura grega. A sua estrutura costuma ser a seguinte: um jovem empreende uma viagem durante a qual supera dificuldades ou cumpre o seu objetivo; ao ter conhecimento dessa aventura, o rei fica com medo do mancebo, que acaba por se revelar o legítimo herdeiro do trono e por causar a morte do «velho rei». Além do caso de Teseu, podemos recordar o de Jasão: Pélias vê o oráculo que lhe predissera a usurpação do trono cumprido quando Jasão regressa da missão de que o rei o incumbira e, através de Medeia, provoca a morte do monarca para vingar não só a «tarefa» que Pélias impusera ao argonauta, mas também o assassínio dos familiares de Jasão. Sobre o motivo da viagem iniciática, vide infra p. 65.

42 Este episódio traz-nos à memória um outro reconhecimento que também envolve descendentes de Erecteu e venenos. No caso de Íon, é a própria mãe (Creúsa, filha de Erecteu), 
Para além de feiticeira exilada, Medeia surge, portanto, mais uma vez como subversora do papel da mulher na família. Neste caso concreto, reexplora a paternidade masculina para alcançar os seus objetivos ${ }^{43}$, prometendo a Egeu ajuda na geração de descendência em troca do asilo necessário a alguém que já não podia contar - devido aos crimes hediondos que praticara - nem com a família de origem, nem com a conjugal. No entanto, confrontada com a presença de Teseu, tentava agora a todo o custo evitar que o rei reencontrasse o filho que desconhecia, ou por temer perder o poder que lhe advinha da influência que exercia sobre Egeu ou por, segundo alguns, não querer pôr em risco os direitos de Medo, filho que gerara do rei ateniense ${ }^{44}$.

Todavia, antes que Medeia conseguisse concretizar os seus planos, Teseu - que optara por não revelar a sua identidade ao pai, mas por lhe fornecer indícios que o levassem a reconhecê-lo como filho - puxou da espada, que estivera tantos anos oculta pela rocha, para cortar a carne. Pressentindo a verdade, Egeu fez com que o veneno da taça destinada ao jovem se derramasse, e, depois de o interrogar e abraçar, apresentou-o aos cidadãos.

Quanto a Medeia, foi expulsa de Atenas e dirigiu-se para Oriente, onde terá reinado sobre a Média ${ }^{45}$, terra cujo nome deriva do da feiticeira ${ }^{46}$. Esta versão que associa a feiticeira e os Medos deu azo a que Medeia se transformasse em símbolo dos Persas e Teseu no herói ateniense que expulsa da Ática o inimigo bárbaro. Não nos podemos esquecer de que Teseu era apontado como elemento decisivo para a vitória de Maratona, pois muitos afirmavam tê-lo visto a combater contra o inimigo. ${ }^{47}$

que, desconhecendo os laços que os uniam, tenta envenená-lo: é que, informada de que o jovem seria filho de uma relação ilícita do seu esposo Xuto, tentava a todo o custo evitar que um bastardo assumisse o poder em Atenas. Cf. E. Ion, 1177 sqq.

${ }^{43}$ Já antes lançara mão da importância que a paternidade tinha para os Gregos a fim de concretizar os seus objetivos. Primeiro sacrificou o irmão Apsirto com o intuito de evitar que o pai continuasse a persegui-la durante a fuga com Jasão (Apollod. Bibl. 1. 9. 23-24; E. Med. 1334). Mais tarde, convenceu as filhas de Pélias a esquartejar o próprio pai (pois a feiticeira fizera com que acreditassem que, uma vez mergulhado numa poção mágica, o pai recuperaria a juventude) para se vingar do rei que desafiara o seu amado a roubar o Velo de Ouro e que lhe executara a família (Apollod. Bibl. 1.9.27). Mas a sua maior audácia é talvez a vingança contra Jasão: optou por matar os próprios filhos por saber que essa seria a única maldade que teria o efeito desejado sobre o homem que a abandonara (E. Med.791-817). Sobre estes episódios, vide Bremmer (1996: 83-100); Visser (1986: 149-165); López - Pociña (2002). Sobre a importância da paternidade para os Gregos, vide Lacey (1968); Slater (1998: 155-169); Patterson (1998).

${ }^{44}$ Apollod. Bibl. 1. 9. 28; Hyg. Fab. 27.

${ }^{45}$ Cf. Paus. 2. 3. 8; D. S. 4. 55. 5, segundo o qual o poder poderá ter sido exercido pelo seu filho Medo. De acordo com D. S. 10.27.1, a Média terá sido fundada por Medo.

${ }^{46}$ Cf. Hdt. 7. 62.

${ }^{47}$ Cf. Thes. 35. 8; Paus. 1.15.3. 


\section{Aventuras}

As aventuras associadas a Teseu não têm todas a mesma antiguidade e importância. De acordo com o que nos é possível saber (através da análise dos testemunhos literários e iconográficos), os episódios mais antigos ${ }^{48}$ são os dos raptos de Ariadne, Helena e Perséfone, o do Minotauro ${ }^{49}$ e a Centauromaquia ${ }^{50}$.

Os Atenienses, quando entenderam que Teseu deveria ser considerado o seu herói nacional, sentiram necessidade de reestruturar o mito de modo a que o perfil do fundador correspondesse aos valores que defendiam ${ }^{51}$. Importava, portanto, deixar cair no esquecimento aventuras menos dignas e acrescentar uma ou outra que ilustrassem a sua condição de herói civilizador.

Por isso, quando Plutarco redige a biografia de Teseu, existia já um leque de aventuras cuja menção era considerada "politicamente correta». Mas o Queroneu, que nunca olvida os seus objetivos pedagógicos, não se coíbe de evocar as que eram, por norma, postas de parte por não convirem ao perfil do herói (os raptos) ${ }^{52}$.

As aventuras de Teseu podem ser divididas em dois grupos: os feitos heroicos (que na sua maior parte são anteriores ao acesso de Teseu ao poder) e as aventuras eróticas, quase todas posteriores a essa ascensão.

É às primeiras que Plutarco dá maior ênfase, na medida em que, enquanto empresas para ajudar o povo oprimido, funcionam - na sua maioria - como argumento em favor do acesso ao poder e põem em evidência as qualidades de homem de Estado e do povo ateniense que caracterizam o herói. Já as

48 Para uma cronologia relativa dos diferentes episódios do mito de Teseu e respetiva importância, vide Walker (1995: 15-25); Mills (1997: 6-25).

${ }^{49}$ Talvez a mais antiga e certamente a mais popular.

${ }^{50}$ Este episódio foi um dos que prevaleceu, porque, no século $V$, os Centauros foram associados aos Bárbaros, logo a luta de Teseu contra eles representava a luta da civilização contra a barbárie.

${ }^{51}$ Nas palavras de García Gual (1990: 141), «dans nulle autre légende n’apparaît si claire l'influence du contexte dans la configuration de la figure du protagoniste. Nul autre personnage n'a subi, comme le héros attique, une telle modification pour devenir un modèle politique. Cet exemple permet de souligner deux traits très caractéristiques des mythes dans la tradition écrite et historique propre à la Grèce classique, et qu'on perçoit de façon significative dans l'évolution de la légende de Thésée.» Sobre a relação entre política e mito na Grécia antiga, cf. Nilsson (1972). Acerca dos valores defendidos pelos Atenienses e da visão que tinham de si próprios, vide capítulo «Atenas, o umbigo da Hélade».

${ }^{52}$ Vide infra p. 79 sqq. 
segundas revelam o lado negro do caráter de Teseu e, a longo prazo, acabam por precipitar a sua renúncia e afastamento da vida política.

Dos «feitos heroicos» fazem parte a «limpeza» do caminho que ligava Trezena a Atenas (Thes. 8-11), a derrota dos cinquenta Palântidas (Thes. 13), a luta com o Touro de Maratona (Thes. 14), a vitória sobre o Minotauro (Thes. 15-23), a guerra contra as Amazonas (Thes. 26-28), a guerra entre os Lápitas e os Centauros (Thes. 30). Das «aventuras eróticas», o rapto de Helena e o de Perséfone (Thes. 31).

O ciclo das façanhas vividas a caminho de Atenas ${ }^{53}$ é um dos que foi introduzido tardiamente, pois o testemunho mais antigo que se conhece a esse respeito é o poema 18 de Baquílides (séc. VI-V a.C.). A inserção desta série de aventuras responde a algumas necessidades estruturais deste género de narrativas, porque permite que o jovem, cuja paternidade foi recentemente revelada, prove o seu valor enquanto herdeiro do trono, ao mesmo tempo que parte ao encontro do pai. Mas, no contexto da Atenas do século $\mathrm{V}$, serve ainda para justificar a insistência na manutenção de determinadas cidades sob a sua "proteção», já que esse tipo de vínculo havia sido estabelecido há muito por $\mathrm{Teseu}^{54}$.É esse o caso de Mégara, que se viu livre de dois flagelos, a javalina de Crómion e o assaltante Ciro, por intermédio do fundador de Atenas. Assim se compreende que a tradição do seu nascimento em Trezena nunca tenha sido escamoteada, pois, como muito bem afirma Mills (1997: 21 e n.80), «Theseus' birth outside Athens is, in fact, more useful to his city than an Athenian birth would have been».

$\mathrm{Na}$ Vida de Teseu, Plutarco segue o critério geográfico tradicionalmente ${ }^{55}$ utilizado para enumerar estes $\tilde{\alpha} \theta \lambda \mathrm{ol}^{56}$. Assim, o herói depara-se, em Epidauro,

${ }^{53}$ Sobre o tratamento destas aventuras na iconografia, vide Taylor (1981: cap. IV). Este ciclo de labores parece ser uma tentativa de colocar Teseu em posição de ombrear com Héracles, de fazer do único herói ático conhecido para lá das fronteiras de Atenas um segundo Héracles. Isso mesmo no-lo sugerem as semelhanças que existem entre as aventuras dos dois heróis: ambos participam em uma Amazonomaquia e em uma Centauromaquia; ambos descem ao Hades; ambos usam uma clava como arma; Héracles luta contra um javali, Teseu, contra uma javalina; Héracles enfrenta Anteu, Teseu, Cércion; Teseu enfrenta o Touro de Maratona que, segundo Paus. 1.27.9-10, é o mesmo que Héracles capturara em Creta.

${ }^{54}$ Como vimos anteriormente, esta viagem tem também uma importância vital para a narrativa de Plutarco. Vide supra p. 58, nota 40.

${ }^{55}$ A título de curiosidade, podemos referir que um dos poucos a não respeitar essa ordem é Pausânias, que, ao contrário de Plutarco, não pretende fazer o relato exaustivo da mesma. Por isso, as façanhas vão sendo invocadas à medida que se torna oportuno. Em Paus.1.3.1 e 44. 8, ocorrem alusões a Ciro; em 1.27. 9, à javalina de Crómion; em 37. 4, a Sínis; em 38. 5, a Procrustes; em 39.3, a Cércion. Em Paus. 2.1.3-4, há uma referência à javalina de Crómion, a Sínis e a Perifetes. $3-26)$.

${ }^{56}$ Sobre a memória literária e iconográfica relativa a estas figuras, vide Brommer (I 972 : 
com Perifetes ${ }^{57}$; no Istmo, com Sínis; em Mégara, com a javalina de Crómion ${ }^{58}$ e Ciro (B. 18; Paus. 1. 3.1 e 1.44.8) ${ }^{59}$; em Elêusis, com Cércion e, em Érino, com Procrustes.

O Queroneu, como é seu hábito, aproveita o relato destes episódios para satisfazer os seus objetivos pedagógicos, morais e biográficos, isto é, para evidenciar as qualidades que admira em Teseu. Recorre por isso a duas técnicas diversas: a primeira consiste em apresentar o modelo negativo dos malfeitores; a outra, em explorar a conduta do herói.

Os bandidos vencidos por Teseu (que Plutarco apelida de $\lambda$ nฺ $\sigma \tilde{\omega} v$

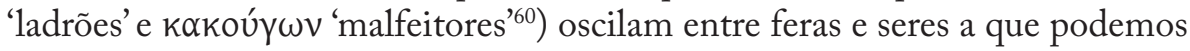
facilmente associar a noção de gigante ${ }^{61}$ : é que o biógrafo começa por realçar

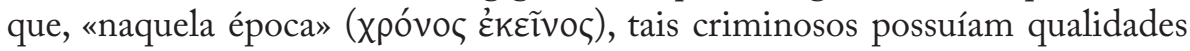

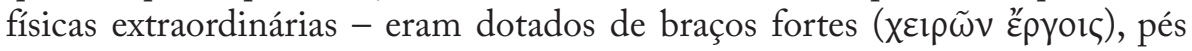

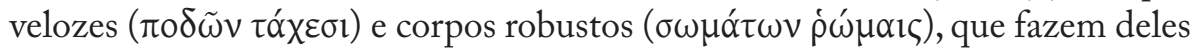

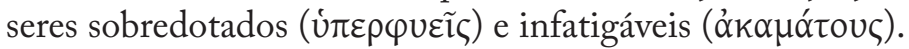

Mas de imediato revela que a opção de vida destes homens não foi a melhor: eram desonestos, alegravam-se com uma violência orgulhosa

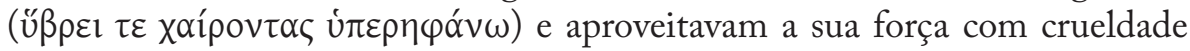

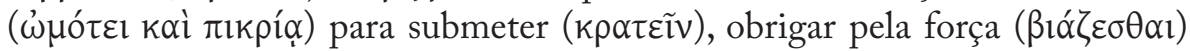
e destruir ( $\delta 1 \alpha \varphi \theta \varepsilon i ́ p \varepsilon i v)$ todos os que se atravessassem no seu caminho ${ }^{62}$. O recurso a palavras (quase todas) com conotação negativa para descrever o comportamento destes seres contrasta com as expressões usadas para enumerar

${ }^{57}$ Segundo Herter (1939: 280), Perifetes é um acrescento tardio (nunca anterior a 460 a.C.) a este conjunto, que teria por objetivo aumentar o número de «trabalhos» de Teseu de modo a que perfizessem metade dos de Héracles.

${ }_{58}$ No caso deste «escolho», é notório que Plutarco tenta, mais uma vez, cumprir a sua promessa de racionalizar o mito, já que aproveita para referir uma tradição segundo a qual a javalina seria uma ladra sem escrúpulos que teria morrido às mãos de Teseu (Thes. 9. 2). Sobre este género de procedimento, vide supra p. 31, nota 5. Sobre este episódio, vide Flacelière (1948: 75-76).

${ }^{59} \mathrm{O}$ Queroneu refere versões diferentes a propósito desta figura. Importa-nos salientar a perspetiva dos Megarenses que, mais uma vez, contradiz a dos Atenienses, tal como acontece, por exemplo, em Per. 30, a propósito do Decreto de Mégara. Sobre esta versão, vide Wickersham (1991: 16-31).

${ }^{60}$ Thes. 6.3.

${ }^{61}$ Parece, assim, estar subjacente à apresentação destes prevaricadores mais uma tentativa de racionalização do mito.

${ }^{62}$ Neste passo (Thes. 6.4), é evidente a influência do Górgias de Platão, diálogo no qual Cálicles defende que os mais fortes têm o direito de satisfazer as suas paixões: «aquele que quiser viver bem deverá deixar crescer à vontade as suas paixões, sem as reprimir, e, por maiores que elas sejam, deverá ser capaz de as satisfazer graças à sua coragem e inteligência, dando-lhes tudo aquilo que elas desejarem» (491e-492a). Segundo ele ( $G r g .483 a-484 b)$, o facto de este comportamento ser considerado injusto resulta da tentativa dos mais fracos de anularem o poder dos que lhes são superiores. A propósito do tratamento do conceito de «lei do mais forte» - cuja defesa esteve muito em voga ao longo do século $\mathrm{V}$ a.C. - neste diálogo platónico, veja-se Klosko (1984: 126-139). 
as suas qualidades físicas, que podiam ser aplicadas a qualquer herói de bom caráter.

Plutarco enumera ainda as virtudes que os malfeitores consideravam despiciendas para aqueles que se podiam impor pela força (mas que, na verdade, segundo o nosso moralista, deveriam caracterizar todo aquele que dedica a sua

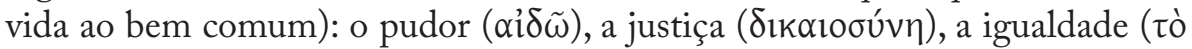

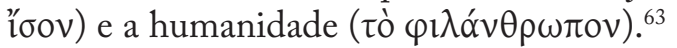

Consequentemente, ao afirmar que Teseu saiu vitorioso do recontro com estes criminosos, Plutarco exacerba indiretamente não só a força física do fundador de Atenas, mas também a virtuosidade do seu caráter.

Passemos à segunda técnica. Através da análise da conduta de Teseu na interação com os malfeitores, é possível particularizar algumas das virtudes do herói.

Importa começar por recordar que algumas dessas qualidades (já referidas anteriormente ${ }^{64}$ e evidenciadas pelo herói desde tenra idade) - como a força, a coragem, a grandeza de alma, a inteligência - e o desejo de emulação de Héracles funcionam como móbil destas aventuras.

No que respeita ao seu comportamento em todo esse percurso, saliente-se o cumprimento do princípio que estabelecera antes de partir - só atacar em

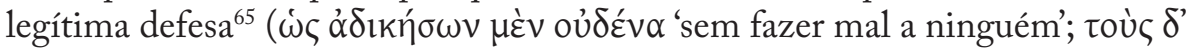

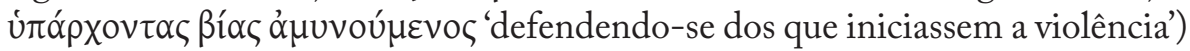
- e a forma justa como o fez, derrotando cada um dos malfeitores com recurso às mesmas sevícias com que aqueles torturavam e dizimavam os viajantes ( $\dot{\varepsilon} v$

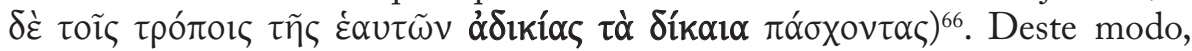
Teseu torna evidente o seu sentido de justiça, a sua coragem e ardor juvenil.

Recordemos pormenores de alguns destes recontros, que contribuem para a caracterização quer de Teseu quer do pensamento e procedimento de Plutarco.

Do contacto com o primeiro «escolho», Perifetes, o herói obtém a arma que, doravante, apenas servirá o bem e que acaba por ser mais uma forma de imitar Héracles ${ }^{67}$. Curiosamente, estas armas/insígnias (quer a de Teseu, quer as de Héracles), que começaram por pertencer a malfeitores, sofrem como

${ }^{63}$ Nota-se, mais uma vez, a influência do Górgias (492a-b). Cálicles defende que os que criticam o comportamento dos poderosos que não reprimem os seus desejos louvam «por cobardia a temperança e a justiça», já que não podem «dar às suas paixões satisfação completa».

${ }^{64}$ Cf. p. 52.

${ }^{65}$ Há que salvaguardar, no entanto, o facto de Teseu/Plutarco defenderem que os homens maus devem ser atacados em legítima defesa, mas que os animais devem ser provocados. É isso mesmo que o biógrafo afirma em Thes. 9. 2, a propósito da javalina de Crómion. Sobre este comportamento de legítima defesa, vide p. 128.

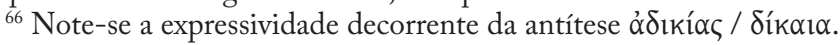

${ }^{67}$ Vide supra p. 54 sqq. Em Thes. 11. 2, o comportamento do herói para com Procrustes é apresentado como resultado da influência de Héracles. 
que uma evolução redentora quando passam a estar ao serviço dos heróis: mal usadas, eram vencíveis; nas mãos deles, tornam-se invencíveis.

Através do recontro com Sínis, «o dobrador de pinheiros», destaca-se o facto de, sem ter experiência naquele tipo de práticas, Teseu conseguir puni-lo com o mesmo método ${ }^{68}$. Comprova, assim, Plutarco, à semelhança do que diz em Per. 1-2, que a virtude está acima de qualquer arte ou treino ${ }^{69}$.

Da luta com Cércion, Plutarco evidencia o modo como Teseu conjuga habilidade intelectual e força física, o que faz com que seja não apenas o herói dotado de «força bruta», mas aquele que sabe usá-la com inteligência. E apresenta-o igualmente como um justiceiro, na medida em que devolve o poder ao neto indesejado que Cércion mandara expor.

Esta viagem iniciática ${ }^{70}$ contribui, assim, para reforçar a figura heroica de Teseu que, depois de livrar o mundo de malfeitores, se torna salvador de Atenas. Como afirma Cornet (2000: 42-43),

«cette première phase de son parcours ajoute à son caractère: d'adolescent inexpérimenté, Thésée est devenu, dans ces entreprises, où, laissé à lui-même, il a risqué sa vie, un jeune homme vigoureux, courageux, vainqueur par sa force mais aussi par sa science et son sens de la justice. Quand il arrive à Athènes, sont déjà présentes en lui les qualités du héros sauveur d'Athènes et civilisateur.»

Demais, estas aventuras estão em sintonia com a perspetiva civilizadora que os Atenienses tinham de si próprios. O facto de Teseu ter livrado o caminho dos perigos com que os viajantes se deparavam vai ao encontro do

${ }^{68} \mathrm{O}$ recurso à pena de talião é, como já se disse, uma influência da emulação de Héracles. Cf. supra p. 56. Sobre o comportamento de Teseu para com Periguna, vide infra p. 79.

${ }^{69}$ Cf. Pi. N. 3. 40.

${ }^{70} \mathrm{O}$ motivo da viagem iniciática é frequente na literatura grega. Podemos, a título de exemplo, recordar a de Ulisses no regresso de Troia, a de Telémaco, que parte à procura do pai, Ulisses, e a de Jasão em busca do Velo de Ouro. De um modo geral, durante essas viagens, os heróis, ainda muito jovens, ultrapassam diversas dificuldades até cumprirem o objetivo a que se haviam proposto. A tradição mitológica sugere, portanto, que terão existido na Grécia ritos de iniciação através dos quais os rapazes passavam a homens adultos, só então sendo reconhecidos como cidadãos. Não surpreende, pois, que Jeanmaire (1939: 245) afirme que o mito de Teseu é «the story of the Athenian ephebe system». De facto, a partir do período clássico, o herói é apresentado como um

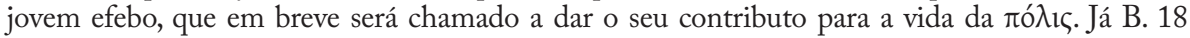

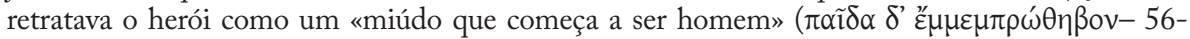
57), que usava um manto ( $\chi \lambda \alpha \mu \tilde{v} \delta$ - 54) e que trazia uma espada ( $\chi i ́ \varphi \circ \varsigma-47)$, dois elementos

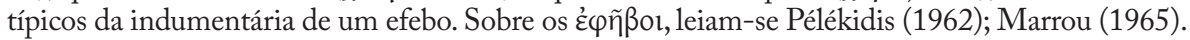
Importa não esquecer que a viagem a Creta também pode ser considerada um segundo ingresso na vida adulta. $\mathrm{O}$ facto de Teseu protagonizar duas viagens iniciáticas - uma feita por terra, outra por mar - prende-se à necessidade de o herói se mostrar à altura de Atenas, que era simultaneamente uma potência terrestre e marítima. A iniciação de Teseu, que tem de dar provas não só de ser um ateniense em idade adulta mas também o legítimo herdeiro do trono, termina com a morte do rei antecessor e com a edificação do Teseion em Atenas. A propósito da viagem iniciática de Teseu, consultem-se Walker (1995: 95-104); Calame (1990: 432-435). 
que Tucídides diz em 2.41. 4:

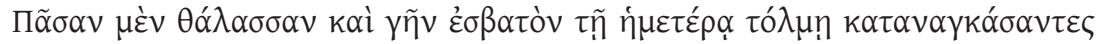

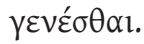

"Com a nossa ousadia, tornámos todo o mar e toda a terra acessíveis."

Os feitos que o biógrafo invoca de seguida prendem-se ao acesso de Teseu ao poder, após o acolhimento em Atenas. Não nos podemos esquecer de que, apesar de ter sido reconhecido por Egeu como filho legítimo, o jovem não conquistou de imediato a simpatia e a confiança dos Atenienses.

Os primeiros a revelarem a hostilidade que alimentavam contra o herói foram os seus primos, que haviam estado - até ao momento da sua chegada convictos de que assumiriam o poder por ocasião da morte do rei. No entanto, alertado a tempo pelo mensageiro do inimigo ${ }^{71}$, Teseu conseguiu derrotar os cinquenta. É curioso notar que Plutarco se demarca da tradição relativa a este episódio $^{72}$ : ao contrário, por exemplo, de Apolodoro (Epit.1.11) que o integra entre a morte de Egeu e o sinecismo, o Queroneu invoca-o logo a seguir ao reconhecimento. Além disso, não menciona nem o exílio ${ }^{73}$ a que Teseu se submeteu para se purificar desse crime, nem o julgamento de Delfínio ${ }^{74}$, que o absolveu. Tal esquecimento parece justificar-se pela necessidade de não entrar em contradiçã $\mathrm{o}^{75}$ com o que afirma em Thes. 24.2, onde apresenta o sinecismo como um processo pacífico.

No âmbito das peripécias vividas na Ática, a que se segue é a do Touro de Maratona ${ }^{76}$. Mais uma vez, o biógrafo prefere a versão ${ }^{77}$ que melhor se

${ }^{71}$ Parece relevante o facto de este arauto se chamar $\Lambda \varepsilon \omega ́ \varsigma$ 'Povo', o que sugere que o povo desejava Teseu no poder. Sobre os aítı relacionados com este episódio, vide infra p. 103, notas 245 e 246.

${ }^{72}$ Embora a conheça, como facilmente se depreende de Moralia 112D, 607A. Cf. E. Hipp. 34 sqq.

${ }^{73}$ Testemunhado por $\Sigma$ E. Hipp. 35.

${ }^{74}$ Cf. Paus. 1. 28. 10.

75 Segundo Larmour (1988: 369), uma das razões para a omissão poderá ser o facto de Rómulo nunca ter estado no exílio.

${ }^{76}$ Sobre o tratamento deste tema e do episódio do Minotauro na iconografia, vide Taylor (1981: capítulo IV) e Brommer (1972: 27-64). Esta aventura é igualmente importante por dar azo a mais um dî́tıov, que explica o nome de um dos demos da Ática, Hécala, assim chamado em homenagem à velha sacerdotisa de Zeus Hecálio. É que, antes de enfrentar o touro, Teseu foi acolhido por ela, que o tratou como se fosse seu neto, isto é, à maneira das mulheres de idade, com carícias e diminutivos. Além disso, Hécala pediu a Zeus proteção para o herói em troca de sacrifícios, promessa que, apesar da morte da sacerdotisa, Teseu cumpriu quando regressou vitorioso. Sobre os demos atenienses, leia-se Lewis (1963: 22-40).

${ }^{77}$ Cf. Apollod. Epit. 1. 5. A versão que apresenta este episódio como uma imposição de Medeia antes do reconhecimento é, segundo Sourvinou-Inwood (1979: 51), a mais recente e deve ser uma consequência da propaganda associada às Guerras Médicas. De acordo com esta 
coaduna com os seus objetivos. Neste caso, opta pela mais antiga (conservada pelos atidógrafos), que apresenta esta aventura como uma opção voluntária de alguém que quer alcançar a popularidade entre os concidadãos ${ }^{78}$. Deste modo, Plutarco consegue conciliar a sede que o herói tinha de enfrentar obstáculos e

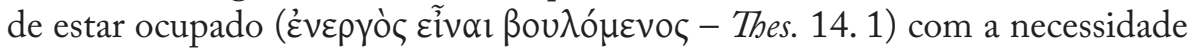
de conquistar a simpatia e a confiança dos Atenienses que o viam como um estrangeiro e não como um deles.

Há um aspeto importante a notar a propósito destes «trabalhos áticos»: Teseu vence, mas já não mata os inimigos (nem os Palântidas, nem o Touro de Maratona, que traz com vida para oferecer em sacrifício aos deuses). Tal comportamento, que põe de parte o barbarismo e contrasta com o do herói nas aventuras que precederam a sua chegada a Atenas, é sinónimo de autodomínio e revela um progresso civilizacional e cívico: antes de chegar a

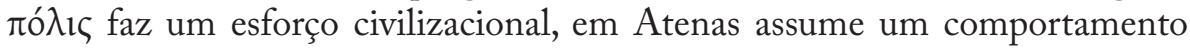
político. Demais, Teseu surge como elemento de uma sociedade organizada, com deuses protetores que devem ser homenageados e aos quais se reconhece um ascendente, como no-lo demonstra o facto de o herói oferecer o touro em sacrifício.

O episódio do Minotauro ${ }^{79}$, o terceiro e último no percurso de Teseu para o poder, apresenta diversas versões, decorrentes talvez do facto de esta ser a aventura mais famosa e uma das mais antigas de todas as que compõem a saga deste herói. $\mathrm{O}$ primeiro elemento problemático prende-se às circunstâncias que envolveram a morte de Andrógeo ${ }^{80}$ (filho de Minos e Pasífae) na Ática. $\mathrm{O}$ segundo diz respeito a pormenores relativos à periodicidade do tributo ${ }^{81}$ que Atenas se viu forçada a pagar a Creta em jeito de trégua, pela guerra que Creta empreendera contra a đó $\lambda ı \varsigma$ para vingar a morte do seu príncipe. Mas, em relação a estes elementos, Plutarco limita-se a dizer que a maioria dos autores concorda que o tributo deveria ser «pago» durante nove anos (Thes. 15.

variante, é este episódio que desencadeia o processo do reconhecimento, pois, quando o jovem puxa da espada para sacrificar o touro a Apolo Delfínio, Egeu avista-a e identifica-a como sua.

${ }^{78} \mathrm{O}$ mesmo acontece com a expedição a Creta, tratada nas páginas que se seguem.

${ }^{79}$ Os primeiros vasos áticos a tratarem este tema datam do segundo quartel do séc. VI a.C.A este episódio estão subjacentes acontecimentos históricos e ritos da antiga Creta, nomeadamente a relação do Minotauro com o Touro de Creta, a importância cultural do labirinto para os ritos ligados ao touro e a dependência histórica da Ática em relação à talassocracia minoica. Sobre este assunto, vide Herter (1973: cols. 1095-1097).

${ }^{80}$ Há quem afirme que o jovem terá sido assassinado quando ia a caminho de Tebas para participar nos jogos fúnebres de Laio, depois de se ter sagrado primeiro vencedor das Panateneias (Apollod. Bibl. 3. 15. 7). Outros contam que Egeu, invejoso dessa vitória, o enviou a combater o touro de Maratona, que o matou (Paus. 1.27.10). Há ainda quem defenda que se tratou de um crime de natureza política: ao descobrir a amizade de Andrógeo com os Palântidas - que queriam assumir o poder em Atenas -, Egeu teve medo de que o jovem cretense convencesse o pai a apoiar os filhos de Palas em uma guerra declarada e optou por eliminá-lo (D. S. 4.60.5).

${ }^{81}$ Sobre esta questão, vide Calame (1990: 132, n. 22). 
2). O tópico ao qual dedicou mais atenção é o terceiro e mais controverso - a natureza do Minotauro e o destino dos sete rapazes e sete raparigas atenienses que lhe eram enviados como tributo. Também por causa do compromisso que assumiu no princípio desta vida, dedica mais tempo às versões que procuram racionalizar o mito ${ }^{82}$, em detrimento da mais corrente (veiculada sobretudo pelos tragediógrafos), segundo a qual os jovens seriam devorados pelo Minotauro.

Se Plutarco se alonga no tratamento deste episódio não o faz apenas pela riqueza de variantes, mas sobretudo porque esta aventura é fundamental para delinear o caráter do herói. Por isso mesmo, o Queroneu opta, de novo, por enfatizar a versão que mais lhe convém ${ }^{83}$ a propósito da associação de Teseu à expedição a Creta. Consequentemente, a participação do jovem surge como iniciativa do herói ${ }^{84}$. Deste modo, ao oferecer-se de livre vontade - e

${ }^{82}$ A mais complexa - e a primeira que Plutarco evoca (Thes. 16. 1, 18. 4-7) - é veiculada por Filócoro e atribuída por este autor aos Cretenses. Faz do labirinto uma prisão de alta segurança, onde os jovens ficavam presos até serem entregues como prémio ao vencedor dos jogos instituídos por Minos em memória de Andrógeo. Além disso, transforma o Minotauro num general influente do exército cretense, chamado Tauro, que, por vencer constantemente os jogos, foi alvo da inveja e da maledicência dos Cretenses, que insinuaram que mantinha um romance com a rainha Pasífae. Esse militar, de caráter duvidoso e pouco afável, era responsável pelo tratamento arrogante e cruel de que eram vítimas os jovens atenienses. Deste modo, quer Tauro quer o Minotauro surgem como forças selvagens e monstruosas, que se assemelham aos seres não civilizados com os quais Teseu se defrontou no caminho por terra para Atenas. Plutarco (Thes. 16. 2) menciona ainda uma versão atestada por Aristóteles, na Constituição da Botieia (Fr. 443 Rose), segundo a qual os jovens morriam de velhos ao serviço de Minos. Refere, inclusive, que os seus descendentes terão integrado uma comitiva que se dirigiu a Delfos para cumprir uma promessa e que acabou por se evadir e fundar uma cidade na Trácia.

${ }^{83}$ Existem três versões. A mais antiga é aquela segundo a qual Teseu, como os demais participantes, foi sorteado (Pherecyd., FGrHist. 3 F 148). Outra, atestada por Helânico (FGrHist 4 F $164=323$ a F 14) e por D. S. 4. 61. 4, atribui a escolha de Teseu a Minos, que se deslocara a Atenas para selecionar as vítimas. A terceira - a que mais convém a Plutarco - ocorre igualmente em Isoc. 10 27, Catul. 44. 80-85 e faz da participação de Teseu um ato voluntário.

${ }^{84}$ Thes. 17.2. Este comportamento de Teseu é semelhante ao de Meneceu, descrito em E.Ph. 991-1018. Do mesmo modo que Egeu quis evitar que Teseu partisse para Creta, Creonte tentou impedir que o filho fosse sacrificado em prol do povo. E, do mesmo modo que Teseu, também Meneceu, colocando o pátrio interesse acima da própria vida, contrariou a vontade do pai. Note-se, no entanto, que o herói ateniense manifestou claramente o seu intento ao progenitor, ao passo que Meneceu preferiu agir em segredo. O tó na literatura grega. De um modo geral, surge como solução apresentada por um oráculo para

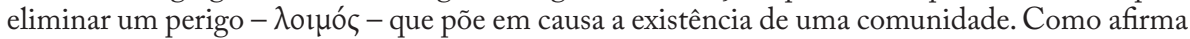
Bonnechère (1998: 211-212), «le sacrifice humain passait pour paradigmatique de la tragique réaffirmation du groupe et de sa primauté sur l'individu». Muitas vezes a escolha da vítima é como indica uma das versões da história de Teseu - feita por sorteio, o que sugere que a ameaça afeta todo o povo (quer as potenciais vítimas, quer as suas famílias). No âmbito do sacrifício humano, podem ocorrer sacrifícios voluntários. Nesses casos, o herói ou é expressamente nomeado por um oráculo e adere à vontade divina (como no caso de Meneceu) ou, ao saber da necessidade de um sacrifício para o qual ainda não há vítima (caso de Macária nos Heraclidas), apresenta-se de livre vontade para ser imolado. Estamos, pois, perante jovens que revelam um grande autodomínio e generosidade (virtudes que os seus parentes ou concidadãos não 
mais uma vez, contrariando o desejo de um dos progenitores ${ }^{85}-$, põe de vez fim às hesitações dos Atenienses que ainda não estavam habituados a vê-lo como um dos seus e que achavam injusto que o filho do causador daquele castigo não fosse elegível para o sorteio. É que este argumento, esta prova de altruísmo e de amor pelo seu povo fazem com que Teseu consiga apagar definitivamente da memória dos concidadãos o que há de controverso na sua origem.

O elemento divino deste episódio também se relaciona com essa necessidade que Teseu sentia de contribuir para a felicidade e para o bem-estar dos compatriotas. Não nos podemos esquecer de que qualquer crime de sangue (neste caso, o que fora cometido contra Andrógeo) polui o solo sobre o qual é derramado. Torna-se, então, imperioso proceder à purificação exigida pela divindade. Teseu surge, neste contexto, como o redentor que, patrocinado por Apolo (Thes. 18), liberta Atenas dessa «dívida».

Esta aventura permite ainda ao biógrafo realçar, através da comparação entre o comportamento egoísta de Egeu e o altruísta de Teseu, a vocação política do herói que põe o bem do povo à frente do seu. E, embora não se diga de forma explícita, é mais uma oportunidade que o autoconfiante Teseu - que promete ao pai voltar são e salvo, depois de livrar os Atenienses do flagelo encontra para saciar a sua sede de ação, de aventura.

Como é na sequência desta vitória que Teseu acede ao poder, não é difícil estabelecer mais um paralelo entre este e Édipo. Na verdade, ambos os heróis, para se tornarem reis, tiveram de provocar a morte dos pais e vencer os monstros que atormentavam os seus concidadãos ${ }^{86}$. De resto, um e outro redimiram as suas cidades do sangue derramado que lhes poluía o solo, trazendo-lhes, assim, tranquilidade, paz e progresso.

partilham) e que põem o interesse coletivo acima das próprias vidas. Importa salientar que, por norma, tais jovens têm sangue real, que simboliza o espírito de doação que deveria caracterizar todos aqueles que se encontram à frente de um povo, cujos interesses deveriam defender a todo o custo. Não admira assim que o sacrifício de tais vítimas, mais do que piedade, suscite admiração. A serenidade que costumam deixar transparecer é também ela uma característica de Teseu que, como sabemos, chega a dar garantias de regressar com vida e de pôr fim ao sofrimento de Atenas. Para uma informação mais completa sobre o tema do sacrifício humano e seu tratamento literário e dramático, leiam-se, para além do artigo já citado, Wilkins (1990, 117-194); Bonnachère (1994); Silva (2005: 125-165).

${ }^{85}$ Quando decidiu dirigir-se por terra a Atenas, também o fez contrariando a mãe (e o avô). Vide supra p. 54.

${ }^{86}$ Este é um tópico frequente nas narrativas sobre as vidas de fundadores. Vide supra p. 51, nota 7. A morte do rei às mãos do jovem príncipe que regressa está relacionada com o motivo da viagem iniciática (vide supra p. 58, n. 40, e p. 65, n. 69) e simboliza a iniciação na idade adulta de uma nova geração. Segundo Genep (1902: 122), representa ainda a destruição do passado. Por isso, o acesso do jovem Teseu ao poder prenuncia uma mudança, uma renovação da sociedade, que, como sabemos, revelar-se-á uma verdadeira revolução em termos do funcionamento da vida política (no sentido etimológico do termo) de Atenas. 
No caso de Teseu, não se pode dizer que ele tenha sujado pessoalmente as mãos de sangue, no entanto, é o causador da morte do progenitor que, ao avistar a bandeira negra (símbolo de desgraça) e não a branca (que deveria anunciar o regresso com vida do herói), não suportou o desgosto e, desesperado, se precipitou no mar que desde então tem o seu nome ${ }^{87}$. Para Plutarco, esta leviandade do jovem deve-se à alegria excessiva que sentia, mas há autores (como D. S. 4. 61. 5; Apollod. Epit. 1. 10; Hyg. Fab. 43) que atribuem o esquecimento à dor sentida por ter abandonado Ariadne ${ }^{88}$.

Independentemente da justificação apontada para o lapso de Teseu, o certo é que a sua associação a uma distração e não a um golpe direto é redentora da imagem do herói. Deste modo, embora acabe por cumprir (ainda que de forma atenuada) as etapas tradicionais deste tipo de narrativas, Teseu é aliviado de uma culpa que o teria impossibilitado de exercer até ao fim a sua missão. Foi o que aconteceu a Édipo, que, penalizado pela força de castigo latente, não pôde concluir a sua missão e pagou um preço altíssimo pelos seus atos. A queda do Ateniense, pelo contrário, desenha-se não como uma consequência do destino, de uma maldição, mas das suas próprias ações, que muitas vezes não soube orientar.

Enquanto rei, Teseu vive ainda duas aventuras famosas e importantes para o desenhar do seu perfil de herói nacional e civilizador: a Amazonomaquia e a Centauromaquia.

O episódio da Amazonomaquia ${ }^{89}$ não fugiu à reestruturação que a generalidade do mito de Teseu foi sofrendo sobretudo até ao dealbar do séc. $\mathrm{V}$ a.C. De início, estava relacionado com um motivo frequente na lenda de Teseu: o rapto de mulheres ${ }^{90}$. Disso nos dão testemunho fontes iconográficas ${ }^{91}$, nomeadamente na cerâmica ática produzida entre 520 e 480 a.C., onde o rapto de Antíope ${ }^{92}$ surge quer como variante do motivo iconográfico do rapto erótico de uma $\pi \alpha \rho \theta \varepsilon ́ v 0 \varsigma^{93}$, quer como variante do motivo do casamento. De

${ }^{87}$ Sobre os $\alpha$ ítı $\alpha$ na Vida de Teseu, vide infra pp. 99-105.

${ }^{88}$ Sobre o relacionamento de Teseu e Ariadne, vide infra p. 79 sqq.

${ }^{89}$ Thes. 26-28. As diferentes versões do mito encontram-se elencadas e analisadas em Boardman (1982: 1-28) e em Portela (2002). Sobre a tradição literária e iconográfica que se prende a este mitema, vide igualmente Brommer (1972: 110-114).

${ }^{90} \mathrm{O}$ mesmo sucedeu a Ariadne, Helena (vide infra p. 85 sqq) e Perséfone (vide infra p. 89 sqq). A propósito do rapto de mulheres por Teseu e seu tratamento iconográfico, vide Sourvinou-Inwood (1987: 131-153).

${ }_{91}$ Este motivo estava igualmente tratado no frontão ocidental do templo de Apolo em Erétria. Vide Boardman (1982: 8 sqq).

${ }_{92} \mathrm{O}$ nome desta Amazona varia consoante as fontes. É Antíope para, entre outros autores, D. S. 4. 28. 1; Paus. 1. 2. 1, 1. 41. 7; Pi. frs 175, 176 Snell; também é conhecida por Hipólita (Clidem. FGrHist 323 F 18; Isoc. 12. 193); segundo Apolodoro (Epit. 1. 16, 5. 2), chama-se Melanipe ou Glauce.

${ }^{93}$ Importa não esquecer que, no plano do mito, raptos como os de Tétis por Peleu e o de Perséfone por Hades funcionam como paradigmas do casamento. Cf. Sourvinou-Inwood (1987: 
facto, quando retratado em vasos, o rapto de Antíope segue, por norma, as convenções iconográficas da representação do casamento grego, pois neles figuram o carro nupcial, um noivo (o jovem guerreiro Teseu), que carrega a noiva nos braços ${ }^{94}$ em direção ao carro que os conduzirá à nova casa (Atenas) e o paraninfo (Pirítoo).

Este mitema foi igualmente tratado naliteratura, como no-lo testemunham, por exemplo, um fragmento de Píndaro (fr. $175 \mathrm{Snell}^{15}$ ) e os ecos que nos chegaram da Teseida ${ }^{96}$.

Ora, não é difícil, a partir de tais indícios, inferir que uma das variantes ${ }^{97}$ do mito de Teseu e das Amazonas conjuga os elementos rapto, casamento (que faz da Amazona uma ateniense), nascimento de um filho (Hipólito ${ }^{98}$ ) e revolta provocada pelo abandono da esposa por outra mulher (o que de imediato nos faz pensar na relação de Jasão e Medeia, preterida pelo marido em prol de uma esposa grega).

O Queroneu, no entanto, relega esta versão para segundo plano e dá preferência às duas variantes que relacionam a «posse» da Amazona não com o rapto erótico, mas com investidas de cariz militar. A primeira a ser invocada - e rejeitada - por Plutarco faz da participação de Teseu (que lhe valeu

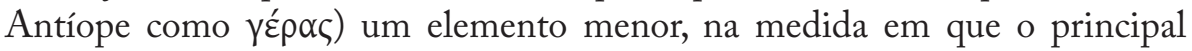

139). Há diversas representações de Teseu associadas a esse motivo, embora nem todas estejam ligadas à Amazona, uma vez que o herói protagonizou outros raptos. $\mathrm{O}$ facto de a vítima ser uma Amazona reveste-se de um significado especial, pois, uma vez sexualmente dominada, esta torna-se uma mulher comum e deixa de ser uma guerreira de caráter viril. $\mathrm{O}$ roubo do cinto

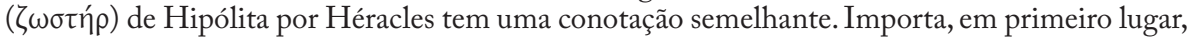

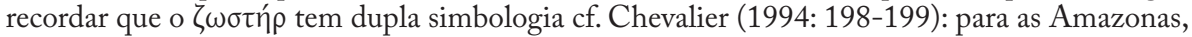
era sinal de excelência guerreira (Apollod. Bibl. 2. 5. 9), mas para a jovem ateniense, despida pelo esposo na noite de núpcias, era símbolo da consumação da sua condição de mulher. Por

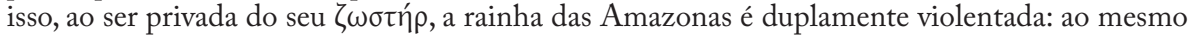
tempo que lhe é negada a excelência guerreira, transforma-se numa mulher comum, com a qual é possível contrair casamento. Sobre esta aventura de Héracles, vide Portela (2002: 66 sqq).

${ }^{94}$ Sobre as sugestões sexuais desta cena, leia-se Sourvinou-Inwood (1987: 137).

95 «A amazona Antíope foi raptada por Pirítoo e Teseu».

${ }^{96}$ Pouco se sabe acerca desta epopeia que teria como tema a vida e as aventuras do herói. Aristóteles (Po. 1451a) é a nossa referência mais antiga à Teseida e dá a entender que existiam vários poemas desta natureza. De acordo com Huxley (1969: 116-122), data de finais do séc. VI a.C. e dava ênfase ao rapto da Amazona enquanto aventura amorosa. Terá sido por influência da sua forte divulgação que o tratamento do tema do rapto ganhou fôlego na cerâmica desse período. Ainda que não saibamos ao certo que episódios tratava, tudo leva a crer que a Amazona era apresentada como esposa de Teseu. Sobre este assunto, leiam-se também Herter (1973: col. 1046); Betalli - Vanotti (2003:100-101).

${ }^{97}$ Cf. Apollod. Epit. 1.17.

${ }^{98}$ Cf. E. Hipp. 307-310, 581-582; Apollod. Epit. 1. 17. Segundo Pi. fr. 176 Snell, o jovem chamava-se Demofonte. 
adversário das guerreiras era Héracles ${ }^{99}$. A segunda - preferida pelo biógrafo ${ }^{100}$ e testemunhada, entre outros, por Ferecides (FGrHist 3 F 151), Helânico (FGrHist 4 F 166) e Herodoro (FGrHist 31 F 25a-b) - faz da expedição que deu origem à refrega (porque o jovem fez de Antíope prisioneira de guerra) uma iniciativa individual do filho de Egeu.

Deste modo, a «primeira Amazonomaquia» terá ocorrido no estrangeiro, no país das Amazonas, que foi atacado pelo(s) herói(s). O mais antigo documento iconográfico a atestar este combate decorava as métopas no Tesouro dos Atenienses em Delfos ${ }^{101}$ e relaciona as duas versões, já que no lado norte estavam representados os labores de Héracles, no sul, os de Teseu e, ao centro, como que a relacioná-los, o combate contra as mulheres guerreiras.

Mas, para o relato de Plutarco, a Amazonomaquia que interessa explorar é a que corresponde à invasão da Ática pelas Amazonas, lenda cuja difusão data de meados do séc. $\mathrm{V}$ a.C.

No âmbito da iconografia ${ }^{102}$, esta incursão está documentada em diferentes suportes: na cerâmica (a partir de 480 a. C.); no friso oeste do Teseion ${ }^{103}$ (ca. de 450 a.C.), da autoria de Mícon e descrito em Paus.1.17.2; no Pórtico Pintado ${ }^{104}$ (ca. 460 a.C.), igualmente da autoria de Mícon ${ }^{105}$ e descrito por Paus. 1. 15; nas catorze métopas ocidentais do Pártenon (439 a.C.) e nos relevos do escudo da estátua criselefantina de Atena Pártenos, da autoria de Fídias (438 a.C.), descrito por Paus. 1.17.2. No âmbito da literatura, o testemunho mais antigo é o de Píndaro (fr. 174 Snell), que atribui a construção do santuário de Ártemis em Éfeso às Amazonas que se dirigiam para Atenas. Também Ésquilo alude à invasão nas Euménides (685-690), quando a deusa Atena, no momento da instituição do tribunal do Areópago, recorda que outrora as Amazonas fixaram o seu acampamento nessa mesma colina.

99 Thes. 26. 1. Hégias de Trezena (que, segundo Jacoby, comm. ad. FGrHist 606 F 1, é um autor helenístico) tornou secundária a participação de Héracles, ao afirmar que este só conseguiu tomar Temiscira quando Antíope, apaixonada por Teseu (que também participava na expedição), franqueou ao herói ateniense o acesso à fortaleza. Cf. Paus. 1.2.1.

100 Thes. 26. 1-2. Embora Plutarco e os historiadores áticos defendam esta versão, a tradição literária prefere, de um modo geral, a anterior, que faz de Teseu companheiro de Héracles nesta aventura. Testemunhos nesse sentido ocorrem em E. Heracl. 215-2 (o mais antigo); Philoch. FGrHist 328 F 110; D. S. 4. 16. 4; Apollod. Epit.1.16.

${ }^{101}$ A propósito da controvérsia existente em torno da data de edificação do monumento, vide Boardman (1982: 3). Leia-se, igualmente, Portela (2002: 80-81) para pormenores da análise desta e de outras representações iconográficas, com os quais não nos demoramos visto que Plutarco não lhes faz qualquer alusão.

${ }^{102}$ Cf. Boardman (1982: 16 sqq).

${ }^{103}$ No Teseion estavam representadas diversas cenas da vida de do herói, nomeadamente a recuperação do anel de Minos, a Centauromaquia, a Amazonomaquia e talvez também o resgate de Teseu do Hades.

${ }^{104}$ Neste pórtico, era possível contemplar-se, por exemplo, as Amazonas na acrópole, os Persas e os Gregos em Maratona e a queda de Troia.

105 Cf. Ar. Lys. 678 sqq. 
A partir dos elementos supracitados podemos concluir, com outros

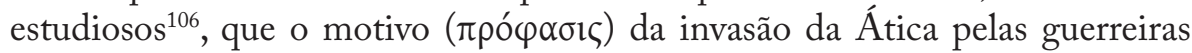
terá sido forjado após as Guerras Pérsicas, provavelmente na década de 470460 a.C. Sabemos que esta variante do mito conheceu grande popularidade nos séculos V-IV a.C., durante os quais foi tratada não só por historiadores ${ }^{107}$, mas também por oradores ${ }^{108}$ (como Isoc. 4. 68-70, 7. 75, 12. 193), que não punham em causa a veracidade da invasão e cujo principal intuito era fazer o panegírico de Atenas.

Por conseguinte, as Amazonas passaram a ser vistas como uma força invasora, uma ameaça bárbara vinda do Oriente, o que permite estabelecer um paralelo com os Persas e com a invasão da Grécia por eles protagonizada.

O episódio das Amazonas acaba por assumir uma conotação política, já que permite sublinhar os valores helénicos, quer através da análise do comportamento de Antíope, quer do das Amazonas enquanto grupo. No primeiro caso, Antíope surge como uma Amazona feminizada e helenizada, que acolhe Teseu ${ }^{109}$ aquando da sua incursão a Temiscira. Apaixonada pelo herói, vai viver para a $\pi$ $^{\prime} \lambda \varsigma^{110}$, onde respeita os costumes locais, nomeadamente a lealdade para com o marido ${ }^{111}$. No segundo caso (Amazonas enquanto grupo), as guerreiras surgem como invasoras derrotadas, o que revela não só

${ }^{106}$ Como Boardman (1982: 14).

${ }^{107}$ Heródoto (9.27), por exemplo, evoca esta vitória como sendo mais uma das alcançadas pelos Atenienses; Helânico (FGrHist 4 F167b), por sua vez, chega a descrever o percurso que as Amazonas fizeram para chegar a Atenas. Curiosamente, Plutarco (Thes. 27. 2) discorda da posição deste autor.

${ }^{108}$ Cf. o testemunho de Arr. An. 7. 13. 6, segundo o qual todos os oradores atenienses, ao produzirem o elogio dos soldados mortos em combate, fazem uma menção especial à empresa dos Atenienses contra as Amazonas. Sobre este assunto, vide Tyrrell (1984: 13-19), que salienta o facto de, neste contexto, a motivação das Amazonas ser não o rapto de uma delas, mas antes o desejo de suplantar a grande fama do povo protegido pela deusa Atena (cf. Lys. 2. 5).

${ }_{109}$ Segundo Bíon de Proconeso - que Plutarco cita em Thes. 26.2 (FGrHist 332) -, as Amazonas eram $\varphi$ í $\alpha \propto v \delta \rho o l$, pelo que acolheram hospitaleiramente o herói que, em troca, lhes raptou a rainha. Trata-se de uma característica marcadamente feminina, que se relaciona com a subserviência própria das mulheres e que é também representada pelo rapto e violação de que, na tradição mítica, são muitas vezes vítimas. Por outro lado, este adjetivo pode associar-se à forma mais liberal que as Amazonas tinham, segundo a tradição, de encarar a vida sexual. Sobre esta versão do mito, vide Ampolo - Manfredini (1988: 242).

${ }^{110} \mathrm{~A}$ integração de alguém que é hostil à cidade permite estabelecer um paralelo com o acolhimento de estrangeiros que caracteriza Atenas, nomeadamente na tragédia. Cf. S. OC e E. $H F$, peças nas quais Teseu recebe como hóspedes Édipo e Héracles.

${ }^{111}$ Menécrates conta que, durante a sua passagem com Teseu pela Bitínia, Antíope rejeitou o assédio sexual de um jovem chamado Solunte. Esta história torna-se ainda mais interessante em termos políticos, porque permite associar a figura de Teseu (e, consequentemente, de Atenas) à fundação da cidade de Pitópolis. Sobre a identidade de Menécrates, vide Ampolo - Manfredini (1988: 242). Clidemo (Plu. Thes. 27. 5) testemunha a lealdade de Antíope - a quem chama Hipólita - para com Teseu ao afirmar que aquela tudo fez para que as Amazonas celebrassem a paz. Um outro autor, Hégias de Trezena (FGrHist 606 F 1; cf Paus. 1. 2. 1), conta que Antíope traiu as companheiras por amor de Teseu. 
a supremacia do herói mas sobretudo a de Atenas. No século IV a.C., este mito assume ainda a função política de incitar os Atenienses a recuperar o seu império.

Independentemente do motivo que levou as Amazonas a atacarem a Ática ${ }^{112}$, importa realçar que esta configuração do mito resulta da necessidade de coaduná-lo com os interesses políticos e sociais de Atenas: do mesmo modo que não convinha que Teseu tivesse um papel subsidiário nessa aventura, também não convinha que a batalha decorresse em território alheio. É que, uma vez que as Amazonas simbolizavam não só o inimigo bárbaro mas também um modo de vida feminino ${ }^{113}$ contrário à tradição grega e particularmente à ática, se os Atenienses fossem ameaçados no seu espaço e saíssem vitoriosos, a sua luta em prol da civilização adquiriria outra dimensão.

Plutarco não insiste na ideia do rapto ${ }^{114}$ (que, como vimos, deve ser anterior às Guerras Médicas ${ }^{115}$ ), fala antes em үépac, que era algo perfeitamente aceitável naquele tempo ${ }^{116}$. Além disso, insiste no amor que a jovem nutria por Teseu ${ }^{117}$, como que a tentar desculpabilizá-lo da invasão. Demais, o comportamento do herói acaba sancionado por causa do sentido que, como acabámos de ver, era atribuído à sua vitória.

Porque este combate com mulheres - que para os Gregos eram seres fracos e desprovidos de capacidades bélicas - poderia parecer algo ligeiro e de somenos importância, Plutarco faz questão de realçar a sua dificuldade, no capítulo 27 da Vida de Teseu, onde descreve pormenores relativos à batalha e a outros locais gregos que registam a memória da passagem das guerreiras ${ }^{118}$.

${ }^{112}$ Há quem diga que a invasão decorre da tentativa de resgate de Antíope, que é uma vingança pelo seu rapto e/ou pela expedição de Teseu ao país das Amazonas, ou ainda consequência dos ciúmes que Antíope sentia por causa do casamento de Teseu com Fedra. Esta última tentativa de justificação é recusada por Plutarco (Thes. 28. 1), que a considera excessivamente fantástica.

113 A respeito da condição da mulher na Grécia antiga, leiam-se Clark (1989); Blundell (1995); idem (1998). Sobre as Amazonas como reverso da mulher grega, vide Tyrrell (I 984 : 40-63).

${ }^{114}$ Como muito bem afirmam Tyrrell - Brown (1991: 167), «the rape practiced by a national hero, however useful it had been in asserting male dominance over women and foreign enemies, had no place in future politicians' intentions for the Amazon invasion». De facto, um político que se pretende herói nacional e rei humanitário não pode ter tais comportamentos...

115 E. g., Mills (1997: 31-33).

${ }^{116} \mathrm{O}$ үépac era tido como sinal de reconhecimento das qualidades do guerreiro, como muito bem no-lo testemunha a tradição homérica. Se alguém se via privado dele, por tudo o que isso implicava, as consequências podiam ser terríveis. Basta-nos recordar a cólera de Aquiles, para a qual contribuiu o facto de ter sido privado de Briseida. Cf., e. g., Il.1.181-192.

${ }^{117} \mathrm{Cf}$. Thes. 26. 1,27. 5 e página anterior.

118 Para mais informações sobre a toponímia em causa, vide Ampolo - Manfredini (1988: 244-246) e bibliografia citada. Plutarco (Thes. 27. 8-9), alude à passagem conflituosa das Amazonas por outras regiões quando se dirigiam para a Ática, evocando como testemunho a existência de túmulos de Amazonas em Mégara, nas proximidades de Queroneia (junto ao rio Termodonte ou Hemon) e na Tessália (nos arredores de Escotussa e Cinoscéfalas). Embora 
$\mathrm{Na}$ verdade, o facto de se ter associado à invasão e aos combates monumentos e toponímia permitiu que se pudesse narrar o desenvolvimento da batalha com tanta verosimilhança que, com o tempo, a simples alusão a locais conhecidos por todos se tornou testemunho de historicidade (cf. Thes. 27.2).

Plutarco começa por mencionar que as Amazonas acamparam no interior da cidade ${ }^{119}$, como prova das suas capacidades bélicas, pois não era qualquer inimigo que conseguia entrar no coração da $\pi$ ó $\lambda \varsigma^{120}$.

Depois de afirmar que os combates decorreram entre a Pnix (colina a ocidente da Acrópole) e a Colina das Musas (colina fronteira à Acrópole), o Queroneu evoca o testemunho de Clidemo, que pormenoriza o decurso da batalha: a ala esquerda das Amazonas estendeu-se até ao Amazónion (que, ao que parece, ficava na vertente noroeste do Areópago); a direita estendeu-se até à Pnix junto do santuário de Crisa ${ }^{121}$. Clidemo conta ainda que a missão dos Atenienses que combateram a ala esquerda das Amazonas foi particularmente difícil, como atestam os diversos túmulos erigidos em ambos os lados da rua que conduz às portas do Pireu, próximas do templo de Calcodonte. Estes Atenienses foram empurrados até ao santuário das Euménides e acabaram por ceder. Já os que enfrentaram a ala direita - a partir do Paládio (tribunal que julgava homicídios involuntários, a ocidente do templo de Terra Olímpica), do Ardeto (colina próxima do estádio, onde os heliastas prestavam juramento) e do Liceu - conseguiram repelir as guerreiras até ao acampamento e matar muitas delas.

Plutarco refere ainda outros locais que se prendem às diferentes tradições sobre o fim da Amazonomaquia. Como Clidemo, o Queroneu acredita que o conflito terminou com um tratado de paz celebrado por intermédio de Antíope (Hipólita, segundo Clidemo). Como «prova» disso, o biógrafo (Thes. 27. 7) alude à existência de um lugar chamado Horcomósion (próximo do Teseion), cujo nome deriva de ő $\rho$ koৎ 'juramento', por ter sido aí que tudo se resolveu ${ }^{122}$. Refere igualmente o sacrifício ${ }^{123}$ outrora celebrado, na véspera do festival de Teseu, em memória das Amazonas.

o biógrafo associe estes túmulos à invasão da Ática, a sua existência é certamente anterior ao aparecimento deste episódio e está relacionada com o culto local.

${ }^{119}$ A. Eu. 685-690 situa o acampamento no Areópago, o que faz todo o sentido na medida em que as guerreiras passavam por filhas de Ares.

${ }^{120}$ Ao enaltecer as capacidades do inimigo e ao exagerar as dificuldades do combate, Plutarco valoriza os Atenienses que conseguiram derrotar semelhante invasor. Pnix.

${ }^{121}$ Desconhece-se a localização deste santuário. É provável que ficasse nas imediações da

${ }^{122}$ Segundo Paus. 1. 18. 4, o acordo que ocorreu neste lugar foi o celebrado entre Teseu e Pirítoo. O juramento de amizade feito pelos dois heróis é mencionado igualmente em $\mathrm{S}$. $O C$ 1593.

${ }^{123}$ Sobre o objetivo de tais sacrifícios, vide Dowden (1997: 120). 
O biógrafo, que atribui a existência de tantas variantes à antiguidade dos acontecimentos, evoca outras versões sobre o fim do conflito. Uma delas associa a estela funerária ${ }^{124}$ existente nas proximidades do templo de Terra Olímpica a uma homenagem feita a Antíope, que aí teria tombado durante a refrega. A outra conta que as Amazonas feridas foram enviadas para Cálcis pela rainha e que muitas delas acabaram sepultadas no Amazónion.

Não deixa de ser digno de menção o facto de a toponímia relacionada com a batalha incluir sobretudo lugares de culto ou profundamente ligados à vida política - como aqueles onde reuniam tribunais ou assembleias. Talvez isso aconteça para mostrar que tais lugares assumiram, desde muito cedo, um papel preponderante na vida de Atenas.

Quanto à Centauromaquia ${ }^{125}$, ocupa o trigésimo capítulo da Vida de Teseu, um dos mais breves desta biografia. Deste episódio, Plutarco transmite duas versões. A primeira (aquela que lhe parece mais verosímil) faz de Teseu convidado de Pirítoo para o casamento deste com Deidamia ${ }^{126}$, durante o qual eclode o conflito com os Centauros, também eles convidados para a boda (Thes. 30. 2). De acordo com a outra versão, veiculada segundo o biógrafo por Herodoro, o herói não assiste ao início da contenda e só posteriormente vem em socorro do amigo (Thes. 30.3).

Assim, independentemente da versão em causa, trata-se de um conflito que não tem origem em nenhum ato de Teseu (como acontece com a Amazonomaquia ou a invasão da Ática pelos Dioscuros) e que, por isso mesmo, decorre longe de Atenas. A Centauromaquia é antes apresentada como uma

${ }^{124}$ Paus. 1. 2.1 também faz referência a um túmulo de Antíope, que parece coincidir com a estela funerária situada nas Portas Itónias, a sul do templo de Terra Olímpica, mencionado em P1. Ax. 365a. Sabe-se que, além do de Antíope, existiam em Atenas outros túmulos de Amazonas, como por exemplo o de Molpadia, à qual algumas versões do mito (nomeadamente Paus. 1.2.1) atribuem a morte da rainha.

${ }^{125}$ As primeiras referências literárias a este combate ocorrem em Il. 1. 265, 2. 742-744, Od. 21.295-304. Sobre a discussão em torno da autenticidade de Il.1.265 (único destes passos que faz de Teseu um participante na Centauromaquia), leiam-se os estudos para os quais Calame (1990: 286, n. 179) remete. No âmbito da iconografia, o primeiro testemunho evidente da participação de Teseu neste combate é o vaso François, pintado por Clítias entre 570 e 560 a.C. Nesta altura, o combate deixa de ser representado como conflito armado e passa a estar especificamente relacionado com as bodas de Pirítoo. Esta nova forma de representação da Centauromaquia confirma a aticização da lenda. Pausânias (1.17.2) testemunha que este era um dos episódios que servia de tema à decoração do Teseion. Sobre esta última representação, vide Woodford (1974: 158-165), que afirma que esta foi a primeira «ethical representation of the theme in terms of the struggle of civilisation against barbarity». $\mathrm{O}$ mesmo acontecia nas diversas métopas do Parténon, onde as batalhas entre Gregos e Amazonas, entre Lápitas e Centauros simbolizam o triunfo do helenismo sobre a barbárie. Para mais informações sobre a tradição literária e iconográfica deste episódio, vide Brommer (1972: 104-109).

${ }^{126}$ Plutarco é o único a dar este nome à noiva de Pirítoo, que, segundo a tradição, se chamava Hipodamia (cf. Il. 2.742; Apollod. Epit. 1.21). É, por isso, provável que se trate de um engano. Sobre a tradição literária e iconográfica que se prende à amizade entre os dois heróis, vide Brommer (1972: 139-140). 
guerra na qual Teseu participa por amizade ${ }^{127}$, para auxiliar um amigo que, neste caso, foi ofendido pelos seus hóspedes.

Os Centauros, que não respeitam um valor fundamental para a sociedade grega $^{128}$, surgem, portanto, como seres não-civilizados, pelo que derrotá-los se conforma perfeitamente com a missão civilizadora do herói ateniense.

De facto, a tradição mítica ligada a estas figuras era, por excelência,

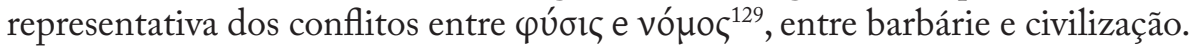
Essa ambivalência manifestava-se não só a nível físico (já que se trata de seres cujo corpo era metade humano, metade de cavalo), mas também a nível do comportamento, pois eram fortes, pouco escrupulosos e violentos - mesmo selvagens -, defeitos esses acentuados sempre que se embriagavam ${ }^{130}$. Essa dualidade era ainda corroborada pela existência de dois Centauros bons, que são penalizados pelas más ações dos restantes: Quíron, que passa por paradigma de civilização e educador de heróis (como Jasão, Asclépio, Actéon, filho de Aristeu, ou Aquiles ${ }^{131}$ ), e Folo, que representa a cultura e a hospitalidade.

Como a Amazonomaquia, a Centauromaquia evoca a vitória sobre os Persas e contribui, durante o séc. V a.C., para a representação da luta heroica dos Atenienses contra os Bárbaros ${ }^{132}$. Deste modo, os Persas eram tidos como seres que se deixam levar por apetites e não pela razão (como os Centauros) e como um exército efeminado (como as Amazonas).

Plutarco (Thes. 29. 3-5) invoca ainda outras aventuras de Teseu, cuja existência não é consensual ${ }^{133}$. Sem entrar em pormenores, o biógrafo menciona três situações em que o herói entra em ação para acudir a outras

${ }^{127}$ Trata-se de mais um valor muito estimado pelos Helenos. A amizade que unia Pirítoo e Teseu era tão forte que se tornou paradigma de fidelidade, como no-lo atesta, por exemplo, Xenofonte (Smp. 8. 31) e veio a dar origem ao nome de um dos demos de Atenas, Pirítodas. Teseu e Pirítoo não são, no âmbito da tradição grega, os únicos representantes de ideia de companheirismo e de amizade verdadeira entre heróis que se admiram e respeitam mutuamente. Também a amizade entre Aquiles e Pátroclo (cantada na Ilíada) e a que uniu Orestes e Pílades (testemunhada pelas Coéforas de Ésquilo, pela Eletra de Sófocles, bem como pela Eletra, pela Ifigénia em Táuride e pelo Orestes de Eurípides) se tornaram lendários. Autores como Bíon de Esmirna (fr. 12), Dio Crisóstomo (57.28) e Plutarco (Moralia 93E) elogiam a amizade que unia aqueles heróis. Sobre o tema $\varphi$ ı $\lambda$ í $\alpha$, vejam-se, e. g., Adkins (1963: 30-45); Dover (1974); Konstan (1997).

${ }^{128}$ Sobre a importância da hospitalidade no mundo grego, consultem-se, e. g., Finley (1988: capítulo IV); Herman (1987).

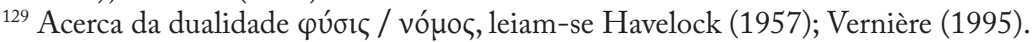

${ }^{130} \mathrm{O}$ vinho representa civilização, mas o seu efeito sobre a barbárie, que facilmente se deixa atrair por ele, é corrente. Trata-se de um elemento convencional nas relações entre civilização e barbárie. Cf. E. Cyc.; Hdt. 1 e 3.

${ }^{131}$ Quíron é apresentado como educador de Jasão, por exemplo, em Hes. Th. 992 sqq; como mestre de Asclépio (ou Esculápio) em Apollod. Bibl.3.10.3; de Actéon, em Apollod. Bibl.3. 4. 4 e de Aquiles, em Il. 11. 832.

${ }^{132}$ Cf. Calame (1990: 263); Bois (1982: 49;1979: 43); Hall (1991); Portela (2002: 102-104).

${ }^{133}$ Plutarco refere Herodoro como sendo o autor que nega a participação de Teseu em outras aventuras, mas não especifica a identidade dos que o contrariam e com os quais parece concordar. 
figuras não menos famosas, como é o caso de Jasão (em busca do velo de ouro $^{134}$ ), Meleagro (no extermínio do javali ${ }^{135}$ ) e Adrasto $^{136}$ (na recuperação dos cadáveres dos que caíram às portas de Tebas). É com base nestes exemplos que o Queroneu aproveita para justificar o uso da expressão «nada sem Teseu»

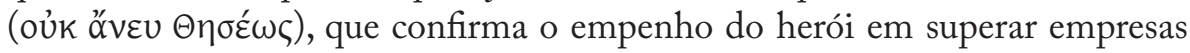
de monta, em auxiliar o próximo e sugere o futuro empreendedorismo de Atenas ${ }^{137}$.

Com intuito semelhante, isto é, para justificar o epíteto de Teseu - que ficou

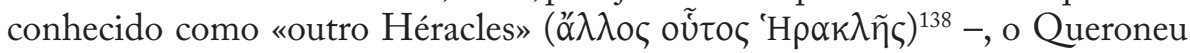
evoca, sem contudo aludir a um único exemplo específico, os diversos problemas ultrapassados pelo herói sem o apoio de ninguém. É provável que a ausência de exemplos se deva ao facto de considerar que o tema já estava suficientemente desenvolvido nos capítulos anteriores e de apenas querer aproveitar o contexto da referência à expressão «nada sem Teseu» para lembrar o epíteto (algo que lhe poderia ter escapado no princípio da biografia, quando desenvolveu o tema da emulação). De qualquer modo, passa-nos a mensagem de que, com todo o seu empenho, o herói conseguiu alcançar o seu objetivo e igualar os feitos e a fama de Héracles.

Esse intento foi de tal modo conseguido que se reflete até no âmbito da vida amorosa de $\mathrm{Teseu}^{139}$, que, também neste campo, imita a maneira de ser do filho de Alcmena, caracterizada por um comportamento sexual excessivo $^{140}$.

A primeira relação mencionada por Plutarco é a que Teseu manteve com Periguna, filha de Sínis, depois de aniquilar o pai da jovem. Curiosamente, o

${ }^{134}$ Embora não seja referido por todos os autores que escrevem sobre os Argonautas, Teseu surge como um deles, e. g., em Apollod. Bibl.1.9.16 sqq.

${ }_{135}$ Paus. 8. 45. 6; Hyg. Fab. 38.

${ }^{136}$ O principal testemunho da participação de Teseu nesta expedição são as Suplicantes de Eurípides, primeiro texto a apresentar o herói como fundador da democracia ateniense. Nele, Teseu é apresentado como modelo de governante do regime democrático e como defensor de valores essenciais para o homem grego. Vide Ribeiro Ferreira (1986: 87-121); Burian (1985: 129-155); Mills (1997:87-128); Walker (1995: 146-169).

${ }^{137}$ Cf. infra capítulo «Atenas, umbigo da Hélade», p. 120.

${ }^{138}$ Cf. supra p. 54 sqq.

${ }^{139}$ Disso nos dá notícia Ath. 557a-b: «No décimo quarto livro da sua História da Ática, Istro [FGrHist $334 \mathrm{~F} 10]$, ao enumerar as mulheres que foram de Teseu, diz que algumas delas se tornaram suas esposas por amor, outras por rapto, outras ainda por casamento legal. Por rapto foram-no Helena, Ariadne, Hipólita e as filhas de Cércion e Sínis. Mas desposou legalmente Melibeia, a mãe de Ájax. Hesíodo, porém, afirma que Teseu casou com Íope e Egla, por causa da qual até quebrou as suas promessas a Ariadne, como diz Cécrope. Ferecides acrescenta Ferebeia. Mas antes da sua aventura com Helena, também raptou Anaxo de Trezena. Depois de Hipólita, casou com Fedra».

${ }^{140}$ Cf. S. Tr. 351-369, 459-460; Apollod. Bibl. 2. 7. 8. A tradição que atribui a Héracles não só várias mulheres como uma prole de setenta filhos deve-se certamente ao caráter nacional do seu culto e ao facto de diversas famílias reivindicarem ser descendentes deste herói. 
Queroneu refere-se a este episódio em dois passos - Thes. 8.3-6 e 29.2 - , que, aos olhos do leitor mais atento, são contraditórios. De facto, em Thes. 8. 3-6, Plutarco evita abordar abertamente o estupro de que Periguna (segundo afirma em Thes. 29. 2) terá sido vítima. É que, na fase inicial da biografia, pretendia retratar um herói virtuoso, pelo que não convinha começar a revelar as suas falhas morais - ainda que deixe no ar uma impressão negativa ${ }^{141}$. Assim, o que se narra em Thes. 8. 3-6 parece ser um mero ato de sedução ao qual a jovem, ante a insistência e promessa de Teseu - e apesar da resistência oferecida de início -, acaba por ceder.

Esta aventura reveste-se, contudo, de importância política, na medida em que dela nasceu Melanipo (vencedor dos Jogos Nemeus no tempo dos Epígonos), que, por sua vez, teve um filho chamado Ioxo, que participou na fundação de uma colónia na Cária e se tornou antepassado dos Ióxidas, o que associa a cidade de Atenas à nova ró $\lambda_{\mathfrak{l}}$. Demais, reveste-se de importância etiológica, pois atribui-se a origem do hábito que esse povo tinha de não queimar nem arbustos espinhosos nem espargos silvestres ao facto de Periguna ter encontrado abrigo entre essas plantas quando fugia de Teseu.

A segunda relação tratada pelo biógrafo é a que uniu Teseu a Ariadne ${ }^{142}$. No capítulo 19, menciona três versões a propósito da forma como se estabeleceu a relação entre a princesa cretense e o herói. As duas primeiras põem em evidência o amor que Ariadne sentiu pelo ateniense. Segundo a maioria (oi

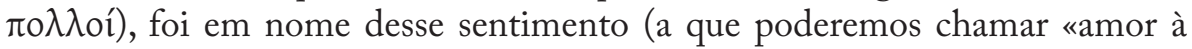
primeira vista») que a princesa instruiu Teseu e lhe deu os meios necessários (fio) para derrotar o Minotauro e, em seguida, partir com ela e com os jovens atenienses. Assim, e de acordo com esta versão, é Ariadne quem seduz Teseu: em troca das indicações para vencer o Minotauro, apenas deseja que o herói a leve como sua noiva quando partir.

A versão da maioria ${ }^{143}$ - que Plutarco não desenvolve - contém todos os elementos típicos do motivo da princesa casadoira que se apaixona pelo príncipe estrangeiro, por amor do qual trai o pai e que, após a fuga (que lhe permite não só continuar ao lado do amado, mas também escapar à cólera paterna), acaba por ser abandonada. Torna-se, por isso, impossível deixar de apontar as

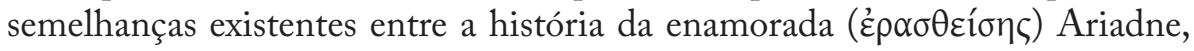

${ }^{141}$ Como afirma Larmour (1988: 373), «the picture of the young woman supplicating the plants to help her hide is so touching and pathetic that it contributes much to the negative impression we form of Theseus when he impregnates her, gives her to someone else and goes off in search of new adventures».

${ }^{142}$ Sobre o mito de Ariadne, leiam-se Webster (1966: 22-31) - que trata não só as diferentes versões do mito como alguns testemunhos iconográficos; Graves (2004: s. v.); Grimal (1992: s. v.). Para a tradição literária e iconográfica, Brommer (1972: 86-92); a propósito da iconografia, consulte-se ainda LIMC Ariadne 55-74 e 75-92.

${ }^{143}$ Cf., e. g., D. S. 4. 61. 4-5; Apollod. Epit. 1. 8; Hyg. Fab. 42. 
sem cujo apoio Teseu não teria vencido o Minotauro, e as de Nausícaa (que, para socorrer o herói estrangeiro, põe em causa a sua reputação de donzela) ou de Medeia (que, para auxiliar Jasão, também põe de parte os laços que deveriam uni-la à família e à terra natal $)^{144}$.

Além do mais, esta versão faz de Ariadne condutora de Teseu ao poder, na medida em que o ajuda a livrar os Atenienses do tributo e, consequentemente, a aumentar a confiança do povo no herói. Esta relação prefigura-se, portanto, como antítese da que une Teseu e Helena, na sequência da qual o filho de Egeu se vê obrigado a abandonar a liderança de Atenas.

De acordo com a versão racionalista de Filócoro, a jovem não presta qualquer auxílio ao herói. É este quem, sozinho, tem todo o mérito da vitória sobre o presunçoso e odiado general Tauro, na sequência da qual consegue recuperar os jovens reféns, fazer com que o tributo seja suspenso e atrair a atenção de Ariadne, que dele se enamora por causa da sua prestação no concurso. Esta versão reforça, assim, não só o papel de Teseu na salvação de Atenas, mas também a ideia de que era um «homme fatal», ao qual as mulheres tinham alguma dificuldade em resistir, algo que é sugerido, por exemplo, pela fidelidade de Antíope ${ }^{145}$ e pelo facto de Periguna, apesar da rejeição inicial, acabar por responder ao seu chamamento. Além disso, parece insinuar que a partida de Ariadne não é consequência de um rapto (como sugerem Od. 11 . 321 sqq.; D. S. 4. 61. 4; Ov. Ars. 1. 509-510, Met. 8. 180; Hyg. Fab. 42) e sim do desejo de uma jovem apaixonada.

A terceira versão, a de Clidemo (FGrHist 323 F 17), é aquela que Plutarco rejeita por considerá-la demasiado fantasiosa, já que relaciona o conflito com a fuga de Dédalo para Atenas e o seu fim com um pacto de amizade celebrado entre Teseu (que já assumira o poder na cidade) e Ariadne que, na sequência da morte do seu irmão Deucalião, estava à frente dos destinos de Creta ${ }^{146}$. Esta versão peca por colocar Teseu no poder antes do tempo. Se Plutarco a refere, fá-lo ou pelo seu pendor racionalista ou para realçar a existência de versões que alteram demasiado o esquema corrente do mito. Para Jacoby (1949: 137 sqq.), estamos perante uma historização da lenda com objetivos propagandísticos pró-atenienses: estes não só respeitam as normas de hospitalidade ao não entregarem o hóspede ao inimigo que o exigia ${ }^{147}$, como ainda conseguem resgatar os reféns atenienses detidos pelos Cretenses e celebrar um acordo de paz. Atenas

${ }^{144}$ Sobre esse paralelo, leia-se García Gual (2001: 154).

${ }^{145}$ Supra p. 73 sqq.

${ }^{146}$ Segundo D. S. 4. 62. 1; Apollod. Epit.1.17, o conflito terminaria com a concessão da mão de Fedra em casamento a Teseu.

${ }^{147}$ Do mesmo modo que Demofonte, filho de Teseu e Fedra, quando assume o poder, rejeita entregar os filhos de Héracles (que se haviam dirigido a Atenas como suplicantes) a Euristeu. Cf. E. Heracl. 236 sqq. 
surge, portanto, mais uma vez, como guardiã dos valores pan-helénicos e protetora dos fracos e oprimidos ${ }^{148}$.

Plutarco dedica o vigésimo capítulo desta biografia aos rumores que se prendem ao fim da relação de Ariadne e Teseu e que considera infundados. Todos têm em comum o facto de a jovem ter sido abandonada - voluntária ou involuntariamente - pelo herói. Segundo Hesíodo, tê-lo-á feito de livre vontade, por estar apaixonado por outra jovem, Egla ${ }^{149}$. Já segundo Péon de Amato (FGrHist 757 F 2) - única versão de abandono involuntário a que o biógrafo alude -, foi por causa de uma tempestade que os impeliu para a ilha de Chipre que Teseu deixou Ariadne: é que, como a jovem estivesse grávida e nauseada e a ilha próxima, aportaram para que Ariadne se pudesse recompor; mas Teseu, que permaneceu a bordo, foi novamente levado para o alto-mar pela procela. Quando o herói conseguiu regressar (o que prova que não tivera intenção de abandonar a jovem), já esta havia falecido durante o trabalho de parto infrutífero. Esta história, além de desculpabilizar Teseu, que fica consternado com a notícia, serve de aítıov para o culto de Ariadne instituído na ilha de Chipre ${ }^{150}$ e para o nome do bosque onde está a sepultura da heroína - bosque de Ariadne Afrodite.

Embora o Queroneu não a registe ${ }^{151}$, corria uma outra versão que resulta certamente de um reaproveitamento político do mito, na medida em que serve para evidenciar as virtudes de Teseu enquanto homem de Estado, capaz de sacrificar a sua felicidade em prol do povo ${ }^{152}$. De facto, segundo esta variante (atestada, iconograficamente, por exemplo, no vaso do pintor Sileu - vide LIMC Ariadne), Teseu foi, em sonhos, impelido pela deusa Atena a partir ${ }^{153}$

${ }^{148}$ Esta perspetiva é apresentada, por exemplo, no Édipo em Colono de Sófocles (tragédia na qual Teseu acolhe Édipo, velho cego e exilado), nas Suplicantes (na qual Teseu auxilia Adrasto a recuperar os corpos dos heróis caídos em Tebas), no Hércules Furioso (na qual Teseu conforta e acolhe o herói pan-helénico depois do massacre que este perpetrou contra a própria família) e nos Heraclidas de Eurípides (protagonizado não por Teseu, mas pelo seu filho e sucessor Demofonte).

${ }^{149}$ Para mais informações sobre esta jovem, vide infra n. 170.

150 Thes. 20. 6-7. Teseu não só deixou um fundo que permitiria custear a homenagem, como ainda indicações precisas: deviam ser feitos sacrifícios e erigidas duas estatuetas, uma de bronze e outra de prata. Durante as celebrações, que ocorrem no segundo dia do mês macedónio de Gorpieu (equivalente a agosto/setembro), um jovem comporta-se como se fosse uma parturiente. A propósito do culto de Afrodite em Chipre, consulte-se Karageorghis (1977: 194 sqq.); Pirenne-Delforge (1994: 34 sqq.).

${ }^{151}$ Esta omissão relaciona-se, provavelmente, com a promessa de apresentar um relato verosímil. Além disso, atribuir a preocupação com o povo e a đó $\lambda$ ıৎ a uma influência divina acabava por diminuir o comportamento do herói, já que sugeria que ele, por momentos, ter-se-ia esquecido da sua missão e que tal comportamento não era totalmente voluntário.

${ }^{152}$ Segundo Hyg. Fab. 43, Teseu não leva Ariadne para Atenas por ter consciência de que isso desgraçaria o seu futuro.

${ }^{153} \mathrm{Cf}$. Eust. Od. 1688, 41 sqq. Esta história encontra paralelo na de Eneias e Dido (Verg. $A$. 4), também ela abandonada pelo herói não por amor de outra mulher, mas porque a sua missão 
para cumprir a missão que o ligava à sua đó $\lambda ı$ c... Mas, neste caso, como que em jeito de compensação, Ariadne era «confortada» por Dioniso.

$\mathrm{Na}$ verdade, este deus assume um papel importante no mito de Ariadne, na medida em que surge como seu companheiro em diversas variantes, a maioria das quais faz dele pai dos filhos da princesa de Creta ${ }^{154}$. Há contudo autores, de entre os quais Íon de Quios (fr. 7 Gentili-Prato - o único mencionado por Plutarco), que asseveram que alguns dos filhos de Ariadne nasceram da sua relação com Teseu: é o caso de Enópion ${ }^{155}$ ('o que bebe vinho'), fundador de Quios, onde introduziu o consumo do vinho tinto, e Estáfilo $^{156}$ ('cacho'). Outros autores, a que Plutarco não alude, conferem a Teseu e não a Dioniso a paternidade de Toas ('impetuoso') de Lemnos ${ }^{157}$. A atribuição da paternidade dos filhos de Ariadne ao herói ateniense (que assim têm, à semelhança do que acontece com Teseu ou Héracles, um pai humano e um divino - que Plutarco não refere) parece ser mais uma tentativa política de readaptação do mito, de modo a que a relação entre Atenas e algumas das cidades súbditas e aliadas surja como ancestral e, portanto, impossível de alterar.

Ora, como já dissemos, a relação entre Dioniso e Ariadne é um elemento importante do mito em causa. Contudo, a participação da divindade põe algumas dificuldades ao biógrafo, que opta por referir apenas duas versões que podemos considerar racionalistas. A primeira (Thes. 20. 1) apresenta como companheiro de Ariadne (após o abandono de Teseu) não o deus mas um seu sacerdote, Enaro, que habitava Naxos, ilha que lhe era consagrada.

Os habitantes de Naxos, por sua vez, contavam uma variante deveras curiosa, que apresenta dois Minos ${ }^{158}$ e duas Ariadnes (Thes. 20. 8-9 = FGrHist 501 F 1). Uma era companheira de Dioniso, do qual deu à luz Estáfilo, e é homenageada com uma festa alegre. A outra chegou a Naxos com uma ama, depois de ter sido raptada e abandonada por Teseu, ${ }^{159}$ e é homenageada com uma festa triste. Deste modo, não só avançavam uma etiologia para a existência

não podia deixar de se cumprir. Segundo outra versão, é o próprio Dioniso que aparece em sonhos a Teseu para, por meio de ameaças, convencê-lo a abandonar a jovem.

${ }^{154} \mathrm{O}$ número de filhos atribuídos a este casal é variável e os seus nomes, todos eles falantes, relacionam-nos com alguns dos atributos de Dioniso. Sobre este assunto, vide Calame (1990: 247).

${ }^{155}$ Cf. Hyg. Astr. 2. 34; D.S. 5.79. 1 e 5.84. 3 e Apollod. Epit. 1. 9 (onde surge como filho de Dioniso).

${ }^{156}$ Apollod. Bibl. 1. 9. 16., Epit. 1. 9; D. S. 5. 62. 1; Parth. Erot. 1. Plutarco, ao afirmar que Íon de Quios também refere Estáfilo, não é rigoroso, pois o verso a que alude apenas menciona Enópion. Cf. Calame (1990: 282, n. 148).

${ }^{157}$ Sobre Toas, vide Apollod. Bibl.3. 6. 4, Epit. 1.9 17; Hyg. Fab. 15, 74, 120, 121, 254, 261.

${ }^{158}$ Segundo D. S. 4. 60.3, o Minos inimigo de Atenas (ou seja, o que é referido nas tragédias) é neto do legislador (que é referido nas epopeias). Flacelière (1948: 79) interpreta esta disjunção como uma forma de evitar que ao juiz do Hades fossem atribuídos feitos tão negativos.

${ }^{159}$ Esta versão difere das restantes que fazem da ilha o local do abandono. 
do túmulo da ama de Ariadne na ilha, como também evitavam que Dioniso, deus protetor de Naxos, surgisse como adversário desleal de Teseu ${ }^{160}$.

Quando Plutarco, na fase final da biografia, volta a abordar o tema das relações amorosas de Teseu, começa por evocar o triângulo Teseu/Antíope/ Fedra. Em Thes. 28, é negada a versão da Teseida ${ }^{161}$, segundo a qual, como já vimos, o ataque das Amazonas decorrera dos ciúmes sentidos por Antíope, preterida pelo herói em favor de Fedra ${ }^{162}$. Segundo o Queroneu, que considera desnecessário entrar em pormenores relativamente à história de Teseu e Fedra ${ }^{163}$, o casamento entre o herói e a jovem só teve lugar após a morte da Amazona.

Portanto, o episódio das Amazonas serve de pretexto para o tratamento da vida amorosa do fundador de Atenas, da qual se escolhem sobretudo os casos sobre os quais os tragediógrafos não escreveram (Thes. 29. 1-2). É interessante notar que o biógrafo, ao abordá-los, contraria a tradição corrente $^{164}$ que, sobretudo a partir do séc. $\mathrm{V}$ a.C., começou a deixar cair no esquecimento estas aventuras menos dignas de um herói nacional. São menos dignas, porque resultam de uma conduta que assenta em princípios menos nobres, pois, para satisfazer os seus apetites, Teseu rapta, viola ou seduz ardilosamente mulheres e jovens indefesas, dando origem a relações

${ }^{160}$ Cf. Calame (1990: 113-114).

${ }^{161}$ Sobre esta epopeia que muito terá contribuído para a elaboração e difusão das aventuras de Teseu, vide supra p. 71, n. 95.

${ }^{162}$ À semelhança de Jasão relativamente a Medeia, também Teseu abandona Antíope para se casar com uma esposa grega, Fedra. Sobre os amores com a Amazona, vide Calame (1990: 261). Cf. supra p. 73 , nota 111.

${ }^{163}$ Segundo o autor, este tema foi corretamente desenvolvido nas tragédias, já que tudo o que nelas se afirma está em conformidade com o que dizem os historiadores. É essa a razão que Plutarco apresenta para não desenvolver o assunto no âmbito da sua biografia. No entanto, esta afirmação parece-nos um subterfúgio através do qual evita aludir a mais um excesso cometido pelo herói por causa do «amor» e que em nada abona o seu comportamento e caráter. Como no-lo testemunha, por exemplo, Eurípides no Hipólito, foi por vingança, por orgulho ferido, por causa da dor causada pela morte de Fedra que Teseu desejou e exigiu a Poséidon a morte do próprio filho. Na opinião de Larmour (1988: 374), o Queroneu não desenvolve o tema para, no momento de comparar Teseu e Rómulo, poder argumentar com mais eficácia contra o comportamento do romano. Efetivamente, Plutarco só menciona o que se passou com Hipólito no terceiro capítulo da synkrisis. Ao comparar a morte de Hipólito com a de Remo às mãos de Rómulo, o Queroneu apresenta o comportamento do herói ateniense (que se deixa

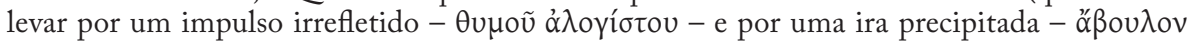

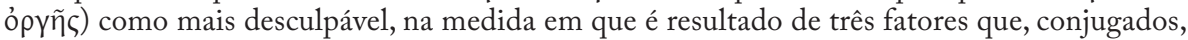

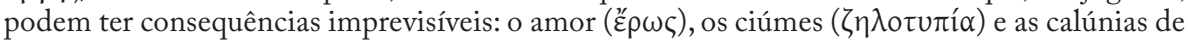

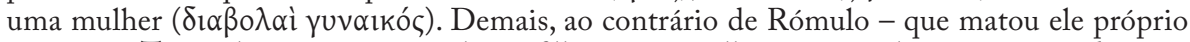
o irmão -, Teseu «limitou-se» a insultar o filho e a rogar-lhe pragas, pelo que o jovem deve ser considerado vítima da fortuna. Sobre este assunto, consultem-se, entre outros, Orban (1981: 3-17); Knox (1952: 3-31); Karsai (1982: 113-127); Mills (1997: 186-221). Teseu.

${ }^{164}$ Isócrates, por exemplo, no «Elogio de Helena», nada diz sobre as peripécias amorosas de 
que não podem ter um final feliz. É provável que ao referir tais aventuras - de modo mais breve do que as restantes, que serviram para delinear o seu perfil político - o tenha feito com a intenção de educar pela negativa (técnica a que raramente recorre $\left.{ }^{165}\right)$, para mostrar que ninguém se deve deixar levar cegamente pelo desejo sexual.

Segundo a tradição que Plutarco evoca - mas não identifica -, o primeiro rapto, cuja vítima tinha o nome de Anaxo, remonta ao período em que viveu em Trezena e as primeiras violações, à sua viagem por terra até Atenas. Foram perpetradas contra Periguna ${ }^{166}$ e Álope ${ }^{167}$, filhas respetivamente de Sínis e Cércion, depois de os seus pais terem sido aniquilados por Teseu.

Plutarco menciona ainda o casamento do herói com outras mulheres, nomeadamente Peribeia ${ }^{168}$, Ferebeia, Ílope ${ }^{169}$ e Egla Elo $^{170}$ (por amor da qual abandonou Ariadne), aproveitando para criticar a atuação de Teseu para

${ }^{165}$ Nas biografias de Demétrio e de António, por exemplo, Plutarco evidencia não as virtudes, mas os vícios, sempre com os mesmos objetivos pedagógicos. Segundo o biógrafo, se a contemplação das qualidades nos incita a imitá-las, a dos vícios permite-nos fazer um autodiagnóstico e põe-nos em estado de alerta, pois já tivemos oportunidade de verificar, através dos paradigmas, quão nefastos são os efeitos de qualidades negativas. Além disso, apreciamos melhor o que é bom se tivermos um termo de comparação...

${ }^{166}$ Vide supra p.79

${ }^{167}$ Consta que Álope, filha de Cércion (cf. Paus. 1. 39.3 e supra p. 78, n. 138) deu à luz Hipótoo, filho de Poséidon, que abandonou por temer a reação de seu pai. Quis o destino que Cércion descobrisse a existência do neto - que mandou expor uma segunda vez - e que mandasse prender a filha, que viria a morrer no cárcere (segundo Hyg. Fab. 187, Poséidon transformou o corpo da jovem em uma fonte). Das duas vezes em que foi exposto, Hipótoo foi amamentado por uma égua (Hyg. Fab. 252). Quando Teseu matou Cércion, o jovem filho de Poséidon pediu ao herói que lhe desse o trono da Arcádia. Hipótoo tornou-se epónimo da tribo ática dos Hipotoôntidas.

168 Segundo Apollod. Bibl. 3. 12. 7; Paus. 1. 42. 2, Peribeia, Eribeia ou Ferebeia é filha de Alcátoo (rei de Mégara) e mãe de Ájax. Antes de ser desposada por Télamon, integrou o grupo de jovens que partiram com Teseu para Creta. Segundo Hyg. Astr. 2. 5, Minos - que havia ido a Atenas reclamar o tributo - apaixonou-se, durante a viagem para Creta, pela jovem que, assediada, rogou o auxílio de Teseu. Como este alegasse que, enquanto filho de Poséidon não era inferior a Minos, filho de Zeus, o rei decidiu pôr o herói à prova e lançou o seu anel ao mar: se, de facto, Teseu fosse filho do deus do tridente, seria capaz de lhe restituir a joia. Foi por essa ocasião que Teseu visitou o palácio do seu pai divino, que lhe devolveu o anel de Minos. Mais tarde casou-se com Peribeia. Esta personagem está representada na cena cretense do vaso François. Cf. LIMC 3. 1, s. v. "Eriboia", 919-921. É provável que Plutarco não se tenha alargado sobre este romance para evitar nova menção à filiação divina do herói ateniense. Vide supra p. 53, nota 14. O facto de desta relação não ter resultado descendência talvez se justifique com a inimizade entre Atenas e Mégara: seria difícil explicá-la se um descendente mítico de Atenas também o fosse de Mégara. No entanto, no séc. V a.C., houve uma tentativa de reformulação genealógica que fazia de Âjax filho de Teseu. Sobre este assunto, vide Calame (1990: 441-442, 464, n. 98).

${ }^{169}$ Filha de Íficles, o gémeo de Héracles. Talvez se trate de mais uma tentativa para relacionar os dois heróis. Não se conhecem pormenores sobre a lenda desta jovem.

${ }^{170}$ Esta versão já havia sido apresentada em Thes. 20. 1, através de um verso que, segundo Héreas de Mégara, Pisístrato terá eliminado dos poemas de Hesíodo (fr. 298 Merkelbach-West),

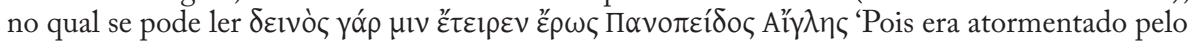
amor da Panopeida Egla'. Egla é um nome falante, já que $\alpha$ ǐ $ү \lambda \eta$ significa 'esplendor', 'luz do Sol'. 
com a jovem cretense, que considera indecente ( $\mu \grave{\eta} \kappa \alpha \lambda \eta ́ v)$ e incorreta ( $\mu \eta \delta \dot{\varepsilon}$ $\pi \rho \varepsilon ́ \pi 0 v \sigma \alpha v)$.

Convém chamar a atenção para o facto de, neste capítulo, não se fazer mais do que uma ligeira referência à relação entre o herói e Ariadne. Tal acontece, porque esta foi desenvolvida até à exaustão a propósito da vitória de Teseu sobre o Minotauro. À semelhança do que acontece com Periguna, o Queroneu, que se abstivera de reprovar o procedimento do herói na parte da obra dedicada à exaltação das suas virtudes, aproveita o teor do vigésimo nono capítulo para censurar o abandono de Ariadne.

Mas, para o biógrafo, o cúmulo do desvario é o rapto de Helena (Thes. 31), ao qual atribui a responsabilidade pela invasão da Ática levada a cabo pelos Dioscuros e a queda ${ }^{171}$, desterro e morte de Teseu.

Este episódio é um dos mais antigos da saga do herói. Um dos primeiros testemunhos dessa ancestralidade ${ }^{172}$ ocorre em Il.3. 144, verso no qual Etra, a mãe do herói, é identificada como uma das criadas de Helena ${ }^{173}$. Curiosamente, embora o motivo do rapto de Helena tenha sido largamente tratado na literatura ${ }^{174}$, nunca é referido nas tragédias protagonizadas por Teseu, o que é consequência de estas (à exceção do Hipólito de Eurípides) já o retratarem com as virtudes que costumam estar associadas à personalidade do fundador mítico de Atenas, o que coibia os autores de referirem este comportamento considerado uma mancha no «curriculum» de Teseu (cf. Isoc. 10. 18; D. S. 4. 63.3).

Por essa mesma razão, este mitema aparece representado em artefatos ${ }^{175}$ (como vasos, a couraça em bronze de Olímpia, os relevos em bronze do escudo de Olímpia e os relevos em ouro do escudo de Creta) anteriores ao séc. V a.C. e oriundos do Peloponeso ou de Creta, e nunca na arte monumental. Segundo

${ }^{171}$ Sobre a queda, vide infra p.109 sqq. A propósito da tradição literária e iconográfica relacionada com este rapto, vide Brommer (1972: 93-96). Para os testemunhos iconográficos, consulte-se ainda $L I M C$ 4. 1., s. v. "Helena", 507-513.

172 Sobre este assunto, vide Mills (1997: 7); Walker (1995: 17-18). (1995: 18).

${ }^{173}$ A autenticidade deste verso tem sido posta em causa por alguns estudiosos. Cf. Walker

${ }^{174}$ E. g. Alcm. frs. 21 e 22 Page; Stesich. fr. 191 Page; Pi. frs. 243 e 258 Snell; Apollod. Epit. 1. 23; Hyg. Fab. 79. Para uma visão alargada do mito de Helena, consultem-se, entre outros, Lindsay (1974); Alsino Clota (1957: 373-394); Komornicka (1991: 9-26); Ghali-Kahil (1955). Corria entre os antigos que Helena, difamada por Estesícoro, cegara o poeta em jeito de castigo (cf. Isoc. 10. 46; P1. Phdr. 243 e R. 586). Contudo, dera-lhe a possibilidade de se redimir e recuperar a visão. Por isso, o poeta compôs um novo poema, no qual negava tudo quanto antes afirmara, com base no pressuposto de que a Helena que acompanhara Páris a Troia

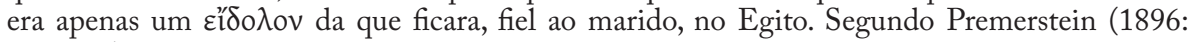
634-653), que procura racionalizar esta lenda, o primeiro poema de Estesícoro terá causado grande descontentamento nas populações que habitavam os locais onde Helena recebia culto, já que os fiéis não podiam aceitar que Helena fosse responsável pela Guerra de Troia.

${ }^{175}$ Cf. Brommer (1972: 96). 
Paus. 5.19. 2 e 3.18.15, respetivamente, era uma das histórias que decorava a Arca de Cípselo e o trono de Báticles. Há apenas notícia de um vaso de finais do século $\mathrm{V}$ a trabalhar este episódio. Nele, a ligação de Teseu com Helena parece ser sancionada pelas leis e pelos deuses, pois Teseu surge como um jovem, que desposa a bela Helena na presença dos pais e irmãos, entre outros convidados $^{176}$.

O primeiro fator a escandalizar o biógrafo - que se refere ao rapto através

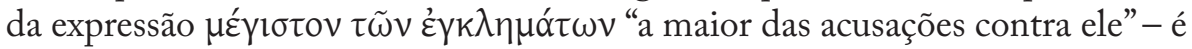
a diferença de idades existente entre Teseu e Helena ${ }^{177}$. Segundo Helânicoo, este ato foi resultado do desvario de um «velho» de cinquenta anos (FGrHist 323a F 18), que não soube respeitar uma criança...de sete (FGrHist 323a 19) ${ }^{179}$.

Outro aspeto a indignar Plutarco é o facto de Teseu ter arrastado a sua cidade - que, enquanto governante, deveria proteger - para um conflito, com a agravante de não estar presente para acorrer em sua defesa ${ }^{180}$.

Além disso, «deixou» que a mãe - decerto com mais de sessenta anos! fosse feita cativa e passasse a servir em Esparta. Isso permite-nos afirmar que o herói foi, ainda que involuntariamente, um mau filho, que falha no que respeita à pietas erga parentes, pois a sua leviandade originou, como já vimos (cf. supra p. 70), a morte do pai e um fim de vida servil para a mãe (Thes. 34$)^{181}$.

${ }^{176}$ Cf. Shapiro (1992: 232-236).

177 Contudo, como muito bem afirma García Gual (1990: 152, n. 25), na maior parte dos vasos da época arcaica e clássica que representam o rapto de Helena, Teseu é retratado com menos idade, como um efebo jovem e elegante. Cf. Shapiro (1990: 232-236). García Gual justifica esta discrepância, argumentando que «comme dans des autres récits biographiques, Plutarque admet la décadence après l'åkuń du protagoniste, comme un fait naturel». De qualquer modo, parece-nos constituir uma atenuante o facto de Teseu, reconhecendo a pouca idade de Helena, não a molestar e deixá-la à guarda de Etra em Afidnas. Há, porém, autores como Estesícoro - que atribuem a paternidade de Ifigénia a Teseu e Helena. Segundo Paus. 2. 22. 7, alguns autores afirmavam que Helena entregara a filha a Clitemnestra para que a criasse como sua. Só assim conseguiria sustentar que permanecia virgem, quer perante os irmãos quer perante o futuro marido, Menelau.

${ }^{178} \mathrm{Na}$ verdade, o relato de Helânico é o que mais denigre a figura de Teseu, ao apresentar o herói como um indivíduo irresponsável, não só por causa da discrepância de idades, mas sobretudo pelo rapto, que decorre da decisão de dois amigos que querem casar-se com filhas de Zeus.

${ }^{179} \mathrm{O}$ biógrafo evoca duas tradições - das quais discorda - que procuraram escusar Teseu de culpas. O herói surge em ambas como «fiel depositário» de Helena, que, segundo uma das versões fora raptada por Idas e Linceu para vingarem o rapto das Leucípides pelos Dioscuros (Apollod. Epit. 1. 24; Tz. ad Lyc. 143) ou, segundo a outra, lhe fora diretamente confiada por Tíndaro que, depois de ter usurpado o trono de Esparta, temia pela segurança da filha (Apollod. Epit. 1.24).

${ }^{180}$ Acerca do comportamento de Teseu enquanto político, vide infra p. 93 sqq.

${ }^{181}$ No sentido de contrariar a má impressão causada e de atestar a pietas erga parentes ateniense e também de aumentar a participação de Atenas na Guerra de Troia (Dem. 60. 29), poemas do ciclo épico, como Il. Pers. 4 e 11 e Il. Parv. 23d, referem que Acamante e Demofonte integraram a expedição a Troia com o intuito de salvar a avó, Etra. 
Mas este episódio tem também uma dimensão política. Por um lado, prefigura-se como uma das causas da ancestral rivalidade entre Atenas e Esparta, que viria a culminar na Guerra do Peloponeso. Note-se que esta rivalidade longínqua tem uma origem semelhante à daquela que é considerada uma das piores guerras de todos os tempos - a Guerra de Troia (que, por sua vez, opôs Gregos e Bárbaros, Ocidente e Oriente) -, também ela provocada pelo rapto de Helena. Por outro lado, relaciona dois heróis epónimos com o demos a que deram nome: Afidno com Afidnas, região onde Helena esteve escondida, e Academo com a Academia, que, por ocasião de invasões posteriores (nomeadamente a Guerra do Peloponeso) sempre foi poupada, por causa do auxílio prestado por Academo aos Dioscuros que andavam à procura de Helena. Esta ajuda é, no fundo, resultado da ação de inimigos de Teseu, como muito bem salienta Heródoto (9.73), que, na sua versão, afirma explicitamente que os irmãos de Helena foram auxiliados por Décelo ${ }^{182}$, que estava irritado com a audácia de Teseu, e por Titaco, habitante de Afidnas, que lhes entregou a região.

Importa ainda ter em conta a versão referida em Thes. 32. 6 e Paus. 1. 41. $4^{183}$, que faz deste rapto um antecedente da inimizade entre Atenas e Mégara, já que menciona o auxílio prestado por um megarense aos Dioscuros quando estes atacaram Afidnas. O jovem megarense terá, segundo alguns (de entre os quais Héreas - FGrHist $486 \mathrm{~F}$ 2), morrido às mãos de Teseu em Afidnas, versão que Plutarco e Pausânias rejeitam com base no facto de Etra ter sido levada como cativa para Esparta - se Teseu não estava presente para acudir à mãe, como seria possível que o inimigo morresse às suas mãos?

Além do que já foi dito, importa recordar que a invasão da Ática pelos Dioscuros foi aproveitada por Menesteu ${ }^{184}$ - que representava a oposição ao herói - para atacar o fundador mítico da democracia ateniense. A repercussão da invasão e do ataque de Menesteu foi tal que, quando regressou, Teseu depressa se viu forçado a abandonar o poder.

O Queroneu critica ainda o pacto que Teseu fez com o seu amigo Pirítoo logo após terem conseguido fugir com a Tindárida: um deles ficaria com Helena e ajudaria o outro a encontrar uma companheira, também ela de ascendência

${ }^{182}$ Décelo é o herói epónimo do demo de Deceleia, que, à semelhança do que se passava com a Academia, foi poupado durante as invasões posteriores. Segundo Heródoto, os seus habitantes tinham também privilégios em Esparta.

${ }^{183}$ Segundo Pausânias, os Dioscuros foram auxiliados por Titaco, filho de Megareu - cf. Loraux (1981: 38 e n. 13). A versão que Plutarco evoca (e atribui a Héreas - FGrHist 486 F 2) alude a um certo Hálico, filho de Ésciron, que deu nome ao local da região de Mégara onde se situava o seu túmulo.

${ }^{184}$ Menesteu era um neto de Erecteu que, aproveitando a ausência do herói, reestabelece o poder aristocrático nos diversos demos, reservando para si o «poder central» recém-fundado e quase logo abandonado por Teseu. 
divina ${ }^{185}$. Ou seja, o primeiro ato de desvario deu azo a outro igualmente grave, o rapto de Perséfone, de que falaremos em seguida.

Podemos verificar, mais uma vez, que, como é seu hábito ${ }^{186}$, Plutarco apresenta diferentes versões (mesmo aquelas com as quais não concorda) e indica a que lhe parece mais verosímil. No entanto, apesar de este ter sido um assunto tratado por vários autores, não enumera tantas variantes e pormenores como, por exemplo, a propósito do que se passou com Ariadne, pois a exploração do rapto de Helena - que é uma falta bastante mais grave - em nada contribui para a dignidade do herói. E, se Plutarco não o omite, é porque, não obstante pretender mostrar os seus heróis como modelos a seguir, não cai na tentação de elaborar perfis demasiado perfeitos, cuja imitação seria humanamente impossível e que, por isso mesmo, acabaria por dissuadir os jovens da emulação. Outrossim lança pistas que permitem ao leitor mais atento inferir as causas longínquas - e mitológicas - de realidades futuras, como os diferendos entre Atenas e Esparta e Atenas e Mégara ou o facto de, na sequência dessas desavenças, certas regiões da Ática serem poupadas pelo inimigo (cf. página anterior).

E impossível deixar de salientar que Plutarco não alude à versão de Isócrates, que dedicou diversas linhas ao tratamento do rapto da Tindárida em um texto intitulado «Elogio de Helena». Não admira: é que o comportamento que causou repulsa ao moralista serviu ao orador de repto para o elogio de Teseu!

Para Isócrates ${ }^{187}$, que não menciona a invasão da Ática pelos Dioscuros,

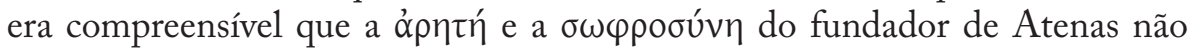
resistissem à beleza da divina Helena. Pelo contrário, defendia que a relação entre a mais formosa das filhas de Zeus e o homem mais nobre do seu tempo era inevitável e motivo de glória para ambos.

Demais, importa realçar que Plutarco não se insurge contra o crime de «rapto» em si mesmo. Em Comp. Thes. -Rom. 6, consegue aceitar esse delito como um mal necessário, tendo em vista o bem do povo, da cidade. Este é um dos pontos em que, na comparação de ambos os fundadores, Rómulo sai vencedor. É que, ao comportamento de Teseu - que não necessitava de mulheres estrangeiras para assegurar a continuação do povo, mas ainda assim colocou Atenas em risco ${ }^{188}$-, faltou um pretexto decoroso

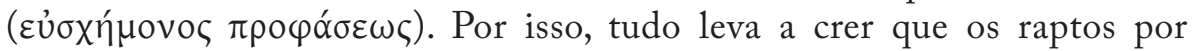
ele perpetrados tenham sido consequência da mera satisfação da sede de

${ }^{185}$ Segundo Helânico, ambas deveriam ser filhas de Zeus.

${ }^{186}$ Plutarco costuma ter o cuidado de apresentar testemunhos divergentes sobre os heróis em causa, de modo a deixar espaço para que seja cada leitor a construir uma opinião sobre o verdadeiro caráter daqueles.

${ }^{187}$ Isoc. 10.38 .

${ }^{188}$ Cf. Comp. Thes. -Rom. 6. 5. 


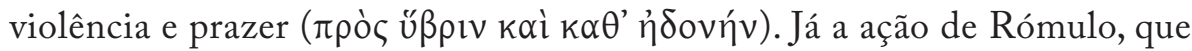
raptou um grande número de Sabinas ${ }^{189}$ que repartiu pelos concidadãos, veio a revelar-se uma ação formosa e de alto valor político (Kó $\lambda \lambda_{1} \sigma \tau$ tov

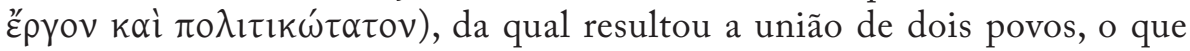

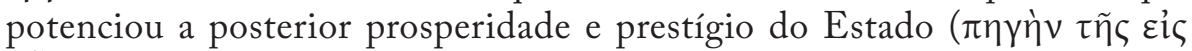

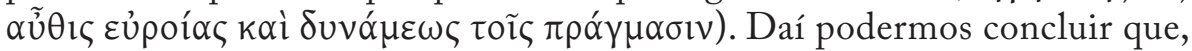
enquanto Teseu lutou por amor ao povo, tudo lhe correu bem e que, quando começou a agir para satisfazer os seus caprichos e desejos, as consequências foram devastadoras.

Isso mesmo no-lo comprova o episódio do rapto de Perséfone ${ }^{190}$, aventura que - já o dissemos - é apresentada como resultado de um pacto entre dois indivíduos para os quais a amizade é um valor inestimável ${ }^{191}$. Contudo, apesar de assente em um valor nobre, não deixa de configurar uma má ação, um ato de űßpıৎ, pelo que fica implícito que virtudes e qualidades, se usadas para o mal, têm más consequências. Segundo D. S. 4. 63. 4, Teseu teria noção disso, na medida em que se manifestou contra o rapto. No entanto, por causa da amizade que o ligava a Pirítoo, sentiu-se obrigado a manter o acordo.

O biógrafo não dedica muitas linhas a esta aventura: trata-se de uma má ação, com más consequências (pois obriga a uma ausência prolongadíssima, que dá azo à detração de Teseu por Menelau), além de ter um pendor excessivamente mítico. Opta, por isso - e no cumprimento dos princípios traçados no proémio da Vida de Teseu -, por evocar apenas uma versão racionalizadora do mito. Contrariando o que era voz corrente (que Teseu e Pirítoo teriam descido aos Infernos para raptar Perséfone ${ }^{192}$, mas, surpreendidos por Hades, teriam ficado detidos nas entranhas da Terra, presos às cadeiras onde se sentaram ${ }^{193}$ ), Plutarco afirma que Hedoneu, o rei dos Molossos, dera à esposa o nome de Perséfone, à filha, o de Cora ${ }^{194}$ e ao

${ }^{189}$ A propósito do número de mulheres raptadas por Rómulo, vide Pérez Jiménez (2000: 233 , nota 60 ).

190 São testemunhos literários desta aventura Hes. fr. 280 Merkelbach-West e Hellanic. FGrHist 4 F 134 = 323a F 20. Para a iconografia, vide Brommer (1982: 99-103). Sobre este episódio, consulte-se ainda García Gual (2001: 53, nota 4).

${ }^{191}$ Cf. Isoc. 10. 20. Sobre o valor da amizade, vide supra p. 76, nota 126.

${ }^{192}$ É interessante lembrar que os três «raptos» maiores de Teseu foram perpetrados contra deusas da vegetação - Ariadne, Helena e Perséfone. Cf. Walker (1995: 15-16); Lindsay (1974: 260); Alsino Clota (1957: 376).

${ }^{193} \mathrm{O}$ testemunho mais antigo desta presença no Hades remonta a Od.11.631. No entanto, este verso é, desde a Antiguidade, considerado uma interpolação. Cf. Calame (1990: 288, nota 180).

${ }^{194}$ Esta versão evemerista do mito situa a ação em Molosso. Isso decorre, provavelmente, do facto de os cães molossos terem fama de ser tão ferozes quanto Cérbero. Cora era o nome de Perséfone antes de ir para o Hades. Segundo Paus. 1. 17. 4 e 18. 4, a vítima escolhida para o rapto foi a mulher do rei de Tesprócia. 
cão, o de Cérbero, e que decidira dar a jovem em casamento ao pretendente que, tendo lutado contra o animal, saísse vitorioso. No entanto, avisado do intento dos dois amigos ${ }^{195}$, fez com que Cérbero devorasse Pirítoo e encarcerou Teseu, que, deste modo, foi impedido de auxiliar Atenas e a mãe aquando do ataque dos Dioscuros.

Esta versão apresenta elementos típicos das histórias de princesas em idade de casar (motivo recorrente em uma das versões do mito de Ariadne referida por Plutarco), nomeadamente a vinda de um príncipe estrangeiro que deve ultrapassar uma prova para conquistar a mão da donzela. $O$ facto de Teseu e Pirítoo pretenderem recorrer a um método menos ortodoxo, mais fácil e rápido, faz-nos pensar em Pélops, que, em circunstâncias idênticas, sabotou o carro do futuro sogro para sair vencedor. Hedoneu, contudo, ao contrário de Enómao, consegue gorar os planos dos heróis.

O Queroneu regressa a esta aventura (interrompida para contar ao leitor de que modo se desenvolveu em Atenas a oposição contra Teseu) no trigésimo quinto capítulo, para revelar que Teseu foi libertado por intercessão de Héracles que, um dia, fora recebido como hóspede por Hedoneu. Na versão tradicional, por ocasião da sua descida aos Infernos ${ }^{196}$ para lutar com Cérbero, o filho de Alcmena aproveitou para libertar o fundador de Atenas, seu primo e amigo, mas nada pôde fazer por Pirítoo.

A libertação do Hades - ou, se quisermos, a libertação do cativeiro em que se encontrava em Molosso - acaba por ser mais uma oportunidade para associar as façanhas de Teseu às de Héracles. De facto, não podia faltar uma catábase no curriculum de um herói que pretendia emular os feitos do filho de Alcmena, mesmo que o seu motivo fosse menos nobre do que o do filho de Zeus. E, ao ser salvo pelo herói pan-helénico, associa-se, no fundo duplamente, ao feito de Héracles. Embora «perca» por ter sido resgatado, isto é, por não ter conseguido libertar-se sozinho (o que não admira, dada a gravidade da üßpıৎ que cometeu - descer aos infernos e tentar raptar uma deusa), «vence» por surgir indiretamente como o primeiro dos dois heróis a ousar dirigir-se ao Hades.

Além disso, este resgate surge como uma espécie de moeda de troca, quando Teseu oferece abrigo em Atenas a Héracles (E. $H F)$. O filho de Egeu não lhe oferece guarida apenas por caridade, por amizade ou para ajudar um familiar, mas sobretudo para pagar o favor em dívida. É esta mesma razão que Plutarco apresenta para justificar o facto de apenas serem conhecidos quatro

${ }_{195}$ Plu. Moralia 96C alude a uma versão de acordo com a qual ambos os amigos eram pretendentes da jovem e cumpriram pena em conjunto.

${ }^{196}$ A descida aos Infernos e o encontro com os que já partiram é um motivo tradicional nas histórias dos heróis. Cf. Mills (1997: 10-11). 
santuários ${ }^{197}$ dedicados a Teseu $(\Theta \eta \sigma \varepsilon i ̃ \alpha)$ : é que, como prova de gratidão, o herói teria oferecido a Héracles todos os outros templos que lhe eram consagrados ${ }^{198}$.

Quando finalmente regressa a Atenas, Teseu depara-se com uma situação política e social, fomentada pela sua longa ausência, que em nada lhe é favorável.

${ }^{197}$ Desses templos, o mais antigo ficava na zona norte da cidade (e não na acrópole, como seria de esperar) e os restantes nos subúrbios - um junto às muralhas, outro no Pireu e um último em Colono. Sobre este assunto, vide Ampolo - Manfredini (1988: 256-257 e bibliografia citada).

${ }^{198}$ Cf. E. HF 1326-1337, segundo o qual um dos muitos argumentos que Teseu utiliza para convencer Héracles a ir para Atenas é a oferta de locais de culto que lhe haviam sido dedicados em agradecimento pela libertação dos jovens que partiram para Creta como tributo. Do ponto de vista histórico, terão sido os templos dedicados a Héracles a ser atribuídos a Teseu, pois eram mais antigos. 


\section{Ação POLÍtICA}

\section{3. $1 \mathrm{O}$ sinecismo e o funcionamento da nova Atenas}

Como veremos no capítulo «Atenas, umbigo da Hélade», os Atenienses só se começaram a afirmar como povo superior depois do advento do regime democrático e do triunfo dos Gregos sobre os Persas. Como muito bem afirma Walker (1995: 54), foi sobretudo a partir desse momento que os Atenienses sentiram necessidade de fazer de Teseu o seu herói:

«they were embarking on a new political adventure and needed the sanction of tradition, a sense of continuity with the past. They were ready to act independently of Sparta and needed to be reassured of their ancient glory. Theseus had never been anything more than one of many Athenian heroes, but after 510 в. c. he became the greatest hero of Athens».

Não surpreende, por isso, que muitas das características atribuídas aos Atenienses - como a imaginação, a iniciativa, a inovação, o empreendedorismo, o gosto pelo risco e pela aventura fora do seu espaço, a capacidade de decisão, a rapidez no projeto e na sua concretização, a ousadia na vitória e na derrota, o patriotismo ${ }^{199}$ - sejam, efetivamente, alguns dos traços estruturantes da personalidade de Teseu.É esse o caso da audácia e da temeridade que manifestou por diversas vezes ao longo das suas aventuras, ou do otimismo, cujo melhor exemplo talvez seja a confiança que demonstrou antes de embarcar para Creta, quando prometeu ao pai e aos concidadãos que regressaria a salvo, depois de libertar a đódıৎ do perigo que o Minotauro representava ${ }^{200}$.

Não causa, portanto, admiração que este herói (a cuja saga estão

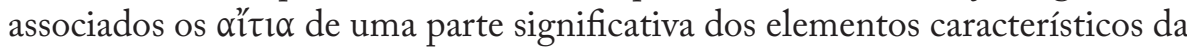
cultura e civilização de Atenas ${ }^{201}$ ) tenha sido o escolhido para funcionar como precursor do ateniense do séc. V a.C., não só em termos morais (apesar das «arestas» que tiveram de ser limadas para eliminar alguns defeitos e excessos de comportamento ${ }^{202}$ ), mas sobretudo em termos de conduta política. É esta última perspetiva que torna o tratamento da figura de Teseu fundamental na

\footnotetext{
${ }^{199}$ Cf. capítulo «Atenas, o umbigo da Hélade» e Thuc. 1. 70. 3.

${ }^{200}$ Cf. supra pp. 61-91, dedicadas às aventuras de Teseu.

${ }^{201}$ Vide infra p. 99-105.

${ }^{202}$ Cf. supra pp. 61-62.
} 
obra de Plutarco, na medida em que é apresentado como fundador do regime que levaria Atenas a conhecer os seus dias de glória. Como veremos adiante,

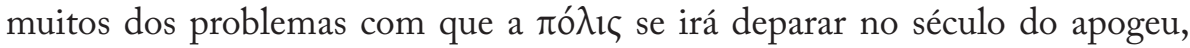
muitos dos traços que caracterizam os políticos desse período e muitas das tradições então vigentes são como que reflexo do que melhor e pior teve a atuação do seu fundador mítico .

O Queroneu, como é seu hábito, procurou mostrar que, desde jovem, o herói revelou potencialidades políticas, algumas das quais podem ser consideradas hereditárias - como é o caso da propensão para promover a unificação cívica, à semelhança do que fizera Piteu ${ }^{203}$. A coragem/audácia ( ó$\mu \alpha \alpha)$, as capacidades militares, o interesse pelo bem-estar do próximo ( $\varphi \imath \lambda \alpha v \theta \rho \omega \pi i ́ \alpha)$ são qualidades que evidencia mesmo antes de chegar a Atenas, quando, contrariando a vontade da mãe e do avô, decide fazer o percurso por terra ${ }^{204}$. São essas virtudes que, uma vez reconhecido como filho legítimo por Egeu, lhe vão abrir caminho para a aceitação pelos concidadãos (que o viam como um estrangeiro), pois dispõe-se a partilhar os perigos que enfrentavam e a ajudá-los, ainda que para isso tenha de colocar a própria vida em risco e contrariar a vontade do pai ${ }^{205}$.

Uma vez sugeridas as virtudes que poderiam vir a fazer de Teseu um excelente homem de Estado, o biógrafo serve-se dos capítulos 24 e 25 para dar a conhecer de que modo o herói as pôs em prática mal assumiu o poder.

Teseu revela-se, nessa altura, senhor de grande perspicácia e visão ${ }^{206}$, adepto de uma política que não procurava apenas o bem-estar imediato dos concidadãos, mas a glória futura da $\pi$ ó $\lambda \iota_{1}{ }^{207}$. Nesse sentido, enceta negociações com as populações, para criar uma ró $\lambda_{\imath \varsigma}$ única, que reunisse os diversos povos da Ática (ao que parece, seriam doze povoações) e suas magistraturas. O herói esperava, deste modo, evitar as desavenças que, não raras vezes, ocorriam entre eles e fomentar uma ação concertada em prol do bem comum ${ }^{208}$.

${ }^{203}$ Cf. supra 51 , nota 6.

${ }^{204}$ A propósito do simbolismo desta decisão, vide supra p. 54.

205 Thes. 12.5. Cf. supra pp. 63-64.

${ }^{206}$ Esta ideia também ocorre em Tucídides (2.15.2), que é - como sabemos - uma das fontes mais queridas e utilizadas por Plutarco. O historiador, como já vimos na página 32 (nota 8), admira a força e a inteligência de Teseu. Estas duas características, que os Atenienses reivindicam como específicas do seu povo, parecem, pois, ser mais uma herança legada pelo fundador mítico da ró $\lambda_{\imath}$. Tucídides enaltece ainda a sensatez do herói que soube, como ninguém, tomar as medidas certas para organizar a cidade. Sobre a história de Atenas, consultem-se, por exemplo, Hignett (1952); Mossé (1971); Trail (1975).

${ }_{207}$ Tucídides (2.15.2) também reconhece a importância do sinecismo - que funciona como embrião de um futuro imperialismo - para o esplendor que Atenas viria a alcançar.

${ }^{208}$ É provável que, ao enumerar as dificuldades vividas antes do sinecismo, Plutarco tivesse em mente o texto de Tucídides, porque, embora não recorra ao mesmo vocabulário, as ideias apresentadas são as mesmas. Sobre o sinecismo em geral e o de Atenas em particular, consultem-se Moggi (1976); Diamant (1982: 38-47); Gelder (1991: 55-64); Luce (1998: 3-31); Valdés Guia (2001: 127-197). 
As classes mais desfavorecidas - que pouco ou nada tinham a perder - aderiram ao projeto sem grandes reservas ${ }^{209}$. A elite, porém, fê-lo, na generalidade, contrariada, para impedir não só a mudança, mas também que Teseu - cujo poder e capacidade de decisão temiam - se visse obrigado a recorrer à força para convencê-los. Tal atitude não surpreende, pois, como podemos continuar a verificar na atualidade, do mesmo modo que as classes inferiorizadas respondem positivamente ao apelo dos reformadores, os poderes instalados são a maior resistência com que se deparam os ventos da mudança, que tentam implementar reformas para melhorar o funcionamento das nações e as condições de vida da população.

É curioso salientar que Plutarco (Thes. 24. 2) se refere à opção da elite dizendo que:

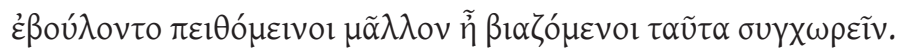

"preferiram aceitar pela persuasão do que pela força."

Este pormenor reveste-se de particular importância, pois faz da persuasão $(\pi \varepsilon \dot{\theta} \theta \omega)$ - enquanto característica própria dos Atenienses e resultado do exercício da retórica - uma competência herdada de Teseu, o primeiro a exercê-la espontaneamente com mestria ${ }^{210}$. Além disso, permite a Plutarco realçar o facto de Teseu não ter recorrido à força para pôr em prática o seu projeto para Atenas ${ }^{211}$.

Para a nova $\pi$ ó $\lambda \iota s$, Teseu propunha um governo democrático

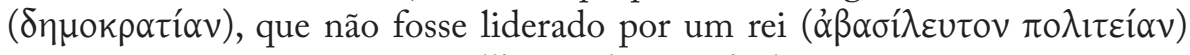
e no qual todos seriam iguais ( $\alpha$ $\pi \alpha \sigma v$ i $\sigma o \mu o \imath \rho i ́ \alpha v)$, com deveres a cumprir e direitos a auferir, em uma clara antecipação da realidade da Atenas do século V). A ele, apenas caberiam duas funções: a de guardião das leis ${ }^{212}$ ( $v o ́ \mu \omega v ~ \varphi v ́ \lambda \alpha \kappa \imath$ )

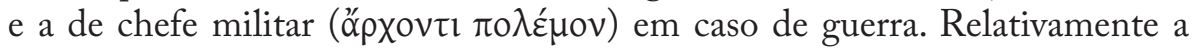
esta última função, podemos dizer que falhou, pois, além de responsável pela

${ }^{209}$ Não obstante a propensão do povo para aceitar a mudança, Teseu demonstra capacidade de negociação e de condução das massas ( $\pi \varepsilon i ́ \theta \omega)$, característica que se revelará típica de qualquer bom político ateniense.

${ }^{210}$ Esta característica dos Atenienses e do seu sistema político remonta ao governo de Teseu, que, segundo Paus. 1. 22. 3 e Isoc. 15. 249, estabeleceu o culto de Afrodite Pandemos e da

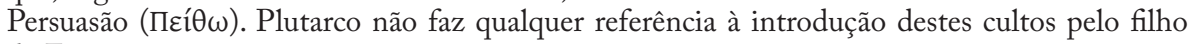
de Egeu.

${ }^{211}$ Esta versão apresentada pelo biógrafo, como já vimos (supra p. 66), contradiz a tradição (nomeadamente a veiculada por Apollod. Epit. 1. 11), segundo a qual, antes de concretizar o sinecismo, Teseu teve de eliminar os cinquenta Palântidas. Sobre a luta entre Teseu e os Palântidas, ver Herter (1973: col. 47-9); Brommer (1972: 137-9).

${ }^{212}$ Remonta, pois, a esta medida de Teseu, o grande orgulho que os Atenienses tinham de si próprios por acreditarem ser o único povo a que vivia sob o jugo da isonomia e que obedecia apenas à lei e não aos caprichos dos déspotas - cf. A. Pers. 241-242. 
Amazonomaquia (Thes. 26-28), não só provocou a invasão dos Dioscuros ao raptar Helena, como não esteve presente para defender a cidade desse ataque (Thes.31-34).

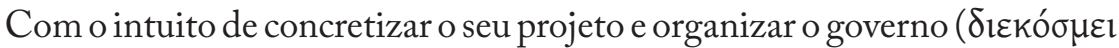

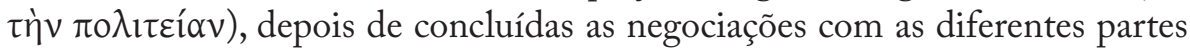
interessadas e de consultadas as divindades ${ }^{213}$, Teseu aboliu as magistraturas, os pritaneus e os conselhos locais e criou um pritaneu e um conselho comuns no lugar da atual cidade ${ }^{214}$, a que deu o nome de Atenas ${ }^{215}$. Além disso, após ter convocado todos os interessados em aderir ao projeto (pois sonhava com a fundação de um povo universal ${ }^{216}$ ) a convergir para a cidade, dividiu os cidadãos - aos quais prometera igualdade - em três classes ${ }^{217}$ : os nobres ( $\varepsilon \dot{\pi} \pi \alpha \tau \rho i ́ \delta \alpha \varsigma$ ), que teriam a seu cargo as «coisas» divinas, as magistraturas, o ensino das leis e a interpretação dos costumes - e que, portanto, eram superiores em dignidade; os

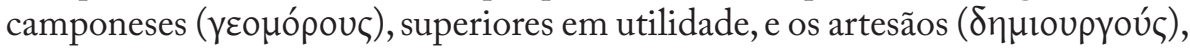
superiores em quantidade. Alargando assim a cidadania, procurava, de forma antecipada e clarividente, estruturar o funcionamento da nova constituição

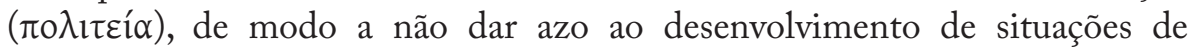
desordem - é que o povo com liberdade em excesso, se não for conduzido por

${ }^{213}$ Como é sabido, os Gregos tinham por hábito consultar os deuses - nomeadamente o oráculo de Delfos - sempre que se propunham uma grande empresa, como é o caso da fundação de uma cidade. Teseu revela-se, por isso, um homem religioso, como já acontecera em momentos anteriores, como por exemplo aquando da sua chegada a Atenas - onde não entrou senão após a purificação a que se deveria sujeitar por ter cometido crimes de sangue (Thes. 12.1) - e, mais tarde, quando, na sequência da vitória sobre o Touro de Maratona, o oferece em sacrifício a Apolo Delfínio (Thes. 14.1). Podemos recordar ainda os sacrifícios a que presidiu em agradecimento pelos sucessos obtidos em Creta e pelo seu regresso (Thes. 22.2). Sobre o ascendente do oráculo de Delfos, vide Parke - Wormell (1956).

${ }^{214}$ Estas medidas encontram-se igualmente descritas em Thuc. 2. 15. 2. Se compararmos Thes. 24. 2-3 com este texto do historiador, fica claro que o biógrafo o conhecia bem e que terá sido influenciado pelo mesmo, sobretudo em termos de escolha do vocabulário, nomeadamente

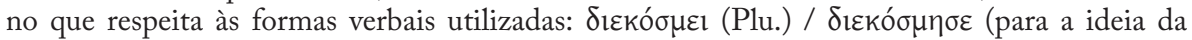

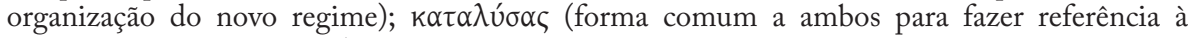
abolição das magistraturas). Sobre a instituição das festividades que também eram um dos elementos da estratégia política de Teseu, vide infra pp. 99-101.

${ }^{215} \mathrm{O}$ aproveitamento da figura de Teseu (tal como acontece com Drácon e Sólon) resulta do tema propagandístico da patrios politeia, desenvolvido em especial no último quartel do séc $V$ e no século IV, e faz com que as ações atribuídas ao filho de Egeu sejam irrealidades históricas. Ao rol das que serão enumeradas nas próximas páginas, podemos acrescentar, por exemplo, a cunhagem da moeda. Para este tema, vide Leão (2001: 43-72).

${ }^{216}$ Este sonho persistiu pelo menos até à Época Clássica, durante a qual Atenas se orgulhava

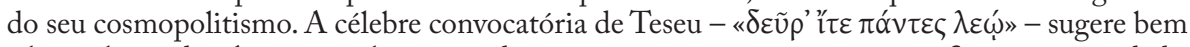
a boa relação dos Atenienses haveriam de manter com os estrangeiros que afluíam à sua cidade. Sobre este assunto, vide p. 122 , nota 41.

${ }^{217}$ É costume estabelecer-se um paralelo entre as reestruturações de Teseu e a remodelação territorial e política que Clístenes efetuou na Ática, fundamentais para a democracia do séc. V. a.C. Vide Schefold (1946: 59-93); Francotte (1976); Bertelli (1987:38-39); Calame (1990: 416424) e passim; Walker (1995: 46-47 e passim). 
um pulso ao mesmo tempo firme e dócil, sente-se perdido (embriagado, no dizer de Platão ${ }^{218}$ ) e acaba por agir em prejuízo do bem comum.

Plutarco (Thes. 25. 3) apresenta-nos, portanto, um Teseu que é, segundo palavras que o biógrafo atribui a Aristóteles (fr. 2. Sandys),

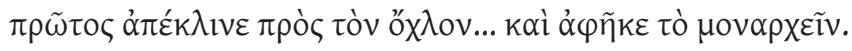

"o primeiro a inclinar-se para as massas e a abandonar o poder absoluto."

No entanto, na Constituição dos Atenienses (41. 2), o Estagirita imputa o aparecimento da democracia a Sólon; de Teseu apenas diz que

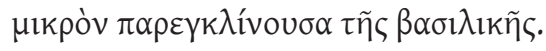

"se afastou um pouco da monarquia ${ }^{219}$."

Sagaz, Teseu procurou não só criar a coesão entre os que haviam passado a constituir um novo e único povo, como também fomentar as relações entre Atenienses e demais Gregos, imprimindo a Atenas o tom de cidade $\operatorname{cosmopolita}^{220}$. Para concretizar tal objetivo, institui as Panateneias e os Jogos Istmicos ${ }^{221}$, respetivamente. Enquanto fundador, Teseu foi ainda autor de outras intervenções consideráveis: a cunhagem de moeda ${ }^{222}$, um fator político e de desenvolvimento fundamental; a criação dos jogos conhecidos por Metécias ${ }^{223}$ (que serviriam para celebrar o sinecismo) e o estabelecimento de fronteiras, considerado por Tucídides um passo imprescindível para o progresso das cidades, na medida em que permitem melhor defesa, reserva de bens e o cultivo da terra (Thuc. 1. 2. 2). Esta última medida destaca-se

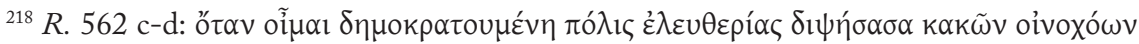

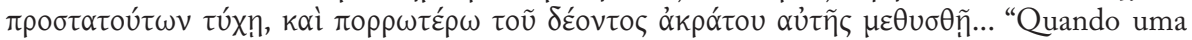
cidade democrática, penso eu, sedenta de liberdade, tem, por força do acaso, no seu comando, maus escanções e se embebeda muito mais do que devia com essa [liberdade] da pura, ..." A tradução apresentada é de Rocha Pereira (2001). Este passo da República é invocado por Plutarco em Per.7. 8.

${ }^{219} \mathrm{Na}$ verdade, este «desvio da monarquia» também caracteriza a ação de Rómulo, que, ao contrário de Teseu, enveredou pela tirania. Não admira, pois, que Plutarco (Rom. 31) considere reprovável o comportamento de ambos. Sobre este assunto, leia-se Larmour (1988: 368).

${ }^{220} \mathrm{Cf}$. página anterior.

${ }^{221}$ Sobre a instituição destes festivais, vide infra p. 101, notas 233 e 235.

${ }^{222}$ Cf. Arist. Pol. 1257a31-40. A cunhagem de moeda denota um forte desenvolvimento e tem implicações sociopolíticas: só uma sociedade minimamente organizada e estável tem condições de proceder a essa atividade que, além de facilitar as trocas comerciais, favorece a justiça entre cidadãos (já que as trocas se baseiam numa escala comum de valores pré-definida) e permite afirmar a autonomia da cidade. Para um aprofundamento desta questão, consulte-se, por exemplo, Will (1954: 209-231; 1955: 5-23); Picard (1986 : 157-171).

${ }^{223}$ Infra p. 101, nota 234. 
pela anexação - obviamente forçada - de Mégara à Ática (mais um prenúncio do convívio atribulado dos respetivos habitantes) e pela colocação da famosa estela que indicava, de cada um dos lados, a localização de quem a contemplava, indiciando também ela as atribuladas relações entre Atenas e Esparta: quem estava do seu lado direito encontrava-se na Iónia e não no Peloponeso; quem estava do seu lado esquerdo, no Peloponeso e não na Iónia.

Não surpreende, por isso, que, a partir de finais do séc. VI a.C., a ação de muitos políticos tenha sido associada - pelos próprios ou pelos concidadãos à de Teseu, figura que passou a funcionar como instrumento de propaganda que conferia aos feitos dos novos políticos maior prestígio. Vários foram os classicistas que procuraram demonstrar, inclusive, que terão sido esses políticos - Pisístrato, Clístenes, Temístocles, Címon, Péricles, segundo a teoria de cada $\mathrm{um}^{224}$ - a fomentar o culto de Teseu, que, até início do séc. $V$ a.C., ainda não tinha a dimensão de herói nacional que hoje lhe conhecemos.

${ }^{224}$ Herter (1939: 244-326); Nilsson (1953: vol. 2, 743-748) são partidários de Pisístrato; Schefold (1946: 59-93); Jacoby (1949: 395), de Clístenes; Podlecki (1975: 1-20), de Temístocles; Barron (1971: 141-143) e Woodford (1974: 158-165), de Címon; Goossens (1932: 9-40), de Péricles. Para uma visão sistemática deste tema, consultem-se Walker (1995: 35-81; 1995b: 3-33). 


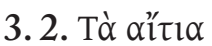

À criação dessa dimensão não é alheio o facto de a Teseu ter sido atribuída a instituição de diferentes elementos não só da cultura ateniense em particular, mas até da cultura pan-helénica, da qual Atenas se tornou modelo. Na verdade, Teseu funciona como dî́tıov para muitas práticas, festas e tradições, cuja origem se acreditava remontar aos primórdios da história da cidade que fundou, definindo-se, por isso, como pai de uma civilização e de uma cultura. Ora, essa especificidade, decorrente da sua condição de fundador e civilizador, tem consequências práticas na redação da Vida de Teseu, que se demarca das restantes pela grande quantidade de aítı nela referidas: Plutarco evoca mais de vinte, que são como que reflexo do que melhor e pior teve a

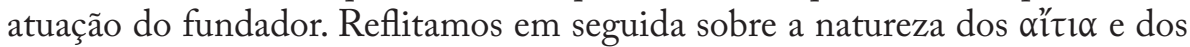
acontecimentos a que deram origem.

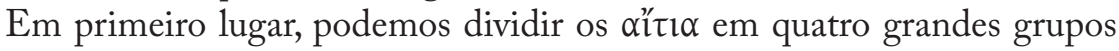
que, grosso modo, coincidem com os feitos que se tornaram mais populares: as façanhas (Touro de Maratona, expedição a Creta, regresso do Hades), a efebia (em Atenas e em Delfos), o exercício do poder na Ática (luta contra os Palântidas e o sinecismo) e os amores (Periguna, Ariadne, Amazonas e Helena). Do mesmo modo, podemos, em traços gerais, agrupar os acontecimentos a que deram origem em seis núcleos: festividades, fórmulas/expressões, costumes, toponímia, monumentos e dança.

Foram as façanhas e os amores os grupos de $\alpha$ î́ı $\alpha$ mais produtivos. Importa, contudo, lembrar que os blocos Creta e Ariadne podem ser lido como um único, na medida em que a relação do herói com esta jovem decorre da expedição àquela ilha. Se olharmos para a questão sob tal prisma, este é, sem dúvida, o núcleo que deu origem a mais elementos. Curiosamente, a grande maioria

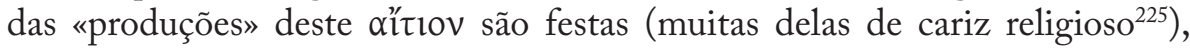
em relação às quais Plutarco fornece pouca informação: as Cibernésias ${ }^{226}$, em homenagem ao comandante e ao chefe de proa escolhidos por Teseu (Thes. 17. 7); a festa de homenagem a Ariadne em Chipre ${ }^{227}$ (Thes. 20. 6-7); o certame de

${ }^{225}$ A profusão de festivais religiosos instituídos por Teseu tem que ver com a importância da

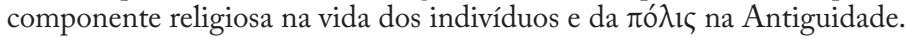

${ }^{226}$ Cf. Philoch. FGrHist 328 F 3. A festa dos pilotos seria celebrada, em data por nós desconhecida, em memória de Nausítoo e de Feácio, nomes certamente inspirados em habitantes da ilha de Esquéria, a ilha dos Feáces na Odisseia. Teseu terá sido obrigado a escolher pilotos estrangeiros, porque os Atenienses ainda não se dedicavam ao mar. Embora a narrativa de Plutarco pareça sugerir que a homenagem (festas e monumentos) tenha sido instituída antes do regresso de Creta, o mais lógico é que o tenha sido apenas no regresso. Alguns estudiosos avançam datas possíveis para esse festival, nomeadamente Deubner (1932: 225), segundo o qual coincidiria com a celebração das Teseias e Jacoby (FGrHist IIIb, Suppl. Notes, 345), que acredita que teriam lugar na abertura ou no fecho do período de navegação.

${ }^{227} \mathrm{Na}$ ilha de Chipre, Teseu encarrega habitantes locais de fazer sacrifícios em memória de Ariadne e de erigir estatuetas, uma em prata e outra em bronze. Durante a festa, que tinha lugar 
Delos em honra de Apolo228 (Thes. 21.2), em que vencedores recebem um ramo de palma; as Oscofórias ${ }^{229}$, festas em honra de Dioniso (Thes. 22. 4 e 23. 2) e as Pianépsias ${ }^{230}$ (Thes. 22. 4-7). Mas este é também o grupo responsável pela dança ritual em honra de Ariadne, a que os Délios chamavam «de grua» (Thes. 21. 2); pelos ì $\rho \tilde{\omega} \alpha$ de Nausítoo e Féax ${ }^{231}$ (Thes. 17. 7), pelo epíteto Epitrágia, de Afrodite ${ }^{232}$ (Thes. 18.3) e pela designação de «Ariadne Afrodite» atribuída a um bosque 233 (Thes. 20.6-7).

Não podemos deixar de chamar a atenção para o facto de as festas até agora mencionadas não serem celebradas em Atenas, o que, como já se disse, faz de Teseu responsável pelo aparecimento de fenómenos pan-helénicos. Mas,

no dia 2 do mês de Gorpieu (mês macedónio equivalente aos nossos agosto e setembro), um jovem assumia o comportamento de uma parturiente.

${ }^{228}$ Cf. Paus. 8. 48. 3; Moralia 724A. A atribuição da origem do certame a Teseu, que teria instituído o festival e o prémio ( $\sigma \pi \alpha \delta_{\delta} \xi$ 'ramo de palma'), prende-se à reorganização das festas de Delos, levada a cabo pelos Atenienses (Thuc. 3. 104. 3-5).

${ }^{229}$ As informações que Plutarco nos dá sobre as Oscofórias, aparecem entrecortadas pelas que dizem respeito às Pianépsias, o que ilustra, mais uma vez, as frequentes divagações do biógrafo. Sem entrar em pormenores relativamente à forma como as festas se desenrolavam, chama a atenção para o facto de nelas se coroar o caduceu e não o arauto (à semelhança do que o herói fez quando soube da notícia da morte do pai) e para a natureza dos gritos proferidos durante as libações, que combinam a dor pela morte de Egeu e a alegria pelo regresso dos que haviam sido condenados ao Minotauro. Revela igualmente a origem da presença de dois jovens vestidos de mulher na procissão: é que quando Teseu partiu para Atenas, ao invés de levar todas as jovens exigidas pelo Minotauro, substituiu duas por dois jovens, que lhe eram próximos, de aspeto efeminado e delicado - mas corajosos e viris - que preparou para que se parecessem ainda mais com mulheres. E ninguém deu pela diferença... No regresso, esses jovens participaram consigo, transportando rebentos de videiras ( $\omega \sigma \chi 0 i ́)$, na procissão em homenagem a Dioniso e Ariadne, em honra dos quais a festa tinha lugar. Sobre esta procissão, vide Kadletz (1980: 363-371). Sobre a relação entre Teseu, Temístocles e as Oscofórias, vide Podlecki (1975: 1-20).

${ }^{230}$ Estas festas tinham lugar a 7 de Pianépsion (quarto mês do calendário ateniense, equivalente aos nossos outubro e novembro, durante o qual se celebravam, além das Pianépsias, também as Teseias, as Tesmofórias e as Apatúrias), um dia consagrado a Apolo. Foi igualmente nesse dia que ocorreu o regresso de Creta. Consta que o nome destas festas deriva de rúavoఢ/ $\kappa u ́ \alpha \mu \circ \varsigma$ 'fava' e do verbo ع́ $\psi \omega$ 'cozo', pois um dos ritos que as constituíam consistia em cozer legumes e cereais de todos os tipos numa única panela. Terá tido origem no facto de os sobreviventes de Creta terem juntado numa única panela todos os restos de alimentos que possuíam e com base nos quais prepararam uma refeição que em seguida partilharam. Sobre esta festividade, vide Calame (1990: 291-324, passim); Parke (1977).

${ }^{231}$ Trata-se dos mesmos heróis em honra dos quais se celebram as Cibernésias. Cf. p. 99, nota 226 .

${ }^{232}$ A conselho de Apolo, Teseu invoca Afrodite como companheira de viagem e celebra-lhe um sacrifício, durante o qual a cabra que estava a ser imolada se transforma em bode, o que vale à deusa o epíteto de Epitrágia. Segundo Simon (1985: 250 sqq), era atribuído a Teseu o culto de Afrodite Pandemos, a deusa do povo unificado pelo herói através do sinecismo (Paus. 1.22. 3), cuja designação se altera para Epitrágia numa fase mais tardia. Vide etiam Calame (1990: 231-2, passim).

${ }^{233}$ Ariadne estava tradicionalmente associada a Afrodite, sobretudo na ilha de Chipre. O bosque em causa era chamado pelos Amatúsios de "Ariadne Afrodite», porque aí existiria um túmulo de Ariadne Afrodite. Paus. 2. 23. 7 dá-nos conta de um túmulo de Ariadne no templo de Dioniso Cretense em Argos, próximo do túmulo de Afrodite Urânia. 
como não poderia deixar de ser, foi na Ática que a «mão» do herói deixou marcas mais abundantes, a todos os níveis, nomeadamente no das festividades, que, para além do seu cariz religioso evidente, são também uma manifestação política, quer no sentido etimológico da palavra, quer no atual, já que estimulam o civismo e o convívio entre os cidadãos.

Aquelas em que essa vertente política ressalta melhor são, sem dúvida, as que decorrem do sinecismo (ou, se preferirmos, as que são consequência do exercício do poder na Ática): as Panateneias ${ }^{234}$ (Thes. 24.3), as Metécias ${ }^{235}$ (Thes. 24. 4) e os Jogos Ístmicos ${ }^{236}$ (Thes. 25. 6), que tinham por principal objetivo estimular a unidade dos cidadãos da Ática unificada. Além de fomentarem o convívio entre os habitantes locais, sugerem desde logo o aparecimento de um novo momento protagonizado pela ação de Teseu, no qual, entre outros sinais, se prenuncia uma nova relação entre povo (até então descontente com um rei, que lhes sacrificava os filhos) e poder político e o importante papel que Atenas viria a ter no contexto pan-helénico.

Plutarco refere ainda o culto ático dos Dioscuros (resultante da presença destes na Ática quando procuravam a irmã Helena que fora raptada pelo

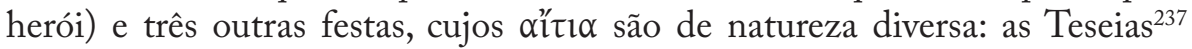

${ }^{234}$ As Panateneias são, por excelência, a festa da nova cidade unificada. Foram, na verdade, fundadas por Erictónio e celebravam-se a 28 de Hecatombéon, dia do nascimento da deusa Atena. Em 566 a. C., durante o governo de Pisístrato, foram objeto de remodelação, passando a incluir um momento de récita dos Poemas Homéricos. Sobre esta festa, vide Deubner (1932: 22 sqq.); Parke (1977: 33 sqq.).

${ }^{235}$ Segundo Ampolo-Manfredini (1988:237), a designação de Metécias dada à festa celebrada no dia 16 de Hecatombéon resulta provavelmente de uma citação errada de Plutarco, que estaria a pensar nas Sinécias relatadas por Thuc. 2. 14. 2. Cf. Bulsot (1895: 92 n. 3). De acordo com

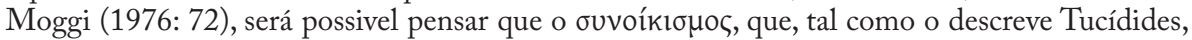
foi, na realidade, meramente político, se transformou em $\mu \varepsilon \tau$ có́kı $\sigma$ o ('migração'), pelo que o

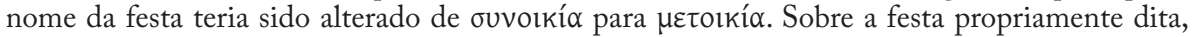
vide Deubner (1932: 36-8).

${ }^{236}$ Estes jogos, ao contrário das Panateneias e das Metécias, têm caráter pan-helénico. A versão mais generalizada atribui a sua institução a Sísifo (em honra de Melicertes-Palémon ou Poséidon e Hélios, que partilhavam entre si o domínio do Istmo) e não a Teseu. Helânico (FGrHist 323a F 15), contudo, já atribuía os jogos a Teseu. São estes os jogos sobre os quais Plutarco melhor se debruça, o que facilmente se compreende, já que as versões sobre a sua origem não são consensuais. Começa por se referir àquela que faz da sua fundação mais um ato de emulação de Héracles: assim como o filho de Alcmena criara os Jogos Olímpicos para homenagear o pai, Zeus, também Teseu, que segundo alguns era filho de Poséidon, cria os Ístmicos com o mesmo intuito. O biógrafo refere também a versão tradicional, adaptando-a aos seus interesses de racionalização do mito: segundo ele, os jogos instituídos por Teseu tinham caráter de festival e não de celebração de mistérios própria dos jogos em honra de Melicertes-Palémon, o que parece sugerir a possibilidade de convívio entre as duas modalidades ou que Teseu reformou os pré-existentes. O Queroneu refere ainda outras versões, de acordo com as quais os jogos teriam sido instituídos para que Teseu, ao homenagear as suas vítimas (Ésciron ou Sínis), se purificasse dos crimes cometidos. Fica, porém, a impressão de que o nosso autor não lhes dá grande crédito.

${ }^{237}$ A celebração das festas de Teseu decorria a 8 de Pianépsion (cf. Thes. 36.4-5), porque coincidiam com o regresso de Creta e porque esse dia também era normalmente consagrado a 
(às quais estavam ligados rituais como o sacrifício a Cónidas ${ }^{238}$ - Thes. 4. 1), as Hecalésias ${ }^{239}$ (Thes. 14. 2) e as Boedrómias ${ }^{240}$ (Thes. 27. 3), associadas respetivamente ao episódio do Touro de Maratona e às Amazonas.

Como consequência da generalidade das façanhas do herói, ficaram famosas duas expressões, cujos sentidos já analisámos anteriormente ${ }^{241} \mathrm{e}$ que põem em evidência não só a emulação do filho de Zeus, mas também a abundância dos feitos do ateniense: «nada sem Teseu» e «outro Hércules».

Da azáfama que foi a vida do filho de Egeu, resultaram ainda outros costumes, monumentos e toponímia mais ligados ao dia-a-dia dos cidadãos. É o caso do corte de cabelo «à Teseu» (Thes. 5. 1) e respetiva oferta a Apolo $^{242}$ em um lugar chamado Teseia ${ }^{243}$ (que tem origem no grupo a que

Poséidon, pretenso pai do herói, ou ainda porque terá chegado a Atenas pela primeira vez a 8 de Hecatombéon. Note-se, contudo, que Plutarco comete uma incongruência cronológica, ao afirmar, em Thes. 22. 4, que o regresso dos sobreviventes do Minotauro ocorreu a 7 de Pianépsion. Tal facto ficará a dever-se a uma tentativa de fazer coincidir em um mesmo dia todas as festividades relacionadas com o regresso ou a motivos religiosos: enquanto o dia 8 é dedicado a Poséidon, o dia 7 é dedicado a Apolo. Plutarco salienta, no entanto, que, para além das Teseias, Teseu era homenageado todos os dias 8. A propósito da data destas festividades, vide Flacelière (1948: 84). De acordo com Thes. 23. 5, terá sido o próprio herói a instituir o seu culto no regresso de Creta, ao consagrar-se um recinto e ao encarregar os Fitálidas da realização do sacrifício. Sobre estas festas, vide Mommsen (1898: 288-90); Mikalson (1975: 70-1); Deubner (1932: 224); Parke (1977: 80-1).

${ }^{238}$ Sobre o precetor de Teseu, vide supra p. 54, nota 17. O sacrifício a Cónidas tinha lugar na véspera das Teseias, ou seja, a 7 de Pianépsion, porque as Teseias decorriam a 8 -cf. Thes. 36.4. Como já referimos, tratar-se-ia provavelmente de um sacrifício gentilício, que já existia, ao qual se associou o nome do herói para que tivesse mais importância. Cf. Herter (1973: 14); Deubner (1932: 225).

${ }^{239}$ Quando se dirigia a Maratona para lutar contra o Touro, Teseu viu-se obrigado a recorrer à hospitalidade de uma jovem chamada Hécala por causa do mau tempo. Esta prometeu então a Zeus (que passou a receber o epíteto de Hecálio) sacrifícios se o jovem príncipe regressasse a salvo da luta contra a besta. No regresso, Teseu, informado da morte da jovem, mandou cumprir-lhe a promessa, como sinal de agradecimento pela hospitalidade e carinho recebidos: tinham assim origem as Hecalésias. Hécala tornou-se também epónimo de um demo de localização incerta, algures entre Maratona, Deceleia e Ploteia. Cf. Jacoby (1949: 128 e 279 n. 279; FGrHist, Suppl., Text, 436 sqq); Deubner (1932: 217).

${ }^{240}$ Boedrómion era o terceiro mês do calendário ateniense e tomou o nome das festas em honra

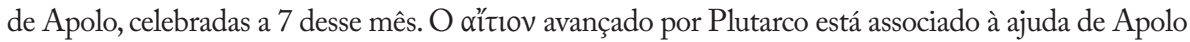
a Teseu contra as Amazonas (cf. Macr. 1.17,18). A versão mais corrente (relatada em Paus. 7. 1. 2; Philoc. FGrHist 328 F 13) é aquela que afirma que Apolo ajudou os Atenienses contra os Eleusínios.

${ }^{241}$ Vide supra p. 78.

${ }^{242}$ Neste caso, importa chamar a atenção não só para a origem de um corte de cabelo com características específicas, mas sobretudo para o ritual de passagem da adolescência para efebia

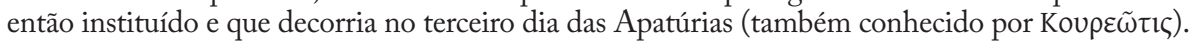
Os jovens de dezasseis anos cortavam o cabelo para ofertar um anel a Apolo Delfínio, sem terem a necessidade de se deslocar a Delfos (cf. Anthologia Palatina, 6. 278). Teofrasto (Char. 21) atribui ao Pedante o hábito de levar efetivamente o cabelo do filho a Delfos, para fazer reviver o ato do fundador. Sobre este rito, vide Nilsson (1970: 136-8). Quanto ao corte de cabelo, caracterizava-se por ser curto na zona da face e comprido no resto da cabeça. Segundo Polieno 1. 4, a opção por este corte tinha como objetivo facilitar a luta corpo a corpo. Seria também essa a razão pela qual os Abantes (povo que Plutarco evoca, citando Homero, Il. 2. 536, 4. 464) usavam assim o cabelo.

${ }^{243}$ Ainda que sejam conhecidos diversos monumentos em honra de Teseu em Delfos, não 
convencionámos chamar «efebia»); do costume dos descendentes de Ioxo de não queimar espargos bravios nem arbustos com espinhos sem lhes prestar culto $^{244}$ (Thes. 8. 6); da impossibilidade de os membros do demo de Palene e os de Hagnunte contraírem matrimónio entre si (Thes. 13.4) e do hábito que os habitantes de Palene tinham de não recorrer à fórmula tradicional para reunir os concidadãos ${ }^{245}$; ou a frase célebre com que Teseu terá reunido os povos da Ática ${ }^{246}$ (Thes. 25. 1). Também a justificação do nome das moedas

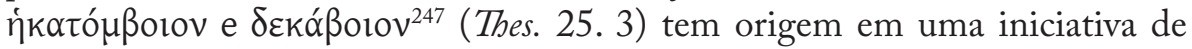
Teseu (todos decorrentes do exercício do poder em Atenas).

Por fim, importa referir que a Amazonomaquia está associada à origem de alguns monumentos atenienses e à história de alguns dos lugares mais famosos

se sabe em que local exato estaria situado o Teseia. Há quem pense que a sua localização terá sido aproveitada para construir o Tesouro dos Atenienses em Delfos (cf. Pauly-Wissowa1924: col. 1279-1280).

${ }^{244}$ A referência, aparentemente fora de contexto, à ligação entre Periguna e Teseu serve para revelar a relação de ascendência que une Teseu a Ioxo e para justificar o respeito dos Ióxidas pelas plantas mencionadas neste episódio. Demais, confere à união entre Periguna e Teseu (que entra no rol dos amores menos próprios do herói) alguma dignidade, já que o fruto que dela nasceu, Melanipo, foi pai de Ioxo, um dos fundadores de uma colónia na Cária. Sobre a fundação de colónias atenienses na Iónia e na Cária, vide Cassola (1957: 84 sqq); sobre Ioxo, Roscher (1965). Existia em Atenas um lugar de culto chamado $\mu \varepsilon \lambda \alpha v i ́ \pi \pi \varepsilon 1 o v$, próximo do demo de Melite (Clidemo FGrHist 323 F 2), ainda que, segundo Jacoby (FGrHist III B, Kommentar a 328 F 2, p. 134), essa referência de Clidemo associe necessariamente Teseu a Melanipo.

${ }^{245}$ Estes dois aítı estão ligados aos habitantes do demo de Palene (cujo epónimo é Palanteu). Como não poderia deixar de ser, os seus antepassados apoiaram os Palântidas na luta pelo poder contra Teseu. Dos partidários dos sobrinhos de Egeu fazia igualmente parte um arauto do demo de Hagnuso, que traiu a causa, revelando ao fundador de Atenas os planos do inimigo, o que lhe permitiu emboscá-los e vencê-los. Tamanha deslealdade fomentou uma profunda aversão dos habitantes de Palene pelos de Hagnuso, inviabilizando a celebração de matrimónios entre eles. Esta ausência do direito de epigamia parece sugerir a existência na Ática de comunidades independentes antes do sinecismo - De Sanctis (1975: 32). Pelo mesmo motivo, os de Palene

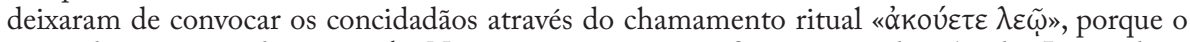
nome do arauto traidor era $\Lambda \varepsilon \omega ́$ c. Note-se que este arauto foi epónimo da tribo dos Leóntidas cf. Kron (1976: 194-198). Sobre o nome do arauto, vide supra p. 66, nota 70.

${ }^{246}$ Quando projetava a formação de um povo universal, Teseu ter-se-á dirigido à multidão

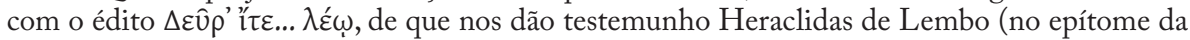
sua Constituição dos Atenienses) e Aristóteles (Ath. fr. 3). Cf. Rhodes (1981: 74 sqq). Sobre este assunto, consulte-se ainda Robertson (1986: 147-176).

${ }^{247}$ Atribuir a instituição da moeda a Teseu não passa de um anacronismo, pois é do conhecimento geral que, em Atenas, esta apenas surgiu no séc. VI a.C. Tal imputação justifica-se pelo facto de as primeiras moedas atenienses terem gravada numa das faces a cabeça de um touro (que facilmente se associa às aventuras de Teseu que envolvem esse animal. Pode, no entanto, estar relacionada com a referência homérica aos bois enquanto unidade de valor e de troca (Il. 6. 119-129). Segundo Plutarco, havia também quem fosse de opinião de que tal cunhagem visava instigar os Atenienses à prática da agricultura. Sobre este assunto, vide Kraay (1970: 57). 
de Atenas: Amazónion ${ }^{248}$ (Thes. 27.3), a Estela ${ }^{249}$, próxima do templo de Terra Olímpica (Thes. 27.6), o nome da Academia ${ }^{250}$ (Thes. 32.5) e o Horcomósion ${ }^{251}$ (Thes. 27.7). Mas é igualmente a esse episódio que estão associados a fundação de uma colónia, Pitópolis, e o nome do rio que a atravessava ${ }^{252}$ (Thes. 23.3-6).

Podemos, portanto, concluir que, segundo o testemunho de Plutarco, a origem da generalidade dos $\alpha$ ítı $\alpha$ associados a Teseu assenta nas melhores ações do herói, dignas do fundador da gloriosa cidade de Atena. Esta perspetiva, que poderia ser posta em causa por tudo quanto diz respeito à desprezada Ariadne ou à Amazonomaquia (se aceitarmos que foi provocada por um rapto), é reforçada pela omissão de um aítııv, curioso e muito conhecido em Atenas, a propósito da forma achatada das nádegas dos Atenienses, relacionado com uma má ação do filho de Egeu. Segundo a tradição, tal característica era justificada com o facto de parte das nádegas de Teseu ter ficado agarrada à rocha (onde permanecera sentado no Hades), no momento em que foi salvo por Héracles ${ }^{253}$.

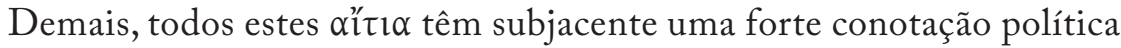
- tanto no que respeita ao dia-a-dia da $\pi o ́ \lambda ı \varsigma$ (a nível religioso, geográfico e de costumes), como no que respeita ao fomento da nova cidadania instituída por Teseu, que é estimulada pelo convívio suscitado pelos festivais religiosos.

Alguns dos $\alpha i ́ \tau \imath \alpha$ relacionados com as aventuras eróticas partilham essa conotação, pois conferem a Atenas o estatuto de cidade imperialista, que desde os primórdios foi deixando a sua marca pelo mundo helénico através da fundação de colónias - algumas pelo próprio Teseu (Pitópolis), outras pelos seus descendentes (Ioxo) - e da congregação de todos os Gregos para a celebração de jogos. Festas e colónias conseguem, assim, fomentar o espírito

${ }^{248}$ A topografia da batalha contra as Amazonas remete para lugares de culto e de atividade política. Neste caso específico, o Amazónion corresponderia ao local do acampamento das Amazonas e ficaria próximo do Areópago. Cf. Apollod. Epit.1. 16; D. S. 4. 28. 2.

${ }^{249}$ Este monumento fúnebre em homenagem a Hipólita ou Antíope é um dos que contribuiu para o desenvolvimento da lenda da Amazonomaquia por ser considerado testemunho da sua autenticidade. Segundo P1. Ax. 365a e Paus. 1. 18.7, ficaria também próximo das Porta Itónias e do templo de Terra Olímpica, respetivamente.

${ }^{250}$ Sobre este $\alpha$ ĭtıov, vide supra p. 87.

${ }^{251}$ Este 'lugar do juramento', onde Amazonas e Teseu celebraram a paz, ficaria próximo do Teseion e, como tal, não está identificado.

${ }^{252}$ De facto, esta aventura amorosa teve consequências a nível da política externa enquanto prenúncio das futuras colónias que Atenas haveria de fundar. Aquando da passagem de Teseu e Antíope pela região da Bitínia, um dos membros da comitiva, Solunte, apaixona-se pela amazona. Esta, conhecedora do seu interesse, mostra não estar interessada, mas nada revela a Teseu para evitar problemas. Solunte, desgostoso, atira-se ao rio, que viria a receber o seu nome por indicação do herói, que relacionou o sucedido com um oráculo da Pítia e deu o nome de Pitópolis à cidade que aí fundou.

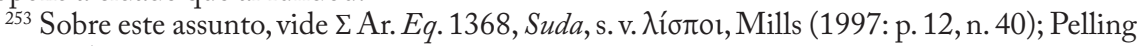
(1999: 432). 
helénico, mas sobretudo reforçar e comprovar a omnipresença e a influência de Atenas no mundo grego.

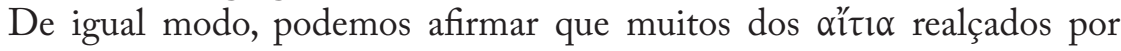
Plutarco têm o dom de apontar o caminho que seria trilhado por Atenas: a viagem a Creta simboliza duplamente o futuro império do mar e a pretensão de defensora dos povos oprimidos; as aventuras de Teseu, de um modo geral, projetam o empreendedorismo e capacidade de liderança da cidade; os seus amores violentos, a propensão para fazer e manter aliados «à força». 


\subsection{O princípio do fim}

Mas regressemos à ação política do filho de Egeu. Uma vez estruturada a nova cidade de acordo com o projeto por si definido, Teseu comete, podemos afirmá-lo, «suicídio político», que talvez seja desculpável pelo facto de ter sido o primeiro a governar em regime democrático e de não ter, portanto, quaisquer referências sobre as desgraças que podem advir quando o povo fica entregue à própria sorte. $\mathrm{Na}$ verdade, o maior erro de Teseu foi descurar a sua missão de demagogo ${ }^{254}$ - no sentido etimológico da palavra - para se dedicar à vida privada. Essa falha acarretou consequências da mais diversa ordem, a mais grave das quais foi o aparecimento daquilo que, de acordo com Plutarco, é o maior óbice de uma democracia, isto é, do sistema instituído pelo herói: o demagogo, indivíduo capaz de instigar insatisfações e de tirar partido delas. Menesteu foi, portanto, o primeiro ${ }^{255}$ exemplar dessa praga de que ainda hoje temos razões de queixa e que foi talvez a principal causa da ruína de Atenas.

Menesteu, que ambicionava governar Atenas, aproveitou a ausência do herói - que deste modo não se podia defender nem usar as suas capacidades de bom político para manter o regular funcionamento da cidade - para despertar ódios e descontentamentos adormecidos e mesmo inexistentes até então. Com efeito, não era difícil prever que os nobres, insatisfeitos desde o início do processo da reforma, rapidamente cedessem à argumentação de que tinham perdido regalias e de que eram tratados como escravos por Teseu e convertessem o medo que lhe tinham em ódio. Mas em relação ao povo, que aderira de coração aberto ao projeto do herói, nada fazia crer que o demagogo fosse conquistar a sua adesão, insinuando que Teseu não lhes dera a liberdade prometida, que os privara de terras e templos e que substituíra reis legítimos por um estrangeiro.

É interessante verificar que a aproximação de ambos os políticos ao povo é descrita pelo biógrafo com conotações distintas. Na página 96, citamos Thes.

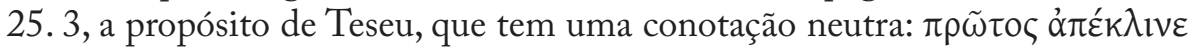

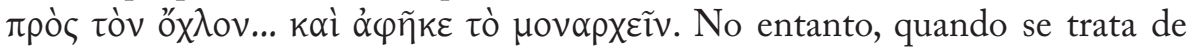

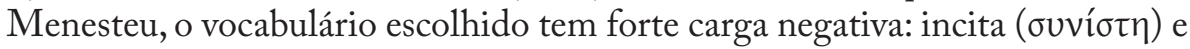

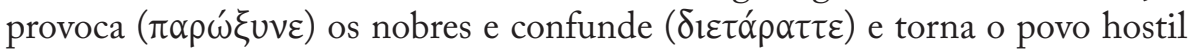
$(\delta 1 \varepsilon ́ \beta \alpha \lambda \lambda \varepsilon v)$.

Ora, ainda que não o diga diretamente, Plutarco aproveita o ensejo para, mais uma vez, criticar a volubilidade das massas (que tão depressa seguem os

${ }^{254}$ Sólon (Comp. Sol.-Publ. 3. 4) cometeria o mesmo erro ao deixar o caminho livre para Pisístrato.

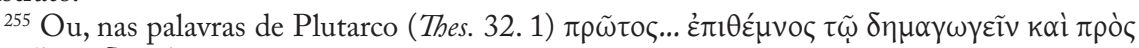

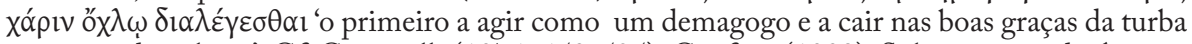
por meio da palavra'. Cf. Cantarelli (1974: 459-505); Canfora (1993). Sobre a ruína de Atenas, consultem-se, por exemplo, Mossé (1962); Kagan (1987). 
que lhes querem fazer bem, como os que apenas pensam no proveito próprio), a sua inépcia para escolher o melhor caminho e a sua ingratidão: é que, corrompido ( $\delta \varepsilon \varphi \theta \alpha \rho \mu \varepsilon ́ v o v)$ pelo demagogo, o povo depressa se esquece de ser

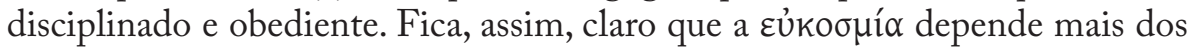
bons chefes do que do povo, facto que corrobora o interesse dos paradigmas individuais de que as Vidas são modelo.

Abalado o prestígio de Teseu, não foi difícil usar contra ele a invasão dos Dioscuros, provocada por um seu desvario ${ }^{256}$. Assim, aquele que, nos capítulos 12 e 17, surgia como restaurador da ordem por causa da sua $\alpha v \delta \rho \alpha \gamma \alpha \theta i ́ \alpha$ e $\varphi \rho o ́ v \eta \mu \alpha$ democráticos, figura, em Thes. 35. 4, como causador da convulsão política. Como se não bastasse ter deixado o povo entregue à sua sorte, ter dado azo à invasão da Ática, quando regressa da terra dos Molossos, faz tudo

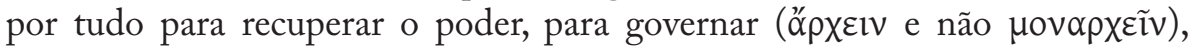
contribuindo assim para o aumento da desordem e da instabilidade.

Deparamo-nos, portanto, nas palavras de Pérez Jiménez (2000: 239), com um «viejo egoísta que ha perdido toda dignidad moral y autoridad política», já que, sedento de poder, se esquece dos objetivos do bom político, a justiça e a paz social, e tudo faz para reassumir o governo da тó $\lambda_{\imath} \zeta$. Assim, Teseu é retratado nesta fase como um ớvał da idade heroica (qual prepotente Agamémnon descrito no primeiro canto da Iliada), pois exige obediência que lhe é devida enquanto "chefe de Estado», mesmo que, ao fazê-lo, contribua para aumentar a instabilidade político-social. No entanto, mostra-se ainda com lucidez suficiente para não usar a força até ao limite e abandona o poder de livre vontade, quando se apercebe de que já nada pode contra o «monstro» que criara ${ }^{257}$.

Este reconhecimento não o impede de se sentir revoltado com o povo que apadrinhara e que agora o atraiçoa, pelo que, antes de partir para o exílio, amaldiçoa os Atenienses, do mesmo modo que Édipo amaldiçoara Creonte e os filhos.

${ }^{256}$ Muito embora corresse uma versão segundo a qual os Dioscuros teriam invadido a Ática de conluio com Menesteu. Cf. Thes. 32.2.

${ }^{257}$ A passagem do poder para Menesteu é um mal necessário, ao qual o objetivo racionalizador de Plutarco não pode fugir, pois só assim se consegue coadunar o reinado de Teseu com o passo da Ilíada (2.551-2) que faz de Menesteu o chefe dos Atenienses que participam na expedição a Troia. 


\section{FIM DE VIDA}

O momento do exílio coincide com a confirmação do declínio do político (que representa o declínio futuro do próprio regime democrático), mas também com a morte do herói. De acordo com a versão preferida por Plutarco, uma vez refugiado na ilha de Esciro, e confiante no acolhimento de Licomedes, que tinha por amigo - mas que, na verdade não queria ter problemas com o homem que então representava o poder (Menesteu) -, Teseu é mais uma vez traído por alguém em quem depositava todas as suas esperanças ${ }^{258}$ (como acabara de acontecer com os concidadãos atenienses) e encontra a morte, empurrado do cimo de um barranco ${ }^{259}$. Deste modo, ao afirmar que Licomedes agiu em

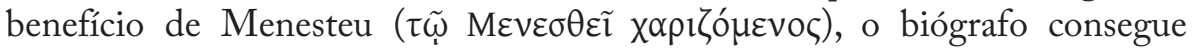
denegrir ainda mais a figura do demagogo.

Curiosamente, não houve reações à sua morte: Menesteu continuou, impávido, à frente dos destinos de Atenas, governando como um rei

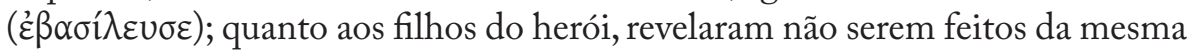
cepa do pai, pois nem se atreveram a vingar a morte do progenitor, nem a reclamar o poder sobre Atenas, limitando-se a aguardar o desaparecimento de Menesteu para, só então, (re)assumirem o poder que fora de Teseu.

A indiferença de todos - povo, inimigos, filhos - para com a morte de Teseu prende-se provavelmente também às circunstâncias inglórias em que ocorreu, impeditivas do normal processo de heroicização, donde resulta que os jogos em honra do fundador estejam relacionados com o episódio central da biografia e não com a sua morte, como é habitual ${ }^{260}$.

O povo, contudo, foi sabendo aos poucos dar valor ao herói que outrora havia atraiçoado. Isso aconteceu sobretudo na sequência do episódio da batalha de Maratona, durante o qual muitos julgaram avistar Teseu

${ }^{258}$ Se se aceitar a versão que atribui a responsabilidade da queda (física) a um descuido do próprio (Thes. 35.7), esta pode ser vista como uma repetição do que acontecera no plano político, no qual o declínio do herói não foi mais do que uma consequência do não cumprimento das suas funções de líder.

${ }^{259}$ Não deixa de ser curioso notar que a morte de Teseu é semelhante à de Egeu, pois também ela resulta de uma queda provocada por outra pessoa e permite que outros assumam definitivamente o poder em Atenas. Há, como não poderia deixar de ser, diferentes versões sobre a morte do herói. O próprio Plutarco faz alusão a outra, segundo a qual Teseu cai por seu próprio descuido; a mais curiosa é, contudo, a que faz de Teseu primeira vítima de ostracismo (cf. Teophr. fr. 131 Wimmer, Char. 26.6). Em Paus. 1.7. 4 sqq., podemos encontrar um resumo das diferentes versões.

${ }^{260}$ Cf. Calame (1990: 264-266). 


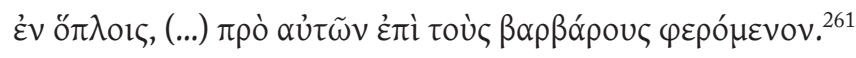

“armado, atacando os bárbaros em sua defesa."

Apenas nessa altura - ou seja, vários séculos após a sua morte e por indicação da Pítia - é que os ingratos Atenienses tentaram recuperar os ossos de Teseu para lhes prestar as homenagens merecidas. Mas só sob a ação de Címon ${ }^{262}$, em 476 a.C., foi possível fazê-lo, já que, tendo conquistado a ilha de Esciro, pôs fim à oposição que os Dólopes ofereciam ao resgate dos ossos de Teseu.

É curioso notar que o processo de recuperação dos ossos de Teseu descrito por Plutarco apresenta paralelos com a descrição que Heródoto (1.67-68) faz da recuperação dos ossos de Orestes ${ }^{263}$. Em ambos os casos, há um oráculo de Delfos que despoleta o processo de recuperação. Este revela-se particularmente difícil, porque, do túmulo - que se situa em território hostil - não se conhece a localização exata, até que aparece um cidadão (Címon, no caso de Teseu), com perspicácia suficiente para compreender as indicações divinas e encontrar as ossadas $^{264}$. Uma vez encontrados os esqueletos, que impressionam pelas suas grandes dimensões ${ }^{265}$, são transportados para um novo túmulo que, a partir desse momento, passa a proteger a cidade em cujo centro se situa.

No que respeita ao túmulo de Teseu, importa realçar que se tornou em um abrigo onde os mais desprotegidos buscavam refúgio. Tal facto evidencia a humanidade $(\varphi \imath \lambda \alpha v \theta \rho \omega \pi i ́ \alpha)$ que caracterizava a personalidade do herói, retratada, por exemplo, nas tragédias de Eurípides ou no Édipo em Colono de Sófocles e na oratória, textos nos quais Teseu surge como alguém sempre pronto a defender os fracos e a justiça ${ }^{266}$. E prenuncia o apoio que Atenas viria a dar àqueles povos que mais tarde pediram o seu auxílio.

Plutarco finaliza a biografia de Teseu com uma alusão às cerimónias que eram anualmente celebradas em sua homenagem. Importa, acerca deste assunto, fazer duas chamadas de atenção: a primeira, para salientar que este é um elemento que só ocorre em algumas biografias de fundadores ou de figuras

${ }^{261}$ Thes. 35. 8. Esta aparição miraculosa foi retratada no Pórtico Pintado; cf. Paus. 1.15. 3.

${ }^{262}$ Cf. Cim. 8. 5-7. A propósito da discussão desta data, vide Podlecki (1975: 1-20).

${ }^{263}$ A semelhança entre os dois casos é mencionada por Pausânias (3. 3. 5-8). Sobre este assunto, vide Moreau (1990, 209-218).

${ }^{264}$ Ao lado da de Teseu foram igualmente encontradas armas de bronze (Thes. 36. 2). Tal achado reveste-se de particular importância, pois o facto de as armas serem de bronze funcionava como «certificado» da antiguidade da ossada, já que as armas dos heróis míticos eram fabricadas, segundo a tradição, nessa liga metálica.

265 Acreditavam os antigos que os primitivos heróis eram verdadeiros gigantes. Cf. Il. 1. 262-272; Hdt. 2. 91. 3.

${ }^{266}$ Cf. supra p. 81 , nota 147. 
de cariz mitológico (como no caso da de Licurgo - Lyc. 30. 6-7), já que, por norma, os políticos «humanos» não eram agraciados com tais cerimónias. $\mathrm{O}$ outro pormenor que sobressai é o facto de essas festas ocorrerem no dia oito do mês de Pianépsion, que coincide com a data do seu regresso de Creta. O oitavo dia de cada mês era consagrado a Poséidon, pelo que muitos defendem que essa coincidência se deve à tradição que fazia de Teseu filho deste deus olímpico ${ }^{267}$.

Do esforço empreendido pelo biógrafo para traçar o perfil de uma figura mitológica em um enquadramento histórico, resulta um Teseu humano que, como o comum dos mortais, possui virtudes e vícios, o maior dos quais é o de se deixar guiar por paixões que põem em causa as suas qualidades inatas de bom político e a obra delas resultante.

A sua ação e as suas virtudes e vícios prefiguram o futuro político de Atenas, incluindo muitos aspetos da maneira de ser dos bons e dos maus homens de Estado. No decurso da análise do perfil de Péricles e Alcibíades (segundo Plutarco), procuraremos comprovar isso mesmo.

${ }^{267}$ Sobre este assunto, vide Flacelière (1948: 84). A propósito da organização das festas em honra de Teseu, leia-se Boer (1969). 
PARTe IV

Atenas, o umbigo da Hélade 
«São Atenienses! Quanto e como diferem de vós em tudo!» ${ }^{1}$

Pensar na Grécia antiga tem como reflexo condicionado evocar Atenas

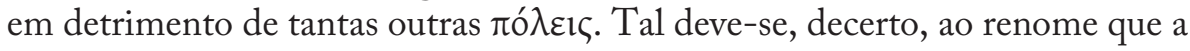
cidade alcançou e que foi conservado e transmitido de geração em geração até aos nossos dias, tantos séculos depois!

No entanto, ao contrário do que sugerem testemunhos literários e mitológicos, Atenas não foi sempre a cidade que hoje, de um modo geral, recordamos. Durante muito tempo, foi apenas mais uma tólıৎ do território helénico, que não sobressaía particularmente de entre as suas congéneres. De facto, a sua localização e condições geográficas colocavam muitos entraves naturais a um desenvolvimento económico sustentável ${ }^{2}$, que lhe permitisse o progresso alcançado no Século de Péricles. Foi sobretudo a partir do advento da democracia e do momento em que Temístocles decidiu rentabilizar a mais-valia que era para Atenas a sua costa, apostando na criação de uma armada poderosa, que a sorte da cidade conheceu uma mudança profunda. $\mathrm{Na}$ verdade, essa esquadra teve um papel fundamental na vitória grega sobre os Persas ${ }^{3}$, triunfo do qual resultou, mais do que uma nova Atenas, uma outra imagem desta aos olhos do mundo e aos olhos dos seus próprios cidadãos: entre os Gregos, tornou-se merecedora de respeito e reconhecimento; entre Bárbaros, gerou temor e ira; entre Atenienses, autoconfiança ${ }^{4}$ e orgulho. Desde

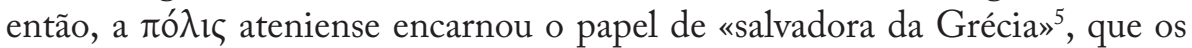
demais Gregos apenas contestaram quando começaram a sentir-se ameaçados pelo crescente poder e pela política expansionista da cidade de Atena.

De acordo com os testemunhos literários que hoje conhecemos, desde então, os Atenienses - ou pelo menos a generalidade deles - não tinham

${ }^{1}$ Thuc. 1.70 .

${ }^{2}$ Thuc. 1. 2. 5 afirma que a Ática não sofreu migrações, por causa de ter um solo pouco fértil que não atraía as populações nómadas. Também Plu. Sol. 22. 1 alude às características desfavoráveis da Ática, que contrasta com as do Peloponeso.

${ }^{3}$ Segundo Isoc. 4. 84, as Guerras Medo-Persas teriam sido inventadas por um deus, para que o valor dos guerreiros atenienses fosse dado a conhecer ao mundo. Sobre esta guerra e a política de Temístocles (descrita em Thuc. 1.90. 3 - 93. 8; Plu. Arist. 4 sqq., Them. 7-19), consultem-se Burn (1984); Lazenby (1993); Green (1996); Lenardon (1978).

${ }^{4} \mathrm{Cf}$. Plu. Them. 8.2, onde se afirma que a confiança é o começo da vitória, e Cim.13.1, onde se menciona a consciência que os Atenienses tinham da sua força e o orgulho que sentiam pela vitória.

${ }^{5}$ Cf. Hdt. 7. 139. Sobre o elogio de Atenas em Heródoto, vide Evans (1979: 112-118); Demand (1987: 746-758). 
pejo $^{6}$ em afirmar a sua condição de povo superior. Disso é exemplo o próprio Péricles, que conferiu a Atenas o título de "escola da Grécia" (por causa da sua maneira de ser e dos bons exemplos que dava) e que também deixou claro que

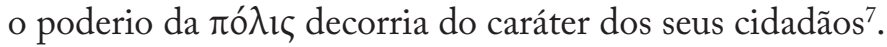

Com efeito, os Atenienses julgavam-se senhores de uma civilização e de uma maneira de ser singulares ${ }^{8}$, assentes em valores básicos como o bom senso, a obediência à lei, a igualdade, a audácia, a amizade, o respeito pelos deuses, a resistência à opressão e à injustiça, a capacidade de persuasão. Não admira, pois, que as virtudes atenienses, antes de a oração fúnebre ${ }^{9}$ se tornar em um género literário propício ao seu elogio, fossem evocadas de modo disperso nos diferentes textos que abordavam a figura de Teseu (que representa o espírito da Atenas idealizada ${ }^{10}$ ), nomeadamente na tragédia, como acontece, por exemplo, no Édipo em Colono de Sófocles ou nas Suplicantes de Eurípides ${ }^{11}$ (onde o fundador surge como personagem), e noutras, como as Euménides de Ésquilo ${ }^{12}$ ou Os Heraclidas e a Medeia de Eurípides (nas quais os soberanos de Atenas, que representam o mesmo espírito, são, respetivamente, Demofonte e Egeu). Também a narrativa e a oratória não foram alheias ao constante autoelogio dos naturais de Atenas à sua maneira de ser e de viver, pelo que vários outros autores - de entre os quais destacamos Tucídides, Isócrates e Lísias - retrataram a imagem que os Atenienses tinham de si próprios e até a que os outros tinham deles. A própria comédia, género, por excelência, dos ataques e da ridicularização do sistema, não consegue ser alheia a este fenómeno, como muito bem afirma Mills (1997: 51) ${ }^{13}$ :

${ }^{6}$ Antes pelo contrário: segundo Ar. Ach. 634-640, os Atenienses gostavam tanto de ser

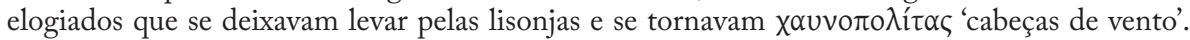
$\mathrm{Na}$ paródia que faz a este excesso de vaidade, o comediógrafo evoca o epíteto "povo coroado de violetas» (cf. Ar. Eq. 1329), que foi pela primeira vez associado à beleza de Atenas por Píndaro (fr. 76 Snell). Tal elogio encheu os Atenienses de orgulho e valeu ao poeta diversas recompensas, de acordo com os testemunhos de Isoc. 15.166 e Paus. 1. 8.4, respetivamente, o título de próxeno e dez mil dracmas e uma estátua. Aristófanes (Ach.634-640) recorda ainda o epíteto «brilhante» (Pi. I.2.20), que era usado com frequência pelos diplomatas, experimentados conhecedores desta sensibilidade ateniense. Também Plutarco se refere a este gosto por elogios em Moralia 799C, onde acrescenta, ao contrário do que poderíamos imaginar, que os Atenienses não reagiam mal aos que os ridicularizavam com palavras espirituosas.

${ }_{7}^{7}$ Thuc. 2. 41. Segundo o estadista, o valor de Atenas era muito superior à sua fama. Sobre a perspetiva que Péricles tinha do caráter ateniense, vide Rusten (1985: 14-19).

${ }^{8}$ Cf. infra p. 117.

9 Para um aprofundamento deste tema, vide Loraux (1981) e bibliografia aí citada. É igualmente interessante consultar Ziolkowski (1981).

${ }^{10}$ Cf. supra p. 56.

${ }^{11}$ Este tema encontra-se desenvolvido em Mills (1997: 87-185); Walker (1995: 146-193) e também em Hook (1931: 26 sqq.); Blundell (1993: 287-306).

${ }^{12}$ Vide Kitto (1966: 74-115).

${ }^{13}$ Para uma visão da perspetiva que os Atenienses tinham sobre si próprios na comédia de Aristófanes, nomeadamente em Acarnenses, consulte-se Silva (2007: 137-151). 
«even comedy can contain a kind of «anti-encomium» of Athens, which necessitates that its audience is familiar with an ideal Athens and what is typical, institutionally and otherwise, of it.»

Esse louvor exacerbado dos Atenienses não era um mero exercício de vaidade através do qual davam a conhecer as suas virtudes. Servia, sobretudo, para justificar aquele que entendiam ser o seu pleno direito à hegemonia ${ }^{14}$, em particular quando esta começou a ser contestada pelos aliados, apesar de se ter revelado de grande utilidade para a Hélade, na medida em que permitiu a expulsão dos Bárbaros e a prosperidade dos Helenos.

Do mesmo modo que as famílias nobres procuravam valorizar a sua linhagem atribuindo a si mesmas heróis mitológicos como antepassados, as cidades pretendiam fazer remontar as suas origens a períodos imemoriais e ter fundadores ilustres ${ }^{15}$. No caso de Atenas, a excelência deriva da sua antiguidade e do facto de os Atenienses acreditarem (e passarem por) ser o único povo grego que não resultava de fusões ou migrações nómadas ${ }^{16}$ :

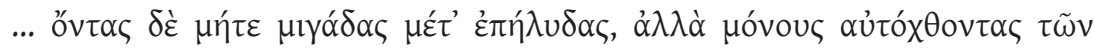
'E $\lambda \lambda \eta \dot{v} v \omega v . . .{ }^{17}$

“... não têm nem sangue misturado nem sangue estrangeiro, mas os únicos de entre os Gregos nascidos no seu território...”

Por isso, como único povo autóctone, que, segundo a tradição, teria brotado do solo da Ática e sido o único a aí ter habitado desde sempre, os Atenienses tinham uma razão de monta para se considerarem Gregos de

${ }^{14}$ Com efeito, porque a hegemonia de Atenas remontava às relativamente recentes Guerras Pérsicas, os Atenienses sentiram a necessidade de lhe conferir antiguidade, com o intuito de reforçá-la e dignificá-la. Não surpreende, por isso, que Isoc. 4.37 afirme que a hegemonia de Atenas é anterior à fundação da maior parte das cidades gregas. Segundo o orador (Isoc. 4.

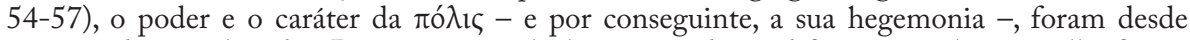
muito cedo reconhecidos. Para comprová-lo, basta recordar as diferentes súplicas que lhe foram dirigidas aos longo dos tempos, como a dos filhos de Hércules (Lys. 2. 11-16 ) e a de Adrasto (Lys. 2. 10), ou, na perspetiva de Hdt. 9. 27, os seus feitos ancestrais, como a participação na Guerra de Troia, na Amazonomaquia e o apoio dado aos Heraclidas.

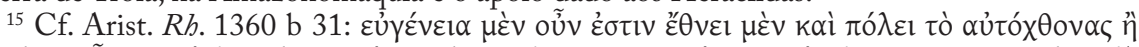

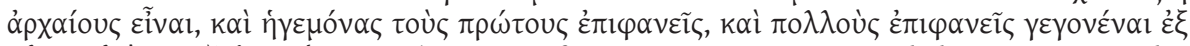

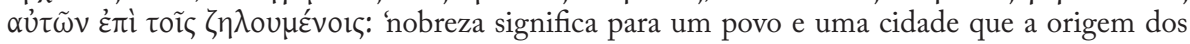
seus membros é autóctone ou antiga, que os seus primeiros chefes foram ilustres e que muitos descendentes se ilustraram em qualidades invejáveis'. A tradução apresentada é da autoria de Júnior, Alberto - Pena (2005).

${ }^{16}$ Cf. Hdt. 7. 161; Thuc. 1. 2. 5, 2. 36. 1; Lys. 2. 17. Sobre a autoctonia, vide Loraux (1979: 1-26; 1996); Rosivach (1987: 294-306); Cohen (2003, em especial o segundo capítulo).

${ }^{17}$ Isoc. 12.124. 
primeira categoria, de raça pura, reforçando a imagem de superioridade que tinham de si próprios. Além disso, sempre que evocavam este mito, rebaixavam os restantes Gregos ${ }^{18}$, apresentavam uma justificação para o ódio que nutriam pelos Bárbaros ${ }^{19}$ e para o seu direito à hegemonia ${ }^{20}$.

A autoctonia (referida, por exemplo por Plu. Moralia 820A; Pl. R. 415a$\mathrm{b}, 416 \mathrm{e})$ configura, assim, um elemento patriótico e cívico, que constitui um apoio fundamental à propaganda externa de Atenas e suporta a unidade dos seus habitantes. De acordo com o que afirma Péricles em Thuc. 2. 38, essa origem é uma das principais responsáveis pelo desenvolvimento de uma cultura única e original (devido à sua autoctonia, Atenas nunca imitou ninguém). É essa mesma autoctonia, essa condição de superioridade inata ${ }^{21}$, que - não sendo aquilo a que podemos chamar uma virtude moral - desperta no povo de Atena a necessidade de viver em regime de igualdade e respeito pela lei, bem como de sair em defesa dos mais fracos e oprimidos ${ }^{22}$. Podemos, por isso, afirmar que as virtudes dos Atenienses como que decorrem da sua origem de exceção e são ampliadas pelo modus vivendi por que decidiram enveredar.

${ }^{18}$ De acordo com D. 60. 4, os demais Gregos são filhos adotivos das cidades onde vivem, ao contrário dos Atenienses, cidadãos de nascimento legítimo. Cf. Lyc. 48.

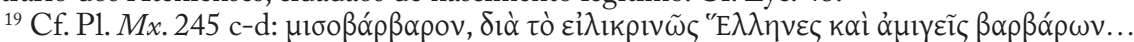
'o ódio natural aos Bárbaros, porque somos Gregos puros e sem mistura com Bárbaros'. Isoc. 14. 66-71 debruça-se sobre a relação dos Atenienses com os Bárbaros e afirma que estes saíram derrotados sempre que atacaram Atenas com o intuito de, conquistando-a, submeter em simultâneo os demais Gregos. Foi isso que aconteceu, por exemplo, com as Amazonas (cf. Isoc. 4. 68; Lys. 2. 4-6) e, mais tarde, com Dario e Xerxes (cf. Hdt. 7.139; Lys. 2. 21-43), o que revela que os Bárbaros tinham uma conceção «atenocêntrica» da Hélade. Ideia semelhante ocorre em A. Pers. 233-234, onde o Corifeu diz à Rainha que o Rei desejava conquistar Atenas para, assim, sujeitar toda a Grécia, e em Plu. Arist. 5.1, segundo o qual Dario envia Dátis sob o pretexto de castigar Atenas, mas com a real intenção de conquistar a Grécia.

${ }^{20}$ Cf. Hdt. 7. 161: diante da pretensão siracusana de comandar a frota, os Atenienses recusam ceder o seu posto, por possuírem a linhagem mais antiga e serem os únicos de entre os Gregos a nunca ter mudado de território. Igual relação de causa e consequência estabelece Isoc. 4. 24-25, quando defende que o único povo grego com origem no próprio solo deve recorrer a esse argumento para reclamar o seu direito à hegemonia.

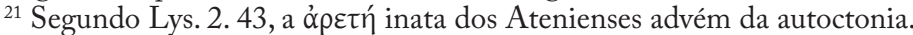

${ }^{22}$ Cf. E. Heracl. 329-332: 'A

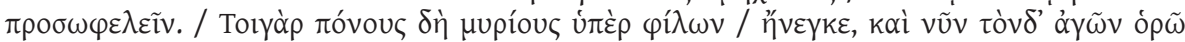
$\pi \varepsilon ́ \lambda \alpha{ }^{\prime}$. Esta terra tendeu sempre a socorrer com justiça quem estava em apuros. Por isso já suportou sofrimentos sem conta em prol dos amigos, e ainda agora vejo que se aproxima o momento da luta' (tradução de Silva: 2000). Esta mesma característica é mencionada em Isoc. 4. 52, onde se afirma que os Atenienses sempre lutaram pelos mais fracos e pelos suplicantes, mesmo em prejuízo dos seus interesses, em vez de se aliarem às injustiças dos mais fortes para alcançar benefícios. Quando era caso disso, entravam em guerra por aqueles e saíam vitoriosos, o que faz com que as intervenções militares de Atenas possam ser vistas como ajuda ao próximo,

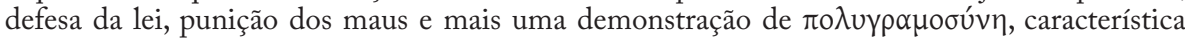
desenvolvida infra a partir da p. 120. 
Vejamos, então, quais os traços inerentes aos Atenienses ${ }^{23}$, que os tornavam «superiores aos demais Gregos», partindo do testemunho de Tucídides, que completaremos - sempre que pertinente - com os de outros autores.

A caracterização elogiosa que o historiador ${ }^{24}$ faz do povo a que pertence, apesar de também ser tratada na oração fúnebre de Péricles (2. 35-46), ocorre sobretudo em dois grandes momentos do Livro I: por ocasião da intervenção dos Coríntios (68-71) e aquando da resposta da embaixada ateniense (73-79). Esta ordem torna-se digna de reparo. Não terá sido, decerto, inocente a opção por apresentar primeiro a visão que os «outros» têm dos Atenienses, a qual consiste em um misto de ódio e admiração, e só depois, em jeito de defesa, a ideia que os visados têm de si mesmos. Deste modo, a própria importância dos Atenienses ganha ênfase: todos falam a seu respeito, demonstrando um não pequeno receio pelo poder que detêm e tentando convencer-se mutuamente da necessidade de fazer frente à ameaça que Atenas representa ${ }^{25}$; no entanto, acaba por ser esta a ter a última palavra na fase de argumentação que precede a sentença dos Lacedemónios.

Igualmente digno de reparo é o facto de os Coríntios caracterizarem os Atenienses por contraste com os Lacedemónios ${ }^{26}$, deixando evidente que Atenas é um inimigo digno de respeito, muito mais do que a Lacedemónia, o seu grande adversário. Esta estratégia, além de realçar a superioridade dos de Atenas (que surgem sempre como «- $\tau \alpha \tau o l »)$ e inferiorizar os seus eternos rivais, serve de aguilhão para incitar a pronta reação dos Lacedemónios que, apesar das críticas, seriam os únicos com condições para fazer frente ao poderio ateniense $\mathrm{e}^{27}$. sqq.).

${ }^{23}$ Sobre os prós e contras da tentativa de definir um perfil ateniense, vide Mills (1997: 43

${ }^{24}$ Ao longo da sua obra, Tucídides oscila entre o elogio e a crítica a Atenas. Há passos em que assume que Atenas é uma tirania (e. g. Thuc. 2.63, 3.37. 1; cf. Ar. Eq.1111-14, 1130, 1133, $V .620$ ) e que a maioria dos Helenos, aliados ou não, a odeiam (Thuc. 2. 8. 4, 11.2).

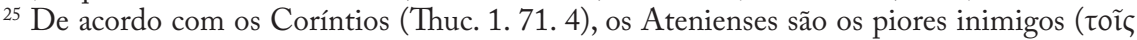
Ė犭 5) - cf. infra p. 130.

${ }^{26}$ Mais do que uma estratégia dos Coríntios, esta é uma das linhas de leitura possível da obra de Tucídides, segundo Luginbill (1999).

$27 \mathrm{O}$ mesmo tema é abordado por Eurípides na Andrómaca, onde Menelau representa o espartano hostil, e por Isoc. 12. 41-48, que louva Atenas por ter contribuído para o engrandecimento da Grécia (cf. etiam Isoc. 4. 26 sqq.) e critica a egoísta Esparta por só pensar em causas próprias, chegando mesmo a acusá-la, ainda que de modo velado, de ter sido um obstáculo à evolução da Hélade (Isoc. 4. 20). Para mais críticas à atuação de Esparta, vide infra nota. 49. Para mais referências ao seu egoísmo, cf. Thuc. 1. 74.3 (onde é acusada de temer pela sua sorte e não pela de Atenas), 3.13.7 (onde é incitada a agir para escapar à acusação de não prestar auxílio). Não deixa de ser curioso notar que, segundo Plu. Cim. 16. 4, que se baseia em Estesímbroto, Címon tinha o procedimento inverso: sempre que queria repreender ou exortar os Atenienses, apresentava-lhe os Lacedemónios como modelo. 
Recordemos o que diz Tucídides.

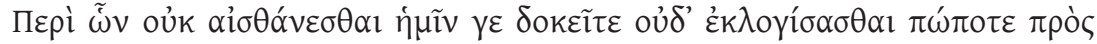

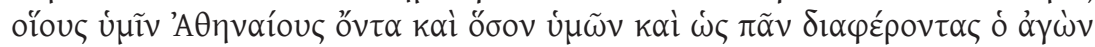

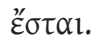

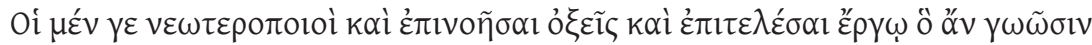

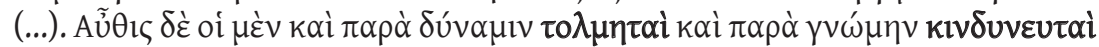

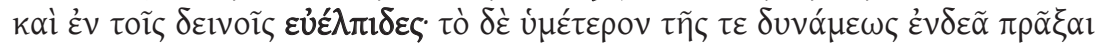

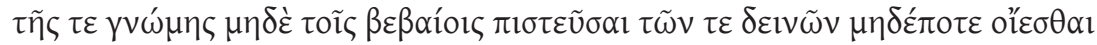

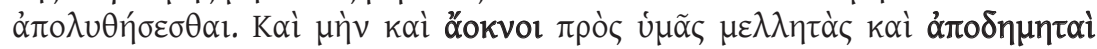
$\pi \rho \grave{\varsigma} \xi \dot{\varepsilon} v \delta \eta \mu o \tau \dot{\alpha} \tau o v \varsigma(. . .)^{28}$

"Nem jamais calculastes contra que tipo de inimigo será a luta. São Atenienses! Quanto e como diferem de vós em tudo!

Eles são inovadores e vivos no planear e realizar o que têm em mente (...). E ainda, são audazes além da força, temerários além da razão, no perigo, otimistas; é característica vossa agir aquém das forças, não confiar nem sequer nas reflexões seguras e julgar que jamais vos livrareis dos perigos. Eles são resolutos e vós, hesitantes; dispostos a deixar a sua terra, e vós apegadíssimos à vossa (...).”

Do excerto que acabámos de transcrever (e da totalidade do parágrafo onde se insere), ressalta a $\pi 0 \lambda \cup \gamma \rho \alpha \mu \sigma \sigma u ́ v \eta^{29}$, considerada por muitos o principal traço do caráter ateniense, embora Tucídides não utilize o substantivo abstrato que o designa. Esse dinamismo, esse empreendedorismo, essa prontidão para a ação que os impede de serem meros espectadores dos acontecimentos é, direta ou indiretamente, responsável por todos os sucessos que Atenas logrou e pela crítica que os Coríntios lhe fazem de nunca deixarem ninguém em paz ${ }^{30}$.

O êxito desta característica está, segundo Péricles (Thuc. 2. 40) ${ }^{31}$,

${ }^{28}$ Thuc. 1.70.1-4. A tradução apresentada é de Prado (1999: 93). Para uma análise linguística e literária do discurso dos Coríntios, leia-se Milman Parry (1981: 126-138).

29 Vide Adkins (1971: 301-327); Allison (1979: 10-22); Ehrenberg (1947: 46-67); Gutglueck (1988: 21-39). Sobre este conceito em Tucídides, vide Gomme (1945-1956: 232) e Hornblower (1991: 115). A maior prova da atividade frenética dos Atenienses é o relato de Thuc. 1. 89-117, conhecido por Pentecontaitia, que descreve os acontecimentos decorridos entre o fim das Guerras Medo-Pérsicas e o debate de Esparta, ou seja a formação do império.

${ }^{30}$ A paródia que Ar. Plu.911-915 faz desta característica não podia estar mais de acordo com a perspetiva dos Coríntios: o Sicofanta considera prestar um serviço à cidade o «meter o nariz»

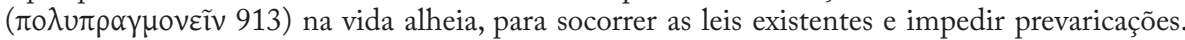
Havia, contudo, logo no início da formação do império, políticos com a perceção de que este excesso de vitalidade dos Atenienses, incapazes de ficar tranquilos e sempre prontos para novas empresas e conquistas, podia desagradar aos aliados. Segundo Plu. Cim.18. 1, foi por isso que Címon, em uma tentativa de direcionar a atenção dos concidadãos para longe dos povos da mesma raça, decidiu realizar uma expedição contra o Egito e Chipre. Sobre o comportamento contrário de Péricles, vide p. 262, n. 238.

${ }^{31}$ Cf. Isoc. 8. 52. 
relacionado com a superioridade do seu povo, o único capaz de combinar ह́pyov (que representa a força física, a dinâmica de ação, a violência) e $\lambda o ́ \gamma o \zeta$ (que representa a paz, a inteligência, a persuasão, o civismo) ${ }^{32}$. Isto significa que a sua ação (que parece desenfreada e intempestiva pela rapidez com que é executada) se baseia na pronta reflexão, ou seja, em uma reflexão que não se arrasta pelo tempo, pondo em causa a execução, antes pelo contrário: permite esclarecer as ideias antes de agir, logo, mostrar audácia com riscos calculados ${ }^{33}$. Porque senhores desta capacidade ${ }^{34}$, os Atenienses preferem surpreender a ser surpreendidos, antecipar em vez de reagir ${ }^{35}$ e mostram-se indignados com a apatia dos outros Gregos. É, por isso, compreensível que os Coríntios atribuam à rapidez que os Atenienses conferem ao processo de decisão/ação ${ }^{36}$ a responsabilidade pelos êxitos por estes alcançados.

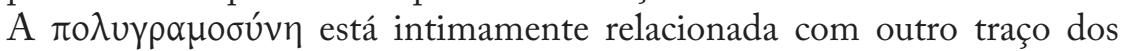
Atenienses, a ambição, a ânsia de sucesso, que fazia com que, sempre insatisfeitos com o que tinham, buscassem mais e melhor, sem se importarem de correr riscos para alcançar os seus objetivos ${ }^{37}$. Foi esta maneira de ser que, de acordo

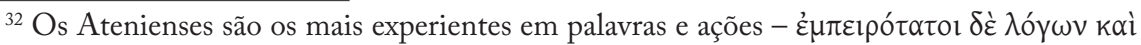

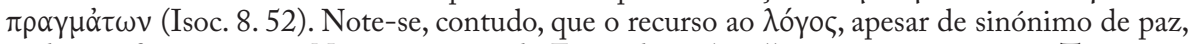
pode justificar a guerra. Nas Suplicantes de Eurípides, a batalha só acontece porque Teseu não consegue persuadir os Tebanos de outro modo.

${ }^{33}$ Cf. Thuc. 7.28, onde se afirma que quem não quer correr riscos protela a ação; quem não se importa de corrê-los passa à execução com maior rapidez.

${ }^{34}$ Como exemplo desta característica, mais uma das que causava a admiração dos seus pares e dos inimigos, podemos recordar a velocidade da construção dos muros em Siracusa (Thuc. 6. 98) e em Atenas (Thuc. 1.93), bem como a rapidez da concretização do programa de obras de

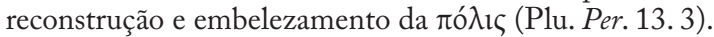

${ }^{35} \mathrm{Vd}$. Thuc. 6. 18, segundo o qual Alcibíades declara que não se devem defender dos ataques dos mais fortes, mas precaver-se antes que ataquem.

${ }^{36}$ Cf. Thuc. 1.57; Isoc. 4.87. Em Ar. Ach. 630-631, o comediógrafo parodia esta característica, quando afirma que os Atenienses estão sempre prontos a tomar decisões e ... a alterá-las. Esta pretensa indecisão pode ser interpretada de dois modos: um, negativo, por sugerir insegurança e desorientação; outro, positivo, pois a abertura de espírito necessária para voltar atrás aponta para natureza superior e magnanimidade. Disto nos dá testemunho Thuc. 3. 36, quando relata que os Atenienses, que haviam decidido executar todos os homens de Mitilene e escravizar as mulheres e crianças, se apercebem da crueldade e exagero de uma tal posição e recuam. Tal comportamento decorre, segundo Plu. Moralia 799C, de o povo ateniense ser propenso à ira e e à conversão desta em piedade, pois prefere suspeitar primeiro e averiguar a verdade depois. Esta maneira de ser faz-nos pensar em Édipo, que, não sendo ateniense, é talvez o exemplo máximo daqueles que pautam as suas vidas por decisões e ações intempestivas. Cf. Knox (1957: 69). Sobre o caráter moderado dos Atenienses, vide infra p. 128 nota 77.

${ }^{37}$ Os riscos corridos por Atenas eram normalmente bem calculados. Recorde-se o discurso de Péricles (Thuc. 2. 40. 3): à sua audácia $(\tau o ́ \lambda \mu \alpha)$, os Atenienses aliavam (além da rapidez e iniciativa) a inteligência, ao contrário dos demais Gregos. Por isso, a audácia dos pares era por ele considerada ó $\mu \alpha \theta$ ía 'ignorância, estupidez'. Segundo Plu. Them. 7. 4, Temístocles foi um dos mais ilustres exemplos da perfeita junção destas características, fazendo com que os Atenienses se mostrassem superiores ao inimigo pela sua coragem e aos aliados pela sua inteligência. Sobre os riscos corridos, vide infra p. 123. 
com a constatação dos Coríntios ${ }^{38}$ - de tom francamente abonatório para os

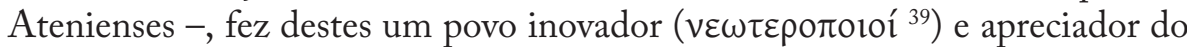
progresso, que aproveitava a experiência ${ }^{40}$ adquirida em diversas áreas (como, por exemplo, a do combate naval) para aperfeiçoar recursos e métodos, de modo a melhor enfrentar os problemas com que se iam deparando. Ficava, por isso, a impressão de que quanto maior a dificuldade, maiores os seus empenho e coragem.

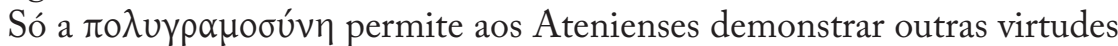

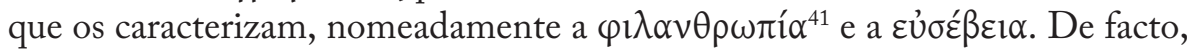
os Atenienses passavam por ser um povo piedoso, que não media esforços para defender as leis ${ }^{42}$ (quer as divinas, quer as humanas), protegendo os mais fracos e oprimidos, os suplicantes ${ }^{43}$ e procurando punir os maus ${ }^{44}$. Uma tal atitude

${ }^{38}$ Thuc. 1.71.3.

${ }^{39}$ Vide Gomme (1945-1956: 230) e Hornblower (1991: 114). Um dos exemplos dessa aptidão dos Atenienses para inovar é mencionado por Plutarco em Per. 27. 3. Através desse passo, ficamos a saber que Péricles era um grande adepto de engenhos de guerra, matéria em que tinha o engenheiro Ártemon como assessor.

40 Thuc. 1. 142. 5. Os Atenienses tinham orgulho na sua atividade constante e na vasta experiência que dela resultava, de tal modo que esta foi usada como incentivo por diferentes generais. Cf. Thuc. 2. 89, 6. 18, segundo os quais Nícias e Alcibíades (respetivamente) apelam à tradição da atividade militar ateniense para encorajar os soldados.

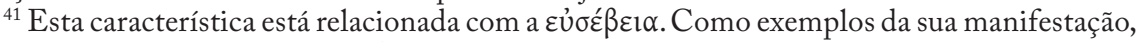
podemos lembrar o facto de os Atenienses não escolherem as suas amizades com base nos benefícios que delas lhes poderiam advir, mas nos que podem conceder aos seus amigos (Thuc. 2. 40. 4); ou ainda o facto de ajudarem os oprimidos por acreditarem no valor da liberdade e não para proveito próprio (Thuc. 2. 40. 5). A relação que mantêm com os estrangeiros que habitam em Atenas, ainda que condicionada pelos limites decorrentes da consciência da sua condição de povo superior, também demonstra essa humanidade: os estrangeiros podem partilhar o dom que é viver em Atenas, mas têm um estatuto próprio, que lhes veda sobretudo a participação na vida política ativa, apenas ao alcance do cidadão autóctone. Apesar desta grande privação, muitos preferem viver em Atenas e beneficiar do seu esplendor cultural, a partilhar direitos políticos com os concidadãos das suas cidades de origem. Sobre o estatuto do estrangeiro em Atenas, vide Austin - Vidal-Naquet (1986); Clerc (1979); Gauthier (1972: 107 sqq.).

${ }^{42}$ De acordo com a crença grega, a lei era uma instituição de origem divina. Os Atenienses,

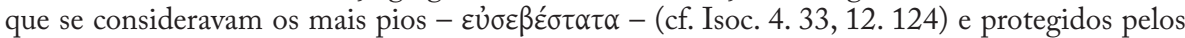
deuses, davam o seu melhor para defender o cumprimento da lei e os direitos dos suplicantes, mesmo que para isso tivessem de entrar em guerra. Foi o que aconteceu, segundo a tragédia, quando os Heraclidas e os Argivos pediram auxílio a Atenas. Sobre o estabelecimento das leis em Atenas, vide etiam Lys. 2.19 e Bonner - Smith (1938); Harrison (1968-71); Gagarin (1989) e Todd (1993).

${ }^{43}$ Cf. Isoc. 4. 52-53; P1. $M x$. 244e, que mencionam a ação desinteressada em prol dos mais fracos e dos Gregos oprimidos. Em S. OC 260-62, 1125, Édipo apresenta Atenas como modelo de piedade e de justiça, por ser a única cidade com vontade e capacidade de proteger e defender os hóspedes. Também em Euménides, Medeia e Édipo em Colono, Atenas é apresentada como a única $\pi$ ó $ı \varsigma$ preparada para aceitar pessoas poluídas por crimes cometidos em outras cidades, logo a única capaz de perdoar e de demonstrar humanidade. Cf. p. 118, nota 22.

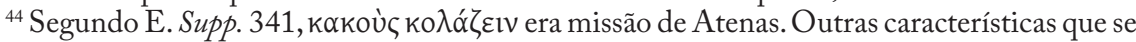
relacionam com o acolhimento de suplicantes e oprimidos (e que, consequentemente são típicas 
não lhes granjeava muita simpatia por parte dos «vilões». Lidar com um suplicante implicava, por isso e sempre, o duplo risco de provocar uma guerra ou incorrer em ü $\beta p \varsigma^{45}$. A piedosa Atenas preferia, como é óbvio, o primeiro para defender os seus ideais. Um tal altruísmo e respeito pelos deuses acabava sempre premiado na proporção do risco corrido, como podemos verificar em tragédias como as Euménides de Ésquilo, o Édipo em Colono de Sófocles ou o Héracles e as Suplicantes de Eurípides, segundo as quais Atenas passa a ficar protegida por divindades antes adversas e por heróis.

A vivência desta $\varepsilon \dot{\sigma} \sigma \varepsilon ́ \beta \varepsilon l \alpha$ beneficia, por isso, da «hiperatividade» ${ }^{46}$ e do dom de combinar força e inteligência ${ }^{47}$ atenienses, acabando por estar também associada ao fomento do poderio militar. Só com meios suficientes era possível dar uma resposta pronta aos pedidos de ajuda que, de todo o lado - e desde sempre -, chegavam a Atenas, pelo que a ação militar acaba por se tornar em

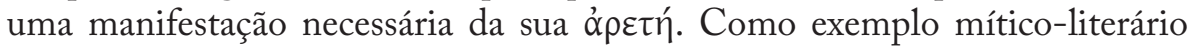
dessa capacidade de resposta pronta - que distinguia Atenas dos demais, em particular de Esparta ${ }^{48}$-, podemos recordar a rápida intervenção de Teseu para ajudar Édipo em S. OC 897, 904, que demonstra a confiança que os Atenienses têm nas suas ações, a consciência da sua força militar, bem como do

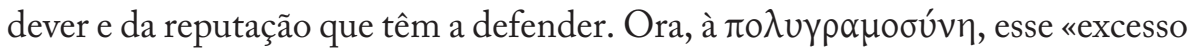
de energia», por causa do qual não viviam nem deixavam os outros viver em paz, contrapõe-se (nas palavras do orador coríntio) a inércia lacedemónia que acabou por contribuir para dar mais liberdade de ação aos sonhos imperialistas de Atenas ${ }^{49}$.

dos Atenienses) são a filantropia, o bom-senso, a coragem, a piedade e a generosidade. Para um estudo aprofundado destes conceitos e do vocabulário grego que os designam, consultem-se Ferguson (1958); Adkins (1960, 1972).

${ }_{45}$ Os Atenienses nunca incorrem voluntariamente em űßpı, porque são moderados, pacíficos e não são exageradamente confiantes. Cf. Mills (1997: 60).

${ }^{46}$ E. Supp. 305-310.

${ }^{47}$ Thuc. 2. 40. 3. A força é necessária para conquistar os que o merecem, a inteligência para fazer a opção entre castigo e perdão. Cf. supra 121, nota 36.

${ }^{48}$ Segundo Thuc. 6.18, os Atenienses socorrem sempre de imediato a quem lhes pede ajuda.

${ }^{49} \mathrm{Na}$ perspetiva dos Coríntios, os Lacedemónios estão sempre a ponderar os perigos e jamais dão o seu melhor quando abraçam uma causa. Ao denegrir a imagem dos Lacedemónios, os Coríntios parecem fazer da omissão daqueles o segundo grande responsável pelo poderio

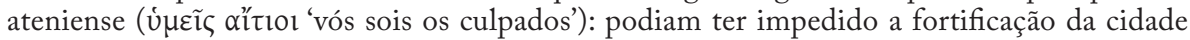
a seguir às Guerras Médicas e não o fizeram; podiam ter travado as suas ambições, mas não esboçaram qualquer reação nesse sentido (cf. Thuc. 1. 69. 1). Não admira, por isso, que

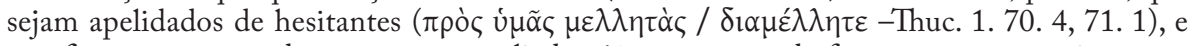
que fique a sugestão de que são maus aliados, já que, apesar da fama, eram um apoio pouco

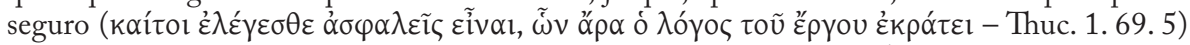
e responsáveis pela ruína de vários dos que neles haviam confiado (como os Potideatas, os Tásios e os Eubeus - Thuc. 1.58.1.101.1-2,1.114). Até os Atenienses se queixam do pouco apoio que os Lacedemónios lhes prestaram por ocasião das Guerras Médicas (Thuc. 1. 74. 2-3; Plu. Arist. 10. 7, Them. 11. 5). Fica, pois, a ideia de que Esparta vivia presa ao passado, à tradição e de que Atenas era símbolo de progresso. Cf. Chatelet (1962: 35): «Sparte tend à 
Essa capacidade interventiva dos Atenienses era coadjuvada pelo facto de

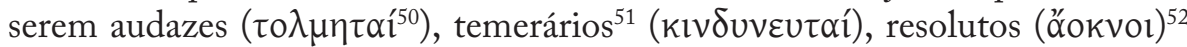

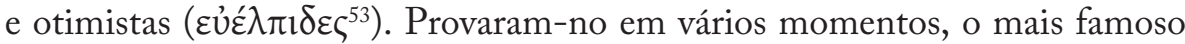
dos quais terá sido, sem dúvida, as Guerras Médicas ${ }^{54}$, durante as quais puseram em prática estratégias nunca antes utilizadas pelos Gregos. Também por essa ocasião foi possível comprovar uma outra qualidade importante dos Atenienses: a abnegação que manifestavam quer em relação à vida, quer em

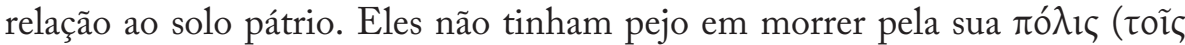

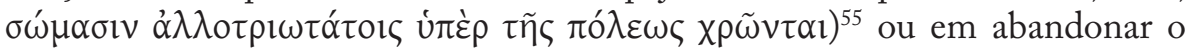

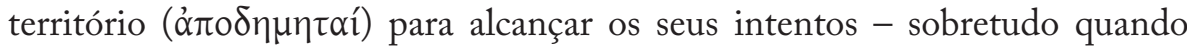
o que estava em causa era a salvação da Hélade ${ }^{56}$, o que exemplifica bem a definição que Tucídides (7.77. 7) dá dessa realidade tipicamente grega:

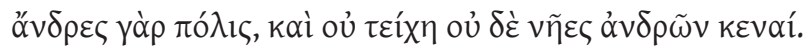

abolir l'histoire; Athènes veut la faire».

${ }^{50}$ Cf. Hornblower (1991: 115). Em Thuc. 1.70. 2 e 1.74. 2 e 4, ocorrem por diversas vezes palavras da família de $\tau o ́ \lambda \mu \alpha$ 'audácia, coragem', quer na boca dos Atenienses, quer na dos Coríntios. A coragem de Atenas suscitava admiração e terror entre os Gregos, porque parecia ser diretamente proporcional às dificuldades enfrentadas. O próprio Péricles reconhece essa capacidade quando, em Thuc. 1.144. 4, afirma que a vitória sobre os Persas se ficou a dever

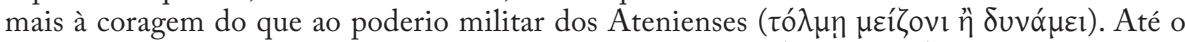
inimigo elogia a audácia deste povo, que, segundo Górgias (DK 82 B6), possui um ímpeto

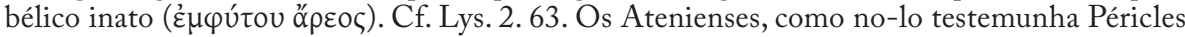
em Thuc. 2.39, tinham a percepção de que a coragem é um dom inato, mais do que algo que se possa aprender através do treino militar precoce, como advogam os Espartanos. A sugestão de que as tropas de Atenas não são profissionais mas amadoras serve para sobrevalorizar as capacidades bélicas e a coragem deste povo e para desdenhar das virtudes aprendidas do inimigo, já que estas são necessariamente imperfeitas (cf. Pi. N. 3. 40 sq.). Vide Loraux (1981b: 150).

${ }^{51}$ Isoc. 4. 95 afirma que a cidade que quiser liderar a Grécia tem de ter a capacidade de afrontar o perigo, em uma clara alusão a esta característica ateniense.

${ }^{52}$ Este traço de caráter revela-se, sobretudo, através da pronta ação dos Atenienses. Cf. supra p. 121 sq.

${ }^{53}$ Cf. Gomme (1945-1956: 230) e Hornblower (1991: 115). Ao destacarmos este adjetivo da caracterização que os Coríntios fazem dos Atenienses, foi impossível não relacioná-lo com Evélpides, uma personagem das Aves de Aristófanes, que personifica o espírito empreendedor, otimista e aventureiro do povo de Atenas. Importa também recordar que esta característica

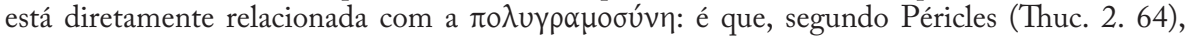
os Atenienses eram conhecidos pelo seu vigor e por terem fé na ação. Como exemplo deste otimismo, vide Thuc. 1. 138 (postura de Temístocles), 4. 10 (em que Demóstenes incita os soldados antes do combate em Esfactéria), 7. 77 (em que Nícias faz o mesmo antes da última batalha de Siracusa).

${ }^{54}$ Cf. infra p. 126: os próprios Atenienses escolhem este acontecimento como contexto supremo da realização das suas qualidades.

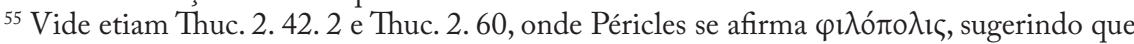
todo o Ateniense que possui esse sentimento para com a sua cidade é capaz de dar a vida por ela. Cf. Gomme (1945-1956: 231).

${ }^{56}$ Lys. 2. 33; Plu. Them. 11. 4-5. 
"é que a pólis são os cidadãos e não as muralhas nem os barcos viúvos de homens."

À ânsia de sucesso e à ideia de superioridade que tais características despoletaram no espírito ateniense, aliou-se o generoso desejo de dilatar pelos povos vizinhos os valores e o modo de vida em que acreditavam. Segundo Isoc. 4. 26-40, Atenas deu alimentos aos que não os tinham, fomentou o aparecimento da maior parte dos bens ${ }^{57}$ e a união entre os Gregos que viviam dispersos e sem leis, uns ultrajados pela tirania, outros pela anarquia.

No cumprimento desse objetivo civilizador e filantrópico, que ajuda a justificar a sua expansão, acabaram por cometer excessos (a que os Coríntios se

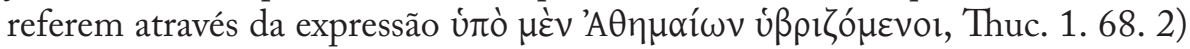
que fizeram com que, aliados ou não, os demais Gregos se sentissem acossados e olhassem para essa empresa como uma tentativa de escravização ${ }^{58}$, da qual

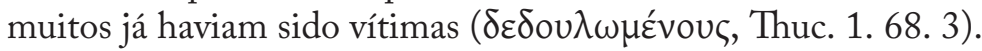

$\mathrm{O}$ discurso ateniense, que é proferido em jeito de resposta ao ataque do orador de Corinto, não contraria em absoluto o que os embaixadores de Atenas ouviram antes. De facto, como o próprio orador ateniense previne a audiência, na sua exposição, não procurará defender Atenas das acusações (decerto injustas!) de que foi alvo, mas tão só justificar a sua superioridade e consequentes direitos ${ }^{59}$, bem como alertar os Lacedemónios para que decidam do melhor modo, sem se deixarem influenciar pela pressão dos aliados. Nesse sentido, o orador salienta que não pretende convencer os Lacedemónios a evitar o conflito bélico, mas alertá-los para a qualidade do inimigo com que se irão defrontar (Thuc. 1. 73. 3). Da sua parte, Atenas não irá entrar em guerra,

${ }^{57}$ Plin. Nat 7. $194 \mathrm{faz}$ o rol dos inventos com origem ateniense. Plu. Moralia 345F, por sua vez, afirma que Atenas foi mãe e ama de muitas artes diferentes. De acordo com Plu. Cim. 10. 6, a generosidade do irmão de Elpinice ultrapassou os limites das famosas $\varphi \imath \lambda \circ \xi \varepsilon v i ́ \alpha$ e $\varphi \imath \lambda \alpha v \theta \rho \omega \pi i ́ \alpha$ dos Atenienses, pois se estes haviam difundido sementes e ensinado quer técnicas de regadio quer a fazer fogo, aquele franqueou as portas da sua casa a quantos precisavam de roupas e alimentos, numa partilha semelhante à mítica comunidade de bens que reinava no tempo de Crono.

${ }_{58}$ Cf. Plu. Cim. 11. 3, segundo o qual esta perspetiva se prende sobretudo ao facto de os tributos terem deixado de ser fornecidos em forma de barcos e homens, por recusa dos próprios aliados. De modo a deixar ambas as partes satisfeitas, Címon sugeriu que aqueles, que preferiam ficar a cultivar os campos e a usufruir da paz, pagassem uma soma para substituir a forma primitiva de contribuição. Aos Atenienses, contudo, não permitiu essa regalia e obrigava-os a treinar diariamente. Isso fez com que o poderio militar de Atenas se desenvolvesse exponencialmente e com que aqueles que o sustentavam passassem a temer o poder ateniense. $\mathrm{O}$ texto de Plutarco, embora reconheça a pretensa situação de escravidão em que os aliados viviam, responsabiliza as vítimas, que se recusaram a servir.

${ }^{59}$ Esta nossa frase sugere a ideia de que os mais fortes exercem, por direito natural, o poder sobre

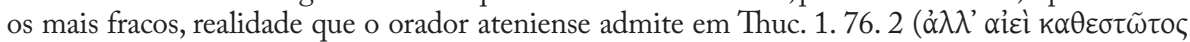

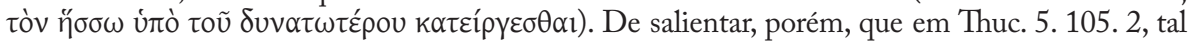
«valor», mais do que assumido, é elogiado pelos Atenienses. Sobre este tema, vide infra p. 128 sq. 
mas defender-se-á de um eventual ataque com todos os meios e forças que estiverem ao seu alcance (Thuc. 1.78. 4).

Esta postura pode, por isso, ser encarada como demonstração da arrogância e egocentrismo de alguém que não pretende prestar contas dos seus atos diante dos pares, e confirma, de certo modo, a perceção dos aliados de que Atenas, a cada dia, se tornava mais prepotente. Por outro lado, se considerada daquela que parece ser a perspetiva ateniense, esta posição exemplifica uma atitude de respeito pela lei e pelos tribunais (cada assunto deve ser resolvido em local e momento oportunos), mas também de autoridade de quem prestou serviços e exige o devido reconhecimento.

O grande serviço que Atenas elege como bandeira da sua ação justiceira e civilizadora em prol da Hélade são as Guerras Medo-Persas (Thuc. 1. 73. 2), que permitiram fomentar a união entre Helenos e a luta contra os Bárbaros $^{60}$. Ao descrever a atuação da sua pátria no contexto desse conflito, o orador confirma qualidades já antes exaltadas pelos Coríntios. Uma delas é o $\operatorname{ardor}^{61}$ ( $\left.\pi \rho \circ \theta u \mu i ́ \alpha v\right)$, superlativamente qualificado como o mais resoluto

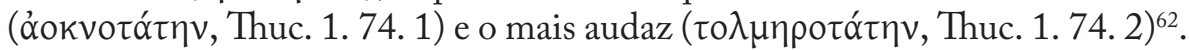
Outra, o desprendimento de abandonar a cidade e os bens ${ }^{63}$ por um objetivo maior: não pôr em causa o sucesso dos então aliados.

Demais, o orador ateniense acrescenta qualidades que os Coríntios certamente omitiram ou por não as reconhecerem ou por, reconhecendo-as, não lhes interessar chamar a atenção para elas. É o caso do espírito altruísta ${ }^{64}$ que se depreende da ação de quem, tendo a sua pátria já sido destruída e quando parecia já não haver solução para o problema, se entrega de corpo e

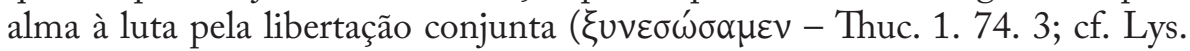
2. 24) das gentes oprimidas pelos Bárbaros, dos que não acorreram em sua defesa $^{65}$ e deles próprios. O mesmo acontece com a inteligência política ${ }^{66}$ e

${ }^{60}$ Estas duas consequências da atuação ateniense nas Guerras Médicas são apontadas por Isoc. 4. 34-37 e Lys. 2. 56 como paradigma dos benefícios que a ação de Atenas trouxe às demais cidades gregas. Sobre os serviços prestados por Atenas durante esta guerra, vide Thuc. 6. 82-83.

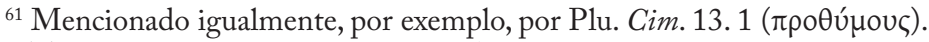

${ }^{62}$ Thuc. 1. 44.2. Cf. supra p. 124. Os Atenienses voltam a referir-se a essa virtude em Thuc.

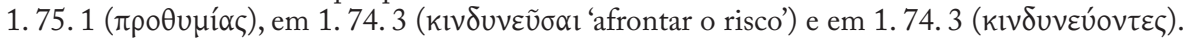

${ }^{63}$ Vide supra p. 124. Cf. Isoc. 4. 94.

${ }^{64}$ Cf. p. 117 , nota 14 e Lys. 2.23.

65 Trata-se de uma postura contrária à dos Lacedemónios que, segundo Coríntios e Atenienses (respetivamente Thuc. 1. 59. 3-5, 1. 74. 3-4), só agem quando veem o seu próprio território ameaçado. Cf. etiam Isoc. 12. 48.

${ }^{66} \mathrm{Cf}$. Hdt. 8. 57-63, onde se descreve a mestria com que Temístocles convenceu os aliados a combater em Salamina. Em Thuc. 1. 144, Péricles salienta que a vitória sobre os Persas ficou

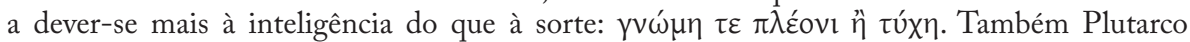

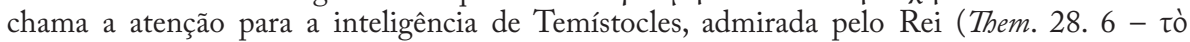

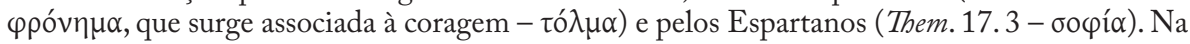


a perspicácia ${ }^{67}$, virtudes personificadas por Temístocles, o ö $v \delta \rho \alpha \sigma \tau \rho \alpha \tau \gamma$ òv

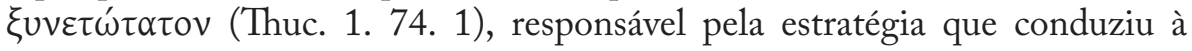
vitória.

Na perspetiva dos «injustiçados Atenienses», toda a má vontade existente

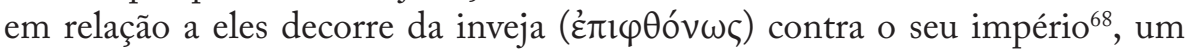
sentimento que é imerecido e sobretudo pouco coerente, porque aquele foi como que um presente dos aliados ${ }^{69}$ e não teve origem em iniciativas de Atenas, apesar da sua natural superioridade.

De facto, os Atenienses atribuem à Lacedemónia uma quota-parte de participação na constituição do império, porque se demitiram de expurgar totalmente os Bárbaros da Hélade (cf. Lys. 2. 44) e porque hostilizaram os aliados (Plu. Arist. 23, Cim. 6. 2) ${ }^{70}$. Foi por essa razão que muitos Gregos, enxovalhados por Pausânias, se dirigiram aos Atenienses - nomeadamente a Aristides e Címon ${ }^{71}$-, pedindo-lhes que os orientassem na condução da estratégia para expulsar definitivamente o inimigo. Com este argumento, Atenas pretende provar que, de início, não tinha qualquer intenção imperialista

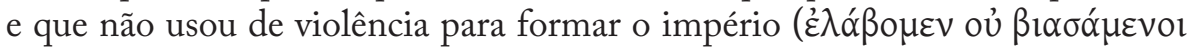
- Thuc. 1. 75. 2), dando provas do seu caráter moderado ( $\sigma \omega \varphi \rho \circ \sigma u ́ v \eta)$. Os únicos culpados pelo despoletar dessa situação foram os que se demitiram de ajudar os aliados e aqueles que se lhes dirigiram a pedir auxílio ${ }^{72}$. Por isso, o primeiro grande responsável pela dimensão que o império ateniense assumiu

verdade, os Atenienses acreditavam na sua superioridade intelectual relativamente aos demais, nomeadamente sobre o inimigo (Thuc. 2.62). Disso nos dão testemunho ainda, por exemplo,

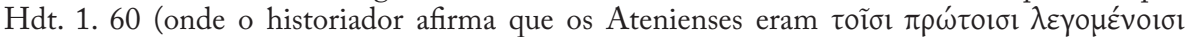

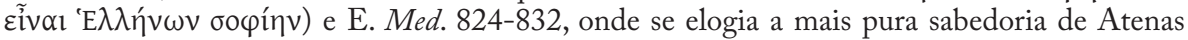

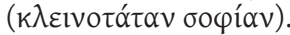

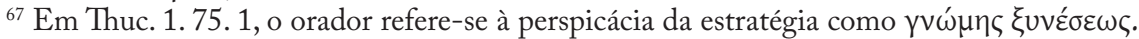
Não deixa de ser curioso notar que os Coríntios, embora não se tenham referido à perspicácia

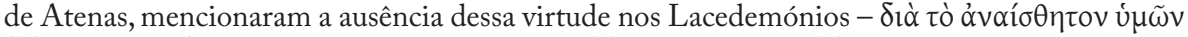
(Thuc. 1. 69. 3). Sobre a natureza intuitiva de Temístocles, vide Thuc. 1.138 e comentários a este passo em Gomme (1945-1956: 442-443); Hornblower (1991: 123); Finley (1947: 95-8); Milman Parry (1981: 141).

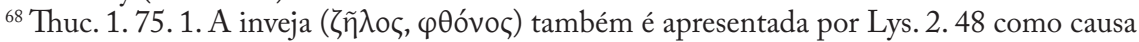
da guerra entre Gregos.

${ }^{69}$ Lys. 2. 47.

${ }^{70}$ Curiosamente, segundo Plu. Arist. 23. 7, a reação de Esparta à perda da hegemonia foi admiravelmente pacífica.

${ }^{71}$ Plu. Cim. 16.2-3 atribui a responsabilidade da hegemonia de Atenas sobre a Grécia não ao poder das armas mas à doçura $\left(\pi \rho \alpha_{1} \omega \varsigma\right)$ e humanidade com que Címon, por causa do seu caráter, acolhia os aliados. O biógrafo faz, contudo, questão de salientar que esta aproximação não foi um processo premeditado pelos Atenienses, quando afirma que Címon e Aristides, apercebendo-se da insatisfação da generalidade dos Helenos, ainda tentaram, sem sucesso, chamar Pausânias à razão. Fica, pois, mais uma vez a ideia de que a hegemonia foi algo que aconteceu a Atenas por incúria de Esparta.

${ }^{72}$ Cf. Thuc. 1. 75. 2, 1.95.1 e 7. Segundo E. Supp.188-190, ajudar é inato aos Atenienses. 
foi o medo ${ }^{73}$ (úrò déouৎ) que a generalidade dos Gregos sentia em relação aos Persas (Thuc. 1. 75. 3). Só o tempo suscitou nos Atenienses outras motivações para o alargamento e manutenção do império: primeiro a honra $(\tau \imath \mu \tilde{\eta} \varsigma)$, o

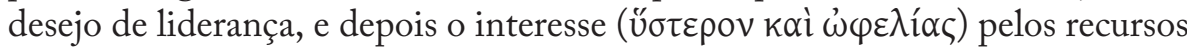
que os partidários ofereciam, como confessa o orador ${ }^{74}$.

Do ponto de vista dos Atenienses, os excessos de que os aliados se

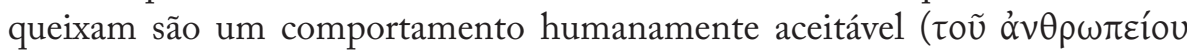

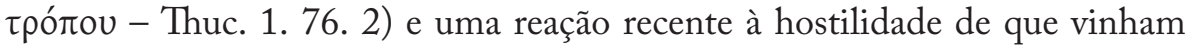

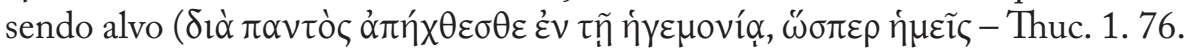
$1)$. Quem quer que estivesse à frente de um império e se sentisse ameaçado pelo ódio dos aliados que almejavam pela sedição teria agido do mesmo modo, em «legítima defesa». Os Atenienses limitaram-se a seguir a lei natural do domínio do mais forte sobre o mais fraco ${ }^{75}$. Mas, até então, sempre haviam procurado ser justos ${ }^{76}$ e moderados ${ }^{77}$, não abusar do poder e tratar os aliados

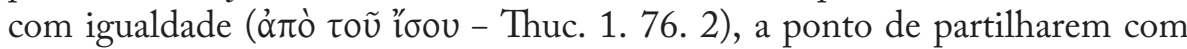

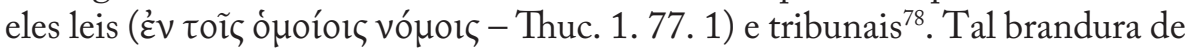

${ }^{73}$ Vide Gomme (1945-1956: 235); Hornblower (1991: 120). Em Thuc. 1. 77. 5-6, os Atenienses responsabilizam o medo pela oscilação de simpatias dos aliados: quando estes temiam os Persas, aproximaram-se de Atenas, que lhes inspirava segurança; quando esta se

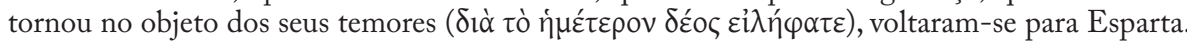
Uma tal análise implica duas reflexões: em primeiro lugar, faz dos aliados interesseiros (de onde resulta, indiretamente, o elogio do altruísmo ateniense); em segundo, enfatiza a dimensão do poder do império, que começava a ser incómodo para muitos.

${ }^{74}$ Cf. Hornblower (1991:120-121). Em Thuc. 1. 76.2, o orador volta a mencionar as mesmas motivações por outra ordem, que se coaduna com a nova fase que o império atravessava: $\tau \iota \mu \tilde{\eta} \varsigma$ (resultante do poder que a hegemonia lhes concedia), déouৎ (dos súbditos, já não dos Persas) e

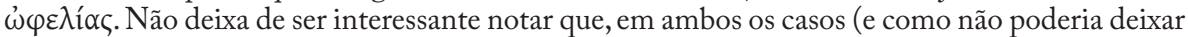
de ser por causa da sua superior natureza), a primeira grande motivação dos Atenienses é a mui nobre $\tau \iota \mu \eta ́$. Medo e interesse surgem como razões secundárias por refletirem características menos dignas. Os aliados de Atenas figuram, assim, como amigos desleais e ingratos, comparáveis aos amigos de Hércules, que, à exceção de Teseu (que tem a noção da obrigação moral de auxiliar um benfeitor), lhe viraram as costas quando ele mais precisou de auxílio (cf. E. $H F$ passim).

${ }^{75}$ Cf. p. 63. Sobre a lei do mais forte em Tucídides, vide Gomme (1945-1956: 126).

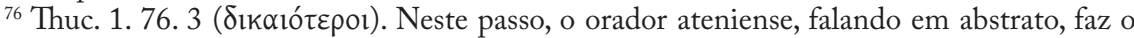
elogio do comportamento que acredita ser também o de Atenas: são dignos de louvor os que, senhores de um poder que lhes permitia abusar, praticam a justiça. Foi com essa atitude, isto é, sem recorrer à força, que durante muito tempo mantiveram um grande império (cf. Isoc. 4. 102-103). Desse comportamento nos dá testemunho o Teseu das tragédias (à exceção do Hipólito), que opta sempre por ser justo e misericordioso a usar do seu poder.

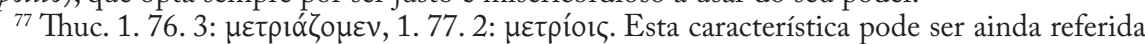

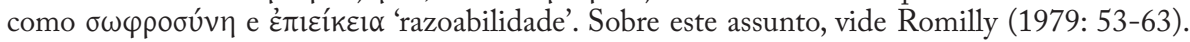
Segundo Lys. 2. 10, Atenas não tem por hábito ser excessiva quando pune ímpios e demonstra sempre magnanimidade e espírito de conciliação. É pelo menos esse o testemunho que nos dá, por exemplo, Hdt. 6. 137, que relata como os Atenienses, tendo surpreendido os Pelasgos a conspirar, se limitaram a obrigá-los a partir, embora por direito pudessem matá-los. No entanto, Atenas foi capaz de pôr em prática medidas brutais contra Egina em 431. Para outro exemplo de moderação, vide supra página 121, nota 36.

${ }^{78}$ Para os aspetos positivos da hegemonia de Atenas, vide Isoc. 4. 103-105. A propósito de 
costumes - que não era usual da parte de quem detinha tão grande poder - não lhes valeu qualquer reconhecimento, só duras críticas quando, em «legítima defesa», se viram obrigados a recorrer ao poder que o facto de encabeçarem um império lhes outorgava. Não surpreende, por isso, que Atenas reconheça como erro tratar os súbditos como iguais: quem age com violência não costuma ser julgado, porque as vítimas não podem exigir justiça, mas, quem está habituado a ela, ao mínimo incómodo, queixa-se com grande alarido.

$\mathrm{O}$ discurso ateniense deixa, assim, a imagem de um povo cheio de méritos que, pelo seu excesso de brandura e de civilidade ${ }^{79}$, é injustamente ameaçado e acusado, facto que o leva a defender-se com mão firme, mas não a atacar de graça os seus aliados. Nas entrelinhas, vislumbramos um povo que quer ser considerado superior, mas que, quando lhe convém (por exemplo, por se sentir em perigo), não se importa de ter o mesmo comportamento do comum dos mortais, ou seja, dos que se guiam pela lei do mais forte.

Com este discurso contrasta o debate que se segue, do qual deveria resultar a posição a assumir pelos Lacedemónios. Os dois intervenientes, cujas palavras Tucídides relata (Arquidamo e Estenelaídes ${ }^{80}$ ), revelam a existência de sensibilidades diferentes em relação à essência do inimigo. Arquidamo assume uma postura mais diplomática (mas nem por isso totalmente favorável aos Atenienses), o que decerto se justifica pelo facto de manter relações de hospitalidade com alguns deles, nomeadamente com Péricles. Admite a clara superioridade bélica dos Atenienses ${ }^{81}$, mas refuta que a excelência daqueles seja uma condição inata ${ }^{82}$. Não deixa, no entanto, de sugerir a visão negativa que os Lacedemónios têm do inimigo, já que afirma que pretende surpreendê-los nos seus embustes (Thuc. 1. 82. 1).

Estenelaídes, mais intempestivo, profere palavras que sugerem a existência de um ódio visceral entre os dois povos. Critica os Atenienses pelo constante autoelogio, pelos discursos longos e ininteligíveis ${ }^{83}$, por não terem

Thuc. 1. 77. 1, vide Gomme (1945-1956: 236-243); Hornblower (1991: 122-123).

79 Isoc. 4. 79-80 apresenta como exemplo de espírito de civismo o facto de se ter como preocupação primeira o bem-comum e afirma que os Atenienses serviam os Gregos sem oprimi-los.

${ }^{80} \mathrm{~A}$ respeito deste éforo, apenas se conhece o discurso referido em Thuc. 1. 86. Sobre os discursos de Arquidamo e Estenelaídas, consultem-se Gomme (1945-1956: 246-252); Hornblower (1991: 125-131).

${ }^{81}$ Segundo Arquidamo (Thuc. 1. 80.3), os Atenienses são os mais bem preparados (โoĩ

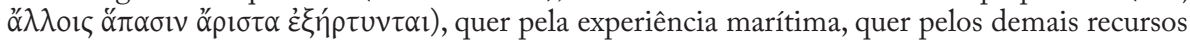
de que dispõem (riqueza, navios, cavalaria, tropas e homens). São um adversário a respeitar. Apesar disso, admite que, bem organizados e com tempo, os Lacedemónios podem vencê-los.

${ }^{82}$ Arquidamo acreditava que a superioridade de um povo relativamente a outro é fruto do tipo de educação recebida (Thuc. 1. 74. 4). Assume, portanto, uma posição distinta da dos Coríntios, que acreditam que os Atenienses são como são por causa da raça a que pertencem (cf.

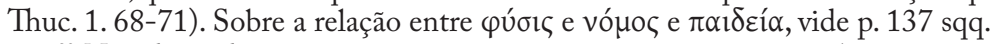

${ }^{83}$ Não deixa de ser interessante notar que a sua intervenção - brevíssima - funciona como 
tentado desmentir as acusações de que foram alvo e apela a uma punição, pronta e pesada, para aqueles que, de «salvadores», passaram a uma espécie de «carrascos» da Grécia, logo, uma ameaça a erradicar ${ }^{84}$.

Todas as características dos Atenienses que fomos referindo fazem deles um povo que só podia viver em democracia, pelo que esta se torna no regime por excelência de Atenas, onde, segundo Lys. 2. 18, foi estabelecido pela primeira vez. Na sua perspetiva, este era um dos aspetos que os tornava superior aos demais Helenos, porque, tendo sido uma constituição por eles inventada ${ }^{85}$, era a única verdadeiramente grega e a única que representava a liberdade, ao contrário da tirania e da oligarquia ${ }^{86}$. Por isso, ao elogio das características do $\delta \tilde{\eta} \mu \circ \varsigma$, é intrínseco o do regime democrático ${ }^{87}$, escolhido, na época clássica, para orientar o seu funcionamento, e sob o qual a đó $\lambda$ ıs alcançou o apogeu.

A constituição democrática torna-se fundamental para a imagem da Atenas idealizada, por assentar no respeito pela lei (nomeadamente a escrita - cf. E. Supp. 426-455) e na igualdade perante esta. Na verdade, esta democracia ficou conhecida, porque, pobre ou rico, qualquer cidadão tinha plena participação nas decisões inerentes ao funcionamento da sua comunidade e podia dar o seu contributo para o engrandecimento da pátria ${ }^{88}$. Por isso, os Atenienses, ao contrário do que acontecia com os Bárbaros, eram governados por todos e não por um só homem (A. Pers. 242; E. Supp. 403-408), o que lhes permitia viver em liberdade, de acordo com as suas próprias opções e não subjugados à vontade alheia ${ }^{89}$.

exemplo de um discurso sucinto e eficiente, em tudo diferente dos que são formulados pelas gentes de Atenas. Importa, contudo, lembrar que os Atenienses eram conhecidos por dominarem a arte de bem falar, que, segundo Isoc. 47-50, era um dom inato deste povo. Plutarco reconhece esta aptidão quando, em Cim. 4. 5, afirma que este era desprovido dos dotes de eloquência

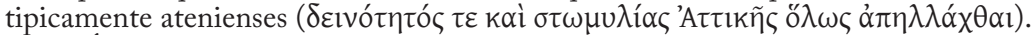

${ }^{84} \hat{E}$ sua uma expressão reveladora da verdadeira razão que levou ao deflagrar do conflito

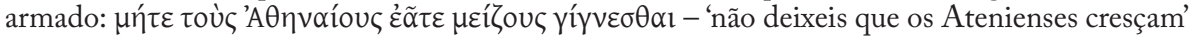
(Thuc. 1.86.5).

${ }^{85}$ É, portanto, um dos traços da civilização que Péricles declara original e não cópia do que já existia. Cf. supra pp.118.

${ }^{86}$ No entanto, Atenas é descrita como uma tirania, e.g., em Thuc. 2.37, 2. 63, 3.37, 6. 85.

${ }^{87}$ Cf. E. Supp. 349-353, 404-5. Como exemplo de elogio do regime democrático vide Thuc. 2.37 sqq. A este propósito, consulte-se, entre outros, Gomme (1945-1956: 108) e Harris (1992: 157-167). Sobre a democracia ateniense em geral, vide Ribeiro Ferreira (1990) e bibliografia por ele citada.

${ }^{88}$ Cf. Hdt. 3. 80. 1; E. Supp. 403-408, 426-455. Segundo Lys. 2. 19, todos são iguais perante a lei que deve proteger os mais fracos e punir o que é indiscutivelmente vergonhoso. A igualdade devia-se ao facto de, em teoria, todos terem a mesma origem autóctone e constituía um eficaz mecanismo de incentivo à participação do conjunto dos cidadãos. Sobre a autoctonia, vide supra pp. 117-118. Note-se, porém, que a democracia ateniense é por muitos considerada uma constituição mista, já que, de um modo geral, só um leque muito reduzido de cidadãos aristocratas acede aos cargos de topo. Para esta problemática, consulte-se, por exemplo, Oliver (1955: 37-40).

${ }^{89}$ Cf. E. Heracl. 423-4. Este era mais um dos elemento a distinguir os Gregos dos Bárbaros na tragédia. 
Demais, esta constituição mostrou-se propícia à realização da missão civilizadora de Atenas, já que lhe permitiu conjugar o elemento cultural e o militar, cultivar a beleza e o espírito sem impedir demonstrações de firmeza, quando necessário (cf. Thuc. 2. 40).

Em jeito de conclusão, recordemos a síntese das características atenienses feitas por Knox (1957: 77):

"A constant will to action, grounded in experience, inspired by courage, expressing itself in speed and impatience but informed by intelligent reflection, endowed with the self-confidence, optimism and versatility of the brilliant amateur, and marred by oversuspicion and occasional outbursts of demonic anger - this is the character of Athens (...);"

e o que diz Megelo, o lacedemónio das $L e i s^{90}$, que, em poucas palavras, resume a superioridade dos Atenienses, como que sugerindo que estes atingiram a perfeição:

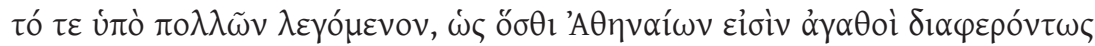

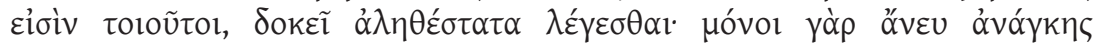

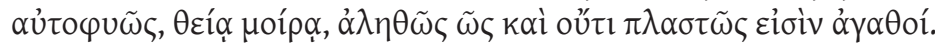

"O ditado que muitos repetem «quando os Atenienses são bons, são-no ao mais alto nível», parece-me um dos mais verdadeiros, porque apenas eles são bons sem se sentirem obrigados, espontaneamente, por graça divina, de verdade e não por fingimento."

${ }^{90}$ Pl. Lg. 642 c. A mesma ideia ocorre em Isoc. 10. 21, a propósito de Teseu - símbolo por excelência de Atenas. 
Parte V

O homem de Estado do sÉculo $V$ 


\section{Do NASCIMENTO AO INGRESSO NA VIDA ATIVA: a EduCaÇão do Político em Atenas ${ }^{1}$}

«Não se pode fazer nada mais importante do que instruir os filhos.» ${ }^{2}$

A formação dos cidadãos - e em particular dos governantes de um Estado - foi na Antiguidade motivo de grande debate e cuidado, porque havia a crença de que a educação da juventude exerce uma influência duradoira sobre os destinos da $\pi$ ó $\lambda \iota^{3}$.

Os testemunhos mais antigos de um tal interesse remontam aos Poemas Homéricos $^{4}$, que nos apresentam uma aristocracia preocupada com o desenvolvimento da personalidade dos seus membros mais jovens, que se quer fundado no cultivo consciente dos ideais e valores considerados primordiais por esse grupo social.

$\mathrm{Na}$ Ilíada, o poeta descreve a educação recebida por Aquiles, que atribui, em dois momentos diferentes, a dois precetores distintos ${ }^{5}$ : Quíron, o precetor mais ilustre da mitologia ${ }^{6}$, e Fénix, um mestre humano. Com o primeiro, terá

\footnotetext{
${ }^{1} \mathrm{~A}$ breve resenha que iremos fazer sobre a evolução do processo educativo na Grécia antiga centrar-se-á no caso específico de Atenas, já que o nosso objetivo é avaliar o seu efeito na formação e ação dos chefes de Estado atenienses. A propósito do tema «educação», vide, entre outras obras citadas ao longo deste capítulo, Cole (1931) e Pfeiffer (1968).

${ }^{2}$ Plu. Moralia 6A.

${ }^{3}$ Isoc. 2. 13.

4 Demais, não podemos deixar de evocar o papel fundamental que estes poemas desempenharam na educação grega, eternizado pelas palavras de Xenófanes (fr. 10 Diels) $\mathfrak{\xi} \xi$

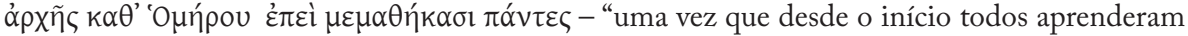
por Homero - e pelas de Platão (R. 606e-607a) - esse poeta [Homero] foi o educador da Grécia." Grécia (tradução de Rocha Pereira: ${ }^{7} 1998$ ) De facto, os textos homéricos serviram de base à transmissão de valores e de comportamentos não só no seio da vida privada, mas também no âmbito da vida pública, por ocasião de festivais e concursos. Sobre este assunto, vide Rocha Pereira (1998a: 146-152) e bibliografia para que a autora remete.
}

${ }^{5}$ Il. 9. 432-605, 11. 830-832.

${ }^{6}$ Cf. Jaeger ( ${ }^{3}$ 1995: 49); Marrou (1965: 27). Segundo Pi.N.3. 43 sqq., terá sido com Quíron que Aquiles adquiriu os seus conhecimentos no âmbito da arte militar, da caça e da excelência moral. Aquiles não foi, contudo, o seu único discípulo. X. Cyn. 1.2 apresenta-nos o rol dos vinte e um heróis educados pelo Centauro. Em E. $L A$, quer Agamémnon (708) quer Aquiles (925926) afirmam que foi na sequência do convívio com Quíron - do qual se diz que é um homem cumpridor - que o príncipe da Ftia adquiriu hábitos simples e diversos dos dos homens viciados. Aquiles surge, mais uma vez, através das palavras de Eurípides, como produto exemplar de uma educação cuidada e rigorosa, por oposição à vigente no período em que decorreu a vida do 
aprendido a caçar, a montar a cavalo, a tocar lira e alguns conhecimentos do foro da medicina; com o segundo, a ser um bom guerreiro e um bom orador. A importância do adestramento das capacidades oratórias e bélicas também é realçada, na Odisseia, por Mentor $^{7}$, amigo a quem Ulisses - de partida para a Guerra de Troia - se vê forçado a confiar Telémaco.

Da análise do que nos é dito sobre a formação de Aquiles e de Telémaco (nos quatro primeiros cantos da Odisseia), podemos inferir que a educação da aristocracia retratada na epopeia homérica assenta em dois elementos fundamentais - o exemplo e o contacto com indivíduos mais velhos (que se destacam pela experiência e ảpetń) - e não na frequência de uma escola formal. Esses indivíduos mais velhos e experientes, a quem se confiava a educação dos jovens, eram, por norma, amigos da família e tinham não só a função de transmitir conhecimentos, valores e ideais partilhados pelo grupo social a que pertenciam, mas também o dever de despertar nos «formandos» o espírito agónico característico da aristocracia, bem como velar para que, no futuro, as ações dos jovens não envergonhassem os mestres e as famílias.

Para alcançarem os seus objetivos, os precetores incitavam-nos a serem sempre os melhores entre os seus pares (cf. Il. 6.208: ảlèv ỏ

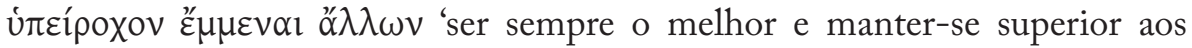
demais') e a rivalizar com figuras apresentadas como modelos ${ }^{8}$. Fénix propõe a Aquiles o exemplo de Meleagro; já Atena/Mentor, por sua vez, apresenta Orestes como paradigma a seguir por Telémaco. Também Aquiles (encarnação moral do perfeito guerreiro homérico) e Telémaco viriam a ser considerados modelos a seguir pelas diversas gerações de leitores/ouvintes dos Poemas Homéricos.

Torna-se, portanto, evidente que a educação homérica privilegia duas áreas fundamentais: a técnica - que inclui o ensino do manejo de armas, desporto, artes musicais (canto, lira, dança) e oratória - e a ética, que transmite os valores próprios da sociedade 9 .

Os grandes teóricos da educação, contudo, apenas surgiram no período que compreende os séculos V e IV a.C. O seu aparecimento foi impulsionado pelas profundas e vertiginosas alterações então ocorridas na vida e na mentalidade

tragediógrafo. $\mathrm{Na} I l .9 .432-605$, a educação de Aquiles surge igualmente associada à figura de Fénix. A este propósito, vide Jaeger ( ${ }^{3} 1995:$ : 49-52).

${ }^{7}$ A importância de Telémaco (ou, se quisermos, a de Ulisses) era tal que Mentor chegou a ser substituído - ainda que por pouco tempo - pela própria Atena disfarçada $(O d .2$. 267sqq., 399sqq, 3. 13 sqq.). E por causa da missão confiada a Mentor que ainda hoje utilizamos este nome para designar qualquer indivíduo sábio e experiente que serve de guia e conselheiro.

${ }^{8}$ Como no caso de Teseu, que sente o desejo ardente de emular Héracles. Vide p. 54.

${ }^{9}$ Sobre a educação retratada nos Poemas Homéricos, consulte-se ainda, por exemplo, Wees (1996: 1-25). 
dos Atenienses, que deram azo a que se passasse a falar em $\alpha \rho x \alpha i ́ \alpha \pi \alpha{ }_{1} \delta \varepsilon i^{10}{ }^{10}$ para fazer referência à prática educativa anterior ao aparecimento dos Sofistas. Importa, em primeiro lugar, ter presente que a $\pi \alpha 1 \delta \varepsilon i ́ \alpha$ a que nos referimos

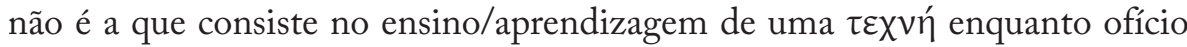
(que era sobretudo transmitida de pais para filhos entre os Gregos livres e não nobres ${ }^{11}$ ), mas a transmissão de valores, conhecimentos e de um modo de vida próprios da aristocracia ${ }^{12}$. Isso mesmo no-lo sugere Sócrates, quando, em conversa com Hipócrates (Pl. Prt. 312b), apresenta como objetivo concreto deste género de formação a aquisição de cultura:

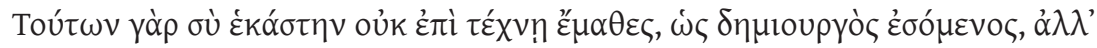

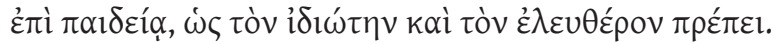

“Com efeito, estudaste cada uma dessas disciplinas [sc. letras, cítara e ginástica] não como uma técnica, para te tornares um profissional, mas para teres cultura, como convém ao leigo e ao homem livre ${ }^{13}$."

De facto, inicialmente, só a aristocracia, que não precisava de se preocupar com o sustento diário, podia dedicar a vida ao otium, preenchendo os dias com a prática de exercícios físicos, jogos, corridas de carros e as noites com uma intensa vida cultural associada aos banquetes, nos quais se dava particular relevo à poesia e à música.

${ }^{10}$ Cf. Ar. Nu. 961. A palavra $\pi \alpha ı \delta \varepsilon i ́ \alpha$ ocorre pela primeira vez no século $\mathrm{V}$ a.C. em A. Th. 18, como sinónimo de $\tau \rho \circ \varphi$ ń 'criação'. Significava, portanto, no início do século do apogeu de Atenas, 'criação de meninos'. Só com o tempo adquiriu os sentidos de 'ensino, disciplina, correção’.

${ }^{11}$ Segundo Plu. Sol. 22. 1, os pais devem ensinar uma profissão aos filhos. A ascensão social e política de indivíduos oriundos da classe não aristocrática atingiu o seu auge no final do século $\mathrm{V}$, sobretudo a seguir à morte de Péricles, e pôs em evidência as disparidades que existiam entre os cidadãos mais privilegiados e os menos no que concerne à educação. Em geral, a educação típica da aristocracia não era acessível a quem não pertencia à elite, não só por ser dispendiosa, mas também por não formar para uma profissão. Ainda assim, há testemunhos de que alguns deles saberiam ler. Cf. Ar. Eq. 188-189, 1235-9, passos em que somos informados de que o Salsicheiro sabe ler mas não tem qualquer formação no âmbito da música ou da ginástica. É nesta comédia que Aristófanes - cuja obra é fértil em alusões à evolução da educação na Atenas do século $\mathrm{V}$ e em críticas à vida política coeva - faz a caricatura dos políticos de sucesso contemporâneos, realçando a «deficiente» educação por eles recebida. É que, de facto, esse óbice, aliado às restantes «qualidades» de um bom demagogo que possuíam (como uma baixa origem e a falta de caráter, que os levava a jurar falso e a roubar), torna-os na negação do protótipo de político ideal em que, devido à conjuntura, Péricles se transformou. Sobre este tema, leia-se Silva (2004: 23-36).

${ }^{12} \mathrm{Ou}$, como afirmou Beck (1964: 72), «the education provided was cultural, not technical, directed towards character training and citizenship, not towards craftsmanship and personal profit».

${ }^{13}$ A tradução deste passo (bem como a de todos os outros que venhamos a citar do Protágoras) é de Elias Pinheiro (1999). 
Assim, podemos afirmar que a $\pi \alpha 1 \delta \varepsilon i ́ \alpha$, enquanto formação cultural e ética, começou por ser apanágio da classe detentora do poder. Aliás, este tipo de educação servia de elemento de distinção entre os aristocratas educados e «superiores» e o povo, que nem tinha tempo para essas atividades nem fora criado para participar nelas. Nesse sentido, é curioso lembrar que diferentes autores chamam a nossa atenção para o facto de a $\pi \alpha 1 \delta \varepsilon i ́ \alpha$ só dar frutos se «aplicada» a alguém que tenha condições conatas para recebê-la. Píndaro $(N$. 3. 40 sqq.), por exemplo, defende que

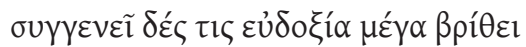

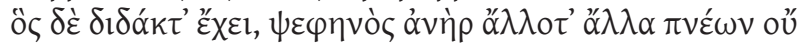

$\left[\pi \circ \tau^{\prime} \dot{\alpha} \tau \rho \varepsilon \kappa \varepsilon \tilde{\imath}\right.$

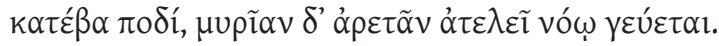

"A glória, só quando é inata, tem real valor.

Quem só tem o que aprendeu é um homem obscuro e [indeciso, nunca caminha com um passo seguro.

Apenas experimenta inúmeras formas de excelência com um espírito [imperfeito."

E afirma ainda em 0.2 .86 sqq.:

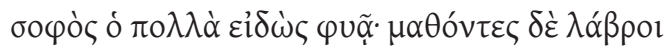

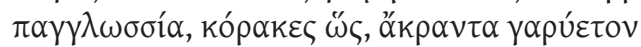

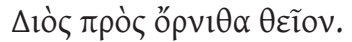

"Sábio é quem muito sabe por natureza.

Os que precisam de aprender são como corvos

alarves na garrulice, que grasnam em vão

contra a ave sagrada de Zeus ${ }^{14}$."

Podemos, por isso, concluir que, segundo este poeta, ainda que a instrução tenha algum valor, só alcançará a sua plenitude se se unir a alguém cuja ascendência seja digna de recebê-la $\mathrm{a}^{15}$.

Já Plutarco (Moralia 8E) apresenta como condição não tanto o «sangue», mas a riqueza ${ }^{16}$ possuída pela família, sem a qual é quase impossível que um pai

${ }^{14}$ A tradução apresentada é de Lourenço (2006: 105).

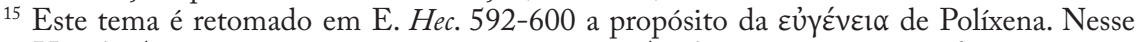
passo, Hécuba (como já antes o coro nos versos 379-381) valoriza a importância da origem para que uma pessoa tenha uma natureza boa, que pode ser ainda melhorada se se tiver acesso a uma educação condigna. Como veremos adiante (p. 148), Platão e Aristóteles têm uma perspetiva semelhante, pois relacionam as qualidades/capacidades das crianças com as dos progenitores.

${ }_{16}$ Platão (Prt. 326c) salienta que os pais que têm possibilidades (e diz os ricos são os que 
possa custear a educação do filho:

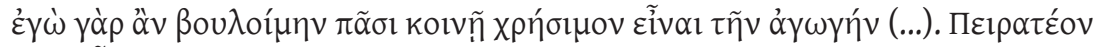

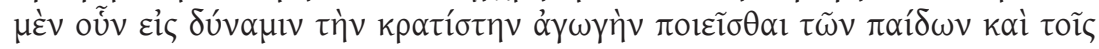

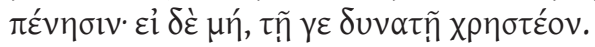

"Eu desejaria muito que a educação fosse para todos igualmente proveitosa. (...) Com efeito, até os pobres devem tentar por todos os meios procurar dar a melhor educação aos filhos. Mas, se tal não for possível, deve dar-se-lhes a que estiver dentro das possibilidades."

Em segundo lugar, devemos salientar que os objetivos deste tipo de $\pi \alpha 1 \delta \varepsilon i ́ \alpha$ eram inevitavelmente formar elites, políticos e fomentar a ả $\rho \varepsilon \tau \eta ́$. Pretendia-se, pois, ajudar a atingir o ideal clássico da $\kappa \alpha \lambda$ okỏy $\alpha \theta i \alpha^{17}$, cujas origens não deixam de estar ligadas à educação homérica, que procurava fomentar no indivíduo o apreço pela $\varphi \imath \lambda i ́ \alpha$ e qualidades de guerreiro, orador, atleta e músico, de modo a que aquele se tornasse o melhor de entre os seus pares.

Consequentemente, os valores desenvolvidos pela prática educativa descrita/prescrita pelos Poemas Homéricos condicionaram a «estruturação do curriculum» da $\alpha \rho x \alpha i ́ \alpha \pi \alpha \_\delta \varepsilon i ́ \alpha$, que tinha uma forte componente desportiva e musical.

De acordo com o uso corrente, as crianças ficavam ao cuidado da mãe e da ama até atingirem os sete anos ${ }^{18}$. Nessa altura, os rapazes eram confiados a um pedagogo ${ }^{19}$ e passavam a frequentar as aulas - pagas - dos mestres (os $\delta 1 \delta \alpha ́ \sigma \kappa \alpha \lambda o l$, responsáveis pela educação formal, que os pais escolhiam a gosto

mais podem) educam o filho de acordo com a tradição (ou seja, custeiam aos filhos a frequência das aulas do mestre das letras, do citarista e do pedotriba) durante um largo intervalo de tempo, muito maior do que aqueles que não têm meios financeiros.

${ }^{17}$ Sobre este ideal, leia-se e.g. Marrou (1965: 77-80); Dover (1974: 41-45).

${ }^{18}$ Segundo Protágoras (P1. Prt. 325d), a educação moral das crianças tinha forçosamente início antes do ingresso no ensino formal. Aristóteles (Pol. 1336a23-25) indica a idade de cinco anos como sendo aquela até à qual as crianças não deveriam ser iniciadas em quaisquer aprendizagens ou trabalhos obrigatórios de modo a não prejudicar o crescimento.

${ }^{19}$ Os pedagogos eram vistos como membros da família (Hdt. 8. 75; E. El. 286-287), dignos de confiança e consideração. Com o advento da época clássica, o pedagogo «delegou» aos diferentes $\delta 1 \delta \alpha ́ \sigma \kappa \alpha \lambda$ ol a função de transmissor de conhecimentos, mas continuou a ter a seu cargo a orientação e vigilância do dia-a-dia das crianças: levava-as à escola, carregava-lhes o material, assistia às aulas com eles, supervisionava-lhes as atividades e aplicava castigos, se necessário. Eram eles e não os $\delta 1 \delta \alpha ́ \sigma K \alpha \lambda$ ol (pagos para ensinar e não para educar) os responsáveis pelo bom comportamento dos pupilos, que, procuraram desde sempre, testar os limites, ver até onde os adultos os deixam ir. Plutarco refere-se à importância da ama e do pedagogo em Moralia 3D-E, 4A-B, 439F-440A, 459A, 529C, 672F, 1008F. A figura do pedagogo é analisada por Beck (1964: 105-109). 
- embora muitas vezes condicionados pela disponibilidade financeira ${ }^{20}$ ) das três grandes áreas de estudo que constituíam aquilo a que poderemos chamar

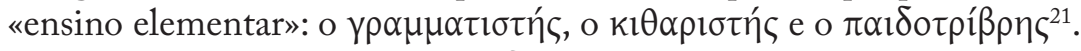

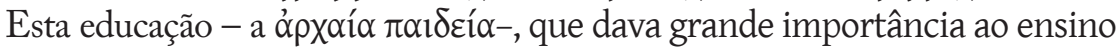
da ginástica, foi a responsável pela formação dos heróis de Maratona ${ }^{22}$ (que simbolizam a coragem, a liberdade, o sacrifício em prol do bem comum e, sobretudo,

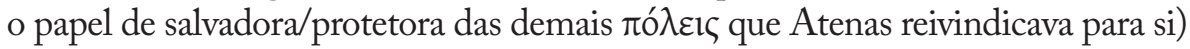
e das principais figuras da Atenas do apogeu, como Péricles ou Sófocles.

Uma vez concluída essa fase de estudos, muitos jovens prosseguiam a sua instrução através do convívio com filósofos. Disso mesmo nos dá testemunho, por exemplo, Péricles que deveu boa parte da sua formação à influência de Anaxágoras (cf. Plu. Per. 4. 6).

Como muito bem sintetiza Marrou (1965: 77),

«telle était cette ancienne éducation athénienne, plus artistique que littéraire et plus sportive qu'intellectuelle. (...) Cette éducation n'est pas du tout technique, elle reste orientée vers la vie noble et ses loisirs; ces aristocrates athéniens ont beau être de grands propriétaires fonciers et des homes politiques, rien dans l'éducation ne les prépare à ces activités».

Não havia, portanto, como nos nossos dias, um sistema de ensino público $^{23}$. A educação formal era uma responsabilidade exclusiva das famílias, que tinham a possibilidade de escolher o tipo de educação a dar às crianças. Note-se, contudo, que, com o apogeu do século $\mathrm{V}$ e a consequente melhoria das

${ }^{20}$ Por questões sobretudo de ordem económica, muitos pais poderiam ponderar privar os filhos da educação musical, mas nunca da aprendizagem das letras. Ainda assim, quem não frequentava as aulas do kı $\theta \alpha \rho \imath \tau \tau$ ́ s passava por ignorante, inculto, rústico. Contudo, devido à longa tradição do ensino da música, os modernos passaram a considerá-lo conservador (cf. Ar. Nu. 1357-1358).

${ }^{21}$ Para pormenores relativos às diversas componentes destas áreas de estudo, consultem-se Beck (1964); Marrou (1965); Barrow (1976); Robb (1994) e Morgan (1999: 46-61).

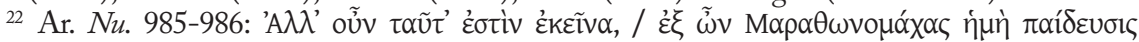
$\varepsilon$ है $\rho \varepsilon \psi \varepsilon v$. 'Pois sim, mas foi com tal pedagogia que se formaram os heróis de Maratona.' (tradução de Magueijo:1984). Segundo o comediógrafo (idem, 959-960), esta educação foi responsável pela transmissão de princípios e valores e lutava pela justiça em uma época em que a moderação era norma.

${ }^{23}$ Platão e Aristóteles discordavam do papel desempenhado pelo Estado na educação do seu tempo e propugnaram para que este tivesse uma participação efetiva na condução de todo o processo educativo e para que a educação fosse um direito universal. Disso nos dão testemunho obras como a República e a Politica, da qual evocaremos um pequeno trecho elucidativo (Pol.

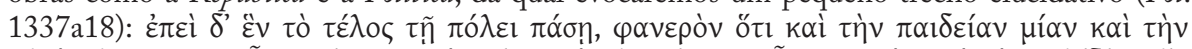

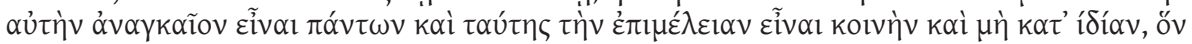

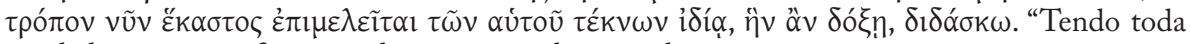
a cidade um único fim, é evidente que a educação deve necessariamente ser uma e a mesma para todos, e que o cuidado posto nela deve ser tarefa comum e não do foro privado, como se tornou prática corrente (pois que cada um se preocupa em particular com a educação dos seus filhos, dando-lhes um ensino privado, segundo parece melhor a cada qual)". Esta tradução é de Amaral-Gomes (1998: 561) 
condições de vida das diferentes classes, cada vez mais jovens tiveram acesso pelo menos a uma formação básica, que se foi moldando progressivamente segundo os interesses dos novos alunos e em sintonia com as alterações do modo de vida que, a cada momento, ocorrem na sociedade.

Ainda assim, a educação pode ser encarada como uma atividade política ${ }^{24}$ (no sentido etimológico do termo), na medida em que a aprendizagem dos deveres de cada um enquanto cidadão ocorria através do próprio convívio social (nomeadamente através de espetáculos como a tragédia ${ }^{25}$ ) e se prolongava para além da infância através da participação na vida das instituições e/ou grupos ${ }^{26}$ (como os cultos locais ou cívicos, os coros, o exército, os grupos profissionais e os de lazer - atléticos, venatórios, entre outros). Era a frequência de tais atividades que permitia a integração de um verdadeiro cidadão, pelo que podemos afirmar que a própria comunidade era fonte de ação e de comportamento. Disso mesmo nos dá testemunho Platão (Prt.326c-d), quando põe na boca de Protágoras as seguintes palavras:

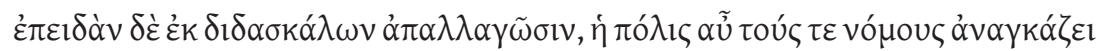

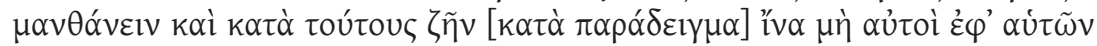

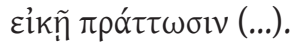

"Logo que saem da escola, é a vez de a cidade os obrigar a aprender as leis e a viver de acordo com elas e com os seus paradigmas, para não agirem apenas como bem thes parecer (...)."

De facto, na Grécia, a lei (vópoৎ) era entendida como mestre, que influenciava a natureza ( $\varphi$ $\sigma ı)$ de cada um, o que equivale a dizer que a $\pi{ }^{\prime} \lambda ı$ era vista como professora de cada cidadão ${ }^{27}$, no qual devia fomentar normas e valores que facilitassem o convívio social ${ }^{28}$.

${ }^{24}$ Este modo de encarar a educação grega é analisado em Lee Too (2001).

${ }^{25}$ Sobre o contributo das representações para a educação da comunidade, vide Euben (1986: 23-24).

${ }^{26}$ Este tema encontra-se desenvolvido em Lee Too (2001: 36 sqq).

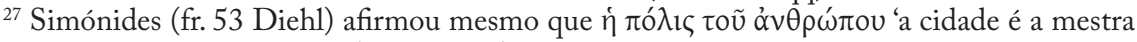
do homem'. Segundo Sócrates (P1. Ap. 24e), as leis tornam os cidadãos melhores, instruindo a juventude com a ajuda dos juízes. De acordo com Aristóteles (EN 1180a23-24), a lei tinha vantagem sobre a ação educativa dos indivíduos particulares por não ser entendida como opressora, mas como uma entidade justa, que ordenava o mesmo a todos os habitantes da ró $\lambda ı$. Não podemos deixar de lembrar que para os Atenienses Atenas era não apenas a sua mestra mas «a escola da Hélade». Cf. Thuc. 2. 41. Convém recordar que, em Atenas, as leis estavam expostas ao público, o que presumivelmente permitia que todos os cidadãos as vissem e consultassem com

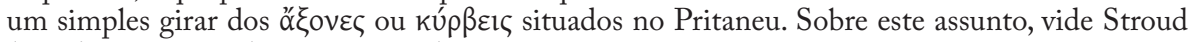
(1979); Robertson (1986: 147-176).

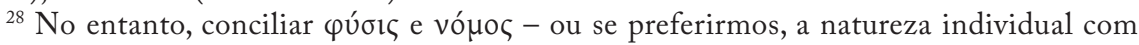
os interesses e valores da sociedade em que se está inserido - não é tarefa fácil, na medida em que isso implica não poucas vezes o sacrifício dos desejos e objetivos de cada um em 


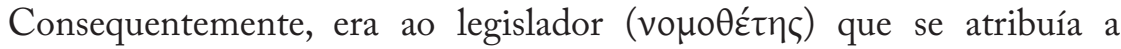
responsabilidade de principal educador, como no-lo demonstra, por exemplo,

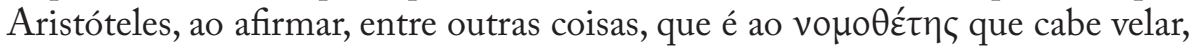
desde o início, pela saúde dos corpos dos cidadãos a educar ${ }^{29}$, pelos princípios a incutir na alma dos homens ${ }^{30} \mathrm{e}$, sobretudo, assegurar que se tornem bons $\mathrm{s}^{31}$.

Só a formação militar tinha um estatuto superior, pois obrigava a um treino formal. Daí que, nas palavras de Griffith (2001:72), «the «schooling» of democratic citizen in the political process and values of their community was left to be acquired through observation and practice, not formal instruction or study».

Não surpreende, por isso, que a evolução da educação esteja intimamente relacionada com a da $\pi$ ó $\lambda_{1} \zeta$ e que resulte da necessidade de formar cidadãos capazes de participar no processo político. E a conjuntura favorável à cada vez maior participação do cidadão atingiu o seu auge em meados do século $\mathrm{V}$ a.C., sobretudo por força do impulso que Péricles deu à consolidação do regime democrático em Atenas, nomeadamente com a instituição das mistoforias, que permitiam que até quem tinha menos recursos pudesse intervir na vida da $\pi \operatorname{\lambda ó}_{\imath} \varsigma^{32}$. Este foi um processo lento, cujo início remonta não só às reformas de Clístenes, como também à mudança de mentalidades provocada pelo papel de líder da Hélade que Atenas assumiu na sequência das Guerras Pérsicas. Ante a liberdade que se respirava nesta $\pi$ ó $\lambda_{\iota \varsigma}$ (para a qual em muito contribuiu a isegoria ${ }^{33}$ ) e o dinamismo económico que o

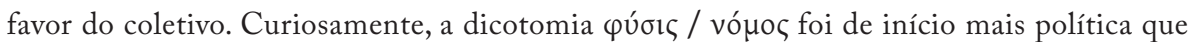
filosófica: é que à aristocracia convinha fazer acreditar que a sua superioridade era inata e não resultado de uma aprendizagem. Essa necessidade tornou-se manifesta sobretudo com a crescente importância das classes mais baixas na vida da $\pi$ ó $\lambda ı$ ç. Foi no contexto do século $\mathrm{V}$ que essa dicotomia alcançou estatuto filosófico, pois, com o aparecimento da sofística e com a crescente importância dada a cada pessoa enquanto ser único, intensificou-se a discussão

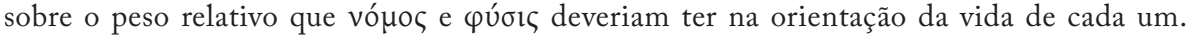
Surgiram então duas posições: alguns indivíduos mais egoístas defendiam a satisfação dos desejos instigados pela natureza em detrimento do bem-estar comunitário (cf. a posição de Cálicles no Protágoras, tema abordado supra pp. 63-64). Havia quem, por outro lado,

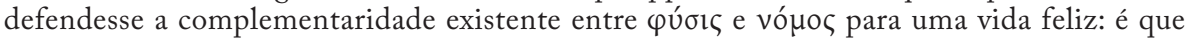
o respeito pelas leis e pelos costumes permite o bom funcionamento da vida em sociedade e o homem, enquanto ser gregário, só se sentirá realizado se não abdicar de uma vida social organizada, sob pena de não poder conviver com os semelhantes. Sobre este tema, vide Kerferd_(1981: 111-130).

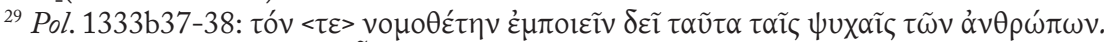

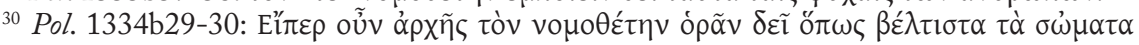

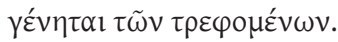

${ }^{31}$ Pol.1333a14.

${ }^{32}$ Legras (1998: 72) faz da igualdade em termos educativos um ingrediente indispensável no processo de democratização: «Athènes est devenue une vraie démocratie: le peuple $\mathrm{y}$ a conquis non seulement, par une extension graduelle, les privilèges, droits et pouvoirs politiques, mais encore l'accès à ce type de vie, de culture, à cet idéal humain dont seule l'aristocratie avait d'abord joui».

${ }^{33}$ Note-se, porém, que a isegoria só pode ser utilizada - na assembleia, no tribunal ou no 
afluxo das contribuições monetárias dos aliados da Simaquia de Delos gerou, Atenas acabou por se transformar no centro cultural pelo qual passaram (e onde se fixaram) os grandes cérebros de então.

Ora, esses indivíduos - que acabariam por receber o nome de $\mathrm{Sofistas}^{34}-$ propuseram-se, entre outras coisas, formar o homem, em especial o político (cf. P1. Prt. 317b, 319a). Essa pretensão veio ao encontro da necessidade premente que os que ascendiam socialmente sentiam de melhorar a sua formação (e sobretudo a dos seus filhos) para combaterem na arena política em pé de igualdade com os aristocratas. É que a crescente solicitação da vida política ativa $^{35}$ havia revelado a disparidade que resultava da «não-educação» dos cidadãos plebeus. Estavam, assim, reunidas as condições para dar formação a todos quantos quisessem dedicar-se com sucesso à carreira política, quer os jovens de origem humilde que buscavam - segundo Marrou - o «savonnette à vilain», quer os oriundos de famílias aristocratas.

Desde então, mais do que nunca até aí, a educação alargou-se a todos aqueles que tinham condições financeiras para pagar os preços - porque não dizê-lo - exorbitantes que a nova classe docente exigia (cf. Pl. Prt. 328b-c).

O ensino apregoado e praticado pelos Sofistas, apesar (e simultaneamente por causa) da grande adesão de que foi alvo, ocasionou uma forte crítica e contribuiu para a contenda entre a educação tradicional e a moderna, que era sobretudo reflexo do conflito social e político mais profundo entre as tradições

conselho - pelos cidadãos que dominam a retórica. É por isso que os principais líderes políticos são os que sabem persuadir, graças à sua eloquência, os concidadãos.

${ }^{34}$ Segundo P1. Prt. 312c-d, os Sofistas eram simultaneamente intelectuais, sábios, filósofos e professores. Embora já houvesse Sofistas na Atenas de Péricles (Protágoras, por exemplo, integrou o círculo do estratego), o grande afluxo destes intelectuais ocorreu após a morte do estadista (429 a.C.). Pródico (frg. 6 Diels), por sua vez, definia os Sofistas como «intermediários

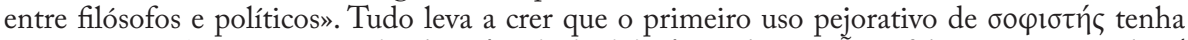

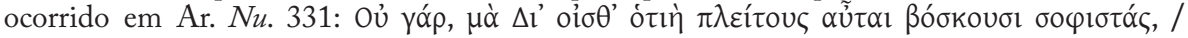

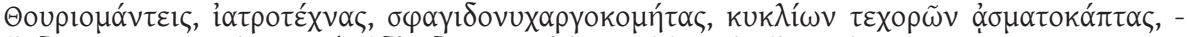

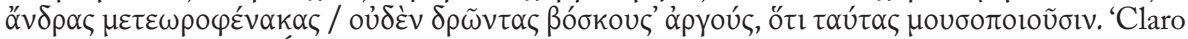
que não, por Zeus.!... É que tu não sabes que são elas que sustentam a maior parte dos sofistas, adivinhos de Túrios, artistas de medicina, calões guedelhudos que só cuidam de anéis e unhas, torneadores de cânticos para os coros cíclicos - enfim, todos esses vigaristas dos astros, que não fazem nenhum, são elas que lhes dão de comer, só porque lhes dedicam versos' (Magueijo: 1984). De facto, não nos podemos esquecer de que Aristófanes era contemporâneo dos Sofistas e de que, por isso mesmo, embora os criticasse, não pode ficar alheio à sua influência, como bem

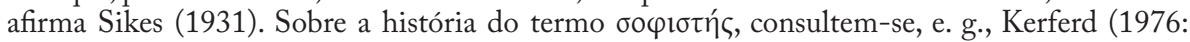
17-28); Cole (1993: 753-763).

${ }^{35}$ Como justifica Legras (1998: 83): «Après la crise de la tyrannie, au VI e siècle, nous voyons la plupart des cités grecques, et surtout la démocratique Athènes, s'animer d'une vie politique intense: l'exercice du pouvoir, la direction des affaires deviennent l'occupation essentielle, l'activité la plus noble et la plus prisée de l'homme grec, l'objectif suprême offert à son ambition. Il s'agit toujours pour lui de l'emporter, d'être supérieur et efficace; mais ce n'est plus dans le domaine du sport et de la vie élégante que sa «valeur», son arête cherche à s'affirmer: c'est dans l'action politique qu'elle s'incarne désormais...» 
conservadoras e aristocráticas da classe privilegiada e os ideais revolucionários e democráticos do proletariado em ascensão.

Dessa crítica e desse conflito, dão-nos testemunho Aristófanes, Eurípides, Platão e Aristóteles - para citar aquelas que foram talvez as vozes mais sonantes dessa contestação -, que culpavam o ensino dos Sofistas ${ }^{36}$ da crescente degradação moral da sociedade coeva. Não nos esqueçamos, porém, de que o ensino levado a cabo por estes profissionais constituía um suplemento à formação inicial que os jovens continuavam a receber, mas que, por força das circunstâncias, se tinha vindo a modificar paulatinamente, de tal modo que, no final do século $V$ a.C., já era evidente que a educação física ${ }^{37}$ e a musical tinham perdido importância em favor do estudo das letras.

De facto, a principal inovação dos Sofistas assentou não na rutura com o sistema educativo tradicional, mas na inclusão de novas matérias e no aumento da importância dada ao estudo das letras, pois continuaram a privilegiar o estudo dos poetas, cujos textos serviam de base para a transmissão da tradição cultural da Grécia.

Ainda que o leque de disciplinas que suscitava o interesse dos Sofistas seja amplo $^{38}$ (por exemplo, matemática, astrologia, religião, filosofia, linguística, poesia), o aspeto que nos interessa é sobretudo aquele que diz respeito à formação do homem de Estado ou, se quisermos, o ensino da virtude política ( de algumas disciplinas para a formação do caráter e a rejeição da teoria aristocrática segundo a qual a virtude ou é inata ou é um dom divino e por

${ }^{36}$ Não nos alongaremos sobre este tema, pois seria impossível num tão curto espaço ter a pretensão de abordar um assunto já tão amplamente analisado. Destacaremos apenas os aspetos que mais se relacionam com o contributo dado por este movimento para o «desenhar» de um novo tipo de homem de Estado. Sobre os Sofistas, leiam-se, e. g, Guthrie (1971); Kerferd (1981); Romilly (1988); Untersteiner (1993).

37 A grande revolução ocorrida no âmbito do ensino superior acabou por ter efeitos práticos a nível do ensino elementar: é que, como aquele dava grande importância ao estudo das letras, este viu-se obrigado a dotar os alunos de instrumentos que facilitassem o acesso àquela formação. Contudo, a dedicação ao exercício físico, ao desporto, não desapareceu. Embora na maior parte das vezes fosse praticado apenas como forma de manter o corpo saudável de modo a poder tirar benefício do esforço intelectual, muitos foram aqueles que passaram a praticá-lo a título profissional, dando azo a duras críticas por parte de Platão e Aristóteles (cf. infra p. 149). Aristófanes (Nu.1005-1019), por sua vez, além de fazer o elogio à prática da ginástica, chama a atenção para as consequências que o sedentarismo provocava: enquanto os que praticavam ginástica eram fortes e viçosos, os adeptos da nova $\pi \alpha 1 \delta \varepsilon i ́ \alpha$ eram amarelentos.

38 Hípias, o sofista natural de Élis, prefigura-se como verdadeiro ideal do homem renascentista. Afirmava conhecer todos os domínios (astronomia, geometria, aritmética, análise da linguagem, genealogias e arqueologia) e até fazia as próprias roupas e joias! Cf. Pl. Hp. Mi. 368b-e. Foi com base nas disciplinas cujo estudo era mais fomentado pelos Sofistas que se vieram a constituir o triuium e o quadriuium. 
isso não se aprende ${ }^{39}$. No entender dos Sofistas, a $\varphi$ ú $\iota^{40} \varsigma^{40}$ não era condição sine qua non para o florescimento da virtude, mas antes e tão-só um terreno ${ }^{41}$ que a educação deveria cultivar.

Assim se justifica que Protágoras defenda que Zeus deu a ỏpetŕ a todos os homens $^{42}$ (embora nem todos a tenham recebido na mesma proporção) e que acredite na possibilidade de desenvolver esse dom em alguns. Tal é o objetivo do curriculum deste sofista (que se afirma educador do político e formador de bons cidadãos - Pl. Prt. 318e-319a), que considera que o ensino pode condicionar a natureza ${ }^{43}$.

Por conseguinte, embora não houvesse muito a fazer no que respeita às qualidades fundamentais e inatas de um homem de Estado, era possível dotar de determinadas ferramentas qualquer indivíduo que se propusesse enveredar por essa carreira. Tendo em conta que as grandes decisões da vida política dependiam da capacidade que os intervenientes tinham ou não de se convencerem mutuamente na assembleia, os Sofistas apostaram no ensino da retórica, que Sócrates (P1. Phdr.261a) define como

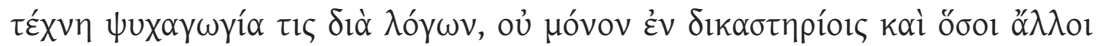

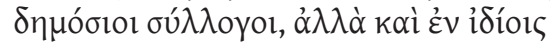

"uma espécie de arte de psicagogia por meio de palavras, não apenas nos tribunais e muitas outras assembleias públicas ${ }^{44}$, mas também nas reuniões privadas (...).”

${ }^{39}$ Cf. supra p. 138.

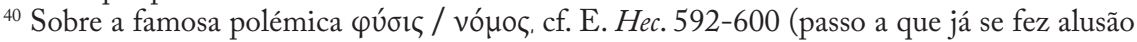
na nota 15, p. 138 ) e supra nota 29.

${ }^{41}$ Cf. infra p. 154.

${ }^{42}$ P1. Prt. 320d-322d. Através do mito de Prometeu e Epimeteu, Protágoras pretende explicar a distribuição das artes e da virtude política. A teoria que o sofista desenvolve por intermédio deste mito é um grande avanço relativamente à antiga conceção da aristocracia que fazia da virtude o privilégio de uma elite. Para uma análise do mito em questão, consultem-se, e.g., Edelstein (1967); Dodds (1973); Brisson (1975: 7-37).

${ }^{43}$ A mesma crença era partilhada por outros pensadores, como Pródico, que alegava que a virtude está ao alcance de todos desde que se empenhem na sua conquista, ou Isócrates, que acreditava na complementaridade entre natureza e treino. Até os seus críticos acabam por, em certa medida, partilhar da mesma opinião: Platão admite a contragosto a possibilidade de as classes inferiores acederem à virtude; Aristóteles (Pol.1337a), por sua vez, acredita que a prática da virtude se consegue com aprendizagem e treino e que a educação tem por objetivo suprir as deficiências da natureza. Também Eurípides, o sofista da tragédia grega, defende essa ideia, sobretudo em Supp. 914 sqq. e em El. 369 sqq.

${ }^{44}$ Górgias (P1. Grg. 452e) especifica as situações políticas em que a retórica é utilizada, quando afirma que esta é 'a capacidade de persuadir pela palavra os juízes no Tribunal, os senadores no Conselho, o povo na Assembleia, enfim, os participantes de qualquer reunião

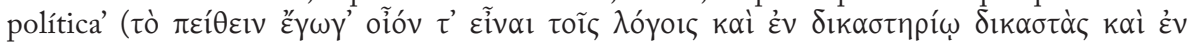

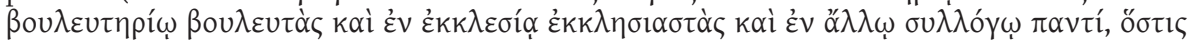

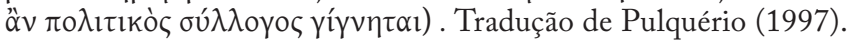


Contudo, a capacidade de pronunciar discursos convincentes e oportunos não depende apenas do domínio das técnicas retóricas. Para que os seus discípulos estivessem sempre aptos a discursar e convencer, os Sofistas procuravam dotá-los de uma ampla bagagem em termos daquilo a que poderíamos chamar cultura geral, assente no estudo das mais diversas matérias.

Demais, os Sofistas - nomeadamente Protágoras - ensinavam aos seus alunos que uma mesma situação podia ser vista de perspetivas diferentes e contraditórias, pelo que era necessário saber apresentar argumentos favoráveis

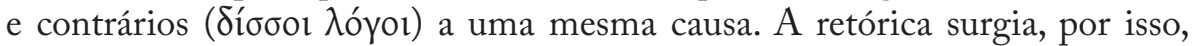
como instrumento que permitia ao orador convencer os interlocutores da

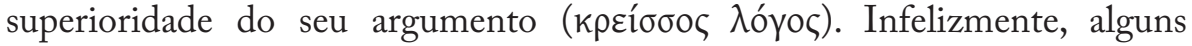
jovens pouco escrupulosos não souberam dar a esses conhecimentos aplicações práticas eticamente corretas; pelo contrário, usaram-nos em benefício próprio e não em prol do bem comum. Por isso, o recurso à retórica passou a ser visto por muitos como uma mera habilidade (adquirida a preços elevadíssimos) para defender um argumento menos válido. Disso mesmo nos dá testemunho Aristófanes, quando afirma que (Nu.98-99):

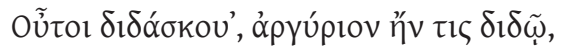

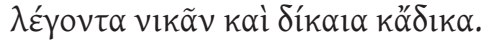

"Tais criaturas [os Sofistas] - em troca de dinheiro, é claro - ensinam uma pessoa a discorrer tão bem, que é capaz de vencer todas as causas, justas ou injustas;"

e quando $\operatorname{diz}(N u .1041-1042)$ :

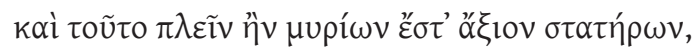

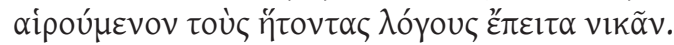

ora, isto de um homem tomar o partido das teses mais fracas e, não obstante, conseguir vencer, é coisa para valer um balúrdio. (a tradução dos passos das Nuvens é de Magueijo: 1984).

Esta habilidade para advogar quer as causas justas quer as injustas deu azo a que os Sofistas ficassem conhecidos como indivíduos sem moral, já que muitos consideravam a ética como um mero conjunto de convenções. É, no fundo, essa a perceção que subjaz às palavras de Fidípides em Ar. Nu. 1399-1405:

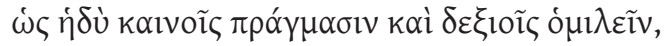

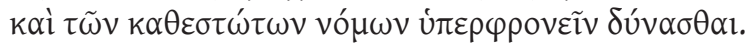

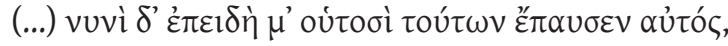




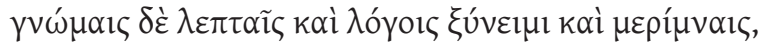

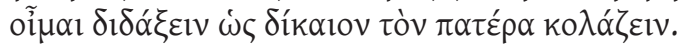

"que coisa mais doce, esta de estar familiarizado com as modernas correntes do pensamento e com as suas subtilezas, poder desdenhar das leis estabelecidas! (...) Agora, porém (...), sou uma barra em conceitos subtis, em dialética e em meditação, estou certo de poder demonstrar que é justo um filho castigar o pai,"

ou ao ợ $\omega ́ v$ de Hécuba na tragédia homónima de Eurípides (1186-1236), que nos dá um importante testemunho sobre o poder da retórica amoral ${ }^{45}$. Com efeito, embora ela comece por condenar a retórica, acaba por revelar grande mestria nessa arte, na medida em que consegue contrapor todos os argumentos avançados por Polimestor.

Mas, como em todas as circunstâncias, importa distinguir o trigo do joio: havia sofistas, como Protágoras, que eram a favor do respeito pelas convenções e outros, como Trasímaco (no Livro I da República), que definiam justiça como $o$ interesse dos mais fortes.

Tal falha (aliada ao facto de os Sofistas se fazerem pagar a peso de ouro) foi um dos principais motivos que provocou a contestação geral a estes mestres que eram peritos em fazer com que a causa pior parecesse a melhor.

Ao movimento sofístico, seguiram-se reações, como a de Platão e Aristóteles, em um século marcado por uma crise política, social, económica e religiosa, que foi, em grande parte, consequência da Guerra do Peloponeso (431-404 a.C.).

A filosofia educativa postulada por estes pensadores críticos da democracia assentava na crença de que o Estado não podia continuar a subtrair-se às suas responsabilidades e de que deveria assumir o seu papel tutelar na educação dos cidadãos ${ }^{46}$. Consequentemente, os projetos que, cada um à sua maneira, apresentaram devem ser entendidos como uma idealização do sistema educativo, cujo principal fim seria, nas palavras de Lee Too, «ensure that experts ${ }^{47}$ were responsible for inculcating the youth with the «right» ethical and political values». Tal justifica-se, segundo Platão, porque só pela educação da alma ser possível construir uma comunidade perfeita. De facto, quer um quer outro procuravam definir uma $\pi \alpha 1 \delta \varepsilon i ́ \alpha$ específica de uma determinada

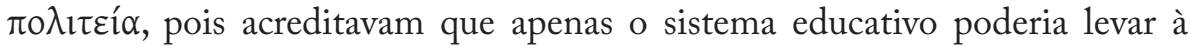

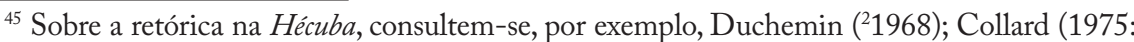
58-71); Conacher (1981: 3-25); Lloyd (1992); Kastely (1993: 1036-1049); Scodel (1999-2000: 129-44).

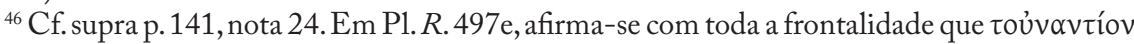

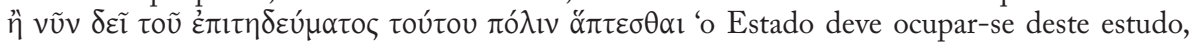
exatamente ao contrário do que faz agora' (tradução de Rocha Pereira: 2001).

${ }^{47}$ Esses expertos eram, na perspetiva de Platão, o filósofo-rei e, na de Aristóteles, o legislador. 
constituição de um corpo de governantes virtuosos ${ }^{48}$.

Embora as teorias de ambos divergissem em questões de pormenor, apresentavam, relativamente aos aspetos mais importantes, pontos convergentes. Quer Platão (R. 458c-461c) quer Aristóteles (Pol.1334b29-1336a) entendiam que o cuidado com a educação deveria ter início mesmo antes da conceção. Advogavam que, na medida em que as características dos progenitores e as circunstâncias em que decorre a fecundação determinam a natureza dos nascituros, futuros educandos e cidadãos, seria necessário orientar as uniões sexuais em função da qualidade que se pretendia obter ${ }^{49}$.

Uma vez nascidas, tornava-se imperioso que se desse atenção à educação das crianças desde a mais tenra idade, cuidando para lhes proporcionar, desde o berço, o melhor ambiente possível ${ }^{50}$. Assim, era preciso velar para que, da proximidade com amas e pedagogos, não adviessem influências nefastas resultantes do contacto com escravos ${ }^{51}$. Nesse sentido, Aristóteles (Pol.1336b) defende a prescrição do uso de linguagem indecorosa, da contemplação de representações da mesma índole ${ }^{52}$, bem como da assistência a sátiras e comédias até à idade adulta.

No que respeita àquilo a que, seguindo a nomenclatura moderna, podemos chamar de «educação formal», eis o que defendem os nossos pensadores. Para Platão, todos (incluindo as mulheres) devem ter acesso a uma formação de base entre os sete e os dezassete/dezoito anos. Em uma primeira fase, Platão admite que o sistema educativo coevo assentava em um critério correto, embora necessitasse de ser expurgado de algumas falhas para se conformar aos objetivos que se propunha: os jovens deviam começar por aprender música (que, enquanto arte das Musas, engloba sons e palavras e, portanto, deve igualmente conter, segundo Platão ${ }^{53}$, o estudo da literatura) e

${ }^{48}$ Aristóteles (Pol. 1337a) chega mesmo a defender que a ausência de educação em uma cidade provoca graves prejuízos ao regime que nela vigora.

${ }^{49}$ Em Ec. 612-650, Aristófanes faz a caricatura destas teorias que estariam, então, decerto em voga. Na nova ordem decorrente do acesso das mulheres ao poder, reinaria uma «promiscuidade orientada», em que homens e mulheres jovens e homens e mulheres de idade mais avançada partilhariam os leitos numa negação total dos cuidados prescritos por Platão. Consequentemente, a paternidade dos jovens que daí em diante nascessem seria «comum».

50 Tais cuidados englobam até a alimentação dada ao recém-nascido que exerce influência sobre a sua futura compleição física (P1. R. 440c-d; Arist. Pol. 1336a).

${ }^{51}$ Eurípides dá testemunho do perigo deste convívio pernicioso, por exemplo, em Hipp. 431 sqq. e no terceiro episódio de Ion. No primeiro caso, a ama revela ser uma má influência ao instigar Fedra a lutar pelo seu amor por Hipólito. Já no Ion é o pedagogo de Creúsa quem assume esse papel, pois incita-a a vingar-se da «traição» do marido.

${ }_{52}$ Ambas apenas aceitáveis no contexto de celebrações religiosas legalmente instituídas.

${ }^{53}$ R. 376e. A aprendizagem dos rudimentos de leitura, escrita e cálculo não é só essencial à vida diária, mas também serve de fundamento para uma fase de estudos mais avançada a que só poucos terão acesso. 
ginástica ${ }^{54}$, duas atividades complementares e imprescindíveis para a formação de um caráter harmonioso: é que a primeira, pela sua simplicidade, gera a temperança na alma e a segunda, a saúde no corpo. Consequentemente, de acordo com Platão $(R .410 \mathrm{~d}, 412 \mathrm{a})$, só a prática de ambas modela um homem ideal: quem só aprende ginástica fica demasiado rude; quem só música ${ }^{55}$, excessivamente mole.

O facto de se concentrar, na República, em pormenores relativos à música e à poesia e de não se referir à matemática significa apenas que o que em relação a esta última se fazia não lhe levantava quaisquer objeções e não que a tivesse banido do seu curriculum, já que o estudo das matérias contempladas nas fases seguintes pressupõe o seu conhecimento, ainda que rudimentar ${ }^{56}$. Além disso, deixa evidente o mérito desta disciplina na formação geral ${ }^{57}$, quando afirma que os conhecimentos que faculta têm uso prático na vida dos cidadãos e soldados, além de estimular o uso da inteligência ( $R$. 526b).

A perspetiva de Aristóteles para esse período não é muito diferente. $\mathrm{O}$ seu curriculum engloba o estudo de gramática (leitura, escrita e rudimentos de aritmética), ginástica, música e desenho ${ }^{58}$. Demais, ambos são de opinião de que os textos a que os mais jovens têm acesso, mesmo antes da frequência escolar (como acontece, por exemplo, com as fábulas), devem passar por um processo de censura ${ }^{59}$. Tendo em conta, segundo Platão (R. 377-398), que os hábitos e princípios adquiridos desde cedo perduram, as crianças não devem contactar em uma primeira fase - aquela em que ainda só estão preparadas para receber informação e não para emitir juízos de valor - com textos que, por exemplo, achincalham os deuses e em nada orientam para o exercício da

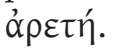

Quanto ao estudo da música propriamente dita, Platão considera-o fundamental, não pelo prazer e entretenimento que advêm da sua audição, mas porque ensina a amar o que é nobre e belo e porque o ritmo e a harmonia ajudam à perfeição da $a l m a^{60}$. No entanto, defende que também deve ser encarado

${ }^{54} \mathrm{O}$ ensino da ginástica, que, entre outras coisas, fomenta o autocontrolo, deve aproveitar a tendência natural das crianças para correr e brincar. Platão $(L g .793 \mathrm{e}-794 \mathrm{~d})$ sugere como normas de orientação para a prática de atividade física por rapazes e raparigas a partir dos três anos, nomeadamente os exercícios apropriados para cada sexo e idade (cf. Lg. 796, 804, 813).

$55 \mathrm{O}$ papel da música na educação grega tem sido tema de diversos estudos, dos quais destacamos Anderson (1966).

${ }^{56} \mathrm{Cf}$. P1. R. 536d, onde se afirma que as crianças devem desde cedo aplicar-se a todos os estudos que precedem a dialética. Em Pl. $L g .809$ c, diz-se que faz parte do curriculum, ao lado da música e da literatura.

${ }^{57}$ Sobre os benefícios que a aprendizagem da matemática, por estimular o esforço, aporta a nível da formação do caráter dos indivíduos, vide P1. Lg. 747b.

${ }^{58}$ Cf. Pol. 1338a. Sobre a educação física, vide 1338b-1339a; sobre a musical, 1339a-1342b.

${ }^{59}$ Sobre está temática, vide Arist. Pol.1336a30.

${ }^{60}$ Vide R. 401d. A mesma ideia ocorre em Prt.326b. Platão reflete sobre os efeitos da música na alma, no livro segundo das Leis. 
com precaução, pois nem todos os instrumentos e ritmos são apropriados ao homem livre que se quer cultivar na virtude (R. 308-402). Aristóteles, por sua vez, não atribui à música outra utilidade que não a ocupação do ócio dos homens livres (Pol. 1338a). Ainda assim, inclui-a no seu curriculum (alegando que os jovens livres não devem aprender música com o intuito de vir a tocar instrumentos na idade adulta, mas para poderem saber apreciar essa forma de arte) e reflete sobre o modo como deve ser ministrada.

O fundador da Academia advoga que, a essa formação inicial, deve seguir-se um período de consagração exclusiva à ginástica, entre os dezassete e os vinte anos. Durante esse tempo, os jovens são treinados para a guerra, enquanto desenvolvem a sua saúde física como meio de proteção contra doenças ${ }^{61}$. Tal dedicação é justificada por Aristóteles (Pol. 1339a), que argumenta que a mente e o corpo, por exigirem práticas opostas, não devem ser exercitadas ao mesmo tempo. Também Platão alega que é impossível nessa fase dedicarem-se a qualquer outra atividade, porque a fadiga e o sono são inimigos do estudo ( $R$. 537a).

Segundo a teoria exposta na República, uma vez concluída a segunda etapa da educação elementar, só os que reunissem as qualidades ${ }^{62}$ necessárias (que raramente eram possuídas pela mesma pessoa) poderiam prosseguir os estudos superiores, cujo objetivo era formar uma elite, a classe de filósofos-governantes.

A formação superior compreendia três períodos distintos: um entre os vinte e os trinta anos, outro entre os trinta e os trinta e cinco, outro entre os trinta e cinco e os cinquenta ${ }^{63}$.

Entre os vinte e trinta anos, os eleitos dedicar-se-iam às disciplinas que pretendem direcionar a alma para o verdadeiro Ser e que nos são apresentadas como áreas da matemática: cálculo e aritmética ${ }^{64}$ (o guerreiro aprende por causa da tática; o filósofo, para atingir a essência), a geometria de planos e de sólidos (porque ajuda a ver a forma do Bem e também é útil para a guerra), astronomia (útil à navegação, à arte militar e à perfeita compreensão das estações, meses e $\left.\operatorname{anos}^{65}\right)$ e a harmonia $(R .531 \mathrm{a}-\mathrm{b})$.

${ }^{61}$ Platão ( $L g .795$ d-f) defende, contudo, que há exercícios que não devem ser praticados, pois apenas existem para satisfazer o gosto da competição pela competição, já que não são próprios para o treino militar.

${ }^{62}$ Como a inteligência, a memória, a coragem, o autodomínio, a força, o gosto pelo trabalho e, se possível, também a beleza (cf. $R$. 503c-e, 535a-b, 537a-b) ou a aptidão para a matemática, que é a base da filosofia (R. 526b). O facto de Platão admitir que a seleção é feita pelas capacidades e não pelo nascimento é curiosamente uma marca democrática, assente não numa igualdade absoluta, mas na igualdade de oportunidades.

${ }^{63}$ Aristóteles (Pol. 1337a) discorda desta divisão, na medida em que afirma concordar com Sólon (fr. 19 Diels), que reparte a vida humana em períodos de sete anos.

${ }^{64}$ A propósito do elogio da ciência do número e do cálculo, vide $R$. 522c-e, 526b. Segundo P1. Phlb. 56b-c, os construtores também devem saber matemática.

${ }^{65}$ R. 529-530. Cf. etiam Lg. 809c-d. 
Entre os trinta e os trinta e cinco, o estudo concentrar-se-ia na dialética, única disciplina que habilita o filósofo a ter a noção da essência de cada coisa, a alcançar

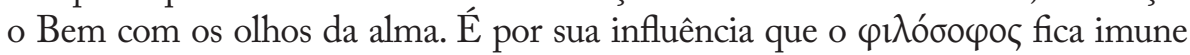
às seduções do poder e honrarias políticas, às tentações do dinheiro e do prazer carnal. A dialética ensina, portanto, a abstração do mundo físico, que impede os homens de alcançar o verdadeiro conhecimento. No entanto, segundo Platão, esta é a fase mais perigosa, porque as pessoas que experimentam a dialética sem reunirem as condições necessárias (a saber, moderação, firmeza e idade adequada, $R$. 539b) acabam por fazer mau uso dela, uso esse que, embora não se diga claramente, recorda o comportamento criticado aos sofistas e seus discípulos:

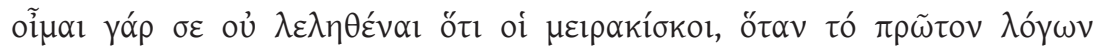

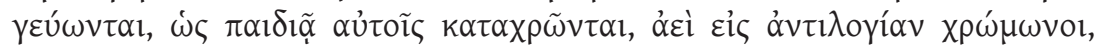

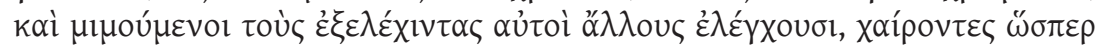

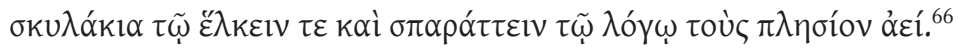

"Calculo que não passa despercebido que os rapazes novos, quando pela primeira vez provam a dialética, se servem dela como de um brinquedo, usando-a constantemente para contradizer, e, imitando os que os refutam, vão eles mesmos refutar outros, e sentem-se felizes como cachorrinhos, em derriçar e dilacerar a toda a hora com argumentos quem estiver perto deles."

Uma vez concluído o estudo da dialética, os que prosseguem os estudos superiores devem ser inseridos no seio da comunidade, nomeadamente nos comandos militares, durante cerca de quinze anos (ou seja, entre os trinta e cinco e os cinquenta anos), de modo a darem prova das suas capacidades e a adquirirem experiência prática $(R .539 \mathrm{e}-540 \mathrm{a})$.

Só terminada esta fase experimental, e já com cinquenta anos, todos os que tiverem conseguido ultrapassar dignamente tão longo e árduo período de formação, serão colocados nos lugares de chefe e guardião da cidade, e passarão a dividir o seu tempo entre o estudo e as obrigações cívicas. É que nessa altura já estarão aptos a usar o Bem como paradigma para orientar o funcionamento da cidade e de todos os que nela habitam (cf. P1. R. 413e-414a, 540b). Ou seja, só quem consegue alcançar a sabedoria e a liberdade de um filósofo é verdadeiramente «educado» e capaz de governar de um modo desinteressado e imparcial, tendo em vista o bem da cidade e dos cidadãos ${ }^{67}$.

Importa-nos, por fim e em jeito de conclusão, recordar o pensamento de Plutarco acerca da educação ${ }^{68}$, na medida em que a sua «teoria» acaba por ser

\footnotetext{
${ }^{66}$ R. 539b; tradução de Rocha Pereira (2001).

${ }_{67}$ Também Plutarco (Moralia 7F-8A) considera que atingiram a perfeição os homens capazes de unir e alternar a atividade política com a filosofia. Péricles enquadra-se nesse modelo.

${ }^{68}$ A propósito desta temática, leia-se, por exemplo, Faure (1960); Teixeira (1991: 223-236);
} 
uma súmula de muito do que os filósofos anteriores disseram, mas também para termos elementos que nos permitam verificar até que ponto os políticos cujas biografias estamos a analisar tiveram ou não uma educação que se coaduna com aquilo que Plutarco defende ser ideal. O seu pensamento sobre a formação dos cidadãos encontra-se sistematizado no opúsculo De liberis educandis (daí que nos vamos centrar nele), embora o tema seja recorrente ao longo quer dos Moralia quer das Vitae $e^{69}$.

$\mathrm{O}$ nosso autor (Moralia 5A-F) considera a boa educação o melhor investimento, porque conduz à felicidade e à virtude ${ }^{70}$. Todo aquele que não recebe uma formação apropriada transforma-se em um adulto que rejeita a vida regrada e entrega-se a prazeres próprios de escravos: uns tornam-se aduladores e parasitas, outros compram a liberdade a cortesãs e prostitutas (que, como veremos, não servem para constituir família), outros passam a vida em banquetes, rodeados de más companhias. Consequentemente, a instrução afigura-se como único bem imortal e divino, que nem a guerra - que tudo destrói - consegue abalar. Demais, por ironia do destino, a instrução (e a sabedoria que dela decorre) é o único bem que realmente importa e o único que se enriquece, que não se degrada, com o correr dos anos, daí que seja tão importante investir nele.

No De liberis educandis, o Queroneu propõe-se, por isso, tecer

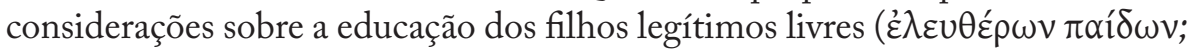

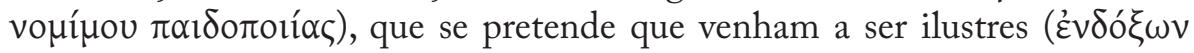
$\tau \varepsilon ́ k \nu \omega v)^{71}$. Para que o processo possa ser bem sucedido, é preciso ter em conta três momentos fundamentais, para os quais a ação dos pais tem importância crucial: a conceção (que depende exclusivamente dos progenitores), a infância e a adolescência (durante as quais se conjugam as influências da natureza individual de cada jovem e da ação de todos aqueles que assumem o papel de seus educadores).

À semelhança do que séculos antes Platão e Aristóteles haviam

Roskam (2002: 175-189).

${ }^{69}$ De facto, a preocupação e o interesse pela formação dos jovens jamais o abandona, já que dela resultam quer a perfeição pessoal quer o bem da sociedade em geral. Ainda que este opúsculo seja considerado espúrio por muitos, partilhamos da opinião daqueles que o aceitam como autêntico. Sobre esta problemática, vide Ziegler, (1951); Faure (1960: 18-22); Eyben (1996: 80) e Albini (1997: n. 2).

${ }^{70}$ De acordo com Plutarco (Moralia 439F, 452C-D), o objetivo primeiro da educação é incutir nos indivíduos sentimentos de prazer por uma boa ação e de vergonha por uma má; ou, se quisermos, assegurar a primazia da razão sobre as paixões.

${ }_{71}$ No entanto, para que o seu projeto educativo pudesse ser implementado, era necessário que os encarregados de educação investissem uma quantia em nada despicienda, o que, certamente, excluía muitos jovens livres dos benefícios que adviriam de uma tal formação (Moralia 8D-E). Sobre o papel da riqueza enquanto condicionante da educação, vide supra p. 137, nota 11 e p. 138 nota 16 . 
defendido, também Plutarco chama a atenção para a necessidade de se fazer uma seleção criteriosa dos progenitores ${ }^{72}$ : quem quer ter filhos legítimos ilustres, não pode dar-lhes mães cortesãs ou concubinas, visto que tais senhoras seriam uma mancha na vida futura dos filhos. De facto, quem poderia agir livremente (em um mundo em que os preconceitos não eram camuflados) sob a ameaça de que lhe fosse apontada uma ascendência ignóbil? Até o mito veiculava essa preocupação, sentida por aqueles que desconheciam as suas origens. Pensemos, por exemplo, em Édipo (S. OT 1062-1063), que, quando descobre não ser filho dos reis de Corinto e decide averiguar quem são os seus pais, diz a Jocasta (que se opõe à investigação) que não tema vir a ser considerada de condição inferior no caso de ele ser filho de escravos. Ou Hércules (E. HF 1261-1262), que afirma que um nascimento mal preparado, isto é, assente em fundações más, dá origem a uma raça amaldiçoada por infortúnios. Ou Íon (E. Ion, passim), que, desconhecendo a identidade dos seus pais até ao encontro com Xuto e Creúsa, refere por diversas vezes a possibilidade de ter uma origem ignóbil, de ser um filho bastardo, ilegítimo ou de uma mulher enganada. Ou ainda Fedra (E. Hipp. 424), que diz à sua ama que o conhecimento das culpas dos pais escraviza até o homem corajoso ${ }^{73}$.

O Queroneu chama também a atenção para a necessidade de os progenitores se encontrarem sóbrios aquando da relação sexual ${ }^{74}$ : assim como pais pouco saudáveis geram filhos pouco sãos, pais cujo procedimento não é irrepreensível darão origem a filhos de comportamento indigno ${ }^{75}$.

Uma vez focados estes dois pressupostos relativos à conceção (de que depende diretamente a natureza de cada um, já que dos pais tanto se herdam virtudes como defeitos), Plutarco volta-se para a educação que se deve fornecer às crianças, começando por realçar que o seu resultado (o homem perfeito, virtuoso) está dependente da conjugação de três elementos essenciais ${ }^{76}$ : a natureza, a razão (que

${ }^{72}$ Plutarco (Moralia 1C-D) conta duas anedotas que ilustram os prós e contras de uma tal escolha. A primeira relaciona-se com o grande estadista grego Temístocles, cujo filho se orgulhava de dizer que as suas decisões eram sancionadas pelo povo ateniense, na medida em que os seus pais concordavam com elas e que os Atenienses queriam sempre o que Temístocles preferia. A segunda tem Arquidamo por protagonista: consta que terá sido multado pelos Lacedemónios por se ter casado com uma mulher baixa, da qual nasceriam reizinhos e não reis. Sobre este tema, vide etiam Moralia 563A.

${ }^{73}$ Dos exemplos citados, este é o único mencionado por Plutarco (Moralia 1C).

${ }^{74} \mathrm{Em} L y c .15 .6$, afirma que os noivos espartanos não se apresentavam diante das noivas nem embriagados nem cansados. Parece acreditar que isso tinha influência na solidez de caráter que geralmente caracteriza os Lacedemónios.

${ }^{75}$ Para ilustrá-lo, recorre a uma anedota protagonizada por Diógenes (Moralia 2A). Este, ao deparar-se com um jovem fora de si, dirige-se-lhe dizendo que o seu pai estava bêbado quando o gerou.

${ }^{76}$ Esta teoria não é original de Plutarco, na medida em que já fora apresentada em Arist. Pol. 1334b6-7, EN 1103a16, segundo o qual a educação está intimamente ligada à natureza ( $\varphi$ vic), 
corresponde à instrução) e os costumes (ou seja, a prática). Segundo o Queroneu, a falha de qualquer um destes elementos compromete o processo.

Plutarco compara a pessoa à terra cultivável (Moralia 2B) ${ }^{77}$ : a terra boa corresponde a uma natureza boa, o semeador entendido, ao mestre, e as boas sementes, aos preceitos e conselhos da razão. Defende que não basta ter uma natureza boa, é preciso cultivá-la, pois quem tem dons e não os exercita (e não os põe a render $^{78}$ ), acaba por perdê-los. Mas a semente também pode germinar em um terreno menos bom: quem não tem dons naturais, pode conseguir colmatar essa falta através de um árduo esforço. A própria natureza dá exemplos do modo como o poder do trabalho e da persistência permitem alcançar um objetivo, permitem moldar o caráter, do mesmo modo que a água, com o tempo, acaba por deixar a sua marca na pedra, ou como as mãos, em contacto com o ferro ou o bronze, conseguem gastá-los.

Parece ficar claro que para o biógrafo o esforço e a dedicação que colmatam «falhas» da natureza têm um valor superior ao da própria natureza boa, quando descurada. É por isso que a educação (ou se quisermos o esforço, a dedicação) faz a diferença ${ }^{79}$.

Plutarco (Moralia 3B-D) considera igualmente que existem duas figuras fundamentais para o desenvolvimento das crianças de tenra idade: a mãe e a ama, à qual só em casos excecionais se deveria recorrer. Ao contrário de Platão (R. 461d-e), que defendia que os que tinham a missão de guardiães não deveriam saber distinguir os seus filhos dos dos restantes ${ }^{80}$, o Queroneu salienta a importância do vínculo afetivo com a mãe e a superioridade do seu amor gratuito e desinteressado ${ }^{81}$ (testemunhado pela relação mãe-cria observável no

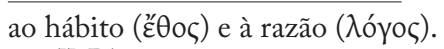

${ }^{77}$ Plutarco compara o processo educativo ao agrícola, fazendo-nos, sem pensar muito, recordar Cícero (Tusc. 2. 13), que afirma ut ager quamvis fertilis sine cultura fructuosus esse non potest, sic sine doctrina animus ("tal como o campo, embora fértil, sem cultura não dá fruto, assim também a alma sem doutrina”) e o Evangelho de Mateus (13.3-23), que narra a parábola do semeador. Em Moralia 4B-C, recorre de novo a uma metáfora agrícola, quando diz que a transmissão de bons princípios é comparável a uma estaca, para significar que o crescimento dos jovens deve apoiar-se em valores corretos, do mesmo modo que uma planta, para crescer direita, se apoia na estaca.

${ }^{78}$ Para usar palavras mais próximas das da parábola dos talentos (Mt. 25. 14-30).

${ }^{79}$ Também Platão defendera que a educação torna a natureza melhor. Cf. R. 424a-b, 491de e 492a. Para exemplificá-lo, o Queroneu conta mais uma anedota em que Licurgo intervém (Moralia 3A-B, 225F). A dois cães com a mesma origem, deu-se uma educação diferente. Com o tempo, um tornou-se guloso e voraz, o outro, um excelente caçador, o que levou Licurgo a salientar a importância dos costumes, da educação, do ensino e da conduta para a aquisição da virtude.

${ }^{80}$ Aristófanes (Ec. 614 sqq.) faz a caricatura deste princípio. Na verdade, ainda que não por um objetivo específico e «louvável», mas antes por causa de uma promiscuidade generalizada (porém legal), também os filhos nascidos na nova ordem estabelecida pelas mulheres (cf. supra página 148, nota 49) passariam a ignorar quem era o seu pai.

${ }^{81}$ Este tipo de $\varphi \imath \imath i ́ \alpha$ entre a mãe e os filhos é analisada por Aristóteles em EN1159a25-35. 
reino animal), por oposição ao das amas, que, de algum modo, são pagas para cuidar de filhos que não os seus.

À semelhança de Platão e Aristóteles ${ }^{82}$, chama a atenção para o facto de a formação do caráter seguir pari passu o crescimento do corpo, logo desde o nascimento. Por isso, é preciso ter cuidado com a atmosfera moral que rodeia os que estão em formação: as amas, escravos e pedagogos devem ser criteriosamente selecionados ${ }^{83}$. É que o exemplo é, para Plutarco, o instrumento educativo por excelência. Pela mesma razão, torna-se imperioso selecionar as lendas contadas às crianças, para que não sejam influenciadas pela corrupção e insensatez, e cuidar para que os seus ouvidos ${ }^{84}$ não tenham acesso à linguagem obscena.

Plutarco demarca-se pela posição que assume relativamente ao papel dos pais (ou se quisermos, dos semeadores) na educação dos filhos (embora o que afirma seja extensível aos mestres) e que se baseia na sua experiência pessoal. Ele crê que os progenitores são o melhor exemplo que os filhos podem ter e que, se tal não acontece, os jovens tornam-se maus. Defende, por isso, que os jovens devem ser educados com bons modos, e que os pais não devem ser muito rudes ou cruéis, mas antes perdoar as faltas menos graves e recordar que também eles, um dia, tiveram aquelas idades.

Segundo o Queroneu, o ideal é conseguir atingir o meio termo entre o elogio e a censura ${ }^{85}$. Além disso, é da opinião de que não se deve ser demasiado

Segundo o Estagirita, as mães sentem alegria em amar os filhos; basta-lhes amá-los e saber estão bem para se sentirem recompensadas por toda essa dedicação. Sobre este assunto, vide ainda Moralia 496C (onde justifica a posição superior dos seios humanos - por comparação com os dos animais - com o facto de a mãe dar alimento mas sobretudo amor).

${ }^{82}$ Vide supra pp. $150-151$.

${ }^{83}$ Cf. Moralia 439F-440A. Amas, pedagogos e escravos devem ser preferencialmente gregos (por terem caráter superior ao dos bárbaros e falarem uma língua comum), ter experiência e bons costumes, pois acompanham as crianças desde a mais tenra idade. É essa a razão pela qual Plutarco (Moralia 4A-5A) aproveita para criticar todos aqueles que se dizem preocupados com a educação dos filhos, mas reservam os melhores escravos (isto é, os mais virtuosos) para os negócios, e também todos aqueles que contratam pedagogos que sabem ser maus só porque cederam a adulações ou quiseram agradar a amigos. $\mathrm{O}$ Queroneu, citando um protesto de Sócrates (Pl. Clit. 407a), condena ainda os que se preocupam mais com a acumulação de riqueza do que com a educação dos filhos, acrescentando que se assemelham a alguém que se preocupa com os sapatos mas não cuida dos pés. E não poupa os que, por serem avarentos, contratam mestres mais baratos. Em Moralia 9D, Plutarco defende ainda que os pais devem mostrar interesse por aquilo que os filhos aprendem, como forma de estímulo aos professores: um assalariado, se não tiver de prestar contas, tem tendência a descurar o seu trabalho.

${ }^{84}$ Em Moralia 38A, D-E, o sentido da audição é apresentado como o mais sensível, na medida em que é o único que permite, além do contacto com o Mal (como os demais), o acesso à virtude.

${ }^{85}$ Como afirma em Moralia 12C-D, quando reflete sobre a orientação dos adolescentes, a prática da virtude é estimulada pela esperança da honra (que predispõe às boas ações) e pelo temor do castigo (que nos torna mais lentos para a prática das más). Os pais devem comportar-se como médicos, que misturam remédios amargos com os doces, fazendo do prazer um caminho para o proveito, combinando rigor com doçura, cedendo por vezes aos desejos dos 
permissivo ou protetor, porque assim se impede o correto desenvolvimento da criança: «amar demasiado é não amar».

O biógrafo dá particular relevo a ação dos pais durante a adolescência dos filhos, porque, talvez, devido à sua própria experiência enquanto pai, tinha a noção de que era mais difícil educar e manter no bom caminho os adolescentes do que as crianças. $\mathrm{Na}$ sua perspetiva, qualquer pai sensato deve redobrar os cuidados com filhos que atravessam essa fase: é que, nessa idade, os jovens possuem uma grande energia que os leva a cometer excessos - na comida, nos jogos, nos amores... Torna-se, por isso, forçoso não deixá-los sem orientação e vigilância, sob pena de se lhes dar involuntariamente licença para a prática de delitos, pois a força dos prazeres é incontrolável e precisa de travão. Para não vir a ter dissabores, os pais devem vigiar, corrigir com prudência, ensinar, ameaçar, pedir, selecionar as companhias - de modo a afastá-los de pessoas perversas e de aduladores ${ }^{86}$ - e mostrar exemplos de pessoas que caíram em desgraça por amor dos prazeres e de outras que foram louvadas e ganharam boa fama pela sua temperança. De facto, o $\pi \alpha \rho \alpha \delta \varepsilon \tilde{i} \gamma \mu \alpha$ é, na perspetiva do nosso autor, o instrumento mais eficaz para a formação dos jovens, quer se trate de um exemplo atual, quer de um exemplo histórico ou lendário. Aliás, é nesse pressuposto que assenta a redação das Vitae. Qualquer pessoa - e sobretudo os jovens - prefere ouvir histórias agradáveis (como as que descrevem feitos excecionais) a sermões. Não admira, por isso, que, ao ouvirem (ou lerem) essas narrativas, os jovens se deixem persuadir com mais facilidade e acabem por desejar imitar essas ações nobres.

O Queroneu entende igualmente perigoso que se exija demasiado aos filhos, isto é, que se queira que sejam os primeiros em tudo e que trabalhem em excesso ${ }^{87}$.

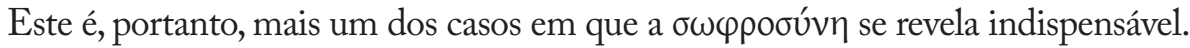
Plutarco ilustra-o com novo recurso a uma metáfora agrícola (Moralia 9B):

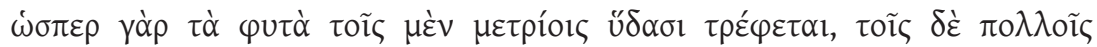

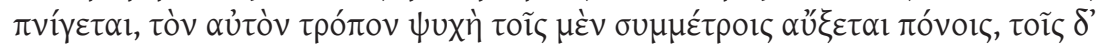

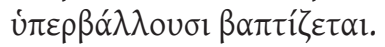

"assim como as plantas crescem se regadas moderadamente, mas se afogam com muita água, do mesmo modo a alma crescerá com trabalhos moderados e com excessivos afogar-se-á."

Plutarco é apologista de um ensino diversificado e abrangente (Ẻvkúk $\lambda$ ıov $\pi \alpha 1 \delta \varepsilon u ́ \mu \alpha)$, embora reconheça que é impossível ser-se perfeito em todas as

filhos, suportando as suas faltas e não se conservando irados por muito tempo.

${ }^{86}$ Sobre os efeitos da influência dos aduladores, vide Plu. Moralia 13A-C.

${ }^{87} \mathrm{Na}$ verdade, como já vimos antes (supra p. 150), quando se está excessivamente cansado, o estudo não dá frutos. $\mathrm{O}$ descanso é o condimento do trabalho. 
áreas $^{88}$. No entanto, considera que o mais importante é o estudo da filosofia, pelo que esta deve ser o principal elemento de qualquer instrução ${ }^{89}$ : é que a filosofia está para a alma como a medicina e a ginástica para o corpo, pois é o remédio contra debilidades e sofrimentos do espírito. Por isso, filosofia e ginástica ${ }^{90}$ devem fazer parte da instrução de qualquer pessoa, até porque incutem disciplina e moderação, viáticos para a velhice.

Plutarco reconhece que é quase humanamente impossível conseguir pôr em prática tantos conselhos ao mesmo tempo. Ainda assim, é perentório ao afirmar que tentar está ao alcance de qualquer um; o que importa não é conseguir um resultado perfeito, mas não descurar a missão educativa. As crianças de hoje são, como é uso dizer-se, os homens de amanhã. E, no futuro, deixarão o espaço limitado da família para assumirem o seu papel de cidadãos; muitas delas ocuparão mesmo lugares cimeiros na condução dos destinos de cada terra. Por isso, se queremos que a vida da sociedade evolua para melhor, temos de dotá-las de ferramentas (de valores) ${ }^{91}$, para que as suas ações possam superar as nossas.

Vejamos, em seguida, de que modo as biografias de Plutarco se coadunam com os princípios defendidos e com aquilo que foi o contexto histórico em que os protagonistas que estamos a estudar viveram.

\footnotetext{
${ }^{88}$ Mais importantes do que demonstrar aptidão para as diferentes matérias, são o gosto pelo estudo e o empenho que a ele se dedica.

${ }^{89}$ Cf. Pl. Grg. 464b.

${ }^{90}$ No que respeita à perspetiva de Plutarco sobre a ginástica, fica evidente a influência do pensamento aristotélico veiculado por Pol.1339a e EN 1104a15.

${ }^{91}$ Até porque a educação - cujo principal objetivo consiste no domínio da razão sobre as paixões, algo que só o progresso na idade e na virtude permite alcançar - é um processo que apenas termina com a morte (cf. Moralia 450F).
} 


\section{O caso de Péricles e Alcibíades}

\section{1. Família, principais características e formação dos Alcmeónidas}

Antes de procedermos à análise do testemunho que Plutarco nos dá sobre o período que se estende do nascimento ao ingresso na vida política daqueles que, por razões diversas, foram talvez os dois estadistas do século $V$ que mais renome alcançaram, importa recordar dois aspetos fundamentais, embora óbvios. Apesar de pertencerem a gerações diferentes (e da maior ou menor variação dos condicionalismos sociais e políticos que decorrem desse facto), Péricles e Alcibíades viveram em uma época na qual o acesso a cargos políticos de topo se encontrava praticamente reservado àqueles que eram oriundos de famílias de renome, ricas e de tradição aristocrática, que, por essa razão, podiam beneficiar de uma educação de nível superior (como vimos em páginas anteriores).

Por isso, no âmbito deste capítulo, pretendemos concluir da pertinência dos elementos «família», «natureza» e «educação» não só na formação de um futuro homem de Estado, mas também na determinação da sua ação política.

Comecemos pela informação relativa à família ${ }^{1}$. Ao contrário do que acontece na Vida de Alcibíades - que abre com o traçar da árvore genealógica do protagonista -, na Vida de Péricles a informação desse cariz só surge no terceiro capítulo. Demais, a própria caracterização da ascendência de cada um dos «heróis» é feita de maneira diversa, o que evidencia o facto de o biógrafo não seguir um padrão rígido para a redação das vidas, apesar de respeitar um fio condutor mais ou menos coeso ${ }^{2}$.

${ }^{1}$ Sobre o papel da família em Plutarco, vide Albini (1997: 59-71).

${ }^{2}$ A importância da influência da hereditariedade na maneira de ser de um indivíduo é algo que os Gregos tiveram desde sempre como premissa. Disso nos dá testemunho Hécuba, que, ao refletir, na tragédia homónima de Eurípides (592-692), sobre o honroso comportamento da

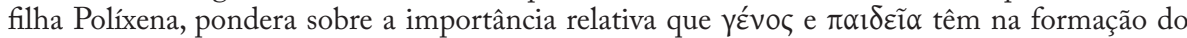
indivíduo (como já vimos supra p. 138 e nota 15). Também Plutarco aborda esta questão nos Moralia (vide infra p. 152 sqq). Consultem-se, a propósito deste tema, Mayor (1952: 18-43); Dover (1974: 88-95); Lesky (1983: 387); Tarkow (1984: 123-136). A alusão aos antepassados no registo biográfico é uma prática adotada do encómio. Em Plutarco, as informações relativas à família dos indivíduos cujas vidas descreve surgem, por norma, nos capítulos iniciais, mas não necessariamente no primeiro, e são objeto de tratamento irregular. A estes dados, acrescenta muitas vezes anedotas e uma breve descrição da natureza (física e/ou psicológica) do herói em causa, bem como a análise da herança familiar - para ilustrar traços hereditários (cf. Ant., Brut.) - ou de aspetos importantes do ambiente em que decorre a infância (cf. CG, Cleom., Cor.). Por vezes o tratamento do үévo s pode surgir como mera curiosidade ou casualidade (Fab., Pyrrh. 
No caso de Péricles, Plutarco tem o cuidado de começar por referir a tribo ${ }^{3}$ e o demo ${ }^{4}$ a que aquele pertence, como um ateniense puro, e por acrescentar que, quer por parte de pai, quer por parte de mãe, tinha origem nobre. No entanto, nunca diz abertamente (ainda que a restante informação o deixe claro) que Péricles estava ligado à família dos Alcmeónidas 5 . Na Vida de Alcibiades, pelo contrário, utiliza o adjetivo $\alpha \hat{\alpha} \kappa \mu \alpha \imath \omega v i ́ \delta \eta \varsigma^{6}$ para identificar Mégacles ${ }^{7}$, o avô de Alcibíades, mas omite alusões à tribo e ao demo ${ }^{8}$.

A consanguinidade existente entre estes dois ilustres membros da não menos ilustre família dos Alcmeónidas fica evidente aquando da apresentação das suas mães: Agariste (a de Péricles) é apresentada como neta de Clístenes ${ }^{9}$

Phoc., ou Aem.). Sobre este assunto, vide Pelling (1990: 213-244); Albini (1997); Duff (1999: 310-311).

3 A tribo de Acamante tinha por epónimo Ácamas, filho de Teseu e Fedra. Embora não figure na epopeia homérica, lendas posteriores (e. g. E. Hec. 123-129) referem o papel importante que este monarca teve, com o seu irmão Demofonte, na tomada de Troia. Para conhecer melhor Ácamas, consulte-se Grimal (21992: s. v). É curioso notar que Péricles acaba, assim, por surgir indiretamente associado à figura do fundador mítico de Atenas como um seu remoto descendente. $\mathrm{O}$ mesmo não se pode dizer de Alcibíades, já que o biógrafo coloca ênfase na ascendência mítica da sua família paterna, associada a Eurísaces, filho de Ájax (cf. Pl. Alc. 1. 121-2).

${ }^{4} \mathrm{O}$ demo de Colarges estava situado no extremo norte da Ática, próximo da encosta nordeste do monte Egáleo.

5 Os Alcmeónidas eram uma família ilustre e poderosa. Embora a sua origem fosse normalmente associada à casa real de Pilos (Alcméon seria, segundo D. S. 12. 38. 7, um bisneto de Nestor refugiado em Atenas após a chegada dos Heraclidas), muitos dos seus membros associavam-na a um Alcméon que teria sido contemporâneo de Teseu - (Graves: 2004: passim). Para informações mais detalhadas sobre esta família, consultem-se, e.g., Hdt. 5. 62-73, 6. 125131; Davies (1971: 368 sqq.); Fornara - Samons (1991: 1-36) e a bibliografia citada pelos autores, nomeadamente Toepffer (1889: 226-28).

${ }^{6} \mathrm{Em} \mathrm{P1.Alc.1.104a-b,} \mathrm{Sócrates} \mathrm{tece} \mathrm{um} \mathrm{grande} \mathrm{elogio} \mathrm{à} \mathrm{família} \mathrm{no} \mathrm{seio} \mathrm{da} \mathrm{qual} \mathrm{Alcibíades}$ nasceu, ao apresentá-la como uma das mais importantes de toda a Grécia e não só de Atenas. Não deixa de ser curioso notar que Sócrates não identifica a família do jovem pelo nome, o que certamente se justifica por causa da contemporaneidade que une os dados e o texto. Se pensarmos que Plutarco também não revela grande preocupação em mencionar o nome da família em causa (sobretudo na Vida de Péricles), concluímos que, apesar dos séculos entretanto volvidos, o renome de Péricles e Alcibíades atingira uma proporção tal que a memória popular continuava a relacioná-los com a família dos Alcmeónidas. A propósito deste testemunho platónico, importa ainda salientar que, segundo Sócrates, a pertença a este $\gamma \varepsilon ́ v o s$ era para Alcibíades um argumento justificativo da sua maneira de ser e ambições.

${ }^{7}$ Filho de Hipócrates de Alópece, foi vítima de ostracismo em 487/6 a.C.

${ }^{8} \mathrm{O}$ demo Escambonide, a que Alcibíades pertence, é referido em Alc. 22. 4, onde Plutarco reproduz o texto da ata de acusação contra o filho de Clínias no âmbito do processo relativo à mutilação dos Hermes.

${ }^{9}$ Clístenes era um dos Alcmeónidas aos quais se atribui a expulsão do tirano Hípias em 510 a.C. Durante a tirania, chegou a ser arconte em 525/524 a.C., mas quando se desentendeu com os tiranos, toda a sua família foi forçada ao exílio. Após 510 a.C., travou um duro combate com Iságoras (apoiado pelo rei Cleómenes de Esparta) para impedir a instauração de uma oligarquia e foi responsável por importantes reformas na senda da democracia (cf. Boardman: ${ }^{2} 1988,305$ sq.). Talvez o breve elogio de Clístenes, enquanto opositor da tirania e impulsionador 
(Per.3.1-3), já a de Alcibíades, Dinómaca ${ }^{10}$, como filha do alcmeónida Mégacles (Alc.1.1). Assim, de acordo com as informações que Plutarco nos dá, Péricles e Alcibíades seriam parentes próximos ${ }^{11}$. Essa ligação foi reforçada (segundo informação que apenas é explícita em Alc. 1.2) pelo facto de Péricles e o seu irmão Árifron ${ }^{12}$ terem sido tutores daquele que passou por ser o mais belo ateniense do seu tempo.

Dos pais de Péricles e Alcibíades, respetivamente Xantipo ${ }^{13}$ e Clínias ${ }^{14}$, Plutarco salienta o papel fundamental que tiveram em combates: é que a referência às qualidades militares dos progenitores de ambos serve, assim, um duplo propósito - ajudar a identificar Xantipo e Clínias, mas sobretudo abrir caminho para o estabelecimento de uma relação de hereditariedade de tais virtudes, já que Péricles e Alcibíades também se distinguiram nesse campo. Este tipo de procedimento é comum na generalidade das biografias de Plutarco, que tem por hábito fornecer nos primeiros capítulos informações selecionadas sobre os ascendentes ou pais do herói, cujas características são partilhadas pelos filhos ${ }^{15}$. É que o biógrafo - segundo no-lo testemunham,

da democracia, pretenda sugerir uma certa hereditariedade na dedicação à causa do povo, como meio de esbater as acusações de exercício de poder monocrático feitas contra Péricles. Sobre este assunto, vide p. 212 sqq.

${ }^{10}$ Verdegem (2005:483) chama a atenção para a importância da etimologia dos nomes

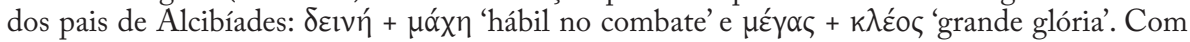
parentes deste calibre, não admira que a habilidade de Alcibíades para a guerra e o seu desejo de glória fossem marcas tão vincadas na sua maneira de ser.

${ }^{11}$ Segundo Cornélio Nepos (Alc. 2), seria enteado de Péricles; Diodoro Sículo (12. 38. 3) considera-os tio e sobrinho. Sobre este assunto, vide Thompson (1970: 27-33).

${ }^{12}$ Embora à época fosse normal identificar os filhos através do pai (fulano, filho de sicrano), não deixa de ser curioso que, advindo o parentesco entre Péricles e Alcibíades do lado materno, Plutarco (Alc. 1. 2) se refira a Péricles e a Árifron como filhos de Xantipo e não de Agariste (o que neste contexto faria mais sentido). Segundo P1. Alc. 1. 104b, apenas Péricles terá sido tutor de Alcibíades.

${ }^{13}$ Filho de Árifron, tornou-se membro da família dos Alcmeónidas pelo casamento com Agariste pouco depois de 500 a.C. Ambicionando seguir uma carreira política, acusou Milcíades de se deixar subornar pelos Persas, o que era uma traição gravíssima ( $\pi \rho \circ \delta \circ \sigma i ́ \alpha)$. Mas em 485 a.C. foi ele próprio vítima de ostracismo; contudo, regressou a Atenas antes da batalha de Salamina. Em 479 a.C., foi eleito estratego. Participou na batalha de Mícale e incentivou Atenas a que continuasse e libertasse o Quersoneso do domínio persa. Foi na sequência desta exortação que os seus homens atravessaram o Quersoneso e ocuparam Sesto. E este é o último dos seus feitos cujo registo chegou até nós (Cf. Boardman: ${ }^{2} 1988,520$ sq.).

${ }^{14}$ Sobre a família de Alcibíades, cf. D. S. 12. 38. 3. Embora Plutarco se refira ao pai de Alcibíades como vencedor de Artemísio (Hdt. 8.17), o facto é que esse Clínias era não o progenitor, mas o seu tio-avô. Sobre este assunto, consulte-se Bicknell (1975: 51-64).

15 Outros exemplos dessa situação ocorrem em Ant. 1 (a liberalidade de António tinha antecedentes na generosidade do seu pai para com os amigos), Sol. 1-2 (Sólon, tal como o pai, levava uma vida cara e profusa), Cim. 4 (à semelhança do avô, Címon também tinha o hábito de se embriagar). Contudo, o biógrafo menciona igualmente casos em que a natureza do filho é diferente (se não mesmo oposta) à do progenitor, como em Brut. 1. 2 (Caio Bruto era meigo e ponderado, apesar de descender de Júnio Bruto, que era inflexível). 
por exemplo, Moralia 497E, 561D-563A - acreditava que a hereditariedade física e moral são uma realidade incontornável e inquestionável: mesmo que os traços comuns (tendência para doenças, semelhanças físicas, propensão para vícios e virtudes) não se revelem de imediato na geração seguinte e pareçam «adormecidos» ${ }^{16}$, mais cedo ou mais tarde acabam por se manifestar.

A estes elementos segue-se (e aqui apenas nos referimos à estrutura comum; a específica de cada uma das vidas será abordada a seu tempo) uma rápida caracterização dos protagonistas, centrada sobretudo em aspetos físicos. Da comparação que podemos estabelecer entre o que nos é dito a respeito de Péricles (Per.3.3),

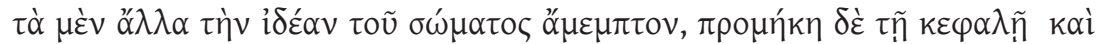

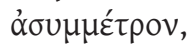

"de aspeto físico em tudo o mais irrepreensível, mas de cabeça alongada e desproporcionada ${ }^{17}$,

e de Alcibíades (Alc. 1.4),

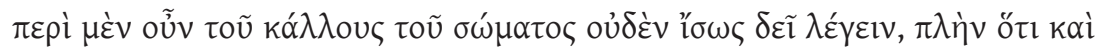

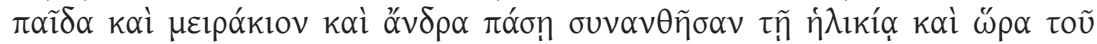

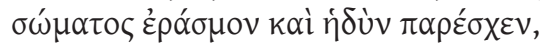

"quanto à beleza física, nada há a dizer, senão que desabrochou e conservou o seu brilho em todas as fases da sua vida: criança, adolescente, homem feito, teve sempre um aspeto gracioso e encantador,"

concluímos que Péricles nos é apresentado como uma pessoa vulgar (à exceção da cabeça) e que Alcibíades é exaltado pela beleza singular que possuía e mesmo por uma pequena mácula da natureza, um defeito de pronúncia (ceceio) que, ainda assim, the confere uma certa graça e amplia a capacidade de persuasão. Uma avaliação nestes moldes é tipicamente grega, pois segue o conhecido critério do kódo $\kappa \alpha \gamma \alpha \theta$ ó $\varsigma^{18}$, segundo o qual importava que todos fossem belos - em termos físicos - e bons - em termos morais.

${ }^{16}$ As semelhanças ficam esbatidas por força da socialização (o contacto com costumes, critérios e leis permite esconder o mal e imitar o bom) até ao momento em que a conjuntura traz ao de cima as características que já nasceram com determinado indivíduo, como por exemplo a tendência para o roubo ou para a tirania. Cf. Moralia 562B.

${ }^{17}$ Daí que, segundo Per. 3. 4, os comediógrafos áticos lhe chamassem 'cabeça de cebola' (esquinocéfalo). Os outros testemunhos de comediógrafos a este respeito serão explorados mais à frente, vide infra p. 164 sq.

${ }^{18}$ Sobre este conceito, vide supra p. 139, nota 17. Segundo Platão ( $R$. 494c), a beleza era um dos indicadores de uma potencial natureza filosófica e, portanto, de um potencial filósofo-rei. 
Se à desconcertante beleza de Alcibíades (ó kó́loৎ) fazem alusão autores dos mais diversos registos - nomeadamente Pl. Alc. 1. 113b, Prt. 309a, 316a; D. S. 13.68. 5 -, ao seu defeito de pronúncia e à disformidade da cabeça de Péricles fazem menção os comediógrafos, já que o ataque baseado na caricatura de «defeitos» físicos (ainda que personalizado em cada caso) faz parte de uma velha tradição cómica ${ }^{19}$. Eram vítimas da mordacidade da comédia sobretudo aqueles que tinham mais influência na vida da đó $\lambda_{\imath} \zeta$ e que, por esse motivo, viam criticadas não só as opções políticas como aspetos da vida pessoal e privada. Assim, não surpreende que Péricles seja o alvo por excelência desses ataques (quer de forma direta, quer indireta - quando os visados são pessoas das suas relações): além de ter sido quem por mais tempo esteve a comandar os destinos de Atenas no século V, o período do seu governo coincidiu com o do apogeu da Comédia Grega, com poetas como Cratino, Teleclides, Êupolis, Aristófanes e Platão Cómico.

Por isso, Plutarco não pôde evitar a referência a tais testemunhos (respetivamente em Per. 3.4-7, Alc. 1.6-8) que abordam, sem piedade, esses deslizes da natureza, o que revela bem a vulgaridade deste género de comentários.

Relativamente a Alcibíades, começa por recordar Ar. V. 44-46:

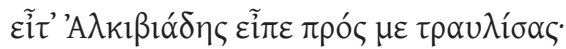

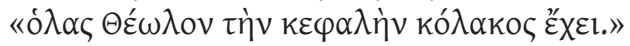

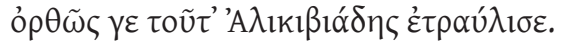

"Então Alcibíades, bleso, disse-me:

«Vês Teolo? Tem cabeça de colvo».

Nunca Alcibíades foi bleso tão a propósito!"

O efeito cómico conseguido no texto original de Aristófanes é impossível de reproduzir em português: é que, por causa do seu ceceio, ao trocar o $\rho$ de кópakos por $\lambda$, Alcibíades qualifica apropriadamente Teoro de adulador

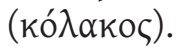

Logo em seguida, o biógrafo invoca um passo de Arquipo (fr. 48 K.-A.).

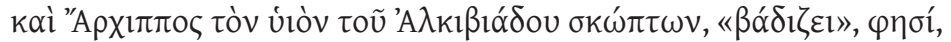

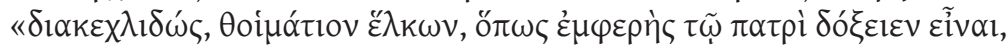

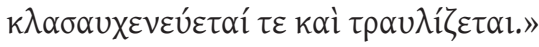

"E Arquipo, zombando do filho de Alcibíades, diz: «caminha com afetação, arrastando o manto, e para se parecer o mais possível com o pai, inclina a cabeça e ceceia»."

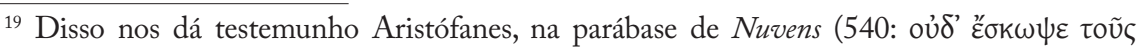
$\varphi \alpha \lambda \alpha \kappa \rho o u ́ \varsigma$ - 'nem goza com os carecas'), ao apresentar a crítica aos carecas como um lugar-comum. 
No texto de Arquipo, Alcibíades é visado de um modo indireto, pois o alvo da zombaria é o seu filho, que tudo fazia para imitar o estilo do pai, sem sequer se esquecer de reproduzir o defeito de pronúncia. Este cuidado do jovem comprova, assim, quão ligada a imagem de Alcibíades estava a essa falha; é como se pensar nele levasse a que de imediato se ouvisse a troca do $\rho$ pelo $\lambda$.

A dimensão da cabeça de Péricles tinha um efeito semelhante, mas produziu (aparentemente) mais comentários dos comediógrafos. Não surpreende, por isso, que Plutarco comece por recordar o testemunho mais geral do grosso dos comediógrafos áticos, que apelidaram Péricles de $\sigma x ı v o k \varepsilon ́ \varphi \alpha \lambda \circ \varsigma^{20}$ cabeça de cebola',

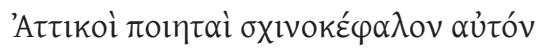

"os poetas áticos chamavam-lhe cabeça de cebola"

e que, em seguida, invoque excertos concretos de autores de renome. O primeiro é um fragmento de Cratino (Quirones ${ }^{21}$, fr. $258 \mathrm{~K}$.-A), onde, além de realçar este pormenor da aparência física do futuro estadista, Plutarco aproveita para nos «apresentar» os «pais» da criança:

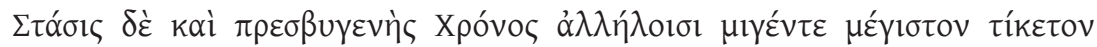

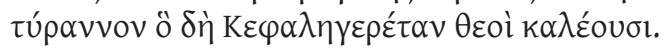

"A Desordem e o velho Crono uniram-se para gerar um tirano todo-poderoso, a quem os deuses chamam «amontoador de cabeças»."22

Este passo de Cratino demonstra o potencial cómico da linguagem épica

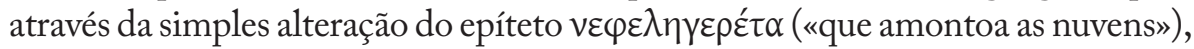
distintivo de Zeus (cf. Il. 1. 511), para que se coadune com a caracterização de

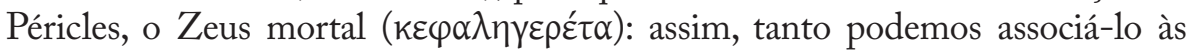
dimensões da cabeça do estadista e à sua capacidade de reunir as massas, como a uma sobreposição da prepotência humana com a divina.

O fragmento merece destaque também pela crítica política que faz: a referência ao «tirano» nascido de divindades relaciona-se com a caracterização

${ }^{20}$ Refere-se à urginea maritima, género de planta herbácea com um bolbo grosso, de forma oval, bastante largo (com cerca de $15 \mathrm{~cm}$. de diâmetro) e que pode atingir o peso de $7 \mathrm{~kg}$.

${ }^{21}$ Quirones (ca. 430 a.C.) é uma comédia cujo coro é constituído por Centauros que lamentam ter de viver num período onde a moral e os bons costumes já não existem. Por isso, fazem regressar do Hades Sólon, político e moralista da Atenas do século VI a.C., para que retome as rédeas da polis.

${ }^{22}$ Sobre a alusão à tirania de Péricles neste passo, vide infra p. 212. 
do governo de Péricles por Tucídides ${ }^{23}$ - sob a aparência de Democracia, apenas um homem (Péricles) detinha verdadeiramente o poder - e a que os cómicos, exagerando a sua autoridade e a capacidade de bater os rivais, chamam tirania.

Ainda no mesmo parágrafo (Per. 3.5) e a propósito do mesmo defeito, Plutarco volta a citar Cratino (Nemesis ${ }^{24}$, fr. 118 K.-A.), que continua a estabelecer comparações entre Zeus e Péricles:

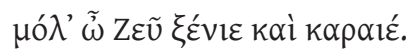

“vem, ó Zeus. hospitaleiro e cabeçudo.”

A comicidade deste fragmento resulta da justaposição dos planos mítico e histórico ${ }^{25}$. Sabemos que Zeus protegia as relações de hospitalidade, daí o seu epíteto $\xi$ Évioc. Péricles, por sua vez, tinha também alguns amigos estrangeiros, como por exemplo Protágoras, Aspásia e Anaxágoras, tendo este último sido protegido pelo estadista aquando do julgamento a que foi sujeito, como relata Plutarco (Per. 32. 3-5). Além disso, temos novamente presentes a noção de tirania e a deformidade da cabeça de Péricles, cuja referência se baseia em um jogo de epítetos: o epíteto kepaúvios 'senhor dos raios' atribuído a Zeus ${ }^{26}$, que simboliza o seu poder absoluto sobre todas as coisas e que também poderia

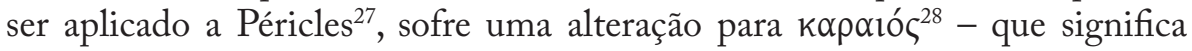

${ }^{23}$ Vide infra p. 211.

${ }^{24}$ Em Nemesis (430-429 a.C.), Cratino narra a união de Zeus (Péricles) e Némesis (Aspásia), da qual resulta Helena e responsabiliza Péricles pelo desencadear da Guerra do Peloponeso, já que este apareceria disfarçado de Zeus para levar a cabo os seus intentos.

25 Estes dois exemplos manifestam, como tantos outros, o efeito cómico de tom épico, cuja omnipresença se verifica em toda a literatura grega. A referência a elementos da tradição mitológica através de epítetos forjados sobre outros oriundos da épica e ligados, por exemplo, a divindades é um estratagema comum; tal adaptação ou «criação de mitos» (como os da ascendência de Péricles, filho de Crono e da Desordem, ou de Aspásia, filha da Impudicícia e o aparecimento de um novo herói que não apresenta as qualidades típicas), demonstra bem a criatividade da comédia. Por trás da referência mitológica, é possível adivinhar-se uma situação histórica. Mito e história unem-se, assim, para fazer crítica política. O efeito da comédia mítica torna-se mais evidente se o compararmos com o uso do mito na épica e na tragédia: os dois

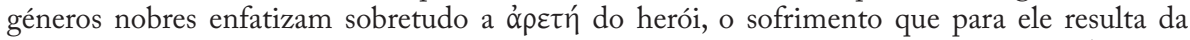
consecução do ideal heroico, mas tendem a reduzir as suas debilidades e fraquezas (como é particularmente visível na obra de Eurípides). A comédia, por sua vez, explora precisamente o aspeto humano do herói, acentua-lhe a fragilidade e zomba do seu ideal, ou então apresenta como pano de fundo do mundo heroico, um ambiente moderno e quotidiano que destrói a grandeza mítica devido ao anacronismo.

${ }^{26}$ E.g. Il. 21. 198.

${ }^{27}$ Em Per. 8. 4, diz-se que o estadista, quando abria a boca, soltava raios e coriscos (vide infra p. 213).

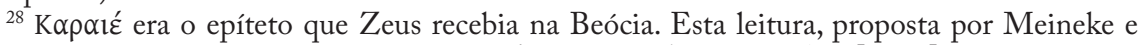
aceite por Ziegler, recorda ainda a palavra kóp $\alpha$ 'cabeça' (vide Re XA 1 [1972] 319 e supl. XV

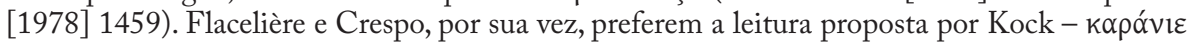


'cabeçudo'. Este trocadilho permite atingir dois objetivos de uma só vez, já que este epíteto consegue ridicularizar a cabeça de Péricles e, em simultâneo, criticar a sua preponderância política.

Em Per. 3. 6, Plutarco apresenta outra referência cómica (fr. 47 K.-A), desta feita de Teleclides $^{29}$, que realça a deformação da cabeça de Péricles:

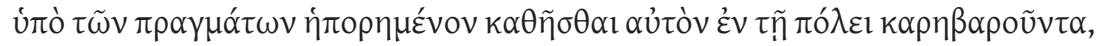

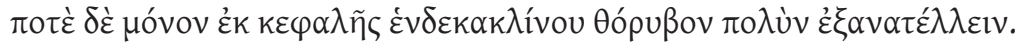

"Às vezes de mãos atadas perante os assuntos de Estado, sentava-se na Acrópole, com dores de cabeça; outras vezes daquela tola de palmo e meio soltava-se-lhe uma arruaça monumental."

Neste passo, merece especial destaque o uso do adjetivo de formação criativa (típica da comédia) $\varepsilon v \delta \varepsilon \kappa \alpha \kappa \lambda i ́ v o v$, que, à letra, significa de 'onze leitos', isto é, 'muito grande, enorme', e que aqui serve, mais uma vez, para caracterizar as dimensões pouco comuns da cabeça de Péricles.

No entanto, apesar do tom jocoso e das quase infindáveis críticas que são feitas a este Alcmeónida, Êupolis, em $\operatorname{Demos}^{30}$ (fr. 115 K.-A), surge como poeta laudator temporis acti ao fazer Péricles - que identificamos através da

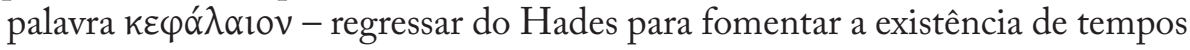
melhores:

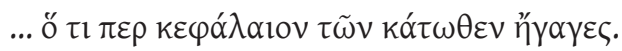

“... eis que trouxeste agora dos Infernos o cabecilha da malta lá de baixo.”

A alusão à deformidade da cabeça de Péricles não se confina a este capítulo inicial da biografia, já que em Per. 13. 9, a propósito das obras de embelezamento da cidade fomentadas pelo estadista, o biógrafo recorda um fragmento de Trácias de Cratino (fr. 73 K.-A):

-, segundo a qual se trata de uma alteração cómica (também alusiva à cabeça) do epíteto de Zeus kepaúvioc 'lançador do raio' (vide Re 1 [1972] 322-323 e supl.XV [1978] 1461). Contudo, a palavra kópıє, que surge em Seitenstettensis saec. XI/XII lembra à audiência Zeus Cário, venerado pela família de Iságoras (cf. Hdt. 5.66.1). Este facto permite estabelecer um paralelo entre Iságoras e Péricles, bastante produtivo para a comédia que quer retratar um Péricles tirano e antidemocrático.

${ }^{29}$ Comediógrafo que parece ter obtido três vitórias nas Dionísias e quatro nas Leneias. Chegaram até nós alguns títulos como Anfictiōes, Hesíodos, Castigo, Pritanes e fragmentos que sugerem a orientação política das suas críticas.

${ }^{30}$ Peça que data de 412 a.C., isto é, já bastante posterior à morte de Péricles. Após a sua morte, a situação em Atenas agrava-se ainda mais, pelo que o período do seu governo adquire uma conotação paradigmática e saudosista. 


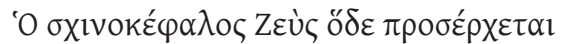

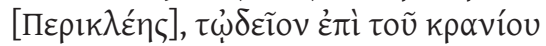

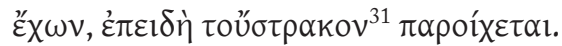

"Aí vem o Zeus-Péricles cabeça de cebola com o Odeão enterrado na tola agora que a história do caco foi à viola."

O facto de se dizer que Péricles traz o Odeão (que era, por assim dizer, a sua obra preferida) sobre a cabeça realça simultaneamente a dimensão desta e o orgulho pela obra, pois sugere-se que está sempre a procurar ostentá-la.

Ao mesmo tempo que abona a popularidade dos dois biografados, a forma como Plutarco organiza a informação é sugestiva de uma conclusão que nos permite extrapolar para aquilo que foi a ação política de cada um destes Alcmeónidas. O que tornava a aparência de Péricles menos perfeita (e que, por isso, os escultores procuravam disfarçar fazendo com que envergasse sempre um elmo $\mathrm{e}^{32}$ ) tornou-se símbolo da sua capacidade de intervenção, da sua inteligência enquanto homem de Estado $^{33}$. Já a cabeça de Alcibíades, que constituía com os restantes membros do seu corpo o exemplo máximo de beleza, embora «abrigasse» inteligência e capacidades admiráveis, foi incapaz de fazer tão bom uso dos seus dotes. $\mathrm{Ou}$, se quisermos, por outras palavras, Péricles, homem de porte comum apesar da forma inusitada da cabeça, revelou-se modelo de homem de Estado, porque tinha (entre outras $^{34}$ ) qualidades, que Plutarco evidencia logo no proémio da biografia em causa

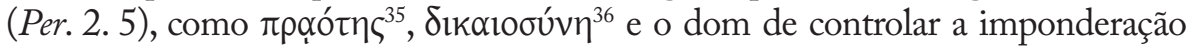

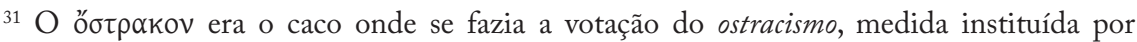
Clístenes para punir aqueles que de algum modo agissem contra a tódıc. Todos os anos, na reunião da Assembleia, cada membro escrevia num «caco» o nome do indivíduo que entendesse dever ser afastado. O nome que reunisse um mínimo de 6000 votos era exilado por dez anos. Este era um meio a que frequentemente se recorria para tentar afastar inimigos políticos. Ao que parece, Péricles terá recorrido a este estratagema, nomeadamente para afastar Tucídides, filho de Melésio (Per. 14. 3; infra p. 203).

${ }^{32}$ Cf. Plu. Per. 3. 4. Conservam-se bustos de mármore, cópias de uma estátua de bronze feita por Crésilas que era seu contemporâneo. Parece que o alongamento da cabeça das estátuas de bronze naquela época era prática corrente, pois facilitava a sustentação do elmo. Pelo menos é o que defende Cohen (1991: 465-502).

${ }^{33}$ Como no-lo comprova a insistência dos cómicos na deselegância física de Péricles, que acaba por se tornar numa forma caricaturada de reconhecer a sua inteligência superior.

${ }^{34}$ Das outras qualidades de Péricles iremos falando «au fur et à mesure», sempre que venham a propósito do desenvolvimento deste trabalho.

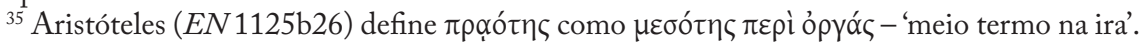

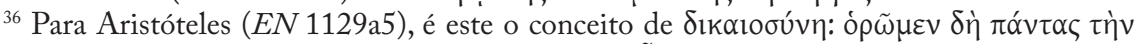

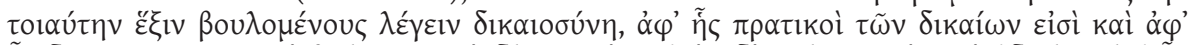

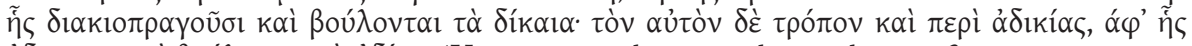

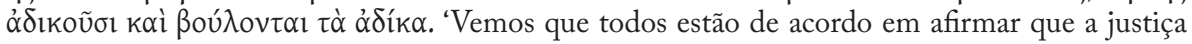
é uma capacidade com base na qual os homens agem com justiça e que os leva a praticar e a desejar o que é justo; do mesmo modo no que respeita à injustiça, que os leva a ser injustos e a desejar a injustiça.' 


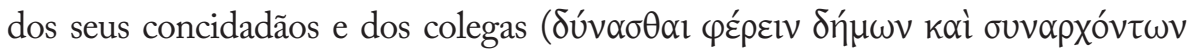

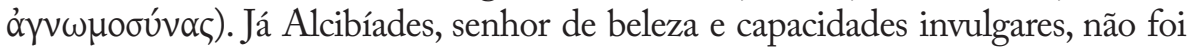
tão bem sucedido, falha que pode ser atribuída à mutabilidade do caráter que possuía, cujos principais traços são as numerosas paixões, das quais se destacam a $\varphi \imath \lambda o v \imath k i ́ \alpha$ e a $\varphi \imath \lambda o \pi \rho \omega \tau \varepsilon i^{37}$, como salienta Plutarco em Alc. 2. 1, único passo desta biografia onde o autor faz uma afirmação explícita sobre a personalidade do protagonista:

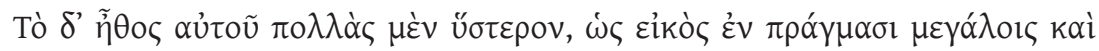

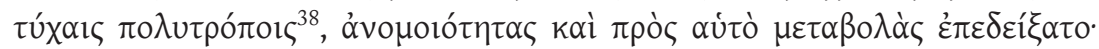

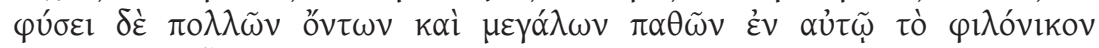

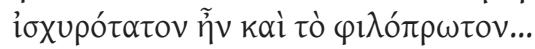

"O seu caráter manifestou mais tarde, como era natural por causa dos grandes acontecimentos em que esteve envolvido e das vicissitudes da fortuna, uma grande inconsistência e várias alterações. Mas as mais fortes das diversas e violentas paixões que a natureza the incutiu eram o desejo de vencer e de ser o primeiro..."

O Queroneu destinou algum espaço à infância ${ }^{39}$ dos seus protagonistas, pois acreditava que os principais traços de uma personalidade começam a revelar-se desde a mais tenra idade. No caso de Péricles, tal acontece ainda nem

${ }^{37}$ Debruçar-nos-emos adiante sobre as anedotas através das quais Plutarco ilustra estas características de Alcibíades. Em Moralia 788E, Plutarco defende que o político deve evitar não só uma vida amorosa atribulada, mas sobretudo o gosto por disputas, pela glória e o desejo de ser o primeiro e principal: é que estes defeitos geram invejas, ciúmes e discórdias. Não há como, diante de tal conselho, não recordar o destino de Alcibíades...

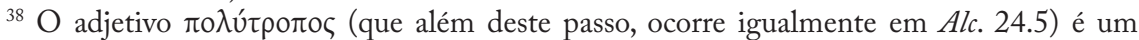
dos epítetos de Ulisses (cf. Od.1.1, 10. 330; Pl. Hp. Mi. 364c-5b), que se tornou num herói paradigmático para os antigos por causa da adaptabilidade através da qual estruturou a sua vida itinerante. Mas o tratamento que a figura recebeu na tragédia (por exemplo, em Filoctetes) fez com que o adjetivo assumisse conotação negativa, pois, nesses registos, Ulisses transforma-se no protótipo do sujeito sem escrúpulos e aldrabão. Tal como Ulisses, Alcibíades sustentou a sua ação na astúcia e em logros pelos quais ficou famoso. Sobre este tema, consultem-se Stanford (1963); Walcot (1977: 1-19); Gribble (1999: 269-271). Essa característica de Alcibíades vai ser acionada sobretudo enquanto exilado. Qualquer desterrado, excluído da vida política da sua cidade, é uma espécie de Ulisses que vai ativar toda a sua inteligência e capacidade de

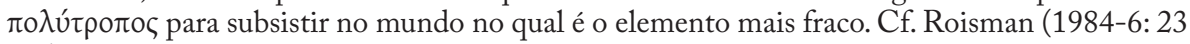
sqq). Vide infra p. 266 sqq.

${ }^{39}$ A importância dada a este período da vida dos indivíduos nas biografias é uma influência do encomium. Nestes textos, a descrição da infância e dos primeiros feitos de quem era alvo do elogio não tinha tanto por objetivo mostrar como se desenvolveu a sua personalidade, mas demonstrar que as virtudes reveladas enquanto crianças se mantêm pela vida fora, ou seja, que se trata de uma espécie de predestinação ou dotes naturais. $O$ interesse pela infância também se estendia à temática da educação: não admira, por isso, que, nas vidas dos indivíduos que se distinguiam por uma marca intelectual mais nítida, os relatos sobre essa fase sejam mais embelezados: é esse, por exemplo, o caso de Per., Them., Phil., Cic. e Luc. Sobre a infância na biografia, vide Pelling (1990: 213-244). 
bem aquele tinha visto a luz do dia. Na verdade, a alusão ao sonho ${ }^{40}$ de Agariste em Per. 3. 3-4 (cuja fonte, embora o biógrafo não a identifique, sabemos ser Heródoto $^{41}$ ) desempenha exatamente essa função de prefigurar aquilo que Péricles viria a ser. Assim, o facto de Agariste sonhar dar à luz um leão pode ser interpretado como presságio da liderança que o recém-nascido viria a exercer em Atenas na idade adulta, bem como da sua coragem e capacidade de chefia. Com efeito, a tradição literária antiga costumava associar criaturas orgulhosas e poderosas (às quais normalmente se atribui uma aptidão para o poder monocrático), que despertam a admiração dos concidadãos, a um leão. Este animal, símbolo, por tradição, do poder real e tirânico ${ }^{42}$ (e da violência que, por norma, lhes está associada ${ }^{43}$ ), não costuma ser um invasor, mas alguém que é criado pela própria ró $\lambda ı \varsigma$, que, mais tarde, tem dificuldades em lidar com a sua natureza indomável (o que, obviamente, também se coaduna com a maneira de ser de Alcibíades).

De facto, Péricles não foi o único Alcmeónida associado à imagem do leão. A primeira das duas anedotas que o biógrafo narra no princípio da Vida

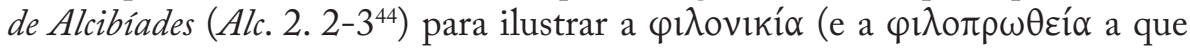
nos referimos em páginas anteriores) menciona essa associação: durante um exercício de luta, Alcibíades não encontra outra maneira de evitar a derrota senão recorrer ao processo de morder o adversário, algo que pode ser considerado uma violação das regras ${ }^{45}$ de fair-play. Acusado de se comportar como uma mulher, contrapõe ter antes agido como um leão.

Esta anedota, além de mostrar a falta de moral do jovem Alcmeónida, que não olhava a meios para atingir os seus objetivos ${ }^{46}$ e era capaz de desafiar

${ }^{40}$ Em jeito de parênteses, importa recordar que o elemento onírico tem origem mitológica e é tradicional na literatura grega (especialmente nos relatos historiográficos e biográficos), quando se trata de prever o nascimento de um herói, do fundador de uma dinastia ou de um monarca poderoso (vide supra pp. 19-20). Basta-nos lembrar - para não fugirmos ao âmbito das biografias que estamos a analisar - que ao nascimento de Teseu está associado não um sonho, mas um oráculo que o proscreve, sugestivo da sua importância futura, bem como da sua responsabilidade na queda/morte de Egeu.

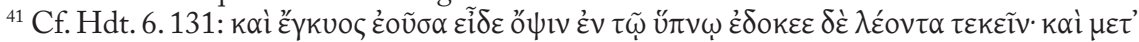

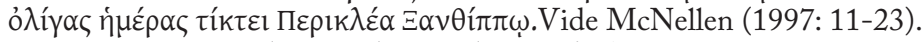

${ }^{42}$ Cf. Hdt. 5.56 (Hiparco), 5.92 (Cípselo); Ar. Eq. 1037. Em Il. 5. 638-9, surge associado a Héracles por causa dos seus feitos heroicos.

${ }^{43}$ Platão explora este tema em Grg. 483e-484a, pela boca de Cálicles, que, como já mencionámos anteriormente, defende que o mais forte deve imperar sobre o mais fraco. Há quem acredite que esta personagem representa Alcibíades, vide Vickers (1994: 85-112); Gribble (1999: 234-238).

${ }^{44}$ Esta anedota ocorre igualmente em Plu. Moralia 186D (onde também está associada a Alcibíades) e 234D (onde está associada a um lacedemónio). Sobre o uso que Plutarco faz das anedotas, vide infra p. 173 e nota 58.

${ }^{45}$ A propósito das regras da luta antiga e pancrácio, vide Harris (1964: 102-109); Poliakoff (1987: 23-63).

${ }^{46}$ Curiosamente, Plutarco não refuta a máxima «os fins justificam os meios», sobretudo 
as normas do comportamento aceitável, estabelece um contraponto entre os dois primos: no caso de Péricles, a comparação com o animal é elogiosa, porque associada ao fundador de uma nova ordem social; no caso de Alcibíades, tem conotação negativa e prende-se a um acontecimento do dia-a-dia. Assim, o mesmo símbolo aplicado aos dois Alcmeónidas aproxima-os, fazendo deles parentes, mas chama simultaneamente a atenção para a sua natureza diversa. $\mathrm{Na}$ biografia de Péricles, o presságio, que é independente da vontade da criança e funciona como anúncio divino do nascimento de alguém excecional, dá ênfase a uma predestinação que não depende da vontade ou atuação do protagonista; em Alcibíades, a anedota (em conjunto com as demais) revela o caráter de alguém que possui demasiados defeitos, propensão para más ações e indica, por isso, falta de caráter. Demais, é curioso salientar que é Alcibíades a intitular-se como leão, com o objetivo de mostrar a sua supremacia e de causar um certo receio, comportamento que ninguém esperaria da parte de Péricles. Este tentava a custo diluir qualquer ligação que pudesse relacioná-lo com um tirano, nomeadamente Pisístrato ${ }^{47}$, com o qual se parecia fisicamente: é que estava consciente de que tal associação não traria boas consequências.

Alc. 2. 2-3 também é importante por ser um dos momentos em que se sugere a feminilidade ${ }^{48}$ própria do caráter de Alcibíades (já que o rival o acusa de morder como uma mulher) e, ao mesmo tempo, a virilidade e coragem próprias de um leão (já que Alcibíades contrapõe morder como o rei da selva $)^{49}$. Deste modo, Plutarco insinua desde o início a ambiguidade do caráter de Alcibíades (cujo comportamento podia ser interpretado como próprio de uma mulher, de um homem ou mesmo de um animal)

quando são os interesses da pátria a estar em causa. Cf., e. g., Moralia 158F. Sobre este assunto, consulte-se Nikolaidis (1995: 301-312).

${ }^{47}$ Em 560 a.C., Pisístrato, cuja vida decorreu entre 600 e 527 a.C., tomou o poder pela força e manteve-o quase sem interrupções até ao fim da sua vida. Segundo Aristóteles (Ath. 14. 3), «governou com moderação e mais como um bom cidadão do que como tirano». Na verdade, o seu governo, bem como o dos filhos que the sucederam, constituiu um período de grande florescimento, nomeadamente no centro urbano de Atenas: foi nesta altura que se construíram várias obras públicas que prestigiaram a cidade (por exemplo, o templo de Atena, na Acrópole; o altar dos Doze Deuses, na Ágora; o santuário de Zeus Eleutério, no sudeste da cidade; a Fonte das Nove Bocas, que garantia o abastecimento de água). Foi também durante a tirania dos Pisístratos que a cerâmica ática atingiu o seu apogeu e que se fomentou o culto de Atena e Dionísio através da importância dada às Panateneias e do aparecimento dos concursos trágicos, respetivamente. Além disso, os tiranos reuniram em Atenas nomes de vulto da cultura de então, como Simónides e Anacreonte. Mas, após a morte de Pisístrato, o comportamento dos seus filhos tornou-se excessivo, causando o descontentamento dos Atenienses e a tirania acabou por ser abolida pelos Alcmeónidas (vide supra p. 160, nota 9). Sobre Pisístrato e sua intervenção política, consulte-se, e. g., Boardman ( $21988: 287-302)$.

${ }^{48}$ Este tema encontra-se desenvolvido na página 268.

${ }^{49} \mathrm{O}$ mesmo episódio é referido em Plu. Moralia 186D. Cf. Gribble (1999: 1-2) e Duff (2003: 97-100). Importa recordar um testemunho de Luciano (Demon. 49), segundo o qual o termo leão era usado como sinónimo popular de lutador no século II d.C. 
que vai marcar toda a biografia (e.g. Alc.16.1,23.6) e acentua também a dificuldade em se formar uma opinião concreta e definitiva sobre a pessoa deste ateniense ${ }^{50}$.

Por outro lado, se pensarmos no contexto em que esta anedota decorre, não podemos deixar de associá-la ao grande número de amantes de Alcibíades ${ }^{51}$ : é que as palestras eram locais por excelência para relações de pederastia ${ }^{52}$; além disso, a linguagem da luta tinha conotações com o sexo ${ }^{53}$. Demais, faz-nos de imediato pensar em P1. Symp. 217b-c, pois, nessa obra, Alcibíades narra um combate entre Sócrates e ele próprio, do qual resultou a impossibilidade de seduzir o filósofo ${ }^{54}$.

A outra anedota que permite antever e/ou confirmar a sua obsessão pela vitória, pelo desejo de ser o primeiro e de levar sempre a sua avante, bem

${ }^{50}$ Não surpreende, por isso, que em Alc.16.2-3, ou seja, no fim da secção que concentra as anedotas, e como que a encerrá-la, Alcibíades volte a ser comparado a um leão, o que sugere a impossibilidade de aplicar a este indivíduo os critérios que por norma servem para julgar o comportamento humano, já que os leões seguem padrões diferentes e são normalmente associados a monarquias e tiranias. É com base neste pressuposto que Plutarco evoca alguns versos de Aristófanes (Ra.1425,1432-3), que salientam o medo que o povo tinha da tirania, pela boca de Eurípides e Ésquilo. O primeiro chama a atenção para a dificuldade que o povo sentia em saber quais os seus verdadeiros sentimentos para

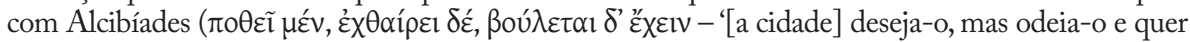
tê-lo'); o segundo, para os perigos decorrentes da criação de um leão na cidade: é que quem o faz acaba, mais cedo ou mais tarde, por ter de se submeter às suas exigências e extravagâncias. Em Alc. 16 . 7, como em Alc. 6. 3, Plutarco recorda Thuc. 6.15.3-4, que, apesar de fazer referência ao apreço que

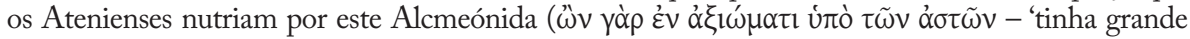

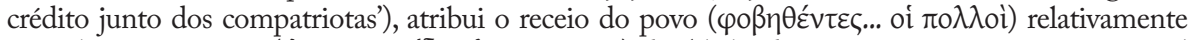

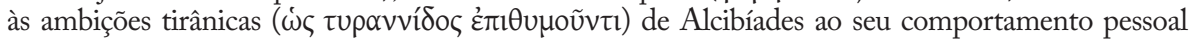
pouco recomendável e que, por isso mesmo, fomentava tais suspeitas. Do confronto do texto de Tucídides com o de Plutarco, salta à vista o facto de em Alc. 16. 7 o biógrafo especificar que os

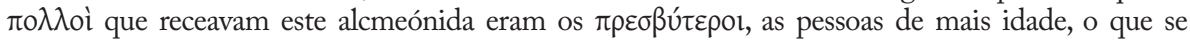
compreende por ainda terem viva na memória a experiência da tirania. Também Xenofonte ( $H G$ 1. 4. 13-17) alude à existência de duas fações: uma, pró Alcibíades, que o considerava o melhor

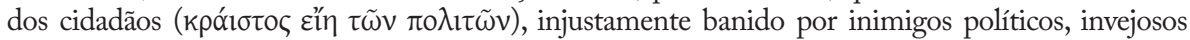
das suas capacidades, que tentavam evitar que pugnasse pelo bem-estar do povo; outra, contrária,

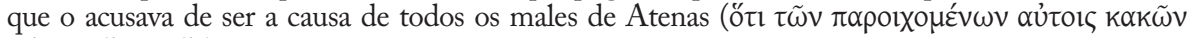

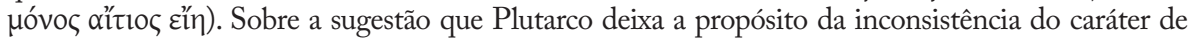
Alcibíades e da impossibilidade de chegar a um julgamento moral satisfatório a seu respeito, vide Pelling (1989: 257-274) e Piccirilli (1989: 5-21).

${ }^{51}$ Cf. Alc. 3-6. Fica, assim, evidente que Plutarco salienta, desde o início da biografia, não só a beleza como a abundância de parceiros homossexuais de Alcibíades, encorajados pela sua aparência, riqueza e estatuto social (cf. para a riqueza, P1. Alc. 1. 104b-c; para a beleza, P1. Alc. 113b-c, Prt. 309 a-c, 316a, 336e).

${ }^{52}$ Cf. Pax 762-3, Ar. Ra. 1025; Pl. Phdr. 255d; Plu. Moralia 752B-C. Sobre este tema, vide Dover (1978: 54-5); Percy (1996: 113-116).

${ }^{53}$ E.g. Ar. Pax 896-8, Ec 964-5. As palavras da família de morder ( $\left.\delta \alpha ́ k v \omega\right)$, por exemplo, eram usadas como metáfora para sexo. Cf. Henderson (1975: 169-170); Poliakoff (1982: 101-136).

${ }^{54}$ Plu. Alc. 4.4 parece aludir en passant a este episódio, ao afirmar que ambos lutavam em conjunto. Nesse contexto, a luta passa a estar associada à influência de Sócrates na educação de Alcibíades. Da comparação dos combates de Alcibíades com os do seu par (cf. Cor. 2), é possível concluir que o primeiro vencia devido à sua habilidade e o segundo por causa da força física. 
como a sua astúcia e maquiavelismo, e introduzir diversos temas explorados nesta biografia, surge em Alc. 2. 3-4, e está, também ela, relacionada com uma brincadeira de infância ${ }^{55}$. Neste caso concreto, Alcibíades revela-se suficientemente temerário para, mesmo pondo em risco a própria vida, lutar para que se faça a sua vontade. Quando a aproximação de um carro ameaça interromper um jogo no preciso momento em que Alcibíades deveria intervir (ou, se quisermos acentuar a ideia, ser o protagonista ${ }^{56}$ ), contraria todas as expectativas (já que os colegas de brincadeira se afastaram), lançando-se para diante do veículo cuja marcha assim detém. Como é óbvio, este comportamento suscita reações diversas: o cocheiro fica assustado e quem estava a observar a cena admirado. Efetivamente, medo e admiração eram os sentimentos que Alcibíades mais costumava despertar nas pessoas (como se pode ver ao longo da biografia ${ }^{57}$ ), o que contribuía para que a sua popularidade fosse inconstante.

Importa, neste momento, chamar a atenção para o facto de, em termos estruturais, as biografias de Péricles e de Alcibíades se distinguirem logo

55 Sobre o jogo em causa (atestado, e.g., em Il. 23. 87-8; P1. Tht. 145c; Plu. Lys. 8. 4-5, Moralia 812A, vide Beck (1975: n. $\left.{ }^{\text {os }} 342-345\right)$; Ricotti (1995: 47-48); Kurke (1999: 283-95). O tópico da brincadeira de infância que revela o caráter excecional e potencialidades de alguém é recorrente na literatura grega, como já o mencionámos em relação a Ciro (Hdt.1.149-119 - cf. supra p. 38).É também esse o objetivo das anedotas/caricaturas que são antecedente da própria biografia, como no-lo demonstra Ar. Eq.: neste caso concreto, o perfil de político do Salsicheiro percebe-se já nas reações de infância.

${ }^{56}$ Esta anedota faz-nos recordar o ressentimento que, segundo Thuc. 5. 43.1-3, Alcibíades nutriu contra os Lacedemónios, que, ignorando a relação de $\xi \varepsilon v i ́ \alpha$ que os ligava, não o consultaram a propósito da paz de Nícias por considerá-lo demasiado novo. Cf. Alc. 14 e infra pp. 206-207 e p. 249. Se relacionarmos este episódio com outros que ocorrem quer na biografia do seu par (Cor. 3.1) quer na de César (32.8) e que têm em comum a alusão

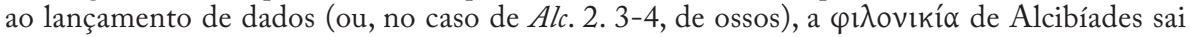
realçada. Isso acontece porque o ato de lançar os dados estava metaforicamente associado ao contexto bélico, onde há sempre qualquer coisa importante em jogo, pelo que o risco de vida a que os protagonistas de tais episódios se sujeitam está justificado; já aquele a que Alcibíades se submete não é mais do que uma vaidade. A associação destes episódios leva-nos ainda a refletir noutro sentido: se Tarquínio era um tirano e lançou os dados e se César também o fez, passando em seguida a exercer um poder de natureza semelhante (cf. Caes. 57. 1), será que Alcibíades não teria pretensões de se tornar um déspota? Cf. Duff (2003: 101). Sobre a tendência tirânica de Alcibíades, vide infra p. 215 sqq.

${ }^{57}$ Medo (e.g. 16. 7, 32. 3); admiração (e. g. 23.3, 32. 3). Esta anedota, por causa da repetição

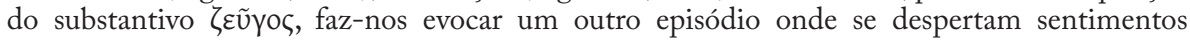
díspares: a vitória olímpica de Alcibíades (Alc. 11-12 - cf. infra pp. 197-198), que lhe valeu admiração de todos pelo feito ímpar, mas também uma forte contestação devido aos rumores de que havia roubado os cavalos com que competiu. A dimensão assumida por este episódio apesar de, para Alcibíades, não ter tido consequências negativas de maior - foi de tal ordem que,

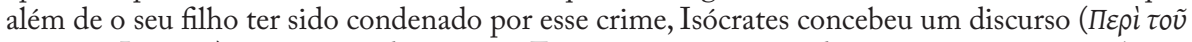

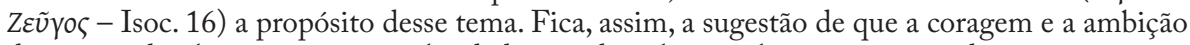
demonstradas, bem como a popularidade trazida pelos cavalos vão, mais tarde, virar-se contra ele. 
nos primeiros capítulos, o que acarreta consequências para a caracterização dos protagonistas. Com efeito, Plutarco dedica um largo espaço à infância de Alcibíades, para cuja narração se serve de inúmeras anedotas. No que respeita a Péricles, se excluirmos o sonho de Agariste (que não pode ser propriamente considerado alusivo à infância de Péricles), tudo o que se refere a esse período prende-se à educação que o futuro estadista recebeu, sugerindo que a educação cuidada do filho de Xantipo e a menos aprumada de Alcibíades tiveram consequências na formação do caráter de ambos. Talvez se possam apontar dois fatores como justificação para a presença residual de anedotas na Vida de Péricles: a austeridade deste Alcmeónida, por oposição a Alcibíades, e o facto de o sonho de Agariste se substituir, de certo modo, à função das anedotas ${ }^{58}$, pois é particularmente sugestivo para a caracterização indireta do filho, deixando antever a sua importância e maneira de ser no futuro. Por outras palavras, este

${ }^{58}$ Plutarco só não menciona anedotas sobre infância quando elas não existem. Cf. Pelling (1990: 216). A importância que as anedotas assumem na descrição de um caráter é mencionada

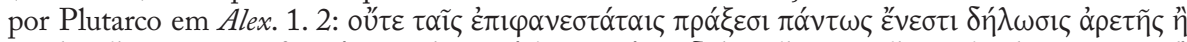

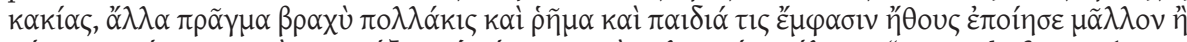

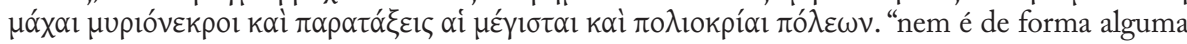
nas ações mais admiráveis que está a explicação da virtude e do vício. Muitas vezes um pequeno feito, uma palavra, ou uma anedota refletem melhor a imagem do caráter do que combates mortíferos, grandes batalhas e cercos das cidades". Também Ca. Mi. 24. 1 e 37.10 sustentam

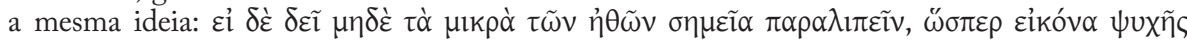

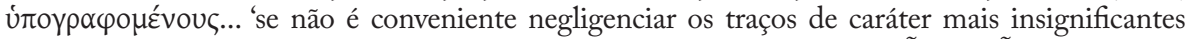

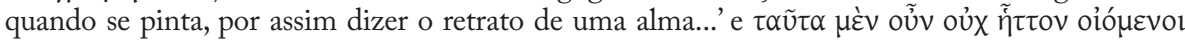

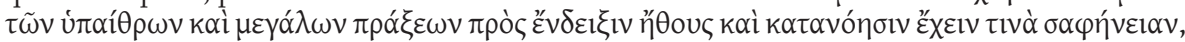

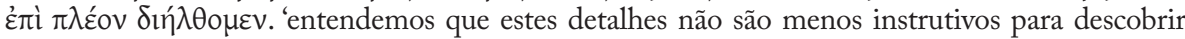
e dar a conhecer um caráter do que as grandes ações públicas, e foi por isso que os relatámos tão aprofundadamente.'Embora possam ocorrer em qualquer parte de uma biografia, costumam concentrar-se na fase inicial, que desenvolve o período da infância (Them.2.1-3, Alex. 4. 8-10. 4, Demetr. 3.1-4. 5, Ca. Mi.1.3 - 3.10, Cic. 2. 1-5), ou nos momentos que correspondem ao relato do apogeu da vida dos heróis (Them. 18.1-9, Lys. 18. 4-19.6, Cic. 24.1-27.6). Este procedimento corresponde ao que faz Heródoto: as suas histórias de ficção incidem na fase de ascensão (origem) e de clímax da vida dos monarcas. Quando utiliza este recurso, Plutarco não tem por objetivo mostrar como se desenvolve o caráter nem fazer uma narrativa dos primeiros anos de vida. É por essa razão que só muito raramente as anedotas são enunciadas numa sequência cronológica - sobre as questões de cronologia nas Vidas, vide Polman (1974: 169-177). De um modo geral, como tão bem exemplifica a Vida de Alcibiades, essas breves histórias, de origens diversas, encontram-se justapostas para ilustrar um traço de caráter particular; é aquilo a que Pelling (1989: 262-3) chama integration of characteristics around a trait. No caso de Alcibíades, o conjunto dos dezasseis capítulos iniciais serve ainda para sugerir a dificuldade - que Plutarco parece recordar a cada passo - de se fazer um julgamento moral sobre este Alcmeónida. Tal efeito resulta da forma vaga e difícil de seguir em que se encontram organizados, sem qualquer nexo cronológico, testemunhos literários diversos. Fica a impressão de se estar diante de um conjunto pouco harmonioso e contraditório de excertos que parecem não desenhar uma figura coerente. Isso está relacionado com a inconsistência

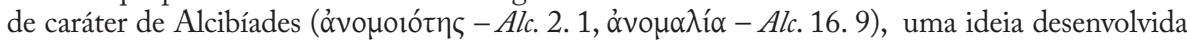
sobretudo no capítulo 16. Esta inconsistência é muitas vezes vista em termos de ética de género: o seu comportamento em relação à luxúria e ao prazer é considerado como tipicamente feminino, mas as suas ambições são masculinas. 
sinal sobre o nascimento de Péricles funciona de predestinação que ultrapassa a natureza do indivíduo, ao passo que as histórias sobre as atitudes de Alcibíades têm sobretudo a ver com a personalidade, donde resulta que este não tem aquele «toque do destino» que existe em Péricles.

$\mathrm{Na}$ Vida de Péricles, a função desempenhada pelas anedotas relativas ao caráter do protagonista é substituída pela análise do «percurso escolar» do filho de Xantipo, algo que não nos surpreende, na medida em que sabemos que Plutarco acredita que o homem é resultado não só da sua própria natureza, mas também fruto da sua vivência em sociedade e, consequentemente, da aprendizagem que nela faz (Moralia 440D-452D). Além disso, a multiplicação de anedotas na Vida de Alcibiades acentua a ideia de menor sobriedade de Alcibíades por oposição à maior sobriedade de Péricles, um indivíduo discreto e que se abstém do convívio social.

Não deixa, contudo, de causar alguma estranheza a ausência de um espaço específico para o tratamento da educação de Alcibíades ${ }^{59}$, nos moldes do que acontece em relação a Péricles. Os poucos dados que dizem respeito a esse tema são abordados no âmbito de anedotas ${ }^{60}$ (como veremos em seguida), nomeadamente aquelas que aludem aos inúmeros admiradores de Alcibíades, desde logo Sócrates e outros de alta categoria. Daquilo que Plutarco narra, podemos depreender que estamos perante um outro tipo de formação, resultante do interesse de altas personalidades por um garoto que tem um caráter de exceção. A conjugação desses elementos (mestres que escolhem o discípulo - e não o contrário, como acontece com Péricles - e caráter de exceção de Alcibíades) tem como consequência uma educação que não produz frutos, apesar do privilégio de se conviver com um educador de excelência como Sócrates ${ }^{61}$. Fica, assim,

\footnotetext{
${ }^{59}$ Importa, contudo, não esquecer que o par Coriolano/Alcibíades realça a importância da educação. Nesse contexto, embora, por comparação com o que se passa na Vida de Péricles, o espaço dedicado à educação seja pouco, a Vida de Alcibiades apresenta uma educação modelo de um jovem apoiado pela família e mestres, por oposição a um Coriolano que cresceu órfão, sem que ninguém se preocupasse com ele (Cor. 1. 2). É sobretudo à educação de Alcibíades (nomeadamente a que recebe junto de Sócrates) que se atribui o sucesso no tratamento com os outros; Coriolano, que não teve acesso a esse complemento modelador da natureza, não tem um convívio fácil com os concidadãos. Cf. Cor. 1.3-5.

${ }^{60}$ Apesar disso, os dados relativos à infância de Alcibíades não se resumem às anedotas. Plutarco manifesta o seu espanto pelo facto de, ao contrário do que acontece com outros grandes nomes do século $\mathrm{V}$, só em relação a este Alcmeónida se saber o nome da ama (Amicla) e do pedagogo (Zopiro). O biógrafo atribui o conhecimento destas informações à amizade existente entre Alcibíades e Sócrates, que fez com que muitos dos discípulos do filósofo (como Antístenes e Platão, cf. Alc. 1. 122b) escrevessem sobre Alcibíades, preservando assim bastantes informações a seu respeito. Demais, como afirma Gribble (1999: 31), «this is partially a result of the importance of Alcibiades' non-public life for his public political career. The wealth of material can also be traced to the intense controversy which surrounded Alcibiades' career, generating the trials and exchange of the written speeches of the 390's b. C. and on the other hand an oral tradition of stories which informed, and was informed by, the literary tradition».

${ }^{61}$ Platão faz eco das debilidades da educação de Alcibíades: como se não bastasse ter
} 
mais uma vez, evidente quão distintos são os dois Alcmeónidas: ao contrário de Péricles, Alcibíades limita-se a cumprir o curriculum mínimo ${ }^{62}$, não tem sensibilidade nem interesse pelo convívio com outros mestres que não Sócrates ${ }^{63}$, convívio esse iniciado não por sua vontade, mas por insistência do filósofo.

Centremo-nos, para já, no que Plutarco tem a dizer sobre a educação de cada um, tendo presente que, no âmbito geral das Vidas, a análise que se faz da educação nem sempre é muito profunda e que existe a tendência para se encarar a educação como algo que se teve ou não: se se teve, fica-se para sempre imune a determinados males, já que esta é vista sobretudo como força civilizacional e restritiva ${ }^{64}$.

Em páginas anteriores, fizemos uma resenha do que caracterizava a educação no século V a.C. Curiosamente, daquilo que constituía o curriculum básico de estudos, o Queroneu destaca, quer em Per. 4. 1-4, quer em Alc. 2. 5-7, a aprendizagem da música ${ }^{65}$. Segundo no-lo relata Plutarco, Péricles teve como mestre nessa área Dámon ${ }^{66}$, um dos mais antigos e importantes

sido confiado por Péricles a um escravo velho, não procurou complementar a sua formação, limitando-se ao mínimo obrigatório, e ainda se recusou, como o próprio jovem confessa, a aprender o que o tutor lhe tentava transmitir. Não surpreende, por isso, como Platão afirma, que, à semelhança da grande maioria dos políticos, não tenha uma formação de base que lhe

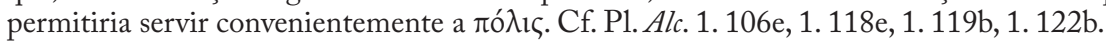

${ }^{62} \mathrm{Cf}$. P1. Alc. 1. 106e (onde o Alcmeónida confessa apenas ter cumprido a «escolaridade obrigatória», sem ter procurado aprofundar a sua formação) e 1.113c (onde Sócrates o acusa de ter negligenciado a aprendizagem - $\alpha \mu \varepsilon \lambda \eta ́ \sigma \alpha \varsigma \mu \alpha v \theta \alpha ́ v \varepsilon \varepsilon v)$. O facto de Plutarco afirmar (Moralia

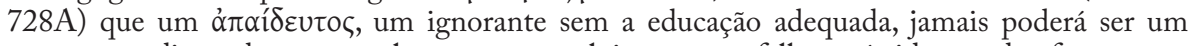
governante digno desse nome leva-nos a concluir que essa falha terá sido um dos fatores que mais contribuiu para que Alcibíades, apesar das suas capacidades inatas, não tivesse alcançado o estatuto de político de excelência.

${ }^{63}$ Note-se que Alcibíades só começou a dar valor a Sócrates depois de conhecê-lo melhor, mas interessou-se mais pela pessoa do filósofo do que pelas teorias daquele.

${ }^{64}$ Cf., e. g., Mar. 2. 2-4, Them. 2. 7, Comp. Num.-Lyc. 4. 10-12.

${ }_{65}$ Embora fizesse parte do curriculum obrigatório, os Antigos defendiam que nenhum homem livre deveria tocar instrumentos com a perfeição de um profissional, ou seja, por norma, a prática de instrumentos era vista, sobretudo a partir do século IV a.C., como uma atividade

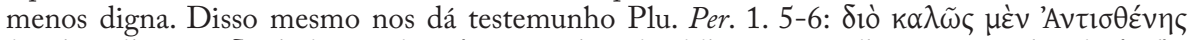

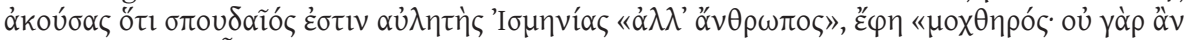

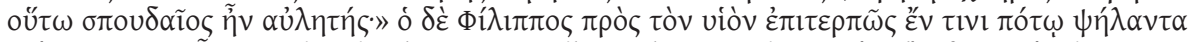

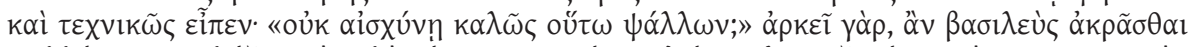

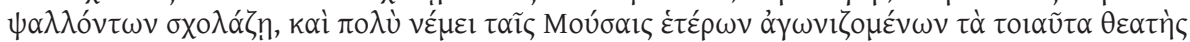

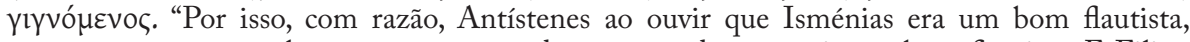
comentou: mas como homem não presta, de outro modo não seria um bom flautista. E Filipe observou ao filho, depois de uma execução com melodia e com arte durante um banquete: «Não tens vergonha de tocar assim tão bem?» Pois é suficiente que um príncipe dispense algum do seu tempo livre a ouvir os que tocam e já muito concede às musas como simples espectador dos que competem em tal matéria." Sobre este assunto, vide Wilson (1999: 58-95).

${ }^{66}$ Dámon era filho de Damónides de Ea, foi discípulo de Pródico e amigo de Sócrates (P1. La. 197d). Ficou conhecido pela sua teoria sobre a música (que não chegou até nós), matéria na qual se iniciou com Agátocles ou Lâmprocles. Segundo Platão, que também confirma a relação deste com Péricles (Alc. 1.118c), Dámon defendia que a música estava intimamente relacionada 
cultores desta arte (muito admirado por Sócrates e Platão). Consta que procurava ocultar a sua inclinação para a tirania (mas terá acabado por ser vítima do ostracismo em consequência desta sua propensão) - o que de imediato nos faz refletir sobre os possíveis efeitos deste convívio no governo do filho de Xantipo ${ }^{67}$, que é invocado por Tucídides como o "governo do primeiro dos cidadãos» (Thuc. 2. 65. 9) e comparado, pelos cómicos, a uma tirania $^{68}$ (Per. 16. 1).

É neste contexto que Plutarco (Per. 4. 4) cita um passo de Platão Cómico (fr. 207 K.-A.) que sugere a influência de Dámon na formação do estadista:

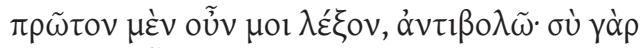

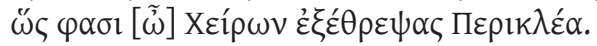

"antes de mais, diz-me cá uma coisa, por favor, porque tu, ao que se diz por aí, foste como um Quíron a educar Péricles."

Ora, ainda que o intuito da comédia seja ridicularizar, o facto é que a comparação entre Dámon e Quíron provoca o efeito contrário. De facto, quer Dámon quer Péricles acabam beneficiados: o primeiro, porque é elevado ao estatuto do maior pedagogo da mitologia; o segundo, porque se torna em um dos poucos discípulos, ao nível de um Aquiles ${ }^{69}$, que teve o privilégio de ser educado por tão ilustre mestre.

Alcibíades, por sua vez, teve uma relação mais conflituosa com o estudo da música. Aliás, a anedota que Plutarco evoca tem um caráter etiológico, na medida em que foi utilizada para justificar a revolução operada no ensino da música a partir de finais do século V. Consta que Alcibíades se recusava a tocar $\alpha u ̉ \lambda o ́ \varsigma^{70}$, porque considerava esse instrumento indigno de um homem

com questões morais (R. 400b, 424c): os vários ritmos podiam provocar efeitos diferentes a nível ético. Foi vítima de ostracismo entre 450-440 a.C., mas pouco mais se sabe a seu respeito. Vide Guthrie (1969: 3, 35, nota 1); Hammond - Scullard (1992: 311). O biógrafo apresenta outra versão, que atribui a Aristóteles (Fr. 401 Rose): de acordo com o Estagirita, o professor teria sido Pitoclides de Ceos, do qual apenas se sabe que foi pitagórico e músico. No entanto, esta informação baseia-se em Platão (Prt.316e, S Alc.118c) e não em Aristóteles, o que pode significar ou que Plutarco confundiu as fontes, ou que esta referência faz parte de uma das muitas obras perdidas.

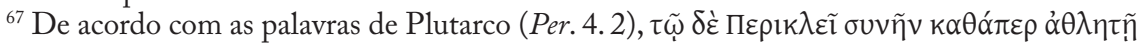

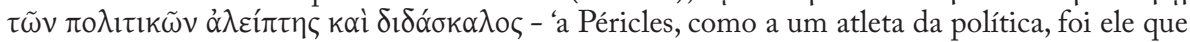
lhe serviu de treinador e mestre'.

${ }^{68}$ Sobre a tendência tirânica de que é acusado, vide pp. 212 sqq.

${ }^{69}$ Esta nossa referência não é gratuita, já que, em Alc. 23. 6, Plutarco menciona um verso de uma tragédia perdida para comparar Alcibíades a Aquiles, por ambos partilharem a capacidade de adaptação às mais diversas circunstâncias. Vide infra pp. 267-268.

70 É provável que, além do testemunho da tradição oral, Plutarco tenha obtido esta informação em P1. Alc. 106e, onde Sócrates afirma que Alcibíades teve uma educação

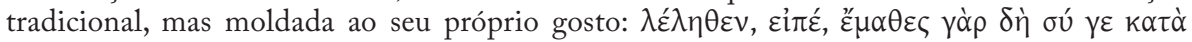


livre: como se não bastasse desfigurar o rosto de quem o tocava (nem a infinita beleza de Alcibíades resistia a essa prova), ainda impedia que a música fosse acompanhada pelo canto de quem utilizava o instrumento, algo que, por exemplo, a lira já permitia ${ }^{71}$ E impedir o canto, mais do que uma questão de estética musical, era sinónimo de impedir o uso da palavra, um valor supremo da cultura de Atenas, pelo que o recurso a um tal instrumento não poderia ser muito bem visto por um ateniense legítimo.

Apesar do cariz etiológico desta anedota, e como o próprio Alcibíades argumenta, existia em Atenas uma tradição mitológica (protagonizada por Atena e por Mársias ${ }^{72}$ ) que indispunha os Atenienses contra a prática desse instrumento $^{73}$. Ao referir-se a essa tradição para justificar o seu ponto de vista, além de demonstrar (desde tenra idade) as suas competências argumentativas e um caráter voluntarioso, Alcibíades compara-se implicitamente a Atena e Apolo, ou seja, aproveita para se valorizar ${ }^{74}$.

Esta anedota permite-nos, ainda, inferir e prefigurar características de Alcibíades, como a sua capacidade de impor a própria vontade e de criar modas (não é difícil recordar Ath. 534b-c, segundo o qual aquele usava umas sandálias específicas, que acabaram por receber o seu nome), bem como a sua popularidade. Demais, o facto de Alcibíades ridicularizar os meninos que aprendiam a tocar

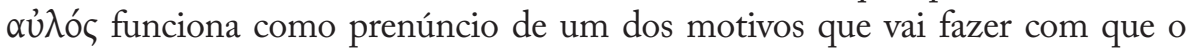

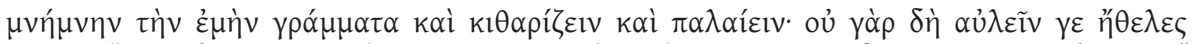
$\mu \alpha \theta \varepsilon \tilde{\imath} v$. "aprendeste, creio, a ler, escrever, tocar lira e lutar; quanto à flauta, puseste-a de parte." Há, contudo, testemunhos controversos. Segundo Ateneu (184d), Dúris de Samos (FGrH 76 F 29) terá afirmado que Alcibíades teve o famoso Prónomo como mestre nessa área. Há até um vaso (Naples 3240), datado de ca. 400 a.C., que recebeu o seu nome, pois retrata um

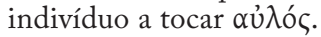

${ }^{71}$ Arist. Pol.13411a16 sqq. apresenta justificações semelhantes para a recusa da flauta. Não deixa de ser curioso recordar que a lira era o instrumento ensinado por Dámon. Embora o texto não faça qualquer alusão, era também o instrumento predileto de Aquiles (cf. Il. 9. 182-192).

${ }^{72}$ Esta referência a Mársias não é inocente. Traz à memória P1. Smp. 215a-216c, passo onde Alcibíades compara Mársias a Sócrates, que está subjacente aos capítulos 4, 5 e 6 desta biografia. Este passo alude ao poder das palavras de Sócrates sobre Alcibíades. Vide Scott (2000: 25-37).

${ }^{73}$ Cf. P1. R. 399d-e; Arist. Pol.1341b2-8, onde tais mitos também são evocados para rejeitar a prática da flauta. Sobre os mitos em causa, vide McKinnon (1984: 204-213). Sobre a prática da flauta em Atenas, vide Wilson (1999: 74-85).

${ }^{74}$ Não é o único momento da obra onde uma tal valorização acontece. De facto, no fim da secção inicial consagrada às anedotas (Alc.16.1-7) e em uma altura em que Plutarco se refere sobretudo a críticas que corriam relativamente à pessoa de Alcibíades, o biógrafo menciona duas obras de arte que sugerem mais uma tentativa do protagonista de aproximar o seu valor do da divindade: um escudo de ouro que tem gravados não os temas tradicionais, mas uma imagem de Eros, e um quadro onde o próprio Alcibíades surge ao lado da deusa Nemeia. Muitos Atenienses consideravam este comportamento como sinal de tendências tirânicas, mas podemos considerá-lo, de igual modo, próprio de um caráter dado à ü $\beta$ pı, ao qual, por isso, não se augura nada de bom. Havia também outros que ficavam entusiasmados com o comportamento de Alcibíades. 
povo lhe retire o seu apoio ${ }^{75}$ : a afetação que lhe era própria e que acaba por ser considerada mais um traço de tendência tirânica ${ }^{76}$ (cf. Alc. 16).

Do período correspondente à formação básica de cada um dos protagonistas, Plutarco (Alc. 2.3 - 2. 4) evoca ainda uma anedota que está provavelmente associada ao contexto das lições do $\pi \alpha 1 \delta$ o $\rho^{\prime} \beta \eta \varsigma$ e que ilustra a $\varphi \imath \lambda$ ovıkía de Alcibíades ${ }^{77}$. Todas as outras informações que avança sobre a educação dos protagonistas em causa dizem respeito à fase seguinte, durante a qual os jovens podiam (e deviam) aproximar-se de indivíduos que lhes pudessem ensinar outros assuntos mais elevados ${ }^{78}$.

No caso de Péricles, destaca o convívio com dois outros mestres, ambos filósofos ${ }^{79}$ : Zenão de Eleia ${ }^{80}$ (Per. 4. 4) e Anaxágoras de Clazómenas ${ }^{81}$ (Per. 4. 5 - 6.5). No que respeita a Alcibíades, só a influência de Sócrates é referida (Alc. 4. 1-4, 6. 1-5) 82 .

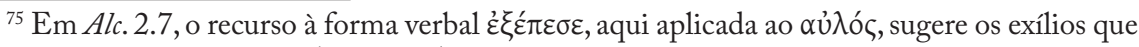
experimentará, pois é um verbo normalmente empregue nesse contexto.

${ }^{76}$ Vide supra p. 212 sqq.

77 Sobre esta anedota, vide supra p. 178.

${ }^{78}$ Cf. supra p. 174.

${ }^{79}$ Um bom e verdadeiro político deve, na visão platónica (como se depreende, por exemplo, de P1. Alc. 118b-c, R. 376 passim), fazer acima de tudo um estudo rigorosíssimo sobre a virtude (i. e. o Bem) - logo, deve dedicar-se à filosofia - pois o seu objetivo é fazer dos concidadãos pessoas melhores, que respeitem a lei. Em Moralia 776F-777A, Plutarco defende igualmente o convívio dos filósofos com os políticos, como sendo a forma mais fácil de disseminar a virtude e a nobreza pelo povo. Como exemplos dos bons frutos que tal relação pode dar, apresenta os casos paradigmáticos de Anaxágoras e Péricles (cf. infra p. 247, nota 177), bem como o de Platão e Díon e o de Pitágoras com os mandatários itálicos.

${ }^{80}$ Zenão (ca. 490 - 445 a.C.), filho de Teleutágoras, foi discípulo e amigo de Parménides. Ficou conhecido pela sua argumentação em defesa das teorias do mestre, que negam a existência de movimento e de multiplicidade. Por isso, o Estagirita considerou-o o inventor da dialética. Interessou-se ainda particularmente pelas ciências naturais, tema que naquela época alcançou um grande desenvolvimento e que se tornou indispensável na formação geral do indivíduo. Até Sócrates as conhecia... Apenas Plutarco apresenta Péricles como discípulo dele. Platão, por sua vez, em Alc. 1. 119a, diz que, em Atenas, Pitodoro e Cálias se contam entre os que o ouviram. Vide Guthrie (1969: II, 80 sq).

${ }^{81}$ Anaxágoras de Clazómenas, que era oriundo de família rica e influente, viveu no século $\mathrm{V}$ a.C. e terá chegado a Atenas em 480. Abdicou da sua herança e das facilidades e sucesso político, que poderia alcançar se dela dispusesse, para se entregar à ciência e à filosofia (cf. Pl. Hp.Ma. 281c, 283a; D. L. 2. 6-7). Acreditava que a vida só tinha valor se servisse para uma melhor compreensão do cosmos a que se pertence; tudo o resto era supérfluo: o apego aos bens materiais e à felicidade terrena não vale a pena, pois todo o homem é mortal e, mais cedo ou mais tarde, todos têm o mesmo destino (vide Guthrie: 1969: II, 266 sq.). Destacou-se pelo seu interesse pelas ciências naturais, nomeadamente pela origem do cosmos e ainda pela negação da religião politeísta e antropomórfica que então vigorava. A perspicácia que revelou no estudo da natureza fez com que os contemporâneos o apelidassem de "própria Inteligência personificada». A escolha dessa designação deve-se ao facto de ter introduzido o conceito de vóoc, Inteligência pura e simples. Segundo ele, vóoc é a força que rege o cosmos, responsável pela separação das substâncias com elementos em comum da massa caótica dos restantes. Vide Guthrie (1969: II, 266 sq).

${ }^{82}$ Vide supra p. 175. 
Parece que poderemos atribuir a Zenão algum contributo para o desenvolvimento da capacidade oratória ${ }^{83}$ de Péricles. Quando a ele se refere, Plutarco diz que o seu método era discutir com toda a gente, empregar os argumentos mais subtis e levar os adversários a não saberem que responder-lhe ${ }^{84}$. Deste passo, facilmente nos recordamos em um dos capítulos seguintes (Per. 8. 5 - cf. Moralia $802 \mathrm{C})$ :

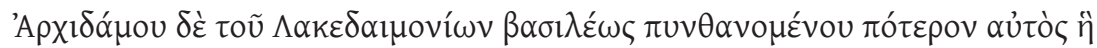

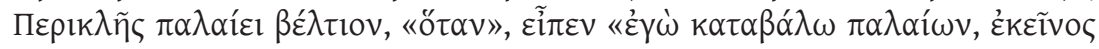

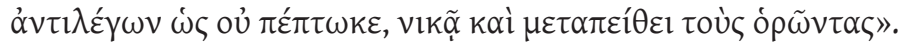

"Quando, certa vez, Arquidamo, rei de Esparta, lhe perguntou se era ele ou Péricles quem combatia melhor, [Tucídides] disse: "Quando eu o derrubo em combate, ele nega ter caído e leva a melhor, pois altera a opinião de quem assiste.»"

Esta anedota, de facto, não poderia caracterizar melhor a eloquência do filho de Xantipo, cuja extraordinária capacidade permitia adaptar os próprios acontecimentos aos seus interesses. Era assim a excelência oratória que os sofistas tanto defendiam e que Platão tão acerrimamente criticava: ser capaz de defender ou criticar o mesmo ponto de vista, de acordo com as conveniências do momento ${ }^{85}$.

Mas será a Anaxágoras que Péricles mais terá ficado a dever - pelo menos segundo Plutarco (e mesmo Platão ${ }^{86}$ ) - em termos de formação pessoal ${ }^{87}$. Dele

${ }^{83}$ Nesta época, começava a ganhar importância crescente o cuidado com o discurso e com a argumentação, que atinge o seu auge com sofistas famosos como Protágoras ou Górgias.

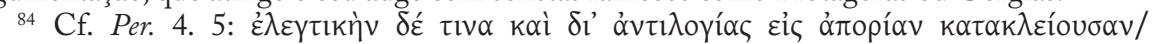

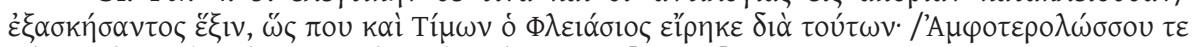

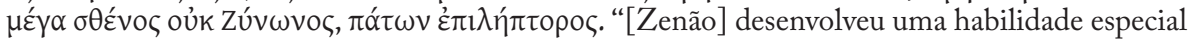
para refutar o adversário e para o reduzir à perplexidade com argumentos contraditórios, como mencionou Tímon de Fliunte em qualquer parte com estas palavras: «Que grande força tem a língua de dois gumes de Zenão, que não dá tréguas, sempre a atacar tudo e todos»."

${ }^{85}$ Alcibíades possuía igualmente dotes retóricos, que podem ser atribuídos à sua condição de ateniense e de alcmeónida e que começaram a revelar-se desde cedo, como vimos anteriormente a propósito da anedota que se refere à sua recusa em tocar flauta.

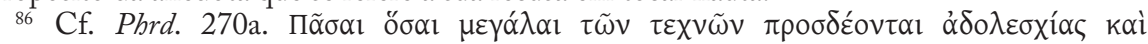

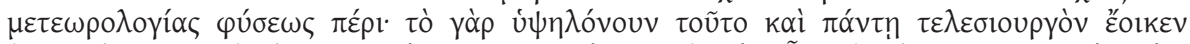

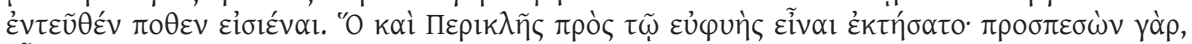

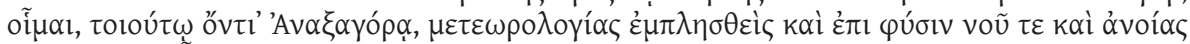

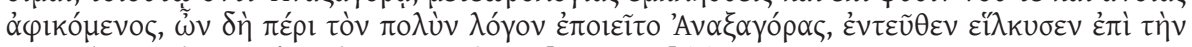

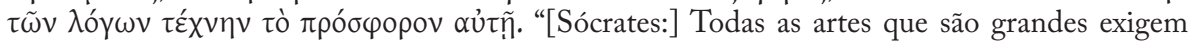
loquacidade e altas especulações sobre a natureza, pois é de algures daí que parece derivar a sublimidade da conceção e a sua inteira realização. Foi isso que Péricles, além dos seus dotes naturais, soube adquirir. Tendo encontrado Anaxágoras, que é, segundo creio, um homem desse género, embebeu-se de sublimes especulações e atingiu a natureza do espírito e da inteligência, assuntos de que Anaxágoras muito se ocupava, dali retirando para a arte da oratória tudo o que lhe fosse útil." A tradução apresentada é da autoria de Ribeiro Ferreira (1997: 109).

${ }^{87}$ Só muito raramente Plutarco analisa com precisão o que alguém aprendeu de específico 
«herda» e com ele aperfeiçoa a maioria - senão a totalidade - das suas virtudes, desde a elevação e nobreza de sentimentos, à grandeza da alma ( $\varphi \rho o ́ v \eta \mu \alpha)$, à

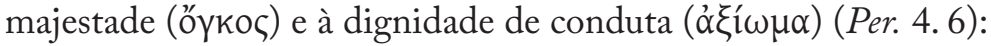

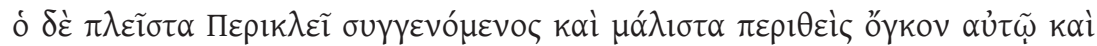

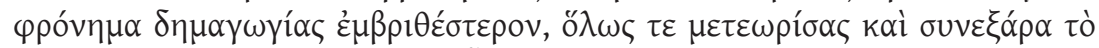

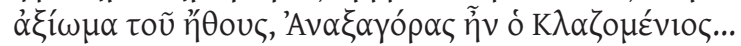

"mas quem mais se relacionou com Péricles e the incutiu sobretudo uma majestade e uma grandeza de alma capaz de suplantar qualquer demagogia, em uma palavra, quem the inspirou a coragem e a dignidade de caráter foi Anaxágoras de Clazómenas,...”

Essas qualidades morais que Péricles desenvolveu com Anaxágoras manifestam-se exteriormente no discurso do estadista e na própria postura. $\mathrm{Na}$ verdade, um bom orador deveria possuir qualidades a vários níveis: interiores - como a inteligência e o caráter - e externas, como a pose, a teatralidade e o tom de voz. Possuí-las na justa medida era atingir a perfeição, da qual Péricles é modelo ${ }^{88}$ (Per. 5. 1):

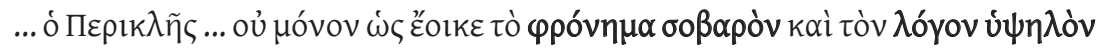

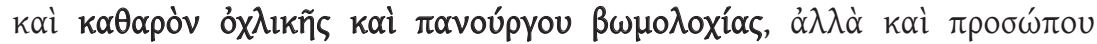

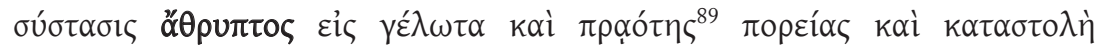

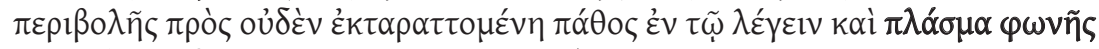

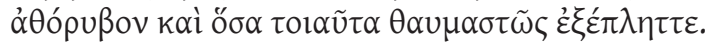

"Péricles não apenas possuía, ao que parece, distinção de espírito; tinha também um discurso elevado e isento de vulgaridades populares e de mau tom; um rosto austero que não se abria em um sorriso; tranquilidade no andar e modéstia no vestir, que nunca se alteravam com a emoção dos discursos; a modulação da voz imperturbável; e outras tantas qualidades que causavam a todos admiração."

Neste último capítulo da parte do relato biográfico dedicada à fase anterior ao ingresso na vida pública ativa, como bem podemos depreender pela transcrição feita, o biógrafo salienta algumas características do discurso ${ }^{90}$ de

com um determinado mestre ou escola filosófica, o que torna o exemplo de Péricles paradigmático. Todos os seus educadores parecem tender para orientá-lo numa mesma direção, ou seja, um estilo político específico.

${ }^{88}$ Nesta avaliação entra a própria formação retórica de Plutarco, que conhece manifestamente as regras da profissão de orador. Sobre as características do bom orador, leia-se, e. g., Russell (1983: cap. V).

${ }^{89}$ Прх⿱㇒́丶

${ }^{90}$ Quanto à eloquência, convém lembrar que será um ponto novamente abordado pelo biógrafo alguns capítulos mais adiante. De facto, uma das principais marcas do estilo biográfico 
Péricles - que era «elevado e isento de vulgaridades populares e de mau tom» e veiculado por uma voz imperturbável - e descreve também a moderação que se manifesta em toda a sua maneira de ser.

Daqui podemos inferir dois traços fundamentais da personalidade de Péricles - que serão mencionados e sugeridos várias vezes ao longo da biografia, ainda que em outros contextos: a sua moderação e o autodomínio. Também a inflexibilidade do olhar, a tranquilidade do andar, a modéstia no vestir - no fundo, a dignidade do porte e mesmo da linguagem - demonstram essas mesmas características e a seriedade do nosso estadista. Outro tanto não se pode dizer de Alcibíades. Segundo testemunho indireto do comediógrafo Arquipo $^{91}$ (que zombava do filho de Alcibíades e não diretamente do próprio), o Alcmeónida caminharia com indolência afetada e com a nuca inclinada, arrastando o manto, e ceceava de cada vez que abria a boca. Deixava, assim, evidente a necessidade que sentia de se mostrar superior e de atrair os olhos de todos na sua direção.

Com Anaxágoras, Péricles aprendeu ainda a não ser supersticioso -

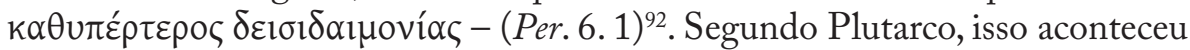
porque a posse de conhecimentos científicos o levou à melhor compreensão e conhecimento dos fenómenos naturais, o que não permite aceitar qualquer justificação sobrenatural para tais incidentes. Esta característica é exemplificada em Per. 35. 2, quando, no momento da partida para Epidauro, tem lugar um eclipse do sol, que quase paralisa todos de pavor. Verificando o medo do piloto, Péricles fá-lo compreender que nada há a temer, que se trata de um fenómeno inofensivo, tal como o é a escuridão provocada pelo cobrir do rosto com um manto. É assim que consegue fazer com que a armada parta.

No entanto, no final desta biografia, em Per. 38. $2^{93}$, quando Plutarco nos informa da doença que viria a vitimar o estadista, invoca Teofrasto ${ }^{94}$ : ao

de Plutarco é a redefinição permanente e progressiva dos traços de caráter das suas personagens. É assim que ele individualiza, que torna mais singulares, as características que pretende realçar; no caso de Alcibíades, por exemplo, com o desenrolar da Vida, o jovem torna-se cada vez mais invulgar: ninguém jamais conseguira comportar-se de um modo tão ultrajantemente encantador, com tanta versatilidade e habilidade.

${ }^{91}$ Alc. 1.8.

${ }_{92}$ Teofrasto (Char. 16) descreve a figura do supersticioso e define superstição como sendo simplesmente o temor do sobrenatural. Neste passo, salienta-se a importância da filosofia para a formação do indivíduo. Lembremo-nos de que, já Platão (Alc. 1.118b-c) o dizia, foi o estudo da filosofia - condição sine qua non para um bom desempenho político - que marcou a diferença entre Péricles e os outros políticos mais distintos do seu tempo.

${ }_{93}^{93}$ Esta anedota pode ter sido retirada de uma obra de ética ou de psicologia.

${ }^{94}$ Uma das questões que parecia preocupar Teofrasto (fr. 463 Fortenbaugh) era saber se a virtude pode ser alterada pelo destino ou por outros fatores exteriores, nomeadamente a dor física. A partir do caso de Péricles, parece que realmente fatores externos, como o sofrimento causado pela peste que acabou por vitimar o estadista, foram capazes de lhe fazer mudar o comportamento. De que outro modo - diz Teofrasto - se poderia compreender que Péricles 
que parece, Péricles estaria de tal modo debilitado que até aceitava recorrer a amuletos, comportamento tipicamente feminino e que demonstra superstição, porque já não tinha nada a perder. Segundo este peripatético, a situação apenas mostra que a dor, o sofrimento e a vivência de momentos difíceis fazem com que uma pessoa altere o seu comportamento. Mas, se de facto isto aconteceu, foi um dos raríssimos momentos em que a moderação de Péricles não conseguiu resistir aos infortúnios do destino por efeito do acumular de situações penosas na fase final da sua vida (recordemos a perda dos filhos legítimos, de outros familiares e amigos em consequência da peste e, agora, o seu próprio contágio). Nota-se, pois, uma certa humanização de Péricles - que, de algum modo, vacila no seu habitual equilíbrio. O que importa é que ele se esforça por se manter inalterável mesmo nas situações de maior adversidade.

Mas a sobriedade de Péricles nem sempre era bem interpretada. É o que nos diz Plutarco com base em Íon ${ }^{95}$, que opõe à delicadeza e afabilidade de Címon o desprezo pelos outros, o orgulho e a arrogância de Péricles (Per. 5. 3):

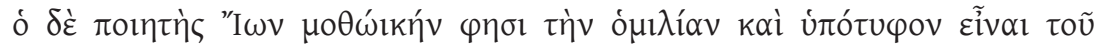

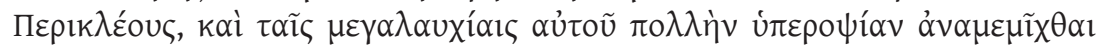

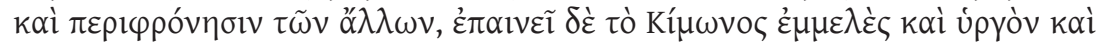

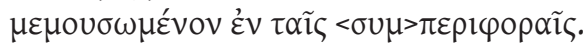

"O poeta Íon fala do contacto insolente e um tanto altaneiro de Péricles e afirma que ele misturava ao orgulho muito desprezo e desdém pelos outros; louva, em particular, Címon, pelo tato, delicadeza e elegância que punha nas relações humanas ${ }^{96} . "$

Para desfazer essa visão negativa - com a qual Plutarco claramente não concorda - recorre ao testemunho de Zenão, que explica que há quem confunda

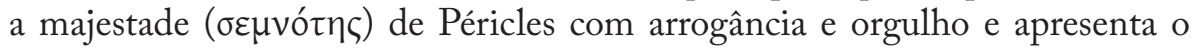
«atacado» como modelo de conduta a seguir (Per. 5.3):

ostentasse ao pescoço um amuleto, considerado tolice de mulheres? Sobre a debatida questão da alteração de caráter e a posição de Plutarco sobre a matéria, leia-se Gill (1983: 469-481); Swain (1989: 62-68); Pérez Jiménez (1994: 331-340). Este episódio volta a ser abordado infra p. 304.

${ }_{95}$ FGrHist 392 F 15. Íon, cuja vida decorreu entre cerca de 490 e 424 a.C., foi um dos poucos tragediógrafos que os Alexandrinos incluíram no cânone, ao lado de Ésquilo, Sófocles e Eurípides. Mas a sua produção escrita estendeu-se por outros domínios, nomeadamente o elegíaco, o filosófico (Triagmo, onde defende que a realidade é trinitária) e o histórico (História da Fundação de Quios). Uma das suas obras mais famosas é Epidemias, que tratava das viagens do seu autor e também das visitas de homens ilustres à sua terra natal. O seu estilo revela gosto pelo retrato e pela anedota. Nascido em Quios, atacava Péricles (provavelmente como consequência do tratamento que os Atenienses deram à sua cidade natal durante a Guerra de Samos - cf. Per. 28. 7). Vide Lesky (1995: 439-441); Guthrie (1969: I, 158).

${ }^{96}$ Sobre estas características de Címon, vide supra p. 127 , nota 71 . 


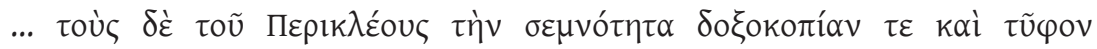

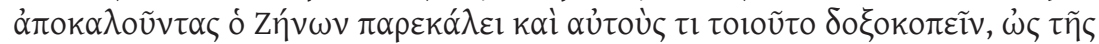

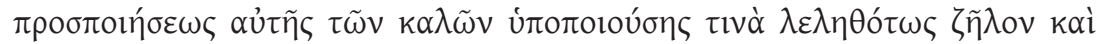

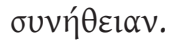

"Zenão exortava aqueles que chamavam à majestade de Péricles ânsia de prestígio e orgulho a terem também eles essa mesma ânsia, pois a procura produz impercetivelmente a emulação e o hábito do bem.”

De facto, a arrogância, o orgulho e o desprezo pelos outros podem ser tidos como características próprias dos Alcmeónidas, ainda que a sua origem seja diferente: Péricles fomentava o distanciamento em relação aos seus concidadãos, porque considerava ser esta a melhor forma de reunir condições para desempenhar, sem problemas, o seu papel de líder. Alcibíades, por sua vez, fazia-o por se considerar superior a todos os outros e porque, de um modo geral, só se preocupava com a sua realização pessoal e a satisfação dos próprios desejos ${ }^{97}$. Mas, curiosamente, esse comportamento de Alcibíades (que, quando acedia ao convívio social, sempre encontrava

${ }^{97}$ Tais sentimentos são revelados por anedotas como as relatadas em Alc. 4.5 e 16. 5, que deixam clara a sua falta de consideração pelos sentimentos e vontade dos outros. No primeiro caso, abusa da boa vontade de Ânito, que nutria uma paixão por ele: como se não bastasse desdenhar do convite que recebera para um banquete, ainda tem a ousadia de aparecer tardiamente, já embriagado (algo que parece ser um hábito, segundo testemunho de P1. Symp. 212d-213a), não para participar do convívio mas para saquear os bens do pobre enamorado. Contudo, o que causa maior admiração é a complacência da reação de Ânito que, ante a indignação dos seus convivas por causa da insolência e arrogância com que fora tratado

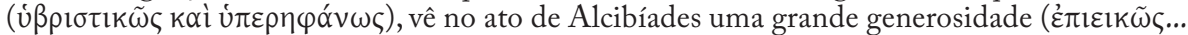

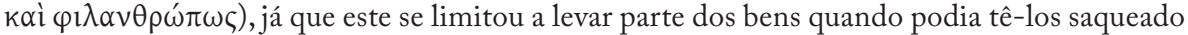
todos. Importa notar que a versão de Plutarco denigre ainda mais o comportamento de Alcibíades por oposição à versão narrada por Ath. 534e-f, segundo o qual o produto do saque teria sido oferecido a um amigo necessitado. É provável que tal alteração tenha por objetivo evitar que esta anedota fizesse par com Alc. 5. 1-5, de acordo com a qual Alcibíades auxilia um amante meteco, o que, nas palavras de Plutarco, terá sido um comportamento excecional. Ou seja, omitindo o destino que Alcibíades deu ao saque de Ânito, o leitor fica diante não de um Alcibíades generoso para com os amantes, mas de um Alcibíades inconstante, que ora os auxilia (nem que, como no caso do meteco, esse auxílio tenha como móbil não um ato de generosidade desinteressada, mas a vontade de vingar um desentendimento com os cobradores de impostos), ora tripudia sobre eles. O episódio narrado em Alc. 16.5 é ainda mais excessivo. Desejando que o célebre pintor Agatarco se encarregasse de lhe pintar as paredes da casa e perante a recusa deste, Alcibíades não se coibiu de aprisioná-lo até que o serviço estivesse concluído. Uma vez satisfeito o seu desejo, pagou-lhe o justo valor e deixou-o partir em liberdade. Fica mais uma vez evidente que o jovem Alcmeónida não olhava a meios para satisfazer os seus intentos. E nem as pessoas de renome estavam a salvo dos seus excessos... Esta anedota é referida igualmente por D. S.21.147 e por [And.] 4. 17. Este último acentua o desmando de Alcibíades, pois afirma que a liberdade do pintor não se fica a dever à iniciativa do Alcmeónida, mas à coragem de Agatarco que consegue escapar do «cativeiro». 
formas de exibição ou de imposição da sua vontade) é normalmente perdoado, o de Péricles não.

A maior parte das qualidades que Péricles desenvolveu ou aperfeiçoou no seu convívio com Anaxágoras - como a austeridade, a tranquilidade no andar, a modéstia no vestir ou a modulação da voz -, tão admiradas por todos, não são partilhadas por Alcibíades. De acordo com a perspetiva que Plutarco sustenta (e que remonta à opinião do próprio Sócrates), Alcibíades também tinha propensão para a excelência, mas não soube cultivá-la. Aliás, terá sido o facto de reconhecer essa propensão de Alcibíades que levou Sócrates a aproximar-se do jovem e a agir de modo díspar de todos os outros amigos/amantes do filho de Dinómaca ${ }^{98}$.

$\mathrm{Na}$ verdade, enquanto Péricles soube optar pela moderação nos seus comportamentos e na interação com os outros, Alcibíades foi sempre - desde pequeno - dado a excessos. Apoiando-se na suas enormes beleza e riqueza e no facto de estar sempre rodeado do apoio de amigos/aduladores, nunca sentiu necessidade de colocar limites às suas ações. Isso mesmo no-lo demonstram anedotas como as relatadas em Alc. 3. 1, 4. 5, 5.1, 7.1-2 e 9.1.

O primeiro episódio evocado em Alc. 3.1 merece particular atenção, porque ilustra não só o comportamento de Alcibíades, mas também o de Péricles. Como, certa noite, Alcibíades - ainda criança - não regressasse a casa (o que, segundo Antifonte ${ }^{99}$, acontecia porque decidira pernoitar com um amante chamado Demócrates $\left.{ }^{100}\right)$, os seus tutores ${ }^{101}$ discutiram sobre o que deviam fazer. Árifron defendia que se denunciasse o sucedido através

${ }^{98}$ Vide infra pp. 186-187.

${ }^{99}$ Sobre a vida e obra de Antifonte (ca. 480-411 a.C.), vide Dover (1950: 44-60) e Gagarin (1997). O facto de Plutarco introduzir testemunhos dos quais discorda é uma prática herdada da tradição historiográfica e recorrente ao longo das Vidas, pois permite-lhe assumir uma atitude de grande independência relativamente às diversas fontes a que recorre: não aceita cegamente toda a informação que recolhe, permite-se discordar do que é dito e avaliar a capacidade de rigor e de isenção dos diferentes autores em que se baseia. Quando, por exemplo, não há consenso sobre determinado assunto, o autor das Vidas apresenta vários pontos de vista e, por vezes, indica também o que lhe parece mais credível (sobre este assunto, vide Pelling (1990: 23-4); Nikolaidis (1997: 333-4). Em Alc. 32. 2, por exemplo, reconhece que existe material sobre Alcibíades que não passa de invenção. Ainda assim, usa alguns desses elementos, quanto mais não seja para rejeitá-los. No caso concreto do testemunho de Antifonte, Duff (1999: 232) afirma que «[the accusations of Antiphon (3.1-2)] do indeed introduce the section on Alcibiades' lovers which follows; but why has Plutarch included what he explicitly believed to be abuse ( and therefore not worthy of credence? The answer is clear; the reader is given a number of conflicting views of Alcibiades drawn from a vast number of different sources. Plutarch avoids making explicit narratorial judgements; the anecdotes and judgements are presented on their own without comment, and form a contradictory and deeply problematic picture of Alkibiades. It is the very 'unevenness' of the picture which in Plutarch's view is the key to Alkibiades».

${ }^{100}$ É provável que se tratasse do pai de Lísis, que é personagem do diálogo homónimo de Platão. Cf. Davies (1971: 359-360).

${ }^{101}$ Péricles e Árifron tornaram-se tutores de Alcibíades em 446, após a morte de Clínias na batalha de Coroneia, instigada por Tólmides, contra conselho de Péricles. Cf. Plu. Per. 18. 3, Alc. 1. 1; P1. Alc.1.112c; Isoc. 16. 28. Alcibíades deveria ter cerca de cinco anos à época. 


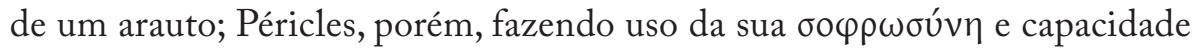
de antevisão, argumenta que, em caso de morte, só ganhariam conhecer o facto mais cedo; no caso de o jovem estar bem, maculariam a sua reputação para sempre. Fica, pois, o testemunho de que Alcibíades e Árifron agiam por impulso, ao contrário de Péricles, que ponderava cuidadosamente palavras e atos. Este relato deixa igualmente a impressão de que Péricles se preocupava com o futuro de Alcibíades e que era mais um daqueles que fechava os olhos às suas leviandades. Note-se, porém, que não o fazia por tolerância imprudente, nem para salvaguardar o nome da família, mas por ter a noção de que esta imprevidência de juventude poderia comprometer o futuro promissor de Alcibíades. Sugere-se, assim, que já naquele tempo os políticos eram um alvo fácil de ataques assentes na sua conduta sexual por parte dos opositores. Aconteceu com Péricles ${ }^{102}$, com Címon (acusado de incesto com a irmã Elpinice e de outras licenciosidades, e.g. Cim. 4. 6) e inevitavelmente com Alcibíades que, conhecido pela sua devassidão ${ }^{103}$, chegou a ser acusado de incesto com a mãe, a filha e a irmã, segundo relato de Antístenes (FGrHist 1004F 5a-b). E, claro!, fica ainda, mais uma vez, a sensação de que Alcibíades conseguia sempre escapar impune por aquilo que

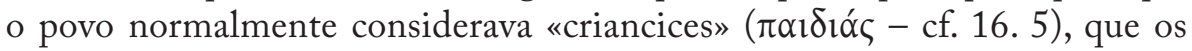
seus tutores - como aliás Sócrates - nunca conseguiram refrear.

Em Alc. 3. 1, Plutarco recorda ainda outra «denúncia» de Antifonte: Alcibíades teria espancado um criado até à morte em uma palestra. $\mathrm{O}$ recinto de combate fica, deste modo, associado a duas anedotas: a primeira (Alc. 2. 2-3) revela-nos um Alcibíades perspicaz, que tudo faz para conseguir os seus intentos, mesmo que isso implique o desrespeito pelas convenções; a segunda (como que a fechar este ciclo de anedotas que antecede o explanar da sua relação com Sócrates), um Alcibíades excessivo, violento, incapaz de dominar os seus impulsos e a sua força e de direcioná-los para o $\mathrm{Bem}^{104}$; mais

${ }^{102}$ Vide infra p. 242.

${ }^{103}$ Este relato introduz, assim, o tema do numeroso séquito de amantes de Alcibíades (desenvolvido entre os capítulos 4 e 6) e a incapacidade por ele sentida de resistir às tentações.

${ }^{104}$ Esta violência desmesurada de Alcibíades, quando comparado com Teseu e Péricles, parece ser uma especificidade do seu caráter. De facto, talvez por influência da sua formação filosófica (que deveria caracterizar qualquer verdadeiro homem de Estado na perspetiva de Platão e Plutarco), Péricles mantinha normalmente uma atitude inalterada perante o insulto, algo que está de acordo com a postura estoica defendida em Fab. 10. 2: o homem virtuoso e honesto não se sente ultrajado ou desonrado. Mesmo quando foi injuriado na Ágora por um homem infame e insolente, manteve a serenidade: não só suportou os impropérios durante o dia enquanto trabalhava, como ainda ordenou a um dos escravos que escoltasse o indivíduo com um archote até casa, porque já havia escurecido (Per. 5. 2). Quando, por ocasião dos funerais dos heróis que tombaram em Samos, Elpinice (cf. p. 262, n. 238) lhe teceu duras críticas por combater contra os Helenos e não contra os Bárbaros, Péricles ter-se-á limitado a sorrir e a recitar um verso de Arquíloco (fr. 27 Diehl, também citado por Ateneu 688e): «Velha como és, não devias encharcar-te em perfumes». 
ainda, um Alcibíades qual lobo sob pele de cordeiro, já que por detrás do seu charme e beleza se esconde um homem perigoso e violento. Essa sua faceta é relembrada várias vezes ao longo da biografia: em Alc. 7. $1^{105}$, ficamos a saber que agrediu um professor que não tinha uma cópia de Homero; em 8.1, que, na sequência de uma aposta (e não por um motivo de peso), agrediu Cálias, que, ironicamente, viria a ser seu sogro ${ }^{106}$; em 8. 5, que usou de violência (ainda que permitida pela lei), para recuperar a mulher que pretendia o divórcio; em 16. 5-6, que deu um murro a um corego rival no teatro ${ }^{107}$; em 16. 6, que foi o principal responsável pelo massacre dos prisioneiros depois da capitulação da ilha de Melos.

Como já dissemos anteriormente, Sócrates tinha consciência não só dos excessos de que Alcibíades era capaz, mas também da sua propensão para a excelência e tentou a todo o custo orientá-lo para o bom caminho. A relação que uniu ambos é reveladora da personalidade do Alcmeónida e foi muito explorada - sobretudo pelos discípulos de Sócrates. Não surpreende, assim, que a influência mais importante na imagem que Plutarco tem de Alcibíades tenha origem em Platão ${ }^{108}$, que também o considera um indivíduo problemático,

Estas reações sugerem-nos um comentário de natureza teórica. Plutarco (Moralia 810C-E) reflete sobre o recurso a insultos pelo homem de Estado. Além de defender que o político não deve insultar ninguém, deixa uma sugestão de resposta que consideramos ter neste episódio da Vida de Péricles um exemplo perfeito: porque é difícil não reagir a uma injúria, a réplica deve ser concisa e não mostrar cólera nem fúria arrebatada, mas suavidade que com humor e graça seja incisiva. Tal comportamento deixa a impressão de que as injúrias se voltam contra quem as proferiu, por causa da inteligência do que foi injuriado. Esta atitude de Péricles, que não se rebaixa a ponto de responder, contrasta com a do político nova-vaga que Aristófanes nos apresenta em Os Cavaleiros. Inconscientes ou descarados, os sucessores de Péricles recebem os insultos como elogios e por isso não ensaiam qualquer resposta ao que deveria ser considerado uma ofensa grave. No que respeita a Teseu, não é possível reconhecer-lhe um autocontrolo na proporção do de Péricles. Contudo, embora use de violência para vencer os criminosos com que se deparou no percurso para Atenas, tal comportamento tem três atenuantes: a violência a que recorreu foi proporcional à dos bandidos, fê-lo em legítima defesa (de outro modo teria perecido) e para libertar o povo da opressão em que vivia. O mesmo não se pode dizer do seu comportamento no campo sexual, já que ficou famoso por raptos e violações.

${ }^{105}$ Cf. Moralia $186 \mathrm{D}$.

${ }^{106}$ De notar que, mais uma vez, o recurso de Alcibíades à violência gratuita suscitou a condenação popular e que, de novo, não houve punição para o seu comportamento indigno, bem pelo contrário... No dia seguinte, Alcibíades apresentou-se a Cálias para que de algum modo o castigasse, mas não só foi perdoado como também acabou, tempos depois, por se casar com a filha da sua vítima. Sobre o casamento de Alcibíades, vide infra p. 244.

${ }^{107} \mathrm{O}$ episódio em causa também é referido por D. S. 21.147 e [And.] 4. 20-21. Segundo este último, Alcibíades terá saído vencedor, porque o júri, por medo ou agradecimento, não cumpriu bem a sua função de imparcialidade.

${ }^{108}$ Platão trata a figura de Alcibíades em Smp., Prt., Grg. e Alc., onde nos é apresentado como alguém que oscila entre a filosofia e as tentações do poder. Parece tratá-la igualmente (embora de forma velada) em $R .491 b$, quando reflete sobre as "grandes naturezas», já que tudo o que afirma a esse respeito faz de imediato pensar em Alcibíades (cujo nome nunca é 
capaz de grandes bens e grandes males, devido à sua natureza ${ }^{109}$.

Ao que tudo indica, a proximidade existente entre eles teria um caráter pederástico, mas Plutarco concentra-se nos aspetos educativos e não nos eróticos que poderiam decorrer dessa relação ${ }^{110}$. Ainda assim, o biógrafo salienta o facto de o interesse de Sócrates por Alcibíades ser diferente do

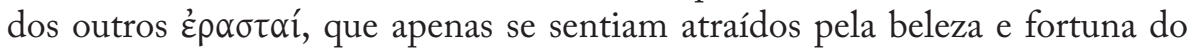
jovem Alcmeónida. Sócrates conseguia ver para além da formosura e enxergar

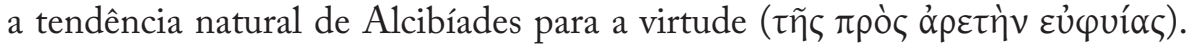
Era esse o dom de Alcibíades que lhe interessava, por isso tentou fazer de tudo para que o jovem não se desviasse do caminho do Bem, mostrando-lhe as fraquezas da alma e censurando-lhe o orgulho desmesurado. Segundo Plutarco (Alc. 4. 1), cuidou dele como quem cuida de uma flor que não deve perecer antes de dar fruto, pois tinha consciência de que o caráter de Alcibíades, a sua riqueza, posição social, bem como as adulações e condescendências das pessoas que o rodeavam constituíam uma massa explosiva que iria afastá-lo da virtude. Aliás, Plutarco mostra alguma surpresa pelo facto de Alcibíades,

evocado). Pela boca de Sócrates, o fundador da Academia alega que uma natureza débil nunca será capaz nem de grandes bens nem de grandes males. Só uma natureza de eleição tem essa capacidade, mas, por norma, acaba pervertida por força de uma educação deficiente. Tais naturezas - a que Platão chama «naturezas filosóficas» -, possuem dons como a facilidade de aprender, memória, coragem e serão desde a infância os primeiros de entre todos (sobretudo se à excelência do espírito corresponder a do corpo). A sua corrupção tem início na juventude: é que quando atingem essa idade, a família e os concidadãos, prevendo que no futuro venham a ter grande poder, começam a adulá-las. É por isso que o povo, que louva ou censura tais naturezas inapropriadamente, é considerado o principal instrumento de perversão dos jovens, pois afasta-os da filosofia. Se a um homem de tal natureza se acrescentar o facto de ser rico, bem-nascido e natural de uma grande cidade, o mais certo é que se torne capaz de tudo. E, ainda que alguém tente chamá-lo à razão, ou se recusará a ouvir ou será afastado do bom caminho pelos «amigos».

${ }^{109}$ Plutarco desenvolve o tema das grandes naturezas em outros textos (e. g. Moralia 552B), nos quais surgem associadas a metáforas agrícolas. O mesmo se passa com a natureza específica de Alcibíades que, em Nic. 9. 1, é comparado ao solo do Egito que, pela sua excelência, tanto produz plantas com poderes curativos como letais (cf. Od. 4. 230). O biógrafo apresenta igualmente exemplos de outras grandes naturezas que não se convertem em indivíduos de caráter duvidoso. É o caso de Temístocles, que, apesar de uma infância difícil e pouco promissora, conseguiu corresponder às melhores expectativas que se tem de alguém com a sua natureza (Plu. Them.2. 7). Sobre este assunto, vide Duff (1999: 313-332); Gribble (1999:13-23).

110 A relação pederástica teria sobretudo um caráter iniciático e educativo. Incitado e ensinado pelo «amado», mais velho e experiente, o jovem sentia maior entusiasmo para realizar grandes feitos nos diferentes domínios em que se deveria distinguir: desportivo, militar e político. Neste tipo de relação, ocorria não raras vezes um envolvimento de cariz homossexual, a cuja polémica, pelo menos em Moralia (11C-12A), Plutarco procura fugir, porque não sabe ao certo que posição tomar. Não surpreende, por isso, que, em Alc. 4. 7, o biógrafo afirme que Sócrates.

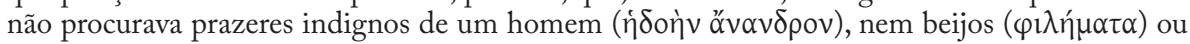

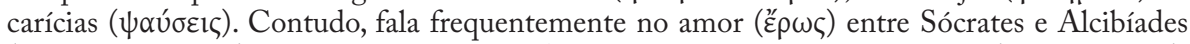
(Alc. 4. 1, 4. 3, 6. 1). Sobre a relação entre Alcibíades e Sócrates, vide Littman (1970: 263-76), segundo o qual não há razões para crer que eles não mantivessem relacionamento sexual. Sobre a pederastia, vide, e. g., Dover (1978); Percy (1996); Hubbard (2003). 
apesar do contexto descrito, ter revelado interesse no convívio com Sócrates (que não tinha qualquer pejo em repreender as suas falhas) em detrimento do convívio com os demais amantes. O Queroneu atribui esse interesse aos «dotes

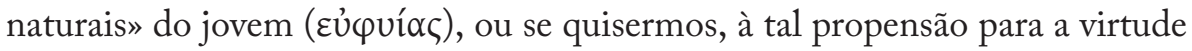
que Sócrates tanto admirava.

Parece-nos, contudo, que o comportamento de Alcibíades vai ao encontro do que hoje se defende em termos de educação; que os filhos, cujos pais são demasiado permissivos e não lhes impõem limites, sentem falta dessa autoridade. Senão, vejamos: Péricles, apesar de excelente estadista e dos esforços que fez, não se mostrou muito capaz de criar descendentes que seguissem a sua natureza moderada ${ }^{111}$ (que, como vimos atrás, se desenvolveu pelo convívio com alguns mestres). Do mesmo modo, Alcibíades, que cresceu sob a sua tutela, assumiu comportamentos desregrados e até teve a audácia de criticar o zelo de Péricles para com o povo e a coisa pública, certa vez que desejava falar com o tutor, que não o pôde atender por estar a estruturar a apresentação das contas aos Atenienses ${ }^{112}$. No entanto, apesar dessa maneira de ser, ouvia com atenção os reparos de Sócrates, o único que, não fossem as distrações mundanas, talvez tivesse conseguido endireitá-lo, pois, segundo Plutarco (Alc. 4. 3), Alcibíades sentia-se intimidado diante dele:

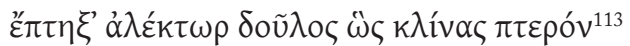

"encolhia-se como um galo vencido, com a asa baixa."

Podemos, por isso, concluir que o facto de a postura de Sócrates em

${ }^{111}$ Segundo Platão (Men. 94b), Péricles deu aos filhos, Xantipo e Páralo, uma excelente educação no que concerne à arte da cavalaria, música e ginástica, mas não conseguiu fazer deles ảy $\alpha$ oí: ambos tinham por hábito ouvir o sofista Protágoras em casa do meio-irmão materno, Cálias (Prt. 314e). Ésquines Socrático (Ath. 220d) critica-os pelas más companhias. Plutarco (Per.36.2-6) revela as dificuldades de convivência que existiram entre Péricles e Xantipo, o filho mais velho. Ao contrário do pai, que controlava cuidadosamente as finanças domésticas, este era esbanjador e rebelou-se quando o estadista se recusou a pagar as suas dívidas. Cf infra p. 253.

${ }^{112}$ Cf.Plu.Alc.32.3, Moralia 186E. Segundo Stadter (1989:301), esta anedota está seguramente relacionada com a proposta de moção de Dracôntides, exigindo que Péricles apresentasse as contas dos dinheiros públicos aos prítanes. Segundo D. S. 12.38.3-4 e 39.3 (e Aristodem., FGrHist 104 F 16 e V. Max. 3. 1), o estratego, seguindo o conselho de Alcibíades, deu início à guerra. Alguns autores identificam o processo em causa nesta anedota com o de 430 a.C., na sequência do qual Péricles foi destituído (vide Gomme: 1969: II, 187). Frost (1964: 69-72) e Donnay (1968: 19-36) não aceitam esta interpretação, argumentando que a acusação de 430 a.C. dizia respeito a questões militares (para estes, o processo em causa data de 438-437 a.C.).

${ }_{113}$ Os Gregos eram grandes apreciadores de lutas de galos. Plutarco cita aqui o mesmo trímetro iâmbico de Frínico que evoca em Pel. 29. 6 e em Moralia 762E (Phryn. fr. 17 Nauck). Não deixa de ser curiosa esta comparação: de facto, ficamos com a imagem de um Alcibíades cheio de empáfia, que desafia tudo e todos, mas que, admoestado pela pessoa certa, reconhece a sua insignificância e fica intimidado. 
relação à sua pessoa ser díspar da dos outros amantes fez com que Alcibíades

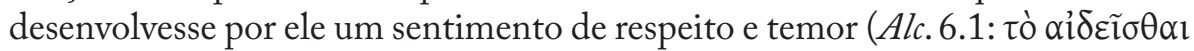

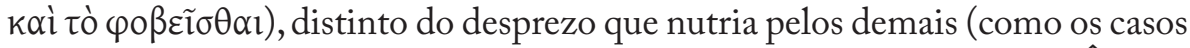
que já abordámos supra, nomeadamente o episódio do assalto à casa de Ânito). Alcibíades reconhecia o valor de Sócrates ${ }^{114}$ e procurava passar muito tempo com ele (jantavam, lutavam e partilhavam a mesma tenda), o que até causava estranheza à sua volta. E, sempre que ouvia os seus discursos, sentia-se tocado pelas palavras proferidas; era como se a sua natureza virtuosa despertasse e lhe provocasse remorsos pelos comportamentos indignos que assumia ${ }^{115}$. Ainda assim, abandonava amiúde o mestre, não em busca de prazer sexual, mas para receber mimos dos outros amantes (com os quais, como já vimos, mantinha uma relação contraditória) que o cobriam de lisonja, um esquema em que Sócrates não alinhava. No entanto, acabava sempre por regressar para junto do filósofo (Alc. 6. 116), que tinha por hábito caçá-lo, como se de um escravo fugitivo se tratasse. Era, segundo Plutarco, nessas alturas que Alcibíades podia ser comparado ao ferro: quando se afastava de Sócrates, ficava moldável à influência nefasta dos bajuladores (do mesmo modo que o ferro o é ao poder do fogo), mas de regresso à companhia daquele, retomava a sua «dureza natural», isto é, ficava permeável à influência de Sócrates e à sua tendência inata para a virtude.

Mas, embora muitas vezes se mostrasse terreno fértil para o germinar da semente socrática, Alcibíades acabou, como Sócrates bem temia, por ceder à pressão dos aduladores e da sua própria maneira de ser. Platão considera que Sócrates não pode ser responsabilizado por tamanho falhanço ${ }^{117}$; faltou a Alcibíades uma sólida formação filosófica de base que fomentasse um bom aproveitamento das suas capacidades inatas; por isso mesmo a sua vida foi vivida «à margem da lei» ( $\pi \alpha \rho \alpha v o \mu i ́ \alpha)$ e cheia de altos e baixos ( $\alpha$ vo $\left.\mu_{\alpha} \lambda \lambda_{1} \alpha\right)$.

Assim, em jeito de súmula, podemos dizer que, embora oriundos da mesma família e senhores de «naturezas filosóficas», Péricles e Alcibíades

${ }^{114}$ Segundo Alc. 4. 4, o jovem considerava a obra de Sócrates como uma incumbência divina

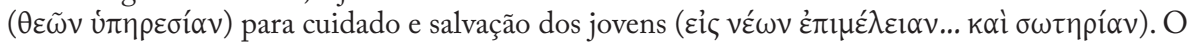
modo como Plutarco entende a missão de Sócrates tem subjacente a definição de amor para os filósofos, nomeadamente Polémon (cf. Moralia 780D). Esta ideia é recorrente em Plutarco, que, por exemplo, considera o amor de Ariadne por Teseu um sentimento de natureza semelhante. Cf. Plu. Rom. 30. 6-7 e Flacelière (1948: 101-102).

${ }^{115}$ Em Plu. Alc. 6.1 é clara a influência de Pl. Smp. 215e, onde o jovem admite que nem as palavras dos oradores mais ilustres - como Péricles - lhe provocavam tamanha comoção.

116 Nota-se mais uma vez a influência platónica, já que a metáfora da caça amorosa é frequente na obra deste filósofo. Vide Louis (1945: 55).

${ }^{117}$ Cf.P1.R. 494d-495c. Nesse passo, Platão não se refere a Alcibíades pelo nome, mas as suas palavras fazem pensar de imediato no Alcmeónida. O facto de Alcibíades não ter modificado o caráter pernicioso que lhe conhecemos terá certamente contribuído para a acusação de corromper a juventude de que Sócrates foi alvo e que muito pesou para a sua condenação à morte (cf. X. Mem. 1. 1.1, 1.2.12-16; P1. Ap. 33 a-b; D. L. 2. 40). 
desenvolveram maneiras de ser opostas. Para justificar tal desvio, resta-nos considerar causas como a existência de tendências de caráter inatas, a orfandade temporã de Alcibíades ${ }^{118}$ (embora Plutarco não dê grande importância a esse percalço), bem como a alteração dos contextos social e cívico em que ambos cresceram e iniciaram a sua atividade política (Péricles precisou de se esforçar por estabelecer o poderio ateniense; Alcibíades, por sua vez, viveu em um período em que o importante era tentar mantê-lo.

118 Outros eleitos de Plutarco ficaram órfãos precocemente. É, por exemplo, o caso de Coriolano (cf. nota 55), Címon (Cim. 4. 4), que ficou sem pai na adolescência, altura em

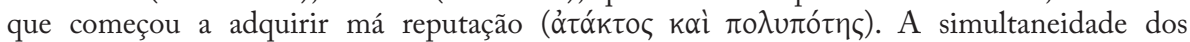
acontecimentos faz-nos crer que Plutarco, ao contrário de Platão, acredita que a orfandade constitui uma influência negativa para aqueles que por ela passam muito cedo. 


\subsection{O ingresso na vida pública}

Só a partir de finais do século $V$ a.C. (altura em que devido à ascensão socioeconómica das classes mais desfavorecidas, a base de escolha dos indivíduos que poderiam ocupar tais posições cimeiras foi alargando de forma mais evidente) é que vemos gente como Cléon a exercer cargos que até então lhe estavam vedados. Antes desse período, embora a participação na vida política ativa em Atenas fosse extensível (pelo menos em teoria) a todos os cidadãos, os cargos de topo (como, por exemplo, o de estratego) estavam, por norma, acessíveis apenas àqueles que tinham berço de ouro, isto é, oriundos de famílias de renome, tradicionais e... ricas. Trata-se, sem dúvida, de condições que os dois Alcmeónidas reuniam.

Vimos, porém, em páginas anteriores, que riqueza e família eram praticamente as únicas coisas que Péricles e Alcibíades tinham em comum. Ainda que seja possível chamar a atenção para um ou outro traço de caráter que partilhavam (e que podemos considerar provenientes de herança genética), o certo é que ambos tinham maneiras de ser e objetivos de vida diametralmente opostos. Não surpreende, por isso, que quer o ingresso na vida pública quer a atuação política de cada um se tenham processado de forma tão distinta.

Como é normal, sempre que um jovem pretende abraçar uma carreira - por melhor preparado que esteja e por mais apoios de que disponha depara-se com dificuldades, inerentes à sua pouca experiência e ao facto de já haver no mercado profissionais da área, que, não poucas vezes, se sentem ameaçados pela vitalidade que os jovens trazem ao dia-a-dia de uma atividade que, para os mais experientes, já se tornou vulgar e, com frequência, cheia de vícios que não se pretende alterar. Existe, portanto, de um modo geral, uma certa desconfiança relativamente à nova geração que quer começar a exercer a sua profissão.

Esta comparação que acabámos de fazer não deixa de estar relacionada com o que dissemos no capítulo sobre as convenções literárias associadas à vida de um fundador: os próprios pais ou ascendentes, com medo de perder o poder, são muitas vezes aqueles que mais se opõem à ação dos filhos, que tentam coartar desde o momento do nascimento ${ }^{1}$.

${ }^{1}$ Vide supra pp. 34 e 52 . Do mesmo modo que a supremacia de Teseu foi anunciada (ainda que indiretamente) pelo oráculo proibitivo do seu nascimento a que Egeu teve acesso, também em relação a Péricles houve indícios sobrenaturais do grande poder que viria a possuir. É o caso do sonho de Agariste (cf. supra p. 169 sqq) e do presságio do corno de carneiro, que, ainda que interpretado por duas individualidades diferentes de acordo com «teorias» distintas, deu origem à mesma conclusão: Péricles iria ser responsável pelo governo de Atenas (cf. infra p. 222, nota 61). 
O próprio Plutarco, na esteira da tradição do pensamento grego ${ }^{2}$ e do que Platão defende na República, é contra uma entrada precoce na atividade política e dá exemplos de maus resultados dessa prática, um dos quais é, como veremos, Alcibíades (Moralia 784C). Para confirmar essa teoria, acrescenta que o governo de Péricles alcançou o maior poder na velhice, quando, com mais de sessenta anos, o filho de Xantipo convenceu os Atenienses a entrar em guerra contra os Lacedemónios e, depois de inflamados os ânimos, os impediu de lutar, ocultando-lhes tanto as armas como as chaves da cidade $(784 \mathrm{E})^{3}$.

Adaptemos, agora, esta reflexão ao ingresso na vida política dos nossos estadistas e vejamos de que modo cada um reagiu a essas dificuldades.

Um dos primeiros passos necessários ao ingresso nesta carreira é, certamente, conseguir a confiança dos concidadãos. $\mathrm{O}$ próprio fundador de Atenas sentiu essa necessidade, já que, por ter sido nascido e criado longe do pai e, por conseguinte, da $\pi$ ó $\iota_{\imath} \varsigma$, era visto por todos como um estrangeiro. Como se tal não bastasse, a população estava revoltada, porque apenas os seus filhos sofriam as consequências do crime de Egeu. Para vencer este óbice, ou seja, para conquistar os concidadãos, Teseu empreende dois grandes esforços: luta contra o Touro de Maratona e decide espontaneamente (mesmo contrariando a vontade do progenitor ${ }^{4}$ ) fazer parte do tributo ao Minotauro ${ }^{5}$. Foram essas provas de altruísmo e de amor pelo povo (de que Péricles também dará exemplos, ao contrário de Alcibíades) que puseram um fim definitivo às

${ }^{2}$ Os Gregos não acreditavam na sensatez nem na capacidade política dos jovens (Plu. Moralia 790A). Um dos maiores óbices apontado aos imberbes é a sua falta de experiência (Arist. EN 1095a2, 1142a15; Plu. Moralia 790D-E). Segundo o biógrafo (Moralia 788C), os mais novos lançam-se nos assuntos públicos levados pela vontade de rivalizar contra alguém ou de obter glória, e arrastam consigo a multidão como um mar agitado pela tempestade. Os mais velhos, por sua vez, tratam com doçura e moderação aqueles com os quais se relacionam (Arist. EN1095a2,1142a15; Moralia 790D-E).

${ }^{3}$ Cf. Thuc. 2. 21-22; Plu. Per. 33.

${ }^{4} \mathrm{O}$ facto de contrariar o desejo do progenitor é uma constante em Teseu, que já antes fora contra a vontade da mãe e do avô ao optar por se dirigir a Atenas por via terrestre e não marítima, ou seja, pelo percurso menos seguro. Deparamo-nos, assim, com um Teseu ousado, mas que o é não por rebeldia ou temeridade, antes por ansiar ser motivo de orgulho para o pai e emular Héracles. Vide supra p. 55. Podemos estabelecer um contraponto entre Teseu e Péricles: enquanto o primeiro desobedece à família por motivos nobres, o Alcmeónida rompe com a tradição familiar para aceder ao poder político. É por uma questão de sobrevivência (isto é, para garantir o seu acesso a um cargo de chefia) que se assume como «cabeça do partido popular» e opta pelo isolamento nas relações com a família (assinalando, assim, o seu desejo de independência). Quanto a Alcibíades, que jamais teve medo de enfrentar tudo e todos, nunca agiu com o intuito de agradar aos concidadãos ou parentes, mas tão-só de satisfazer vaidades pessoais.

${ }^{5}$ Sobre estes feitos de Teseu, vide p. 68 sqq. Importa, contudo, recordar que, na sequência da vitória sobre o Minotauro, Teseu ganhou não só a confiança do povo, mas também minou - ainda que involuntariamente - o maior obstáculo para o seu acesso ao poder, já que, por negligência, provocou a morte do próprio pai (cf. supra pp. 69-70). 
hesitações dos Atenienses em relação à sua pessoa, convertendo-se, assim, no caminho que o conduziu diretamente ao poder.

É logo desde esta primeira fase que podemos apontar diferenças entre os percursos de Péricles e Alcibíades, que se revelam consequências naturais do caráter de cada um deles.

Segundo Plutarco, aquele que pretende ingressar na vida pública quer prefira a carreira política quer a militar - deve possuir determinadas características inatas ( $\dot{\eta} \varphi u ́ \sigma ı)$, que podemos agrupar distintamente, embora devam sempre coexistir para que os indivíduos tenham bons desempenhos:

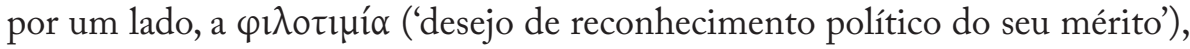
a $\varphi \imath \lambda \circ \delta \circ \xi i ́ \alpha$ ('desejo de glória') e a $\varphi \imath \lambda o v ı k i ́ \alpha$ ('desejo de vitórias'), entre outras

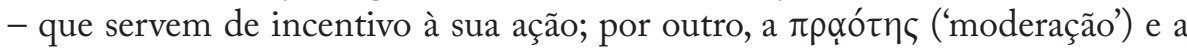
$\varphi \imath \lambda \alpha v \theta \rho \omega \pi i ́ \alpha$ ('humanidade').

As do primeiro grupo, se isoladas das do segundo, podem ter consequências nefastas, já que estão diretamente relacionadas com a ambição de honras e poder; logo, quando não são bem «doseadas», levam a excessos ${ }^{6}$. Se o homem público apenas possuir as do segundo grupo, pode não se sentir suficientemente motivado para a aç̧ão e não intervir.

${ }^{6}$ Daí que o conceito de $\varphi \imath \lambda o \tau \iota \mu i ́ \alpha$ se tenha tornado ambíguo, ao adquirir, com o passar do tempo (e sobretudo a partir do século $\mathrm{V}$ a.C.), uma conotação fortemente negativa. De início, como a própria etimologia da palavra sugere, mais não era do que o desejo de obter honras, o reconhecimento dos cidadãos (a $\tau \imath \mu \eta ́)$. Nesse caso, é entendida como uma característica positiva que serve aos mais jovens de motivação para ações virtuosas; como força psicológica que pode acarretar valor moral positivo ou neutro para aqueles que se inspiram nos feitos dos

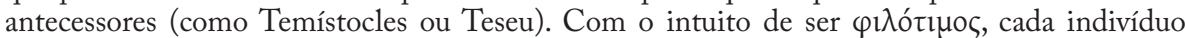
procurava ser generoso, sobretudo em prol da sua $\pi$ ó $\lambda ı$, e subsidiava a cidade de modo a obter o reconhecimento pretendido. Após a morte de Péricles, a ascensão ao poder de um novo tipo de políticos, que mais do que servir quer ser servido - isto é, retirar benefícios dos cargos ocupados - e que entende por honra não o reconhecimento do mérito das suas ações mas a ostentação de uma determinada posição social, faz com que a noção de $\varphi \imath \lambda o \tau \iota \mu i ́ \alpha$ seja desvirtuada. Neste caso, a ambição que lhe estava associada deixa de ter um caráter nobre e passa a ser um conceito vazio e perigoso, consistente com a corrida atrás do aplauso fácil, tornando-se destrutiva para o indivíduo e a sociedade. Este é um tópico muito abordado por Eurípides, nomeadamente em $I A$, onde a $\varphi \imath \lambda o \tau \imath \mu i ́ \alpha$ surge associada quer a Agamémnon quer a Ulisses. O Atrida é acusado por Menelau de ter procurado agradar os líderes gregos na expectativa de ser escolhido como comandante supremo e assim satisfazer a sua ambição, ainda que para isso tivesse de sacrificar a filha ( $L A 337-342 ; 385)$. Na mesma tragédia ( $I A$ 527), Ulisses é criticado por estar também ele tomado de $\varphi \imath \lambda o \tau \iota \mu i ́ \alpha$, uma doença terrível. Eurípides deixa, assim, evidente que, o objetivo de $\varphi \imath \lambda o \tau \iota \mu i ́ \alpha$ aplicado a uma natureza sem qualidade torna-se simples egoísmo e crueldade. Plutarco, que vários séculos mais tarde, considera que a $\varphi$ ı aborda o tema em diversos momentos, dos quais destacamos Ages. 5.5 (sobre os perigos da ambição política excessiva). Em Moralia $819 \mathrm{~F}$, afirma inclusive que, apesar de aparentemente ser um defeito menos feio que a ganância, pode ter consequências piores para a vida política, na medida em que suscita uma audácia maior. Trata-se de uma virtude que apenas se encontra em pessoas de caráter forte e atrevido e que se transforma em perigo/defeito por causa das exaltações e aplausos que a multidão consagra a esses indivíduos. Sobre este assunto, vide Dover (1974: 229-236); Frazier (1988: 109-127). 
Péricles demonstra desde o início a sua famosa $\varphi \rho o ́ v \eta \sigma r \varsigma^{7}$, pois, ao contrário de Teseu e Alcibíades, num primeiro momento, teme enfrentar o povo. Não se tratava de um medo infundado, sinónimo de mera cobardia ${ }^{8}$, mas antes de uma maneira de evitar a forte contestação popular. É que, apesar de a família dos Alcmeónidas estar associada à implantação da democracia em Atenas ${ }^{9}$, Péricles apresentava semelhanças com Pisístrato, o tirano que o seu antepassado Clístenes ajudara a derrubar. A memória da tirania era, portanto, algo ainda muito presente, sobretudo no espírito das pessoas de mais idade e Péricles não podia (nem queria) correr o risco de provocar suspeitas de pretensão de restaurar novamente esse regime, sob pena de desenvolver contra si grande oposição. É que além das semelhanças com Pisístrato, quer em

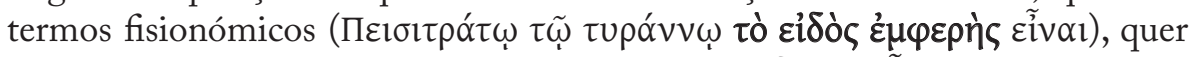

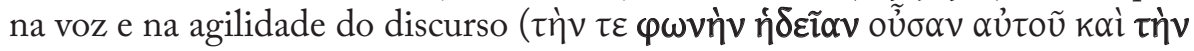

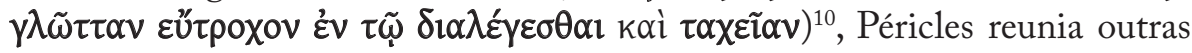
condições que podiam fazer com que o seu nome fosse votado para ostracismo: riqueza, o facto de ser membro de família ilustre e de ter amigos poderosos ${ }^{11}$.

Por tudo isso, e para evitar problemas desnecessários, numa primeira fase, opta por se dedicar à vida militar (onde se revela corajoso ${ }^{12}$ e empreendedor -

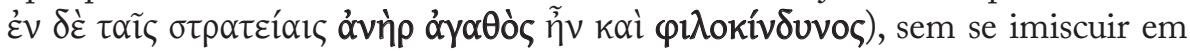
assuntos de natureza política e consciente de que era necessário esperar pelo momento oportuno.

Enquanto Péricles parece ter um plano e age cuidadosamente, deixando a sugestão de que o ingresso na vida política não é simples, Alcibíades fá-lo despreocupadamente, sem demonstrar (como aliás lhe era próprio) qualquer prurido com a opinião dos outros a seu respeito e sem sequer pôr a hipótese de não ser bem sucedido ${ }^{13}$. Uma tal atitude provoca-nos maior admiração ${ }^{14}$,

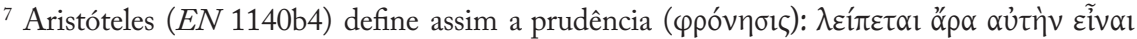

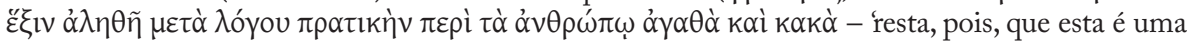
capacidade autêntica e racional, que leva a agir segundo aquilo que é bom ou mau para o homem.'

${ }^{8}$ Péricles foi por diversas vezes acusado de cobardia. Basta-nos recordar os ataques de que foi vítima por causa da estratégia adotada na Guerra do Peloponeso - cf. Per. 33. 7. Fábio Máximo foi alvo de acusação semelhante (Fab.5.3). Sobre este assunto, vide infra pp. 225, 269.

${ }^{9}$ Disso nos dá testemunho, por exemplo, Isoc. 16.25-28, a propósito de Alcibíades. Segundo o orador, era antiga e nobre a amizade que unia o povo à família dos Alcmeónidas.

${ }^{10}$ Per.7.1. Estes traços são aproveitados com alguma frequência pelos cómicos que o acusam de querer restaurar a tirania em Atenas (Per. 16.1).

${ }^{11} \mathrm{Em}$ Arist. 1. 7, Plutarco afirma que qualquer homem cuja reputação superior se devesse ao nascimento ou à eloquência era um potencial alvo deste mecanismo e apresenta como exemplo Dámon, o mestre de Péricles, banido por causa da sua inteligência.

${ }^{12}$ Sobre esta virtude - áv $\delta \rho \varepsilon i ́ \alpha$ - vide EN 1115a6-1116a10.

${ }^{13}$ Péricles corresponde, assim, ao exemplo do bom político, cujo ingresso na atividade é meticulosamente planeado (Moralia 798C, 799A); já Alcibíades tipifica aqueles que optam por esta carreira movidos por um impulso, pelas circunstâncias, ou simplesmente por vanglória (Moralia $798 \mathrm{C}-\mathrm{E})$.

${ }^{14}$ Plutarco (Moralia 804D) menciona que o povo acolhe melhor os políticos que iniciam a 
porque sabemos que também sobre ele incidiam suspeitas de tendência tirânica: é que, além de possuir as mesmas características suscetíveis de Péricles (família, riqueza e amigos), era senhor de um comportamento que, a cada passo, fazia recair sobre si a desconfiança de intenções de restaurar a tirania. Este comportamento sugere, por isso, a excelente opinião e a extraordinária confiança que Alcibíades tinha sobre si próprio. É caso para dizer que se achava, de facto, irresistível.

Mas a verdade é que o ingresso de Alcibíades na vida política não obedeceu a um propósito como no caso de Péricles. Por outras palavras, enquanto Péricles estabeleceu uma estratégia para esse efeito, Alcibíades limitou-se a ser conduzido por uma série de circunstâncias favoráveis ao início temporão da sua atividade pública.

Uma delas foi a influência daqueles a que Plutarco chama $\delta 1 \alpha \varphi \theta \varepsilon i ́ p o v \tau \varepsilon \zeta$, que, conscientes das forças que faziam mover Alcibíades - a $\varphi \imath \lambda o \tau \imath \mu i^{15}{ }^{15}$ e a $\varphi \imath \lambda o \delta$ o $\xi i ́ \alpha$, o convenceram de que as suas capacidades eram tais que desde logo iria ofuscar a fama dos outros generais, mas sobretudo (e até) a fama e o poder do próprio Péricles ${ }^{16}$. Não podemos deixar de abrir parêntesis para chamar a atenção para uma certa rivalidade que parece adivinhar-se por detrás da reação de Alcibíades, ainda que não sejamos capazes de justificá-la como consequência de mera ambição ou como ressentimento pelo facto de o tutor nem sempre ter estado disponível para lhe dar atenção (cf. Alc. 32. 3) ou de não lhe ter imposto os limites de comportamento necessários à educação de qualquer jovem (cf. supra p. 188).

Outro fator que contribuiu para o seu ingresso na vida política ativa prende-se à atividade militar: ainda adolescente, Alcibíades participa na expedição a Potideia ${ }^{17}$ (431 a.C.; Alc. 7. 3-5) e a Délio (424 a.C.; Alc. 7. 6). Importa salientar que, ao contrário do que se passa em relação a Péricles (sobre cuja atividade militar anterior à intervenção política propriamente dita nada se revela), o biógrafo não só enumera aquelas em que Alcibíades participou, como também revela pormenores a seu respeito. No entanto, essa atenção especial prende-se certamente ao facto de ambas as batalhas servirem para ilustrar

sua atividade de forma rápida e fulgurante, porque quebram a monotonia própria das carreiras mais tradicionais, de começo lento mas seguro.

${ }^{15}$ Este termo é recorrente na Vida de Alcibiades, onde surge por nove vezes (6. 4, 7. 5, 11.2, 12. 2-3, 16. 4-5, 24. 3, 27. 6, 34. 3, 39. 7), demonstrando, assim, a importância que o reconhecimento tinha para este Alcmeónida.

${ }_{16}$ Cf. Thuc. 6. 2. 4; Pl. Alc. 1. 105a-b, onde Sócrates afirma que o maior objetivo que Alcibíades tem na vida é conseguir que a assembleia dos Atenienses o considere superior a todos, especialmente superior a Péricles. Fica, assim, a impressão de que o filho de Clínias teria como objetivo suplantar as capacidades retóricas de Péricles, ou seja, de que Alcibíades se consideraria, como orador, superior ao primo. 205).

${ }^{17}$ Sobre esta batalha, a que Plutarco também faz referência em Per. 29. 6, vide Lewis (1992: 
melhor a relação que existia entre o jovem e Sócrates ${ }^{18}$, mais do que com o facto de chamar a atenção para as capacidades militares do Alcmeónida, que, de resto, até são postas em causa por parecer que as honras the foram dadas sobretudo em função do nome de família.

Plutarco aduz ainda outros fatores que anteciparam o início da vida ativa de Alcibíades: os seus donativos ao Estado (Alc.10.1) e a sua vitória olímpica (Alc. 11-12) ${ }^{19}$.

O episódio da oferta dos donativos ${ }^{20}$, tão revelador do caráter de Alcibíades, reveste-se de contornos de uma cena de comédia ${ }^{21}$. Aquela que deveria ter sido uma ação consciente, premeditada, como convém à primeira intervenção pública de alguém com os dotes naturais, família e capacidades oratórias do Alcmeónida, mais não é do que a reação intempestiva de quem orienta a sua vida pela sede de reconhecimento e aplausos e que, quando alcança o seu objetivo fica de tal forma siderado que se esquece de tudo o resto. A caça à codorniz, algo aparentemente sem importância, revela grande desrespeito para com as instituições ${ }^{22}$ : imagine-se o ridículo que é todos os «deputados» andarem a correr e a gritar atrás de uma ave em pleno parlamento! Mas, mais do que isso, configura um presságio do trágico fim de Alcibíades, já que é por

${ }^{18}$ Cf. Pl. Smp. 219e-221c; Isoc. 16. 29. O relato de Plutarco deixa transparecer o carinho e preocupação que uniam o filósofo e Alcibíades: quando este se viu em apuros, Sócrates não só o protegeu, como permitiu que recebesse os louros em seu lugar (batalha de Potideia); quando foi Sócrates a ver-se em apuros, em uma ocasião em que os Atenienses estavam em debandada, Alcibíades não hesitou em lutar ao seu lado (batalha de Délio). Não deixa de ser curioso notar que Coriolano recebeu uma condecoração pela coragem demonstrada ao salvar um companheiro, ao passo que Alcibíades, por ser salvo. Plutarco salienta, assim, a dificuldade que o romano tinha em lidar com as pessoas por oposição à facilidade que Alcibíades tinha em conquistá-las.

${ }_{19}$ A vitória em jogos pan-helénicos trazia ao vencedor honra e estatuto na cidade de origem e podia ser decisiva para a obtenção de um cargo político. Segundo Thuc. 4.121. 1, ao vencedor eram garantidas honrarias proverbiais, que passavam por uma procissão triunfal, por lugares privilegiados nas refeições públicas e festivais. Em Thuc. 6. 16. 2, Alcibíades refere a importância dessa vitória para Atenas em um discurso que profere por ocasião dos preparativos para a expedição à Sicília. Sobre este tema, vide Gribble (1999: 48-50); Kurke (1998: 131-163, particularmente 159 nota 40$)$.

${ }^{20}$ Como veremos adiante, quem quer singrar na carreira política recorre frequentemente a esse estratagema da distribuição de dinheiros pelo Estado e pela população. No entanto, no

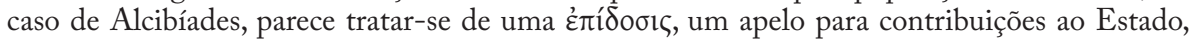
que ocorria na assembleia em tempo de crise. Teofrasto (Char. 22.3), a propósito do Forreta que, ao contrário de Alcibíades, tudo faz para não contribuir, dá testemunho da frequência dos peditórios públicos como forma de angariar, entre os cidadãos, fundos para obstar às dificuldades

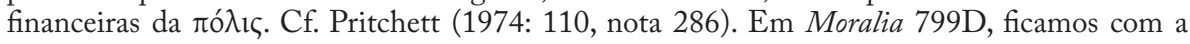
impressão de que o episódio narrado em Alc. ocorreu noutro contexto.

${ }^{21}$ Para uma análise detalhada dos pormenores cómicos deste episódio, vide Salcedo Parrondo (2005: 179-186).

22 Plutarco (Moralia 799D) afirma mesmo que tal episódio só foi possível por causa do caráter espirituoso dos Atenienses (cf. supra p. 116, nota 6), que no contexto dos Praecepta gerendae reipublicae, compara com o dos Cartagineses, povo mais opressor, oprimido e sisudo. 
causa de Antíoco ${ }^{23}$, o salvador da codorniz que o Alcmeónida acolhe como um amigo, que Atenas é derrotada.

O triunfo olímpico, por sua vez, está envolto em controvérsia. Alcibíades ficou conhecido por ser o único, de entre privados e soberanos, a concorrer com sete carros e por ter conseguido alcançar três prémios em simultâneo ${ }^{24}$. Estas vitórias provocaram a admiração dos Atenienses, mas em especial das cidades estrangeiras, como Quios, Éfeso e Lesbos, que lhe enviaram, respetivamente, uma tenda magnificamente ornada, alimentos para cavalos e vítimas para sacrifícios, e provisões para a sua mesa, já que Alcibíades recebia muita gente ${ }^{25}$. É provável que todo o empenho que depositou na participação desta prova se

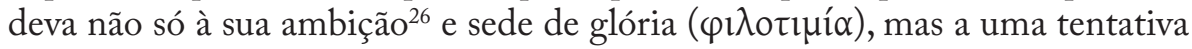
de homenagear e manter a tradição da sua família nas corridas de cavalos (iniciada por Alcméon) ${ }^{27}$. No entanto, como Plutarco refere - ainda que sem confirmá-los ou desmenti-los -, este triunfo ficou associado a rumores ${ }^{28}$ que maculam a glória de Alcibíades, mas que, devido ao caráter deste Alcmeónida, são muito plausíveis. Contudo, o que a nós importa é que fica no ar a suspeita de mais uma homenagem pouco merecida (como a que recebeu quando foi

\footnotetext{
${ }^{23}$ Apesar da amizade que o uniu a Alcibíades do início ao fim da vida política deste, o piloto Antíoco só é novamente referido no clímax da tragédia (Alc. 35). Cf. infra p. 255, nota 207.

${ }^{24}$ Além do primeiro e segundo prémios, terá alcançado, consoante as versões, o terceiro (segundo Isoc. 16.34 e ode atribuída a Eurípides) ou o quarto (de acordo com Thuc. 6. 16. 2).

${ }_{25}$ É importante recordar que Alcibíades viria a valer-se deste «reconhecimento internacional» para mostrar aos seus pares que a sua participação na vida política era uma mais valia para as relações de Atenas com as cidades vizinhas. Disso nos dá testemunho Thuc. 6.16-18, a propósito do debate sobre a Sicília, no qual Alcibíades afirma: «No que respeita àquilo que me fez objeto de tanta controvérsia, é matéria que trouxe honras aos meus antepassados e a mim, e também à nossa pátria». Segundo Thuc 1. 130. 1 - 132. 2, já Pausânias, o vencedor de Plateia, tivera um comportamento semelhante, a que Gribble (1999: 60) chama «syndrome of excessive selfvaluation». É pertinente chamar ainda a atenção para a grande distância que existe entre o comportamento de Alcibíades e o de Péricles: o primeiro participava em grandes banquetes (ora como convidado, ora como anfitrião), enquanto Péricles não recebia ninguém nem frequentava a casa dos outros. Sobre este assunto, vide infra p. 199 sqq.

${ }^{26}$ Ao passo que a ambição de Alcibíades é uma referência, se não constante, pelo menos muito vincada, até ao décimo sexto capítulo da sua biografia, a de Péricles é salientada por duas vezes. Uma ocorre em Per. 13. 11, onde se pode ler que foi por ambição política que Péricles instituiu concursos de música nas Panateneias; a outra, em Per. 11. 3, a propósito da luta que Péricles e Tucídides travaram pelo poder.

${ }^{27}$ Segundo Davies (1971: 12, 376, 379 e 381), do lado materno (portanto, da família dos Alcmeónidas), sagraram-se vencedores Mégacles IV e Mégacles V; do lado paterno, o bisavô Alcibíades I.

${ }^{28}$ Consta que a pedido do seu amigo Diomedes (que conhecia a sua influência em Argos), Alcibíades adquiriu um carro para que aquele pudesse realizar o sonho de participar nos Jogos Olímpicos. No entanto, o Alcmeónida acaba por ficar ele próprio com o carro e por se apresentar como concorrente nos jogos, o que causou a indignação do amigo. Este episódio deu, vinte anos depois (396 a.C.), origem a um processo contra o filho homónimo de Alcibíades, de que nos

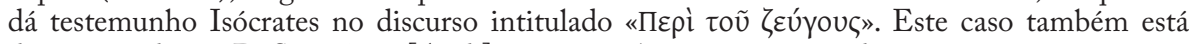
documentado em D. S. 13. 74 e [And.] 4.26, com ligeiras variações de pormenor.
} 
salvo por Sócrates, como se tivesse sido ele a salvar o filósofo - cf. nota 18, p. 196), o testemunho de uma capacidade inata para se aproveitar dos outros, da

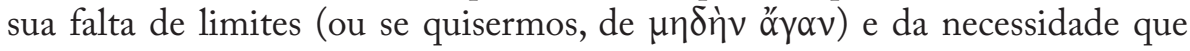
tinha de viver rodeado de luxo ${ }^{29}$ e riqueza. Além disso, é mais um elemento que corrobora a tendência tirânica do seu caráter, já que os Jogos Olímpicos eram, por excelência, uma das ocasiões em que os tiranos demonstravam o seu poder diante dos outros Gregos e já que quer os preparativos da prova quer os festejos foram excessivos a ponto de poderem ser comparados ao fausto persa ${ }^{30}$.

Vistos que estão os fatores que influenciaram o início da atividade política de Alcibíades, vejamos como se processou o de Péricles que, como já dissemos, começou por se dedicar à vida militar.

Da estratégia que Péricles pôs em prática, podemos depreender que o ingresso na atividade política implica a espera pelo momento oportuno, a procura de apoio na área oposta à do rival e uma alteração de comportamento para alcançar o objetivo em causa. Senão vejamos: apenas decidiu intervir quando os «dinossauros» da política daquele tempo já não estavam no ativo ${ }^{31}$. Assim, considerou que estavam reunidas as condições favoráveis quando Aristides morreu, Temístocles foi exilado e Címon se ausentou de Atenas em campanhas militares.

Mas não lhe bastava aproveitar essas circunstâncias. Era necessário encontrar o aliado certo, nem que para isso fosse obrigado a contrariar a sua própria natureza, que, segundo Plutarco (Per. 7. 4), era muito pouco populista ( $\varphi$ б́øı

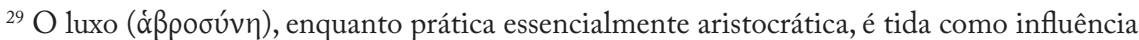
bárbara e feminina. Cf. Xenófanes fr. 3W.

${ }^{30} \mathrm{Cf}$. [And.] 4. 29-30. Sobre a relação entre a tendência tirânica e prestação olímpica de Alcibíades, vide Gribble (1999: 60-67, 136). Fica, mais uma vez, evidente que Alcibíades, ao contrário de Péricles, não tinha qualquer problema em ver o seu comportamento ser conotado com o de um tirano.

${ }^{31}$ Durante as cerca de duas décadas que se seguiram às batalhas de Maratona (490 a.C.), Salamina (480 a.C.) e Plateias (479 a.C.) - decisivas para esbater o perigo persa -, Aristides (ca. 540-468 a.C.) e Temístocles (ca. 528-462 a.C.) ocuparam posições de relevo na vida política de Atenas, pois tinham dado grande contributo para a derrota do inimigo: o primeiro alcançara a glória em Maratona; o segundo, além de ter sido o responsável pela organização da frota que viria a ser a mais poderosa da Grécia, tinha sido o comandante da batalha de Salamina, na qual Címon participou sob as suas ordens. Aristides, conhecido pelo seu sentido de justiça e rigor, foi incumbido da constituição de uma aliança entre Atenas e os seus aliados que tinha por objetivo fazer frente ao inimigo bárbaro: com a Simaquia de Delos, os Gregos pretendiam estar preparados para eventuais retaliações e libertar os muitos Helenos que ainda se encontravam sob o jugo do Rei. Durante esta fase, Aristides foi também o comandante da frota de Atenas. Só em 476 a.C. é que Címon, até então seu subordinado, o substituiu nesta função, passando a ausentar-se com mais frequência de Atenas. Quanto a Temístocles, depois de ter sido arconte em 493 a.C. (período no qual organizou a frota), não voltou a ser eleito para nenhum cargo importante e terminou os seus dias no exílio, acusado de se ter aliado aos Persas (472 a.C.). Vide Lewis (1992: 40-67). 
maioria popular à minoria dos ricos. Tal decisão revela grande racionalidade e controlo de si mesmo. A preferência pela fação popular mostrou ser a mais correta, porque, ao fazê-lo, Péricles conseguiu, ao mesmo tempo, garantir a sua segurança (evitando conotações com a tirania) e um apoio de peso contra o rival (pois Címon tinha a simpatia da aristocracia).

Importa, neste momento, refletir sobre a forma de agir de Péricles. À primeira vista, parece-nos que a alteração de comportamento em função de um objetivo a alcançar é uma capacidade que caracteriza os dois estadistas alcmeónidas em causa. No entanto, devemos ter em conta que, enquanto Alcibíades faz dessas alterações de comportamento um modo de vida, que parece ser-lhe inato, Péricles modifica a sua maneira de agir contrariado, mas pensando no bem comum. Demais, a mudança é passageira, funciona como meio para atingir um fim ${ }^{32}$, já que só se aproximou do povo para vencer Címon, que recorria a medidas demagógicas, como a distribuição de bens privados, ao que Péricles se viu obrigado a responder com a distribuição de bens públicos, porque, apesar de rico, era mais pobre do que o rival (Per.9.1-2).

Este tipo de comportamento não é muito desenvolvido por Plutarco na Vida de Péricles, o que é compreensível, já que o facto de o filho de Xantipo adotar medidas populares para subir ao poder constitui uma dificuldade para a caracterização do herói, que ele pretende apresentar como um dos melhores exemplos de estadistas de todos os tempos ${ }^{33}$. Na Vida de Alcibiades, pelo contrário, o biógrafo parece tratar o tema com mais à-vontade, como veremos adiante no capítulo relativo à atividade política propriamente dita dos dois estadistas.

A forma como Péricles encarava a vida política levou-o ainda a modificar - a título permanente - alguns hábitos de vida social, por entender que a exposição não se coaduna com a austeridade que deve caracterizar um verdadeiro político e que pode mesmo comprometer o respeito que o povo lhe tem (Per. 7. 5). Segundo Plutarco (Per. 7.6), isolando-se assim, pretendia conservar a admiração que se tem pela virtude daqueles cujos feitos são de renome, mas com os quais não privamos no dia-a-dia. Esta era uma prática corrente, sobretudo nas monarquias orientais. Segundo Hdt. 1. 99, Déjoces, um antecessor de Ciro, tem uma atitude semelhante ao cultivar, também ele, o isolamento como forma de impor autoridade.

Penso que este é um critério válido: todos sabemos que a familiaridade pode levar a situações de extremo à-vontade, o que aumenta a probabilidade de se cometer um deslize que macule a opinião que os outros fazem de alguém. E isso sobretudo no caso de figuras públicas - como os políticos. Ainda nos

${ }^{32}$ Sobre a posição de Plutarco a respeito da relação entre meios e fins, vide supra p. 169, nota 46.

${ }^{33}$ Cf. Stadter (1987: 251-269). 
nossos dias há a preocupação de julgar as capacidades e os atos políticos com base na vida privada, inclusivamente de atribuir decisões políticas importantes à necessidade de esbater os comentários sobre "pequenos» tropeços da vida familiar ${ }^{34}$. Assim, quanto menor fosse o tempo de exposição no convívio com as massas - talvez também Péricles o pensasse -, menores seriam as possibilidades de ser apanhado em falso e de perder o respeito que por ele sentiam (o que é importante sobretudo em início de carreira) ${ }^{35}$.

Consequentemente, Péricles só era visto na rua a fazer o percurso casatrabalho-casa e deixou de participar em banquetes, mesmo os que eram oferecidos pela família ${ }^{36}$. Diz-nos o biógrafo que apenas abriu uma exceção por ocasião do casamento do primo, Euriptólemo; mas, mesmo nessa altura, só ficou até ao final das libações. Plutarco justifica esta atitude com o argumento de que as festas não facilitam a manutenção da dignidade e de que o convívio torna difícil conservar a seriedade que leva à boa reputação ${ }^{37}$.

Assim, Péricles põe ao serviço da democracia uma atitude fortemente aristocrática, já que se nota uma certa aversão pelo convívio popular. Mas, por outro lado, esta atitude em exagero tem os traços do arrogante que Teofrasto descreve no capítulo 24 de Carateres...

${ }^{34}$ Cf. Per. 31-32, onde a eclosão da Guerra do Peloponeso se justifica, segundo alguns, pelo facto de Péricles não ter cedido às exigências dos Lacedemónios como forma de dispersar as atenções das acusações feitas contra Fídias, Aspásia e Anaxágoras. Os comediógrafos partilhavam desta perspetiva: Ar. Ach. 524-527 atribui esse mesmo acontecimento ao rapto da prostituta de Aspásia; Cratino, em Nemesis (430-429 a.C.), narra a união de Zeus (Péricles) e Némesis (Aspásia), da qual resulta Helena e responsabiliza Péricles pelo desencadear da Guerra do Peloponeso, já que este apareceria disfarçado de Zeus para levar a cabo os seus intentos. Sobre este assunto, vide infra pp. 212 e 244 sq.

${ }^{35}$ Como afirma Connor (1971: 121-122), «this was a means of winning the support of the demos of the city. There are perhaps two ways in which such a restraint contributed to obtaining that support. The first is by presenting Pericles as the indispensable expert in the complexity of public business; the second is by presenting him as an impartial public servant, without dangerous obligations to philoi.» Sobre este assunto, consulte-se ainda Humpreys (1983: 24).

${ }_{36}$ Segundo Plu. Nic. 5, Nícias adotou uma postura próxima da de Péricles, já que era circunspeto em relação aos sicofantas, não jantava com cidadãos, não se relacionava com ninguém no dia-a-dia e não consagrava tempo ao lazer. Também era difícil de abordar, pois, quando não estava no trabalho, estava em casa. A sua dedicação ao trabalho foi de tal ordem que deixou de tomar conta dos seus assuntos pessoais (nisto, diferente de Péricles, cf. Per. 16. 3 - vide infra pp. 252-253), perdeu a fortuna, os amigos e agravou o seu já débil estado de saúde. Conta que fazia correr o rumor de que levava essa vida infeliz por causa da sua grande dedicação à cidade. Nícias era, portanto, o inverso da maioria dos demagogos do seu tempo que se aproveitavam da tribuna para fazer amigos e enriquecer. Sobre este comportamento pouco sociável e democrático, vide etiam Nic. 11. 2. Em Moralia 823C, Plutarco elogia aqueles que, como Nícias e Péricles, se preocupam continuamente com os assuntos públicos e consideram a política não um passatempo, mas um modo de vida.

${ }^{37}$ Em Moralia 800B-D, volta a referir-se a esta alteração no comportamento de Plutarco, que considera prudente, na medida em que os políticos têm de prestar contas da sua vida pública e privada (aparência, amores, diversões, alimentação), aspetos esses que também são responsáveis pela admiração ou aversão que o povo lhes dedica (800F-801A). 
Mais uma vez é espantoso o contraste entre o comportamento de Alcibíades e o de Péricles. O filho de Clínias não abdicava do convívio social e da participação em faustosos banquetes; também não tinha qualquer moderação no que respeita aos excessos que costumam caracterizar esses convívios, como a embriaguez. Além disso, não dava mostras de se preocupar muito com o que o povo dizia a seu respeito. Enquanto Péricles evitava andar na boca dos populares por motivos que não estivessem relacionados com a causa pública, Alcibíades parecia fazer questão de ser tema de conversa, como o próprio afirma a propósito do cão cuja cauda cortou ${ }^{38}$. Não surpreende, por isso, que a enorme popularidade de Alcibíades se tenha vindo a transformar em impopularidade ${ }^{39}$.

Quanto a Péricles, além das precauções já referidas, procurou evitar que o povo se saturasse da sua intervenção. Nesse sentido, apenas se aproximava dele a intervalos, porque evitava falar sobre qualquer assunto e estar constantemente a aparecer em público; guardava-se para ocasiões importantes e as demais resolvi-as por meio de amigos e outros oradores ${ }^{40}$. O Queroneu defende esta conduta do estadista, por considerar que ninguém tem condições de fazer sozinho tudo o que é necessário para o bom funcionamento da vida de um Estado. O que importa é que se tenha a capacidade de trazer todos os assuntos controlados e de delegar funções, reservando para si as tarefas mais importantes ${ }^{41}$. Péricles, se vivesse nos nossos dias, daria um excelente consultor de imagem para os políticos, pois sabia geri-la muitíssimo bem, analisando corretamente os prós e os contras de um aparecimento excessivo, e, mais importante, escolhendo o momento oportuno para as suas intervenções.

Como é óbvio, Péricles, mesmo tendo esperado pelo momento mais oportuno para o início da sua carreira, deparou-se com forte oposição,

${ }^{38}$ Alc. 9.

${ }^{39}$ Este tema está desenvolvido adiante na página 230.

${ }^{40}$ Em 812C-D, o Queroneu defende a existência daquilo a que hoje chamaríamos «ministros» (que deveriam ser leais, honestos e ter funções correspondentes às suas capacidades) para aumentar a eficácia da gestão, do mesmo modo que o facto de a mão ter cinco dedos não limita mas amplia as suas capacidades. Apresenta como exemplo deste modelo a atuação de Péricles, que confiou o comando dos exércitos a Menipo (Per. 13. 15), a redução dos poderes do Areópago a Efialtes (Per. 9. 5; Arist. Ath. 25); a aprovação do Decreto de Mégara a Carino (Per. 30. 3) e a fundação da colónia em Túrios a Lâmpon (Per. 6. 2-3, 11. 5). Aristides, por seu turno, também apresentou algumas propostas através de terceiros, mas o seu objetivo era evitar que Temístocles não as contestasse por causa da sua origem (Plu. Arist. 3. 4). Abordaremos o tema dos amigos de Péricles mais à frente (p. 236 sqq), quando tratarmos da ação política propriamente dita, já que os principais acabaram por ser perseguidos pelos inimigos do estadista.

${ }^{41}$ Em Moralia 811D, Plutarco evoca o filósofo peripatético Critolau (século II a.C.), segundo o qual o político só deve intervir quando a importância das questões assim o exijam, do mesmo modo que as naus Salamínia e Páralo estavam reservadas a missões oficiais do Estado. Cf. Plu. Per. 7. 7. Neste contexto, o biógrafo refere ainda um passo de uma tragédia desconhecida de Eurípides (fr. 974 Nauck), onde se pode ler que os deuses também só se ocupam dos assuntos mais importantes, deixando as questiúnculas nas mãos do destino. 
sobretudo até atingir a supremacia. Vejamos, por isso, como procedeu para conquistar e afirmar o seu espaço na cena política.

O seu maior rival começou por ser Címon, que, como já dissemos, recorria a medidas demagógicas (como a distribuição de bens privados) para conquistar o povo, o que fez com que Péricles executasse uma série de medidas favoráveis ao demos - como a instauração da mistoforia ${ }^{42}$. Por isso, quando aquele regressou das campanhas militares além fronteiras, o jovem filho de Xantipo viu-se forçado a tentar afastá-lo da cena política. Ainda que esta afirmação possa sugerir uma certa deslealdade da parte de Péricles, o certo é que - sobretudo por comparação com o comportamento de Alcibíades em situação similar ${ }^{43}$ - agiu com grande dignidade, «às claras», recorrendo a um instrumento consagrado pela lei, o ostracismo, e à grande influência que tinha sobre o povo. Conseguiu, assim, que o rival fosse desterrado sob a acusação de laconismo ${ }^{44}$, em 461 a.C. No entanto, não se tratou de uma vitória definitiva: é que mesmo antes de o exílio daquele ter chegado ao fim, o bom-senso de Péricles fê-lo satisfazer a vontade da população, que exigia o regresso de Címon, na sequência da derrota de Tanagra ${ }^{45}$. Consta que terá sido o próprio Péricles a redigir o decreto que permitia o regresso do

${ }^{42}$ Vide infra pp. 218-219.

${ }^{43}$ Vide infra pp. 205-206.

${ }^{44}$ Címon foi acusado de laconismo por causa da admiração que nutria por Esparta, bastante compreensível se tivermos em conta que era um antidemocrata saudosista da oligarquia aí vigente. $\mathrm{O}$ irmão de Elpinice não negava essa condição, antes pelo contrário: segundo Plu. Cim. 14. 4, assume-se como próxeno da Lacedemónia. O biógrafo conta que os filhos dele, além da origem lacedemónia tinham nomes lacedemónios, facto que o próprio Péricles utiliza como arma de ataque contra o opositor e respetiva prole (Per. 29.1-2 - cf. infra p. 277, nota 306). Por isso, Címon procurava auxiliar os Espartanos em questões militares, valendo-se da aliança que ambos os povos haviam celebrado aquando das Guerras Médicas. Mas Atenas, que se sentia cada vez mais confiante no seu poder, já não estava muito interessada em manter o pacto - basta lembrar que Efialtes tentou impedir (embora sem êxito) que Címon partisse para a Messénia em auxílio dos Lacedemónios em 462 a.C. A insistência de Címon acabou por ser a sua própria desgraça: consta que as tropas sob o seu comando não tiveram o desempenho que os Espartanos esperavam. Como estes começavam a temer o poderio de Atenas, pensaram que essa «falta de êxito» era propositada e dispensaram as forças atenienses. A autoridade de Címon ficou desacreditada e, quando ele tentou opor-se à reforma do Areópago, não foi difícil acusá-lo de laconismo e votá-lo ao ostracismo. Vide Lewis (1992: 69-72).

${ }^{45} \mathrm{Na}$ primavera de 457 a.C. (cf., e. g., Thuc. 1.107.2 - 108.1), os Espartanos tinham partido em socorro da Dórida que fora atacada pela Fócida. Cumprido o intento, no regresso a casa, foram atacados em Tanagra pelos Atenienses, que suspeitavam das intenções dos Lacedemónios: temiam um ataque dos defensores da oligarquia, incitado pelos antidemocratas de Atenas. Címon apressou-se a combater ao lado dos concidadãos, mas foi prontamente afastado da refrega pelos aliados de Péricles. Este por sua vez, teve uma excelente prestação, que não foi suficiente para que os Atenienses alcançassem a vitória. Stadter (1989: 123) considera que a participação de Péricles nesta batalha talvez seja invenção de Plutarco. Nessa altura, o povo, que já contava com a continuação da guerra na primavera seguinte, mostrou-se arrependido por ter permitido o afastamento de Címon. E o certo é que, quando este regressou, foi o responsável pela paz, por causa da simpatia que os Lacedemónios tinham por ele. 
rival, depois de, ao que parece, ter firmado um acordo com a irmã daquele ${ }^{46}$, segundo o qual Címon iria comandar o exército no exterior para conquistar o território do Grande $\mathrm{Rei}^{47}$, enquanto Péricles ficaria a exercer o poder na cidade (Per.10.5).

Plutarco conta ainda que já anteriormente Péricles havia poupado Címon, em uma altura em que «enfrentava uma acusação capital» ${ }^{48}$. É que, eleito acusador do adversário, Péricles ter-se-ia limitado a cumprir a sua função, sem tirar partido da conjuntura ${ }^{49}$. É certo que as más línguas insinuam que tal benevolência terá resultado dos pedidos feitos por Elpinice ao general, mas o biógrafo sugere que o estadista recusou o que quer que ela lhe tenha oferecido em troca.

Depois da morte de Címon (ca. 450 a.C.; Per. 10. 8), por ocasião da campanha em Chipre, Péricles tornava-se, pela segunda vez (a primeira correspondia ao exílio de Címon), o mais poderoso dos cidadãos, mas foi de imediato confrontado com o aparecimento de um novo rival, Tucídides de Alópece ${ }^{50}$. Este era apoiado pelos aristocratas que queriam evitar que o regime

${ }^{46}$ Desconhece-se a fonte desta anedota, que pode ser uma versão modificada de uma outra da autoria de Antístenes. Este autor, entre outras alusões mordazes que faz à vida sexual de Péricles, afirma que Elpinice teve de pagar o preço do regresso do irmão (Ath. 589e). Sobre este tema, vide infra p. 241, nota 152 .

${ }^{47}$ De acordo com Plu. Cim. 18. 1, este teria assumido voluntariamente a tarefa na tentativa de evitar a guerra entre os Gregos. Em Moralia 812E, pode ler-se que Péricles optou por repartir o poder com Címon por ter uma natureza mais apta para a política enquanto o rival era mais dotado para as questões bélicas. A alusão a esta partilha de poder é mais um dos muitos exemplos que o biógrafo apresenta para confirmar a tese de que o bom político sabe delegar funções. Sobre este assunto, vide supra p. 201, nota 40. No entanto, em Phoc.7.5-6, Plutarco elogia os estadistas que, como Péricles, são senhores de qualidades políticas e militares.

${ }^{48}$ Em Cim. 14. 3-5, o Queroneu, com base em Estesímbroto (FGrHist 107 F 5), conta que este incidente teve lugar depois da redução de Tasos (ca. 463 a.C.). Nesta altura, acusaram-no de ter aceitado subornos para não atacar a Macedónia.

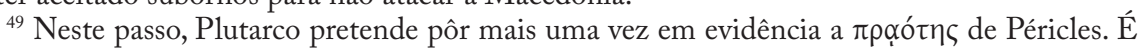
provavelmente por essa razão que o relato do episódio assume contornos totalmente diferentes consoante a personagem que é objeto de biografia: aqui, o Queroneu sugere que Péricles deu pouca importância à oportunidade de prejudicar o adversário; porém, em Cim. 14. 5, afirma que aquele soube tirar partido das circunstâncias em benefício da sua carreira. $\mathrm{Na} \mathrm{Vida} \mathrm{de}$ Címon, Plutarco parece partilhar da opinião de Aristóteles (Ath. 27. 1), que faz coincidir o acontecimento com a primeira vitória política de Péricles antes de se tornar líder dos populares. Sobre este assunto, vide infra p. 205, nota 57.

${ }^{50}$ Tucídides, filho de Melésio, foi um orador exímio, escolhido pelos aristocratas para ocupar o lugar que a morte de Címon - de quem era parente por afinidade - deixara vago na oposição a Péricles. Apesar de ter sido uma figura importante na política da década de 440 a.C., pouco se sabe a seu respeito, sobretudo porque foi muitas vezes confundido com homónimos, nomeadamente o historiador. Uma das suas principais tentativas para derrubar a influência do estadista, que crescia visivelmente a cada dia, consistiu no ataque ao programa de reconstrução da cidade. No entanto, o único poder que conseguiu abalar foi o seu próprio, já que acabou votado ao ostracismo, deixando o caminho livre para o seu adversário e para o florescimento da democracia. Segundo Diógenes Laércio, terá sido Tucídides a acusar Anaxágoras de impiedade (vide infra p. 248, nota 180), por rivalidade contra Péricles. 
se convertesse por completo em uma monarquia. Desta feita, criou-se um equilíbrio de forças políticas que conduziu à cisão da população em duas fações: a do povo e a oligarca. Foi então que o filho de Xantipo recorreu novamente ao favorecimento do povo para consolidar a sua posiçãa ${ }^{51}$, mas só entre 444/443 a.C. (consoante as versões) conseguiu que Tucídides fosse votado ao ostracismo e que a oposição fosse dissolvida (Per.14.3), tornando-se, ainda que dentro dos limites legais, no homem mais poderoso de Atenas ${ }^{52}$.

Vejamos, agora, qual foi o comportamento de Teseu e Alcibíades para com os seus adversários.

Teseu tinha, por assim dizer, dois grandes rivais: o pai, que ocupava o trono, e os seus cinquenta primos, que esperavam com ansiedade a morte de Egeu para se tornarem senhores de Atenas. A versão que Plutarco narra é aquela que podemos considerar politicamente correta: Teseu comete um parricídio involuntário ${ }^{53}$, ao ser o móbil do falecimento do pai, mas, porque não suja diretamente as mãos, não desencadeia o castigo divino e fica ilibado de uma culpa que o impediria de exercer o poder. Embora Alcibíades não tenha feito nada de parecido, é difícil não associar a esta ação do fundador o facto de um dos motivos que antecipou o ingresso de Alcibíades na vida ativa ter sido o seu desejo consciente de rivalizar com um «antepassado», Péricles, do mesmo modo que, em outros contextos, fizeram Ciro, em relação ao avô, e Rómulo, ao tio-avô.

É, porém, sobretudo relativamente aos Palântidas que se nota que a opção de Plutarco por uma determinada versão da história responde a objetivos específicos de construção da biografia em causa ${ }^{54}$. O Queroneu queria fazer passar a ideia de uma evolução política tranquila em Atenas (cf. Thes. 24. 2), pelo que não the convinha relacionar a morte dos Palântidas com o sinecismo (cf. Apollod. Epit. 1. 11). Por conseguinte, situa a vitória de Teseu sobre os Palântidas (que sonhavam impedir o acesso dos descendentes de Egeu ao poder) logo a seguir ao reconhecimento e não menciona que, por causa da morte dos primos, o jovem teve de se submeter a rituais de purificação e ao julgamento delfínio ${ }^{55}$ que o absolveu.

${ }^{51}$ Vide infra p. 221.

${ }^{52}$ De um modo geral, aponta-se como data do ostracismo de Tucídides, filho de Melésio, o ano de 443 a.C., pois em Per. 16. 3, Plutarco afirma que a supremacia de Péricles se prolongou por quinze anos após este acontecimento. No entanto, esta data não é aceite sem controvérsia: se admitirmos que o último ano de Péricles no poder é o da sua deposição (outono de 430 a.C.), então o ostracismo de Tucídides foi votado no início de 444 a.C.; se considerarmos que Péricles só abandona o poder com a morte (novamente reeleito estratego na primavera de 429 a.C.) a data é, de facto, 443. Cf. Lewis (1992: 474, n. 7).

${ }^{53}$ Tal como Édipo. Vide supra p. 69

${ }^{54}$ Moralia 112D e 607A confirmam o conhecimento de outras variantes da história, o que confere maior significado à versão que o biógrafo segue na Vida.

${ }^{55}$ Cf. supra p. 66, notas 72 e 73 respetivamente. 
Deste modo, Plutarco reforça a ideia de um progresso civilizacional e cívico, já que Teseu se limita a vencer os inimigos, sem os matar, assumindo assim um comportamento civilizado ${ }^{56}$.

É certo que o próprio Alcibíades não chegou a matar ninguém, mas o seu comportamento para com os adversários foi muito menos ético do que o de Teseu e o de Péricles ${ }^{57}$. Quando se lançou na carreira política, Alcibíades conseguiu, com facilidade e de acordo com as previsões daqueles que o incitaram a ingressar na vida ativa, obscurecer os demais oradores, ainda que dois the tenham oferecido maior resistência: Féax $^{58}$, um jovem também ele em início de carreira (mas relativamente ao qual Plutarco faz questão de salientar uma ascendência quando este regressou e qualidades, inferiores às de Alcibíades sobretudo no que respeita à oratória), e Nícias, um general de idade avançada (Alc. 13.1).

Nícias e Alcibíades acabaram por se tornar nos principais representantes de cada um dos partidos. Juntos, deram provas de que os políticos de um modo geral - e desde tempos imemoriais - embora sejam adversários na cena, sempre que sentem o seu lugar ameaçado, se aliam para tentar evitar perdê-lo.

Segundo o relato de Plutarco (Nic. 11, Arist. 7. 3-4, Alc. 13. 4-9), estabeleceram uma espécie de pacto de regime quando descobriram que um deles estava na iminência de ser condenado ao ostracismo ${ }^{59}$ : Alcibíades, por causa da vida que levava e da sua desfaçatez; Nícias, porque além de a sua riqueza causar inveja, tinha um comportamento pouco social e pouco democrático. Unidos, conseguiram fazer de Hipérbolo ${ }^{60}$, um homem sem

${ }^{56}$ Vide supra p. 57. Recorde-se, ainda, que a luta de Teseu com os bandidos que infestavam o caminho por terra para Atenas se reveste de contornos semelhantes: o jovem só atacava para se defender e recorria aos mesmos meios que eram utilizados contra os viajantes; não aproveitava para dar largas a uma violência gratuita (cf. supra pp. 56 e 64).

${ }^{57}$ Embora Plutarco se recuse a atribuir a Péricles qualquer responsabilidade pela morte do seu amigo Efialtes e saia em sua defesa, não deixa de referir que Idomeneu havia acusado o estadista de, por inveja e ciúmes da reputação, ter matado o companheiro de política (Per. 10. 7). Esta é, sem dúvida, uma das ocasiões em que o biógrafo apresenta o Alcmeónida como um ser humano imperfeito, que poderia cometer alguns erros, mas jamais tão hediondos: $\pi \alpha ́ v \tau \eta\rceil$

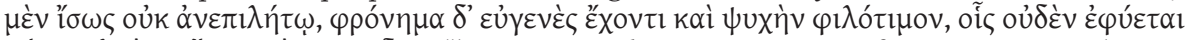

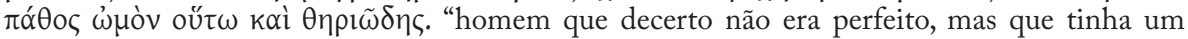
espírito nobre e alma sedenta de glória, onde uma paixão tão cruel e selvagem não teria lugar." Parece-nos que tal calúnia seria mais plausível se o visado fosse Alcibíades, não porque haja relatos de que tenha cometido crimes desta natureza, antes porque o seu espírito era mais permeável a reações apaixonadas.

${ }^{58}$ Consta que Féax terá redigido um «Contra Alcibíades», onde acusa o Alcmeónida de abuso de poder, por usar no dia-a-dia vasos de ouro e de prata propriedade da ró $\lambda_{\imath \varsigma}$. Cf. Alc. 13. 3. Sobre este jovem de boas famílias, vide Thuc. 5. 4-5; Ar. Eq. 1377.

${ }^{59}$ Alc. 13.7 é o único dos textos em causa a incluir Féax no rol dos «candidatos» a ostracismo.

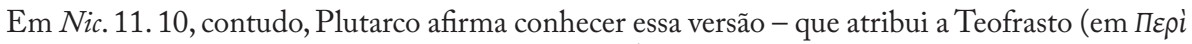
vó $\mu \omega \nu$, segundo o escoliasta do Tímon de Luciano) - mas admite preferir a versão que narrou, que é a da maioria. Vide Carcopino (1935: 206-239); Vanderpool (1970: 28-29).

${ }^{60}$ Sobre a figura de Hipérbolo, vide Nic. 11.3-4. Também Hipérbolo não escapou à sátira 
mérito mas que vinha ganhando influência em razão da sua audácia (e que estava empenhado em que ou Nícias ou Alcibíades fosse exilado), o último alvo do ostracismo. De facto este era um instrumento que até então sempre fora aplicado sobre pessoas que, pelo seu mérito, incomodavam os pares e não sobre pessoas indignas ${ }^{61}$. Não era uma reação a comportamentos imorais ${ }^{62}$, antes à grandeza de alguém que se destacava de entre os seus pares; mais do que um castigo, era uma estratégia para prevenir a ameaça que muitas vezes os indivíduos de natureza superior representam na rivalidade política ${ }^{63}$. Por isso, quando o povo tomou consciência da degeneração deste mecanismo, resolveu não mais aplicá-lo.

É certo que também podemos analisar este episódio de uma perspetiva mais positiva: em troca de alguém que não fazia grande falta, permanecem ativos à frente do governo da cidade dois homens com valor. O que é sobretudo condenável é que o exílio de Hipérbolo tenha sido orquestrado por quem não queria perder o poder.

Ora, uma vez ultrapassado o problema da ameaça de ostracismo, Alcibíades continuou a ter de lidar com Nícias como seu adversário na cena política. Tratava-se para o Alcmeónida de uma situação penosa, já que o facto de o general ser apreciado e admirado pelo povo - e sobretudo pelo inimigo estrangeiro - era algo que mordiscava a sua vaidade pessoal e o impedia de satisfazer a sua $\varphi \imath \lambda o \pi \rho \omega \tau \varepsilon i ́ \alpha$. O apreço que os Lacedemónios nutriam por Nícias foi intensificado pelo protagonismo do general na celebração das tréguas conhecidas por Paz de Nícias e pelo facto de lhes ter devolvido os prisioneiros de Pilos ${ }^{64}$.

Como bem no-lo testemunha a nossa própria experiência enquanto seres humanos, a inveja não é o melhor incentivo para a prática de boas ações. Não

política da comédia, que explorou quer a sua vida pública, quer a privada (cf. Ar. $N u$. 551-558). Foi atacado por ser um político «nova-vaga», de origem social duvidosa e pouco culto (mal sabia soletrar - Eup. fr. 193 K.-A), ou seja, que preenchia todos os requisitos para essa atividade, no contexto que se seguiu à morte de Péricles. Por conta da sua ascendência, foi apelidado de «mercador de lanternas» (já que foi essa a profissão do seu pai, Antífanes - cf. Ar. Eq. 739, Nu. 1065; Pax 690), foi apresentado como um estrangeiro (talvez por não provir das classes que até então forneciam homens de Estado) e viu a sua paternidade posta em causa. Plutarco fala deste indivíduo com algum desenvolvimento em Alc. 13. 4-9 e Nic. 11. Cf. Connor (1971: 163-169).

${ }^{61}$ A este propósito, Plutarco (Alc. 13. 9) cita três trímetros de Platão Cómico (fr. 187 K.-A.), que condenam a aplicação do ostracismo a Hipérbolo. Arist. Pol. 1284a15-20 afirma que os estados democráticos, que buscam a igualdade acima de todas as coisas, instituíram o ostracismo para afastar, por períodos fixos de tempo, todos os que se revelavam especialmente poderosos por causa da sua riqueza (Plu.Arist.1.2) ou popularidade, ou por qualquer outra forma de poder político (Plu. Them. 22. 4-5).

${ }^{62}$ Ainda que [And.] 4.33 apresente, como causa para o ostracismo de Címon, o facto de este manter relações incestuosas com a irmã Elpinice.

${ }^{63}$ Cf. Plu. Arist. 7. 2.

${ }^{64}$ Plutarco desenvolve este tema em Nic. 9. 
admira, por isso, que Alcibíades tenha, nessa altura, começado (pela primeira vez em contexto político) a ter comportamentos excessivos e censuráveis e a revelar-se alguém capaz de tudo para atingir os seus propósitos. É essa falta de moderação e de escrúpulos que distingue a sua ação da de Péricles e Teseu, que sempre demonstraram um mínimo de respeito pelo adversário político ${ }^{65}$. Nícias, que ainda há pouco havia sido seu aliado para o afastamento de Hipérbolo algo que, como vimos, ocorreu igualmente em um contexto pouco edificante -, torna-se em um inimigo a abater e vai ser alvo da perfídia do Alcmeónida.

Assim, por se sentir preterido pelos Espartanos (ele que até era conhecido pelo seu filolaconismo ${ }^{66}$ ) apesar de ter cuidado dos que tinham sido feitos prisioneiros em Pilos, opôs-se, desde o início, às tréguas celebradas e tudo fez para incitar o povo, descontente com algumas atitudes dos Lacedemónios, a retomar o conflito. A sua estratégia passava por minar a credibilidade de Nícias, principal guardião da paz homónima ${ }^{67}$. Foi nesse contexto que Alcibíades aproveitou a presença de uma embaixada espartana em Atenas para, por meio de uma intriga maquiavélica, destruir a confiança dos Atenienses - mais do que a dos Lacedemónios - em Nícias. A concretização do seu plano só foi possível, porque os Espartanos

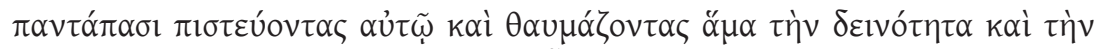

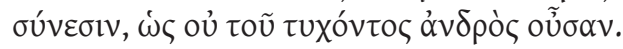

\footnotetext{
${ }^{65}$ Péricles não foi alheio a rivalidades e ambições. A sua disputa com Tucídides e com Címon foi acérrima, mas «limpa», honesta. Enquanto acusador de Címon, não aproveitou a oportunidade para prejudicá-lo. Limitou-se a cumprir o seu papel de testemunha, sem cair na tentação de beneficiar do momento oportuno. É essa a postura que o biógrafo defende em Moralia 810A: o homem de Estado deve testemunhar a favor dos seus adversários nas causas justas e socorrê-los nos processos frente aos seus delatores e não dar crédito a calúnias que são alheias à tendência política: é que (acrescenta em Moralia 816A) o que mais honra uma magistratura é a concórdia e amizade entre colegas. Do mesmo modo, quando sentiu que o povo ansiava pelo regresso de Címon, foi o próprio Péricles que propôs o fim do exílio do rival. Tal comportamento merece da parte do biógrafo um comentário que estabelece a cisão entre os «verdadeiros» políticos e provavelmente os da sua época; o certo é que também se aplica à diferença que existe entre os dois Alcmeónidas. Em Cim. 17. 9, Plutarco afirma que, no tempo do irmão de Elpinice (e, portanto, de Péricles), as inimizades políticas eram moderadas e cediam facilmente ante o interesse geral e que até mesmo a ambição $(\varphi \imath \lambda o \tau \iota \mu i ́ \alpha)$ cedia às necessidades da pátria. Esta afirmação pode ser ilustrada pela relação que existia entre Aristides e Temístocles, através de dois eloquentes passos de Plutarco. Em Moralia 809B, o biógrafo, além de afirmar que toda a atividade política suscita inimizades e dissensões, chama a atenção para a maturidade do comportamento de Temístocles e Aristides, que deixavam a sua inimizade nas fronteiras de cada vez que participavam em uma embaixada ou saíam à frente do exército e voltavam a retomá-la no regresso. Em Arist. 25. 10, Plutarco conta que Aristides, apesar de já ter sido vítima da conspiração do seu inimigo figadal, Temístocles, não o atacou quando a fortuna se virou contra este.

${ }^{66}$ Alc. 14. 1. Cf. Thuc. 5. 43-44, 6. 89. 2. Sobre este tema vide infra p. 257 e Daux (1937: 117-122); Hatzfeld (1940: 74).

${ }^{67}$ Aristóteles, ainda que não aluda diretamente a este episódio, critica o político que, na flor da idade, se intromete em todos os assuntos por insaciável desejo de glória ou inveja dos que com ele partilham o poder na cidade (EN 1142A10-15, Top. 116b29-30793c-d).
} 
"tinham inteira confiança nele, admiravam a sua habilidade e inteligência e consideravam-no um homem excecional. ${ }^{68 \text { " }}$

Nícias, apanhado de surpresa, não conseguiu reverter a situação e foi destituído (ainda que não lhe tenha sido aplicado nenhum castigo); Alcibíades, por sua vez, foi, finalmente, eleito estratego e recomeçou a guerra ${ }^{69}$. Em Alc. 15. 2, Plutarco afirma abertamente que ninguém aprovou a conduta do Alcmeónida. No entanto, como Atenas tirou dela benefícios, também não houve quem se lhe opusesse. Alcibíades sai, assim, mais uma vez, impune e recompensado por um feito que apenas deveria merecer a recriminação geral: é que um político que se preze não pode pautar a sua ação por motivos tão baixos como a vingança pelo orgulho $(\varphi \rho o ́ v \eta \mu \alpha)$ ferido. Contudo, trata-se de um comportamento habitual naqueles que têm uma "grande natureza» ${ }^{70}$ sempre que sofrem uma contrariedade ou desconsideração - nessa altura, sentem necessidade de empreender uma vingança proporcional ao seu descontentamento, sem ter em conta que além dos visados, toda a comunidade pode vir a sofrer as consequências do seu capricho.

Podemos, assim, afirmar (de acordo com o relato de Plutarco,) que Péricles tem para com os rivais um comportamento mais próximo do do fundador de Atenas do que Alcibíades.

$\mathrm{Na}$ sequência da reflexão que temos vindo a fazer ao longo das últimas páginas, parece-nos pertinente concluir que a pertença a uma mesma família apenas tem como implicação o acesso a valores que de outro modo lhes seriam inacessíveis: educação, riqueza, círculo de amigos influente e a tradição da casa dos Alcmeónidas (sobretudo no que respeita a feitos políticos e militares). É certo que podemos acrescentar a este rol de benefícios, a transmissão de características inatas (como a habilidade militar e política), mas não mais do que isso. Toda a restante ação de cada um dos nossos protagonistas resulta da soma das suas próprias qualidades e defeitos (que os individualizaram desde a infância) com a conjuntura do momento em que viveram.

No caso específico de Alcibíades, é ainda possível colocar a hipótese (que Plutarco parece não equacionar) de a sua conduta ter sido influenciada pelo facto de não ter sido criado pela família mais próxima, já que o pai faleceu quando tinha cerca de cinco anos. Após tal acontecimento, teve Péricles como tutor, o que, como já vimos, não terá sido uma mais-valia, pois o grande estadista

\footnotetext{
${ }^{68}$ A grande consideração que os Lacedemónios pareciam nutrir por Alcibíades vai revelar-se importante para a sua opção por viver exilado em Esparta. Vide infra pp. 232 e 286.

${ }^{69}$ Cf. Nic. 10. 4-9, Alc. 14. 3 - 15. 1.

${ }^{70}$ Este conceito foi apresentado supra p. 186. Não foi apenas contra Esparta que Alcibíades se virou. Quando exilado, também Atenas irá sofrer as consequências da sua revolta. Vide infra p. 254.
} 
não foi bem sucedido nem na educação dos próprios filhos. Fica, portanto, a impressão de que a família apenas consegue dar um pequeno contributo para a vida dos que nascem no seu seio ${ }^{71}$. São sobretudo as suas qualidades e defeitos e o modo como encaram a própria existência (muitas vezes influenciado pela educação recebida e diferentes conjunturas) que determinam a ação do homem de Estado.

${ }^{71}$ Cf. supra p. 159 , nota 2. 


\subsection{A ação política}

«O cargo dá a conhecer o homem.»

Segundo Aristóteles (Pol.1253a, Top.128b15, EE 1242a22-26), o homem

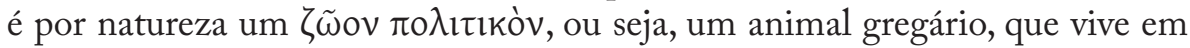
uma comunidade - neste caso a $\pi$ ó $\lambda ı$ - em cujo funcionamento intervém de um modo ativo, com o intuito de contribuir para a glória da cidade e para a melhoria do bem-estar dos concidadãos. Não é, por isso, de estranhar que, aos olhos de Plutarco (e. g. Moralia 791C, 823C), como eco da sensibilidade grega, o ser humano deva, por natureza, dedicar-se à ação política ${ }^{1}$.

Com base nesta definição, não é difícil compreender que o homem político da Grécia Antiga, nomeadamente o ateniense, tivesse um campo de intervenção mais vasto do que o atual. No moderno mundo democrático ocidental, a atividade política assenta, regra geral, na representatividade parlamentar (que substitui a intervenção direta), na separação dos poderes e é sobretudo exercida através de cargos executivos ou legislativos (não acumuláveis em um mesmo momento), sem que seja possível associá-la à militar. $\mathrm{Na}$ Atenas antiga, a participação na vida política ativa era, por assim dizer, mais abrangente, na medida em que um mesmo indivíduo podia chefiar o exército ou a armada e participar na assembleia, onde se tomavam decisões que orientavam o governo da cidade e onde se aprovavam decretos e leis; em toda esta atividade, os dotes oratórios sempre foram de grande relevância.

Nesse sentido, pareceu-nos, de início, que a melhor estratégia para cotejar os dois Alcmeónidas de que nos ocupamos seria estruturar esta análise com base nas diferentes facetas do homem de Estado de então (político, legislador e militar). Tal opção acabou por revelar-se improdutiva, na medida em que, em relação a Alcibíades, Plutarco quase só menciona informação sobre a sua conduta enquanto militar. Esta realidade pode dever-se, por um lado, à escassez de elementos sobre a atividade política e legislativa nas fontes ${ }^{2}$ a que o biógrafo recorreu para redigir a Vida de Alcibiades; por outro, àquilo que Duff

1 Rodríguez Somolinos (2003: 225) resume a perspetiva do biógrafo relativamente à atividade política: «(...) por encima de todo es un modo de vida al que no se puede renunciar, no un medio para lograr otro objetivo ni una actividad pasajera, el modo de vida proprio del hombre completo que, bajo la guía constante de la razón y la filosofía, persigue el bien más sublime hasta el fin de sus días».

${ }^{2}$ Esta falta de elementos poderá ser um mero reflexo do que foi a atuação ou resultado da sobrevalorização da área onde, efetivamente, Alcibíades se destacou. De facto, como fica claro, por exemplo, da leitura de Per. 11. 1, há políticos melhores ou piores em determinadas áreas (Címon era mais dotado para a guerra, Tucídides de Alópece, um seu parente, era melhor orador e político). Apenas Péricles e Alexandre, apesar dos seus pequenos defeitos, parecem ser apresentados como exemplo de políticos modelo, que têm capacidades para liderar nos diversos domínios da vida pública. Sobre Tucídides, o rival de Péricles, vide p. 203, nota 50. 
(1999: 325) considera ser a estratégia de Plutarco na conceção e redação desta biografia:

«in many ways, (...), this life is not about Alkibiades himself, but about his doxa - that is, his reputation and other people's opinion about him».

Optámos, por isso, por subdividir o capítulo em dois grandes momentos, que designámos por «O Político»e «O Militar».

\subsubsection{O político}

O facto de, quer sobre Péricles quer sobre Alcibíades, terem recaído suspeitas de aspirações tirânicas pareceu-nos merecer o estatuto de tema de abertura do subcapítulo, por se tratar de uma acusação paradoxal. É que ambos faziam parte de uma família de tradição democrática, na medida em que os seus antepassados - nomeadamente Clístenes - tiveram um papel fundamental na abolição da tirania dos Pisístratos e na consolidação do regime democrático ${ }^{3}$. Podemos, por isso, atribuir à genética a facilidade que ambos revelavam no trato com a turba, sobretudo no que respeita a Péricles. Este tinha o dom de fazer com que o povo acolhesse as suas ideias, de conduzi-lo; no caso de Alcibíades, essa habilidade foi limitada pela sua maneira de ser que provocava sentimentos controversos na população ${ }^{4}$.

A hereditariedade, contudo, não impediu que neles aflorassem alguns rasgos de índole tirânica. Péricles, por exemplo, defrontou-se, desde o momento em que decidiu ingressar na atividade política, com o fantasma da tirania. Como já vimos ${ }^{5}$, o seu aspeto físico e a sua voz traziam à memória Pisístrato, pelo que se esforçou por se associar ao povo com o intuito de desfazer quaisquer suspeitas que o ligassem a esse tipo de regime ${ }^{6}$. Mas, apesar de todas as precauções, a sua forma de estar na política e a supremacia que por causa dela alcançou fez com que a democracia ateniense nesse período fosse vista como um regime aristocrático, que poderia mesmo vir a transformar-se em tirania, nomeadamente por Tucídides que afirma que

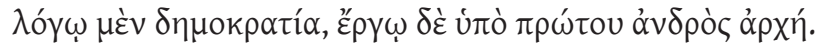

${ }^{3}$ Sobre credenciais democráticas dos Alcmeónidas, vide Isoc. 16. 25-28 e Thomas (1989: cap. 5 e pp. 131-154).

${ }^{4}$ Infra p. 229.

${ }^{5}$ Supra p. 194.

${ }^{6}$ Se tivermos em conta que Aristides foi votado ao ostracismo, na sequência de uma intriga de Temístocles, invejoso, que o acusou de governar a cidade como um monarca (Plu. Arist. 7. 1, Them. 5.7), os receios de Péricles afiguram-se pertinentes. Sobre os efeitos nefastos da inveja na vida política, vide infra p. 231, nota 102 . 
"sob o nome de democracia, era, na prática, o primeiro dos cidadãos quem governava ${ }^{7}$."

Os comediógrafos, por seu turno, não são tão complacentes. Exageram a sua autoridade e capacidade de bater os rivais, de modo a assemelhá-lo a um $\tau u ́ p \alpha v v o \varsigma^{8}$. De todos aqueles que Plutarco cita na Vida de Péricles, é Cratino o que mais ataca o filho de Xantipo a propósito deste tema. Em Per.3.5, por causa da forma da cabeça do estadista, Plutarco recorre a um fragmento de Quirones (fr. 258 K.-A) e a outro de Nemesis (fr. 118 K.-A), que se referem àquele como «tirano» e o assemelham a Zeus ${ }^{9}$. A insistência na comparação de Péricles com Zeus sugere que teria sido recorrente no dia-a-dia, algo que vai ao encontro do cognome por que ficou conhecido: Olimpico. O Queroneu menciona-o em dois momentos: logo no início da vida, em Per. 8. 1-4, e no capítulo final, deixando a ideia de que o epíteto em causa, que o terá acompanhado ao longo do período em que permaneceu no poder, sintetiza na perfeição o caráter de Péricles e a sua conduta política.

Ainda que muitos pudessem considerar este epíteto uma ofensa - pois simbolizava a arrogância e até a tendência tirânica do Alcmeónida -, ele não deixa de ser lisonjeiro ${ }^{10}$, porque sugere autoridade, dom de guiar o povo e capacidade de intervenção em diversas áreas. Até a acusação de envolvimento ilegítimo com diversas mulheres (que, como veremos, Plutarco não considera verdadeira ${ }^{11}$ ) corresponde ao perfil do filho de Crono, cujas sucessivas traições irritavam sobejamente a sua consorte, Hera.

Com efeito, perante a sugestão de que Péricles seria a incarnação de Zeus entre os humanos ${ }^{12}$, a alcunha não podia ter sido mais bem escolhida. Tendo em conta que a mitologia nos apresenta o filho de Crono como deus supremo, fica ainda a sugestão de que Péricles é um dos representantes máximos do bom

${ }^{7}$ Thuc. 2. 65. 9. Em Per. 9. 1, Plutarco recorda essas palavras de Tucídides com o intuito de desmentir aqueles que, como Platão, acusavam Péricles de ter corrompido o povo com a implantação de um regime democrático puro. Sobre este assunto, vide p. 220 sqq.

${ }^{8}$ Morrison - Gomme (1950: 76-77); de Vries (1975: 65-66).

${ }^{9}$ Para uma interpretação mais pormenorizada destes fragmentos, vide supra pp. 169-170.

${ }^{10}$ Segundo Plutarco, aliás, só pode ser visto numa perspetiva elogiosa, porque a divindade é por natureza boa e comedida, pouco dada a paixões e confusões, bem diferente do retrato que os poetas dela apresentam (como acontece, por exemplo, com a descrição que é feita do Olimpo no canto VI da Odisseia). Péricles, enquanto imagem humana da divindade, revelou um caráter benévolo e levou uma vida limpa e imaculada no exercício do poder.

${ }^{11}$ Cf. p. 261.

${ }^{12}$ Plutarco considera que o bom governante é um reflexo da divindade na terra, que deve procurar manter o equilíbrio entre a autoridade necessária e os excessos que conduzem à tirania, evitar a dissensão, fomentar a concórdia, controlar as paixões mais do que nenhum outro. Ainda que não tenha sido, obviamente, ele a escolher a alcunha, o facto é que ela se coaduna com essa posição. 
político, que, como o marido de Hera, tem qualidades e defeitos, mas nunca terá um sucessor à altura. Fica, contudo, igualmente a ideia de que, tal como Zeus, ao instaurar uma nova ordem, propiciou a decadência da Idade do Ouro, assim Péricles, ao estabelecer uma democracia radical, inaugura uma nova era na qual se verifica um deteriorar progressivo da moral tradicional.

Na reflexão que faz, em Per. 8. 3, sobre a possível origem deste epíteto, Plutarco revela concordar com quem defende que ele decorre da combinação das diferentes qualidades do estadista (como a autoridade no governo e no comando militar) e com as obras de embelezamento da cidade. No entanto, mostra-se mais adepto da versão tradicional, que faz dos dotes retóricos daquele o principal fator para o aparecimento da alcunha e para o seu controlo sobre o povo. A defesa desta perspetiva é apoiada por uma referência genérica ao testemunho dos comediógrafos, que podemos exemplificar através de Ar. Ach. 530-532:

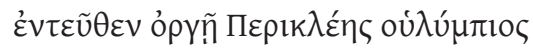

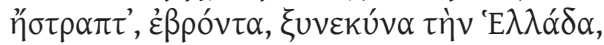

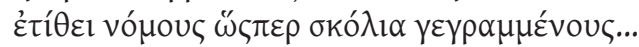

"Irritado com o facto, Péricles o Olímpico lançou o raio, fez ouvir o trovão, pôs a Grécia em polvorosa e estabeleceu leis redigidas à maneira de cantilenas....

Este é praticamente o único momento em que Plutarco parece estar de acordo com os artistas do género cómico, que, aqui e além, apesar das críticas, lá vão reconhecendo o valor do filho de Xantipo. Mas essa sintonia dura pouco. Em Per. 16. 1 Plutarco elogia a correta interpretação de Tucídides a propósito do poder de Péricles (se não fosse o pulso forte de Péricles, a inconstância do povo tornaria caótica a vida em Atenas), por oposição à distorção que os comediógrafos dele fazem, chegando mesmo a chamar os seus correligionários de «nova geração de Pisistrátidas» e a obrigá-lo a jurar que não será um tirano.

Voltemos, pois, à reflexão sobre a natureza do poder exercido pelos Alcmeónidas. Péricles mostrou-se mais diretivo, talvez porque tivesse um plano bem concebido daquilo que pretendia para a ródıc. Nesse sentido, procurou dar ao povo liberdade de atuação - ou pelo menos o sentimento de que eram livres de agir -, mas manteve-se vigilante e pronto para evitar desaires ${ }^{14}$. $\mathrm{O}$ momento em que esta postura é mais visível coincide com os primeiros tempos da Guerra do Peloponeso. Então, ante o descontentamento popular generalizado, Péricles impôs como nunca a sua autoridade, tendo

\footnotetext{
${ }^{13}$ A tradução apresentada é de Silva (1980).

${ }^{14}$ Supra p. 280.
} 
mesmo chegado a impedir a reunião da assembleia, algo que é muito pouco democrático. Segundo Thuc. 2. 22. 1, o estratego não reúne a assembleia com medo de que o povo decida mal; já Plutarco (Per.33.6) afirma que o objetivo do estadista era evitar sofrer pressão por parte da turba ${ }^{15}$.

No entanto, Plutarco não menciona que o povo se tivesse mostrado muito revoltado com esse procedimento, apesar de as suas relações com Péricles não serem as melhores naquela altura. Tal omissão pode dever-se a dois fatores: a própria posição do biógrafo, que, apoiante da estratégia de Péricles ${ }^{16}$, «se esqueceu» de apresentar as queixas da multidão nesse sentido; o facto de o povo, mesmo revoltado, continuar, bem no fundo, a saber que podia e devia confiar em Péricles. É que o filho de Xantipo, que tinha uma excelente capacidade de prognóstico, já dera prova da sua preocupação com os concidadãos e do cuidado e diligência com que tratava

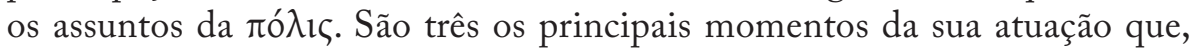
na nossa perspetiva, comprovaram essa realidade aos olhos do povo. Um teve lugar durante o governo do estadista: trata-se da derrota de Tólmides, que Péricles instara a não combater e que se revelou danosa para Atenas ${ }^{17}$; os outros, já depois da sua morte, prendem-se à expedição à Sicília e com a alteração da estratégia que traçara para vencer os Lacedemónios na Guerra do Peloponeso. A «desobediência» a Péricles e a cedência aos demagogos ${ }^{18}$, que apenas buscavam o seu próprio bem em detrimento do coletivo, viriam a provocar nos Atenienses saudades do governo que antes haviam apelidado de monárquico e tirânico e o reconhecimento de que o filho de Xantipo tinha sido bem sucedido no controlo dos vícios do povo ${ }^{19}$. As saudades sentidas foram tais que os comediógrafos - nomeadamente Eupolis - chegam a colocar a hipótese de ir ao Hades buscar Péricles para que Atenas pudesse ter alguma esperança ${ }^{20}$. Podemos, por isso, concluir com Plutarco que o que

${ }^{15}$ Segundo Prandi (2004: 141), há uma transferência de poder das massas para o indíviduo, que se prende à natureza do relato de Plutarco, que pretende narrar os feitos de um «indivíduo/ protagonista».

${ }^{16} \mathrm{Se}$, de facto, este for o motivo para a omissão de Plutarco, podemos considerar que o fez a exemplo de Tucídides, que não mencionou, também ele, momentos menos favoráveis à imagem do estadista, como o ataque aos amigos de Péricles, o esmagar da revolta de Samos, a revolta do povo por ocasião da primeira invasão da Ática.

${ }^{17}$ Sobre este assunto, vide supra p. 184 , nota 101. 110).

${ }^{18}$ Para mais informações sobre a atuação dos demagogos, consulte-se Lewis (1992: 106-

${ }^{19}$ Este comportamento protetor e paternalista de Péricles para com a $\pi$ ó $\lambda_{\imath} \varsigma$, apesar de alguns reveses, surtiu maior efeito do que no seio da sua própria família, já que Xantipo e Alcibíades se revelaram rebeldes e menos sérios do que seria previsível para pessoas educadas pelo estadista. Sobre o fracasso de Péricles enquanto educador dos seus «descendentes», vide p. 188.

${ }^{20}$ Sobre este assunto, vide supra p. 166. De facto, o povo teve muita sorte em ter Péricles, um homem sério, justo e prudente, como líder. A cedência aos políticos que lhe sucederam, ainda 
levou os concidadãos a acusarem Péricles de exercer um governo monocrático foi pura maledicência provocada pela inveja que dele sentiam (Per.39.3-4).

Mutatis mutandis, pode dizer-se o mesmo de Alcibíades. A acusação de tendência tirânica de que foi alvo prendia-se mais ao seu comportamento individual ${ }^{21}$ e ambição excessiva do que com a sua atuação política ${ }^{22}$. De facto, o uso de dados da vida privada para construir o perfil dos indivíduos e fazer um aproveitamento político dessa informação é uma constante de todos os tempos. Alcibíades parecia gostar de fornecer matéria para esse tipo de intriga. Ele não respeitava os semelhantes, os animais e nem mesmo a lei ${ }^{23}$ (Alc. 16. 2-7). Segundo Plutarco, tratava os conhecidos com insolência e arrogância (Alc. 5. 6) e os amantes - à exceção de Sócrates - com desprezo (Alc. 6. 1); e não se coibia de matar os próprios escravos ${ }^{24}$ (Alc. 3. 1). Este comportamento

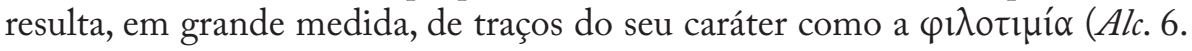

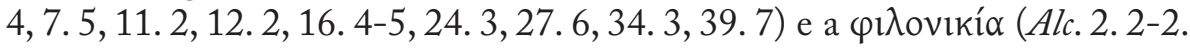
7 ), mas em muito também da complacência que o povo quase sempre teve para com os seus desvarios e excessos ${ }^{25}$.

Demais, adorava luxos, prazeres e extravagâncias (Plu. Alc. 6. 2-3; Ath. 534d-e), era dado a todo o tipo de congeminações para afastar os opositores (recordemos, por exemplo, o seu comportamento com a embaixada lacedemónia para estragar os planos a Nícias ou o ostracismo de Hipérbolo ${ }^{26}$ ) e ser o primeiro de entre os poderosos ${ }^{27}$. Não admira que, perante este perfil, que costuma caracterizar aqueles que exercem governos de índole despótica (como os reis da Pérsia ${ }^{28}$ ), se associasse a Alcibíades a intenção de instituir um regime

que mais limitada, mostrou-se ruinosa e também sinal da falta de discernimento dos Atenienses.

${ }^{21}$ Sobre o contributo da variabilidade de caráter de Alcibíades (mencionada em Alc. 2. 1) e do desregramento da sua vida privada para a sugestão de tendência tirânica, consulte-se Gribble (1999: 31-32, 70-82).

${ }^{22}$ Cf. Thuc. 6.15, onde o historiador afirma que era por causa da vida ultrajante que levava que Alcibíades levantava suspeitas de querer ser tirano. Seager (1967: 6-18); Bearzot (1988: 39-57).

${ }^{23}$ Cf. [And.] 4. 19, onde se afirma que para Alcibíades o correto era não ser ele a submeter-se às leis da cidade, mas estas à sua maneira de ser.

${ }^{24}$ Esta é uma daquelas informações que Plutarco não deixa de recordar, embora a considere sem fundamento (Alc. 3. 2). Contudo, a simples alusão ao boato, que o biógrafo não acredita verosímil, semeia em nós a dúvida, já que este Alcmeónida é caracterizado por uma ousadia desmedida, que o torna capaz de tudo.

25 Este tema está desenvolvido nas páginas 184 e 231. [And.] 4. 21 responsabiliza os Atenienses pelo facto de o poder e o prestígio de Alcibíades terem alcançado uma proporção excessiva.

${ }^{26}$ Sobre estes assuntos, vide supra p. 205 sqq.

${ }^{27}$ Esta sua tendência foi, como já vimos, incentivada pelos aduladores (Alc. 6. 4), que o faziam acreditar na sua capacidade para obscurecer os feitos de Péricles.

${ }^{28}$ Sobre a maneira de ser dos Persas e o seu gosto pelo luxo, vide Anderson (1972: 166-174); Keaveney (1996: 23-48); Balcer (1983: 257-267). 
tirânico ${ }^{29}$. Essa foi, aliás, uma das leituras que o povo, sempre desconfiado ${ }^{30}$, fez da mutilação dos Hermes, à qual os inimigos políticos de Alcibíades quiseram à viva força associá-lo ${ }^{31}$.

Acresce a tudo isto o facto de o Alcmeónida reunir as características daqueles que são considerados pessoas de "grande natureza», ou seja, os indivíduos que, por se distinguirem dos demais, deixam, a certo altura, de se sentir integrados na estrutura político-social vigente e procuram mudar o sistema, de modo a satisfazerem as suas necessidades e vaidades. É neste contexto que Aristófanes ( $R a$.1432-1433) compara Alcibíades a um leão, que, a qualquer momento, vai atacar a comunidade que o acarinhou e viu crescer $^{32}$. Tal comparação deixa transparecer que o povo tinha não só a consciência do perigo que um indivíduo de «grande natureza» representava, mas sobretudo a experiência do que era ficar à mercê de um Alcibíades ferido no seu orgulho e dignidade, pois o texto é posterior ao exílio do Alcmeónida e à sua vingança contra Atenas.

Ao contrário de Péricles, que, como já vimos, não queria ser associado à tirania ${ }^{33}$, não se conhece o pensamento de Alcibíades a este respeito (Plu. Alc. 35. 2). Isócrates (16. 38) parece sugerir que o Alcmeónida não estava interessado em comandar um governo tirânico, pois afirma que aquele, apesar de reunir todas as condições para enveredar por este tipo de regime, não quis seguir por esse caminho ${ }^{34}$.

${ }^{29}$ Cf. [And.] 4. 24. Essa associação atingiu um nível tal que, segundo Gribble (1999: 37), Alcibíades e as suas ambições tirânicas acabaram por se transformar em tótoఢ̧ das aulas de retórica.

${ }^{30}$ Os Atenienses estão sempre atentos e receosos de que alguém tente destruir o regime democrático. Disso nos dá testemunho Tucídides, a propósito da batalha de Tanagra (1. 107) e da mutilação dos Hermes (6. 53-60). Não admira, por isso, que Péricles, conhecedor dessa característica do seu povo, se tenha antecipado a Arquidamo, oferecendo à ró $\lambda_{1} \varsigma$ todos os seus bens, no caso de os Espartanos os pouparem (Thuc. 2. 13). Sobre a destruição dos Hermes, vide p. 233, nota 117 e passim.

${ }^{31}$ Tucídides parece sugerir, através da sua digressão sobre o governo de Pisístrato (Thuc. 6. 53.3 - 6. 60. 1), que os Atenienses fizeram mal em condenar Alcibíades pelas suas ambições tirânicas, porque considera que nem toda a tirania tem de ser má. Do mesmo modo, quer Aristóteles (Pol. 1279a17) quer Plutarco acreditam que a base de um bom governo não está tanto no regime (monarquia ou aristocracia), mas na qualidade do governante, que há de olhar pelo bem da comunidade e não pelo seu próprio interesse. Sobre o pensamento político de Plutarco, consulte-se Aalders (1982: 33 e 44).

32 Antes mesmo de os Atenienses o compararem ao rei da selva, já o filho de Dinómaca o havia feito, numa associação que, como vimos, tem conotação negativa. Cf. supra p. 169.

${ }^{33}$ Vide supra p. 194.

${ }^{34}$ Mais do que isso, refere mesmo que os dois períodos durante os quais Atenas passou novamente por regimes oligárquicos (dos Quatrocentos e dos Trinta), que cometeram excessos tirânicos, corresponderam aos exílios de Alcibíades. Não deixa de ser curioso notar que o dos Quatrocentos (bem como a reposição da oligarquia em Samos - Alc. 25) foi instituído por influência sua, já que parecia acreditar que seria mais fácil regressar a Atenas se o povo que o exilara não estivesse no poder (Alc. 26). Alcibíades deixa-nos, por isso, sinais contraditórios da 
Ficamos, por isso, com a ideia de que tal acusação resultou, mais do que da verdadeira intenção do jovem, da conjugação dos seguintes fatores: tendências anticívicas, "grande natureza» e inveja popular perante o seu cada vez maior ascendente sobre os destinos da cidade. Mas, em nós, permanecerá para sempre a dúvida: o que teria acontecido se Alcibíades não tivesse sido assassinado e se tivesse ajudado Atenas a ganhar a guerra?

Não deixa de ser curioso notar que o biógrafo se refere a esta tendência tirânica em dois grandes momentos: o capítulo 16, que é aquele em que faz a síntese do caráter do Alcmeónida por ocasião do seu ingresso na vida política ativa, e o 34, aquele em que se aborda a restauração da procissão de Elêusis ${ }^{35}$. No primeiro, são os Atenienses mais notáveis (Alc. 16. 2) e os mais idosos (Alc. 16. 7) que, com alguma apreensão, se apercebem desse traço de caráter através das ações do jovem. Em Alc. 34. 7, são os cidadãos das classes mais desfavorecidas - ou seja, os que mais sofrem com a crise e normalmente os mais apegados à religião - quem, de livre e espontânea vontade, se lhe dirige para exortá-lo a destruir a ordem vigente e a tornar-se tirano. É que, além de todos os outros feitos que trouxeram novamente glória e esperança a Atenas, o restabelecimento da procissão incutiu nas gentes mais pobres a expectativa de que, sem oposição - e, como Plutarco salienta, sem sicofantas e invejosos, sem charlatães que cada vez faziam mais mal a Atenas -, Alcibíades seria capaz de empreender grandes benefícios em favor da sua $\pi \lambda^{\lambda} \varsigma^{36}$. Deste modo, o povo, que odiava a tirania, revela o seu desespero e cansaço ao fim de tantos anos de guerra, de privações e de um regime que não se mostrava capaz de suprir as necessidades do seu senhor. Só assim se compreende que pusesse a hipótese de se sujeitar novamente a tal regime. Mas, mais uma vez, os poderosos inimigos de Alcibíades não nos dão oportunidade de saber qual seria a reação do filho de Dinómaca. Temendo que aquele aceitasse a proposta, apressam a expedição (cuja primeira paragem ocorreu em Andros), cedendo, sem questionar, tudo aquilo que o estratego exigia ${ }^{37}$.

Discutida que está a questão do posicionamento dos Alcmeónidas face à tirania e a democracia, debrucemo-nos sobre a sua ação política.

Qualquer homem de Estado que se preze deve pautar as suas ações e decisões por objetivos nobres e favoráveis ao engrandecimento do povo e da

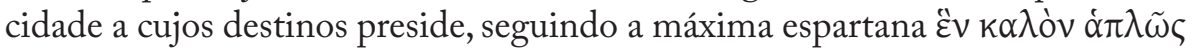

sua posição: embora se tenha aproximado da oligarquia para alcançar os seus objetivos, ajudou a repor a democracia em Argos, após a batalha de Mantineia (Alc. 15. 3). Podemos por isso questionar-nos: fê-lo por apreço pela democracia ou para ganhar mais um aliado contra os Lacedemónios?

${ }^{35}$ Sobre este assunto, consulte-se Verdegem (2001: 451-459).

${ }^{36}$ Cf. D. S. 13. 68.

${ }^{37}$ Vide infra p. 300. 


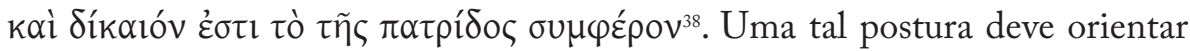
toda a atividade do político, desde o momento em que decide enveredar pela vida pública ativa até àquele em que esta chega ao seu termo ${ }^{39}$.

Como já dissemos em páginas anteriores, o modo como os dois Alcmeónidas iniciaram as suas carreiras é, desde logo, um elemento que reflete as suas diferentes maneiras de ser e sugere aquilo que almejam para Atenas. Como veremos mais adiante, ambos pretendem a glória da sua cidade. No entanto, ao passo que Péricles se mantém sempre fiel a esse propósito (porque a sua entrada na vida política ativa foi conscientemente desejada e planeada), Alcibíades (que ingressou nesta batalha sobretudo instigado por terceiros e levado por circunstâncias favoráveis) só se dedica à causa enquanto isso não colide com os seus interesses pessoais e com o seu orgulho ${ }^{40}$.

De acordo com a perspetiva de Plutarco (Moralia 799B), um dos principais objetivos de um governante na demanda do bem-comum deve ser melhorar o caráter do seu povo ${ }^{41}$. A essa convicção estão, decerto, subjacentes o facto de a $\pi$ ó $\lambda$ lৎ ser, no dizer de Tucídides, o próprio povo ${ }^{42}$ (de onde se conclui que querer o melhor para a $\pi$ ó $\lambda_{1} \varsigma$ equivale a querer o melhor para o povo e vice-versa), e a má fama de que este gozava. A uma tal reputação não será alheia a constituição da turba, uma massa numerosa e heterogénea, difícil de orientar, mas que, para seu bem e segurança, tem de ser constantemente guiada e, porque não dizê-lo, controlada. Em um contexto de regime democrático, essa orientação torna-se mais difícil, porque, em teoria, o povo está no poder, participa nas decisões, logo, alcança pouco a pouco mais liberdade.

É por causa da «excessiva» liberdade de que os Atenienses usufruíram sob o comando de Péricles (mas também com alguns dos seus antecessores e colegas, por exemplo, Milcíades, Temístocles e Címon) que o fundador da

${ }^{38}$ Plu. Alc. 31. 8: a coisa mais bela e justa é o bem da pátria. Esta máxima é ilustrada pelo argumento que Anaxilau dá aos Espartanos para justificar o facto de ter aberto as portas de Bizâncio a Atenas: foi a melhor forma que encontrou para proteger da guerra a cidade e os concidadãos.

39 Sobre a oportunidade da ida do homem de Estado para a reforma segundo Plutarco, consulte-se Moralia 783A-797F.

${ }^{40}$ Sobre este assunto, vide supra p. 183 e infra passim.

${ }^{41} \mathrm{O}$ vocabulário que o biógrafo utiliza para designar as massas encontra-se analisado por Saï (2005: 9-13). Qualquer governante que se preze tem de começar por conhecer a fundo o caráter do povo que lidera. Esse é o ponto de partida para o complicadíssimo e moroso processo de transformação do seu caráter, a que o político se deve dedicar com força e sem medo (Plu. Moralia 799B-800A). Um tal conhecimento, contudo, pode condicionar a interação entre ambos. Em Per.7.1, Plutarco afirma que o Alcmeónida «temia enfrentar o povo», porque não só era jovem e inexperiente, como tinha a consciência de que as suas figura e maneira de ser traziam à memória a imagem de Pisístrato (cf. supra p. 194). Alcibíades revela-se a antítese do político ideal, na medida em que, em vez de conduzir o povo, se deixa levar pelo aplauso público. Por isso, Plutarco apresenta-o não como modelo para imitatio, mas para reiectio. Sobre este assunto, consulte-se Salcedo Parrondo ( 2005: 179-186).

42 Thuc. 7. 77. 7. Cf. p. 124. 
Academia condena não só a democracia como o estadista, por terem afrouxado as rédeas deste «cavalo quase indomável». Disso nos dá testemunho Per. 7. 8 , onde Plutarco cita um passo de Platão ${ }^{43}$, que salienta a má gestão que o povo faz da liberdade (sobretudo se esta for desmedida), e um fragmento de comédia $^{44}$, que compara a populaça a um cavalo empinado ${ }^{45}$ :

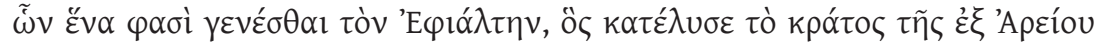

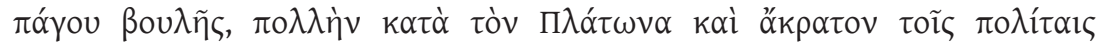

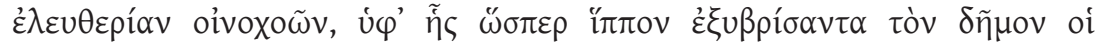

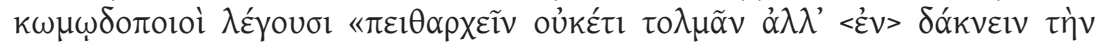

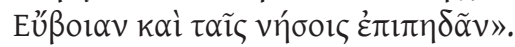

"um deles foi, ao que se diz, Efialtes ${ }^{46}$, que arrasou o poder do conselho do Areópago, dando a beber, nas palavras de Platão, aos cidadãos liberdade a mais e da genuína. Dizem os comediógrafos que, graças a ela, o povo empinado que nem um cavalo, «não tolerou mais obedecer, mas morde Eubeia e salta sobre as ilhas»"”

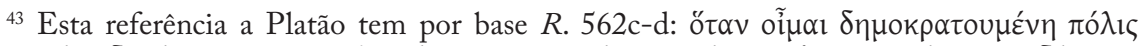

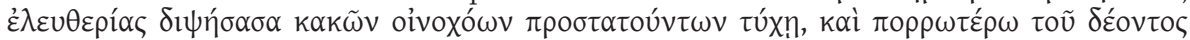

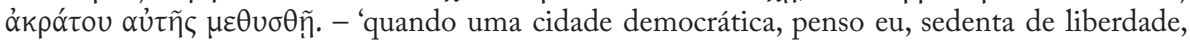
tem, por força do acaso, no seu comando maus escanções e se embebeda muito mais do que devia com essa [liberdade] da pura...' Plu. Cim. 15. 2 também se refere à democracia em que Atenas passa a viver após a partida de Címon em uma expedição como ökpatov (adjetivo normalmente relacionado com o vinho puro) $\delta \eta \mu o k \rho \alpha \tau i ́ \alpha v$ e atribui à ação de Efialtes o facto de, a partir de então, o povo ter ultrapassado todos os limites. Sobre a reforma do Areópago, vide infra p. 236, nota 131.

${ }^{44}$ Adesp. 700 K.-A. Este verso alude ao tratamento pouco correto que os Atenienses tiveram em relação aos aliados, nomeadamente a Eubeia, quando esta tentou deixar de pertencer à Simaquia. Atenas usou de uma política de repressão contra todos aqueles que, achando desnecessário manter uma aliança contra o inimigo persa que já não oferecia perigo, quiseram libertar-se do compromisso. Vide Ribeiro Ferreira (1990a: 131-146). Aristófanes (Nu. 211-213) apresenta uma anedota semelhante, também relacionada com Péricles: duas personagens estão a observar um mapa da Grécia e uma diz: «Aqui está a Eubeia que, como vês, se estira bem longe, a todo o comprimento». Ao que a outra personagem replica: «Bem sei. Demos-lhe um bom estirão, nós e Péricles».

${ }^{45}$ De facto, sobretudo a partir do século $V$ a.C., o povo foi por diversas vezes comparado a animais grandes e fortes, cheios de vontade própria, nomeadamente por P1. R. 493a-b. Plutarco utiliza o mesmo recurso em Moralia 802D, a propósito da incapacidade de Nícias de dominar o povo. Segundo Moralia 822A, o que confere ao povo essa audácia e força é a sua corrupção pelos políticos.

${ }_{46}$ Aliado político de Péricles, responsável pela reforma do Areópago (462 a.C.). Deste estadista ateniense, conhecido, como Péricles, pela sua incorruptibilidade, sabe-se muito pouco. Filho de Sofonides, foi um dos poucos líderes atenienses que não era rico. Substituiu Temístocles na liderança dos populares e, consequentemente, teve em Címon o seu principal opositor. Mas os aristocratas, pouco satisfeitos com a supressão de poderes do Areópago, mandaram assassiná-lo no ano seguinte (Per. 10.8). As más-línguas chegaram a responsabilizar Péricles pelo crime (Per. 10.7; infra p. 240). 
Esta perspetiva, que surge no seio de uma democracia, é própria de um pensamento aristocrático ${ }^{47}$, mas acabou por se revelar verdadeira, na medida em que o excesso de liberdade do povo, que se deu particularmente quando este deixou de ter alguém que o soubesse conduzir como Péricles, levou à ruína da ró $\lambda_{\imath}$. Segundo o fundador da Academia, a liberdade desregrada do povo conduz à degradação moral de toda uma sociedade e a longo prazo trará o descrédito e a ruína desse tipo de constituição. E Platão podia afirmá-lo com segurança, pois no final do século $V$ a.C. já era possível verificar, pelos acontecimentos, o mau efeito dos excessos democráticos. Fica assim bem demonstrado que apenas o passar dos anos permite constatar as reais consequências das medidas governativas anteriores.

Ainda que esta crítica possa ser apontada a Péricles pelos seus adversários e sobretudo pelos que se opõem à democracia, a verdade é que a sua atitude para com as massas foi quase sempre a contrária, à exceção dos dois momentos ${ }^{48} \mathrm{em}$ que lutou pela supremacia no poder. $\mathrm{O}$ primeiro teve lugar, quando, jovem e timorato, procurando ingressar na vida política, Péricles buscou o seu favor ${ }^{49}$. Para isso usou de alguma demagogia, sobretudo devido ao peso do principal opositor que então defrontava, Címon, um indivíduo muito rico e generoso, que brindava os mais pobres e os estrangeiros com roupa, alimentos e dinheiro. Como a reação típica da população nestas circunstâncias é agradecer o benefício com o seu apoio, Péricles viu-se obrigado a alinhar no esquema ${ }^{50}$. Só que, como a sua fortuna não era tão vasta quanto a de Címon, o aspirante a um lugar de peso concedeu benesses ao povo não a expensas próprias, mas com dinheiros do Estado. Foi nessa altura que, segundo Per. 9. 1-3, a multidão teve direito

${ }^{47}$ Esta visão preconceituosa das massas, como muito bem enfatiza Saïd (2005: 7, 18), decorre do facto de os textos onde essa opinião é manifestada serem escritos por aristocratas para aristocratas.

${ }_{48} \mathrm{Na}$ verdade, Plutarco recorda um terceiro momento em que o estratego recorre à demagogia, que se distingue dos outros dois por não ter como objetivo a conquista do poder mas aplacar a ira do povo, descontente com a estratégia assumida para a Guerra do Peloponeso. Em Per. 34. 2, o Queroneu afirma que Péricles ofereceu subsídios, propôs cleruquias e sorteou Egina pelos Atenienses, conseguindo, assim, controlar o povo por mais algum tempo. Segundo Stadter (1989: 314), a alusão aos subsídios e cleruquias é da responsabilidade de Plutarco (ou de outra fonte desconhecida), já que Thuc. 2.27.1 apenas menciona o sorteio de Egina, que terá tido como principal intuito não o domar a fera ateniense, mas sim pôr termo à ameaça que Egina, apoiante dos Lacedemónios, constituía para Atenas. Sobre a revolta do povo contra Péricles, vide infra p. 236 sqq.

${ }^{49}$ Cf. supra p. 202.

${ }^{50}$ Não deixa de ser curioso verificar o diferente aproveitamento (consciente ou não) que Plutarco faz de um mesmo material em biografias diferentes. Enquanto em Per. 9. 2 chama «demagogia» aos donativos que Címon faz aos mais pobres, como que para justificar a conduta de Péricles, em Cim. 10. 5-6 atribui essa generosidade à $\mu \varepsilon \gamma \alpha \lambda \circ \varphi \rho \circ \sigma u ́ v \eta$ 'grandeza de alma' do irmão de Elpinice e afirma que este não agia com intuitos demagógicos, porque era seguidor de uma política aristocrática e laconizante. 
às mais diversas mistoforias e subsídios, nomeadamente o $\theta \varepsilon \omega \rho \iota k o ́ v^{51}$, e foi incentivada a formar cleruquias ${ }^{52}$.

Esta é talvez a única circunstância em que se serve do cargo em seu benefício, ao contrário de Alcibíades, que foi acusado de se aproveitar da sua posição por diversas ocasiões ${ }^{53}$. Não deixa de ser interessante notar que Plutarco, citando Aristóteles ${ }^{54}$, afirme que Péricles não o fez por iniciativa própria e sim a conselho de Damónides de $\mathrm{Ea}^{55}$. O facto é que esta cedência do discípulo de Anaxágoras causava algum embaraço ao Queroneu (que critica a distribuição de fundos públicos como meio de conquistar as massas $\left.{ }^{56}\right)$, pois é uma das poucas máculas

${ }^{51}$ Trata-se do fundo do Estado com que se financiavam as festas públicas e com que se provia o pagamento de dois óbolos aos cidadãos pobres, para que pudessem assistir às representações dramáticas. No entanto, a atribuição desta medida a Péricles é controversa, pois só temos informações sobre este subsídio a partir do século IV. Sobre esta problemática, vide Stadter

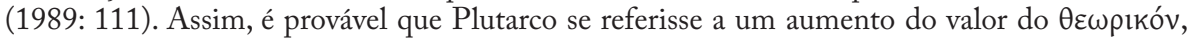
que certamente agradaria ao povo. Sobre este fundo e as outras mistoforias, leia-se Lewis (1992: 29, 101-104) e Mossé (1979: 474).

${ }^{52}$ Nos territórios que foram libertando do domínio bárbaro ou naqueles que tentavam abandonar a Simaquia de Delos, os Atenienses estabeleceram cleruquias, que eram lotes de terras distribuídos aos cidadãos de Atenas. Aí, os próprios clerucos cultivavam as suas propriedades (ou recebiam rendas dos antigos donos que se tornavam seus granjeiros) e exerciam funções militares. Os clerucos mantinham a cidadania ateniense, ao contrário do que acontecia nas

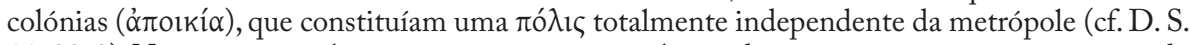
11.88.3). No entanto, as cleruquias possuíam órgãos locais de governo, cuja existência é atestada por documentos epigráficos. Este fenómeno, que teve início nos finais do século VI a.C., atingiu o desenvolvimento máximo no século $\mathrm{V}$ a.C.; foi através dele que os Atenienses conseguiram conciliar a hegemonia sobre as cidades aliadas com a democracia - ao mesmo tempo que distribuíam terras aos cidadãos mais carenciados, conseguiam controlar e punir militarmente aqueles que queriam fugir do jugo ateniense. Plutarco refere vários nomes de cleruquias, como Naxos e Andros, em Per. 11. 4. Sobre este tema, vide Ribeiro Ferreira (1990a: 321); Lewis (1992: 59-60, 96-97); Mossé (1992: 111-112).

${ }^{53}$ Alcibíades foi acusado por um dos seus adversários, Féax (no discurso Contra Alcibiades), de se servir dos bens do povo (como os vasos sagrados de ouro e prata) no seu dia-a-dia (Alc. 13. 3). Cf. [Andoc.] 4. 29. Sobre a corruptibilidade de Péricles e Alcibíades, vide infra p. 249 sqq.

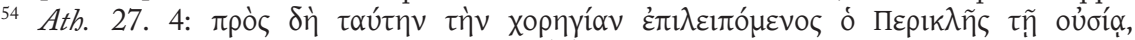

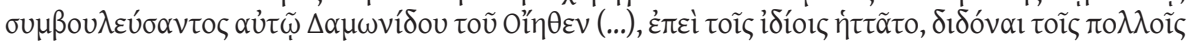

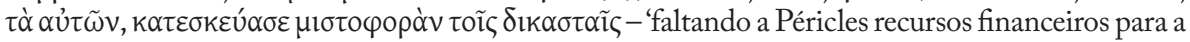
tal coregia, a conselho de Damónides de $\mathrm{Ea},(. .$.$) já que os seus bens particulares eram insuficientes,$ deu ao povo aquilo que ao próprio povo pertencia e instituiu uma mistoforia para os juízes.' É de realçar que o texto de Plutarco não nos apresenta nenhum juízo de valor de Aristóteles a propósito

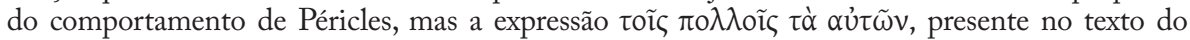
Estagirita, parece sugerir que o estadista estaria a agir com justiça, pois simplesmente devolvia ao povo o que lhe pertencia. Esta posição é, evidentemente, bastante diferente da de Platão, que, como já vimos, culpa estas medidas de terem provocado a decadência moral em Atenas.

55 Aristóteles apresenta Damónides como influente conselheiro de Péricles que, por esse motivo, foi votado ao ostracismo. Não deve ser confundido, o que aliás Aristóteles faz, com o filho Dámon (Per. 4. 1-4; supra p. 175, nota 66), que também foi conselheiro de Péricles na década de 30. Vide Rhodes (1981: 341).

${ }_{56}$ Moralia 818C. Apesar da crítica, em Moralia 818D, o biógrafo refere a prodigalidade de Péricles como um bom exemplo da concessão de benesses ao povo e, em $822 \mathrm{~B}$, defende que as doações podem e devem ocorrer se associadas ao culto divino e sem a exigência de contrapartidas. 
que se pode apontar à conduta do estadista, responsável, segundo Platão ${ }^{57}$, não

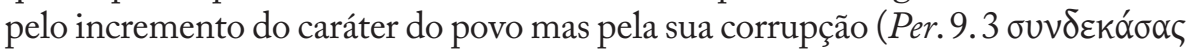

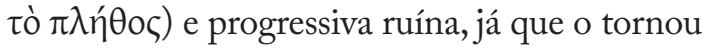

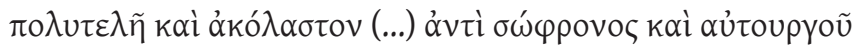

"esbanjador e libertino, em lugar de ser prudente e trabalhador."

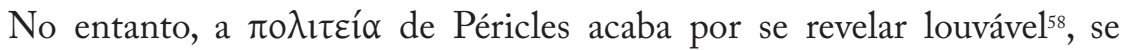
tivermos presente o difícil equilíbrio entre demagogia e moderação. Plutarco parece, de facto, enaltecer esta dicotomia de difícil controlo, na medida em que, sendo o povo instável, Péricles fazia bem em tentar manter-se no poder, pois ninguém melhor do que ele - com a sua moderação - poderia orientá-lo.

A segunda vez que Péricles envereda pelo caminho da demagogia ${ }^{59}$ não é mais do que um prolongamento da primeira, pois, mal conseguiu desembaraçar-se do Areópago ${ }^{60}$ e de Címon, foi presenteado pelos aristocratas com outro rival à altura, Tucídides de Alópece ${ }^{61}$. Desta feita, como a luta fosse mais renhida, Péricles vê-se forçado a contrariar ainda mais a sua natureza aristocrática (a que já nos referimos na página 210) e a afrouxar

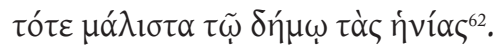

"as rédeas do povo mais do que em qualquer outra ocasião."

${ }^{57}$ Grg. 515e-516e.

${ }^{58}$ São diversos os momentos em que o biógrafo faz o elogio da conduta política de Péricles em Moralia 759D, 784E, 789C, 800C, 802C, 826D, passim.

${ }^{59} \mathrm{O}$ recurso a esta estratégia não foi, como é óbvio, uma arma apenas utilizada por Péricles. Segundo Plu. Nic. 3, Nícias ultrapassava todos os antecessores nas inúmeras ofertas que fazia ao povo para rivalizar com Cléon pelos favores das massas. Aristófanes faz a caricatura desta atitude como própria do demagogo ideal em Eq. 870-911.

${ }^{60}$ Sobre a ação de Péricles e Efialtes contra o Areópago, vide infra p. 236 sqq.

${ }^{61}$ Como já vimos supra p. 191, nota 1 . Péricles, no entanto, teria a noção de que seria o vencedor desta disputa, por causa da interpretação que Lâmpon fez do corno de um carneiro unicorne trazido da propriedade do filho de Xantipo (Per.6.2).O poder (já que o corno era visto como um símbolo de poder e de liderança) acabaria nas mãos daquele que tinha recebido o sinal. As anomalias da natureza eram consideradas prodígios que poderiam revelar os desejos e as intenções dos deuses. Quanto a Lâmpon, era um adivinho ateniense e amigo de Péricles, que participou, em 443 a.C., na expedição à Magna Grécia que tinha por intuito fundar a colónia de Túrios. Os comediógrafos não perderam a oportunidade de atacá-lo por ser um mantis (aquele que é considerado capaz de interpretar os sinais dos deuses, mas que não ocupa cargo oficial na máquina do Estado) e um grande comilão, já que tinha o direito de comer no Pritaneu a expensas públicas (cf. Ar. Nu. 332, Av. 521, 987-988; Cratin. fr. 66 K.-A). Podemos, portanto, considerá-lo mais uma vítima indireta dos ataques a Péricles, ainda que Plutarco não o mencione com o intuito de fornecer tal informação.

${ }^{62}$ Per. 11. 4. Cf. infra p. 228, nota 92. 
Curiosamente, apesar de ter adoptado medidas condenadas pelos grandes teóricos (já que, como qualquer político que se preze, fomentou a constante organização de festas, solenidades, espetáculos e banquetes para todos os gostos), também teceu um plano de incentivo à ocupação profícua do povo ${ }^{63}$, que, embora não seja abertamente elogiado por Plutarco, parece merecer a sua anuência (Per. 11. 6, 12. 5). Foi com esse intuito que promoveu a formação de mercenários e a colonização como forma de se desfazer dos inativos que poderiam querer prejudicar as suas reformas políticas, aproveitando para diminuir a miséria e conter possíveis revoltas dos aliados ${ }^{64}$ (Per. 11). Além disso, deu impulso às obras públicas ${ }^{65}$ para

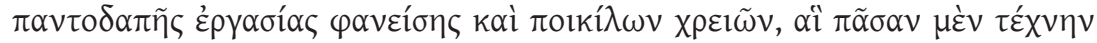

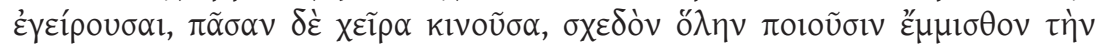

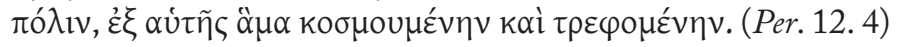

"proporcionar todo o tipo de trabalho e necessidades diversas, que, ao incitar as várias artes e ao pôr em movimento todas as mãos, darão emprego à cidade quase inteira, que se auto-embeleza ao mesmo tempo que se alimenta com os próprios recursos.”

Foi assim que, contrariando as acusações de que foi alvo ${ }^{66}$, segundo Per.12.5, o estadista providenciou o sustento para todos os cidadãos, independentemente da idade ou condição (Per.12.6), pois queria melhorar a qualidade de vida dos Atenienses sem pactuar com pagamentos pelo ócio e inatividade. Mais, queria que todos beneficiassem por igual do tesouro público, tanto os que ficavam como os que partiam em missão, facto revelador de que, à sua maneira, também Péricles era adepto da tão proclamada igualdade ateniense.

${ }^{63}$ Esta preocupação de Péricles de conceder um sustento digno aos menos favorecidos é comparável à de Sólon, que concedeu dignidade aos mesteres para ocupar a multidão ociosa e indolente. Cf. Sol. 22. 3. Do mesmo modo, o objetivo de não dar azo ao desenvolvimento de situações de desordem com recurso à ocupação do povo é semelhante ao de Teseu com a divisão da população em classes (cf. p. 96). Fica, portanto, a ideia de uma certa influência do fundador sobre o comportamento preventivo de desacatos, por parte de alguns daqueles que são apontados como exemplos de bons políticos. Alcibíades não parece mostrar preocupações similares, pelo que, ao que a esta característica diz respeito, destoa não só do modelo familiar como do «nacional».

${ }^{64}$ Sobre esta política de Péricles, vide Lewis (1992: 59-60).

${ }^{65}$ Foi Isócrates (15. 234) que atribuiu as construções do século V a.C. à responsabilidade individual de Péricles, que interpreta como manifestação da vontade imperialista de Atenas (7.66). Em Arist. 25. 9, Plutarco dá-nos conta das críticas que Platão fez às obras de embelezamento de Atenas, quando afirma que o fundador da Academia defendia que Aristides havia sido superior a outros políticos, nomeadamente Péricles, que encheram a cidade de pórticos, riqueza e frivolidades, ao passo que o filho de Lisímaco governou tendo em vista a virtude. Sobre as obras, tema que Plutarco aborda em Per. 12-14, vide infra p. 253 sqq. e Lewis (1992: 167, 175, 448).

${ }^{66}$ Cf. supra p. 218 sqq. 
E o certo é que o povo, guiado por aquilo a que Plutarco chama uma «demagogia transigente e por vezes branda, qual melodia florida e delicada», foi aderindo à sua causa; Tucídides acabou exilado e Péricles senhor de Atenas, o que comprova a teoria romana do efeito obtido pela política do panem et circenses $^{67}$ (Juv. 10. 81): quando tem comida e diversão, a populaça é toda sorrisos e apoios ${ }^{68}$; só quando esses bens de primeira necessidade falham é que ela revela a sua verdadeira natureza.

Mas esta estratégia demagógica de favorecimento ${ }^{69}$ do povo cessa tão logo Péricles ganha a confiança das massas e um lugar seguro no governo ${ }^{70}$ (cf. Per. 15.1). Nessa altura, o lobo despe a pele de cordeiro, como qualquer político que, em fase de campanha, a tudo diz que sim e que uma vez no poder, esquecendo as promessas, age de modo a obter a sua satisfação pessoal, isto é, zela pelo seu próprio proveito, colocando-o à frente do bem-estar geral. Contudo, ao contrário do político comum, o «nosso» passa a agir como deve um homem de Estado rigoroso e consciente da sua missão, à boa maneira do que defendem Platão e Plutarco. E a música que Péricles antes dava ao povo muda de estilo, pois este passa a tanger

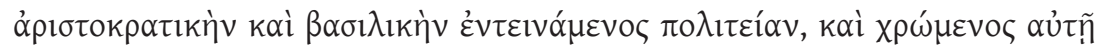

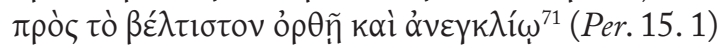

"as cordas de um governo aristocrático e régio que usou com as melhores intenções de modo justo e inflexível."

${ }^{67}$ Em Moralia 802D-E, o biógrafo critica os líderes que atraem o povo pela barriga, pela bolsa e através da organização de espetáculos. Tal comportamento - afirma - é próprio para lidar com animais e não com pessoas, que devem ser persuadidas através da eloquência. Em Moralia $821 \mathrm{~F}$, afirma que essas concessões são carinhos de prostitutas, a quem o povo concede, em troca dos serviços prestados, uma glória efémera e inconstante. Podemos mesmo afirmar que existe um padrão comparativo entre o comportamento de um mau político (que apenas incentiva o que a natureza do povo tem de pior - Moralia 822C) e um comportamento sexual impróprio (cf. Moralia 785D-F, 788E, 790C). Sobre este assunto, leia-se Trapp (2004: 116).

${ }^{68}$ Apoia Péricles contra o Areópago (Per. 9.3; vide infra p. 236), exila Címon (Per. 9. 4; infra p. 202) e Tucídides (Per. 14. 3; infra pp. 203-216).

${ }^{69}$ Este apoio excessivo ao povo contribuiu para uma profunda separação das classes, como fica implícito em Per. 11.3- 4.

${ }^{70}$ Cf. Plu. Moralia 800A, onde se defende que o político deve tentar modificar o caráter dos concidadãos quando já goza de influência e confiança junto daqueles e Phoc. 3.1, segundo o qual o verdadeiro político só cede aos desejos da populaça quando esse é o método mais fácil de conseguir o que é melhor para os concidadãos. Disso mesmo é exemplo a descida do preço do trigo, proposta por Catão o Jovem ao Senado para evitar que o povo aderisse à causa de César (Ca. Mi.26.1).

${ }^{71}$ A terminologia que Plutarco usa neste passo é de influência aristotélica (Pol.1289a26-b26). Cf. Stadter (1989: 189). Em Plutarco, é frequente ver a ação do homem de Estado comparada à de um músico, que procura reverter as dissonâncias com doçura, conferindo às cordas mais ou menos tensão, consoante as circunstâncias. Desta forma de governar em democracia nos dão testemunho, por exemplo, Moralia 809E, 827A-B, Phoc. 2. 7-9, Num. 23. 6. 
É que o estadista sentia-se no dever de fazer o melhor pelos concidadãos, de pôr os interesses da Tó $\lambda$ ıৎ à frente dos seus próprios ${ }^{72} \mathrm{e}$ daquilo que o povo acreditava ser o mais acertado, porque tinha a consciência de que este é uma massa de opinião inconstante (Per. 15.1 fala-nos dos desejos da multidão, que

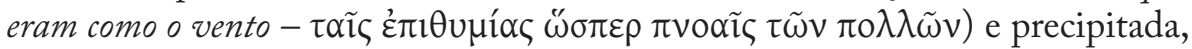

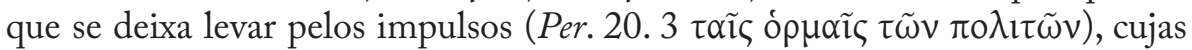
consequências para o futuro podem não ser as melhores ${ }^{73}$. Péricles chega a ser insultado e acusado de cobardia ${ }^{74}$, no entanto, o seu bom-senso e autodomínio fazem com que suporte com calma e em silêncio as injúrias dos inimigos ${ }^{75}$ : é isso que acontece quando ele, perante a invasão lacedemónia, se recusa a combater no solo da Ática, optando por mostrar o valor dos Atenienses no $\operatorname{mar}^{76}$ (Per. 33.6).

É por causa desta atitude (e da capacidade do filho de Xantipo para controlar a imponderação dos cidadãos e dos seus colegas ${ }^{77}$ ) que Plutarco, por influência da teoria política de Platão ${ }^{78}$ (Grg. 456b), compara algumas vezes a

${ }^{72}$ Tal postura aparenta ser uma incongruência com as medidas demagógicas que tomou no momento de acesso ao poder. Mas não o é: Péricles tinha um projeto político, que só poderia implementar uma vez criadas as condições para isso, ou seja, com o poder nas mãos e o apoio da população. A demagogia foi, neste caso, um mau meio, perdoável pelo bem que do governo de

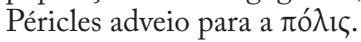

${ }^{73}$ Esta perspetiva que Plutarco apresenta em Per. 15 é certamente influenciada por Thuc. 2. 65.9, que identifica Péricles com a razão ( $\gamma v \omega ́ \mu \eta)$ e os Atenienses com as paixões. Cf. Edmunds (1975: 7-14).

${ }^{74}$ Esta acusação contrasta com a posição de Aristóteles (EN 1116a 10), segundo o qual

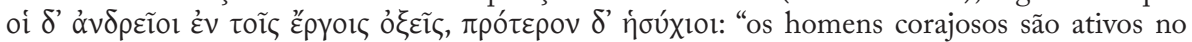
momento de agir e calmos antes”. Era precisamente o que acontecia com Péricles. Ele sabia que há momentos oportunos para levar a cabo todas as ações. É então que devemos dar o nosso máximo; até lá, a serenidade é a melhor forma de reunir as energias necessárias.

$75 \mathrm{O}$ comportamento de Péricles coincide com o defendido por Aristóteles (EN 1100b 35):

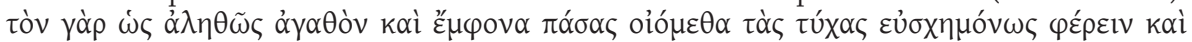

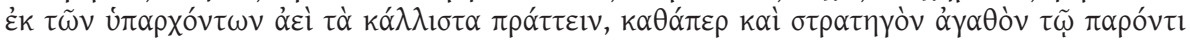

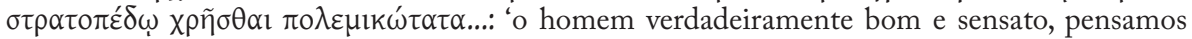
nós, suporta decentemente todas as vicissitudes e executa sempre as ações mais nobres, como também um bom general faz o melhor uso possível do exército sob o seu comando.'

${ }^{76} \mathrm{O}$ principal motivo que terá levado os Lacedemónios a invadir a Ática e a assentar arraiais em Acarnas foi a crença de que os Atenienses, belicosos e dados à ação, teriam uma reação imediata, movidos pela raiva e pelo orgulho ferido e sairiam prejudicados, porque os Espartanos eram superiores em combates terrestres. Só não contaram com a oposição de Péricles a esse recontro, ou melhor, com a capacidade que este tinha em refrear a fúria da turba. Sobre a ação do Alcmeónida neste momento delicado da vida de Atenas, vide p. 280 sqq.

${ }_{77}$ Per. 2. 5. Esta é uma das maiores virtudes do nosso estadista e uma daquelas que partilha com o seu par, Fábio Máximo. Cf. Fab. 3. 7, 5.5, 10. 1. Outros políticos, como Nícias (Nic. 11. 2) e Demóstenes (Dem. 14. 3), mostraram determinação semelhante ao tentar fazer frente

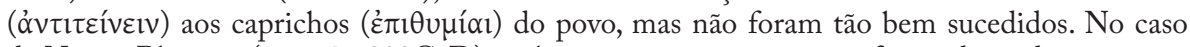
de Nícias, Plutarco (Moralia 802C-D) atribui esse insucesso aos seus fracos dotes de oratória.

${ }^{78} \mathrm{Em}$ Lg.905e-906a, o fundador da Academia compara os governantes (neste caso específico, os deuses que comandam os destinos do mundo) a médicos, pilotos, generais, 
ação de Péricles à de um médico ${ }^{79}$ ou à de um pai ${ }^{80}$, que, conhecedor do caráter do doente ou do filho, age em conformidade com aquilo que julga ser o melhor:

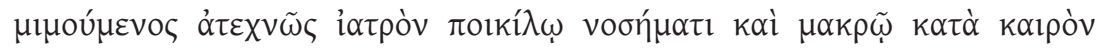

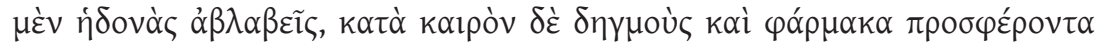

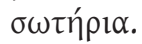

"parecia realmente um médico que, perante uma doença complicada e longa, conforme a ocasião, consente prazeres inofensivos ${ }^{81}$, ou prescreve remédios cáusticos que trazem a cura.”

Como um médico, que não pode dar ao paciente (sobretudo a um doente crónico, como neste caso) apenas o remédio mais saboroso, mas que tem

pastores, jardineiros, condutores de carros, o que faz dos membros do povo seres inferiores (animais, doentes, ovelhas...). Para exemplos deste recurso em Plutarco, vejam-se Ages. 1.2 (onde o político surge como pastor das massas), Fab. 20. 4 (segundo o qual o jardineiro deve podar árvores selvagens para que deem fruto) ou Moralia 802D (onde se afirma que Nícias não soube pôr rédeas curtas no seu cavalo).

${ }^{79}$ Em Phdr. 270b-d, Platão compara o verdadeiro orador a um médico; em R. 425a-426b,

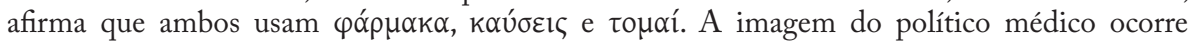
também em $G r g$. 521e-522a e $R$. 564b-c, onde o povo é, respetivamente, comparado a uma criança doente e à própria doença. Para um estudo aprofundado da metáfora do médico em Platão, vide Vergetti (1966: 3-39; 1967: 251-270; 1968: 251-267; 1969: 3-22); Jouanna (1978: 77-91). Sobre o uso que Plutarco faz da imagética médica quando se refere ao homem de Estado (e.g. Moralia 815 B-C, 818 D-E, 824A), leia-se Fuhrmann (1964: 238-240). Para o Queroneu, até os pais, enquanto educadores, devem adoptar o comportamento de um médico - cf. supra p. 155.

${ }^{80}$ A atitude paternalista de Péricles perpassa a biografia de Plutarco: aquele tudo faz para que a vida dos Atenienses melhore ou para evitar que cometam erros. É com esse objetivo que, por exemplo, tenta impedir a expedição de Tólmides (Per.18.2-3) ou a que os Atenienses pretendem organizar contra Siracusa (Per.21.1). A reação popular às suas iniciativas nem sempre é a mais doce e comedida, pelo que Plutarco a compara à de alguém doente que, desnorteado, se vira contra aqueles que apenas pretendem ajudar, como é o caso de um médico ou de um pai (Per. 34. 5). Segundo o Queroneu (Nic. 2. 1), também Nícias teve pelo povo uma amizade e dedicação paternal ímpares, que demonstrava, como Péricles, ao resistir às opiniões e caprichos das massas (Nic.11.2). Mas, ao contrário do filho de Xantipo, não conseguiu evitar os danos que a ação do povo causaria a Atenas sob o influxo de líderes menos conscientes, nomeadamente de Alcibíades. Note-se, contudo, que este comportamento protetor e paternalista de Péricles para com a $\pi$ ó $\lambda_{\imath}$, , apesar de alguns reveses, surtiu mais efeito do que no seio da sua própria família, já que não conseguiu criar os mesmos laços com o seu filho Xantipo ou com Alcibíades: o primeiro chega a fazer do pai alvo de troça pública (cf. p. 253); o segundo define como um dos seus principais objetivos de vida ultrapassar a glória daquele (cf. p. 195).

${ }^{81}$ De facto, segundo Arist. Rh.1373a25 (e, na sua peugada, Plu. Moralia 818A, 827B, Phoc. 2. 7-8), um bom governante deve, de quando em vez, fazer pequenas concessões ao povo, de modo a poder fazer-lhe frente em assuntos de maior monta. Aquele que nunca cede apenas consegue fazer com que o povo se torne mais inflexível e obstinado na resistência; as recriminações constantes deixam de fazer efeito, como um medicamento fora de validade, ou, como, diríamos nós hoje, um antibiótico contra o qual as bactérias desenvolveram resistência. 
de saber receitar o que é mais apropriado para a doença manifestada ${ }^{82}$ (Per. 15. 1), também Péricles toma as medidas que, consoante as circunstâncias, entende mais adequadas. Doseia, como se de medicamentos se tratasse, medos e esperanças ${ }^{83}$ dos Atenienses para obter um efeito paliativo ${ }^{84}$ para a sua arrogância e paixões ( $\pi \alpha ́ \theta \eta, P e r .15 .2)$, decorrentes do grande poder que detinham ${ }^{85}$ e constantemente inflamadas pelas más influências dos políticos de baixa categoria e pelos inimigos do filho de Xantipo. Foi isso que aconteceu, por exemplo, quando conseguiu impedir novo ataque ao Egito, adiar o sonho

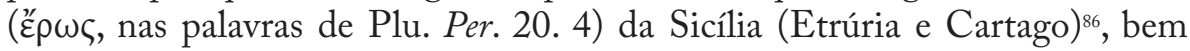
como manter a estratégia contra a Lacedemónia por ocasião da invasão da Ática ${ }^{87}$, decisões fundamentais para a manutenção do império, mas que os políticos que lhe sucederam, gananciosos e menos prudentes, deitaram a perder. Ou quando tudo fez para consolar e encorajar os concidadãos, na altura em que, além de martirizada pela peste, Atenas saiu derrotada do cerco contra Epidauro $^{88}$ (Per. 35.3).

${ }^{82} \mathrm{P} 1 . L g .684$ c afirma mesmo que na política, como na medicina, não há tratamentos sem dor. A ideia de que a cura pode implicar medidas radicais e causadoras de sofrimento no imediato surge também em $G r g .521 \mathrm{e}-522 \mathrm{a}$ e $R$. 564b-c. Plutarco refere-se a medidas desta natureza, por exemplo, em Cor. 12. 5, Cam. 9.3, mas de um modo geral deixa a ideia de preferir soluções menos drásticas (Num. 8. 2, Ca. Mi. 47.2, Caes. 31.7). Sobre a importância da doçura nas Vidas, vide Romilly (1979: 275-292).

${ }^{83}$ A capacidade de escolher a medicação e posologia corretas decorre do profundo conhecimento que o estadista deve possuir acerca do caráter do povo que governa. Só assim se pode dedicar à árdua e morosa tarefa de lhe melhorar o caráter, uma das principais funções de um líder de excelência (cf. Moralia 799B-C, 800A). Ainda que no nosso texto associemos esta dosagem hábil à faceta de médico do nosso político, o certo é que, em Plutarco (Per. 15. 2), tal ideia remete para o comportamento de um piloto que, como ninguém, controla o leme. Pretendemos com esta referência tornar mais evidente o facto de um bom governante ser simultaneamente um excelente médico, pai e piloto.

${ }^{84}$ A opção pelo termo "paliativo» foi bastante ponderada, pois, como o futuro viria a comprovar com políticos como Alcibíades, Péricles não conseguiu curar o povo, apenas camuflou as causas dessa sua doença crónica.

${ }^{85}$ Em Moralia 779D, Plutarco recorda uma anedota protagonizada por Platão em Cirene, cuja moral é a seguinte: aqueles que, como os habitantes de Cirene, se encontram em um momento de grande prosperidade, transformam-se num povo (mais) arrogante, arisco e ingovernável. Terá sido, pelo menos, essa a desculpa que o fundador da Academia deu para se recusar a elaborar a constituição de Cirene.

${ }^{86}$ Plu. Per. 21.1, Alc. 17.1.

${ }^{87}$ Esta foi talvez a maior dificuldade por que passou, já que o contexto era particularmente difícil por causa da contestação de que Péricles vinha sendo alvo desde antes do início da guerra e que se intensificou por causa da sua teimosia em manter uma estratégia que, além de aparentemente não estar a surtir grandes resultados, também não se coadunava com a maneira de ser ativa dos Atenienses (cf. supra p. 120 sqq). Sobre este assunto, vide infra p. 255 sqq.

${ }^{88}$ Epidauro era a segunda cidade da Argólida e forneceu oito navios em Artemísio e dez em Salamina. A sua hostilidade com Argos, primeira cidade da região, fez com que fosse partidária de Esparta. Epidauro era famosa pelo santuário dedicado a Asclépio. O facto de Péricles atacar esta região durante uma situação de peste causa admiração, pois era mais lógico que tentasse pedir ajuda ao deus da medicina. 
Contudo, mais do que isso, tal como um médico, Péricles revela-se senhor da paciência necessária para não dar importância a descontentamentos e protestos (Per. 33.6), nem às injúrias proferidas nos momentos de maior sofrimento (Per. 34. 5), sobretudo quando a Guerra do Peloponeso causava graves danos à população; animava-o a convicção de que a sua estratégia permitiria a Atenas alcançar a vitória.

Devido a esta atitude protetora, e também por influência platónica ${ }^{99}(R$. 488a-e, Grg. 512b-d), o biógrafo compara igualmente ${ }^{90}$ o comportamento do estadista ao de um piloto (Per.33.6) que tem de ignorar as lágrimas, as náuseas e o medo dos passageiros para poder agir de modo a que não naufraguem todos. De facto, não deixa de ser curioso notar que Péricles atua como pai, médico e piloto sobretudo quando a contestação do povo e o perigo que corre são maiores, pois é nessa altura que o seu bom-senso e prudência se revelam fundamentais.

E o povo ateniense, apesar de muito fustigado por várias «doenças» decorrentes do poder que a ró $\lambda_{\imath \varsigma}$ detinha (Per. 15. 2), embora por diversas vezes discordasse e até se manifestasse contra as suas decisões, raramente deixava de o seguir e, por norma, acabava por concordar com as opções por ele tomadas (Per. 15.1). Uma das ocasiões em que Péricles não foi bem sucedido a convencer o povo foi a da expedição proposta por Tólmides ${ }^{91}$ (Per. 18. 2-3). É caso para dizer que este falhanço foi importante no sentido de mostrar ao povo a clarividência do estadista, a sua preocupação com a đó $ı$ ı e também porque serviu de lição: pelo sim pelo não, em próxima situação semelhante, seria melhor ouvir os conselhos que lhe dava.

Péricles era um demagogo inato, no sentido etimológico do termo. Tinha, como nenhum outro, o dom de conduzir os Atenienses, que, em Per. 15. 2, são mais uma vez comparados a um cavalo, animal que gosta de galopar em liberdade, mas que é domesticável pelo rigor do freio ${ }^{92}$. Sempre que o «seu

${ }^{89}$ Note-se, contudo, que esta imagem tem muita tradição mesmo antes de Platão, algo que podemos comprovar, por exemplo, através de Archil. fr. 105 West e A. Th. 654.

${ }^{90} \mathrm{Em}$ Per. 15.2, esta ideia surge de modo indireto, já que é a ação de Péricles que é associada

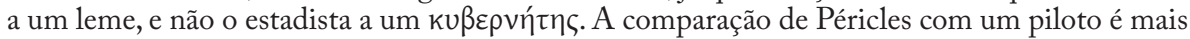
pertinente do que qualquer outra, na medida em que está relacionada com a metáfora da nau do Estado (P1. R. 488a-e). Segundo Breebart (1987: 56), a ideia da manipulação subjacente a esta metáfora é particularmente cara à elite imperial, que acredita que «the people can only be the subject of politics through its leadern. Para uma análise mais cuidada deste passo de Plutarco por comparação com a sua fonte (Thuc. 2. 65.9, onde a imagem do piloto não é utilizada), consulte-se Romilly (1988: 24). Ambos os paralelos - Péricles-médico/Péricles-piloto - revelam as preocupações literárias do biógrafo, que procura adornar a imagem do político ateniense como homem sábio e prudente, que, em situações difíceis, apenas ouve a voz da razão.

${ }^{91}$ Cf. supra p. 184, nota 91.

${ }^{92}$ No entanto, esta imagem de um Péricles cavaleiro volta a ocorrer em 15.1 e realça os dotes do nosso protagonista para este tipo de equitação, pois sabia como ninguém puxar ou soltar as rédeas do seu cavalo. De um modo geral, Plutarco descreve o povo (à boa maneira de Platão) 
cavalo» não aquiescia a bem às propostas que fazia (algo que aconteceu sobretudo em momentos chave da governação, como por ocasião das obras de embelezamento da cidade e dos primeiros anos da Guerra do Peloponeso), Péricles recorria a esse processo para obrigá-lo a agir do melhor modo, ou seja, a seguir pelo caminho que entendia mais vantajoso. É como se deixasse o povo viver na ilusão de estar no comando dos interesses da cidade e de que apenas intervinha quando via esses mesmos interesses ameaçados ${ }^{93}$.

O que fazia com que o $\delta \tilde{\eta} \mu \circ \zeta$, sempre desconfiado ${ }^{94}$ e renitente - que não escondia a sua animosidade para com a classe política (Moralia 813A) -, aderisse aos conselhos e opções que apresentava era sobretudo a sua enorme capacidade de persuasão e a conduta irrepreensível (Per. 15. 2-395), que geravam nos Atenienses uma confiança quase cega, a ponto de, como parodia Teleclides ${ }^{96}$, lhe terem confiado

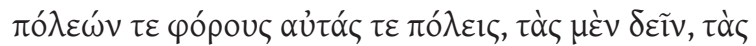
$\delta$ '̊̀ $\alpha \lambda u ́ \varepsilon i v$,

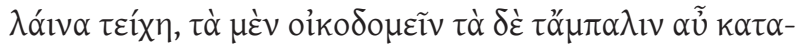

ßá $\lambda \lambda \varepsilon i v$

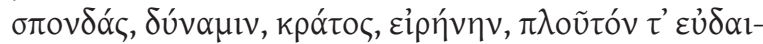

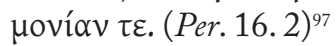

como um cavalo teimoso e caprichoso, que deve ser mantido com rédea curta para o seu próprio bem (Moralia 800C, 802D, 814C, 821A, 823E-F). Embora reconheça que as pessoas não devem ser tratadas como animais (Fab. 20. 4, Moralia 821D), Plutarco aceita o uso de «argumentos» físicos (sugeridos, por exemplo, pelo recurso ao verbo $\imath \_\theta \alpha \sigma \varepsilon v ́ \omega$ 'domesticar' - em Num.8. 3 e Dem. 5.5) para impor a obediência, sobretudo se a natureza do povo em causa não for boa.

${ }^{93} \mathrm{Cf}$. Per. 39.3, onde se afirma que muitos estavam descontentes com o seu poder, porque se sentiam obscurecidos.

${ }^{94}$ Em Moralia 821B, Plutarco recorda D. 6. 24, segundo o qual a desconfiança é para as cidades um modo de se precaverem contra a tirania.

95 Cf. Moralia 801C, onde o biógrafo afirma que o caráter é responsável pela confiança ou desconfiança que o povo nutre por um líder. Em Per. 15. 2-3, Plutarco analisa as causas da liderança de exceção que Péricles exerceu sobre Atenas e do respeito e consideração que a população, de um modo geral, nutria por ele, a saber: a eloquência (que tem por fontes Pl. $P h d r$. 270a e, naturalmente, Tucídides, que o apresenta tantas vezes no uso da palavra), a reputação de vida e ainda (neste contexto, a principal) a incorruptibilidade do estadista (cuja fonte é Thuc. 2. 65. 8-9). Acresce o que o historiador chama inteligência ( $\gamma v \omega ́ \mu \eta)$ e consideração pública ( $\alpha \xi \iota \omega \mu \alpha)$ e Plutarco confiança ( $\pi i ́ \sigma \tau \iota c)$ : assim se salienta que o povo não tinha mera consideração ou respeito pela integridade de Péricles, mas sim que, por causa dessa mesma integridade, tinha total confiança no político (embora saibamos que, por vezes, hesitava). Fica deste modo evidente que Tucídides, correligionário de Péricles, partilhava, de uma forma geral, das opiniões políticas do estadista. Não nos surpreende, por isso que lhe tenha tecido rasgados elogios (cf. Thuc. 2.6566) e que tenha omitido as críticas que lhe foram feitas e as acusações dos seus opositores (vide infra p. 238, nota 139).

${ }_{96}$ Comediógrafo que parece ter obtido três vitórias nas Dionísias e quatro nas Leneias, a primeira das quais terá ocorrido em 446 a.C. Chegaram até nós alguns títulos como, Anfictiôes, Hesiodos, Castigo, Pritanes e fragmentos que sugerem a orientação política das suas críticas.

${ }^{97}$ Fr. 45 K.-A. Este fragmento, esclarecedor do profundo domínio do governante sobre a 
"as taxas das cidades e as próprias cidades, umas para serem subjugadas, outras libertadas; as muralhas de pedra, umas para construir, outras, pelo contrário, para deitar de novo abaixo, as alianças, a força, o poder, a paz, a riqueza e a felicidade."

De facto, segundo Plutarco, era só a Péricles que os Atenienses entregavam as questões verdadeiramente importantes (Per. 32. 6); a sua confiança nele era tal que, à exceção das críticas que de início fizeram aos gastos excessivos com as obras de embelezamento, não questionavam as despesas que apresentava ${ }^{98}$, nem mesmo aquelas que vinham apenas rotuladas de «gastos diversos» (Per.23.

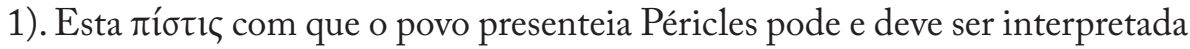
como aquilo que Plutarco considera o único prémio [honra] a almejar pelo bom político em troca da devoção que consagra à $\pi$ ó$\iota^{99}$. É que, segundo o biógrafo (Moralia 820B-821C), as maiores honras não devem ser manifestadas

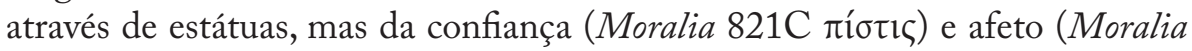
821C $\varphi \imath \lambda \circ \varphi \rho \circ \sigma u ́ v \eta$ ) ou marcas materiais discretas (como inscrições ou decretos), porque são um reconhecimento simbólico (no caso particular de Péricles, pela forma correta e séria como conduzia os destinos da cidade) e não um pagamento pelas benfeitorias recebidas.

O mesmo não se pode dizer de Alcibíades.

Apesar da sua capacidade inata de liderança e destreza política, o próprio Péricles, à semelhança do que sucedeu a inúmeros outros políticos de renome ${ }^{100}$, não saiu ileso da sua relação com as massas. Tal facto não deve ser encarado com surpresa por três razões: a primeira é que nenhuma relação humana é sempre feliz e pacífica. A segunda consiste no caráter volúvel da popularidade, principalmente se o político em questão se apresenta diante do povo sempre à vontade, tão ou mais à vontade do que se estivesse no recesso do lar (foi assim que Alcibíades começou por agir), ao invés de optar por um comportamento preventivo, de pouca exposição, à semelhança do que caracteriza, por exemplo, Péricles e Nícias ${ }^{101}$. A terceira decorre da natureza sui generis do povo, e em

vida ateniense (sobretudo no que respeita à política externa), revela a sintonia que, por norma, pautava a relação entre Péricles e o povo e que é realçada pelo facto de, antes de apontar este testemunho da comédia, Plutarco (Per. 15. 1) ter afirmado que foi aquele quem «se confiou» essas e outras responsabilidades. Podemos, por isso, concluir que as vontades do filho de Xantipo acabavam muitas vezes por se transformar nos desejos do povo.

${ }^{98}$ Sobre a honestidade de Péricles no que toca a dinheiro, vide infra p. 251 sqq.

${ }^{99}$ Para este assunto, vide Boulogne (2004: 197-212).

${ }^{100} \mathrm{~A}$ escolha da expressão «de renome» para caracterizar os políticos que sofreram às mãos do povo não é inocente, pois como veremos de seguida, este não convivia muito bem com os sucessos dos seus homens de Estado.

${ }^{101}$ Cf. supra p. 190 sqq. Segundo Plu. Nic. 2. 4, a influência considerável que Nícias obteve junto da populaça prende-se ao receio que demonstrava ter-lhe. De facto, é próprio do povo temer os que o desdenham e elevar os que o temem. 
especial do ateniense, que tinha um comportamento altamente imprevisível: tão depressa idolatrava um político quanto se deixava mover por uma enorme inveja do sucesso que aquele alcançava, em uma relação de amor e ódio insana. Segundo Plu. Arist.7.1, o povo não suportava aqueles cujos nomes e reputação se distinguiam dos demais ${ }^{102}$ ou os que atingiam um elevado grau de poder ${ }^{103}$. Por causa dessa inveja, tornava-se irascível e recetivo a todo o tipo de calúnias que os inimigos de um político difundissem contra ele (Moralia 805C, Per. 32. $3,35.5)$. Nessa altura, vinham ao de cima todos os aspetos que, ao longo da atividade política de alguém, haviam desagradado ao povo, mesmo que até então este não se tivesse manifestado a respeito. Foi isso que sucedeu entre outros, com Temístocles (Them.22), com Péricles, que viu os seus amigos perseguidos (Per. 31-32), e com o próprio Alcibíades (Alc. 20.6), como veremos a seguir.

Mas, ainda que, segundo Plutarco, os pequenos defeitos assumam proporções maiores na vida de um político ${ }^{104}$, enquanto um qualquer líder estivesse em fase de graça, tudo lhe era permitido. É esse, por exemplo, o caso de Alcibíades, a quem, de início, o povo - seduzido pela sua riqueza e consequente munificência ${ }^{105}$ para com a $\pi$ ó $\lambda ı$, pela glória dos antepassados e pela sua bravura, bem como pela beleza e dotes oratórios que o caracterizavam - suportava todos os desmandos ${ }^{106}$, que não eram poucos, como se se tratasse de simples infantilidades ( $\pi \alpha_{1} \delta 1 \alpha$ $\alpha$ ) e de uma enorme vontade de se fazer

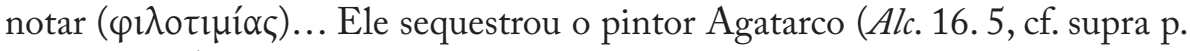
183, nota 97), agrediu, entre outros, o futuro sogro e um corego rival a murro (Alc. 8.1 e 16.5-6, respetivamente; supra p. 186), gerou uma criança em uma

${ }^{102}$ Isso aconteceu, por exemplo, com Fídias por causa da fama dos seus trabalhos e de ter gravado a própria figura no combate das Amazonas que cinzelou. Cf. Per. 31. 3. Duff (1999: 220) afirma que a inveja do povo é um dos maiores perigos com que se depara o homem de Estado de sucesso, pois pode destruí-lo. Segundo Plutarco (Moralia 787C), a inveja é o maior mal da política.

${ }^{103}$ Em Moralia 805C e Per. 35.5, Plutarco mostra-se indignado pelo facto de Símias caluniar um homem valioso que, pela sua virtude, ocupa o primeiro posto.

${ }^{104}$ Moralia 800E.

${ }^{105}$ Importa chamar a atenção para o facto de Plutarco considerar a liberalidade de Alcibíades

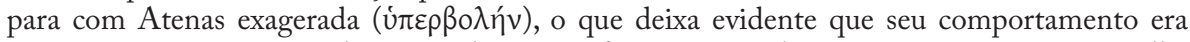
excessivo não só para o mal, mas também quando praticava o bem, como que a sugerir que lhe era impossível ser de outra maneira. Cf. (Alc. 16. 4).

${ }^{106} \mathrm{O}$ facto de Alcibíades levar uma vida desregrada, desgovernada, é um claro indício de que não terá competência para conduzir convenientemente as massas. Segundo Plutarco (Moralia 780B-C), isso acontece, porque quem não se governa a si mesmo não pode governar os outros, uma ideia partilhada quer por Pl. Grg. quer por D. Chr. 62. 1. Em Moralia 800D, o biógrafo responsabiliza o desgoverno e a devassidão da vida que Alcibíades levava pelo seu infortúnio e pelo facto de a cidade não ter tirado benefício das suas qualidades. Não deixa de ser curioso notar que Címon, também fortemente criticado pelo seu alcoolismo e devassidão no campo sexual (Cim. 4. 4, 15.4), tenha acabado por ser visto pela posteridade como um político melhor do que o filho de Clínias. 
prisioneira ${ }^{107}$ por ocasião da conquista de Melos (Alc. 16. 5; supra p. 186)... e o povo não reagiu. $\mathrm{O}$ mesmo aconteceu, por exemplo, quando enganou a embaixada de Esparta (Alc. 14): neste caso, apesar de condenar moralmente o comportamento do jovem, os seus concidadãos não atuaram, porque ficaram satisfeitos com os benefícios dele resultantes ${ }^{108}$.

Importa abrir um parêntesis para recordar que Alcibíades não foi vítima apenas da inveja dos Atenienses. Durante o exílio, «adotou» quer os Lacedemónios quer os Persas como concidadãos e auxiliou-os na prossecução das respetivas metas com todo o empenho próprio de quem se vinga ${ }^{109}$. Por isso, tornou-se poderoso e célebre, quer na Lacedemónia, quer na corte de Tissafernes. Em ambos os casos, tanto os nobres mais influentes e ambiciosos como Ágis ${ }^{110}$ e Tissafernes começaram a sentir-se invejosos e incomodados com o seu prestígio, o que revela o dom que Alcibíades tinha de se fazer amado e odiado ${ }^{111}$. Em ambos os casos, Alcibíades foi «traído» e obrigado a fugir para se manter vivo, o que corrobora a ideia de que a inveja em política é um perigo em qualquer lugar do mundo (Alc. 24.3). Todavia, nunca fraqueja ou aparenta desanimar e depressa busca uma solução para o seu problema.

No entanto, quando a lua de mel cessava, porque - por iniciativa própria ou instigado pelos inimigos dos políticos em causa - o povo ficava descontente com a atuação privada, política ou militar daqueles, a sua reação era imprevisível e até perigosa, pois a fúria dos Atenienses era implacável ${ }^{112}$. Os políticos, de um modo geral, tinham essa noção e temiam enfrentar esse

107 [And.] 4. 22-23, segundo o qual a crueldade de Alcibíades chegou ao ponto de este matar os pais e familiares desta mulher. Cf. [And]. 2. 14 e Ath. 534c.

${ }^{108}$ Cf. supra p. 205 sqq.

${ }^{109}$ Infra p. 285 sqq.

${ }^{110}$ Quer Alcibíades (Alc. 24.3-4) quer Coriolano (Cor.31.1-3) desagradavam às elites locais. No entanto, o Alcmeónida sai prejudicado relativamente a Coriolano nesta comparação, na medida em que este nunca teve comportamentos ofensivos para com aqueles que o acolheram, ao passo que Alcibíades se fez amante da mulher do rei (Alc. 23. 7-9). Não surpreende, por isso, que a inveja que indispôs Ágis com Alcibíades tenha tido um duplo motivo: por um lado, o obscurecimento do seu mérito nos sucessos de Esparta, que todos atribuíam ao Alcmeónida; por outro, o facto de este não ter sabido respeitar o seu anfitrião e lhe ter engravidado a mulher. Por essas razões, o rei condenou-o à morte (Alc. 24. 4). Sobre este assunto, vide Thuc. 8. 45; Hatzfeld (1940: 227); Verdegem, (2005: 175). A relação que uniu Alcibíades a Timaia será abordada com mais pormenor adiante (p. 246).

${ }^{111}$ Esta capacidade de Alcibíades é demonstrada em diversos momentos da sua vida. Um deles é mencionado por Plutarco em Alc. 25 e decorre do serviço prestado pelo Alcmeónida a Tissafernes: o Persa foi aconselhado a deixar Esparta e Atenas lutarem até à mútua destruição; deste modo, o poder do inimigo seria destruído sem esforços e custos para o Rei. Como não poderia deixar de ser, Espartanos e Atenienses, que em período não muito distante idolatraram Alcibíades, ficam furiosos com ele.

${ }^{112}$ Cf. Moralia 799C. Disso nos dão testemunho, por exemplo, Ar. Eq. 537, V. 243. Em Arist. 26. 5, Plutarco enumera as injustiças dos Atenienses para com os seus estrategos. Sobre este tema, vide Knox (1957: 76). 


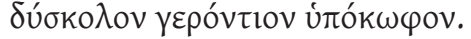

"velhinho de maus fígados, duro de ouvido ${ }^{113}$."

Nícias, por exemplo, quando a expedição à Sicília se revelou o fracasso que ele - e também antes Péricles - previra, afirmou preferir morrer às mãos do inimigo do que regressar para junto dos concidadãos, pois temia os seus famosos processos e delações ${ }^{14}$, aos quais nem Péricles escapou.

O próprio Alcibíades, cuja popularidade inconstante ora o afastava ora o aproximava das massas ${ }^{115}$, fugiu de enfrentar o seu veredito. Quando, por ocasião da partida para a expedição à Sicília, foi acusado ${ }^{116}$ de, embriagado, ter destruído estátuas e ridicularizado as cerimónias dos Mistérios de Elêusis ${ }^{117}$, Alcibíades, começou por sentir grande medo, já que os Atenienses

${ }^{113}$ É assim que Aristófanes (Eq. 41-42) se refere ao povo. A tradução apresentada é da autoria de Silva (1991: 39). Em Ar. Eq.1111-1114, o coro chega a afirmar que todos temem o povo como se de um $\tau u ́ p \alpha v v o \zeta$ se tratasse, o que é um paradoxo digno de nota, já que os Atenienses, apesar de detestarem o regime monárquico, agiam como se estivessem à frente de um. Plu. Moralia 799D afirma declaradamente que o povo de Atenas infundia pavor até aos seus governantes.

${ }^{114}$ Cf. Thuc. 7.48 e Plu. Nic. 22.2-3. Não deixa de ser curioso salientar, que embora fossem adeptos de intrigas e reagissem a quente e normalmente de modo excessivo, os Atenienses eram capazes de se dar conta dessa falta e de tentar voltar atrás, como aconteceu no caso de Mitilene (Thuc. 3.36). Mas, se o recuo não era possível, desviavam a sua frustração e ira do alvo primordial, dirigindo-a contra aqueles que provocaram a situação. Cf. X. $H G$ 1. 7.35. Sobre este assunto, vide supra p. 121, nota 36.

115 Segundo Gribble (1999: 268, 277-279), a atitude do povo para com Alcibíades era tão inconsistente como a vida deste.

${ }^{116}$ De acordo com Alc. 19.3 e 22. 4, foi Téssalo, o filho de Címon (mencionado em Per. 29. 2), quem acusou Alcibíades de impiedade para com Deméter e Perséfone. Independentemente de o Alcmeónida ser culpado ou inocente, podemos acreditar que a atitude de Téssalo tenha sido uma forma de retaliação pela constante perseguição que Péricles dedicou a ele e aos seus irmãos (cf. infra p. 277, nota 306). Em Alc. 20.6, Plutarco chama a atenção para o facto de Tucídides não nomear os delatores do Alcmeónida e apresenta como fonte do nome que indica - Dioclides - um passo de uma comédia de Frinico (fr. 58 CAF I 385). Este é um dos raros momentos (se comparado com a Vida de Péricles) em que o biógrafo usa citações de comédia na Vida de Alcibiades. Sobre este assunto, vide p. 242.

${ }^{117}$ Esta acusação ocorreu pouco depois do episódio da mutilação dos Hermes, entendido por alguns como um mau presságio para a expedição que se avizinhava (cf. Thuc. 6. 27.1-3; D. S.13.2. 3; Nep.Alc. 3). Houve, por sua vez, quem defendesse tratar-se de uma manobra de intimidação dos Coríntios, que eram colonizadores de Siracusa cf. Cratipo (FGrHist 64 F 3) e Filócoro (FGrHist 328 F 133) e também quem atribuísse o sucedido ao desvario de jovens embriagados. O povo não se deixou convencer por nenhuma destas teorias e, desconfiado como sempre da existência de conspiração para abolir a democracia, apressou-se a investigar de modo a encontrar um bode expiatório para punir (cf. Thuc. 6.60, onde se descreve a reação do povo por ocasião dos Hermes). Os inimigos de Alcibíades, representados pelo orador Ândrocles, souberam tirar proveito da conjuntura para envenenar os Atenienses contra aquele, acusando-o de ter participado na mutilação de outras estátuas (Plu. Alc. 19. 1), ou, na versão de Tucídides (6. 28), da própria mutilação dos Hermes e da profanação dos Mistérios. Tais acusações ganharam um peso proporcional à ambição de Alcibíades, pelo que as suas consequências para o jovem Alcmeónida foram dramáticas, mas não suficientes para calar a sua empáfia. De qualquer modo, seria pouco provável que o grande 
rapidamente esqueceram a veneração que por ele sentiam e se tornaram hostis $^{118}$. Contudo, depressa ficou mais tranquilo, porque se apercebeu de que todos os participantes na expedição estavam do seu lado, a ponto de os aliados Argivos e Mantineus se recusarem a seguir sem ele ${ }^{119}$. Por isso, inteligente - e sabedor de quão influenciável era o povo pelos inimigos daqueles em relação aos quais já estava descontente -, ao sentir que ainda era senhor do apoio de quem detinha o poder militar e que o povo ansiava pela partida da expedição ${ }^{120}$, tudo fez para ser julgado (e ilibado) antes da partida. Mas, apesar dos seus grandes dotes oratórios ${ }^{121} \mathrm{e}$ da anterior admiração que o povo nutrira por ele, não atingiu os seus propósitos ${ }^{122}$, pois os inimigos, que chegaram a temer que $o$ povo ignorasse - mais uma vez - a leviandade do jovem e decidisse a contento deste ${ }^{123}$, conseguiram apelar às enormes expectativas dos Atenienses em relação ao projeto Sicília e convencê-los de que não deviam adiar a sua execução. Deste modo, os adversários puderam ficar a conspirar na sua ausência, sem que tivesse hipóteses de defesa ${ }^{124}$. Por isso, pouco tempo depois, estava a ser

impulsionador da expedição à Sicília empreendesse ações que pudessem pô-la em causa. Sobre este assunto, consultem-se Lewis (1992: 286-287); Westlake (1968: 221-222); Hatzfeld (1940: 158-203, especialmente 178, n. 1); MacDowell (1962: 192-193).

${ }_{118}$ O texto de Plutarco (Alc. 19.3) é particularmente sugestivo dessa fúria: $\tau \rho \alpha \chi u v o \mu \varepsilon ́ v o v$

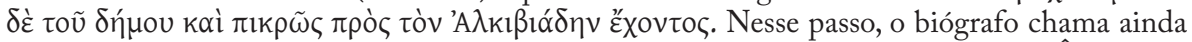
a atenção para o facto de o povo se ter deixado influenciar pelo veneno instilado por Ândrocles, um dos maiores inimigos do Alcmeónida. Sobre o papel que este orador desempenhou no descrédito de Alcibíades, cf. Thuc. 8. 65. Os Atenienses voltariam a dirigir a sua cólera contra Alcibíades (como no-lo indicam a ocorrência de ópүńv e kakóvolav, em Alc. 36. 4, e da expressão

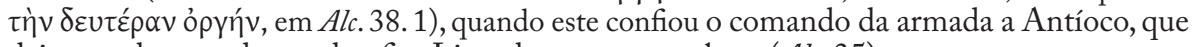
deitou tudo a perder ao desafiar Lisandro para o combate (Alc. 35).

${ }^{119}$ Esta informação ocorre igualmente em Thuc. 6. 29.3, 6.61.5.

${ }^{120}$ Recordemos que este afã pela Sicília havia sido recuperado e reforçado pelo próprio Alcibíades, como no-lo diz Plutarco em Alc. 17.

${ }^{121}$ Alcibíades, confiando certamente no amor que o povo já lhe dedicara, arrisca afirmar que era preferível que o condenassem à morte se não conseguisse provar a sua inocência ou que o ilibassem para que partisse sem receio dos sicofantas que ficavam para trás. A opção dos Atenienses por deixar alguém suspeito de conspirar contra a democracia comandar um exército tão grande não é muito inteligente nem muito sensata e revela bem o quanto precisavam de um líder com cabeça para orientá-los: é que, se Alcibíades quisesse mesmo atacar a democracia, estar à frente de um exército tão poderoso seria vantajoso para ele e prejudicial para Atenas.

${ }^{122}$ Facto que, de certo modo, surpreendeu os que conspiravam contra ele.

${ }^{123}$ Como veremos adiante (p. 237), os adversários de Péricles também não estavam seguros da reação que o povo teria diante dos diversos ataques de que Péricles foi alvo. Nesse sentido, Plutarco (Per. 31.2) afirma que havia quem quisesse experimentar, através de Fídias, «que tipo de juiz o povo seria para Péricles». Em ambos os casos, a atuação do povo ultrapassou largamente as expectativas daqueles que iniciaram a difamação dos Alcmeónidas.

${ }_{124}$ Em Alc. 20. 4- 20. 8, Plutarco deixa transparecer que não acredita na participação de Alcibíades no caso dos Hermes e alude ao forjar de testemunhos contra o Alcmeónida, já que nenhuma prova se revelou suficientemente fidedigna. Para apoiar esta tese, menciona mesmo o facto de uma das testemunhas falsas afirmar ter reconhecido os rostos à luz da lua... em noite de lua nova, como se veio a verificar. Mas nem diante desta evidência o povo passou a refletir melhor sobre as diversas denúncias falsas que ia recebendo; bem pelo contrário, parecia sentir 
chamado para prestar contas: é que nem o facto de Andócides ${ }^{125}$ ter confessado o crime para conseguir imunidade aliviou suficientemente a cólera do povo. Assim, uma vez encerrado o caso dos Hermes, a populaça concentra toda a sua ira em Alcibíades. Nessa altura, o lobo vestiu a pele de cordeiro, pois ordenou à delegação que tinha por objetivo trazer Alcibíades de volta a Atenas o uso de tato e persuasão e o não recurso à violência (que estaria à sua espera no momento oportuno...). Aquele deveria acreditar que o povo o chamava de volta para lhe dar a oportunidade de limpar a sua imagem e o seu bom nome. $\mathrm{O}$ povo revela, deste modo, a prudência que não manifestou durante a instrução do processo contra o Alcmeónida: é que, conhecendo o seu feitio intempestivo - tipicamente ateniense - e a estima que o exército nutria por ele, não queria correr o risco de uma sublevação militar (instigada ou não pelo general) nem que as tropas, que iriam ficar apenas sob o comando de Nícias e Lâmaco ${ }^{126}$, se sentissem ainda mais desmotivadas ${ }^{127}$.

Mas, tal como Nícias viria a fazer mais tarde, Alcibíades receou pela sua vida se cumprisse as ordens do povo e... escapou-se! ${ }^{128}$ A esta fuga ficou associada uma frase do filho de Clínias que mostra bem a desconfiança própria dos Atenienses, aqui representada pelo próprio fugitivo, que não confia a vida à própria mãe, quanto mais aos concidadãos em fúria' ${ }^{129}$... Ferido no seu orgulho por este supremo desrespeito pela sua soberania, o povo acabou por condená-lo à morte, o que remeteu Alcibíades ao exílio e despoletou nele a reação imatura

prazer em acolhê-las e em mandar para os calabouços todos os que, com ou sem justiça, eram delatados. Para o relato deste episódio, Plutarco teve como fontes [And.] 1. 38 e D. S. 13. 2. 4.

${ }^{125}$ Vide infra p. 240, nota 145.

${ }^{126}$ Sobre este estratego, vide infra p. 284, nota 351.

${ }^{127}$ A redação de Alc. 21.7 baseia-se em Thuc. 6. 61-64, mas fornece menos informações sobre as reais intenções dos Atenienses e sobre o contexto histórico que fez aumentar a desconfiança (e, consequentemente, a ira) contra o Alcmeónida, como a deslocação das tropas lacedemónias para o Istmo e a suspeita em que incorriam os amigos que aquele tinha em Argos. No primeiro caso, o povo desconfiou que a movimentação dos Lacedemónios não tinha por objetivo ajudar os Beócios, mas antes Alcibíades, que teria a intenção de tomar Atenas. No segundo caso, julgavam que os amigos daquele planeavam um ataque contra o povo. Estamos, mais uma vez, perante o famoso caráter desconfiado dos descendentes de Teseu.

${ }^{128}$ Fugiu de barco em Túrios (Thuc. 6. 61. 6-7, 74. 1; D. S. 13. 5). Daí foi para o Peloponeso, mas, antes de avançar para Esparta, por precaução, instalou-se em Argos, de onde enviou um mensageiro aos Lacedemónios, propondo-lhes uma aliança. Encontrava-se em Argos, quando os Atenienses o consideraram traidor e pronunciaram a sua sentença de morte (Isoc. 16. 9). Segundo Thuc. 6. 88. 9, Alcibíades não esteve em Argos, mas na Élide. Sobre este assunto, vide Hatzfeld (1940: 207 n. 2).

${ }^{129}$ Alc. 22. 2, Alc. 21. 7, Moralia 186D. Este apego à vida manifestado por Alcibíades parece contrariar o que dissemos no capítulo «Atenas, o umbigo da Hélade» (p. 124) a propósito do desapego que os Atenienses revelavam pela vida. De facto, o povo de Atenas dispunha-se a morrer por aquilo em que acreditava, mas não em vão. Péricles, por exemplo, vangloriava-se de nunca ter posto em risco desnecessário a vida de um concidadão (cf. p. 266). Não é, contudo, esse o contexto em que se encontra Alcibíades, que não pretendia morrer, condenado por algo que, aparentemente, não fizera... 
de atacar a pátria para dar a conhecer que estava vivo e bem vivo (Alc. 22.3, Moralia 186D).

O povo e Alcibíades envolvem-se, assim, em uma disputa de «vale-tudo», cujo objetivo cego e teimoso é provar ao inimigo quem é, afinal, o mais poderoso e capaz. Este comportamento, visto pelos olhos de Alcibíades, pode ser entendido (e até desculpabilizado) como o de um inocente que se recusa a pagar por um crime que não cometeu ou o de alguém a quem tudo era permitido e, a quem, de repente, tudo passa a ser negado. Mas não deixa de ser um comportamento infantil e impróprio de um homem de Estado, que tudo deve fazer pelo bem da

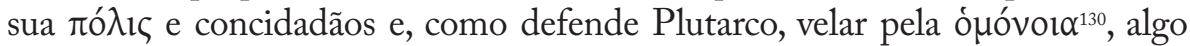
que Alcibíades só muito raramente - e se calhar até de modo inconsciente e com segundas intenções - fez. Trata-se de um comportamento inadequado para quem pretendia rivalizar com a glória do filho de Agariste. Em jeito de parêntesis, podemos evocar aqui uma intervenção de Péricles, que, pela forma como Plutarco a descreve (Per.9.3,), é comparável a esta de Alcibíades: trata-se da remoção de poderes do Areópago, pela qual o jovem filho de Xantipo pugnou através do seu amigo Efialtes ${ }^{131}$. De facto, ainda que o biógrafo (que em Moralia $813 \mathrm{C}$, se refere ao interesse excessivo pelas magistraturas eletivas e à obsessão por cargos como comportamento indigno e impopular) nunca o afirme declaradamente, ficamos com a impressão de que Péricles se associa a Efialtes por obstinação e imaturidade política: é que, como não podia aceder, dentro da legalidade, àquele órgão (cujo concurso assentava em pré-requisitos que Péricles não reunia), então tornava-se imperioso limitar-lhe os poderes.

Mas voltemos à ira popular e ao caso concreto de Péricles. Como já tivemos oportunidade de mencionar, uma vez conquistado o apoio das

${ }^{130}$ A defesa que Plutarco faz da ónóvola (Moralia 823F-825F) prende-se sobretudo ao contexto da atuação de um político grego sob a alçada de Roma, que tudo deve fazer para fomentar a concórdia entre concidadãos e entre estes e o poder dominante, de modo a garantir a manutenção dos benefícios inerentes à pertença ao império latino, nomeadamente a fruição

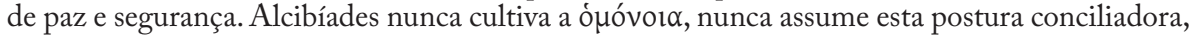
que o biógrafo defende própria de um bom chefe de Estado, bem pelo contrário: sempre que pode, instiga as diferenças entre os cidadãos para colher benefícios próprios. É isso que se passa em Alc. 25.3- 26.6, quando propõe aos Sâmios a reposição do regime oligárquico (vide infra p. 289 sqq.). Sobre a óuóvola, consulte-se de Blois (2004: 57-66).

${ }^{131}$ A intervenção de Efialtes contra o Areópago em 462 a.C. é um assunto controverso no que respeita à sua autoria, moral pelo menos. Plutarco, em Per. 7. 8, 9. 5 e 10. 7-8, apresenta-nos Efialtes como um mandatário de Péricles. No entanto, Plu. Cim. 15.2 e Arist.Ath.25.1-2 atribuem a autoria daquilo que os aristocratas consideraram uma afronta ao poder estabelecido e venerável pela sua antiguidade exclusivamente a Efialtes. Tal perspetiva é compreensível, já que este era o líder dos populares e Péricles apenas um correligionário. Sobre Efialtes, vide supra p. 219, nota 46. Para mais informações a propósito da reforma do Areópago, uma das últimas medidas para retirar poder da aristocracia e transferi-lo para o povo, que Plutarco, em Moralia 805D, toma como um ato louvável, por considerar o Areópago um conselho opressor e oligárquico, leiam-se Lewis (1992: 98 sq.); Wallace (1974: 259-269); Jones (1987: 53-76); Ostwald (1986: passim); Ribeiro Ferreira (1990a: 47 sq) e Mossé - Schnapp-Gourbeillon (1994: 249). 
massas, o filho de Xantipo nunca foi alvo de uma contestação séria por parte dos Atenienses (à exceção do burburinho que se levantou por ocasião das obras de embelezamento da cidade, que o estadista prontamente serenou), embora ocasionalmente a sua vida privada fosse devassada sobretudo pelos comediógrafos ${ }^{132}$. O povo só se rebelou contra ele na fase final da sua carreira política, um período particularmente conturbado, que coincidiu com o deflagrar da Guerra do Peloponeso. Plutarco dá-nos uma clara imagem dessa contestação ao concentrar nos capítulos 33, 34 e 35 expressões e frases reveladoras do crescente descontentamento popular, que culmina no afastamento de Péricles do poder: em Per. 33. 8, menciona a «ira - ỏ $\rho \tilde{\eta} \varsigma$ - dos concidadãos»; em

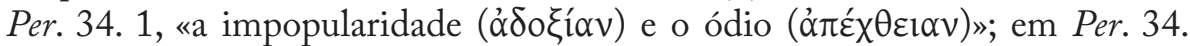

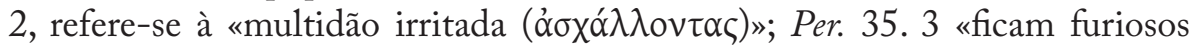

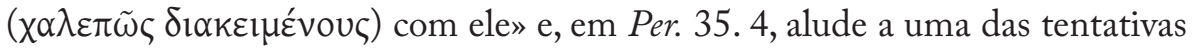
que Péricles empreendeu para lhes «apaziguar a cólera (ỏ $\left.\rho \gamma^{\prime}\right) »^{133}$.

Tamanha revolta, que deita por terra todo o esforço de conciliação empreendido por Péricles desde o início da sua carreira, é consequência direta de dois fatores. O primeiro é a guerra que, pela sua natureza, altera a serenidade da população, pois destrói aqueles bens que Plutarco (Moralia 824C) considera fundamentais para que o povo viva feliz ${ }^{134}$ e para que até o bom governante consiga realizar a sua missão: a paz, a liberdade, a prosperidade e a concórdia. O segundo é o aproveitamento político que a oposição fez desta escolha de Péricles, atacando-o em todas as frentes com argumentos que, dadas as circunstâncias, foram acolhidos pelas massas. Os adversários quiseram fazer crer que o estratego ${ }^{135}$ optara pela guerra como manobra para distrair da

${ }^{132}$ Sobre este assunto, vide infra p. 242 sqq.

${ }^{133}$ A influência de Tucídides nesta fase da biografia parece-nos evidente, sobretudo no que respeita ao vocabulário e à concentração da ideia da ira dos concidadãos, que, no historiador, ocorre entre 2. 59 e 2.65. Cf. Thuc. 2. 21. 3, 2. 60. 1, 2.65. 1, 2.65. 3 (ỏpyń irritação/rancor); 2.

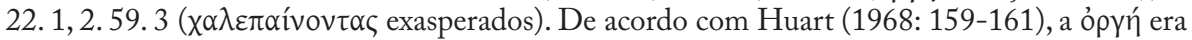
uma característica inata dos Atenienses para Tucídides. Plutarco partilha da mesma opinião em Moralia 799C.

${ }^{134}$ Segundo Moralia 823F, as maiores provas da felicidade do povo são a sua tranquilidade e mansidão. Podemos, por isso, deduzir que, até à eclosão do conflito armado com Esparta, o povo estava satisfeito com a atuação do estadista.

${ }^{135}$ Os estrategos constituíam um colégio de dez membros oriundos da classe censitária mais elevada (pentacosiomedimnos). Não eram sorteados como a maioria dos magistrados, mas eleitos anualmente (à razão de um por tribo) pela Assembleia, que lhes indicava as diretrizes a seguir e à qual tinham de prestar contas. Os membros desta magistratura - que nos séculos V e IV a.C. foi uma das principais do regime democrático - podiam ser reeleitos sem limite de mandatos, como aconteceu com Péricles durante quinze anos consecutivos. Além do poder militar, que era o que originalmente possuíam, tinham também autoridade política e administrativa, pelo que necessitavam de ser bons oradores para convencerem a Assembleia das suas opções políticas. A partir do início da Guerra do Peloponeso, porque ficavam muito tempo no campo de batalha e afastados da tribuna, vão-se assumindo cada vez mais como técnicos militares desligados da política e passam a ser eleitos, já não um por tribo, mas indiferentemente dentre todos os 
crescente contestação de que vinha sendo alvo, na figura dos seus principais amigos e colaboradores ${ }^{136}$. De facto, ao mesmo tempo que se agudizavam os problemas com Esparta e os aliados, o escultor Fídias ${ }^{137}$, o filósofo Anaxágoras e até Aspásia $^{138}$ foram acusados de crimes gravíssimos com o intuito de macular a idoneidade de Péricles, aquela sua imagem de estadista perfeito e incorruptível ${ }^{139}$.

No que respeita a Fídias, Plutarco (Per. 31.2) considera que o escultor foi vítima de duas forças distintas: os seus próprios inimigos, que o invejavam pela amizade e influência junto de Péricles ${ }^{140}$; os do estadista, para os quais este era apenas o primeiro assalto por meio do qual pretendiam estudar a

cidadãos. Para mais pormenores sobre esta magistratura, leiam-se, por exemplo, Ribeiro Ferreira (1990a: 112-113); Mossé (1992: 457-459); Lewis (1992: 85-87).

${ }^{136} \mathrm{O}$ próprio Plutarco parece concordar com essa perspetiva em Per. 32. 6. Voltaremos a este assunto mais à frente (p. 279 sqq.). Sobre o pensamento do biógrafo relativamente às amizades do homem de Estado, vide, por exemplo, Moralia 807-808.

${ }^{137}$ Arquiteto, escultor e pintor ateniense do século $\mathrm{V}$ a.C. Foi amigo de Péricles e morreu na prisão (Per. 31). Os seus trabalhos mais famosos são estátuas criselefantinas de deuses, nomeadamente de Atena Pártenos (instalada no Pártenon) e a de Zeus (de Pisa ou Olímpia). Para outras informações relativas à escultura grega e ao papel que nela teve Fídias, leia-se, por exemplo, Barron (1971) ou Woodford (1982). Fídias ficou também conhecido pela sua participação nas obras da Acrópole enquanto artista e supervisor de todos quantos trabalharam para o embelezamento da cidade (informação que apenas ocorre em Per. 13. 6, 13. 14). No entanto, não é possível identificar as fontes que Plutarco utiliza para fazer tal afirmação. Parece, porém, pouco provável que este escultor tenha sido tão influente. Este passo é certamente hiperbólico e provavelmente consequência da famosa história segundo a qual Péricles e Fídias eram amigos íntimos.

${ }^{138}$ Sobre a referência na comédia às amizades que Péricles mantinha com estrangeiros, como Anaxágoras ou Aspásia, vide supra p. 165.

${ }^{139}$ Sobre este assunto, vide Andrewes (1978: 1-8); Prandi (1977: 10-26); Lewis (1992: 175176). Note-se, contudo, que Tucídides, por ser correligionário de Péricles, omite as críticas que lhe foram feitas e as ações dos adversários políticos que queriam prejudicá-lo (nomeadamente os ataques contra os seus amigos). Sobre a tendência de desculpabilização do estadista manifestada por Tucídides, consulte-se Comamala Malo (1995: 7-20).

${ }^{140} \mathrm{~A}$ menção aos inimigos do escultor prende-se certamente à exemplificação da tese, muito defendida por Plutarco, de que os homens influentes são alvos apetecíveis dos invejosos. Plutarco sugere que este mau sentimento foi agravado pelo facto de o escultor ter caído na tentação de incluir no escudo da estátua criselefantina de Atena, que retratava a batalha de Teseu contra as Amazonas (descrito em Thes. 26-28), um retrato seu e outro de Péricles. É perfeitamente natural que o escultor sentisse a necessidade de estabelecer uma ligação mais estreita com a sua obra - e, para isso, nada melhor do que fazer uma espécie de autorretrato disfarçado. Essa fraqueza, parece, afetou outros artistas, mesmo séculos mais tarde: há, por exemplo, quem afirme que a pessoa retratada por Leonardo da Vinci em Mona Lisa é o próprio pintor. Quanto a Péricles, é talvez difícil saber se a sua representação foi um tributo inocente de Fídias, para imortalizar o político nunca esquecido nos séculos seguintes por causa das suas qualidades morais e de estadista, ou se foi feita a pedido do Péricles. O certo é que Fídias parece ter previsto que a imagem de Péricles eternizada na sua obra suscitaria, nos detratores e invejosos do filho de Xantipo, o desejo de destruição. Mas, segundo voz corrente na Antiguidade, o escultor aprendera com Péricles a ser previdente, pois a imagem estaria de tal modo posicionada, que retirá-la implicaria a destruição de toda a estátua (cf. e.g. Arist. Mu.399b; V. Max. 8. 14. 6). 
reação do povo a uma tão forte investida contra Péricles, de modo a poderem prosseguir com a estratégia de desmoralização através do ataque aos amigos que assim iniciavam ${ }^{141}$. Neste caso concreto, foi fácil comprovar que a acusação de desvio do ouro durante a criação das esculturas era infundada: é que Péricles, notável estratego, do alto da sua previdência, não se deixava desconcertar pelas jogadas dos inimigos. Qual exímio jogador de xadrez, calculava rigorosamente todos os movimentos, quer os seus, quer os que estes pudessem vir a originar da parte do inimigo, de forma a não ser surpreendido por um xeque-mate. Por isso, prevendo que mais tarde viessem a ser acusados de ter ficado com o ouro, Péricles, famoso pela incorruptibilidade, ordenara a Fídias que o usasse na estátua criselefantina ${ }^{142}$ de Atena Pártenos, de maneira a que pudesse ser facilmente retirado e conferido. Mal os inimigos acusaram o escultor, o prevenido estadista respondeu, dizendo simplesmente para confirmarem o peso do ouro do monumento (Per. 31.3) ${ }^{143}$.

No entanto, apesar da apresentação do ouro, Fídias foi considerado culpado $^{144}$, o que, juntamente com o «prémio» que o delator, Ménon, recebeu

${ }^{141}$ De acordo com Diodoro Sículo (12. 39. 1), os inimigos de Péricles fizeram com que alguns colaboradores de Fídias se sentassem junto ao altar dos Doze Deuses (no centro da Ágora) para denunciar o roubo que o arquiteto realizara com o conhecimento de Péricles.

${ }^{142}$ A estátua em questão, com cerca de dez metros de altura, era constituída por uma estrutura de madeira abundantemente recoberta de ouro (no que respeita às roupas) e de marfim (no rosto, nas armas e nos pés) - daí ser chamada de criselefantina.

${ }^{143}$ Em Thuc. 2.13. 5, a existência de ouro na estátua é tratada sob outro ponto de vista, já que Péricles a menciona, antes da primeira invasão da Ática, quando relembra a estratégia de guerra e procura incutir confiança na população, referindo os meios financeiros disponíveis,

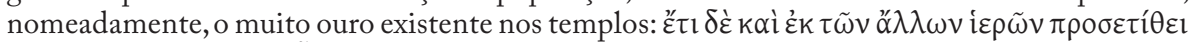

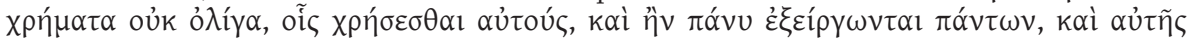

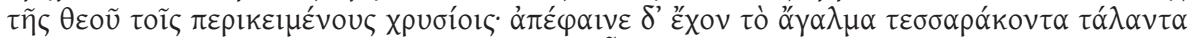

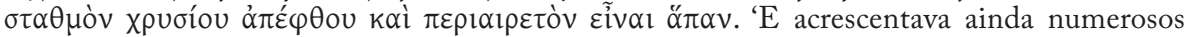
bens de outros santuários, aos quais, se fossem absolutamente forçados, poderiam recorrer, bem como à riqueza que envolvia a própria deusa. Referia-se à estátua com quarenta talentos de peso de ouro em barra, totalmente amovível.' A existência de tamanha riqueza - em relação à qual o historiador apenas refere a quantidade, a localização e a possibilidade de ser removido em caso de necessidade - mostra, indiretamente, que a ró $\lambda$ ıc estava a ser bem governada, o que deixa transparecer o caráter laudatório de Tucídides em relação a Péricles (cf. supra p. 247, nota 98 e p. 257, nota 140). Em Plutarco, não deixa de haver um tom elogioso, pois o autor realça ainda a clarividência e perspicácia de Péricles. É que no contexto em que o biógrafo faz a citação, o ouro existente na estátua é mencionado como forma de «limpar» os nomes de Fídias e Péricles, acusados de o terem desviado. Assim, não obstante as diferenças contextuais, nos dois autores o ouro aparece como meio de salvação: em Tucídides, das dificuldades que a guerra pode trazer no plano coletivo; em Plutarco, da acusação de corrupção e de cedência ao dinheiro que, através do ataque aos seus amigos, se dirige pessoalmente contra o estadista para lhe denegrir a imagem.

${ }^{144}$ Como nos relata Plutarco, a defesa proposta por Péricles não resultou e Fídias foi condenado. Segundo Diodoro Sículo (12.39.1), Fídias foi preso e Péricles acusado de roubar o templo (apud Pérez Jiménez: 1996, 496). Filócoro (FGrHist 328 F 121), porém, indica-nos que o escultor foi desterrado para a Élide, onde executou a estátua de Zeus em Olímpia, e que pouco depois foi assassinado pelos habitantes, acusado de roubo. Leia-se o comentário de Jacoby ao 
pelo seu comportamento de sicofanta ${ }^{145}$, demonstra que o povo já tinha o discernimento toldado pela ópyń e pela inveja. Uma vez na prisão, o escultor não haveria de viver por muito tempo, pois, consoante as versões, foi vítima de uma doença ou envenenado pelos inimigos de Péricles, com intuito de fazer recair sobre o estadista novas calúnias e suspeitas ${ }^{146}$. Importa recordar que, antes desta contestação generalizada, Péricles foi por diversas vezes atacado na sua honra. Uma das acusações que lhe foi imputada foi a de ter tido participação na morte de Efialtes, algo que, a ser verdade, faria dele um político calculista, que se livrava dos amigos quando estes deixavam de lhe ser úteis e passavam a ser um risco para o seu poderio. Esta possibilidade é veementemente criticada por Plutarco, que, apesar de reconhecer que, como qualquer mortal, Péricles não tinha um comportamento totalmente irrepreensível (Per. 10. 7), nega a acusação de Idomeneu ${ }^{147}$ (FGrHist 338 F 8) e cita, em Per. 10. 8, Aristóteles (Ath. 25.4), que atribui o crime a inimigos da vítima, na pessoa de Aristódico de Tanagra.

FGrHist 328 F 121.

${ }^{145}$ Ménon teve, por decreto proposto por Glauco, direito ao perdão dos impostos e a seguranças, o que configura uma benesse excessiva, mesmo para a prática corrente em Atenas, já de si sedutora para os criminosos que queriam entregar os cúmplices. Sempre que um réu quisesse fornecer informações ao Conselho ou à Assembleia sobre um delito, tinha direito a imunidade ( $\alpha \delta \varepsilon l \alpha)$, a menos que a acusação não tivesse fundamento - nesse caso, poderia incorrer em pena de morte. Era a Assembleia que decidia quem seria responsável pelo julgamento: o Tribunal da Helieia, o Conselho ou a própria Assembleia. No caso de Ménon, tudo leva a crer que seria cúmplice no roubo. Plutarco deve ter tido acesso ao decreto de Glauco na coleção epigráfica do macedónio Crátero (cf.Plu. Cim.13.1; Arist.26.1-2). Foi esta facilidade que fez com que Andócides (a conselho de Timeu) confessasse o seu envolvimento no caso dos Hermes (Alc. 21.5) e denunciasse uns quantos para obter a amnistia. Sobre este episódio, cf. Thuc. 6. 60 .

146 Plutarco não esclarece de que modo a morte de Fídias poderia influenciar a reputação de Péricles. Assim, são três as hipóteses que podemos levantar: ou o estadista era afetado, já que ficava desacreditado por não ter conseguido ajudar o amigo; ou porque o aparente suicídio resultava numa confissão de culpa (logo, Péricles estaria, também ele, implicado); ou ainda visto que Péricles acaba por surgir como um indivíduo capaz de matar o cúmplice para se proteger.

${ }^{147}$ Idomeneu de Lâmpsaco (cerca de 325-270 a.C.) foi amigo de Epicuro e participou ativamente na vida política da sua cidade. Conservam-se fragmentos de três obras com

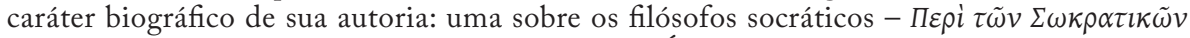
- (da qual apenas conhecemos o fragmento sobre Ésquines que surge em D. L. 2. 20); outra intitulada Dos Demagogos - Пepi $\delta \eta \mu \alpha \gamma \omega \gamma \tilde{\omega} v$-, muito utilizada por Plutarco e Ateneu, onde

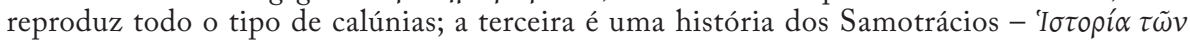
$\kappa \alpha \tau \dot{\alpha} \Sigma \alpha \mu 0 \theta \rho \alpha \hat{\alpha} \kappa \eta v-$, cheia de anedotas polémicas. Este autor seguiu o método peripatético no que concerne à elaboração de anedotas e reproduziu muitos escândalos pouco credíveis para atacar políticos de cujas ideias discordava. O biógrafo refuta a acusação de Idomeneu com base no comportamento de Péricles para com Címon, quando este enfrentou uma acusação capital: se o estadista não fez mal nem aos inimigos, como poderia cometer tal atrocidade contra um amigo? Sobre a relação do bom político com os seus adversários, vide p. 207 , nota 65 . 
A vítima que se seguiu a Fídias foi Aspásia ${ }^{148}$, acusada pelo comediógrafo Hermipo $^{149}$ de impiedade ${ }^{150} \mathrm{e}$ de organizar encontros entre Péricles e mulheres livres, o que, segundo Stadter (1989: 297), sugere que esse recrutamento ocorreria no interior de santuários ou durante a celebração de ritos sagrados, que lhe seriam interditos devido à sua fama de prostituta e/ou proxeneta.

Importa aqui abrir outro parêntesis para recordar a tradicional curiosidade do povo - intriguista por natureza - em relação à vida privada dos seus governantes. Foi o conhecimento deste traço de caráter das massas que fez com que Péricles, desde o início da sua carreira política, evitasse ter uma vida social agitada (ao contrário do que fez Alcibíades que, desde a sua primeira intervenção pública, demonstrou ter consciência de que imiscuir político com privado diverte e agrada ao povo ${ }^{151}$ ), como já vimos na página 200 sqq. Mas, apesar de todos os cuidados, ou porque realmente fosse verdade ou por mera tentativa de detração, o filho de Xantipo teve fama de manter várias relações extraconjugais ${ }^{152}$. Disso nos dá conta Plutarco,

${ }^{148}$ A extraordinária influência que se atribui a Aspásia na sociedade ateniense fez com que fosse a mulher grega que melhor se conhece. No entanto, a informação de que dispomos é invariavelmente escassa e por vezes pouco fidedigna. As principais fontes sobre esta figura são as comédias e diálogos socráticos, nomeadamente as duas Aspásia de Ésquines Socrático e de Antístenes e o Menéxeno de Platão. Importa desde já lembrar que da mulher ateniense não se esperava um empenho ativo na vida pública; o próprio facto de se conversar ou beber com um homem era sinónimo de vida devassa. Para um melhor conhecimento da situação da mulher na Grécia antiga, leiam-se, por exemplo, Mossé (1983); Gomme (1937: 89-115).

${ }^{149}$ Hermipo foi um comediógrafo que obteve a sua primeira vitória nas Dionísias de 436435 a.C. e outras quatro nas Leneias. Conheciam-se quarenta peças da sua autoria, das quais apenas onze títulos chegaram até nós. Os temas abordados eram a política contemporânea e a paródia de mitos e teorias filosóficas. Péricles não foi a única vítima dos seus ataques: Hipérbolo e talvez mesmo Alcibíades sentiram na pele esse incómodo. A atribuição da autoria desta acusação a Hermipo é talvez consequência dos frequentes ataques que fazia a Péricles nas suas comédias - cf. e. g. Montuori (1981: 92, nota 33). Em Moĩp $\alpha_{l}$ (430 a.C.), ataca violentamente o estadista pela sua estratégia na Guerra do Peloponeso (vide Per. 33. 8).

${ }^{150}$ Esta informação surgia no diálogo Aspasia de Antístenes Socrático (cf. Ath. 589e; $\Sigma$ Ar. Eq. 969; Hermog. $\Sigma$ 7. $165 \mathrm{Walz}$ ). A historicidade da acusação de asebeia é negada por Montuori (1981: 87-109), nomeadamente porque Aspásia não era cidadã ateniense, logo não podia incorrer neste delito. Sobre as ofensas que eram consideradas asebeia, vide MacDowell (1978: 197-200); sobre a veracidade desta acusação, cf. Stadter (1989: 297).

${ }^{151}$ Vide Salcedo Parrondo (2005: 179-186). Enquanto Alcibíades se deixa levar pelo clamor da multidão, Péricles refugia-se daquela na acrópole para meditar nos assuntos que o preocupam (Per. 3.6).

${ }^{152} \mathrm{~A}$ fogosidade parece ser um atributo comum a diversos políticos atenienses e remonta a Teseu. Foi essa a principal razão que fez com que o povo, revoltado com o abandono a que foi sujeito, se tornasse influenciável pelo nefasto demagogo, Menesteu (como já vimos supra pp. 106-107). A título de exemplo, podemos recordar igualmente o caso de Címon, cuja fama de mulherengo Plutarco recorda sem rodeios. No rol das suas conquistas, incluía-se, segundo Cim. 4. 6-10, a própria irmã, Elpinice, que também não seria muito séria... A ideia da promiscuidade da esposa de Cálias é atestada por duas anedotas (de conotação sexual evidente) que Plutarco reproduz em Per. 10.5-6, segundo as quais, pelo menos por duas vezes, Elpinice terá «comprado» junto de Péricles favores para o irmão. A que o biógrafo relata em primeiro lugar (10.5) consiste 
que se serve dos testemunhos da comédia para nos revelar a dimensão do fenómeno, mas que também se recusa a atribuir grande crédito às más línguas dos comediógrafos, pois reconhece a sátira à vida sexual dos indivíduos como elemento tradicional da caricatura do político-tipo na comédia. $\mathrm{Na}$ verdade, da leitura desta Vida ficamos com a ideia de que o Queroneu não vê com bons olhos os comediógrafos, por considerar que são tendenciosos e maledicentes. É por isso que condena com frequência o constante levantar de falsos testemunhos que estes empreendem contra figuras proeminentes da sociedade, como Péricles ${ }^{153}$ :

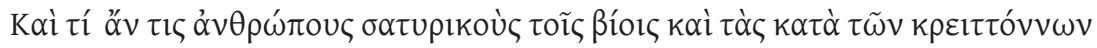

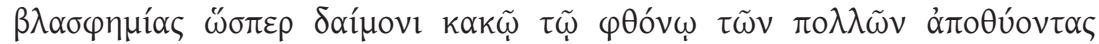

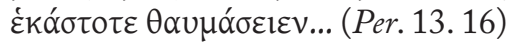

"porque há de alguém surpreender-se de que homens que levam a vida de sátiro sacrifiquem constantemente à inveja geral, como a uma divindade malfazeja, calúnias contra quem lhes é superior...”

No entanto, verificamos que não deixa de citá-los com frequência. Aliás, a Vida de Péricles é notável pelas abundantes citações de comédia. Não é difícil compreender este facto: por um lado, a comédia, tal como a biografia, tem objetivos pedagógicos e moralizantes, mas, para alcançá-los, serve-se do ataque e da crítica e não da admiração e desejo de imitação (isto é, a comédia pretende educar pela negativa, mostrando o que não se deve fazer, e a biografia usa precisamente o método contrário). Por outro lado, tendo em conta que, a partir dos últimos anos do século $\mathrm{V}$ a.C., a comédia entra em uma segunda

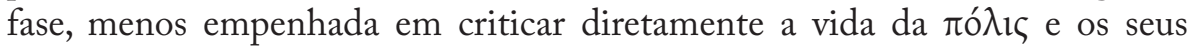
governantes, é natural que, nas Vidas de personagens posteriores, seja citada com menor frequência (como acontece no caso de Alcibíades ${ }^{154}$ ).

Assim, ficamos com a impressão de que, se com todas as precauções que aparentemente tomou, Péricles foi alvo de tantas intrigas, se não se tivesse

no regresso de Címon do exílio. Plutarco fala-nos em «acordo secreto», o que nos faz ponderar que esta anedota possa ser uma versão modificada de uma outra da autoria de Antístenes, autor que, entre outras alusões mordazes que faz à vida sexual de Péricles, afirma que Elpinice teve de pagar o preço do regresso do irmão (Ath. 589e). Em Per.10.6, é mencionada a benevolência que Péricles teve para com Címon em uma ocasião em que este enfrentava uma acusação capital. Apesar de ter acolhido o pedido de Elpinice, o filho de Xantipo replicou-lhe que estava demasiado velha para se «meter em tais sarilhos».

${ }^{153}$ Alguns dos passos em que Plutarco os critica são Per. 13.15 (sobre a hipotética ajuda que Péricles teria dos amigos para obter favores femininos) e Per. 16.1 (sobre a forma como os cómicos veem o poder de Péricles). Esta desconfiança relativamente aos cómicos, Plutarco herda-a do seu mestre Platão.

${ }^{154}$ Alc. 1. 7-8, a propósito da sua pronúncia. Cf. supra p. 163. 
precavido, o rol de acusações de devassidão sexual teria sido bem maior. Péricles, como se não lhe chegassem as investidas dos comediógrafos e inimigos políticos, foi alvo de insinuações deste teor por parte do próprio primogénito, Xantipo, revoltado com a parcimónia com que o pai administrava a vida doméstica ${ }^{155}$. Acusou-o, por isso, segundo o testemunho de Estesímbroto ${ }^{156}$, de se ter envolvido com a própria nora. Plutarco não se alonga em comentários sobre o caso, porque não lhe atribui qualquer veracidade, não só por acreditar na retidão de caráter do estadista, como também por causa do contexto em que a acusação é feita.

Alcibíades foi igualmente acusado por Antístenes (FGrHist 1004 F 5a-b) de manter relações incestuosas ${ }^{157}$ com a mãe, com a irmã e com uma filha. Mas, embora o biógrafo também não se alongue em considerações sobre o assunto, somos mais tentados a pôr em causa a inocência do filho de Dinómaca por causa do seu historial de devassidão.

Concentremo-nos, porém, de novo em Aspásia. e, já agora, também nas investidas dos comediógrafos a propósito dos amores de Péricles ${ }^{158}$.

A única ligação extraconjugal que o nosso estadista seguramente manteve, pela qual pôs fim ao seu casamento, foi a que o uniu a Aspásia. Neste caso, mais uma vez, tem um comportamento distinto do de Alcibíades: não se sentindo feliz no casamento que mantinha com a mãe dos filhos, Péricles entregou-a - de comum acordo - a outro ${ }^{159}$. Já Alcibíades, que recebeu a mão da esposa (que lhe dedicava grande afeição) em circunstâncias especialíssimas ${ }^{160}$, não soube respeitar os sentimentos daquela: em primeiro lugar, mesmo depois de

155 Sobre este assunto, vide infra p. 253. A este propósito, é interessante recordar que Aristóteles (Pol.1327b39) discorda do seu mestre, Platão, que, na República (375c), defende que os guardiães se devem mostrar duros para com os desconhecidos e amáveis para com conhecidos. É que o Estagirita tinha a noção de que é nos amigos e familiares contrariados que têm origem os maiores ódios...

${ }^{156}$ FGrHist 107 F 11. Estesímbroto foi rapsodo, comentador dos Poemas Homéricos e, nos finais do século V, ensinou em Atenas como sofista. Escreveu uma obra intitulada Пвpi

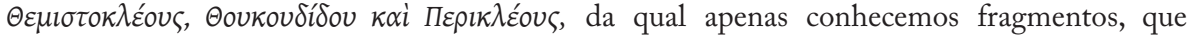
chegaram até nós por intermédio de Plutarco, onde, com recurso constante a anedotas, ataca esses políticos atenienses. Cf. Hammond - Scullard (1992: 1013a).

${ }^{157}$ Cf. Ath. 220c, 535c; Lys. 14. 41-42. Péricles e Alcibíades não foram os únicos acusados de incesto. Também Címon o foi, como já referimos na página 241, nota 152.

158 As que se referem ao desencadear da Guerra do Peloponeso serão abordadas mais à frente.

${ }^{159}$ Per. 24. 8. Não se sabe ao certo quem foi a primeira esposa de Péricles. Bicknell (1972: 79) defende tratar-se de uma irmã de Dinómaca, mãe de Alcibíades. Já Cromey (1982: 203-212) admite que se trata da própria Dinómaca.

${ }^{160}$ Vide supra p. 186, nota 106. Não deixa de ser curioso chamar a atenção para o contexto do tratamento do tema casamento nas biografias dos Alcmeónidas: no caso de Alcibíades, é mencionado logo no capítulo 8, pois vem a propósito dos muitos devaneios do filho de Dinómaca; no de Péricles, decorre da reflexão sobre a influência de Aspásia nas decisões do estadista. Os diversos «casos» que Plutarco tem como meras calúnias ocorrem sempre que o contexto invoca ataques a Péricles. 
casado, continuou a envolver-se descaradamente com prostitutas nacionais e estrangeiras ${ }^{161}$; em segundo, quando a mulher (depois de ter saído de casa sem que aquele tivesse feito qualquer tentativa de reconciliação) se dispôs a ir pessoalmente pedir o divórcio ${ }^{162}$, aquele dirigiu-se ao tribunal para recuperá-la. Alcibíades surge, de novo, como alguém que não respeita os sentimentos alheios. Não surpreende, portanto, que, pouco depois de regressar a casa, a jovem Hipáreta tenha morrido...

A relação extraconjugal de Péricles foi um ingrediente objetivo que maravilhou a criatividade dos poetas, que visavam o estadista através de Aspásia. Um dos momentos em que podemos verificá-lo é em Per. 24. 10 (baseado em Cratino, fr. 259 K.-A.), onde surge como Hera ${ }^{163}$ (já que Péricles é Zeus), filha da Impudicícia, e tem olhos de cadela:

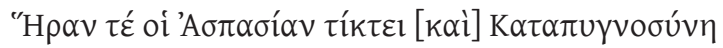
$\Pi \alpha \lambda \lambda \alpha \kappa \eta ̀ v ~ K v v \omega ́ \pi t \delta \alpha$.

"A Sem-Vergonhice dá à luz esta Hera, Aspásia, uma marafona de olhos de cadela."

Neste fragmento faz-se a genealogia de Aspásia ${ }^{164}$, transformando a normal conotação de dignidade e nobreza do tom épico em vulgaridade gritante. O epíteto homérico de Hera - $\beta$ ow̃ $ı \iota \varsigma$ - cujo significado literal é «de olhos de vaca», ao que parece, a simbolizar a grandeza dos olhos e a mansidão

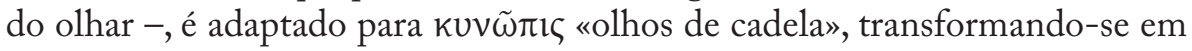
paradigma de sem-vergonhice, o que mostra bem que, pelo menos entre os comediógrafos, Aspásia não era muito bem vista ${ }^{165}$.

${ }^{161}$ Plutarco faz inclusive menção a relações de cariz homossexual e pederástico. Este assunto já foi abordado no capítulo dedicado ao ingresso na atividade política, p. 187 sqq. Sobre os amores de Alcibíades, leia-se Isoc. 16. 31 e Littman (1970: 263-276).

162 Sobre o divórcio em Atenas, consultem-se, por exemplo, Harrison (1968: 1-60); Modrzejewski (1979: 39-71) e Patterson (1991: 48-72).

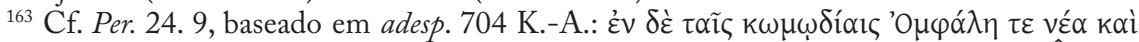

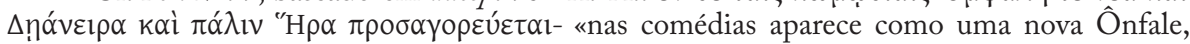
Dejanira e como Hera».

${ }^{164}$ Tal como em Per. 3. 4, com base em um fragmento de Cratino (Quirones, fr. 258 K.-A.), se fazia a genealogia de Péricles (vide supra p. 164).

${ }^{165}$ Havia quem a admirasse e a considerasse uma grande mestra de retórica. Disso nos dá testemunho Platão, que não a critica tão abertamente quanto os comediógrafos. Na sua perspetiva, tal como Péricles, ela teria forte aptidão para a arte dos discursos (cf. $M x .235 \mathrm{e}$, onde chega mesmo a dizer que teria sido Aspásia o mestre de Péricles nessa arte). Era por esse motivo que o próprio Sócrates a visitava, bem como outros companheiros, que chegavam a levar as esposas - apesar da má fama desta Hera - para que se instruíssem na arte de bem falar. Isso é o que nos dizem Per. 24. 5, 24. 7 com base no Menéxeno de Platão, diálogo segundo o qual, durante um encontro com Menéxeno, Sócrates recita uma oração fúnebre fictícia destinada às celebrações públicas dos caídos em 386 a.C., na expedição à Sicília, e que teria sido escrita por Aspásia. 
E como a relação entre Péricles e Aspásia deu fruto, nem o filho bastardo de ambos é poupado. Plutarco (Per. 24. 10) evoca Êupolis, que, em uma comédia intitulada Demos (fr. 110 K.-A.), nos apresenta Péricles, na sua figura de pai zeloso, a perguntar pelo mais novo dos seus filhos ${ }^{166}$ :

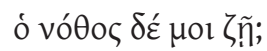

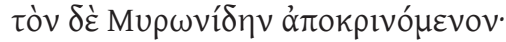

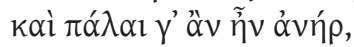

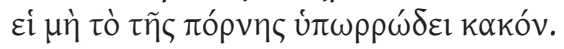

“« o meu bastardo, está de boa saúde?»

E Mirónides responde-lhe:

«Está e de há muito seria um homem feito, se não o abalasse o raio da marafona.»"

A resposta que a personagem obtém parece sugerir que Aspásia seria possivelmente uma má referência para a vida pública do filho, que não seria seguramente, segundo os cómicos, o único a sofrer a influência nefasta daquela mulher...

O amor de Péricles por este filho em particular, mas também por Páralo ${ }^{167}$ e Xantipo ${ }^{168}$ (demonstrado pelo sofrimento que a morte destes dois últimos the causou e pelo empenho em fazer do bastardo legítimo ${ }^{169}$ ) contrasta, mais uma

${ }^{166} \mathrm{O}$ fruto do relacionamento de Péricles com Aspásia recebeu o nome do pai e deve ter nascido por volta de 440 a.C. Em 406 a.C., foi um dos generais que participou na batalha de Arginusas (arquipélago constituído por três pequenas ilhas a Sul de Lesbos), no final da qual os Lacedemónios, comandados por Calicrátides, foram derrotados. No entanto, uma tempestade que os apanhou de surpresa impediu que resgatassem e sepultassem os cadáveres. O povo, furioso, levou a tribunal os seis comandantes que regressaram e condenou-os à morte (cf. X. $H G$ 1.6.28).

${ }^{167}$ Recebeu o seu nome, como uma das duas trirremes sagradas, do filho de Poséidon, herói de Atenas e protetor dos marinheiros (vide supra p. 201, nota 41). Pouco se sabe a seu respeito. Cf. Pl. Prt. 315, 319e, 328c.

${ }^{168}$ Também ele filho da primeira esposa de Péricles, provavelmente nascido em 457 a.C. Era costume dar ao filho mais velho o nome do avô paterno.

${ }^{169}$ Cf. Per. 36 e 37. 2- 6, respetivamente. Péricles instou o povo a revogar uma lei contra os filhos ilegítimos, pela qual ele próprio pugnara em 451-450 a.C., durante o arcontado de Antídoto (cf. Arist. Ath. 26. 4). Segundo essa lei, para que um filho fosse legítimo, ambos os pais teriam de ser cidadãos de Atenas. Para mais pormenores sobre as leis atenienses que concernem casamentos entre cidadãos e não cidadãos e também sobre filhos ilegítimos, veja-se Harrison (1968: 61-68). Segundo Aristóteles, a única fonte antiga a avançar com uma explicação, o que conduziu à aprovação desta lei foi a dimensão excessiva do corpo de cidadãos (Ath. 26. 4; cf. Pol. 1278a). Os estudiosos modernos apresentam justificações várias (vide Stadter: 1989: 334-335) , das quais podemos destacar a de Jacoby (FGrHist 3B suppl., 1, 477-481) que acredita que Péricles tinha motivações políticas, que pretendia atacar os inimigos, nomeadamente Címon (cuja mãe não era ateniense). Mas esta não parece ser a melhor opção, pois esta lei não atingia Címon, por não ser retroativa. Sobre esta lei, vide Lewis (1992: 101-102, 167-168). Em Alc. 17. 6, Plutarco narra um episódio que se pode comparar a este, pois revela o cuidado dos pais com a proteção da descendência. $\mathrm{O}$ astrónomo Menão, quando a partida para Siracusa se mostrou 
vez com o comportamento de Alcibíades. Também ele teve filhos, pelo menos três: um de uma prisioneira de guerra ${ }^{170}$ (Alc. 16. 5), outro de Timaia, a mulher do rei Ágis ${ }^{171}$, que tivera de se ausentar (Alc. 23. 7-9), e um da própria esposa Hipáreta (provavelmente aquele que lhe imitava os gestos - cf. Alc. 1. 8). Mas Plutarco em nenhum momento sugere que lhes dedicasse particular atenção. Antes pelo contrário, revela-nos um Alcibíades que vê na prole um meio para atingir os fins a que se propunha: em Alc. 23. 8, Plutarco conta que Alcibíades afirmava que o seu objetivo com o filho de Timaia não havia sido nem saciar um desejo carnal, nem afrontar o rei, mas tão só gerar o herdeiro da coroa da Lacedemónia ${ }^{172}$. Já em Alc. 8. 3-4, somos colocados perante um jovem pai que, mal a criança nasce, se apressa a ir buscar junto do sogro dez talentos como pagamento da sua fertilidade ${ }^{173}$.

Como já vimos, Hermipo acusa Aspásia de favorecer encontros entre o «seu» Péricles e outras mulheres ${ }^{174}$. No entanto, somos levados a encarar essa hipótese como inverosímil, por duas razões de monta. A primeira é a caracterização que o biógrafo faz da relação entre ambos (Per.24. 8-9), que sugere uma cumplicidade e comunhão tão grandes que não se coadunam com traições engendradas pelos dois. A outra é o facto de, em Per. 13.15, através de um fragmento anónimo cujo conteúdo é atribuído a vários cómicos (adesp. 702 K.-A), Plutarco apresentar um outro exemplo desses ataques: Péricles é acusado de receber favores femininos, nomeadamente da mulher de um seu companheiro - Menipo - e de várias outras, com o auxílio de outro amigo chamado Pirilampes:

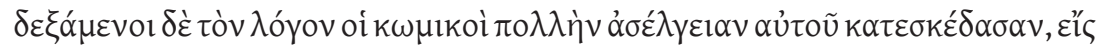

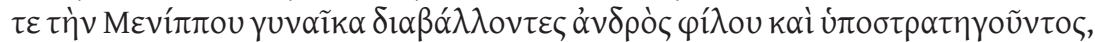

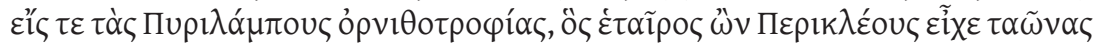

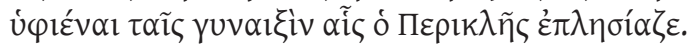

“os cómicos deitaram mão à história e espalhavam muita sem-vergonhice a seu respeito, com insinuações contra a mulher de Menipo, seu amigo e subalterno,

inadiável, também fez tudo o que estava ao seu alcance para evitar que o filho fosse alistado.

${ }^{170}$ Cf. supra p. 232, nota 107.

${ }^{171}$ Plutarco também consagrou uma biografia a este estadista, rei de Esparta entre ca. 427 400 a.C., onde é possível saber mais a seu respeito.

172 Segundo Ath. 535b-c, Alcibíades defende-se da acusação de adultério com toda a desfaçatez, atribuindo ao seu relacionamento com a mulher de Ágis a intenção de auxiliar Esparta: a linhagem que dele nascesse melhoraria a que descende de Héracles. Mas os planos de Alcibíades saem de novo gorados, como quase tudo na sua vida... Ao aperceber-se da traição, o rei renegou o filho de Timaia, impedindo assim o seu acesso ao trono. Sobre os amores de Alcibíades e Timaia e a reação de Ágis, vide Plu. Lys. 22. 6-8, Agis. 3.8-9, Moralia 467F; Ath. 574d; X. HG 3. 3. 2-3; Paus. 3.8. 9.

${ }^{173}$ Sobre este assunto, vide Isoc. 16. 31 e [And.] 13, que apresenta uma versão ainda mais indigna de alguém com o potencial de Alcibíades.

${ }^{174}$ Cf. supra p. 241. 
e contra a criação de aves de Pirilampes, também amigo de Péricles, que era acusado de se servir dos pavões para subornar as mulheres com quem Péricles andava metido."

Mais uma vez, as palavras do biógrafo revelam o pouco crédito que tais insinuações lhe merecem. Mas, a bem ver, a menção a essas acusações prévias à de Aspásia funcionam, da parte do Queroneu, como uma estratégia atenuante, na medida em que mostra que havia um historial de acusações infundadas nesse sentido. A própria reação de Péricles diante dos juízes, por ocasião do julgamento daquela, insinua o amor que os unia: trata-se da primeira vez em que o filho de Xantipo deixa transparecer em público sentimentos de cariz privado, algo que só ocorre em momentos de grande sofrimento (o outro foi a morte do seu último filho legítimo, vítima da peste ${ }^{175}$ ). Note-se, no entanto, que estas não são (provavelmente) as lágrimas ${ }^{176}$ de suborno do político poderoso que procura influenciar o veredito dos juízes para salvar a sua amada, mas a reação do defensor de Aspásia. Segundo Montuori (1981: 93), como aquela era meteca, é muito provável que, por altura da sua chegada de

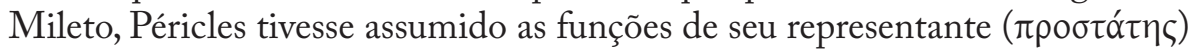
e consequentemente a responsabilidade pela sua conduta moral e civil.

Aspásia, enquanto mulher da vida de Péricles (se, como Plutarco, não valorizarmos as referências a outros casos amorosos do político) é também uma marca de distinção entre ele e Alcibíades. Péricles escolhe uma mulher que, segundo as fontes, era uma sua igual, uma mulher com cérebro, algo não muito apreciado na altura (Per. 24. 5-7; supra p. 241, nota 149 e infra p. 271 sqq). Alcibíades, por sua vez, tinha mulheres que cuidavam dele, do seu bem estar, mas que não eram verdadeiramente a sua «cara-metade». Disso são exemplo a esposa legítima e a concubina que assistiu à sua morte.

Quase em simultâneo, também o seu grande mestre e conselheiro, Anaxágoras ${ }^{177}$, é atingido pelas investidas contra Péricles. Podemos considerar que

175 Per. 36. 9.

${ }^{176}$ Per. 32. 5. Plutarco tem em Ateneu (589e) a sua fonte para atribuir esta informação a Ésquines, segundo o qual Péricles chorou mais por Aspásia do que nos momentos em que a sua vida ou riqueza correram perigo. Pouco se sabe acerca de Ésquines Socrático, natural de Esfeto, um dos demos de Atenas. Escreveu alguns diálogos socráticos, dos quais conhecemos sete títulos - Aspásia, Alcibiades, Cálias, Axioco, Milciades, Rinon e Telauges - e foi, dentre os amigos mais próximos de Sócrates, um dos poucos a estar com ele durante as horas que antecederam a sua morte. Vide Guthrie (1969: III, passim).

177 Nos Moralia (e na senda do que Platão afirma na República), o biógrafo defende a importância desse convívio para ajudar à evolução do povo (cf. supra p. 178, nota 79). Um dos muitos motivos responsáveis pelo grande apreço que Plutarco nutria por Péricles é precisamente a relação deste com o filósofo Anaxágoras. Também o filho de Xantipo considerava essa ligação importante, não só pela amizade que os unia, mas também por causa de aquele ser o seu principal conselheiro político (cf. Per. 16. 7, onde se relata a reação de Péricles ao tomar conhecimento de que Anaxágoras se preparava para morrer). Alcibíades, à exceção de Sócrates, 
o caso do filósofo, conhecido por «Inteligência», foi o menos «acutilante» ou o mais subtil, já que a moção $0^{178}$ proposta por Diopites ${ }^{179}$ contra todos os que não acreditavam nos deuses ou ensinavam doutrinas sobre os fenómenos celestes, apesar de não visar um nome concreto, pretendia fazer recair as suspeitas de heresia sobre Anaxágoras e, consequentemente, sobre Péricles. E o estadista, que já tinha problemas de sobra, de sobreaviso por causa da condenação de Fídias e para tentar evitar empolamentos, envia Anaxágoras para fora da cidade ${ }^{180}$ (Per. 32.2).

Também Alcibíades (Alc.20.6) viu os seus familiares e amigos serem alvo da perseguição popular, quando, ausente por causa da expedição à Sicília, os adversários tentaram a todo o custo incriminá-lo de conspiração revolucionária pela participação na destruição dos Hermes (supra p. 234, nota 124) ${ }^{181}$.

Há uma grande diferença entre os momentos que o povo, uma vez enfurecido, escolhe para «espetar o seu ferrão» nos amigos e familiares daqueles contra os quais a sua fúria se dirige, neste caso, Péricles e Alcibíades. Os de Péricles são visados para destruir a imagem do estadista; os de Alcibíades, apenas são atacados depois de este ter sido banido e condenado à morte. É provável que tal discrepância se relacione com a diferença de caráter dos dois Alcmeónidas: o comportamento de Alcibíades era suficiente para destruir a sua credibilidade, pelo que o ataque a familiares e amigos foi mais uma vingança pelo facto de não se ter conseguido tornar efetiva a acusação e condenação de Alcibíades (Alc. 20.6). No caso de Péricles, cujo comportamento era, de acordo com Plutarco, quase irrepreensível (Per. 10.7), tornava-se necessário inventar argumentos para atingi-lo.

nunca fez por se rodear de bons conselheiros; à sua volta só gravitavam interesseiros que o elogiavam constantemente. Sobre a importância da amizade entre governantes e filósofos, vide Pérez Jiménez (1988: 89-113).

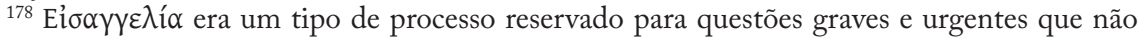
admitiam atrasos. Inicialmente decorria no Areópago e, mais tarde, na Ecclesia ou na Boulê. Estas, se necessário, poderiam remetê-lo para os tribunais da Helieia.

${ }^{179}$ Adivinho que os comediógrafos (e.g. Ar. Eq. 1085, V. 380, Av. 88) ridicularizavam com bastante frequência pelo seu fanatismo, pelo que se compreende que fosse contra uma interpretação racional dos fenómenos naturais. Segundo Aristófanes ( $\Sigma E q$. 1085), foi companheiro de Nícias, o que, por si só, não permite considerá-lo um extremista de direita. Era sobretudo um oportunista, que aproveitava as superstições dos Atenienses nas suas intervenções políticas.

${ }^{180}$ Segundo Diodoro Sículo (12. 39. 2), Anaxágoras foi acusado de impiedade e, em Plu. Nic. 23. 4, diz-se que chegou a estar preso. Note-se que o biógrafo aborda este processo sem se alongar em pormenores, apesar da existência de algumas fontes sobre o tema. É provável que isso aconteça ou por considerar este ataque o menos grave, ou para avançar para as outras investidas de que Péricles foi vítima. Sobre a data deste processo e outras fontes que Plutarco certamente conhecia, mas cuja informação não aproveitou, vide Stadter (1989: 298-230).

${ }^{181}$ Trata-se, na verdade, de um comportamento que remonta aos primórdios da fundação de Atenas. Plutarco não desenvolve o tema, mas deixa a sugestão de que os amigos de Teseu também foram perseguidos, pois afirma que, depois de ter sido libertado e de ter regressado a Atenas, aqueles ainda não tinham sido derrotados por completo (Thes. 35.3). Depois de ter sido definitivamente afastado do comando da cidade, o fundador também teve a preocupação de encontrar um local de exílio para os filhos, de onde podermos concluir que também eles corriam perigo (Thes. 35.5). 
De igual modo, a atitude dos Alcmeónidas para com amigos e familiares atacados por causa deles é diferente. Péricles tudo fez para ilibá-los, ou pelo menos para protegê-los das consequências das acusações de que foram alvo (mostrou a Fídias como provar a inocência; defendeu Aspásia em tribunal; «exilou», ele próprio, Anaxágoras). Alcibíades, porém, limitou-se, em um primeiro momento, a fugir, temendo pela própria segurança. $\mathrm{E}$, por certo, o seu plano de vingança em Esparta não terá contribuído para que as condições de vida daqueles que sofriam represálias no seu lugar fossem melhoradas... Tal postura não nos deve causar muita surpresa, porquanto, em Alc. 12, o biógrafo refere um boato, segundo o qual o jovem Alcmeónida era acusado de trair um amigo para alcançar a vitória nos Jogos Olímpicos ${ }^{182}$.

Uma vez iniciado o processo de desacreditação do estadista, o povo e os seus detratores encontram sempre novos motivos de crítica. Plutarco tem uma frase bastante sugestiva da disposição popular naquele momento e que vai ao encontro da maneira de ser das massas, que gostam de escândalos, mexericos e de ver a ruína

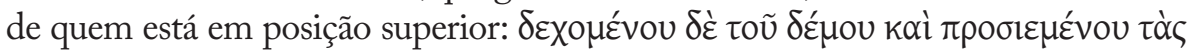
$\delta 1 \alpha \beta$ ¡ $\alpha$ ́́ - "o povo acolhia e aceitava este tipo de ataque" (Per. 32.3).

Para aproveitar este ambiente propício, os inimigos de Péricles resolveram ainda requerer a prestação de contas dos dinheiros públicos. Uma tal exigência supõe desconfiança de malversação e reforça a acusação contra Fídias, que pretendia pôr em causa a seriedade de Péricles no que toca a dinheiros. Somos levados a crer que, em outro contexto, com o povo sereno e de feição, nenhum Dracôntides $^{183}$ nem nenhum Hágnon ${ }^{184}$ se atreveriam a levantar semelhante suspeita.

Não deixa de ser curioso notar que, na Vida de Péricles, o biógrafo não faz qualquer comentário às reações do visado a propósito desta acusação. No entanto, em Alc. 7.3 conta uma anedota que está certamente relacionada com este episódio ${ }^{185}$ : Alcibíades, ao saber da preocupação de Péricles com este

${ }^{182}$ Vide supra p. 197.

${ }^{183}$ Dracôntides e o seu decreto são mencionados apenas por Plutarco. Trata-se provavelmente do mesmo Dracôntides que era epistastes da Boulê por altura da aprovação do decreto de Cálcis em 446-445 a.C. e do general que, em 433-432 a.C., acompanhou Glauco na expedição a Corcira. Segundo Meinhardt (1957: 61), a fonte de Plutarco em relação a este assunto terá sido a coleção de decretos de Crátero.

${ }^{184}$ Filho de um homem de nome Nícias, participou na Guerra de Samos, em 440 a.C., como estratego (Thuc. 1.117). É comummente aceite como provável fundador de Anfípolis (Thuc. 4. 102. 3, 5.11.1). Foi novamente estratego em 431 a.C. (por ocasião do cerco de Potideia - cf. Thuc. 2. 58) e em 429 a.C. (Thuc. 2. 95. 3). Participou na assinatura da Paz de Nícias (Thuc. 5. 19. 2, 5. 24. 1) e, em 413 a.C., foi eleito proboulos. Esta sua emenda ao decreto sugere que era apoiante de Péricles.

${ }^{185}$ Esta é também a posição de Stadter (1989: 301). Alguns autores identificam o processo em causa nesta anedota com o de 430 a.C., na sequência do qual Péricles foi destituído - vide Gomme (1945-1956: II, 187). Frost (1964: 69-72) e Donnay (1968: 19-36) não aceitam esta interpretação, argumentando que a acusação de 430 a.C. dizia respeito a questões militares (para estes, o processo em causa data de 438-437 a.C.). 
assunto, diz que o seu tutor não devia pensar na forma de apresentar as contas e sim em como não fazê-lo.

A maneira de ser que tal sugestão revela é diametralmente oposta à de Péricles e demonstra não só o à-vontade com que Alcibíades gere as mais diversas situações, mas sobretudo o desrespeito para com os outros, nomeadamente para com as massas. Só depois de se ter visto em apuros (isto é, após o regresso do exílio) é que parece ter começado a agir com mais cuidado e consideração. Péricles, que estava em uma posição delicada - ainda que, como sugere Plutarco, estivesse inocente -, sentia-se (segundo a anedota) obrigado (pela sua prudência, pela sua fama de incorruptibilidade, pelo seu bom nome e até para evitar dar mais argumentos aos seus detratores) a ter o único comportamento digno de um homem de caráter, que não tem quaisquer problemas em prestar contas das suas ações.

Note-se, contudo, que Plutarco não menciona, na Vida de Péricles, de que modo se resolveu este problema, que testemunhos diversos apontam como um dos motivos que o terá levado a iniciar a Guerra do Peloponeso ${ }^{186}$. Tal «esquecimento» pode dever-se a dois fatores: por um lado, a inocência de Péricles, cuja idoneidade Plutarco tantas vezes enalteceu; por outro, exatamente o facto de ter dedicado sobretudo o capítulo 16 ao elogio da relação de rigor que o estadista mantinha com o dinheiro, quer o público, quer o seu próprio (ou seja, depois de tanto desenvolver o tema, não valia a pena perder tempo a tentar ilibar o político de mais uma acusação infundada).

No entanto, se Péricles vivesse nos dias de hoje não seria considerado tão honesto como naquele tempo, porque agora fazemos distinção entre corrupção passiva e ativa. E, se, relativamente ao primeiro tipo de corrupção, a sua folha de serviço não registava qualquer notificação ${ }^{187}$, o mesmo não se pode dizer do segundo. De facto, o filho de Xantipo não se coibia de oferecer dinheiro a quem estivesse disposto a fazer cedências que o auxiliassem na prossecução

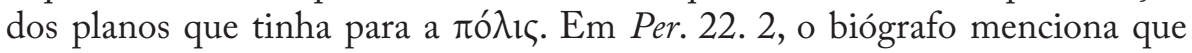

${ }^{186} \mathrm{O}$ estratego, seguindo o conselho de Alcibíades, terá dado início à guerra (D. S. 12. 38. 3-4 e 39. 3; Aristodem., FGrHist 104 F 16 e V. Max. 3. 1).

${ }^{187}$ Se alguma notificação tivesse, seria uma menção honrosa. De facto, Plutarco (Per. 25. 2-3) menciona que, por ocasião da incursão de Atenas contra Samos, o filho de Xantipo foi, por três vezes, tentado a alterar os seus planos em troca de dinheiro: uma pelos reféns, outra pelos que não queriam a democracia na cidade e a derradeira pelo persa Pissutnes, amigo dos Sâmios. Ao referir estas tentativas de suborno, o biógrafo foge ao texto de Tucídides, que nada diz a esse respeito. Ao que parece, era até normal tentar dar dinheiro em troca de reféns. Outras fontes, no entanto, não apoiam de forma tão evidente a incorruptibilidade de Péricles. Diodoro Sículo (12.27.2), por exemplo, diz que recebeu oitenta talentos dos Sâmios e que enviou para Lemnos oitenta crianças. 
Péricles abordara com sucesso Cleândridas ${ }^{188}$, tutor do jovem rei Plistóanax ${ }^{189}$, no sentido de retirar as tropas peloponésias da Ática. Em Per. 23. 1-2, alude à apresentação de uma despesa anual de dez talentos, jamais especificada pelo estadista e nunca contestada pelos Atenienses ${ }^{190}$, tal era a confiança que o povo outrora nele depositava! Essa verba teria servido para, adiando o início da guerra, dar mais tempo ao estratego para preparar a sua tática ${ }^{191}$.

A primeira grande alusão à sua incorruptibilidade surge em Per. 15. $3^{192}$, onde se afirma com todas as letras que era

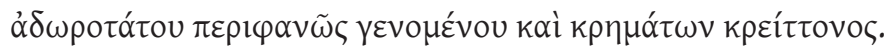

${ }^{188}$ Era provavelmente um éforo (cf. Suda, s. u. है $\varphi$ opo ) que lutara com Terina (Polyaen. 2.10.1) e Tégea (Polyaen. 2.10.3). Após o desterro a que Plutarco alude em Per. 22.3, participou na fundação de Túrios (Polyaen. 2. 10.), onde viveu exilado e ficou famoso como general (cf. D. S. 13. 106. 10; Antioch. Hist. FGrHist 555 F 11; Thuc. 6. 93.2; Polyaen. 2.10). O suborno de Cleândridas (cf. D. S. 13. 106.10) é apontado como causa da retirada espartana em Thuc. 2.21.1, 5.16.3. Éforo (FGrHist 70 F 193) relaciona-o com os vinte talentos que faltavam nas contas apresentadas por Péricles (em Per. 23. 1, o valor indicado é de apenas dez talentos). De acordo com Per. 22. 4, a tendência para o suborno e para a pouca seriedade nas relações com o dinheiro surge como um traço de caráter hereditário que Cleândridas partilha com o filho, Gilipo. Este, foi desterrado porque, após a rendição dos Atenienses, roubou trinta dos mil talentos do saque que Lisandro lhe confiara e escondeu-os debaixo do telhado da sua casa (cf. Plu. Lis. 16.2-17; Nic. 28. 4).

${ }^{189}$ Filho de Pausânias que reinou entre 458 e 408 a.C. (cf. D. S. 11. 88. 3). Por esta altura devia ser muito jovem - com cerca de vinte e cinco ou trinta anos - já que Plutarco salienta a sua juventude. Depois do fracasso desta expedição, refugiou-se no santuário de Zeus Liceu, na fronteira com a Arcádia (cf. Per. 22. 3). Foi-lhe permitido regressar a Esparta e ao trono em 427 a.C., após a morte de Arquidamo, e por influência de um oráculo pítico - vide Lewis (1992: 226). Segundo Tucídides (5.16.1-3), apoiou a Paz de Nícias em 421 a.C. e reinou até à sua morte em 408 a.C. Sobre a invasão liderada por Plistóanax, vide Lewis (1992: 90).

${ }^{190}$ Este episódio também é mencionado por Aristófanes em Nu. 858-859. Segundo o escoliasta deste passo, que provavelmente se baseou em Éforo (FGrHist $70 \mathrm{~F} \mathrm{193),} \mathrm{a} \mathrm{soma}$ era de vinte talentos. Suda s. v. ¿źov refere cinquenta talentos. É, porém, provável que Plutarco

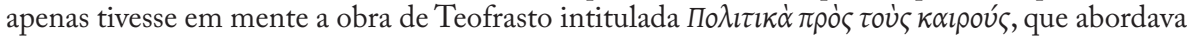
as diferentes respostas de um governante face a situações peculiares, exemplificando com acontecimentos históricos, já que este episódio não é relatado em mais nenhuma parte - vide Stadter (1989: 230). No entanto, a reação dos Espartanos face ao comportamento de Plistóanax e Cleândridas não confere grande veracidade ao testemunho de Teofrasto: se não conseguiram admitir um suborno momentâneo, como iriam suportá-lo por dez anos?

${ }^{191}$ Sobre as qualidades de Péricles enquanto estratego, vide infra p. 263 sqq.

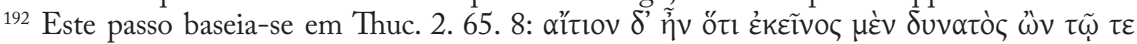

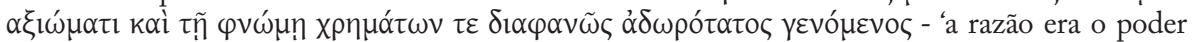
que lhe adveio da consideração de que gozava e da capacidade intelectual que possuía, além de ser extraordinariamente íntegro em questões de dinheiro (...)'. Também em Thuc. 2.60.5, durante o discurso que faz para acalmar a população encolerizada contra ele por causa da situação vivida, agravada pela epidemia, Péricles diz que não é justa essa posição do povo, já que ele, entre outras

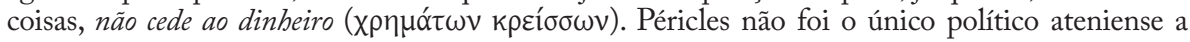
possuir esta virtude, que terá sido uma das principais razões que lhe valeu a boa relação que no geral manteve com o povo. Podemos recordar, através do testemunho de Plutarco (para não nos alongarmos demasiado), por exemplo, Aristides que, não só não se deixava corromper, como ainda denunciava aqueles que não resistiam à tentação, como Temístocles (Arist. 3. 4, 4. 3, 5. 6, Them. 21). 
“alguém manifestamente incorruptível e inacessível a subornos.”

E, acrescenta o biógrafo, apesar de ter deixado Atenas mais rica do que quando subiu ao poder, não aumentou a fortuna que herdara do pai em uma única dracma ${ }^{193}$. Conta o Queroneu que, por causa do excesso de trabalho e preocupações que tinha com o governo de Atenas, o filho de Xantipo confiou a gestão dos seus bens privados a um escravo chamado Evângelo - provavelmente ele próprio dotado para esta atividade -, que seguia à risca o plano traçado pelo estadista para o efeito ${ }^{194}$. Esta gestão eficiente da sua casa é mais um dos motivos pelos quais Plutarco o admira, pois considera que, só aliando este fator à sabedoria e a uma vida privada bem estruturada, um político pode servir de exemplo aos concidadãos e inspirar confiança pelo seu modo de vida ${ }^{195}$.

${ }^{193}$ Isócrates (8.126) afirma que Péricles não conseguiu conservar na íntegra a fortuna que o pai lhe legara. Esta perspetiva, porém, não se coaduna com o elogio que Plutarco faz à administração dos bens pessoais do herdeiro de Xantipo (cf. Per. 16.3). Importa chamar a atenção para o facto de, nas biografias de Teseu e de Alcibíades, não haver qualquer menção de preocupações deste género. No caso do fundador mítico, isso pode justificar-se pelo próprio caráter lendário da história e pelo altruísmo que o caracteriza. Quem, como ele, se dispõe a arriscar a vida para ajudar os fracos e oprimidos não tem perfil compatível com o de alguém que cede à influência do dinheiro. No caso de Alcibíades, tão-só pelo facto de se tratar de um jovem de famílias ricas, pouco responsável, que tem como uma das suas principais atividades delapidar a fortuna herdada - característica que, de resto, parece partilhar com os filhos do próprio Péricles.

${ }^{194}$ Segundo Plutarco, embora não caísse em tentação por causa de dinheiro, Péricles não era indiferente aos negócios. Esta postura do estadista merece uma atenta reflexão do biógrafo, porque diverge dos ensinamentos de Anaxágoras, que, apesar de oriundo de família rica e influente, abdicou da herança, das facilidades e sucesso político, que poderia alcançar se dela dispusesse, para se entregar à ciência e à filosofia (cf. P1. Hp. Ma. 281c, 283a; D. L. 2. 6-7). Para ele a vida só tem valor se servir para uma melhor compreensão do cosmos a que se pertence; tudo o resto é supérfluo: o apego aos bens materiais e à felicidade terrena não vale a pena, pois todo o homem é mortal e, mais cedo ou mais tarde, todos têm o mesmo destino - vide Guthrie (1969: II, 266 sq.). Péricles, embora admirasse Anaxágoras como ninguém (supra 5. 1), tinha uma visão mais pragmática da vida e nisso não seguia os ensinamentos do seu mestre, como nolo diz Plutarco em Per. 16. 7. De facto, segundo Van Raalte (2005: 88), nas Vidas, o Queroneu opta por apresentar a filosofia em contraste com a atividade política e a diferença que mais sobressai entre o estilo de vida de um filósofo teórico e o de um político é a atitude perante os bens materiais. Enquanto teorizador político, não condena o homem de Estado que se preocupa com a riqueza. Pelo contrário, em Cor. 10.8, defende que o correto uso dos bens materiais é mais proveitoso que a excelência nas armas. Já em Sol. 2. 5, considera que o homem bem formado e bom cidadão, desde que não tenha ambição em demasia nem deseje o supérfluo, deve fruir do necessário e do suficiente, pois é impossível fazer face à dura realidade sem dinheiro. $\mathrm{O}$ Queroneu, que tem por hábito atribuir a virtude da caridade às suas personagens (cf. Sol. 2. 1), bem como refletir sobre o uso que um político deve fazer do dinheiro (cf. Publ. 1. 2, Fab. 7. 7, 8, Comp. Per.-Fab.), afirma mesmo que a riqueza pode ser uma virtude, se o político a usa para fazer bem aos mais necessitados, como no caso de Péricles. Mas a verdade é que não consta que Péricles fosse possuidor de uma generosidade desinteressada, no que contrasta com Címon (Cim. 10) e Nícias (Nic.3.1).

195 Moralia 800C-801B. Sobre este tema, vide De Blois (2004: 57). Esta postura do filho de Xantipo é oposta, por exemplo, à de Nícias, que descurava os seus bens, porque tinha como 
Mas o rigor orçamental que se vivia em casa de Péricles era pouco comum em casas abastadas, pelo que lhe valeu problemas com Xantipo ${ }^{196}$, o filho mais velho (gastador por natureza) e com a nora ${ }^{197}$, jovem, oriunda de famílias ricas, naturalmente esbanjadora, que se revoltava por não conseguir obter do sogro os vinténs necessários aos seus pequenos luxos.

Plutarco (Per.36.3) chega a narrar um episódio que azedou definitivamente a relação entre pai e filho, que morreu de relações cortadas com o progenitor (Per.36. 6): como o pai não lhe facilitasse o montante que pretendia, Xantipo pede um empréstimo junto de um amigo da família, dando a entender que era em nome de Péricles que o fazia. Como nem um nem outro pagassem a dívida, o dito amigo solicitou o reembolso do montante em dívida ao estadista, que levou o caso a tribunal. Envergonhado e irritado com o caso, Xantipo decidiu, também ele, expor o pai ao ridículo, revelando episódios da sua vida privada (tão a gosto da curiosidade e dos mexericos populares), como a parcimónia com que geria a casa e as discussões que mantinha com os sofistas (Per. 36. 5).

O único grande momento de liberalidade que se lhe conhece ${ }^{198}$ corresponde às obras de embelezamento da cidade e foi justificado, pois imortalizou o nome da $\pi$ ó $\lambda ı$ ı desde o século $\mathrm{V}$ a.C. aos nossos dias ${ }^{199}$. Note-se, contudo, que tal

prioridade única e exclusiva os interesses do Estado (Nic. 5. 4).

${ }^{196}$ Este assunto tem como fontes possíveis Estesímbroto, que recorda os problemas entre Péricles e o seu filho (Per. 36. 6), uma fonte peripatética - talvez Teofrasto, de acordo com Meinhardt (1957: 46-47) - ou mesmo algum diálogo socrático, já que em Per. 16. 7-8 se invoca Anaxágoras. A referência à contenção diária, que tanto irritava os filhos e as noras, pode também ter surgido em comédias, onde a vida privada serve muitas vezes de analogia para a política.

${ }^{197}$ A referência à natureza dissipadora das mulheres de boas famílias faz recordar as queixas de Estrepsíades em relação à sua consorte (vide Ar. Nu. 46-68).

${ }^{198}$ Segundo Plu. Cim. 13. 7, o primeiro político a ter a preocupação de embelezar Atenas depois das Guerras Médicas foi Címon. Sobre esta empresa de Péricles, vide infra p. 223, nota 65. Não deixa de ser curioso chamar a atenção para o facto de o estadista, que tinha (pelo menos em casa) fama de avarento, se ter dedicado entusiasticamente à reabilitação da cidade. Disso nos dá testemunho Per. 12. 5. Igualmente digno de nota é a humana variação de

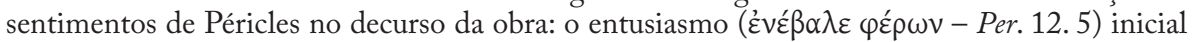

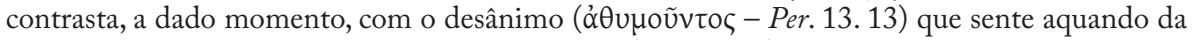
queda de um dos artífices que se feriu gravemente (Per.13.13). Nessa altura, o filho de Xantipo, com a ajuda de um sonho inspirado por Atena Higia, transforma-se efetivamente no médico a que tantas vezes Plutarco o assemelha metaforicamente enquanto bom político (cf. supra pp. 226-227). Este entusiasmo, com que Péricles procurou contagiar todo o povo para que as «suas» obras alcançassem o esplendor que ainda lhe reconhecemos, é comparável àquele que Alcibíades instigou na população a propósito da conquista da Sicília (Alc.17.2, Nic. 12. 1). Sobre a Sicília, vide infra p. 283 sqq, passim.

${ }^{199}$ Para um grego que, como Plutarco, vivia sob o domínio de Roma, esses monumentos - que cinco séculos depois de edificados (consequentemente em melhor estado de conservação do que hoje) - eram a única prova de que os relatos dos autores não eram mera ficção. Não surpreende, por isso, que o biógrafo lhes tenha dedicado nada menos do que três capítulos, que podemos considerar em harmonia com a admiração que os monumentos causaram não só no século $\mathrm{V}$ a.C. (pela rapidez e qualidade com que foram executados - Per. 13. 1), como nos vindouros. O relato do Queroneu sugere que o estadista pretendia que as suas obras fossem «aere perennius». E isso de 
magnificência ${ }^{200}$ não foi feita a expensas próprias. Nisso Péricles foi afortunado, porque sempre teve à sua disposição verba para levar a cabo os planos que tinha para Atenas ${ }^{201}$. O mesmo não se pode dizer de Alcibíades ${ }^{202}$ que, no contexto de uma longa guerra, se foi deparando progressivamente com menos recursos. Foi a escassez do vil metal que, em última instância, azedou em definitivo a relação deste com o povo. Necessitado de meios para manter a produtividade

facto aconteceu: se hoje, passados mais de vinte séculos, conseguimos vislumbrar a magnificência original dos monumentos - apesar das diversas vicissitudes naturais e humanas por que já passaram -, qual não seria o seu esplendor no tempo de Plutarco? Stadter in Santoni (1991: 100) vê no elogio que o biógrafo pronuncia (Per.12.1) uma espécie de encorajamento aos contemporâneos de Plutarco - sobretudo os Romanos - que procuravam alcançar fama imortal com o financiamento de obras públicas monumentais, como teatros e termas. Apesar da reconhecida rapidez das obras, que ficaram prontas sob «o reinado» de Péricles» (do mesmo modo que o apogeu da cidade coincide praticamente com o período de vida do estadista), ainda houve quem criticasse atrasos na sua execução. Como não poderia deixar de ser, trata-se da maledicência de um comediógrafo, Cratino, por causa da lentidão que caracterizou a construção da grande muralha, que unia o Pireu diretamente a Atenas, paralela ao muro mais a norte, construído entre 445-443 a.C. As palavras

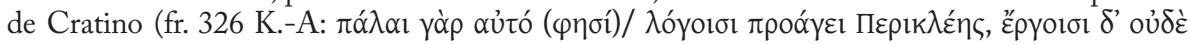
Kıvعĩ - 'há tempos infinitos que Péricles, em palavras, é um vê se te avias, em obras nem se mexe', poderiam ser aplicadas a qualquer político, já que têm fama de só prometer e não cumprir. No caso concreto da muralha, contudo, foi a própria conjuntura que dificultou o seu avanço e não a inércia ou falta de palavra de Péricles. É que em 446 a.C. (as obras haviam começado no ano anterior), Atenas viu-se a braços com a crise política que levou à destituição do filho de Xantipo, entrou em guerra com Mégara e Eubeia, além de ter sido invadida pelos Lacedemónios... Sobre a lentidão das obras, vide etiam Plu. Moralia 351A.

${ }^{200}$ Embora Plutarco não recorra a este termo nem faça uma caracterização direta relativamente a esta qualidade, a atuação de Péricles nestas circunstâncias faz lembrar a caracterização da magnificência - $\mu \varepsilon \gamma \alpha \lambda$ o $\rho \varepsilon \pi \varepsilon i ́ \alpha$ - proposta por Aristóteles em EN1122b 6-10: $\delta \alpha \pi \alpha v \eta ́ \sigma \varepsilon 1 \delta \dot{\varepsilon}$

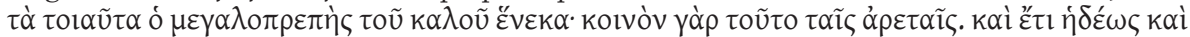

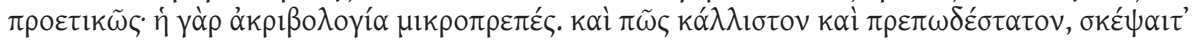

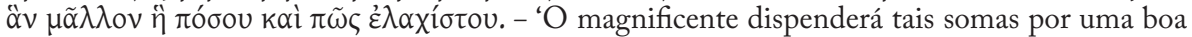
causa: é que isso é comum às virtudes. $\mathrm{E}$ além disso, fá-lo-á com alegria e prodigalidade, pois a parcimónia é mesquinha. E refletirá sobre como obter o melhor e o mais conveniente, mais do que sobre o preço e do que sobre o como pagar o menos possível.'

${ }^{201}$ Foi Isócrates $(15.234)$ que atribuiu as construções do século $\mathrm{V}$ a.C. à responsabilidade individual de Péricles, que interpreta como manifestação da vontade imperialista de Atenas (7.66).

${ }^{202} \mathrm{O}$ nome deste Alcmeónida também surge associado a uma obra de grande envergadura: a construção da muralha que ligava Argos a Atenas, por ele proposta quando ajudou esta cidade aliada a repor o regime democrático (Alc. 15.4-5). Nessa ocasião, Alcibíades deslocou de Atenas para Argos um grande número de artífices (nomeadamente carpinteiros e canteiros), gerando uma atividade que, mutatis mutandis, nos faz pensar nas obras de Péricles. Cf. Thuc.5. 82. 2-6; Romilly (1961: 169, n.3). , n. 3; Lewis (1992: 278). Também convenceu os habitantes de Patras a construir um muro semelhante, apesar de estes terem sido alertados para a possibilidade de virem a ser «devorados» pelos Atenienses. Para tal, argumentou que estes podiam até devorá-los, mas fá-lo-iam de um modo mais lento do que os Lacedemónios em iguais circunstâncias (Alc. 15.6; Thuc. 5.52.2). Esta anedota sugere que o tratamento dos Espartanos para com os vencidos era muito mais cruel que o dos Atenienses, uma ideia que podemos comprovar não só pela forma excessiva como os Lacedemónios se comportam na sequência da vitória de Egospótamo, como pela descrição da atitude moderada que os Atenienses adotam na maior parte das vezes para com os vencidos (pp. 129-130, 270). 
das tropas, uma vez que combatia contra inimigos profusamente financiados pelo Rei, o general viu-se obrigado a ir angariá- $1^{203}$. Na sua ausência, delegou o comando ao amigo Antíoco, que, por não cumprir as suas ordens ${ }^{204}$, provocou a derrota dos Atenienses, em Nócio no ano de 406 a. $\mathrm{C}^{205}$. Estes, devido ao caráter esbanjador de Alcibíades ${ }^{206} \mathrm{e}$ à má fama que foi construindo ao longo da vida, deram novamente crédito às acusações dos inimigos (que até já estavam instalados no campo de batalha) e afastaram-no definitivamente do comando do exército (Alc. 35-36). Eis um dos poucos momentos em que Plutarco se põe ao lado deste Alcmeónida: considera-o vítima da sua fama, da pouca compreensão dos Atenienses, da irresponsabilidade de Antíoco e do conluio dos inimigos para arrasarem de vez a sua aura junto do povo ${ }^{207}$.

O facto de Atenas dispor de dinheiro para a execução das obras de embelezamento não impediu que os inimigos (ainda no tempo em que Tucídides, filho de Melésio, representava a oposição) criticassem duramente a estratégia de Péricles ${ }^{208}$. Alegavam que essa medida indispunha os aliados contra Atenas, por estar a ser gasto dinheiro oriundo do fundo constituído

${ }^{203}$ Segundo Alc. 35. 5, enquanto Lisandro, o comandante das tropas inimigas sobre o qual Plutarco também redigiu uma biografia, aumentou o salário dos soldados de três para quatro óbolos, Alcibíades pagava a custo os três que devia a cada um dos seus homens. Plutarco é o único autor a justificar a ausência de Alcibíades com este argumento. Para possíveis explicações para esta situação, consulte-se Verdegem (2005: 141-150). De acordo com Xenofonte (HG 1.5. 11) e D. S. 13.71. 1, o motivo da ausência de Alcibíades foi outro, respetivamente uma reunião com Trasíbulo (que estava a construir uma muralha em redor de Foceia) e uma reunião em Clazómenas (que estava a ser saqueada por uns desterrados).

${ }^{204}$ Sobre Antíoco, vide p. 197, nota 23. Este episódio também é narrado por X. HG. 1. 5. 11-15 e D. S. 13. 71. Alcibíades ordenara expressamente ao amigo que, mesmo se provocado pelo inimigo, não participasse em nenhum combate naval. Qual fanfarrão, Antíoco, que, apesar de bom piloto, era, nas palavras de Plutarco, um homem «estúpido e comum», fez exatamente o contrário do que Alcibíades dissera, colocando o amigo em apuros, já que foi responsabilizado pela derrota. Este caso confirma a ideia - que já mencionámos supra p. 243, nota 155: os amigos e familiares próximos são, não poucas vezes, mais perigosos que o inimigo. Demais, a delegação de poderes em Antíoco sugere uma de duas verdades em relação a Alcibíades: ou era ingénuo a ponto de confiar no amigo ou a situação financeira do exército estava realmente muito má.

205 Sobre este assunto, vide Lewis (1992: 353); Verdegem (2005: 178).

${ }^{206}$ Apesar de ser amigo de gastar, em nenhum momento Plutarco sugere que Alcibíades tivesse cedido ao dinheiro, isto é, que se tivesse deixado corromper. Os únicos argumentos que o faziam vacilar e influenciavam o seu comportamento eram a lisonja e a vontade de ser o primeiro. É nesse sentido que Nícias acusa o jovem de se lançar na expedição à Sicília por interesses pessoais e ambição (Nic.12.4). O comportamento de Alcibíades que mais se aproxima de corrupção é o de abuso de poder, a que já nos referimos (supra p. 221, nota 53), pois, ao que parece, servia-se de bens do Estado como se fossem seus.

${ }^{207}$ Retomaremos este assunto mais à frente.

${ }^{208}$ A opção pelas obras deu azo ao único grande momento de contestação de que Péricles foi vítima antes de o povo entrar em verdadeiro conflito com ele. Revela, no entanto, mais uma vez, a enorme perspicácia e capacidade de antecipação por que o estadista ficou conhecido: as obras não só foram responsáveis pela resolução de problemas no imediato (como a reconstrução da cidade e a ocupação dos Atenienses desempregados - como já vimos supra p. 223), mas também se tornaram na imagem de marca do apogeu da civilização grega em geral. 
pelos tributos daqueles. $\mathrm{E}$ acrescentavam, como agravante, a transferência do fundo de Delos para a đó $\lambda_{1} \varsigma$, a que se procedera com o argumento de que aqui estaria mais protegidos de eventuais ataques bárbaros, mas que agora parecia a saque dos Atenienses ${ }^{209}$. É verdade que, em termos de política externa, as obras não terão sido uma opção muito feliz, pois deram aos aliados mais um argumento para a sua vitimização enquanto alvo de violência e tirania por parte do império ateniense ${ }^{210}$.

Péricles, servindo-se dos seus dotes oratórios e da perspicácia e bom-senso que o caracterizavam, desmontou tais objeções: quem recebe dinheiro pela prestação de um serviço - desde que o forneça efetivamente e com qualidade tem o direito de usar o dinheiro recebido a título de pagamento como bem lhe aprouver (Per. 12. 3-4). Demais, conhecedor da vaidade ateniense, avançou a hipótese (quanto a nós, meramente retórica ${ }^{211}$ ) de custear do seu bolso todas as despesas e, consequentemente, apenas fazer constar o seu nome das inscrições (Per. 14. 1-2). Diante desta sábia posição radical, o povo assumiu as obras como suas e pôs termo a esta contestação ${ }^{212}$.

${ }^{209}$ A legislação sobre o tributo que os aliados deviam aos Atenienses foi produzida por Aristides, cujo caráter justo e incorruptibilidade eram reconhecidos por todos (Arist. 24). Inicialmente, o tesouro constituído pelos tributos dos diversos membros da Simaquia de Delos encontrava-se depositado na ilha que dá nome à coligação. Foi transferido para Atenas por volta do ano 453 a.C., sob o pretexto de que em Delos estaria mais exposto a um hipotético saque bárbaro. Sobre este assunto, vide Pritchett (1969: 17-21). Embora não o mencione na Vida de Péricles, em Nic. 24. 3-5, o biógrafo conta-nos que o filho de Xantipo procedeu a um aumento do tributo, que, após a sua morte, foi agravado pelos demagogos.

${ }^{210}$ Não deixa de ser interessante recordar que, de acordo com os testemunhos que chegaram até nós (nomeadamente Thuc. 1), quando a crispação entre Atenas e os aliados sobe de tom antes do deflagrar da Guerra do Peloponeso, ninguém se queixa da violência que as obras (segundo Per. 12. 2) terão constituído. Os inimigos de Péricles chegaram a afirmar que, por causa das obras, os aliados (forçados a contribuir para a guerra) acusavam Atenas de ser uma «mulher vaidosa», que gosta de se embelezar e adornar de ouro. Esta visão da toda poderosa Atenas como entidade feminina sugeriu-nos três reflexões. Por mais que agisse como uma mulher em

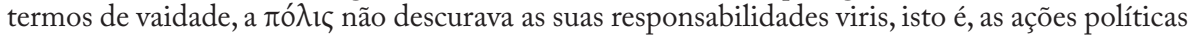
e militares que lhe permitiam controlar inimigos e aliados. Por outro lado, o povo, que, de início, tanto critica o embelezamento de Atenas enquanto traço de feminilidade, partilha com ela um temperamento próprio de mulher: vive feliz se adulado; torna-se furioso e vingativo se contrariado. Destas duas reflexões baseadas em Per. 12. 2, decorre a terceira: esta Atenas, que parece oscilar entre feminino e masculino, terá a sua representação máxima em Alcibíades, que funde como nenhum outro as oscilações próprias de Ares e Afrodite.

${ }^{211}$ Plutarco, por seu turno, aponta como causas da mudança de posição do povo quer a vaidade dos Atenienses, quer o reconhecimento e admiração destes pela grandeza de alma de Péricles. Não deixa também de ser notável o facto de Péricles, «injustamente» acusado de gastar os fundos para embelezar Atenas, não se propor suspender a obras, mas antes continuá-las com o seu próprio dinheiro. Esta opção revela não só um profundo conhecimento do povo, mas sobretudo que ele não era homem de interromper o que de bom estava a fazer pela cidade apenas para ceder a um capricho da população.

${ }^{212}$ Segundo Moralia 813A, é muitas vezes por mera animosidade e desconfiança para com os políticos que o povo considera controversas e rejeita muitas medidas úteis. 
Ora, é caso para afirmar que Péricles foi atacado por todas as frentes, pelos inimigos, pelo próprio filho (o mais penoso de todos os ataques) e até pelo destino, que, através da peste, em pouco tempo lhe roubou muitos familiares (Per. 36. 6. 7). Não deixa, por isso, de ser curioso chamar a atenção para uma outra frente: a do inimigo lacedemónio. De facto, a rivalidade entre Atenas e Esparta é imemorial (cf. supra p. 87), mas tornou-se particularmente acesa depois que os Atenienses assumiram a hegemonia, outrora espartana, sobre a Grécia ${ }^{213}$. Persistiram, contudo, ligações profundas de cidadãos de Atenas (inclusive políticos, como Címon ${ }^{214}$ ou Alcibíades ${ }^{215}$ ) com os da Lacedemónia. Péricles, responsável em larga escala pelo engrandecimento do império ateniense, também tinha amigos entre os adversários, nomeadamente o rei Arquidamo ${ }^{216}$, mas era um acérrimo opositor dos Lacedemónios. Essa sua oposição intransigente valeu-lhe uma tentativa de sabotagem política por parte daqueles que, além de recearem cada vez mais o poderio de Atenas, se viam a braços com um Péricles que não aceitava ceder a nenhuma das exigências feitas para evitar a guerra, para não abrir precedentes que fragilizassem a posição ateniense. Por isso, julgavam que a única maneira de reverter o impasse a que se havia chegado (e de neutralizar o perigo que Atenas constituía) passava por afastar o filho de Xantipo da cena política. Assim, ao se aperceberem do momento de contestação que Péricles atravessava e de que havia muita oposição interna à sua perspetiva belicista, cheios de esperança, resolveram contribuir para o ataque ao estadista. Exortaram, então, os Atenienses a exigir a expiação do crime sacrílego de Cílon ${ }^{217}$ (Per.33.1), no qual a família materna de Péricles estava envolvida.

Ao contrário de todas as previsões, os Espartanos não foram bem

${ }^{213}$ Sobre esta alteração de papéis, vide supra p. 127.

${ }^{214}$ Vide supra p. 202, nota 44.

215 A proxenia que ligava Alcibíades aos Lacedemónios é mencionada por Plutarco em

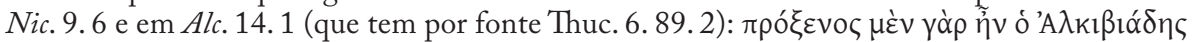
$\tau \tilde{\omega} \nu \Lambda \alpha \kappa \varepsilon \delta \alpha \iota \mu v i ́ \omega v$. Em Alc. 14. 9, pode ler-se também que o Alcmeónida, por ocasião da embaixada que se dirigira a Atenas para tentar nova conciliação com Nícias, promete aos Lacedemónios tudo fazer para lhes agradar. Sobre o papel de Alcibíades na falha desta

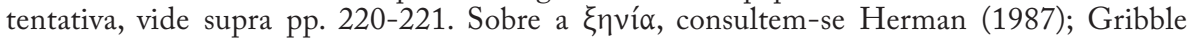
(1999: 82-89).

${ }^{216}$ Arquidamo II que reinou entre 469 e 427 a.C. Foi ele quem comandou as invasões à Ática durante a Guerra do Peloponeso em 431, 430 e 428 a. C, pelo que o primeiro período da guerra recebe o seu nome. Cf. Thuc. 2. 10-12, 18-20.

${ }^{217}$ Este passo tem como fonte Thuc. 1. 126-127. Cílon, ateniense nobre e influente, vencedor dos Jogos Olímpicos, casou-se com a filha do tirano de Mégara. Quando, certa vez, consultou o oráculo de Delfos, convenceu-se de que devia tornar-se tirano em Atenas, ocupando a Acrópole. Falhada a tentativa - os Atenienses apercebem-se e há um confronto -, Cílon foge com o irmão, mas os outros que o ajudaram são assassinados, alguns dos quais no interior dos templos, pelo que se considerava que os assassinos tinham cometido sacrilégio contra os deuses. Exortar à exclusão dos que eram amaldiçoados por assassinar suplicantes deve ter parecido uma excelente réplica àquela a que os Atenienses votaram os de Mégara por sacrilégio. 
sucedidos. Face a esta acusação, os Atenienses, sempre imprevisíveis, apoiaram Péricles, naquele que é um dos poucos momentos em que Plutarco (e a sua fonte para este passo, Tucídides) apresenta o povo dotado de um rasgo (esporádico) de inteligência ${ }^{218}$. É que entendeu que se ele estava a ser indiciado pelos Espartanos era porque estes o temiam (e não se teme quem não oferece perigo...). Trata-se, por assim dizer, de um reconhecimento indireto da capacidade de liderança e de condução do povo e dos assuntos militares pela qual Péricles ficou conhecido.

Antes que Arquidamo, com o qual mantinha laços de hospitalidade, tivesse tempo de congeminar nova estratégia para desacreditá-lo, o Alcmeónida, como bom estratego e político previdente, tomou as devidas precauções (Per. 33.3) ${ }^{219}$. Prometeu doar ao povo todas as suas terras, se o inimigo agisse de acordo com a suspeita popular, ou seja, se, por ocasião da invasão da Ática, poupasse apenas as propriedades de Péricles ${ }^{220}$. Assim, minando a possível pretensão do inimigo, o filho de Xantipo - e, por sua vez, os Atenienses - veem reforçada a sua superioridade relativamente aos Lacedemónios: por mais que estes tentem, são os protegidos de Atena que levam a melhor.

Alcibíades foi alvo de uma investida semelhante, cujo desfecho não foi tão lisonjeiro para Atenas. Os Lacedemónios consideraram que aquele era o único político de que a đó $\lambda ı \varsigma$ dispunha com capacidade para fazer reverter a situação e impedir que os Atenienses saíssem derrotados da Guerra do Peloponeso ${ }^{221}$. É caso para se dizer que, mais uma vez, Péricles representa o apogeu e Alcibíades

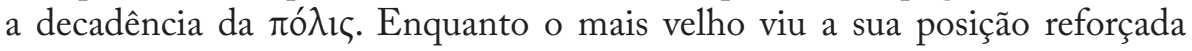
na sequência dos ataques de que foi alvo, o mais novo destes Alcmeónidas não conseguiu anular os efeitos da tática do inimigo e acabou por morrer às suas mãos. Sem ele, Atenas ficou órfã e não teve forças para reagir com a determinação necessária.

${ }^{218}$ Per. 33.2.

${ }^{219}$ A fonte deste passo é Thuc. 2. 13.1. Como se sabe a relação de hospitalidade era muito importante para o homem grego. Temos exemplos disso já nos Poemas Homéricos - Il. 6, 119-129 (Glauco e Diomedes, ao reconhecerem a existência de laços de hospitalidade entre as suas famílias, recusam-se a combater); Od. 7 (receção de Ulisses no palácio de Alcínoo e Arete), entre outros. Sobre as relações de $\xi \varepsilon v i ́ \alpha$ de Péricles, vide supra p. 165 e Gribble (1999: 50).

${ }^{220}$ Fábio Máximo, par de Péricles na obra de Plutarco, passa por uma situação semelhante. Mas, neste caso, as suas terras são efetivamente poupadas por Aníbal (Fab. 7. 4).

${ }^{221}$ Embora nesta altura os Atenienses estivessem novamente de relações cortadas com o Alcmeónida, também eles acreditavam que aquele seria a sua única hipótese de salvação: enquanto Alcibíades vivesse, havia esperança (Alc. 38. 3). O mesmo sentimento era partilhado pelos Trinta, que colocaram Alcibíades sob vigilância e instigaram os Lacedemónios a ajudá-los: se Atenas voltasse a viver em democracia, seria mais difícil para aqueles assegurar a hegemonia sobre a Grécia. Sobre este assunto, vide Nep.Alc. 10. 12; Lewis (1992: 369). Plutarco (Alc. 38. 6) aponta como outra causa possível para a perseguição que os Lacedemónios fizeram a Alcibíades a vontade daqueles de agradar ao rei Ágis, que nunca perdoara ao ateniense o facto de ter engravidado a sua real esposa. Sobre este assunto, vide supra p. 246. 
Reflitamos um pouco sobre a reação dos dois Alcmeónidas quando confrontados com a investida do povo, não sem antes distinguir, em traços gerais, as penas de que foram alvo.

A descrição que Plutarco faz da primeira perseguição movida contra Alcibíades resulta menos contundente (e até mais breve, apesar de ter ocorrido em dois momentos distintos) do que a de Péricles, não obstante as consequências para o mais novo terem sido mais graves em termos pessoais. Aquando da primeira desavença com os concidadãos (que podemos considerar mais séria para o político), além de privado dos seus bens, Alcibíades foi amaldiçoado ${ }^{222}$, condenado à morte e viu-se obrigado ao exílio para sobreviver ${ }^{223}$. Péricles, aparentemente mais fustigado pelos ataques populares, apenas se viu, por pouquíssimo tempo, afastado do comando da cidade e foi condenado a pagar uma "pequena» multa 224 (Per. 35.4). No entanto, a reação de ambos aos ataques e à condenação a que foram sujeitos foi inversamente proporcional à realidade que acabámos de descrever. Péricles, ao ser alvo de pressões cada vez mais intensas por parte de inimigos e amigos, resistiu convictamente, demonstrando a serenidade ${ }^{225}$ de quem tem formação filosófica e perfil de verdadeiro homem de Estado, que tudo faz para manter o bem-estar da população acima dos seus interesses pessoais ${ }^{226}$. Alcibíades, por sua vez, respondeu como um jovem mimado que, ao ver recusado um pedido ou a satisfação de um desejo, passa a ter como único objetivo infernizar a vida daqueles que o contrariaram. Para isso, alia-se, sem pudor, ao inimigo do povo que o traiu, pagando-lhe na mesma moeda. Esta postura é a negação daquele que deve ser o comportamento de quem tem por missão proteger os concidadãos e os interesses da coletividade ${ }^{227}$. Podemos, por isso, associar o comportamento de Alcibíades ao de Teseu. Também ele se mostrou agarrado ao poder, porque tentou recuperar o

${ }^{222}$ Cf. Nep. Alc. 4. 5. Plutarco (Alc. 22. 5) conta que uma das sacerdotisas, Téano, alegando que a sua função era abençoar os indivíduos, se recusou a amaldiçoar Alcibíades. O biógrafo elogia a sua postura em Moralia 275D.

${ }^{223}$ Em Alc. 22. 4, o biógrafo transcreve o decreto da acusação contra Alcibíades.

${ }^{224}$ Sobre a multa aplicada a Péricles, vide infra p. 283, nota 339.

${ }^{225}$ No entanto, embora Plutarco apenas veladamente faça alusão ao receio ou incómodo que Péricles terá sentido com toda esta contestação (sobretudo através da referência à opção pela guerra como forma de abafar as acusações que lhe eram dirigidas - cf. p. 277 sqq. ), Tucídides (2.59-60) e Aristófanes (Pax 606-7) afirmam com clareza que o estadista sentiu medo do povo.

${ }^{226}$ Esta postura foi assumida sobretudo no que respeita ao seguimento da estratégia que defendeu para a Guerra do Peloponeso, que foi largamente contestada pela oposição. Não nos alargaremos aqui sobre este tema, pois pareceu-nos mais oportuno desenvolvê-lo no subcapítulo que se segue, dedicado à faceta de estratego.

${ }^{227}$ Este é o tipo de reação própria dos indivíduos de «grande natureza» sempre que se sentem feridos no seu orgulho, já antes exemplificado com a «vingança» de Alcibíades, que engana a embaixada de Lacedemónios, porque tratavam a paz com Nícias e não com ele. Sobre estes assuntos, vide supra pp. 207-208 . 
comando da cidade à força (Thes. 35. 4-5), ao invés de procurar contribuir para a resolução dos problemas da $\pi$ ó $\lambda \mathfrak{l} \varsigma^{228}$.

Ora, depois de instalada a confusão, por entre ataques e condenações, o povo revela-se desconcertantemente interesseiro e complacente. É que, apesar de impiedoso para com os seus políticos, acaba por lhes perdoar as falhas, quando (privado da boa influência das suas ações e depois de, reinvestido na sua autoridade ${ }^{229}$, ter descarregado a sua ira como um ferrão ${ }^{230}$ ) sente a necessidade premente de voltar a beneficiar das suas medidas. Nesses casos, sem qualquer pejo que não o de se ter prejudicado a si mesmo durante o período em que prescindiu ${ }^{231}$, por sua própria responsabilidade, das ações do estadista, manda chamá-los de volta ${ }^{232}$. Uns, como Alcibíades, aceitam de imediato o convite/ pedido de desculpa. Só não vêm mais depressa, porque, por precaução, querem chegar a casa com provas dadas dos benefícios que a sua ação pode oferecer à cidade ou, porque, segundo Plutarco, pretendem retribuir a compaixão e o favor do povo com feitos favoráveis e dignos de registo (Alc. 27.1-2233). Outros, como Péricles, por cansaço ou para se valorizarem, adiam um pouco mais a rentrée em glória, e só regressam instigados pelos amigos ${ }^{234}$ (Per.37.1-2).

${ }^{228}$ Vide supra pp. 106-107.

${ }^{229}$ Cf. Per. 35. 4.

${ }^{230}$ Aproveitámos esta imagem de Per. 36. 1, onde Plutarco sugere que os problemas com o povo, apesar de graves, foram passageiros, já que este se acalma depois de descarrregar a sua ira como um ferrão. Esta comparação do comportamento das massas ao de uma abelha é só mais um dos muitos exemplos de comparação do povo com animais, como já vimos antes (p. 225, nota 78), e terá sido influenciada por Platão (Phd.91c) e Aristófanes ( $V .405$ sq., onde os juízes atenienses deliberam, como quem distribui ferroadas, para punir os que têm comportamentos menos dignos).

${ }^{231}$ Em Alc. 25. 2, os Atenienses mostram-se arrependidos da afronta que lhe fizeram ao condená-lo à morte e obrigá-lo ao exílio, por serem alvo da sua represália; do mesmo modo, em Alc. 32. 3, recriminam-se por não o terem deixado à frente do exército na Sicília.

${ }^{232}$ A falta que o povo sente destes estadistas e o convite que lhes faz para regressarem ao convívio político estão em consonância com Moralia 811F, onde Plutarco afirma que o político se deve aproximar do povo quando este o ama e deixá-lo com saudades suas se se ausenta. Neste contexto, importa ainda recordar o que o biógrafo afirma, em Moralia $813 \mathrm{C}$, que os políticos não devem recusar os cargos legalmente oferecidos pelo povo. Esta terá sido uma das razões que levam Péricles e Alcibíades a regressar depois de afastados do poder pelos concidadãos. Em Moralia 788C, a propósito da defesa da atividade política dos anciãos, Plutarco afirma que as cidades, quando sofrem algum revés ou sentem medo, preferem ser governadas por homens de idade avançada. Chegam mesmo a chamar de volta aqueles dirigentes que elas próprias já haviam afastado (como acontece com Péricles).

${ }^{233}$ Neste passo da biografia, Plutarco resume Thuc. 8. 89-97.

${ }^{234} \mathrm{Um}$ desses amigos terá sido, de acordo com o biógrafo, o próprio Alcibíades. A reeleição de Péricles é mencionada por Thuc. 2. 65. 4; D. S. 12. 45. 5. A sua data é controversa: Tucídides diz que tal aconteceu pouco depois do afastamento de Péricles - assim, ou foi convocada uma eleição extraordinária algumas semanas após a destituição, ou os Atenienses aguardaram o escrutínio regular, que teria lugar na primavera de 429 a.C. (neste caso, Péricles apenas teria reassumido funções em julho do mesmo ano). Importa frisar que, muito provavelmente, o estratego nunca chegou a pagar a multa determinada (Per. 35.4). 
É caso para dizer que o povo não aprendia com os erros. A entrega da cidade aos líderes que sucederam a Péricles (um homem sério, justo e prudente ${ }^{235}$ ), ainda que mais limitada, mostrou-se ruinosa e também sinal da falta de discernimento dos Atenienses. Mas, se Péricles não tivesse sucumbido à peste, provavelmente teria tido o mesmo destino que Alcibíades que, como já vimos, foi afastado uma segunda vez do cargo de estratego, sem hipótese de regresso, pois foi assassinado pouco depois. Tal insensatez torna-se mais gritante se tivermos em conta que este tipo de procedimento era apanágio do povo ateniense desde tempos imemoriais. $\mathrm{O}$ próprio fundador, Teseu, foi afastado pela população ingrata e descontente. Só veio a ser valorizado quando, confrontada com a sua ausência irreversível e com a propagação da praga dos demagogos, a turba se sentiu órfã e desamparada, sem vislumbrar qualquer solução para o caos em que Atenas, por sua própria responsabilidade, mergulhara ${ }^{236}$. Se os Atenienses tivessem aprendido com a história (ou o mito), a queda do império não teria ocorrido daquela maneira.

Vejamos, em seguida, o lado militar dos dois Alcmeónidas.

\subsubsection{O militar}

Ao abrir este subcapítulo, pareceu-nos importante tecer duas considerações. A primeira prende-se ao facto de, apesar de ambos os Alcmeónidas também se terem evidenciado, no domínio militar, como soldados, apenas nos debruçarmos sobre a sua atuação enquanto estrategos. Tal acontece, porque o biógrafo nada menciona de concreto dessa fase da vida de Péricles, limitando-se a referir que nas expedições militares era um homem corajoso e empreendedor (Per. 7. 2). No que a Alcibíades respeita, embora Plutarco afirme na synkrisis ${ }^{237}$ (Alc. 4.1) que este esteve quase sempre ao serviço de Atenas ou enquanto soldado ou enquanto estratego, o corpo da biografia não dá grande relevo ao desempenho deste Alcmeónida como soldado (informação que apenas é mencionada em Alc. 7. 4 e 7.6, como já vimos nas páginas 195 e 196).

${ }^{235}$ Aristóteles (EN 1140b7) tem uma opinião bastante positiva acerca da prudência de

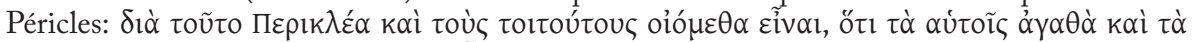

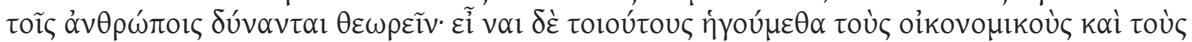

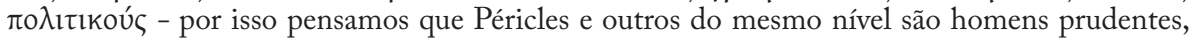
porque são capazes de ver o que é bom para eles e para a sociedade. Consideramo-los hábeis administradores do património e do Estado.

${ }^{236}$ Sobre este assunto, vide supra p. 106-107.

${ }^{237} \mathrm{O}$ mesmo não acontece em Coriolano. Esta diferença reflete carateres distintos: Coriolano tem um perfil mais militar, por causa de uma educação limitada ao treino físico e ao exercício com armas; ao contrário de Alcibíades, que recebeu uma educação mais liberal e beneficiou do convívio com Sócrates. Sobre a educação de Alcibíades, vide subcapítulo «Famíla, principais características e formação dos Alcmeónidas». 
A segunda consideração decorre da necessidade de recordar algo evidente: a atividade militar da Atenas liderada por Péricles e Alcibíades já não se dirige contra o inimigo por excelência dos Helenos, os Bárbaros, sobretudo os Persas. Estes ainda ofereciam algum perigo ocasional, mas nada que pudesse dar grandes preocupações aos Atenienses ${ }^{238}$, a quem, no entanto, ainda era conveniente deixar transparecer a importância da prevenção contra eventuais investidas do inimigo oriental. É que foi a eficiência de Atenas no combate a esse perigo que valeu à cidade a hegemonia sobre os demais Gregos e o enriquecimento dos seus cofres com os tributos que deles recebiam.

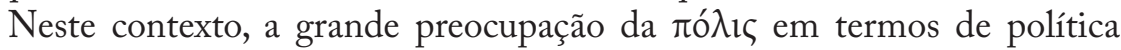
externa e de atividade militar acaba por ser a manutenção de um império unido - porque dele dependia o grosso da riqueza da cidade sob a forma de tributos - e a luta contra Esparta que, incomodada pelo crescente poderio da cidade de Atena, tentava a todo o custo pôr fim à hegemonia que aquela detinha sobre a quase totalidade da Hélade 239 (Per. 21.1,22.1).

Como é óbvio, o esforço necessário para empreender esta missão era muito grande. Péricles teve consciência disso e, enquanto homem prudente e cheio de visão, entendeu que não seria o momento oportuno para «dilatar» o império ${ }^{240}$. Valeu a Atenas - pelo menos temporariamente - o seu pulso forte sobre os concidadãos, pois havia uma fação que ansiava já por esse alargamento. Este

${ }^{238}$ Um exemplo da atividade de Atenas contra os Bárbaros é a expedição do Quersoneso, por volta de 447 a.C. - segundo parece indicar uma inscrição ( $I G \mathrm{I}^{2943)}$-, que libertou a região do flagelo dos piratas - vide Lewis (1992: 95). Em Per. 19. 1, Plutarco considera esta empresa como a mais apreciada pelas massas, provavelmente porque teve como alvo o inimigo comum dos Gregos e não um povo heleno. De facto, o comentário que Elpinice faz a Péricles a propósito das celebrações fúnebres dos que pereceram em Samos sugere a existência de uma fação descontente com aquilo que

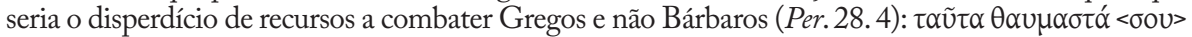

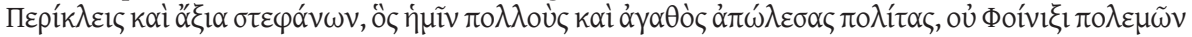

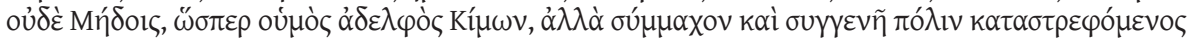
- 'que feitos admiráveis e dignos das coroas os teus, Péricles! Tu que fizeste perecer muitos dos nossos valorosos cidadãos, não a fazer guerra contra os Fenícios e contra os Medos, como o meu irmão Címon, mas a destruir uma cidade aliada e da mesma raça da nossa.'Em Cim.19. 3, Plutarco afirma mesmo que, depois da morte de Címon, nenhum outro general grego fez algo de admirável contra os Bárbaros. Pelo contrário: excitados por demagogos e belicistas, os Gregos voltaram-se uns contra os outros, tornando-se nos principais responsáveis pela ruína da Grécia. Esta expedição teve ainda a vantagem de ter permitido a fundação de uma nova cleruquia em um território que, além de possuir um solo muito fértil, era estratégico porque se situava na passagem da Europa para a Ásia, pelo que o seu domínio permitia controlar a afluência dos cereais vindos do Mar Negro para Atenas. No século VI a.C., foi propriedade da família de Milcíades; no princípio do século V a.C., a região ficou sob o domínio persa até que, por volta de 450 a.C., os Atenienses a integraram na Simaquia de Delos.

${ }^{239}$ Sobre esta rivalidade, veja-se o capítulo «Atenas, o umbigo da Hélade».

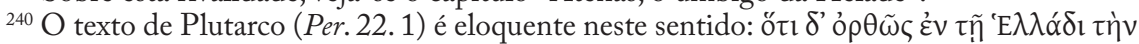

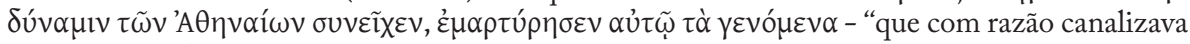
as forças dos Atenienses para a Grécia, os acontecimentos testemunharam-no”. De facto, não demorou muito para que diversas cidades aliadas, das quais Eubeia e Mégara foram as primeiras, dessem mostras de descontentamento e tentassem a secessão. 
sonho não nos surpreende, porque o ateniense é por natureza empreendedor e desde muito cedo definiu a meta de expandir o seu território e a sua cultura. Basta recordar Teseu, fundador do «primeiro império de Atenas», que procedeu ao sinecismo, porque tinha a ambição de formar um povo universal ${ }^{241}$. Como ele, quer Péricles quer Alcibíades pretendiam a glória da sua cidade e a difusão do império. No entanto, ao passo que Péricles se mantém sempre fiel a esse objetivo e revela moderação ao excluir a Sicília e o Egito ${ }^{242}$ dos seus planos, Alcibíades tudo arrisca e tudo perde, porque só se dedica ao sonho enquanto isso não colide com os seus interesses pessoais e com o seu orgulho ${ }^{243}$. É que Péricles, exemplo máximo do poderio militar de Atenas, sabia que a dispersão de objetivos pode ser fatal; que as estratégias devem ser cuidadosamente

${ }^{241}$ Cf. supra pp. 96-97. Embora «fisicamente» este objetivo nunca tenha sido conseguido, o certo é que, em termos culturais, podemos considerar que a sua concretização ultrapassou todas as expectativas. Hoje, um pouco por todo o mundo, de forma mais ou menos direta, existe um sinal da cultura ateniense. Atenas conseguiu, assim, uma universalidade perene que nem Teseu nem os Alcmeónidas jamais terão imaginado.

${ }^{242}$ Em Per. 20. 4, como que em jeito de premonição, o biógrafo refere-se à fixação pela Sicília como sendo uma obsessão desgraçada e infeliz e menciona que havia até defensores para uma incursão à Etrúria e a Cartago. Podemos considerar como um presságio do mesmo teor a interpelação que o misantropo Tímon faz a Alcibíades, felicitando-o por estar destinado a ser um grande mal para todos os Atenienses (Alc. 16. 9; Ant.70.1-2). O interesse de Atenas pela Sicília e pelo Sul de Itália de um modo geral era muito anterior à primeira expedição que empreenderam àquela zona entre 427-424 a.C. (Thuc. 3. 86, 88, 90, 99, 103, 4. 1-2, 25, 48. 6, 65; Plu. Alc. 17. 1). Na verdade, o crescente poderio de Siracusa constituía uma ameaça para o império ateniense, já que esta era aliada da inimiga Corinto. Péricles, porém, não julgava necessária uma intervenção de peso contra esse perigo, nem oportuno alargar o domínio ateniense para Oeste, numa altura em que alguns aliados começavam a manifestar interesse pelo abandono da Simaquia de Delos. Consequentemente, como diz Plutarco, o estadista fez o possível por evitar o avanço das propostas expansionistas e limitou-se a fomentar uma aliança com Régio e Leontinos, de modo a ter um observador atento dos movimentos de Siracusa. Porém, em 427 a.C.,já depois da morte de Péricles, os Atenienses acabaram por se envolver com os problemas da Sicília, visto que os aliados de Atenas combatiam contra Siracusa e estavam a passar por sérias dificuldades. $\mathrm{O}$ apoio seguiu sob a forma de vinte trirremes comandadas por Laques e Caroéades que regressaram em 424 a.C. A segunda expedição à Sicília ocorreu em 415 a.C., mais uma vez para socorrer os aliados. Desta feita, os habitantes de Segesta e uma fação de Leontinos buscaram o auxílio de Atenas para a guerra que travavam com Selinunte, cidade apoiada por Siracusa. Embora houvesse a obrigação de não abandonar um aliado que se encontrava em dificuldades, o certo é que nem todos se mostravam a favor desta expedição que viria a ser o desastre que faltava para o princípio do fim do império ateniense. Nícias representava aqueles que não viam o aparecimento de uma nova frente de batalha com bons olhos: segundo Tucídides (6. 9 sq.), aquele general desconfiava das pretensões expansionistas que estariam por trás do nobre propósito de socorrer quem se encontrava em dificuldades; por isso defendia que não precisavam de mais inimigos (pois já tinham que fazer frente ao inimigo espartano) e que deviam conservar o que já possuíam e deixar de lado ambições desnecessárias. Alcibíades era a favor: defendia acerrimamente o apoio devido aos aliados e menosprezava quer o poder de Siracusa, quer o dos Espartanos; o que o movia era o sonho de, conquistada a Sicília, os Atenienses verem o seu poder reforçado e assim terem meios para subjugar toda a Grécia. Sobre este tema, vide Boardman (1988: 446 sq.), Lewis (1992: 282-311); Kagan (1981: 157 sq.).

${ }^{243}$ Cf. supra p. 183 , passim. 
delineadas: Atenas só podia alargar os seus horizontes para além da Hélade depois de ter a sua posição bem consolidada intra muros. Durante o seu governo, esse sonho, apesar de parecer viável devido à hegemonia de Atenas e ao curso favorável dos acontecimentos, foi «adormecido» (Per. 20. 4 - 21- 1). Mas pouco depois da sua morte, quando o poder da cidade já não era tão forte, Alcibíades, como veremos, haveria de despertá-lo com sérias consequências

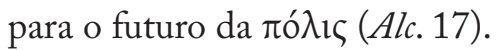

Esta divergência de opções relativamente ao interesse pela Sicília é sintomática das diferentes personalidades destes indivíduos, cuja habilidade no domínio militar é, em grande medida, imputada à genética, já que a família dos Alcmeónidas tinha grande tradição neste campo ${ }^{244}$. De facto, apesar de ambos serem considerados corajosos e empreendedores ${ }^{245}$ (Per. 7. 2; Alc. 38. 3), Péricles era mais prudente (Per. 18. 3, 19.2), avesso a grandes mostras de valentia, mas extremamente eficaz ${ }^{246}$, como no-lo testemunha Plutarco em Per. 18. 1:

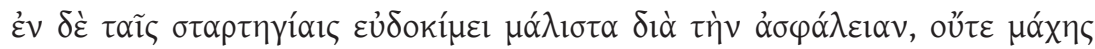

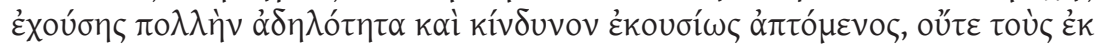

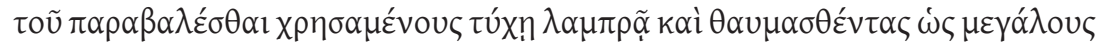

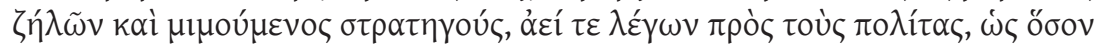

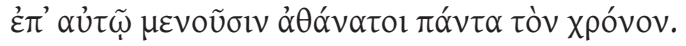

"Nas questões militares tem boa reputação sobretudo pela prudência, pois não se aventurava voluntariamente se a guerra oferecesse um risco muito incerto, nem invejava ou imitava os grandes generais que se expunham ao perigo, dele tiravam grandes sucessos e colhiam muita admiração. Dizia muitas vezes aos cidadãos que, no que dependesse dele, permaneceriam para sempre imortais."

Este excerto deixa claro que, regra geral, o filho de Xantipo só jogava para ganhar, isto é, só enveredava pela guerra se acreditasse que o risco a correr não era excessivo. Mas sugere também uma crítica a todos os generais que, como Alcibíades, são arrojados e incitam a população a correr riscos desnecessários, pensando no renome que alcançarão com a vitória e que lhes permitirá suplantar

${ }^{244}$ Cf. supra p. 161.

${ }^{245}$ Em Per. 38. 3, recordam-se os nove troféus (compostos das armas capturadas e erigidos, normalmente no fim de cada batalha) que erigiu, enquanto general vitorioso, em honra da cidade. Alcibíades também ergueu uns quantos durante o período que antecede o regresso a Atenas na sequência do primeiro exílio. Plutarco menciona-os em Alc.27.6 (vitória de Abido), 29.5 (vitória de Cízico).

${ }^{246}$ E.g. Per. 19. 3: Péricles planeava tudo tão bem que nenhum obstáculo, nem mesmo acidental, surpreendia os soldados; só falhou quando o divino interveio. Sobre a intervenção dos deuses na queda do império, vide infra p. 266, nota 252, p. 181, nota 330, p. 285, nota 354 . 
a fama de outros generais famosos que os antecederam ${ }^{247}$. De facto, Péricles

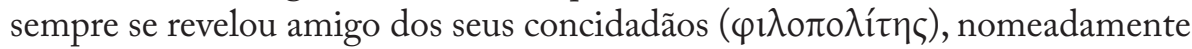
através da preocupação de não arriscar qualquer vida sem necessidade. Um dos momentos em que isso aconteceu teve lugar por ocasião da invasão da Ática por Plistóanax ${ }^{248}$ (Per. 22. 2): então, perante o reconhecido valor do inimigo e a possibilidade de negociar com o corrupto Cleândridas (tutor do jovem rei) a retirada das tropas, o discípulo de Anaxágoras preferiu evitar o combate para poupar a vida dos seus homens em troca de algum dinheiro ${ }^{249}$. Outro ocorreu durante a Guerra de Samos. Depois de duas aparentes vitórias, como os Sâmios reconquistassem o poder, Péricles optou por sitiar a cidade. Deste modo, além de aumentar a probabilidade de vitória, e apesar de investir mais tempo e dinheiro, não punha os seus soldados em risco desnecessário (Per. 27. $1{ }^{250}$. Este era um dos princípios que norteavam a conduta de Péricles enquanto

${ }^{247}$ Como já vimos, Alcibíades tinha como grande objetivo suplantar Péricles (Alc. 6. 4-5). Temístocles nem dormia com o desejo de igualar os feitos de Milcíades (Them. 3. 4). O próprio Teseu pautou a sua conduta pela ideia de emular os feitos de Hércules (Thes. 6. 9). Trata-se, portanto, de uma tendência aparentemente hereditária nos Atenienses, que Péricles parece não partilhar devido à prudência que o caracteriza. Mas, na verdade, esta é uma marca comum em grandes generais: recordemos, por exemplo, Alexandre que, ao pretender um Homero que cantasse os seus feitos, procurava ultrapassar a glória de Aquiles. Cf. Cic. Arch. 24, Leão de Nápoles, Historia de preliis Alexandri Magni, 42; L. de Camões, Os Lusíadas, 10. 156. Sobre este assunto, vide p. 56 , nota 25.

${ }^{248}$ Este episódio já foi tratado atrás na p. 251, nota 189.

${ }^{249}$ Fica, mais uma vez, comprovada a perspicácia de Péricles, que previu - e muito bem - a retirada do inimigo.

${ }^{250}$ Exemplo disto é a expedição de Tólmides, que lhe valeu o reconhecimento da estima que tinha pelos concidadãos (vide supra p. 228). A opção por sitiar uma cidade exige, como é óbvio, tempo e paciência, dois requisitos que não se coadunam com a personalidade do povo em causa. Sobre esta característica dos Atenienses, vide supra p. 120 sqq. Esta é, decerto, uma das principais razões que contribuiu para que Péricles alcançasse o poder que alcançou e sobressaísse de entre os seus concidadãos. Ao contrário destes, Péricles sabia esperar com paciência pelo momento oportuno e resistir ao ímpeto de reagir a quente. Por isso fez a diferença. Se a sua morte não tivesse deixado os Atenienses órfãos, muito provavelmente Atenas não teria perdido a guerra. Foram as decisões e reações repentinas de Alcibíades e do povo que precipitaram a destruição do império ateniense. Ora, a estratégia que engendrou para distrair os soldados que participaram no cerco de Samos (que, cada vez mais impacientes, queriam combater à viva força) mostra bem a sua perspicácia e capacidade de levar o povo a fazer o que a longo prazo será mais benéfico. Além disso, tal atitude ilustra o princípio defendido por Plutarco em Moralia 818F-819A: quando há projetos prejudiciais, o governante tudo deve fazer para evitar que estes ponham a sua estratégia em risco. Foi nesse sentido que Péricles organizou um sorteio, no qual o exército participaria dividido em oito partes. Aquela a quem calhasse a fava branca (o método de sorteio mais frequente em Atenas consistia em retirar de um recipiente a fava branca que estava misturada com pretas) tinha direito ao descanso e a um festim; as demais tinham de se empenhar o melhor possível na sua missão. Foi esta a razão do aparecimento da expressão «dia branco» com que os Atenienses designavam os dias festivos. Péricles surge, assim, também ele, como responsável pelo aparecimento de costumes ou ditos que caracterizaram a cultura de Atenas, à semelhança do que aconteceu com o fundador, Teseu (supra p. 99-105). O mesmo pode dizer-se de Alcibíades, cujo nome passou a designar jardins luxuosos (Alc. 24. 7) e as sandálias. 
estratego, que ele próprio considerava o seu feito mais belo e importante ${ }^{251}$. Quando, já sem esperança de cura, agonizava no leito, o filho de Xantipo interveio na conversa das visitas que elogiavam a sua superioridade ${ }^{252}$ e poder, para chamar a atenção exatamente para isso:

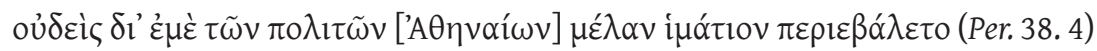

"nenhum Ateniense se vestiu de luto por culpa minha."

Seria injusto negar a Alcibíades, que, à primeira vista, deixa passar uma imagem de desvario e pouca prudência, algum reconhecimento pela sua cautela, perspicácia e até preocupação com o povo. É facto que as primeiras características são sobretudo postas em prática quando se trata da sua segurança e vida: basta recordar como, por diversas vezes, soube antecipar as decisões do inimigo, que pretendia matá-lo, e fugir atempadamente. Primeiro, escapou aos Atenienses (por altura da sua condenação a propósito da mutilação dos Hermes) e pediu asilo aos Espartanos ${ }^{253}$ (Alc. 22); mais tarde, fugiu destes, quando também eles se preparavam para matá-lo, refugiando-se junto de Tissafernes (Alc. 24); por fim, evadiu-se da prisão em que este o encarcerara (Alc. 27), e regressou à cidade nata ${ }^{254}$.

Além da capacidade manifestada para antever os ataques e escapar-lhes com vida, o Alcmeónida conseguiu sempre, por prudência, qual camaleão, moldar a sua maneira de ser aos costumes dos locais onde pedia abrigo, medida avisada para quem era conhecido por um comportamento desconcertante $(\text { Alc. 23. 3-5 })^{255}$. Por isso, podemos afirmar que, à cautela e por amor à própria existência, pôs em prática o ditado «Em Roma, sê romano»: em Esparta, foi

${ }^{251}$ Esta opinião é partilhada por Plutarco (Moralia 781), que defende que o bom governante deve temer prejudicar os seus súbditos. Neste contexto, o biógrafo esboça a distinção entre reis e tiranos, afirmando que os primeiros têm medo pelos súbditos, enquanto os segundos têm medo dos súbditos.

${ }^{252}$ Neste contexto, Péricles atribui todas as suas glórias enquanto general à Fortuna (Per. 38 . 4). Este comportamento decorre certamente da ideia que Plutarco defende em Moralia 815D: os homens atribuem a sua glória à sorte e não ao seu mérito pessoal para evitar que o $\varphi \boxminus$ óvo $\theta \varepsilon \tilde{\omega} v$ lhes tolha os passos. Quer na Vida de Péricles, quer na de Alcibíades, quer na de Nícias, o desastre que provocou a ruína de Atenas é associado à intervenção divina. Sobre este assunto, vide p. 281, nota $330 ;$ p. 285 , nota 354 .

${ }^{253}$ Infra p. 286.

${ }^{254}$ Antes de ser obrigado a escapar de Tissafernes, temeu que a estratégia proposta ao Persa viesse a pôr a sua vida em risco, caso os Lacedemónios saíssem vitoriosos da Guerra do Peloponeso. Por isso, tornou-se aliado de Samos, em um claro movimento de antecipação. Sobre este assunto, infra p. 288 sqq.

${ }^{255}$ Cf. Moralia 52E. Em Alc. 24. 5, Plutarco afirma mesmo que estes o admiravam

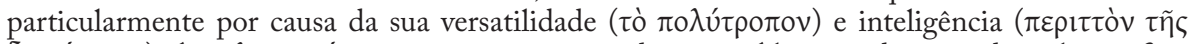

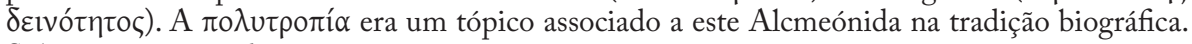
Sobre este tema, vide supra p. 168 , nota 38. 
literalmente espartano ${ }^{256}$; entre os Persas, comportou-se como tal, chegando mesmo a ultrapassar o fausto e a magnificência daqueles (Alc. 23. 5). Quem quer que o tivesse conhecido nos seus dias áureos em Atenas, não diria tratar-se do mesmo indivíduo. Em Alc. 23. 6, Plutarco procura salientar a facilidade que Alcibíades tinha para agir em conformidade com as expectativas sem, contudo, alterar o seu verdadeiro modo de ser. Tratava-se, pois, de uma manobra que apenas produzia efeitos exteriores. Nesse contexto, o biógrafo afirma:

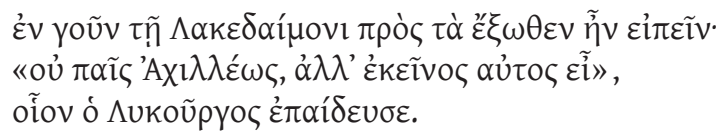

"em todo o caso, na Lacedemónia, se o julgassem pelo exterior, poder-se-ia dizer: «tu não és o seu filho, mas o próprio Aquiles», um homem como os que Licurgo formou."

A referência a este verso - que subentende, como é óbvio, todo o contexto da peça a que pertence - contém ilações que associam indubitavelmente Alcibíades a Aquiles ${ }^{257}$, já que o recurso a disfarces ilustra não só a capacidade de mudança e adaptação, mas também a constante transgressão da fronteira entre o que é próprio do sexo masculino e o que o é do feminino ${ }^{258}$, explorada por Plutarco ao longo desta biografia. Demais, outro verso de tragédia (desta feita de E. Or.129), igualmente evocado em Alc.23. 6, vem reforçar esta faceta de Alcibíades e o facto de as transformações que aparenta apenas serem exteriores:

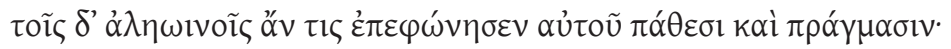

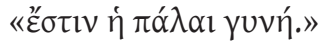

"Mas, se se observassem os seus verdadeiros sentimentos e ações, poder-se-ia dizer:

«É a mulher de outrora!»"

${ }^{256}$ Segundo Alc. 23. 3, passou, por exemplo, a barbear-se e a tomar banho em água fria, a comer pão espartano e a tomar caldo negro, ele que já tivera um cozinheiro particular e que usara bons perfumes e roupas feitas de tecido de Mileto. Em Alc. 23. 5, Plutarco refere

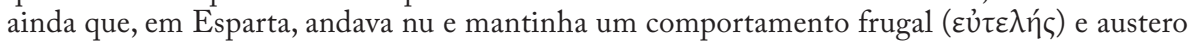

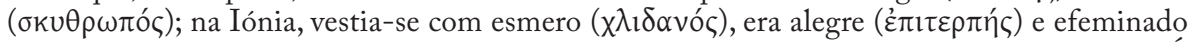

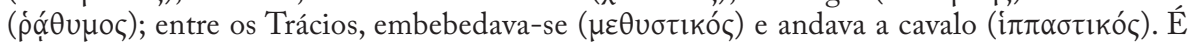
provável que Plutarco tenha tido como fontes para esta informação Sátiro (FHG III 1 60), Nep. Alc. 3-5, Ael. VH 4. 14.

${ }^{257}$ Alcibíades terá sido comparado a Aquiles por vários autores, nomeadamente Antístenes - fr. V A 199 Giannantoni.

${ }^{258}$ A propósito deste tema (já aflorado na página 170), consultem-se Gleason (1990: 389416, especialmente 404-405); Loraux (1990) e Duff (1999: 237). 
No seu contexto original, este verso é proferido por Eletra, que acusa Helena de fingir dor pela morte da irmã Clitemnestra e de preservar intacto o esnobismo de sempre. Adapta-se, portanto, ao tema «habilidade de Alcibíades para mudar (aparentemente) o seu comportamento», mas não o caráter, e reforça a feminilidade associada ao Alcmeónida ${ }^{259}$. Com efeito, ao longo da biografia, são atribuídos ao herói traços e comportamentos que sugerem (e ilustram) o modo como desrespeita as fronteiras entre os sexos. A vida licenciosa que leva (ilustrada pelas anedotas sobre a sedução de Timaia) costuma ser apontada como característica própria de mulheres e sugere, mais uma vez, uma natureza tirânica (pois os excessos sexuais, além de associados à natureza feminina, estavam também ligados à do tirano ${ }^{260}$ ).

Assim, embora aparente agir com a rigidez e correção de um Espartano, quando se vê obrigado a abandonar a Lacedemónia, deixa a prova viva de que continuava o mesmo libertino de sempre, já que a mulher do rei por quem foi acolhido fica grávida de um filho seu ${ }^{261}$. Demais, quando deixa de poder confiar a sua segurança aos Espartanos, vai pedir asilo ao persa Tissafernes, em cuja corte depressa ganha proeminência. Nessa altura, volta a revelar um caráter vingativo, pois denigre a imagem do primeiro anfitrião junto do segundo (Alc. 25).

Mas Alcibíades, que pelas suas reações intempestivas e sede de vitória parecia disposto a arriscar tudo, também se preocupou com a segurança dos seus concidadãos e de Atenas. Em Alc. 26. $5^{262}$, o biógrafo dá-nos a dimensão do desastre evitado pelo Alcmeónida quando os Sâmios o nomearam estratego para restabelecer a democracia em Atenas ${ }^{263}$. Ao opor-se a que os soldados partissem de rompante, impediu um confronto entre Atenienses e que a guerra chegasse à cidade; ao mesmo tempo que salvaguardou o império, não deu azo a que os inimigos controlassem a Iónia, o Helesponto ou as ilhas. Plutarco chama a atenção para a forma, quase paternalista, como persuadiu a multidão e cada homem em particular, revelando grande preocupação com o destino dos

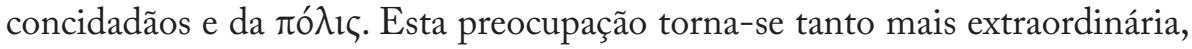
vinda de um Alcibíades, se tivermos em conta que tinha acabado de ser eleito

259 Plutarco alude a essa natureza feminina ( $\theta \eta \lambda u ́ \tau \eta \varsigma)$ de Alcibíades em Alc. 1. 4-8 (a propósito da sua beleza), 2.3 (ao afirmar que morde como uma mulher), 3-6 (onde podemos ler anedotas sobre os seus amantes), mas sobretudo em 16.1 (por causa das roupas de púrpura). Este traço da personalidade de Alcibíades contrasta fortemente com a $\alpha \nu \delta \rho \varepsilon i ́ \alpha$ do seu par, Coriolano.

${ }^{260}$ Cf. Antístenes - fr. V A 141 Giannantonini, passo onde se faz a aproximação entre o comportamento sexual de Alcibíades e o seu desejo de se tornar um tirano. Sobre este assunto, consulte-se, por exemplo, Duff (1999: 236-237). O perfil tirânico de Alcibíades encontra-se tratado entre as páginas 215-217.

${ }^{261}$ Sobre esta relação que Alcibíades manteve com Timaia, vide supra p. 246.

${ }^{262}$ Este passo baseia-se em Thuc. 8. 86. 4.

${ }^{263}$ Vide infra p. 288 sqq. 
estratego e deveria estar ansioso por fazer jus à sua fama de excelente general... Algo semelhante terá acontecido a propósito da revolta dos Calcedónios ${ }^{264}$ (Alc. 29. 6): nessa altura, sabendo que já não havia bens a saque intra muros, Alcibíades não ataca de imediato a cidade. É que a investida seria um desperdício inútil de energia, meios e... homens. Do mesmo modo, através da estratégia que delineia para tomar Bizâncio (Alc.31.3-7), sugere a intenção de proteger os seus soldados: simula uma deslocação à Iónia para reprimir outra revolta, mas regressa à noite, como combinara com alguns conjurados, de entre os quais Anaxilau ${ }^{265}$. Apesar deste estratagema digno de um Ulisses, não consegue evitar o combate quando os Peloponésios, Beócios e Megarenses, que tentavam impedir o desembarque dos Atenienses, se apercebem de que um bom número de inimigos já se encontrava em terra ${ }^{266}$. Mas, o exemplo mais desinteressado da sua perspicácia e preocupação com o povo consiste no facto de ter tentado prevenir os estrategos no poder para o perigo em que incorriam se mantivessem a mesma estratégia, que se viria a revelar fatal na batalha de Egospótamo (Alc. 36. 6, 37. 4).

A Péricles, tal prudência e perspicácia valeram-lhe grandes elogios, mas também algumas acusações menos simpáticas de cobardia. Foi esse o caso com a expedição de Tólmides contra a Beócia ${ }^{267}$, com a expedição à Sicília ${ }^{268}$, com as incursões contra o Egito ${ }^{269} \mathrm{e}$ as zonas costeiras da Pérsia, que impediu

${ }^{264}$ Cf. X. $H G 1.3$.

${ }^{265}$ A razão que levou Anaxilau a entregar-lhe Bizâncio é apresentada por Plutarco como um ato de nobreza e não de traição à pátria, em Alc. 31. 8: assegurar a proteção da cidade e dos concidadãos, evitando uma guerra que não era sua. Cf. X. $H G$ 1.3.19. Vide supra p. 218, nota 38 .

${ }^{266} \mathrm{Em}$ relação a este conflito concreto, Plutarco parece seguir uma fonte distinta das que por norma segue quando aborda esta fase do exílio de Alcibíades. De facto, fornece muita informação complementar à mencionada por X. $H G$ 1. 3. 14-22; D. S. 13. 66.5 - 67.7: dá o nome dos traidores, refere a presença de Beócios e Megarenses. Sobre este assunto, vide Pérez Jiménez (2006: 180, n. 147).

${ }^{267}$ Vide supra p. 184 , nota 101.

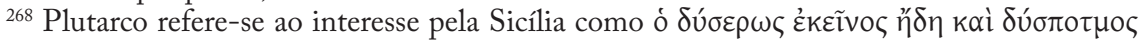
है $\rho \omega \varsigma$ «uma obsessão infeliz e desgraçada» (Per. 20.4), sem adiantar pormenores para além do facto de ter sido inflamada por Alcibíades. Esta forma abreviada e discreta como aborda o assunto na Vida de Péricles é eloquente: deixa em nós, que comparamos a atuação dos dois Alcmeónidas, a noção clara da diferença entre um e outro enquanto estrategos.

${ }^{269}$ A primeira campanha terá sido organizada em 460-459 a.C. para ajudar Ínaro, rei da Líbia, que pretendia criar no Egito um reino independente do persa. Depois de conquistar Mareia (região próxima da futura Alexandria), sentiu dificuldades em controlar o resto do território e, consequentemente, pediu ajuda aos Atenienses. Os aliados, escolhidos sobretudo pelo seu poderio naval, não hesitaram, já que era uma ótima oportunidade de mostrar à Pérsia que era preferível ter Atenas do seu lado do que como inimiga. Na sequência do pedido de Ínaro, partiu em direção ao Egito parte do contingente da Simaquia de Delos que então se encontrava em Chipre. Nos primeiros tempos, os Atenienses conseguiram corresponder ao objetivo (Thuc. 1. 104). Mas ao fim de seis anos, foram derrotados por Megabizo e perderam duzentos navios junto à ilha de Prosopítis (Thuc. 1. 109-110). Porém, no verão de 450 a.C., Címon, que ia a 
(Per. 20. 3), e até o da estratégia adotada por altura do eclodir da Guerra do Peloponeso ${ }^{270}$. Mas, na verdade, foram mais numerosos os momentos que the proporcionaram o reconhecimento popular. Disso são exemplo a circum-navegação do Peloponeso ${ }^{271}$ (Per.19.2-3), a expedição ao Ponto (Per. 20. 1) ou a Guerra de Samos (Per. 25-28), na sequência das quais Péricles passou a ser visto pelo inimigo como uma ameaça terrível. Note-se, contudo, que o filho de Xantipo sempre se esforçou por agir com humanidade em relação aos inimigos. Em Per. 23. 4, essa ideia fica clara: apenas os habitantes de Hestieia foram alvo de tratamento inflexível, pois tinham feito refém uma nau ática e matado toda a tripulação ${ }^{272}$. O facto de só esses serem maltratados mostra que Péricles tinha um forte sentido de justiça e grande moderação não se deixou tomar pela dor e pela ira de ver os concidadãos mortos para, como vingança, massacrar o maior número possível de inimigos ${ }^{273}$. Quanto a Alcibíades, ao qual estamos habituados a associar um caráter excessivo, também ele se revelou, no contexto das campanhas militares, um general moderado e de bom coração: tratou bem os prisioneiros lacedemónios (Alc. 14. 1-2); deixou partir em liberdade, sem cobrar qualquer resgate, os sacerdotes e sacerdotisas que fizera reféns aquando da investida contra a terra de Farnábazo ${ }^{274}$ (Alc. 29. 6); não permitiu que os Trácios que integravam o seu exército pilhassem Selímbria, nem fez mal aos seus habitantes, aos quais apenas exigiu dinheiro e impôs uma guarnição (Alc. 30.10); optou por fazer prisioneiros os adversários que sobreviveram em Bizâncio, em vez de matá-los ou exilá-los (Alc. 31.6).

Esta humanidade e civismo que caracterizam a atuação dos dois Alcmeónidas enquanto estrategos é um traço que têm em comum com Teseu,

caminho de Chipre, dispensou sessenta navios da sua frota a Amirteu, um príncipe egípcio, que ainda mantinha o braço de ferro com os Persas (Thuc. 1.112.3-4; Plu. Cim. 18.5-6). Vide Lewis (1992: 77-78, 83-87).

${ }^{270}$ Vide infra pp. $280-281$

${ }^{271}$ Esta expedição, que apenas é mencionada por Plutarco, terá ocorrido entre a Guerra de Samos e a do Peloponeso e, segundo Stadter (1989: 217), é natural que tenha sido uma tentativa de demonstração de poder da parte de Péricles aquando da ascensão de uma nova dinastia no Bósforo (cf. D. S. 12. 31. 1). Este episódio revela-se, assim, um bom exemplo de perspicácia e previsão político-militar de Péricles, que, com um único gesto, alcança dois objetivos distintos: intimidar os Bárbaros, que, perante tamanho poderio, pensarão duas vezes antes de atacar, e satisfazer os aliados, mostrando-lhes que os Atenienses cumprem a missão pela qual recebem o tributo.

${ }^{272}$ Esta explicação é exclusiva de Plutarco.

${ }^{273}$ Este exemplo funciona como excelente argumento contra a acusação de crueldade no tratamento dos reféns de Samos feita por Dúris de Samos, em Per. 28. 2, e que logo aí Plutarco nega, citando o silêncio de Éforo, Tucídides e Aristóteles em relação a esse acontecimento.

${ }^{274}$ Sobre Farnábazo, vide infra p. 292, nota 405. Este comportamento torna-se ainda mais curioso por vir de alguém que, regra geral, não tinha qualquer problema em faltar ao respeito à divindade, como no-lo testemunha a sua imitação dos Mistérios de Elêusis (Alc. 19-20, Moralia 621C; Isoc. 16. 5-7). 
que também procurou ser justo com os inimigos com que se defrontou ao longo da sua vida ${ }^{275}$.

Destas expedições que Péricles comandou, a Guerra de Samos ${ }^{276}$ foi aquela que o biógrafo tratou com mais pormenor antes de abordar a Guerra do Peloponeso. Esta sua opção pode justificar-se por dois motivos. Um é o o próprio orgulho que Péricles sentia na vitória alcançada sobre os Sâmios; o outro é a razão pela qual Péricles terá envolvido Atenas em uma guerra que não era sua.

Comecemos pelo segundo. A guerra em causa, não fosse pela diferença de desfecho, serviria perfeitamente de prenúncio do que viria a ser, para Atenas, a Guerra do Peloponeso. De facto, em ambos os casos, os detratores de Péricles acusaram-no de enveredar pela solução militar para satisfazer os caprichos de Aspásia. No que concerne à primeira guerra, a prostituta ${ }^{277}$ teria sido movida pela rivalidade que opunha a sua cidade natal, Mileto, a Samos; no que concerne à segunda, a razão teria sido o «roubo» de algumas das suas «funcionárias» ${ }^{278}$. Ora, a possibilidade desta motivação leva-nos ao seguinte raciocínio: pelo menos duas das invasões de que a Ática foi objeto por parte da Lacedemónia estão relacionadas com o «fator mulher»: a mais antiga de todas foi consequência do rapto de Helena por Teseu ${ }^{279}$; a que sobrevém no contexto da Guerra do Peloponeso decorre da influência que Aspásia exercia sobre Péricles. Assim sendo, fica a sugestão de que a vida pessoal de um político, por melhor que ele seja, pode pôr em risco o bem-estar da cidade. ${ }^{280}$

${ }^{275}$ Vide supra p. 64.

${ }^{276}$ A Guerra de Samos ocorreu entre 441-439 a.C., cinco anos após a celebração do tratado de paz por trinta anos entre Atenas e Esparta (Thuc. 1. 115. 2). Samos fazia parte da Simaquia, mas tinha uma frota própria e tinha entrado em guerra com Mileto pela posse de Priene, uma pequena cidade iónia na foz do Meandro, próxima de Mileto (a Norte) e de Mícale, que controlava o santuário comum de Paniónion. A guerra pode ter sido motivada pela mudança da festa de Priene para Éfeso - cf. Hornblower (1982: 241-245). A razão «oficial» para o apoio a Mileto contra Samos foi a desobediência destes últimos à proposta dos Atenienses de mediar a resolução do conflito, provavelmente sob o argumento de que os membros da Simaquia de Delos deveriam respeitar os aliados uns dos outros. Sobre este assunto, vide Lewis (1992: 169-171).

${ }^{277}$ Em Per. 24. 5, Plutarco aceita como histórico o facto de Aspásia ser uma alcoviteira. A explicação que atribuía a Péricles e a Aspásia a responsabilidade da Guerra do Peloponeso surge,

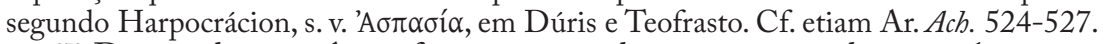

${ }^{278}$ De acordo com Aristófanes, a causa da guerra terá sido tão nobre como o é a

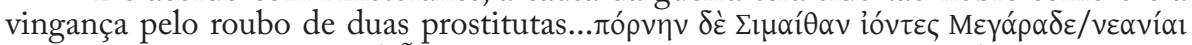

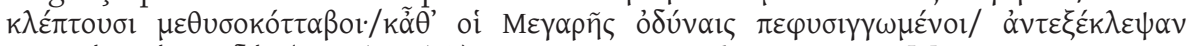

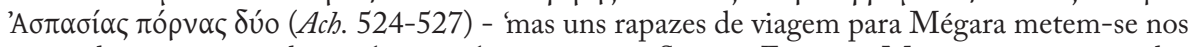
copos durante o jogo do cótabo e roubam a cortesã Simeta. Então os Megarenses, espicaçados pelo desgosto, roubam a Aspásia, como represália, duas cortesãs.' A tradução apresentada é de Silva (2006).

${ }^{279}$ Vide supra pp. 80 e 96.

${ }^{280} \mathrm{O}$ facto de os Atenienses terem esta perceção está na base da fúria que dirigem contra Alcibíades quando este deixa a frota sob o comando de Antíoco: a fama da vida desregrada do 
No entanto, de acordo com o perfil que Plutarco traça do estadista, não nos parece coerente aceitar a versão que faz da opção pela guerra um gesto de cedência à mulher amada. É que a ideia de que Péricles não costumava arriscar em vão a vida dos seus homens assume uma dimensão muito importante na caracterização deste político. Assim, é caso para acreditar que Péricles até poderá ter cedido à influência de Aspásia, mas não para satisfazer um mero capricho feminino. Não nos podemos olvidar de que esta «prostituta de Mileto», como os comediógrafos a designam, era uma mulher muito avançada para a época: dominava questões do foro da retórica e da política em vez de receitas de culinária ${ }^{281}$. Por isso, é muito possível que ela, além de amante, fosse conselheira do filho de Xantipo em diversos assuntos. E os planos conjuntos de ambos tinham tudo para dar bons frutos, não fosse a «intervenção divina... ${ }^{282}$, cuja vontade se opôs à humana - Per. 34. 4.

Em relação à Guerra do Peloponeso, houve também quem dissesse que tinha como objetivo distrair a população, que, no período que antecedeu o deflagrar do conflito, estava determinada em perseguir o filho de Xantipo ${ }^{283}$. Aristófanes ${ }^{284}$, bem como alguns historiadores ${ }^{285}$, explica a obstinação de Péricles na não revogação do decreto de Mégara como meio de desviar a atenção dos processos que corriam contra os seus amigos e que eram causa do decréscimo da sua popularidade. Para isso, nada melhor do que provocar uma guerra $^{286} \ldots$ Ainda que este fator possa ter tido algum peso na decisão tomada por Péricles, parece-nos que os verdadeiros motivos terão sido o ódio figadal que o estadista nutria pelos Espartanos e sobretudo a perceção de que Atenas deveria afirmar o seu poder diante dos aliados e de Esparta, para que esses deixassem de sonhar com uma aliança que pusesse fim ao crescente poderio de Atenas.

Debrucemo-nos agora sobre o segundo motivo que terá levado Plutarco a alongar-se sobre a Guerra de Samos: o orgulho que o Alcmeónida sentiu com essa vitória. A Guerra de Samos, tal como viria a acontecer com a do Peloponeso, prolongou-se por um período superior ao previsto pelo estadista. A

Alcmeónida permitiu-lhes aceitar de imediato a hipótese veiculada pelos detratores daquele, segundo os quais a sua ausência se devera à satisfação de necessidades pessoais (Alc. 35). Sobre este episódio e as razões que o motivaram, vide supra p. 255.

${ }^{281}$ Sobre Aspásia, vide supra p. 240, nota 148, passim. Cf. Blomqvist (1997: 73-97).

${ }^{282}$ Cf. p. 281 , nota 330.

${ }^{283}$ Sobre este assunto, vide supra 237 sqq.

${ }^{284}$ Ach. 515-539, Pax 601-611.

${ }^{285}$ D. S. 12. 39. 3-4; Aristodem. FGrHist 104. 16; Ephor. FGrHist 70 F 196.

${ }^{286}$ Este tipo de comportamento costuma ser associado aos políticos de todos os tempos. Recordemos, por exemplo, a Guerra do Kosovo, na década de noventa do século XX, cuja responsabilidade muitos atribuíram à necessidade que Bill Clinton terá sentido de fazer cair no esquecimento o escândalo provocado pelo seu relacionamento extraconjugal com Monica Lewinsky. 
de Samos pareceu, de início, ganha em um curto espaço de tempo. No entanto, mal Péricles partiu, julgando que já podia voltar para casa e dedicar-se a outras situações pendentes, a resistência aboliu a recém-instaurada democracia ${ }^{287}$, repôs o regime oligárquico, pelo que o estratego se viu obrigado a regressar. Consequentemente, podemos considerar que a forma como esta guerra se desenvolveu foi importante para provar que a obstinação de Péricles por limitar os objetivos expansionistas da população era fundamentada. É que, apesar de ter evitado dispersar os recursos bélicos com expedições além-fronteiras, houve ocasiões em que, como nesta, se viu obrigado a circular entre cenários de guerra ${ }^{288}$ : nomeadamente quando, confiando o cerco aos concidadãos que vieram de Atenas para reforçar a frota ${ }^{289}$, se afastou das muralhas para ir ao encontro dos navios fenícios ${ }^{290}$ que vinham em auxílio dos Sâmios ${ }^{291}$.

O relato que Plutarco faz da Guerra de Samos demarca-se dos que foram feitos a propósito de outras incursões comandadas por Péricles. Dos anteriores, sobressaem a invencibilidade e a eficácia ultrarrápida do estratego ${ }^{292}$, que ainda

${ }^{287}$ Enquanto Péricles empreende um grande esforço para criar um regime democrático em Samos (Per.25.2), Alcibíades tudo faz para repor a oligarquia, o que acaba por ter consequências nefastas para Atenas (Alc. 25-26). Sobre este assunto, infra p. 288-289. Apesar desta discrepância no que diz respeito a Samos, Alcibíades, quando assumiu pela primeira vez o cargo de estratego, ajudou a população de Argos a repor a democracia na sequência do golpe de estado dos oligarcas (Alc. 15.3-4).

${ }^{288}$ Outro exemplo desta situação ocorreu quando defrontava os Eubeus (Per. 22.1-2). Nessa altura, além de se ver a braços com os Megarenses que começavam a dar problemas, foi obrigado a acorrer em socorro da Ática, invadida pelos Lacedemónios comandados por Plistóanax (cf. supra p. 251, nota 189$)$.

${ }^{289}$ Constituída por quarenta navios vindos de Atenas e vinte e cinco de Lesbos e Quios, o que perfazia o total de cento e vinte e cinco embarcações (cf. Thuc. 1.116.2).

${ }^{290}$ Cf. Thuc. 1.116. 3; D. S. 12.27. 5. Os Atenienses, por causa de Pissutnes, temiam que a Pérsia tentasse aproveitar-se da revolta de Samos para fragilizar o controlo que tinham do mar Egeu, muito embora a Paz de Cálias estivesse em vigor. Esta não foi a única vez em que as tropas fenícias constituíram ameaça para Atenas. Também Alcibíades - ainda que indiretamente - se

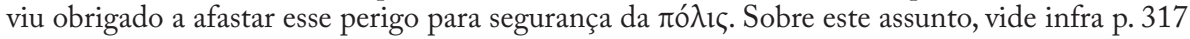
sq.

${ }^{291}$ Plutarco, a partir do testemunho de Estesímbroto (FGrHist $107 \mathrm{~F}$ 8), apresenta um outro motivo para esta deslocação: o interesse por Chipre. A nós, como já antes a Plutarco, tal propósito afigura-se pouco verosímil por causa da opção pela contenção do alargamento do império acima exposta. Independentemente do motivo, Plutarco considera que Péricles cometeu um erro, porque deu azo a que os Sâmios se tornassem senhores do mar (durante catorze dias, segundo Thuc. 1.117.2), destruíssem barcos dos Atenienses e se abastecessem para a guerra. Se compararmos o comportamento de Péricles com o de Alcibíades, verificamos que ambos foram infelizes sempre que, cheios de boas intenções, confiaram o comando da frota a terceiros. Sobre Alcibíades e a delegação de poderes em Antíoco, vide supra p. 255, nota 204 e infra p. 295 e 300.

${ }^{292}$ Parece-nos que tal celeridade resulta sobretudo da descrição abreviada de cada uma das expedições anteriores a Samos. Consequentemente, a sugestão do prolongamento temporal desta guerra decorre do facto de Plutarco se estender mais sobre o assunto. Neste caso, o nosso ponto de comparação é Tucídides (1.115. 2 - 1.117. 3), que, como não poderia deixar de ser, enquanto historiador, se alonga mais sobre os pormenores que dizem respeito ao conflito. Ao Queroneu, interessava-lhe apenas mencioná-los na medida em que revelam traços de caráter do 
é sugerida em Per. 25.1-3. No entanto, no contexto da Guerra de Samos, a situação inverte-se e a vitória revela-se demorada e difícil de alcançar. Logo em Per. 25. 4, o biógrafo dá-nos conta de uma inesperada mudança, recorrendo

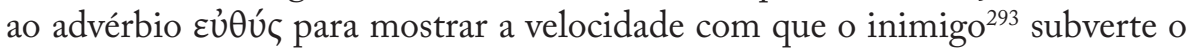
curso natural dos acontecimentos, ou seja, a rápida vitória do filho de Xantipo. Os Sâmios, contudo, não conservam o título de vencedores por muito tempo, porque Péricles mostra-se à altura do comando de Atenas e depressa volta

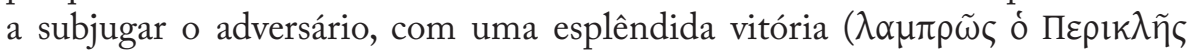

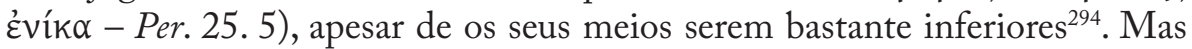
também este sucesso dura pouco tempo: em Per. 26. 2, desta feita por causa da intervenção de um ousado estratego, Melisso 295 (que, pasme-se!, já antes teria derrotado o experiente Péricles $\left.{ }^{296}\right)$, Atenas surge novamente em situação delicada. Péricles vem, de novo, em seu socorro e não volta a abandonar o comando das tropas no local até ao derradeiro momento da vitória.

Da descrição que acabámos de fazer desta guerra, impõem-se algumas ilações. Péricles, por mais que consiga antever os passos dos inimigos, é humano, logo existe alguma possibilidade de que nem sempre saia vitorioso. Foi assim em Samos; será assim contra os Lacedemónios... Não surpreende, por isso, que o estratego, consciente das suas humanas limitações e do grande perigo que o império ateniense correu ${ }^{297}$, revele um orgulho ${ }^{298}$ digno de Alcibíades. O filho de Xantipo chega a ter a ousadia de considerar este feito superior à vitória de Agamémnon sobre os Troianos: é que ele combatera contra os Sâmios, o mais importante dos povos Iónios, e não contra uns bárbaros quaisquer. E,

estadista: a capacidade de comando e previsão, o facto de não desanimar diante dos obstáculos ou o empenho com que protege e anima os concidadãos.

${ }^{293}$ Importa chamar a atenção para a caracterização que Plutarco faz dos adversários de Atenas, e da opinião que estes tinham dos Atenienses que ficaram a cercar Samos quando Péricles se ausentou para intercetar os navios dos Fenícios. Em Per. 25. 4, o biógrafo apresenta os Sâmios como homens ativos, sem medo e decididos a vencer, que julgavam estar cercados por um pequeno número de embarcações sob o comando de estrategos inexperientes (Per.26.2). Tal descrição acaba por se transformar no elogio indireto dos Atenienses que conseguiram, não sem grande esforço e mérito, vencê-los.

${ }^{294}$ Per. 25. 5. Nesta fase do conflito, Atenas dispunha de quarenta e quatro barcos, contra os setenta dos Sâmios.

${ }^{295}$ Pouco se sabe acerca da vida de Melisso, filho de Itágenes e um dos últimos representantes da escola eleática, além do facto de ter sido estadista de Samos e de ter derrotado Péricles no combate naval de 441 a.C. Este filósofo seguia as ideias de Parménides, embora não se possa

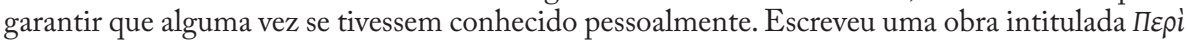
$\Phi v ́ \sigma \varepsilon \omega \varsigma$ - vide Guthrie (1969: II, 101 sq.).

${ }^{296}$ Segundo Plutarco (Per. 26. 3), esta informação tem Aristóteles (fr. 577 Rose) como fonte. É provável que o fragmento seja oriundo da Constituição de Samos ou de fontes sâmias que consideravam a batalha de Trágia vitória sua, já que os Sâmios tinham sido capazes de regressar de Mileto em segurança.

${ }^{297}$ Sobre os perigos em causa, cf. Thuc. 8. 76. 4.

${ }^{298}$ Plutarco atribui esta informação a Íon (FGrHist 392 F 16). 
apesar de ter lutado contra um inimigo mais difícil, não precisou de dez anos para alcançar a vitória; bastaram-lhe uns escassos nove meses ${ }^{299}$.

Outra ilação que devemos retirar é o facto de Péricles ser indispensável para que Atenas se consiga reerguer, quando as coisas correm menos bem. Também nesse sentido a Guerra de Samos constitui um prenúncio da do Peloponeso, igualmente cheia de altos e baixos, mas infeliz para os Atenienses, porque Péricles, que morre vítima da peste logo no segundo ano de conflito, deixa de poder acudir-lhes. Note-se, no entanto, que Alcibíades também virá a revelar-se imprescindível para que Atenas cumpra os seus objetivos: das duas

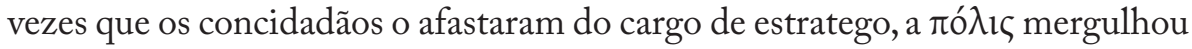
em graves crises. Este Alcmeónida, à semelhança de Péricles, salvou-a da primeira, mas foi impedido pela morte de repetir a proeza.

Como não poderia deixar de ser, por causa dos seus interesses biográficos ${ }^{300}$ e da trágica importância que assumiu para Atenas em particular e para a Hélade em geral, a outra guerra sobre a qual Plutarco se debruça em pormenor na Vida de Péricles é a do Peloponeso. Este conflito é o culminar do antagonismo que caracterizava a relação entre Atenas e Esparta e que se agravou, como já vimos (cf. supra p. $127 \mathrm{sqq}$ ), depois que os Atenienses assumiram a hegemonia da Hélade após as Guerras Médicas. Péricles foi um dos maiores opositores dos Lacedemónios nesse período, a ponto de ter dirigido grande parte da sua ação militar (e mesmo da diplomática ${ }^{301}$ ) contra esse inimigo fatal ${ }^{302}$ (Per. 21.1).

${ }^{299}$ O Queroneu também menciona esta comparação em Moralia 350E.

${ }^{300}$ Por causa desses mesmos interesses biográficos que o levam a salientar o protagonismo de Péricles, Plutarco omite várias vitórias que tiveram lugar entre a expedição contra Samos e a embaixada de Corcira, motivada pela disputa da posse de Epidamno com Corinto (em meados de 443 a.C.). Sobre o intervalo de tempo que o Queroneu não descreve, vide Lewis (1992: 171-177).

${ }^{301}$ Em Per. 17, Plutarco menciona a convocatória para um congresso pan-helénico. $\mathrm{O}$ facto de este ser o único autor que conhecemos a mencioná-lo tem gerado controvérsia quanto à sua autenticidade, data e natureza. A indicação temporal que o biógrafo avança é muito vaga quando os Lacedemónios começaram a ficar incomodados com o ascensão dos Atenienses -, o que sugere que também ele não deve ter tido acesso a informação mais precisa ou, pelo menos, não sentiu necessidade de fornecer esse elemento. Assim, de acordo com o que o Queroneu nos diz, este decreto pode datar de qualquer altura entre 460 a.C. e o início da Guerra do Peloponeso. Tendo em conta que não faria sentido debater a destruição dos templos levada a cabo pelos Persas após a reconstrução do Pártenon (447 a.C.), podemos indicar essa data como terminus ante quem. Para terminus post quem, é possível sugerir que coincida com o período da Paz de Cálias, o que faz com que a data oscile entre 460 e 449 a.C. Sobre este decreto, vide MacDonald (1982:120-123); Lewis (1992: 93-94). O maior indício de que se trata de um decreto verídico é a redação de Per. 17. 2-3, pois reflete o estilo formular dos decretos do século V a.C. Se o considerarmos autêntico, aceitamos, com Plutarco, que se trata de uma importante indicação acerca da política externa de Péricles, que queria ultrapassar a proeminência de Esparta relativamente aos aliados.

${ }^{302} \mathrm{O}$ biógrafo, no entanto, de toda a conflituosidade que ocorreu durante o governo de Péricles antes do eclodir da guerra, apenas se debruça sobre o boicote dos Espartanos ao congresso pan-helénico, a Guerra Sagrada (Per. 21) e a invasão da Ática por Plistóanax (Per. 22). A Guerra Sagrada recebeu este nome pois a sua causa foi o controlo do santuário de 
Podemos até acrescentar que o Alcmeónida não se coibiu de espicaçar o inimigo. Ciente do cada vez maior descontentamento de alguns aliados (que se voltavam para Esparta em busca de auxílio contra a «tirania» de Atenas ${ }^{303}$ ) e do crescente medo dos Lacedemónios por causa do poder que detinham, Péricles parecia querer esclarecer rapidamente a natural ordem das coisas. Julgava que, quanto mais depressa a guerra tivesse lugar, mais depressa colocaria termo às contestações dos aliados e às manobras clandestinas com que Esparta tentava boicotar o «seu» império. Foi certamente com esse objetivo que tomou algumas decisões nos meses que precederam o deflagrar do confronto armado. Convenceu o povo a auxiliar os Corcireus que tinham problemas com Corinto ${ }^{304}$, um dos povos que mais se opunha a Atenas (Per.

Delfos e do seu tesouro (Thuc. 1. 112. 5), disputado por Fócios (aliados de Atenas) e pelos naturais de Delfos. Sobre este acontecimento bélico, há versões distintas da responsabilidade de Filócoro (FGrHist 328 F 34), Teopompo (FGrHist 115 F 156) e Eratóstenes (FGrHist 241 F 38), mas Plutarco parece ter seguido a de Tucídides, segundo o qual os Atenienses reagiram imediatamente a seguir à intervenção dos Lacedemónios (em 448 a.C.). O facto de os Atenienses apenas avançarem após a retirada dos Espartanos evitou o recontro que seria uma violação da paz firmada entre as duas cidades. Vide Lewis (1992: 88). A Guerra Sagrada em causa foi a segunda; a primeira ocorreu por volta de 590 a.C. e as duas últimas já no século IV a.C., respetivamente entre 356 e 346 a.C. e entre 340-338 a.C. Sobre o oráculo de Delfos e as Guerras Sagradas, vide Parke - Wormell (1956) Sobre a invasão da Ática por Plistóanax, vide supra p. 251, nota 189.

${ }^{303}$ Esses foram, por exemplo, o caso de Egina, que se julgava oprimida e maltratada (Per. 29. 5), e de Potideia, outra cidade aliada de Atenas, apesar dos fortes laços que a uniam à sua metrópole, Corinto (Per. 29.6). Uma das cláusulas da Trégua dos Trinta Anos foi a concessão de autonomia a Egina, embora a ilha continuasse a pagar tributo a Atenas e a fazer parte da Simaquia de Delos. Nos debates em Esparta, que antecederam o eclodir da Guerra do Peloponeso, os Eginetas acusaram os Atenienses de não terem cumprido o combinado, pelo que incorriam em violação do acordo, legitimando assim o início de hostilidades militares. Sobre a Trégua dos Trinta Anos, vide Lewis (1992: 90-92); sobre Potideia, ibidem, 184-186. Quanto a Potideia, descontente por ter visto o valor do seu tributo duplicar, revoltou-se em 433 a.C. (Thuc. 1. 56-66). A sua deserção foi muito importante para a antecipação da guerra. Vide Lewis (1992: 184-186). Apesar de estas deserções (ou tentativas) terem contribuído para a origem da guerra, o certo é que aquelas a que Plutarco se refere no período em que Atenas esteve sob o domínio de Péricles são em número inferior às referidas na Vida de Alcibíades.

${ }^{304}$ Corcira era colónia de Corinto e, por sua vez, tinha Epidamno como colónia. Epidamno, situada na costa norte da Ilíria, viu-se devastada por uma luta interna que culminou em guerra com os Bárbaros vizinhos, incitados pelos aristocratas que exilara. Aos democratas, devastados por terra e mar, não restou alternativa senão pedir auxílio a Corinto, depois de Corcira lho ter recusado. Se o objetivo de Corinto era atacar a sua colónia, foi bem sucedido, pois Corcira de imediato contactou os Epidamnianos para que se servissem da sua ajuda e dispensassem a dos Coríntios. Aqueles recusaram e Corcira cercou então a sua colónia. Como verificou que os Coríntios persistiam, determinados, naquela política, enviou, em 435 a.C., uma embaixada à sua metrópole, mas não alcançou os seus intentos. Na primavera de 433 a.C., depois de cerca de um ano e meio de combates, e como Corinto persistisse na guerra, Corcira cumpriu a ameaça feita por ocasião da embaixada e pediu ajuda a Atenas. Depois de um debate aceso entre Atenienses, Coríntios e Corcireus, os primeiros decidiram auxiliar Corcira. Sobre os argumentos do debate e outros pormenores sobre o episódio de Corcira, vide Lewis (1992: 177-184). Aristodemo (FGrHist 104, 17) resume este episódio e, como Tucídides (1. 55. 2), 
29. 1), e hostilizou os Megarenses, através do famoso «decreto de Mégara», que os impedia de estabelecer relações comerciais nas regiões controladas por Atenas (Per. 29.4).

A intervenção no conflito que opunha Corcira a Corinto permitiu-lhe satisfazer intuitos diversos: por um lado, enfurecer os Coríntios ${ }^{305} \mathrm{e}$, indiretamente, os Espartanos; por outro, garantir que, quando a guerra eclodisse, teria o apoio de Corcira, senhora de um considerável poder naval; por fim, desacreditar os filhos de Címon, algo que, de acordo com Plutarco, parecia ser o único "passatempo maquiavélico», a única ação excessiva do estadista $^{306}$. Mas aquela que é considerada a principal motivação da maior guerra a opor os Helenos entre si (segundo Thuc. 1. 1) foi verdadeiramente o conflito com Mégara. De facto, os Lacedemónios mostraram-se iguais a si mesmos ${ }^{307}$ e, na pessoa do rei Arquidamo ${ }^{308}$, tudo fizeram para resolver as queixas sem danos maiores: enviaram embaixadas a Atenas e conseguiram encontrar uma base de negociação para evitar o confronto - bastava que os Atenienses revogassem o decreto de Mégara e se reconciliassem com os seus cidadãos ${ }^{309}$. Péricles, no entanto, mostrou-se tão irredutível ${ }^{310}$ e obstinado que foi acusado de ser o único responsável pela contenda (Per. 29. 8, 30. 1, 31. 1$)^{311}$.

A sua posição originou um aceso debate sobre qual seria a causa de tamanha teimosia, sem que se tenha chegado a consenso (Per. 31.1). Partindo de diversas fontes e perspetivas, Plutarco constrói a sua opinião. Para ele é óbvio

apresenta-o como uma das causas da Guerra do Peloponeso.

305 Sobre as acusações em causa, feitas em Esparta durante uma reunião que decorreu em 432 a.C. (Thuc. 1. 67), as fontes nada nos dizem de concreto. De acordo com Tucídides, os principais instigadores da guerra foram precisamente os Megarenses e os Eginetas (Thuc. 1.67. 2), mas refere-os por ordem diferente da de Plutarco, o que realça a importância que o biógrafo dá ao decreto de Mégara (cf. 30.2-4) como causa do conflito.

${ }^{306}$ Per. 29.1-2. Como já vimos, a família de Címon era conhecida pelo seu filolaconismo. No tempo em que este era seu rival, Péricles votou-lhe uma acesa perseguição por causa da relação que mantinha com Esparta. Depois que aquele morreu, concentrou-se nos seus filhos. Este Alcmeónida não tinha por hábito atacar tão ferozmente os seus rivais atenienses, pelo que somos levados a crer que esta sua obsessão pela família de Címon se prende exatamente ao apreço que esta nutria pelos Lacedemónios, a ponto de Címon ter dado aos filhos nomes como Lacedemónio, Téssalo e Eleio. Sobre a intervenção a favor de Corcira, Lewis (1992: 177-184). p. 119.

${ }^{307}$ Sobre o perfil menos ativo dos Lacedemónios por oposição aos Atenienses, vide supra

${ }^{308}$ Para mais informações acerca de Arquidamo, vide supra p. 257, nota 216.

${ }^{309}$ Thuc. 1. 139. 1. Diodoro Sículo (12. 39) afirma que essa era a condição imposta pelos Lacedemónios.

${ }^{310}$ Em Per. 30. 1, o biógrafo ilustra a irredutibilidade de Péricles com um episódio de cariz anedótico: Péricles escusou-se a revogar o decreto, alegando que não era legalmente possível destruir a tábua onde aquele fora gravado. Perante tal alegação, o embaixador lacedemónio, Polialces, instou-o a virá-la ao contrário. Mas nem assim conseguiu convencê-lo...

${ }^{311}$ Sobre o papel de Péricles enquanto instigador da guerra, vide Lewis (1992:186-192). 
que Péricles tinha motivações pessoais, que precisavam de ser escamoteadas. E que um político da sua estirpe não deve deixar que problemas da esfera privada interfiram em decisões políticas ${ }^{312}$, sobretudo naquelas que envolvem questões bélicas e principalmente se a inimizade pessoal se prende a assuntos tão pouco dignos quanto a prostituição ${ }^{313}$, ou a tentativa de distrair a opinião pública dos ataques de que era vítima ${ }^{314}$. Por isso, o filho de Xantipo teve o cuidado de disfarçar a verdadeira causa com razões de peso que, entretanto, por ingenuidade ou não, os Megarenses lhe foram fornecendo. Uma delas foi a ocupação da terra sagrada ${ }^{315}$ (Per. 30.2). Esta ofensa acabou por dar origem à segunda, já que motivou o envio de um arauto com um decreto ${ }^{316}$ que devia denunciá-la primeiro quer aos Lacedemónios quer aos Megarenses. Ora, Antemócrito, o arauto, foi assassinado, facto que os Atenienses atribuíram aos cidadãos de Mégara, que, em vão, se declararam inocentes ${ }^{317}$. Na sequência deste crime, que para os Gregos era uma enorme impiedade, o diferendo agudizou-se: na pessoa de $\mathrm{Carino}^{318}$, os Atenienses redigiram um novo decreto dando conta da impossibilidade de reconciliação.

No entanto, bem lá no íntimo, o nosso biógrafo não se devia sentir muito realizado com uma justificação, que nos revela um Péricles menos politicamente correto $^{319}$. É também com o intuito de disfarçar essa imagem pouco digna que Plutarco adere ao ponto de vista daqueles que atribuem a pertinácia de Péricles às suas capacidades de estratego e de bom político, que, ao obrigar Atenas a

${ }^{312}$ Em Moralia 785D, Plutarco afirma que a dignidade e grandeza da virtude política se perdem, quando esta se desvia para os assuntos domésticos e para a ganância. Não surpreende, por isso, que tenha tentado encontrar outras justificações para a postura daquele que é um dos seus estadistas favoritos.

${ }^{313}$ Sobre este assunto, vide supra pp. 200 (nota 34) e 271 (nota 277).

${ }^{314}$ Cf. p. 272

${ }^{315}$ Refere-se a ópyó́, uma terra fértil que não se podia cultivar por estar consagrada à deusa de Elêusis, na fronteira com Mégara. A violação de território sagrado era uma ofensa muito grave (incorria-se em asebeia) e deu origem a outros conflitos ao longo da história da Grécia antiga: o cultivo da planície sagrada de Delfos, por exemplo, foi a causa da Guerra Sagrada de 350 a.C. (supra p. 275, nota 302). Para mais pormenores e bibliografia, leia-se a nota correspondente de Stadter (1989: 277).

${ }^{316}$ Plutarco terá tido acesso ao decreto, pois afirma que é prudente e moderado, características que atribui à autoria de Péricles (Per. 30.3).

${ }^{317}$ Esta responsabilidade não foi provada e talvez a morte de Antemócrito tenha sido utilizada como propaganda ateniense para justificar o decreto. Quando, em Per. 30. 4, Plutarco menciona os Megarenses, pode estar a referir-se aos historiadores de Mégara que de um modo geral são evocados em grupo - Piccirilli (1975) -, ou aos Megarenses coevos do biógrafo Connor (1970: 305-308); de Ste. Croix (1972: 387).

318 Colaborador de Péricles. Plutarco justifica este decreto contra os Megarenses com o cultivo da terra sagrada e do assassinato de Antemócrito. Stadter (1989: p. 279) pensa que a atribuição desta lei a Péricles é provavelmente uma simplificação cómica da parte de Aristófanes (Ach. 532). Seja como for, fica mais uma vez a ideia de que Péricles tinha o hábito de delegar funções em terceiros da sua confiança.

${ }^{319}$ Cf. supra nota 312 . 
aderir à solução militar, apenas pretendia estabelecer definitivamente a posição do império ateniense no seio da Hélade:

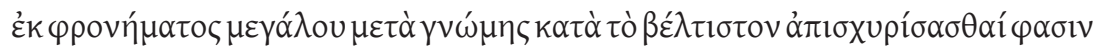

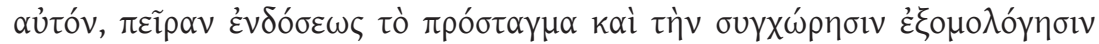

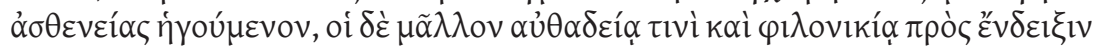

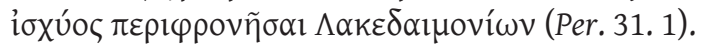

"ele não cedeu por grande prudência, com a convicção de que agia pelo melhor, pois julgava aquela exigência uma tentativa de evidenciar a cedência, transigência e uma confissão de fraqueza. Outros dizem que desdenhou dos Lacedemónios por uma certa arrogância, desejo de vencer e demonstração de autoridade."

Deste modo, a prudência e a grandeza de alma de Péricles surgem também como responsáveis pela não anulação do decreto de Mégara, o mesmo é dizer, pela Guerra do Peloponeso. Essas suas qualidades fizeram-no ver que essa seria a melhor opção, pois as exigências dos Lacedemónios - que temiam o crescente poder ateniense - tinham por principal objetivo verificar se «os mais fortes» cediam (o que seria uma inegável prova de fraqueza ${ }^{320} \mathrm{e}$ um precedente incontornável para exigências ainda maiores). Houve, porém, quem o acusasse de agir assim por pura arrogância (que já vimos ser um dos traços mais criticados da personalidade deste estadista ${ }^{321}$ ) e vaidade, apenas para demonstrar o seu poderio.

Plutarco menciona ainda outro motivo para a teimosia de Péricles, que já abordámos em diferentes ocasiões: a necessidade de desviar a atenção do povo que estava determinado em arranjar-lhe problemas, nomeadamente através dos ataques que fazia aos seus amigos ${ }^{322}$ :

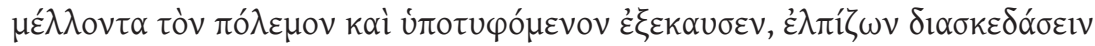

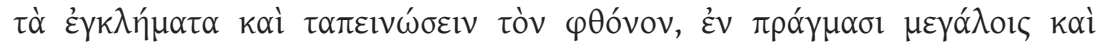

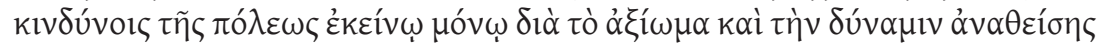
غ̇avív. (Per. 32.6)

"avivou então o fogo ${ }^{323}$ da guerra que estava iminente e que ardia em segredo, esperando dissipar as acusações e diminuir as más vontades; é que, nas empresas grandes e arriscadas, era só nele que a cidade confiava por causa do prestígio e do poder que detinha."

\footnotetext{
${ }^{320}$ Cf. Thuc. 1. 140. 5 .

${ }^{321}$ Vide supra p. 238.

${ }^{322}$ Per. 31.2. Sobre este assunto, vide supra p. 256 sqq.

${ }^{323}$ Imagem também usada por Aristófanes (Pax 608-610).
} 
Este argumento também não parece convencer totalmente Plutarco, que, no fim de apresentar todas as versões, continua a considerar a verdade incerta (Per. 32. 6). A nós, parece-nos que a posição de Péricles decorre de toda a conjuntura que temos vindo a expor e não de um único fator. $\mathrm{E}$ concordamos com o biógrafo que, embora não o diga de modo claro, não acredita que a opção pela guerra tenha sido uma mera manobra de diversão para distrair o povo dos ataques de que vinha sendo alvo. O episódio narrado em Per. 23.1-2 (suborno de Cleândridas, já abordado noutra perspetiva na página 251, nota 188) é prova disso. De facto, o testemunho de Teofrasto clarifica o destino dos dez talentos que Péricles apresentava como gastos diversos no orçamento: serviam para comprar o adiamento da guerra, de modo a Atenas poder preparar-se melhor para ela. É de salientar a ênfase dada a um pequeno pormenor: Péricles não comprava a paz - como alguns poderiam defender para reforçar a tese da cobardia -, simplesmente, como bom estratego, procurava ganhar tempo para que - na hora certa - os seus homens estivessem verdadeiramente aptos a combater sem qualquer restrição e sem correr riscos desnecessários.

Este é mais um daqueles momentos em que podemos distinguir os dois Alcmeónidas. Ao contrário de Péricles, Alcibíades só pensa no imediato. A espera da melhor oportunidade, da reunião de condições, não é opção para ele. Parece acreditar que o futuro é bic et nunc e que os êxitos são manipuláveis, isto é, que dependem exclusivamente do seu empenho e querer. E o certo é que os próprios acontecimentos nos fazem pensar que ele tinha razão: o que dizer de alguém que, empenhado em atacar o inimigo desprevenido, é auxiliado pela própria natureza, que lhe faculta todos os elementos necessários para a prossecução do seu plano: chuva, trovoada e nevoeiro ${ }^{324}$ ? Como veremos, embora pouco prudente, esta tática pode revelar-se de sucesso em pessoas que parecem agir por ímpeto, mas, no fundo, têm uma grande visão e um raciocínio rápido, como um bom jogador de xadrez ${ }^{325}$. Alcibíades agiu quase sempre assim, por impulso, sobretudo quando ferido no seu orgulho, nomeadamente quando, perseguido pelos próprios concidadãos, se viu obrigado a pedir socorro aos Lacedemónios ou quando, perseguido por estes, se refugiou entre os Persas ${ }^{326}$.

Mas Péricles, previdente e protetor do povo, tinha a sua própria estratégia para a Guerra do Peloponeso, que não se coadunava com uma resposta imediata e «a quente». Ele considerava arriscado combater contra uma força tão grande às portas da cidade: é que, como ele própio disse, as árvores cortadas podiam renascer, mas os homens não (Per. 33.5). E porque acreditava que o indicado era contemporizar, procurou acalmar os que se indignavam por não

\footnotetext{
${ }^{324}$ Nem todos eram auxiliados pela natureza: cf. Nic. 21. 10.

${ }^{325}$ Fizemos comparação semelhante a propósito de Péricles. Vide p. 239.

${ }^{326}$ Cf. infra p. 285.
} 
combater logo; ignorou protestos, pressões, ameaças, acusações e insultos ${ }^{327} \mathrm{e}$ tomou as medidas que considerava apropriadas, como a suspensão das reuniões da assembleia ${ }^{328}$ e o encerramento das portas da cidade. A sua estratégia (pelo menos para ele) era clara: os Atenienses não deveriam combater nas proximidades de Atenas, deveriam atacar o inimigo por mar e ao estadista cabia impedir reações precipitadas do povo, distraindo-o ${ }^{329}$. Foi nesse sentido que Péricles tentou agradar à população com novos subsídios e cleruquias (Per. 34. 2) e com investidas por mar contra o Peloponeso e Mégara - nas quais não participou, porque julgou que a sua presença era mais necessária em Atenas, onde podia vigiar o inimigo e os concidadãos mais de perto. A vitória teria sido alcançada em um intervalo de tempo relativamente curto, como aliás Péricles previra, não fosse a intervenção divina ${ }^{330}$ através do surto de peste que atingiu Atenas ${ }^{331}$. Nessa altura, Péricles sofre nova contestação, porque o povo o responsabiliza duplamente: além de ter dado origem à guerra, seguiu uma estratégia que obrigou a população de Atenas e arredores a viver encarcerada na cidade sem o mínimo de condições (Per. 34. 5). O filho de Xantipo engendra, mais uma vez, uma forma de acalmar os ânimos. Só que desta feita, a divindade parece abandoná-lo de novo, porque o cerco de Epidauro corre mal, naquilo que poderemos considerar o cumprimento do presságio de mau augúrio que antecedeu a partida da expedição. De facto, no momento em que as trirremes se preparavam para zarpar, houve um eclipse da lua, que deixou todos estarrecidos, à exceção de Péricles ${ }^{332}$. O seu comportamento prende-se à

${ }^{327}$ Per. 33. 6. Este é um dos momentos em que Péricles é comparado a um piloto que, durante a tempestade, vela pelo bem-estar da tripulação que só faz queixar-se (cf. supra p. 228). Em Per. 34. 1, Plutarco insiste na imperturbabilidade do estadista, que não se deixa abalar nem pelos ataques de Cléon nem pela ira dos concidadãos e suporta com calma e silêncio a impopularidade e ódio de que é vítima.

${ }^{328}$ Sobre a relação desta medida com o perfil tirânico de Péricles, vide pp. 211-215.

${ }^{329}$ Tucídides mostra-se favorável a estratégia de Péricles e acredita que, se tivesse sido mantida, Atenas teria alcançado a vitória (Thuc. 2. 65. 7). Sobre esta estratégia, vide Lewis (1992: 193-200).

${ }^{330}$ Em Per. 34. 4, Plutarco aproveita a única referência de Tucídides à divindade (2.64.1) como elemento que altera a seu prazer os planos humanos. Note-se o paralelo com Fab. 17.1, quando Aníbal se desvia de Roma por vontade divina.

${ }^{331} \mathrm{O}$ surto surgiu nos começos do verão de 430 a.C. Porque ocupado a associar à peste e à derrota de Atenas uma causa divina, Plutarco omitiu determinados acontecimentos cruciais no decurso do conflito (cf. Thuc. 2.47 e 55; D. S. 12. 45. 1), nomeadamente a segunda invasão lacedemónia que motivou a concentração da população no interior das muralhas. Para mais informação sobre este surto epidemiológico, consulte-se Alsina Clota (1987: 1-13). Este acontecimento faz-nos lembrar a dizimação do exército dos Aqueus pela peste enviada por Apolo a pedido do seu sacerdote, Crises (Il.1.33-52). Sobre o papel da intervenção divina, vide infra p. 285 , nota 354 .

${ }^{332} \mathrm{O}$ eclipse aqui mencionado teve lugar a 3 de agosto de 431 a.C., como afirma Tucídides (2.28). Cícero (Rep.1.16) e Valério Máximo (8.11, ext.1) mostram Péricles a explicar o eclipse, sem no entanto relacionarem tal explicação com o momento da partida da expedição. Segundo Stadter (1989: 320), esta pequena incongruência de Plutarco relativamente a outras fontes (já 
formação filosófica de base que teve, da qual resultou um espírito esclarecido ${ }^{333}$. E conseguiu convencer os Atenienses a partir, pois explicou-lhes a mecânica do fenómeno. Mas o certo é que, apesar de Péricles considerar a associação do eclipse a um mau presságio uma forma de superstição e ignorância, os Atenienses saíram derrotados.

Importa abrir aqui um parêntesis para chamar a atenção para o facto de este não ter sido um episódio único durante a Guerra do Peloponeso. Efectivamente, também a expedição à Sicília foi precedida de inúmeros «avisos», aos quais Nícias ${ }^{334}$ ainda tentou dar ouvidos, como a mutilação dos Hermes ${ }^{335}$, ou a festa em honra de Adónis ${ }^{336}$. No entanto, Alcibíades, na esteira de Péricles, não se deixava intimidar por esse tipo de argumentos, pelo que a sua posição vingou e a armada partiu. E Atenas acabou humilhada... Algo semelhante aconteceu por ocasião do regresso do filho de Clínias a Atenas após os anos de exílio: apesar de ter sido recebido com entusiasmo e esperança em um futuro melhor para a cidade, o Alcmeónida regressou em um dia considerado nefasto ${ }^{337}$. E foi relativamente curto o intervalo de tempo que mediou o seu retorno e a ruína definitiva...

Plutarco, que consagra um dos seus opúsculos ao tema das superstições ${ }^{338}$, não tece nas biografias em causa qualquer comentário a favor dessas crendices. No entanto parece ficar no ar uma ideia que permanece nos nossos dias: não é raro ouvir-se dizer «eu não acredito em bruxas, mas que as há, há...». É que, na sequência de todos os presságios referidos, Atenas sofreu sempre um revés.

Depois do fracasso do cerco a Epidauro, Péricles tenta novamente encorajar o povo, mas o descontentamento deste já atingira uma dimensão

que combina uma expedição que teve lugar em 430 a.C. com um eclipse que, como já vimos, ocorreu em 431 a.C.) resulta do próprio método de composição do biógrafo: embora estivesse a seguir de perto o texto de Tucídides, ao dedicar-se à narrativa da peste, ter-se-á esquecido da referência que o historiador faz ao fenómeno e de imediato passa para a anedota (de fonte diversa). Assim, pode-se partir do princípio de que lia as notas para organizar o pensamento, mas que nem sempre ia reconfirmar os dados.

${ }^{333}$ Sobre a formação filosófica de Péricles, vide supra p. 178 sqq.

${ }^{334}$ Nícias (Plu. Nic. 4, 23. 1) é-nos apresentado como exemplo máximo daqueles que se deixam afetar por superstições, em muito por causa da sua pietas erga deos. Em Nic. 23, o biógrafo refere-se a mais um eclipse lunar, tido como sinal de grandes calamidades enviadas pelos deuses, e desenvolve o tema da superstição e da luta do progresso científico contra esses temores infundados, personificada, entre outros, por Anaxágoras e Platão. Em Nic. 13, Plutarco menciona exemplos dos vários presságios e estratagemas através dos quais se tentou, sem sucesso, evitar a expedição.

${ }_{335}$ Alc. 18. 6; Nic. 1. 2. Sobre este assunto, veja-se p. 233, nota 117.

${ }^{336}$ Alc. 18. 5. Cf. Nic. 13. 11 (onde este presságio é apresentado antes do da mutilação dos Hermes, ou seja, em ordem inversa relativamente à Vida de Alcibiades) e Ar. Lys. 387-397. Trata-se de uma festa associada à morte, durante a qual se expõe imagens que representam os mortos e se imitam ritos fúnebres. Sobre este festival, vide Hammond - Scullard (1992: s.v.)

${ }^{337}$ Sobre esta data, vide infra p. 299 , nota 447.

${ }^{338}$ Moralia $164 \mathrm{E}-171 \mathrm{~F}$. 
que não lhe permitia recuar sem antes descarregar toda a sua fúria... o filho de Xantipo acaba por ser destituído do cargo e condenado a pagar uma multa ${ }^{339}$. E quando o povo acordou para a falta que Péricles lhe fazia, era tarde demais: o estadista ainda voltou ${ }^{340}$, mas sucumbiu pouco depois, também ele vítima da peste. Plutarco não torna, por isso, a referir qualquer outra intervenção de Péricles no desenvolvimento da guerra.

Consequentemente, o conflito foi seguindo o seu curso com outros estrategos à frente dos destinos de Atenas. De todos, destacamos (como não poderia deixar de ser) Alcibíades, cuja intervenção - decorrente da acidentada relação que mantinha com o povo - foi fundamental para o trágico desfecho da guerra, de tal maneira que podemos afirmar que a Guerra do Peloponeso foi um fogo que deflagrou e se extinguiu por causa dos Alcmeónidas.

Antes, porém, de nos debruçarmos sobre o papel de Alcibíades na Guerra do Peloponeso, importa abrir um parêntesis para refletirmos sobre a sua atuação enquanto general. Neste sentido, podemos considerar que a sua vida militar passa por dois grandes momentos: o que antecede e coincide com o exílio e o que se lhe segue.

Do primeiro, importa destacar a influência de Alcibíades no reacender do conflito com Esparta e na expedição à Sicília. Na sequência do logro com que minou a Paz de $\mathrm{Nícias}^{341}$, Alcibíades foi eleito estratego e, de imediato, celebrou uma aliança com Mantineus, Eleus e Argivos, com o intuito de avivar as hostilidades com a Lacedemónia, chamando a si as principais cidades do Peloponeso $^{342}$. Por essa ocasião, provocou a batalha de Mantineia ${ }^{343}$, da qual Atenas saiu derrotada, e ajudou a restaurar a democracia em Argos $^{344}$.

Destacamos também a expedição contra a Sicília (415 a.C.), porque está para a Guerra do Peloponeso sob o domínio de Alcibíades, como a de Samos o estivera sob o de Péricles. Por outras palavras: do mesmo modo que a de Samos

${ }^{339}$ Sobre este assunto, vide Tucídides 2. 65.3 (em parte parafraseado por Plutarco) e Diodoro Sículo 12.45.4. Segundo Platão (Grg.516a), o facto de o povo afastar Péricles do comando é sinónimo de que o estadista não estava a tornar os cidadãos melhores. De acordo com esta mesma fonte,

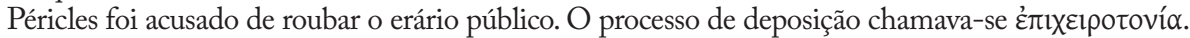
Votava-se, então, no princípio de cada pritania, a avaliação dos generais e magistrados. Se essa fosse considerada negativa, o general ou magistrado seria objeto de julgamento: se fosse condenado, o tribunal estabeleceria a pena; se fosse absolvido, reassumiria o seu cargo (cf. Arist. Ath. 61.2).

${ }^{340} \mathrm{O}$ Alcmeónida foi reeleito em março de 429, mas só viria a ficar no poder por três meses. Sobre a peste e o declínio de Péricles, consulte-se Lewis (1992: 200-203).

${ }^{341}$ Plu. Alc. 15, Nic. 10. 9, Moralia 351B e Thuc. 5. 43. Sobre este assunto, vide Lewis (1992: 249-252).

${ }^{342}$ Cf. Thuc. 5. 52. 2; Isoc. 15.15; Plu. Moralia 804E.

${ }^{343}$ Esta batalha, que tem lugar em 418 a.C., é descrita por Thuc. 5. 66-74. O texto de Plutarco é brilhante, porque chama a atenção para o perigo que Esparta correu, refere que em caso de derrota Atenas não seria muito afetada, porque a refrega teria lugar longe da Ática, mas nunca diz abertamente que foram os aliados a sair derrotados.

${ }^{344}$ No ano de 417 a.C. Cf. Thuc. 5. 81-82; D. S. 12.80-81. 
serviu de prenúncio da do Peloponeso pela sua extensão e pelas capacidades que os Atenienses tinham para levá-la a bom termo, também a da Sicília foi um presságio do grande desastre que estava reservado a Atenas.

Como já temos visto, o interesse pela Sicília era antigo ${ }^{345}$. Enquanto Péricles viveu, conseguiu refrear o sonho da turba. Mas, após a sua morte, o povo começou a preparar lentamente a expedição, procedendo como o filho de Xantipo em relação à Guerra do Peloponeso ${ }^{346}$. Neste caso concreto, Plutarco refere que os Atenienses se dispunham a partir em socorro da Sicília sempre que um dos povos que aí habitava era atacado por Siracusa. Esta atuação permitia uma aproximação gradual, enquanto esperavam pelo momento oportuno para uma investida de maior peso. Mas Alcibíades não tinha feitio para delongas, pelo que arrebata o espírito da multidão e convence-a a avançar de vez para a Sicília (Alc. 17. 2), que via não como um fim em si mesmo, mas como ponto de partida e plataforma de aprovisionamento, por exemplo, para Cartago e a Líbia, para a Itália e o Peloponeso ${ }^{347}$ (Nic. 12.2). Nícias assume a luta de Péricles e faz de tudo para evitar a expedição ${ }^{348}$ (Alc. 17. 3, 18. 2), mas o povo só tinha olhos e ouvidos para os argumentos do Alcmeónida ${ }^{349}$ (Alc. 17. 4). Apesar de se decidirem (insensatamente) pela expedição, os Atenienses, em um dos raros momentos em que, enquanto conjunto, revelam alguma sensatez, optam por enviar três estrategos no seu comando: Alcibíades, Nícias ${ }^{350}$ e Lâmaco ${ }^{351}$. Procuravam, deste modo, limitar o excesso de ambição ( $\left.\varphi \imath \lambda o \tau \imath \mu i ́ \alpha\right)$ e de ousadia $(\tau o ́ \lambda \mu \alpha)$ pelos quais Alcibíades era conhecido ${ }^{352}$.

${ }^{345}$ Vide supra p. 263, nota 242.

${ }^{346}$ Comprava tempo e não a paz. Vide supra p. 380.

${ }^{347}$ Cf. Thuc. 6. 15.2, 6. 90.2-3; D. S. 12.83.5 - 84. Sobre este assunto, vide supra pp. 263-264.

${ }^{348}$ Como não poderia deixar de ser, o biógrafo aprofunda esta questão em Nic. 12.

${ }^{349}$ Plutarco descreve com especial pormenor a atitude dos jovens, que conseguimos visualizar embevecidos a ouvir os mais velhos falarem sobre a expedição e a fazer desenhos das ilhas no chão. Cf. Nic.13.1.

${ }^{350} \mathrm{Em}$ Alc. 18. 1, o biógrafo menciona que Nícias aceitou o cargo contra a sua vontade. Cf. Thuc. 6. 8. 4. Importa chamar a atenção para o facto de Nícias ter um comportamento nobre enquanto estratego de uma guerra que não era a sua: tentou até ao último momento evitar que a expedição fosse realizada; no entanto, quando viu que a decisão era irreversível, deu o seu melhor. Não surpreende, por isso, que o biógrafo teça rasgados elogios à sua sabedoria e honestidade em Nic. 14.1. Alcibíades não seria, decerto, capaz de uma atitude semelhante. Basta recordar o que fez quando se sentiu preterido na celebração dos acordos de paz com Esparta (Alc. 14)... Sobre este assunto, vide supra pp. 206-208.

${ }^{351}$ Filho de Xenófanes e natural do demo de Ea, participou em diversas expedições, nomeadamente na que foi enviada a Esparta para celebrar a Paz de Nícias (422/421a.C.). Apesar de ser mais velho, Lâmaco tinha um espírito muito parecido com o de Alcibíades. Em Nic. 12. 3-6 salienta-se a sua temeridade ( $\theta \rho \alpha \sigma u ́ \tau \eta \tau \alpha)$, característica que, juntamente com a sua posição belicista na guerra do Peloponeso, lhe valeu o ataque de Aristófanes em $A c h .270$ e Pax 304. Note-se, contudo, que o comediógrafo (Th. 841) soube prestar-lhe a devida homenagem pelo heroísmo que demonstrou por ocasião da sua morte em Siracusa. Também é mencionado por Plu. Per. 20.1.

${ }^{352}$ Cf. Nic. 12.3-6. Não deixa de ser curioso notar que o biógrafo utiliza neste contexto 
As primeiras investidas levadas a cabo no âmbito desta expedição foram bem sucedidas: os estrategos conseguem submeter Régio ${ }^{353}$, na Itália, e Catânia, na Sicília (Alc. 20. 3). No entanto, na sequência do processo que deixara pendente em Atenas, Alcibíades é convocado a regressar para o julgamento. Daí para a frente, nada voltaria a ser como antes... Podemos, contudo, acreditar que, do mesmo modo que Atenas poderia ter vencido a Guerra do Peloponeso, se Péricles tivesse continuado à frente do governo e das tropas, também Alcibíades (se não tivesse sido afastado pelos Atenienses) poderia ter levado a bom porto a expedição à Sicília. Podemos, se quisermos, considerar, como Péricles (Per. 34. 4) e Plutarco, que a mudança de sorte de Atenas se deveu à intervenção divina ${ }^{354}$. Mas os deuses apenas foram verdadeiramente responsáveis pela derrocada de Atenas por terem afastado Péricles. Alcibíades surge, na sua ambiguidade, como uma nova oportunidade promissora, uma espécie de Pandora, um presente envenenado: apesar de ter muito potencial, a sua maneira de ser acaba por fazer com que o povo deixe de confiar nele e, assim, desperdice a segunda hipótese que os deuses lhe deram de sair vencedor do conflito com os Lacedemónios.

Não podendo dar o seu melhor enquanto estratego a favor de Atenas, Alcibíades fá-lo contra aquela ${ }^{355}$, naquele que, na nossa opinião, Plutarco considera o único momento em que, verdadeira e conscientemente, o estratego fez mal aos concidadãos ${ }^{356}$. Ainda que possa ter tido alguma participação na mutilação dos Hermes ${ }^{357}$, não foi a maldade que o moveu mas a sua maneira leviana de ser. Pelo contrário, quando se sentiu traído pelos concidadãos, que até então lhe haviam dedicado múltiplos $\operatorname{carinhos}^{358}$, teve a atitude própria de

(Alc. 18. 1-2) vocabulário relacionado com o vinho, pois fala na necessidade de misturar

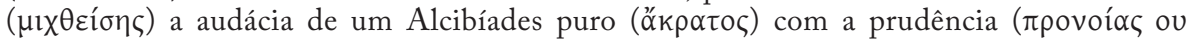
$\varepsilon u ̉ \lambda \alpha ́ \beta \varepsilon ı \alpha-N i c .12 .5)$ de Nícias. Este tipo de metáfora ocorre também em Per. 7.8 a propósito do povo e da liberdade que este conseguira sob o governo de Péricles.

${ }^{353}$ Esta informação que Plutarco fornece em Alc. 20. 2 diverge do que afirma Thuc. 6. 44, segundo o qual Régio não foi conquistada, porque optou por uma posição de neutralidade. Os Atenienses ter-se-ão limitado a acampar nessa região.

${ }^{354}$ Esta ideia é reforçada em Nic. 17. 4, onde o biógrafo afirma que os Atenienses obtiveram oito vitórias sobre os Siracusanos, antes que uma oposição ( $\alpha v \tau i ́ \sigma \tau \alpha \sigma \iota)$ ), vinda dos deuses ( $\theta \varepsilon o i ́)$ ou da fortuna ( $\tau$ xи́), parasse os Atenienses no apogeu do seu poderio.

355 É bem verdade que, Alcibíades, se não fosse mimado e voluntarioso, poderia ter enveredado por outro caminho, como Címon que, também ele exilado, acorreu a acudir a cidade quando a viu em apuros (Per. 10). Alcibíades, que amadureceu muito com a experiência do exílio, teve esse comportamento da segunda vez que os Atenienses o afastaram do comando. No entanto, a sua atuação anterior, que em tudo corresponde à reação de um indivíduo de "grande natureza», fez com que ninguém acreditasse na sua boa vontade. Infra p. 301.

${ }^{356}$ A vingança de Alcibíades acossado no exílio é igual à reação de um leão. Cf. supra p. 230. Sobre a reação de Alcibíades, consulte-se Gribble (1999: 274).

357 Supra p. 233, nota 117.

${ }^{358}$ Cf. Thuc. 6. 15. Foi a oscilação de afeições para com Alcibíades durante os dez últimos anos de guerra que deitou por terra a possibilidade da vitória ateniense. 
um indivíduo de «grande natureza», que, como Aquiles, também prejudicou os seus companheiros de armas, os Aqueus, por ter sido ferido na sua honra por Agamémnon (Il.1.488-492). Decidiu, então, fazer com que os Atenienses sentissem o duplo efeito da sua ausência: não só não dispunham das suas capacidades para fazer frente ao inimigo, como ainda tinham de vê-las usadas contra eles próprios. É com esse intuito e por ter o seu orgulho ${ }^{359}$ ( $\varphi \imath \lambda$ $\lambda \iota \mu$ í $\left.\alpha\right)$

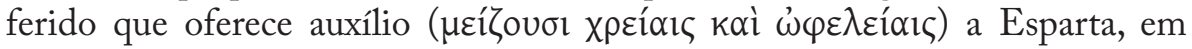

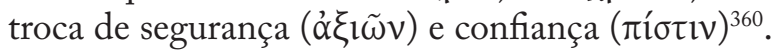

Aos Espartanos, tal proposta pareceu um presente dos deuses, pelo que, em um momento de rara agilidade, não demoraram a enviar resposta afirmativa ${ }^{361}$. E Alcibíades, mal chegou a Esparta, mostrou-se igual a si mesmo: determinado, empreendedor, dando início à campanha de destruição de Atenas com base em medidas diversas ${ }^{362}$, com o mesmo empenho com que se dedicara a convencer os Atenienses a avançar com a expedição à Sicília. A primeira consistiu em invalidar os planos para que Messina ${ }^{363}$ se entregasse à $\pi$ ó $\lambda ı$, algo que não era difícil para quem participou na definição dessa estratégia: bastou-lhe denunciar a Siracusa os membros do partido que pretendiam aliar-se a Atenas. A segunda assentou na grande diferença que existia entre Atenas e Esparta: a velocidade de resposta. Alcibíades «obrigou» os Lacedemónios, que há muito hesitavam, a enviar de imediato socorro aos habitantes de Siracusa ${ }^{364}$. Deste modo, retomavam a guerra ${ }^{365}$ contra Atenas e concretizavam um dos maiores receios de Péricles, a dispersão das forças por várias frentes de batalha. A última foi aconselhar os seus anfitriões a fortificar Deceleia ${ }^{366}$, algo a que Plutarco atribui importância capital na futura derrota de Atenas. Sem querer desfazer das suas capacidades, o certo é que, no que concerne ao auxílio que prestou a Esparta (e à Pérsia) durante a fase de vingança do seu exílio, uma boa parte dos resultados alcançados se devem ao conhecimento profundo que ele tinha dos assuntos da cidade (nomeadamente os seus segredos e fraquezas) e da maneira de ser dos Atenienses ${ }^{367}$.

${ }^{359}$ Trata-se do mesmo sentimento que o inspirou em Selímbria ou durante a reposição da procissão de Elêusis.

${ }^{360}$ Alc. 23.1.

${ }^{361}$ Sobre a hesitação própria dos Espartanos, vide supra p. 120.

${ }^{362}$ Para outras medidas que Plutarco não refere na Vida de Alcibiades, consulte-se Thuc. 6. 88. 10 - 93. 2. Sobre esta em especial, vide Lewis (1992: 292).

${ }^{363}$ Thuc. 6.74.1.

364 Embora Plutarco aponte o nome de Gilipo enquanto comandante da expedição, Tucídides não lhe faz qualquer alusão no discurso de Alcibíades que reproduz (6. 91. 4-6). Cf. D. S. 13. 7.1-2.

${ }^{365}$ A importância do reacendimento do conflito é salientada por Nep. Alc. 4. 6-7; D. S. 13. 5. 4.

${ }^{366}$ Cf. Nep. Alc. 4. 6-7; D. S. 13. 5. 4, 13. 9. 2. Deceleia era um pequeno demo da Ática, que já existiria quando Teseu procedeu ao sinecismo (Philoc. FGrHist 328 F 94). Para mais informações, consulte-se Hammond - Scullard (1992: 435).

367 Sobre este assunto, vide Gribble (1999: 199). 
As suas indicações, como não poderia deixar de ser, surtem o efeito pretendido: Atenas sofre uma pesada derrota na $\operatorname{Sicília~}^{368}$ (Alc. 24. 1), pelo que o Alcmeónida passa de instigador do sonho a responsável pelo pesadelo ${ }^{369}$. Nessa altura, foram vários os aliados que, como Quios, Lesbos e Cízico, consideraram oportuno quebrar o pacto e coligar-se a Esparta ${ }^{370}$. Por influência de Alcibíades, que passou então das palavras aos atos - pois acompanhava os generais espartanos ${ }^{371}$-, Quios foi ajudada em primeiro lugar e quase toda a Iónia desertou.

Quando as relações com Esparta se degradam e Alcibíades é informado do risco de vida que corre, procede com discrição, como se não se passasse nada, mas depressa busca uma solução para o seu problema ${ }^{372}$. Desta feita, contrariando, como era seu hábito, todas as expectativas, procura asilo na corte de um sátrapa do Rei ${ }^{373}$, Tissafernes ${ }^{374}$ de seu nome, conhecido, segundo Plutarco, como o persa mais cruel e o que mais odiava os Gregos. Com a sua capacidade de cativar, Alcibíades consegue - pelo menos aparentemente - torná-lo seu aliado (Alc. 24). Nessa altura, o Alcmeónida, mais do que traidor de Atenas ${ }^{375}$ (que prejudicou muito os Atenienses -

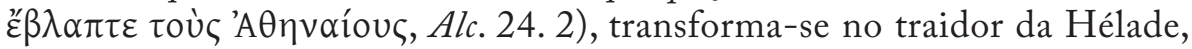
pois sugere ao grande inimigo da Grécia uma estratégia para destruir Atenas e Esparta em simultâneo e sem grande esforço ${ }^{376}$. Não surpreende, por isso, que, mais tarde, quando promete anular o efeito nefasto que as tropas fenícias poderiam ter para Atenas, seja acusado de estar de novo a fazer este jogo duplo ${ }^{377}$.

${ }^{368}$ Sobre a expedição e o seu trágico desfecho, vide Lewis (1992: 282-311).

369 Verdegem (2005: 167-178) sintetiza diferentes posições de autores antigos (Lísias, Tucídides, Isócrates e Plutarco) sobre o comportamento de Alcibíades enquanto exilado.

${ }^{370}$ Thuc. 8. 6. 1-3; D. S. 13.34. 2. Vide Lewis (1992: 312-317).

${ }^{371}$ Não para pegar em armas, mas apenas para poder aconselhar melhor. Para Plutarco, este pormenor é fundamental, pois permite-lhe considerar o mal que Alcibíades faz à sua pátria menos grave do que igual comportamento por parte de Coriolano (Comp. Cor.-Alc. 2. 6-9). Esta desculpabilização decorre do facto de Alcibíades, que, como Coriolano, tinha ótima reputação no novo meio (Cor. 29. 1, Alc. 23. 3, 24. 3), nunca se ter tornado oficialmente comandante do exército espartano, ainda que os seus conselhos tenham tido muito peso nas decisões do inimigo (Alc. 23. 2, 24. 1-2).

${ }^{372}$ Sobre os planos de Ágis e de alguns Lacedemónios para eliminar Alcibíades, vide Thuc. 8. 45.1 e Nep. Alc. 5. 1-2.

${ }^{373}$ Nessa altura, era Dario II quem estava no poder.

${ }^{374}$ Plutarco segue Thuc. 8. 45. 2 - 46. 1 e não D. S. 13.37. 4-5, segundo o qual Alcibíades se aliou não a Tissafernes mas a Farnábazo.

375 Alcibíades é considerado um dos maiores traidores da antiguidade. Cf. Gribble (1999: 55, 58-60). Note-se que, segundo Thuc. 8. 47, ao propor esta estratégia, o Alcmeónida já tinha em mente uma aproximação aos concidadãos, ideia que fica esbatida no texto de Plutarco, que dá mais atenção ao facto de os Atenienses se mostrarem, mais uma vez, arrependidos por terem repudiado Alcibíades (Alc. 25.2).

${ }^{376}$ Cf. Thuc. 8. 46; X. $H G$ 1. 5. 8-9.

377 Alc. 26. 7. Sobre este assunto, vide supra p. 273, nota 290. 
Não deixa de ser curioso notar que, proposto a Tissafernes o estratagemaque, como é óbvio, inflamou ainda mais os ressentimentos de Lacedemónios e Atenienses contra Alcibíades-,o próprio Alcmeónida revele, eufemisticamente falando, um certo incómodo ${ }^{378}$ ("’ $\left.\chi \theta \varepsilon \sigma \theta \alpha 1, \varphi \circ \beta \varepsilon \tilde{\sigma} \sigma \theta \alpha \mathrm{l}\right)$ pela sua «brilhante» ideia: daí em diante, o risco que a sua vida corria era acrescido, pois quem quer que saísse derrotado do conflito iria decerto procurar vingança ${ }^{379}$.

Ora, quando se apercebe de que a estratégia proposta aos Persas poderia deixá-lo em situação delicada com os Espartanos, depressa tece novo plano e tenta aliar-se a Samos, com o objetivo oculto de regressar a Atenas ${ }^{380}$. Como já vimos, no tempo de Péricles, Atenas e Samos estiveram envolvidas em confrontos militares que considerámos um prenúncio da Guerra do Peloponeso ${ }^{381}$. Enquanto Péricles lutou para estabelecer a democracia naquela cidade, Alcibíades, por conveniência própria (mais do que para agradar aos oligarcas e fazer frente ao povo ${ }^{382}$ ), vinha agora propor aos oligarcas locais a abolição do regime popular e o restabelecimento do oligárquico. Como era habitual sempre que o Alcmeónida sugeria uma estratégia a alguém, os Sâmios aderem ao seu projeto, à exceção de Frínico ${ }^{383}$, que, com razão ${ }^{384}$, desconfia

${ }^{378}$ Como veremos ao longo das próximas páginas, o medo é um sentimento que assalta este Alcmeónida com alguma frequência. Trata-se, contudo, de um sentimento sui generis: não afeta a sua capacidade de arriscar e a sua determinação, apenas o põe de sobreaviso quando sabe que a sua segurança está em perigo. É uma espécie de instinto de sobrevivência. O mesmo não se pode dizer de Péricles, a quem apenas conhecemos dois receios: ser associado à tirania (supra pp. 170, 194) e ver Aspásia condenada pelo tribunal (p. 247).

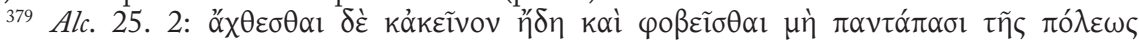

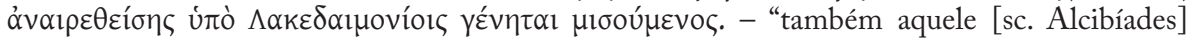
estava inquieto e temia ficar sob o jugo dos Lacedemónios, que o odiavam, se a cidade fosse completamente destruída por eles". O texto de Plutarco deixa a sugestão de que o rancor de Alcibíades contra Atenas estava quase totalmente dissipado, na medida em que refere que o exilado sentia receio quando pensava na possibilidade de os Atenienses serem derrotados. Isso, quanto a nós, significa que ele depositava esperanças no sucesso dos seus concidadãos, para o qual procurava contribuir ao evitar que Persas e Lacedemónios se aliassem. Se Atenas saísse vitoriosa, decerto reconheceriam o valor da sua intervenção e, em troca, chamá-lo-iam de volta. Se perdesse, teria de fugir da fúria não só de Esparta mas também de Atenas.

${ }^{380}$ Mais uma vez, Plutarco, por razões que se prendem aos seus objetivos enquanto biógrafo, afasta-se de Thuc. 8. 47 sqq, que expõe minuciosamente os planos de Alcibíades para regressar a Atenas.

${ }^{381}$ Cf. supra p. 271 sqq.

382 Esta aproximação que Alcibíades faz aos oligarcas de Samos é mutatis mutandis comparável à que Péricles, em início de carreira e contrariando a sua natureza, fez ao povo (supra p. 199): revela que estes Alcmeónidas são indivíduos determinados a tudo fazer para alcançar os objetivos a que se propõem. Segundo Duff (1999: 220), esta intervenção de Alcibíades é o exemplo inverso da ófóvola que caracteriza Péricles e a que fizemos referência na p. 236, nota 130.

${ }^{383}$ Plutarco atribui a posição e a reação de Frínico à de um traidor, movido pela inveja de Alcibíades e pelo medo de Tissafernes. A inveja é, pois, mais uma vez, associada aos perigos e traições de que Alcibíades é vítima. Sobre este assunto, vide supra p. 231, nota 102.

${ }^{384} \mathrm{Em}$ Alc. 25. 6, por influência de Thuc. 8. 48.1-4, Plutarco faz um comentário que atesta 
da posição pró-oligárquica de Alcibíades, que atribuía ao desejo secreto de regressar a Atenas. No entanto, vinga a vontade da maioria, pelo que, Frínico, inimigo declarado do Alcmeónida, põe em marcha um plano maquiavélico ${ }^{385}$ : denuncia ao comandante da frota adversária ${ }^{386}$ as intenções e o jogo duplo de Alcibíades. Este, porém, não se deixa ficar e retalia, mandando avisar os Sâmios de que um dos seus revelara a estratégia ao inimigo. Desta feita, Frínico vai mais longe e propõe aos Persas, através de Astíoco, entregar-lhes Atenas; ao mesmo tempo, por precaução e maldade, anuncia aos Atenienses que os inimigos, por ação de Alcibíades, iriam atacá-los. Não surpreende, por isso, que estes tenham duvidado das verdadeiras intenções do Alcmeónida, que informado por Astíoco - os aconselhou a ficar de sobreaviso em relação a Frínico. Como é hábito do povo, só mais tarde, quando aquele foi assassinado na Ágora, reconheceu as boas intenções do estratego exilado ${ }^{387}$.

$\mathrm{Na}$ sequência da alteração do regime em Samos, Atenas vive um dos piores períodos do século $\mathrm{V}$ a.C. Os amigos que Alcibíades aí tinha enviam Pisandro à $\pi$ ó $\lambda ı \varsigma$ para convencer os poderosos a aceitar a condição que aquele impunha para vir em seu socorro e conseguir-lhes uma aliança com Tissafernes: nada mais nada menos do que substituir o regime democrático por um oligárquico ${ }^{388}$ ! Ora, os cidadãos que de há muito ansiavam pela mudança de constituição basearam-se neste pretexto para assumir o poder; mas o seu intuito real era, com esta opção, tornar os Lacedemónios, partidários deste tipo de regime, mais dóceis. Uma vez deposta a democracia, deixaram de investir na Guerra do Peloponeso e os Quatrocentos ${ }^{389}$ passaram a oprimir o povo

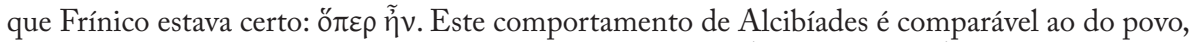
que volta atrás na sua posição depois que a raiva esmorece (cf. supra p. 260). O muito mal que fez à sua pátria permitiu-lhe aliviar a fúria, do mesmo modo que o povo descarregara a sua ira atacando os políticos que o governavam. Neste sentido, Alcibíades é um excelente exemplar da maneira de ser de um ateniense legítimo.

${ }^{385}$ Cf. Thuc. 8. 50-51.

${ }^{386}$ Astíaco assumiu esse cargo em 412/411 a.C. Para mais informações a respeito deste espartano, consultem-se Hammond - Scullard (1992: 199) e Westlake (1968: cap. 15).

387 Alc. 25. 14. A desconfiança dos Atenienses em relação a Alcibíades também é mencionada por Polyaen. 3. 6. A forma um tanto ou quanto confusa como Plutarco descreve as circunstâncias em que ocorreu a morte de Frínico não segue o testemunho de Thuc. 8. 92 . 2. Frínico, que era um dos líderes do regime dos Quatrocentos, foi destituído do seu cargo por causa do problema em que se envolveu com Alcibíades e Astíoco (e.g. Thuc. 8. 90. 1; Arist. Pol. 1305b).

${ }^{388} \mathrm{Cf}$. Thuc. 8. 49, que indica que esta embaixada teve lugar muito antes da morte de Frínico e até que antecedeu a sua querela com o Alcmeónida. Trata-se, por isso, de mais uma das ocasiões em que Plutarco realmente veste a pele de biógrafo e aproveita os dados históricos sem grandes preocupações de índole cronológica ou factual, apenas visando alcançar os efeitos pretendidos na composição das suas personagens. Sobre este assunto, vide supra p. 23.

${ }^{389} \mathrm{Em}$ teoria, o novo regime era constituído por cinco mil oligarcas, dos quais quatrocentos assegurariam as funções executivas (cf. Thuc. 8.67.3). 
e eliminaram a oposição ${ }^{390}$. Este comportamento provocou a indignação dos Sâmios que decidiram socorrer os Atenienses e escolheram Alcibíades para liderar a expedição contra os tiranos.

O Alcmeónida torna-se, então (de acordo com o retrato que Plutarco dele traça entre os capítulos 27 e 31), no único grande responsável pela reversão da sorte de Atenas ${ }^{391}$. É neste contexto que nos deparamos com um novo Alcibíades, que abandona o seu comportamento impulsivo de exilado errante e assume aquilo a que poderíamos chamar a "postura de um Péricles» para prestar o seu primeiro grande serviço à cidade. De facto, com o feitio que lhe conhecemos, seria de esperar que, recém-eleito estratego ao comando de uma frota e exército consideráveis, Alcibíades tivesse cedido aos desejos da multidão e reagido de forma mais instintiva ${ }^{392}$. No entanto, como afirma Plutarco:

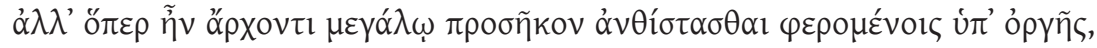

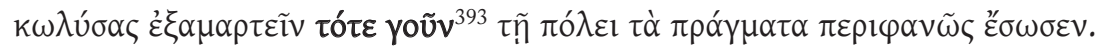
(Alc. 26. 4)

"comportou-se como um grande chefe, resistiu aos soldados tomados pela cólera, impediu-os de fazer uma asneira e salvou manifestamente, pelo menos nesta ocasião, os interesses da cidade."

A este "primeiro serviço», seguiu-se um segundo, que não foi visto com bons olhos, porque quer Espartanos quer Atenienses já não sabiam o que esperar de Alcibíades. Referimo-nos ao facto de este, cumprindo uma promessa feita aos Atenienses, ter impedido - através de Tissafernes - que os Fenícios se aliassem a Esparta. O Persa, no entanto, não permitiu que o Alcmeónida cumprisse a outra parte da promessa feita aos Atenienses: tornar os Fenícios seus aliados ${ }^{394}$. Este acontecimento motivou uma forte crítica por parte de Atenienses e Lacedemónios, que o acusaram de aconselhar o Bárbaro a deixar que se destruíssem mutuamente. Ainda assim, a iniciativa do Alcmeónida foi louvável, pois aqueles a quem as tropas se tivessem aliado teriam destruído os demais.

Apesar das críticas, que foram mais fruto da matreirice de Tissafernes do que de segundas intenções de Alcibíades, a sua vida estava para sofrer

\footnotetext{
${ }^{390}$ Plutarco fala em «não poucos» assassinatos (Alc. 26.2) por oposição a Thuc. 8. 70.2 («não muitos»).

${ }^{391}$ Cf. Lys. 3. 1, Moralia 349E. Esta posição exagerada de Plutarco é diversa da que Cornélio Nepos apresenta em Alc.5.6 e Thr.1.3. E é tanto mais exagerada quanto Alcibíades, no fundo, vem salvar os Atenienses de um mal cujo instigador foi ele próprio.

${ }^{392}$ Sobre a preocupação que Alcibíades revela para com os Atenienses e a $\pi$ ó $\lambda$ ı contexto, vide supra p. 268.

${ }^{393}$ É impossível ignorar o rasgo de ironia do biógrafo...

${ }^{394}$ Alc. 26.7 segue de perto Thuc. 8. 88 .
} 
uma reviravolta: depois de nomeado estratego pelos Sâmios, os Atenienses que permaneciam na cidade, mal os Quatrocentos foram depostos, abriram os braços para recebê-lo de novo ${ }^{395}$. Ainda que extasiado e ansioso pelo regresso, Alcibíades, sempre igual a si mesmo no que respeita à vaidade e desejo de vencer, protela esse momento, porque queria fazer algo de grandioso (como recuperar uma boa parte do império que já havia sido perdido e evitar que outras cidades aliadas se desvinculassem), não só em jeito de agradecimento pela «bondade» do povo, mas sobretudo (pensamos nós) para mostrar as suas capacidades e ter um regresso apoteótico ${ }^{396}$ (Alc. 27.1).

Perante esta conjuntura, Alcibíades revela todo o seu potencial ${ }^{397} \mathrm{e}$, arriscamos dizer, age, pela primeira vez, «oficialmente» em favor da sua cidade, fazendo-lhe um bem proporcional (ou até maior) às suas capacidades e ao mal que lhe fizera. Esta mudança de comportamento no exílio acaba por transformá-lo em algo de positivo para Atenas, que volta a beneficiar do excelente general que Alcibíades era ${ }^{398}$. Importa notar que, ao contrário de Péricles - que tinha uma estratégia bem delineada para levar a Guerra do Peloponeso a bom porto ${ }^{399}$-, a ação de Alcibíades é uma resposta direta a cada acontecimento com que se depara. Já havíamos visto ${ }^{400}$ que a ação por reação é um traço do comportamento deste Alcmeónida que, por norma, lhe permite alcançar grandes sucessos. Aliás, Plutarco parece até entender que o reconhecimento do valor de Alcibíades enquanto general resulta de este ter sido bem sucedido de todas as vezes em que defendeu as causas de Atenas e dos grandes danos que lhe provocou quando passou para o lado do inimigo ${ }^{401}$.

Através desta estratégia de reação, o general consegue devolver a Atenas o império marítimo, que então se encontrava reduzido a uma ínfima parte do que fora no tempo de Péricles. No entanto, a sua primeira intervenção

${ }^{395} \mathrm{O}$ decreto através do qual os Atenienses chamam Alcibíades de volta data de 411 a.C. e foi proposto por Crítias, filho de Calescro (um poeta trágico e lírico), segundo o testemunho de uma elegia da sua própria autoria (Alc.33. 1). Sobre este assunto, vide Hatzfeld (1940: 256-258).

${ }^{396}$ Sobre a postura de Alcibíades por ocasião do regresso a Atenas, vide infra p. 298.

397 Ninguém ousaria negar que, enquanto estratego, o Alcmeónida era excelente a planear esquemas para alcançar os seus objetivos. Só se lhe pode apontar como defeito o facto de não ter colocado essa capacidade exclusivamente ao serviço da população, como Péricles. O seu único intuito foi sempre satisfazer o seu ego: saciar a sede de vingança, zelar pela sua segurança pessoal ou, quando cansado do exílio, regressar a casa.

${ }^{398}$ Verdegem (2005: 176).

${ }^{399}$ Sobre a estratégia de Péricles, vide supra p. 277.

${ }^{400}$ Cf. supra p. 286.

401 Nenhum ateniense jamais fez um percurso tão recriminável. O próprio Temístocles, quando procurou a proteção dos Persas, recusou-se a cumprir a promessa feita ao Rei de agir contra Atenas. Quando aquele lha cobrou, o Ateniense, em atitude de grande nobreza, preferiu suicidar-se a trair a própria pátria (Them. 31. 4-5). 
pró-Atenas, que ocorre durante a batalha naval de $\mathrm{Abido}^{402}$, esteve muito próxima de surtir o efeito contrário, naquilo que podemos considerar um exemplo vivo da fábula em que o pastor, depois de tantas vezes anunciar a falsa presença do lobo, acaba por não ser ajudado quando realmente é atacado. Alcibíades esteve tanto tempo ao lado dos Lacedemónios e contra Atenas que, quando se dirige ao Helesponto ${ }^{403}$ para ajudar os concidadãos que perseguiam o inimigo, o primeiro impulso de ambas as partes é achar que o Alcmeónida vinha em socorro de Esparta ${ }^{404}$. Consequentemente, os Lacedemónios recobram o ânimo e os Atenienses ficam inquietos, até ao momento em que se apercebem da sua real intenção. Então, Alcibíades obriga a frota lacedemónia a dirigir-se para a costa, o que permite que muitos homens se salvem a nado e que Farnábazo ${ }^{405}$ lhes preste auxílio por terra. No entanto, os Atenienses acabam por sair vitoriosos ${ }^{406}$ de uma batalha a que Plutarco se refere como

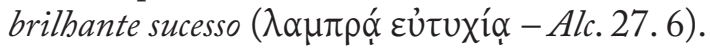

Tal facto dá azo a que Alcibíades perca, por momentos, a lucidez por que vinha pautando a sua atividade desde que fora nomeado estratego pelos Sâmios: decide ir vangloriar-se junto de Tissafernes, levando consigo um cortejo digno de um general e diferentes presentes de hospitalidade. Este retrocesso tem uma dupla consequência: por um lado, demonstra, mais uma vez, que Alcibíades age em conformidade com as circunstâncias sem que o seu

${ }^{402}$ Cf. X. $H G$ 1.1. 6; D. S. 13. 46. 3. Note-se que as fontes em causa atribuem o sucesso de Alcibíades à superioridade numérica dos Atenienses, informação que Plutarco omite para dar ênfase à coragem e à capacidade empreendedora do Alcmeónida enquanto general. Abido era o melhor porto da costa asiática do Helesponto. Depois da vitória de Atenas sobre os Persas, passou a fazer parte do império ateniense até 411 a.C., ano em que se revoltou (Thuc. 8. 61-62). Para mais informações, consulte-se Hammond - Scullard (1992: s. v.).

${ }^{403}$ Esta batalha naval ocorre em 410 a.C. Enquanto Plutarco afirma que Alcibíades se dirige consciente e propositadamente ao Helesponto para ajudar os concidadãos (Alc. 27. 2), outras fontes (X. $H G$ 1.1.5) afirmam que não foi intencional.

${ }^{404}$ Esta batalha é descrita por D. S. 13. 45. 6- 46. 3. Quanto ao número de trirremes que Alcibíades trouxe consigo, cf. X. $H G$ 1.1.5.

${ }^{405}$ Este filho de Farnaces foi, por herança, sátrapa da Frígia. Tal como Tissafernes, procurou cumprir as instruções que tinha para recuperar o controlo das cidades gregas da Ásia. Para isso, aliou-se a Esparta e interveio em Abidos, Cízico e Calcedónia. Foi o responsável pela morte de Alcibíades a pedido de Lisandro. Como pagamento pela sua colaboração, viu o seu território invadido pelos Lacedemónios pouco depois. Sobre este persa, vide Hammond - Scullard (1992: s. v.) e bibliografia aí mencionada. X. $H G$ 1. 1.6 e D. S. 13. 46. 4-5 terão servido de fontes a Plutarco para o relato da perseguição que Alcibíades moveu contra o inimigo e do auxílio que Farnábazo lhe prestou.

${ }^{406}$ É provável que a experiência adquirida com este recontro tenha estado na base do maior cuidado que colocou na batalha de Cízico, durante a qual tudo fez para minimizar a possibilidade de fuga e os efeitos do previsível auxílio que os Lacedemónios receberiam por terra (cf. página seguinte). Esta preocupação vai ao encontro da perspetiva de Péricles, que defendia que Atenas deveria basear as suas investidas contra Esparta em ataques marítimos: é que a superioridade ateniense era maior nesse campo, ao passo que os Lacedemónios se distinguiam nos combates terrestres. 
caráter tenha sofrido qualquer transformação de fundo $\mathrm{o}^{407}$; por outro, coloca-o em situação embaraçosa, bem merecida por quem, não obstante o seu mérito, não sabe ser humilde e corre em busca de aplausos e do reconhecimento da sua superioridade. De facto, do mesmo modo que, outrora, o povo ateniense e os Lacedemónios o traíram e abandonaram por inveja, em atitude que contrariava os mimos a que estava habituado por parte daqueles, também Tissafernes o rejeitou, porque não queria provocar o descontentamento dos Lacedemónios e a fúria do Rei. No entanto, não é alheia a esta mudança de posição o ciúme que o sátrapa sentia do jovem e que teria alcançado o seu limite com o «brilhante sucesso» de que o Alcmeónida se viera vangloriar. Por isso, mandou encarcerar Alcibíades em Sárdis ${ }^{408}$, com o intuito de dissipar qualquer suspeita de favorecimento. O Persa, contudo, parece não ter avaliado bem o adversário com o qual estava a lidar, embora conhecesse o seu passado. Alcibíades não tinha perfil de quem se resigna e/ou de quem perdoa traições sem dar o troco. Em menos de um mês, escapa da prisão, refugia-se em Clazómenas ${ }^{409}$ e paga a afronta de Tissafernes na mesma moeda, fazendo correr o boato de que aquele lhe facilitara a fuga.

Apesar do contratempo, Alcibíades continuava empenhado na sua missão e depressa parte de Clazómenas para se juntar aos Atenienses e inteirar-se da situação. Ao tomar conhecimento da presença de Míndaro e de Farnábazo em Cízico, incita os soldados ao combate e à vitória completa por terra e por mar. A sua estratégia passava por uma aproximação discreta do inimigo ancorado na região do Proconeso ${ }^{410}$, de modo a que este fosse surpreendido pela sua chegada. Nesta ocasião concreta (Alc. 28.4), Alcibíades teve a natureza do seu lado: quando menos se esperava, começou a chover ${ }^{411}$, a trovejar e formou-se um intenso nevoeiro, o que ajudou a encobrir a manobra de aproximação. Mas, para a vitória, mais importante do que o contributo da natureza foi a inteligente estratégia de Alcibíades, que conseguiu neutralizar antecipadamente a potencial superioridade do adversário em combates terrestres ${ }^{412}$. Com esta

${ }^{407}$ Sobre este assunto, vide supra p. 266-268.

408 Ainda que o encarceramento de Alcibíades também seja mencionado em X. HG 1.1.9, apenas Plutarco avança a razão da visita do Alcmeónida ao sátrapa e os motivos que levaram este último a fazer do Ateniense seu prisioneiro.

409 Clazómenas acaba por ser uma cidade de extrema importância para os dois Alcmeónidas: além de ter oferecido refúgio a Alcibíades em um momento de grande necessidade, presenteara Péricles com o filósofo Anaxágoras, que teve, como já vimos (supra p. $178 \mathrm{sqq}$ ) um papel determinante na formação do estadista e na sua conduta enquanto tal. Em X. $H G$ 1. 1. 11, afirma-se que Alcibíades parte de Clazómenas, em D. S. 13. 49.3 diz-se que vem de Lesbos.

${ }^{410}$ Em D. S. 13. 49. 3, tal estratégia é atribuída aos generais atenienses e não apenas a Alcibíades. Estamos, assim, perante uma liberdade do biógrafo, que pretende realçar o papel desempenhado por Alcibíades nas campanhas em que participou antes de regressar a Atenas.

${ }^{411}$ Cf. X. $H G$ 1.1.16. Cf. supra p. 280.

${ }^{412}$ Quando os Atenienses iniciaram a investida contra os Lacedemónios, estes tinham as 
vitória, Atenas assenhorou-se da frota inimiga presente em Cízico e da própria cidade, recuperou o domínio sobre o Helesponto, expulsou os Lacedemónios do resto do $\operatorname{mar}^{413}$ e recuperou psicologicamente do desastre da Sicília. Mas, mais do que isso, minou a autoconfiança e a crescente soberba de Esparta, a ponto de os sobreviventes terem afirmado:

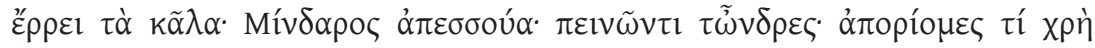
$\delta \rho \tilde{\alpha} v^{414}$.

“a frota está perdida; Míndaro morreu ${ }^{415}$; os soldados têm fome; não sabemos o que fazer."

De acordo com esta descrição, Alcibíades cumprira, ainda que não em definitivo, o seu intento e seguramente também o objetivo que Péricles visara com a sua estratégia.

Com o desespero lacedemónio contrasta a euforia e empáfia dos soldados que combateram ao lado do Alcmeónida e que terão sido acometidos do «mal de orgulho» que o caracterizava. Se nos referimos ao estado de espírito destes homens é porque nos parece oportuno refletir sobre o tipo de relação que uniu cada um dos Alcmeónidas aos seus companheiros de armas. Já o fizemos na perspetiva general/soldado, quando mencionámos o cuidado que Péricles (e Alcibíades a seu modo) tinha de evitar que os seus homens corressem riscos desnecessários ou a preocupação com o seu treino militar e remuneração condigna (Per.11.4). É chegado o momento de abordar a forma como os soldados se relacionavam com os seus superiores hierárquicos. No que a Péricles diz respeito, Plutarco não dá qualquer informação específica, fala apenas no reconhecimento geral da população. Mas, em relação a Alcibíades,

suas embarcações ancoradas no porto de Cízico, o que lhes permitiria procurar refúgio em terra mal se apercebessem da dimensão da presença do inimigo. Perspicaz, Alcibíades ordena que os demais estrategos permaneçam na retaguarda e avança, ele próprio, com quarenta navios para desafiar o inimigo. Ora este, ao ver tão reduzido número de embarcações, agarra o isco do Alcmeónida, pois sobrevaloriza a sua superioridade e desdenha do adversário, comprovando a tese de que a confiança em excesso pode causar grandes males. A carnificina que se seguiu foi enorme, porque Alcibíades aprendera por experiência que não devia facilitar o acesso dos Lacedemónios à terra durante um combate. Escorregadio por natureza, o Ateniense fura por entre a frota lacedemónia com vinte das suas melhores embarcações e impede a fuga por terra do adversário. Cf. D. S. 13.50.1-4.

${ }^{413}$ Plu. Alc. 28. 9. Cf.X. HG 1.1.14-18, D. S. 13.50 e Hatzfeld (1940: 271-274). Esta vitória, que ocorre em 410 a.C., foi decisiva para o regresso de Alcibíades a Atenas.

${ }^{414}$ Alc. 28. 10. Esta informação de caráter telegráfico, ou - se preferirmos - lacónico, foi recolhida de uma mensagem que os vencidos enviaram para Esparta em dialeto lacónico e que os Atenienses intercetaram. Cf. X. $H G$ 1.1.23.

${ }^{415}$ Sobre a morte de Míndaro e a fuga de Farnábazo, vide D. S. 13. 50.5 - 51. 7; X. HG 1. 1.18 . 
o caso muda de figura, muito provavelmente por causa da especificidade desta biografia ${ }^{416}$. Assim, o Queroneu alude à fidelidade e admiração que unia os soldados ao filho de Clínias (Alc. 19.4) e também ao orgulho que sentiam por combater ao seu lado (Alc. 34. 7). Na sequência da batalha de Cízico, ficamos, como já dissemos, com a impressão de que se tornam orgulhosos por contágio: recusam-se a conviver com os soldados que combatiam sob as ordens de Trasilo, por se considerarem invencíveis e superiores desde que sob o seu comando ${ }^{417}$. O mesmo sentimento invade os seus soldados, quando, de volta a Atenas, reestabelece a procissão de Elêusis ${ }^{418}$.

Mas as intervenções militares de Alcibíades antes do regresso a Atenas ainda não tinham terminado. Logo a seguir à batalha de Cízico, os Calcedónios resolvem também eles desertar. Alcibíades avança contra a cidade, mas é surpreendido pelo golpe de mestre dos dissidentes que, por precaução, enviaram tudo o que corria o risco de ser objeto de saque para a região de Bitínia, que era sua aliada. Os Atenienses sitiam, então, a Calcedónia e dirigem-se a Bitínia com um arauto. Intimidados por aqueles, os habitantes locais entregam os bens que estavam na sua posse e celebram uma aliança com Alcibíades ${ }^{419}$. Entretanto, Farnábazo e o harmosta Hipócrates ${ }^{420}$ unem esforços para libertar a Calcedónia do cerco. O Alcmeónida põe o primeiro em fuga e torna-se responsável pela morte de muitos espartanos ${ }^{421}$, de entre os quais Hipócrates, o que nos permite dizer que também Alcibíades, à semelhança do que fora sugerido em relação a Péricles ${ }^{422}$, passa por uma fase de invencibilidade que, no seu caso, se prolonga até ao momento em que confia a armada a Antíoco.

Resolvido o problema com os Calcedónios, Alcibíades regressa ao Helesponto para arrecadar mais contributos e conquistar Selímbria ${ }^{423}$. Este episódio é significativo, porque nos revela um Alcibíades contraditoriamente igual a si mesmo. É certo que estamos habituados a um homem de

${ }^{416}$ Não traça propriamente um perfil de Alcibíades, já que este tem uma personalidade difícil de definir, mas procura sugerir a opinião controversa e variável que o seu caráter desperta nas pessoas.

${ }^{417}$ Cf. X. $H G$ 1.1.15; D. S. 13. 66. 1. Trasilo e os seus homens haviam sofrido pouco antes uma pesada derrota em Éfeso, na sequência da qual os Efésios erigiram um troféu que muito envergonhou os Atenienses (X. HG 1.2.7-10; D. S. 13.64.1 - segundo este último, o general em causa chama-se Trasibulo e não Trasilo). Note-se, contudo, que esta desavença entre os militares de Atenas viria a ser rapidamente superada: é que, pouco depois, Alcibíades e Trasilo juntos puseram em fuga Farnábazo, que os atacara na região de Abidos. Nessa mesma noite, os soldados reconciliaram-se (cf.X. $H G$ 1.2.15-17).

${ }^{418}$ Sobre este assunto, vide infra p. 217

${ }^{419}$ Cf. X. $H G$ 1.3. 2-3.

${ }^{420}$ Este era filho de Míndaro. Cf. D. S. 13.66.2.

${ }^{421}$ Cf. D. S. 13. 66. 2

${ }^{422}$ Supra p. 273.

${ }^{423}$ Sobre a conquista de Selímbria, X. HG 1. 3. 10; Hatzfeld (1940: 283-284). O relato de Plutarco é mais pormenorizado do que os de Xenofonte e Diodoro Sículo. 
comportamentos inesperados, mas, tendo em conta todo o seu historial de indivíduo zeloso pela sua segurança ${ }^{424}$, seria de prever que não arriscasse demasiado. No entanto, o Alcmeónida mostra-se, mais uma vez, um ateniense legítimo: quanto maior o desafio, quanto maior o perigo a enfrentar, maior a intrepidez com que age ${ }^{425}$. É que um dos conjurados revela intenções de trair o plano estabelecido com Alcibíades, pelo que os demais se veem forçados a antecipar a execução do estratagema. O Alcmeónida é apanhado de surpresa e fica em situação de grande perigo; mas o seu orgulho e o seu estado de invencibilidade até àquele momento impedem-no de fugir. A sua postura e

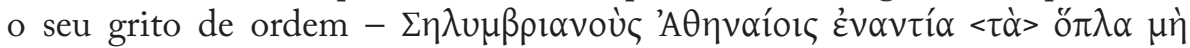
$\tau i ́ \theta \varepsilon \sigma \theta \alpha l^{426}$ - inflamam o ardor dos seus soldados e despertam nos habitantes daquela cidade esperança de um entendimento (Alc. 30. 8).

Os Atenienses celebram a paz com Farnábazo, em representação da Calcedónia, e exigem que esta permaneça submissa a Atenas e pague uma indemnização; que Farnábazo garanta segurança à embaixada que os Atenienses pretendem enviar ao Rei e, prometem, em troca, poupar a região dominada pelo sátrapa (Alc. 31. 1). No contexto da celebração do acordo de paz, Alcibíades revela, mais uma vez, uma certa semelhança com Péricles, que tem o hábito de se negar a ceder, ou se preferirmos, a mostrar-se complacente diante do inimigo. Como já vimos, o filho de Xantipo considerava que um gesto de simpatia/cortesia podia ser entendido pelo adversário como um sinal de fraqueza ${ }^{427}$. Do mesmo modo, Alcibíades, desafiado por Farnábazo a jurar o tratado de paz (que havia sido acordado pelos concidadãos, mas que devia ser ratificado por ele ${ }^{428}$ ), recusa-se, em um gesto de cortesia irónica, a fazê-lo sem que o seu interlocutor o faça primeiro.

Ultrapassados os problemas em Selímbria, Alcibíades ainda marcha contra a desertora Bizâncio, que acaba por se render ${ }^{429}$. Mas, igual a si mesmo, já não conseguia adiar o reencontro com a pátria nem a exibição da sua glória. O momento da sua chegada a Atenas reveste-se de particular importância, na medida em que revela um novo Alcibíades e o caráter da população. $\mathrm{O}$ Alcmeónida que então se apresenta aos olhos dos Atenienses, apesar de orgulhoso dos seus feitos e consciente do reconhecimento que lhe era devido, participa, segundo Plutarco, em um cortejo digno de um general ${ }^{430}$ que obteve

${ }^{424}$ Sobre este assunto, vide supra p. 235.

${ }^{425}$ Este comportamento é comparável ao gesto que teve para com Sócrates na batalha de Délio (Alc. 7. 6), salvando-o, quando todo o exército ateniense debandava diante do inimigo. Supra pp. 195-196.

${ }^{426}$ Que os Selímbrios não peguem em armas contra os Atenienses!

${ }^{427}$ Cf. supra pp. $278-279$.

${ }^{428}$ Alcibíades não participou desde o início na reunião da qual saiu o tratado de paz, porque estava ocupado com a conquista de Selímbria - X. HG 1.3.10

${ }^{429}$ Sobre a rendição de Bizâncio, supra pp. 218, nota 38 e 269, nota 265.

${ }^{430} \mathrm{O}$ cortejo é descrito de forma muito próxima em D. S. 13.68.2. 
as suas vitórias, mas sem a ostentação que seria de esperar, sobretudo em se tratando de Alcibíades. Esta perspetiva do biógrafo é contrariada por Dúris de Samos, que fala em um regresso triunfal excessivo. O Queroneu atribui esta posição de exagero ao facto de Dúris se considerar descendente do Alcmeónida ${ }^{431}$. Plutarco justifica a sua posição com um argumento pertinente: apesar da aparente reconciliação, Alcibíades já não era ingénuo a ponto de acreditar que o povo estaria sempre ao seu lado. Por isso, ter-lhe-á parecido mais prudente não desafiá-lo nem suscitar inveja pela glória alcançada com um retorno exibicionista. O receio que acompanhava o Alcmeónida no regresso só se dissipa quando avista em terra parentes e amigos que festejam e o incitam a desembarcar ${ }^{432}$. O gáudio dos seus familiares e amigos era extensível à multidão, que já se esquecera dos desentendimentos anteriores e corria na sua direção com flores e gritos de alegria. Até os mais velhos, que antes se mostravam receosos em relação a ele, fazem questão de apontá-lo aos mais novos. Com a sua curta memória, os Atenienses recebem-no como se fosse o único estratego responsável pelo sucesso alcançado, afirmando que lhes restituíra o império marítimo quase perdido ${ }^{433}$ (Alc. 32.4).

A postura que Plutarco assume diante deste «novo» Alcibíades é muito próxima deste sentimento do povo. De facto, no caso desta vida, o biógrafo faz um aproveitamento muito especial das fontes ${ }^{434}$, com o intuito de reforçar a importância do contributo do Alcmeónida para o vigor que, qual moribundo, Atenas alcançou antes do desastre final. Isso acontece, a título de

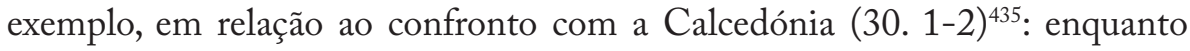
o Queroneu atribui a ação apenas a Alcibíades, Diodoro Sículo (13. 66. 1) menciona a intervenção igualmente importante de outros dois generais

${ }^{431}$ Embora o cite algumas vezes, nomeadamente em Per. 28. 2-3 e em Alc. 32. 2, o biógrafo costuma discordar dos seus testemunhos, acusando-o de falta de isenção e de diferirem de outros mais credíveis como os de Tucídides e de Éforo (em relação a Péricles) e os de Teopompo, Éforo e Xenofonte (em relação a Alcibíades). Segundo Dúris de Samos (FGrHist 76 F 6), o navio

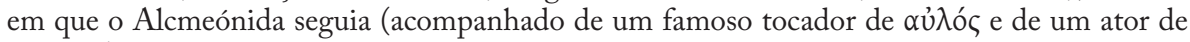
tragédia) trazia hasteada uma bandeira de cor púrpura. Plutarco acrescenta que o músico e o

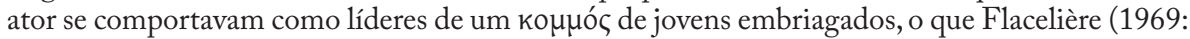
248 ) atribui à influência de P1. Symp. 212c-d, texto no qual Platão menciona a participação de

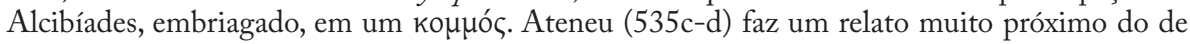
Dúris, que lhe serviu de fonte.

${ }^{432}$ Cf. X. $H G$ 1. 4. 18-19.

${ }^{433}$ Cf. Nep. Alc. 6. 1; X. HG 1. 4.13; D. S.13.69.1. Sobre a chegada de Alcibíades, consulte-se Salcedo Parrondo (2001: 223-250).

${ }^{434}$ De acordo com Alc. 32. 2, podemos inferir que as principais fontes para esta fase da biografia são Éforo, Teopompo e Xenofonte.

${ }^{435}$ Vide Verdegem (2005: 170-171). 
atenienses, Trasibulo ${ }^{436}$ e Terâmenes ${ }^{437}$. Além disso, para sobrevalorizar o mérito de Alcibíades ${ }^{438}$, Plutarco afirma que este se defrontou em simultâneo com as tropas comandadas por Farnábazo e Hipócrates; Xenofonte ( $H G 1$. 3. 7), no entanto, afirma que Farnábazo se vira obrigado a retirar-se para o Heracleion, porque os Atenienses haviam erigido um muro que o impediu de se juntar a Hipócrates. Mas foram diversas as situações em que Plutarco omitiu comentários de outros autores que, de algum modo, desmereciam o valor de Alcibíades: disso são exemplo a retirada bem sucedida de Hipócrates da Calcedónia (X. HG 1.3.6; D. S. 13.66.2), que o biógrafo não menciona em Alc. 30.1-2, ou a ausência de Clearco quando Alcibíades tomou Bizâncio (X. $H G$ 1.3.17; D. S. 13.66. 6), a que não faz referência em Alc.31.3-6.

Do mesmo modo que Péricles, ao regressar de Samos, profere uma oração fúnebre celebrizada por Tucídides ${ }^{439}$, também Alcibíades sobe à tribuna (Alc. 33 . $\left.2^{440}\right)$. No primeiro caso, talvez por causa da fama que o discurso do filho de Xantipo alcançara, Plutarco apenas lhe faz uma breve referência e concentra-se na crítica que Elpinice lhe tece por ter escolhido um povo grego para seu inimigo ${ }^{441}$. No segundo, o biógrafo aborda o assunto com mais pormenor. Primeiro, apresenta-nos um Alcibíades que chora de arrependimento pelas suas faltas. Não chegamos, contudo, a ser capazes de avaliar a sinceridade do gesto: as suas lágrimas seriam fruto do amadurecimento que sofreu durante o exílio ou apenas uma estratégia demagógica para provocar no povo uma consternação maior pela perseguição que lhe havia movido? Se o objetivo era esse, podemos considerar que, de imediato, se esforçou por aliviar a tensão que poderia aumentar em crescendo se insistisse em responsabilizar a turba pela sua má sorte. Por isso, o Alcmeónida atribui o seu infortúnio ao azar e à divindade ciumenta ${ }^{442}$, e incentiva o povo, ao qual pretende dar esperança, a acreditar que dias melhores virão. Este cuidado que o Alcmeónida manifesta em revigorar o ânimo dos concidadãos foi algo que também caracterizou o governo de Péricles, que sempre tentou encorajar os Atenienses nos momentos mais difíceis (cf. supra p. 309). Parece-nos, no entanto, mais uma daquelas reações que o Alcibíades do período que precedeu o exílio não teria tido, pelo menos com igual empenho.

${ }^{436}$ Foi responsável pela organização da revolta contra os oligarcas e pela promoção do regresso de Alcibíades. Em 410 a.C., participou com o Alcmeónida na batalha naval que opôs Atenienses e Lacedemónios em Míndaros.

${ }^{437}$ Tomou parte no golpe que ocorreu em Atenas em 411 a.C. e fez parte do Conselho dos Quatrocentos. Enquanto general, assistiu à conquista de Bizâncio. Sobre a sua popularidade, vide $R a$ 538-541.

${ }^{438}$ Plutarco também exagera o mérito de Alcibíades na batalha de Abido. Vide supra p. 292, nota 402 .

439 Thuc. 2. 34 .

${ }^{440}$ Do mesmo discurso nos dão testemunho X. HG. 1. 4. 20; D. S. 13. 69.1 e Nep. Alc. 6. 4.

${ }^{441}$ Supra p. 185 , nota 104.

${ }^{442}$ Sobre a intervenção da divindade ou da Fortuna, vide supra p. 285, nota 354. 
$\mathrm{Na}$ sequência desse discurso, Alcibíades foi eleito estratego com plenos poderes, viu os seus bens serem-lhe restituídos e retratadas as maldições. Este regresso triunfante ${ }^{443}$ sugere que a tensão que existia entre o estratego e as massas se havia dissipado por causa da sua mudança de comportamento ${ }^{444} \mathrm{e}$ que este reconquistara a sua popularidade por causa dos triunfos que alcançou, enquanto general, no Oriente ${ }^{445}$, de acordo com a estratégia que planeara para regressar a casa em glória ( $̇ ̉ \delta o ́ \xi \omega \varsigma$ - cf. Alc. 32. 1). No entanto, o Queroneu afirma que o Alcmeónida continuava a causar incómodo ${ }^{446} \mathrm{e}$ a ver as suas ações associadas a maus presságios. Neste caso concreto, o dia do seu regresso ${ }^{447}$ coincidiu com as Plintérias (Alc. 34. 1-2), o que parecia sugerir que Atena não o via com bons olhos. Ainda assim, tudo parecia correr a contento de Alcibíades. Este episódio acaba por ser um reflexo do que foi toda a vida deste estadista: tudo corre segundo os seus planos até ao momento em que a situação se inverte e ele cai em desgraça.

Antes de voltar para a frente de batalha, Alcibíades tem um magnífico gesto de pietas erga deos, que, de certo modo, lhe permite retratar-se aos olhos dos deuses e dos homens pela ridicularização das cerimónias de Elêusis ${ }^{448}$ : decide oferecer a todos quantos participavam nessas festividades a segurança necessária para que se pudesse voltar a realizar o cortejo por terra, algo que a Guerra do Peloponeso há muito impedia. Aos seus olhos de estratego, a tarefa não seria difícil, porque o inimigo seria forçado a deixá-los passar tranquilamente sob pena de se envolver em uma guerra santa. No entanto, por trás desta decisão, que resulta em outra afronta a Ágis, está também o intuito de levar a cabo mais um ato que permita ampliar a sua fama.

A verdade é que este foi, de acordo com o relato de Plutarco, o seu último grande momento de glória, não porque se esforçasse menos ou sofresse

${ }^{443}$ Foram duas as vezes em que Alcibíades entrou em Atenas nestas circunstâncias: esta e a primeira, quando se sagrou vencedor dos Jogos Olímpicos. Sobre este assunto, cf. supra pp. 197-198.

${ }^{444}$ Alc. 32.3. Cf. X. $H G$ 1. 4.13-16 e D. S. 13. 68. 4.

${ }^{445}$ Alc. 32. 4. Cf. Nep., Alc. 6.1-2; X. HG 1. 4.13-19; D. S. 13.68. 2 - 69.1

${ }_{446}$ Segundo Plutarco, eram poucos (Évíous - Alc. 34. 1) os que não partilhavam dessa alegria, nomeadamente o sacerdote Teodoro (Alc. 33. 3). Em X. HG 1. 4. 17, é apontado como responsável por desgraças passadas e futuras por aqueles que não viam o seu regresso com bons olhos. Sobre o desconforto que o regresso de Alcibíades provocou, vide Salcedo Parrondo (2005: 223-258).

${ }^{447}$ Cf. X. HG. 1. 4. 12. Alcibíades desembarcou no Pireu a 25 de maio (Targélion) de 407 a.C. Anualmente nessa data, procedia-se à lavagem ritual do $\pi \dot{\varepsilon} \pi \lambda$ o५ de Atena. Sobre esta cerimónia, consultem-se Nagy (1994: 275-285); Salcedo Parrondo (2005). Nagy avança a hipótese de o Alcmeónida ter regressado nesse dia na sequência de um engano engendrado pelos seus inimigos políticos. Estes ter-lhe-iam feito crer, a ele que não era muito atento no que diz respeito a datas de festividades sagradas, que as Plintérias já haviam ocorrido.

${ }^{448}$ Cf. X. $H G$ 1. 4. 20. Sobre a restauração do cortejo de Elêusis, vide Salcedo Parrondo (2005) e, principalmente, Verdegem (2001: 451-459). 
derrotas, mas porque os Atenienses, mais uma vez, o impediram de agir em favor da cidade. Com efeito, assustados com o facto de a reposição do cortejo ter ampliado o apreço dos Atenienses pelo Alcmeónida ${ }^{449}$, os cidadãos mais influentes tudo fizeram de modo a apressar a sua partida para a frente de batalha ${ }^{450}$ (Alc. 35. 1). Mas, uma vez em ação, Alcibíades, que já mostrara ser capaz de alcançar os mais inesperados sucessos, não apresentou logo resultados que correspondessem às enormes expectativas que os Atenienses tinham criado. O simples facto de não ter tomado de imediato Andros, Quios e o resto da Iónia foi visto como um gesto de falta de interesse e de empenho ${ }^{451}$. Parece-nos que a rapidez com que os Atenienses se sentiram defraudados se prende ao facto de Alcibíades ser alguém a quem foi dada uma segunda hipótese ${ }^{452}$ e que, por isso, já não era merecedor de confiança plena.

Diante das circunstâncias, e do historial da sua relação, os Atenienses, que se caracterizam pela velocidade de decisão e ação (nem sempre bem sucedida), não podiam contemporizar, pois tentar compreender por que razão Alcibíades não apresentava logo os resultados esperados poderia significar que the estavam a dar tempo para pôr de novo em prática planos danosos para a cidade. Simultaneamente, para quem estivesse longe do cenário de guerra e fosse, como os cidadãos, um «recipiente» que acolhia com facilidade todo o tipo de intrigas que dissessem respeito a um político, a contemporização de Alcibíades só podia ser lida como falta de empenho, porque todos lhe conheciam a crença excessiva nas suas capacidades, que era tão forte que parecia ter o condão de tornar os seus objetivos concretizáveis ${ }^{453}$.

Estas desconfianças dos Atenienses foram agravadas pela derrota sofrida quando Alcibíades se ausenta e confia o comando a Antíoco ${ }^{454}$ e pelo facto de o Alcmeónida ter construído uma fortaleza na Trácia (Alc.36.3), que foi entendida como um sinal de que este não podia nem queria viver em Atenas. Mais uma vez, Alcibíades é afastado do comando militar pela fúria dos concidadãos, profusamente instigada pelos seus inimigos políticos ${ }^{455}$. Deparamo-nos, então,

${ }^{449}$ Vide p. 217.

${ }^{450} \mathrm{O}$ Alcmeónida nomeou os colegas que queria que o acompanhassem. Em D. S. 13. 69. 3 e Nep.Alc. 7.1, somos informados de que indicou Adimanto e Trasibulo.

${ }^{451}$ Nem Xenofonte (HG 1.4.22) nem Diodoro Sículo (13.69.4) referem o efeito que o facto de não tomar Andros provocou. Em contrapartida, revelam, respetivamente, que o Alcmeónida, após a vitória, partiu para Samos ou para Cós e Rodes. Em Alc. 35. 3, Plutarco parece concordar com o povo, pois afirma que nada do que interessava a Alcibíades lhe conseguia escapar. Esta ideia é partilhada por Nep. Alc. 7. 1-3.

452 Sobre este assunto, vide Duff (1999: 238); Gribble (1999: 55, 58-60, 281); Verdegem, (2005: 178).

${ }^{453}$ Cf. p. 280.

${ }^{454}$ Sobre este assunto, vide supra p. 255.

${ }^{455}$ Em Alc. 36. 1, Plutarco menciona o nome de Trasibulo, filho de Tráson. D. S. 13. 73. 6 não especifica nenhum nome, apenas refere que os delatores eram oriundos do acampamento. Diodoro Sículo e Cornélio Nepos (Alc.7.7.1-3) associam as acusações ao ataque de Alcibíades 
de novo com um Alcibíades cheio de medo. Desta vez, contudo, talvez por causa da experiência adquirida com a idade, não tem a mesma reação que por altura do exílio. Em vez de se voltar contra o seu povo, opta por ajudá-lo desinteressadamente, revelando nobreza de caráter.Primeiro, Alcibíades resolve aliar-se a um grupo de mercenários trácios e combater a expensas próprias, o que lhe permite enriquecer e proteger os Gregos da região das incursões dos Bárbaros. Depois, ao aperceber-se de que os estrategos atenienses adotavam uma estratégia perigosa ${ }^{456}$ (Alc. 36. 6), não consegue manter-se indiferente e tenta aconselhá-los ${ }^{457}$. Mas, estes, em um gesto ressabiado de quem teme vir a perder o lugar, reagem de forma insolente e não lhe dão ouvidos ${ }^{458}$. Desta feita, o Alcmeónida fica ferido no seu orgulho e decide não interferir mais, mesmo quando pressente a desgraça, algo que é confirmado por uma sua afirmação que, para não variar, provocou reações diversas. Alcibíades terá dito aos Atenienses que o acompanharam até à saída do acampamento que, se não tivesse sido ultrajado, teria obrigado os Lacedemónios ou a combater ou a abandonar a frota (Alc. 37. 2-3). Houve quem visse nas suas palavras a descrição de um plano possível de concretizar, mas também houve quem achasse que se tratava de mera fanfarronice (Alc.37.3).

O certo é que Alcibíades não interveio e Atenas sucumbiu, em pouco tempo, às mãos dos Lacedemónios comandados por Lisandro, que, com grande crueldade, esquartejaram os prisioneiros ${ }^{459}$, queimaram a frota inimiga $^{460}$ e destruíram os longos muros (Alc. 37. 4-5). E, como se tal não bastasse, entregaram a cidade aos Trinta. Os Atenienses têm, então, a infeliz oportunidade de se aperceber do erro cometido ao dirigirem, uma segunda vez, a sua cólera contra Alcibíades (Alc. 38.1).

Perece, assim, sem glória, durante a vida de Alcibíades, o império que atingira o auge da sua grandiosidade sob o domínio de Péricles.

a Cimes, que Plutarco não menciona.

${ }^{456}$ Mais uma vez fica claro que o excesso de confiança nas capacidades e o desleixo que dele resulta é a causa de muitos infortúnios. Sobre a estratégia (ou falta dela) dos Atenienses, que se limitavam a provocar o inimigo pela manhã e se dedicavam ao ócio à tarde, cf. X. $H G$ 2. 1 . 24-25.

${ }^{457}$ D. S. 13. 105. 3 e Nep. Alc. 7.8. 3 afirmam que Alcibíades lhes ofereceu a ajuda de dois reis trácios das suas relações, Médoco e Seutes, mas não mencionam estratégias de qualquer dos adversários.

${ }^{458}$ Esta informação que Plutarco menciona em Alc. 37. 2 tem por fonte D. S. 13. 105. 4. Xenofonte ( $H G$ 2.1.26), pelo contrário, é mais específico e indica o nome de dois generais que terão sido insolentes para com o Alcmeónida: Tideu e Menandro.

${ }^{459}$ Para mais informações sobre o destino dos Atenienses capturados como prisioneiros de guerra, vide X. $H G$ 2.1.30-32.

${ }^{460}$ De acordo com Xenofonte ( $H G$ 2. 1.29), do imenso contingente de trirremes de que Atenas dispunha, apenas nove escaparam. Plutarco fala em oito, porque não conta com a Páralo, que Cónon enviara a Atenas para anunciar a derrota. 
$\mathrm{Na}$ sequência desta derrota, Alcibíades volta a sentir medo ${ }^{461}$ dos Lacedemónios, os novos senhores da terra e do mar (Alc.37.2). Refugia-se na sua fortaleza da Bitínia, onde os seus bens são pilhados pelos Trácios. Decide, por isso, procurar novamente ajuda junto dos Persas, então governados por Artaxerxes. Desta vez não tinha a intenção de oferecer serviços contra os seus cidadãos, mas buscar auxílio para a pátria e contra os inimigos, pois não tinha meios para impedir os males que os Lacedemónios infligiam aos Atenienses. Sempre preocupado com a sua segurança, o Alcmeónida pede a Farnábazo que lhe sirva de intermediário e é tratado com honra por aquele que já fora um dos seus maiores inimigos ${ }^{462}$. Mas em breve o Alcmeónida seria traído pela derradeira vez, arrastando consigo a infeliz Atenas, que apesar de todo o mal que lhe fizera, ainda via nele a sua única hipótese de salvação (Alc.38.3).

${ }^{461}$ Sobre este sentimento que por diversas vezes assolou o Alcmeónida, vide supra p. 235.

${ }^{462}$ Cf. D. S. 14. 11; Nep. Alc. 9. Sobre a inimizade que opôs estes homens, que combateram várias vezes um contra o outro, vide supra p. 292 sqq. Alcibíades acreditava que Farnábazo lhe seria favorável, porque se dispunha a revelar ao Rei uma conspiração organizada por Ciro e pelos Lacedemónios (D. S. 14.11.2). 


\section{Morte}

Como não poderia deixar de ser, Plutarco tem por hábito consagrar alguns capítulos das suas biografias ao tratamento do contexto em que decorreu a morte do herói cuja vida está a tratar. De um modo geral, segue uma estrutura comum que contempla a descrição de tónol como as circunstâncias da morte, as exéquias, o local de sepultura e a referência ao impacto do desaparecimento do protagonista na comunidade e ao destino da família ${ }^{463}$. Curiosamente, nas Vidas que constituem o corpus do nosso trabalho, o Queroneu foge a esse padrão, o que é sugestivo do caráter de exceção de Teseu e dos Alcmeónidas.

No caso de Péricles, esta parte (constituída pelos capítulos 38 e 39) não segue os moldes gerais, porque Plutarco «se distraiu» com o elogio do estadista, com as reflexões sobre a sua importância política e com o excurso sobre o cognome de Olímpico ${ }^{464}$. É essa a razão que leva o biógrafo a, por exemplo, esquecer-se de mencionar as indicações relativas à sua sepultura ${ }^{465}$ - que seguramente visitou mais do que uma vez ${ }^{466}$. Além disso, os seus filhos legítimos já haviam morrido (também eles vítimas da peste - Per. 36) e o destino da companheira Aspásia e do filho ilegítimo de ambos já havia sido indicado (Per.24,32), logo nada havia a dizer sobre o destino dos seus familiares mais próximos.

$\mathrm{Na}$ Vida de Alcibiades, Plutarco omite igualmente os parâmetros em causa. Embora o biógrafo também não faça qualquer alusão à localização do túmulo deste Alcmeónida, esta era conhecida, já que Ateneu (574e), que afirma tê-lo visitado, o situa em uma aldeia chamada Melissa, na Frígia, onde aquele viveu os

${ }^{463}$ A estrutura desta parte final da biografia, bem como a organização dos textos das Vidas na generalidade, sugere a formação retórica de Plutarco. Sobre este assunto, consulte-se, por exemplo, Pérez Jiménez (1996: 257): "Parece seguir Plutarco, en primer lugar, un esquema que combina los tópicos retóricos fijados desde Isócrates y Jenofonte por la teoría del encomio biográfico, incardinado en las etapas cronológicas que marcan la evolución ético-política del personaje biografado. De acuerdo con este esquema, las referencias al үर́vo , padres, nacimiento, caracterización física y espiritual, formación e imitación, vocación pública, primeros hechos (que ejemplifican esa vocación y confieren al personaje la popularidad que posibilita su papel histórico como rey, legislador, militar o polítco), la ơkuń, la vejez, muerte, exequias y significado póstumo del biografado, pueden entrar en el relato por derecho proprio."

${ }^{464}$ Vide supra p. 212 sqq.

465 A referência às sepulturas é um topos comum às outras Vidas que escreveu, pelo que só assim se justifica este esquecimento. Segundo Pausânias (1. 28. 2-3), ficava próxima da Academia, junto às de Trasibulo, Cábrias e Fócio (cf. Cic. Fin. 5.5).

${ }^{466}$ Stadter (1989: 350). 
últimos dias da sua vida. No que concerne à ausência de dados relativos à sorte dos filhos, além do fator esquecimento, é provável que a omissão do Queroneu se deva ao facto de, ao longo da biografia, não ter dado grande importância à relação do Alcmeónida com a sua prole ${ }^{467}$. Já agora, não deixa de ser pertinente recordar a tendência dos Alcmeónidas para o amor de prostitutas, junto das quais acabam por falecer.

No que respeita às circunstâncias que envolvem a morte do herói, o Queroneu alude ao facto de Péricles ter sido, também ele, vítima da peste por cujo deflagrar o povo o responsabilizara ${ }^{468}$ (Per. 34. 5). No entanto, até a epidemia parece mostrar reverência diante deste político de exceção, pois manifesta-se de forma pouco comum. Regra geral, as pessoas acometidas desta doença eram atacadas de modo agudo e intenso. Em Péricles, a peste mostrou-se branda, mas prolongada, e em vez de o vitimar rapidamente, esgotou-lhe aos poucos o corpo e, ainda mais importante, a força do espírito. Como exemplo desta última situação, o biógrafo menciona o recurso de Péricles, que no auge das suas capacidades se mostrara avesso a superstições ${ }^{469}$, a amuletos ${ }^{470}$, comportamento considerado por ele pouco digno e tolice de mulheres. Esta sua atitude é apresentada pelo biógrafo como um exemplo dado por Teofrasto, na sua obra Ética ${ }^{471}$, para ilustrar a tese de que o sofrimento físico (ou a intervenção divina) é capaz de destruir a excelência moral. Apesar desta ligeira transformação do seu caráter, Péricles manteve-se consciente até ao final, como no-lo demonstra a alusão que o biógrafo faz a uma conversa que o estadista entabula com as visitas que elogiavam os seus feitos imponentes ${ }^{472}$, mas não aquela que considerava a sua principal virtude: ter zelado sempre pela vida dos concidadãos ${ }^{473}$.

Importa, contudo, interpretar a contemporização da peste para com Péricles na perspetiva dos seus opositores políticos. Para estes, o facto de a doença ter levado o seu tempo até provocar a morte do filho de Xantipo pode ser entendido como dar-lhe a provar um pouco do mesmo veneno. Por outras

${ }^{467}$ Supra pp. 245-246.

${ }^{468}$ Cf. supra p. 281.

${ }^{469}$ Sobre este assunto, supra pp. 181 e 281 sq.

${ }^{470}$ Os amuletos eram habitualmente usados por ocasião de doenças e febres (cf. Pl. R. 426b; Plu. Moralia 920B).

${ }^{471}$ Sobre este assunto, vide supra p. 181.

${ }^{472}$ Em Moralia 539D e 786E (por influência de X. Mem. 2. 1. 31), o Queroneu considera que a maior alegria de um homem provém não dos elogios recebidos, mas da contemplação das próprias obras levadas a cabo durante os períodos em que exerceu cargos, ou seja, do sentido de dever cumprido. Embora Plutarco não faça qualquer comentário nesse sentido, podemos considerar que Péricles é um daqueles privilegiados que alcança a felicidade suprema: no leito de morte, não só ouve os merecidos elogios, como ainda tem a hipótese de aludir àquele que entende ter sido o seu feito mais importante.

${ }^{473}$ Sobre este assunto, vide p. 264 sqq. 
palavras, do mesmo modo que o estratego enveredou por uma estratégia de sucesso previsível mas lenta para vencer a Guerra do Peloponeso, também a enfermidade que lhe seria fatal prolongou a sua intervenção.

Contrariamente a Péricles, que teve uma morte natural (apesar de poder ser considerada consequência da ação - ou traição - divina a que Péricles e Plutarco atribuem a responsabilidade pela falha da estratégia do Alcmeónida ${ }^{474}$ ), a de Alcibíades foi provocada pela traição humana, depois de uma série de tentativas falhadas dos seus inimigos para lhe retirar a vida. Como já vimos, a maneira de ser do filho de Clínias despertava sentimentos contraditórios em todos aqueles que o rodeavam, pelo que não surpreende que a sua morte interessasse a muitos. Por três vezes Alcibíades foi condenado à pena capital: a primeira, pelos próprios concidadãos, feridos na sua soberania e no seu orgulho, porque Alcibíades não acatou a voz de prisão que lhe deram (Alc.22.3); a segunda por Ágis, que lhe dera abrigo aquando da condenação de Atenas, mas que entretanto também já não conseguia suportar a presença e a glória de quem lhe maculara o leito e lhe roubava os louros dos êxitos militares conseguidos contra Atenas (Alc. 24. 4). Desta feita, o Alcmeónida, avisado por alguns amigos, conseguiu discretamente escapar à morte sob a proteção dos Persas, representados por Tissafernes. Nessa altura, ficamos com a impressão de que havia sempre alguém pronto a acudir-lhe. Mas, como diz o povo, «à terceira foi de vez!» De facto, das duas vezes anteriores, a sua condenação à morte havia sido decretada sobretudo pelo mal da inveja ${ }^{475}$. No entanto, no momento da derradeira sentença, a esse mal somou-se o perigo que o Alcmeónida constituía não só para o poderio recém-conquistado por Esparta, como também para a permanência no comando de Atenas daqueles que ficaram conhecidos como os Trinta: é que Alcibíades, embora os concidadãos ainda estivessem de relações cortadas consigo, era visto pelos Atenienses como única

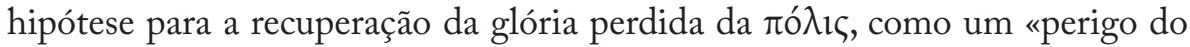
foco da resistência democrática», para utilizar a expressão de Duff (1999: 240). Logo, para os inimigos, era um alvo a abater e a sua morte uma questão de Estado ou de segurança nacional (Alc. 38.5). De início, apesar de incitado pelos Trinta na pessoa de Crítias, Lisandro nada $\mathrm{fe}^{476}$. Contudo, quando recebeu ordens superiores dos Espartanos ${ }^{477}$ para eliminar a ameaça representada por

${ }^{474}$ Podemos, por isso, afirmar que a morte de Péricles simboliza uma conspiração dos deuses contra a glória de Atenas. Este assunto está tratado no subcapítulo anterior. 102.

${ }^{475}$ Sobre o perigo que a inveja constitui para a segurança de um político, veja-se p. 231, nota

${ }^{476}$ Esta informação veiculada por Plutarco diverge do testemunho de Cornélio Nepos (Alc. 10. 1-2), segundo o qual Lisandro terá mandado executar Alcibíades por influência da intervenção de Crítias.

${ }^{477}$ Em Alc. 38. 6, o Queroneu avança dois motivos para essa condenação: ou o medo da

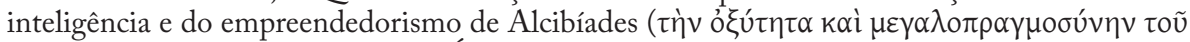

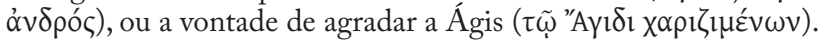


Alcibíades, não se fez rogado, ainda que não tenha sujado pessoalmente as mãos. Nesse sentido, podemos considerar que a morte de Alcibíades é uma repetição, um «déjà vu» da de Teseu, já que ambos são assassinados no exílio ${ }^{478}$ às mãos daqueles que lhes deram abrigo e em quem pensavam poder confiar. Lisandro ordenou a Farnábazo que se livrasse do Ateniense e o falso amigo do Alcmeónida, por sua vez, delegou essa função a um tio e a um irmão.

Em Alc. 39. 9, Plutarco avança outra motivação para o crime contra Alcibíades. Neste caso concreto, mais do que vítima de um destino injusto, personificado por diferentes inimigos políticos, o Alcmeónida seria vítima de si mesmo, da sua vida desregrada, da sua ü $\beta p \iota \varsigma$, pois teria perecido às mãos dos irmãos de uma jovem de boas famílias que corrompera. Esta segunda versão que o biógrafo apresenta como causa do homicídio fez-nos pensar de imediato nos famosos versos de Camões:

"Erros meus, má fortuna, amor ardente

Em minha perdição se conjuraram.”

É que estes versos também se aplicam ao declínio, à morte anunciada de Atenas ${ }^{479}$, que o homicídio de Alcibíades efetiva. Foram os «erros» (ou seja, a forma como dispensou, sem um motivo verdadeiramente válido, os serviços de Alcibíades ${ }^{480}$ ), a «má fortuna» (que remonta à morte de Péricles que não pôde levar a sua estratégia a cabo, algo que o próprio atribui à Fortuna ou à ação dos deuses ${ }^{41}$ ) e o «amor ardente» (o desejo insaciável de mais glória e mais poder, que se materializa na expedição à Sicília ${ }^{482}$ ) que determinaram a queda do império.

Enquanto, no que respeita a Péricles, o seu nascimento fora precedido de um sonho ${ }^{483}$ que prefigurava a glória que viria a alcançar, no caso de Alcibíades foi a sua morte que teve direito a anúncio onírico. Podemos, por isso, mais uma vez associar Péricles ao apogeu de Atenas e do seu império e Alcibíades

${ }^{478}$ A decadência de Atenas é insinuada pelo exílio (ou se preferirmos, afastamento temporário, no caso de Péricles) e morte dos estadistas, que funcionam como símbolo de um período de glória que chega ao fim. No entanto, o «exílio» de Péricles e o seu posterior regresso (do mesmo modo que o primeiro exílio de Alcibíades, seguido, também ele, de um regresso temporário) parecem sugerir uma esperança para Atenas, como aquele revigorar que muitas vezes precede a morte do doente terminal. Alcibíades, no contexto da comparação dos três estadistas que nos ocupam, afigura-se como um D. Sebastião, única hipótese de salvação para a guerra em que Péricles envolvera Atenas. Mas também ele «desaparece no nevoeiro» e deixa órfãos os concidadãos, que, sem forças nem capacidade para lutar mais, sucumbem ao poderio do inimigo.

${ }^{479}$ Prenunciada pela morte de Teseu. Vd. supra p. 109.

${ }^{480}$ Alc. 38. 1-2.

${ }^{481}$ Supra p. 281 (nota 330) e 285 (nota 354).

${ }^{482}$ Cf. p. 263, nota 242.

${ }^{483}$ Vd. supra p. 169 , nota 40. 
à sua ruína. Neste sentido, podemos dizer que enquanto Teseu foi o A e o $\Omega$, isto é, enquanto a sua vida prenunciou o princípio e o fim do império e da democracia atenienses, os Alcmeónidas partilharam entre si esse simbolismo: a glória, representada por Péricles e o declínio, por Alcibíades.

Tal como avançou duas causas alternativas para o assassínio de Alcibíades, Plutarco apresenta duas versões desse sonho: uma em que Alcibíades se via vestido com as roupas de Timandra ${ }^{484}$, hetera com a qual vivia na Frígia, que segurava a sua cabeça nos braços enquanto lhe penteava os cabelos e pintava o rosto ${ }^{485}$. De acordo com a outra versão, o Alcmeónida viu o próprio Bageu (irmão de Farnábazo) a cortar-lhe a cabeça e a incendiar-lhe o corpo.

A forma como, em Alc.39.4-7, o Queroneu descreve a morte de Alcibíades apresenta muitos pontos de coincidência com os sonhos enunciados ${ }^{486}$ e sugere não só a coragem com que aquele enfrentou o numeroso inimigo bárbaro ${ }^{487}$ como também a perfídia deste. Em um gesto ainda mais cobarde do que o ato de assassinar alguém, os «carrascos» do estratego, que não ousaram defrontá-lo diretamente, cercaram-lhe a casa e incendiaram-na. Do alto da sua coragem - a mesma que o fez enfrentar com bravura a difícil situação da tomada de Selímbria ${ }^{488}$ - o Alcméonida atravessou o fogo e abandonou o interior da casa. Foi de longe, sem ousar uma aproximação, que os assassinos o atingiram com lanças e flechas.

Nesta biografia, ao contrário do que acontece nas de Teseu e de Péricles, Plutarco faz referência às exéquias «brilhantes e dignas» ${ }^{49}(\lambda \alpha \mu \pi \rho \tilde{\omega} \varsigma$ k $\alpha \grave{i}$ $\varphi \imath \lambda o \tau \imath \mu \tilde{\omega} \varsigma-A l c .39 .7)$ que, tendo em conta as circunstâncias, Timandra lhe dedicou depois de recolher o cadáver e cobri-lo com as suas próprias roupas ${ }^{490}$. $\mathrm{O}$ facto de a sua morte ter sido presenciada apenas ${ }^{491}$ por esta famosa cortesã

${ }^{484}$ Segundo Littman (1970: 269), Ateneu menciona que a hetera se chamava Damasandra ('domadora de homens'), divergência que o classicista atribui a um trocadilho cómico com o nome de Timandra ('que honra os homens').

${ }^{485}$ Alc. 39. 2.

${ }^{486}$ E também com Nep. Alc. 10. 3-6, que apenas acrescenta que a cabeça de Alcibíades foi entregue a Farnábazo.

${ }^{487}$ Embora o autor moral da morte de Alcibíades - e, consequentemente, do declínio de Atenas - sejam os Lacedemónios, esta é, de facto, executada pelos Bárbaros, deixando a sugestão de que a queda da $\pi$ ó $\lambda_{\imath \varsigma}$ foi, efetivamente, fruto do conluio dos dois grandes inimigos dos Atenienses.

${ }^{488}$ Supra p. 295.

${ }^{489}$ Cf. Duff (1999: 240). Pelling (1996: lvi-lvii) considera que este funeral, dentro do contexto em que ocorre, acaba por ser digno da ambição que caracterizou Alcibíades em vida. Embora sem honras de Estado ou militares, o cadáver do Alcmeónida foi homenageado pelo amor da mulher que assistiu à sua morte.

${ }^{490}$ Este detalhe reveste-se de particular importância, na medida em que traduz o cumprimento do sonho. Cf. Nep. Alc. 10. 6; Cic. Div. 2. 143; V. Max. 1.7 ext. 9. Sobre a morte de Alcibíades, consultem-se igualmente Hatzfeld (1940: 341-349) e Gribble (1999: 281-282).

${ }^{491}$ Esta realidade contrasta com a juventude e os tempos áureos do estratego, quando este vivia rodeado de amigos e bajuladores. Quando se cai em desgraça, a solidão e o abandono são 
(bem como o segundo móbil que o Queroneu apresenta para explicar o homicídio) recorda-nos a licenciosidade que caracterizou a sua vida. Mas faz-nos lembrar que, nos momentos que antecederam a sua partida, Péricles esteve acompanhado de amigos e de individualidades poderosas que lhe vieram prestar uma última homenagem (Per. 38.3) e que Teseu, por sua vez, morreu sozinho, sem que nem o povo, nem os inimigos, nem a própria família tenham manifestado mais do que indiferença pelo seu falecimento (Thes. 35. 7-8 e supra pp. 109-111). Isto permite-nos afirmar com Gribble (1999: 281) que,

in Plutarch, the death of the hero is often deeply suggestive of his character as a whole.

$\mathrm{Ou}$, se preferirmos, parece ser o desfecho merecido pela forma como conduziram as suas vidas. De facto, no caso específico de Alcibíades, a sua morte põe em evidência o grosso dos traços do seu comportamento em vida: a coragem, o desejo de glória, a üßpıৎ, a vida dissoluta. Até a inconsistência por que pautou a sua conduta e os sentimentos e reações contraditórios que suscitou nos seus contemporâneos aparecem refletidos nas incertezas que rodeiam as circunstâncias da sua partida. No caso de Teseu, a sua morte só e à traição surge como consequência do abandono a que votou a cidade que fundara, que ter-se-á sentido qual esposa trocada por outra mulher. Até a morte rápida que Teseu e Alcibíades tiveram decorre, por assim dizer, da forma pronta, célere (e tantas vezes precipitada) como sempre agiram.

Péricles é o único que sucumbe à morte ideal...ou quase. É certo que a doença lhe provocou um sofrimento prolongado, mas essa provação por que o Alcmeónida passou revelou-se consistente com a paciência e o saber esperar que o caracterizavam e fizeram dele um ateniense superior. Lembremo-nos de que ficou conhecido por ter, durante anos, suportado insultos com grande serenidade $^{492}$. Dos três, só ele morreu com o sentimento de dever cumprido ${ }^{493}$.

Resta-nos abordar um dos tópicos que, de um modo geral, faz parte da estrutura dos parágrafos que Plutarco consagra à morte dos seus heróis: o impacto do desaparecimento do protagonista na comunidade. Trata-se, com efeito, de um elemento cuja abordagem é absolutamente diversa em cada uma destas vidas. No caso de Teseu, parece ter havido uma total indiferença por parte dos inimigos, dos concidadãos e até dos próprios filhos. Segundo Plutarco, só por ocasião da batalha de Maratona é que o fundador voltou a ser lembrado em glória (Thes. 36. 1). Em relação a Alcibíades, Plutarco não faz qualquer reparo nesse sentido no único capítulo que dedica à morte deste Alcmeónida.

algo de garantido.

${ }^{492}$ Supra p. 281.

${ }^{493}$ Supra p. 304, nota 472. 
No entanto, desta feita, a sua omissão justifica-se, decerto, pelo facto de, no capítulo anterior, o biógrafo se ter debruçado sobre o arrependimento que o povo sentia por ter afastado precipitadamente Alcibíades. Já então, ainda durante a vida do estadista, o povo reconhecera todo o mérito e potencial que aquele tinha. Quanto a Péricles, o Queroneu tece-lhe um rasgado elogio, ao qual acrescenta a notícia de que o povo não demorou a reconhecer o mérito do Alcmeónida e a sentir saudades da sua intervenção, pois nunca mais voltou a ser liderado por alguém que, apesar dos seus muitos defeitos, concentrasse e empregasse com proveito tantas qualidades (Per.39.3). 


\section{Notas FinaIs}

Finda a análise das biografias de Teseu e dos Alcmeónidas, parece-nos pertinente sistematizar algumas ideias que fomos abordando ao longo das páginas anteriores.

Comecemos por tentar responder a uma das primeiras questões que nos colocámos no início do trabalho: até que ponto Teseu e a sua vida podem funcionar como prenúncio do que viriam a ser os políticos da época clássica?

A nosso ver, o filho de Egeu apresenta, de facto, traços de caráter - como a ousadia, os dotes retóricos, o desapego pela vida ou o empreendedorismo que definem a maneira de ser de Péricles e de Alcibíades, mas que, sobretudo, definem a maneira de ser dos verdadeiros atenienses. De acordo com o nosso corpus, estamos perante uma influência exercida pelo fundador sobre os concidadãos das gerações vindouras. No entanto, a história sugere que foi o caráter de Teseu que sofreu alterações em função da reformulação da tradição sobre esta figura, ocorrida sobretudo nos séculos IV e $\mathrm{V}$ a.C. Podemos, por isso, concluir que, de facto, no contexto do nosso corpus, Teseu acaba por funcionar como uma espécie de base de dados de valores, à qual os Atenienses vão buscar a maneira de ser que os caracteriza e que abordámos no capítulo intitulado «Atenas, o umbigo da Hélade».

Ao mesmo tempo, importa recordar que, no âmbito do nosso estudo, Teseu e a sua vida acabam por funcionar como prenúncio preciso das vidas de Péricles e Alcibíades. É que a fundação de uma nova Atenas com o sinecismo e os sonhos imperialistas que, desde cedo, o filho de Egeu revela, simbolizam a glória que Atenas haveria de alcançar com Péricles. Do mesmo modo que o afastamento de Teseu do governo da cidade, substituído pelo demagogo Menesteu, prefigura simultaneamente a situação de abandono em que Atenas cai após a morte de Péricles e aquela em que cai após os exílio e morte de Alcibíades.

Por outro lado, quer Péricles quer Alcibíades têm uma atuação que se revela herdeira da maneira de ser de Teseu, no que esta tinha de bom e de mau. No que respeita a Péricles, podemos acrescentar que, segundo a perspetiva de Plutarco, foi sobretudo influenciado pelos traços positivos da personalidade e da atuação do fundador, que, regra geral, até superou. Apenas a forma como envolveu Atenas na Guerra do Peloponeso pode ser considerada uma ascendência negativa, sobretudo se recordarmos o ponto de vista daqueles que culpavam Péricles por ter dado início ao conflito por razões do foro pessoal, 
como a cedência aos caprichos de Aspásia ou a necessidade de desviar as atenções da sua pessoa, que vinha sendo vítima dos mais diversos ataques e críticas por parte dos concidadãos.

O problema maior que a análise destas Vidas nos coloca prende-se à natureza de Alcibíades. O retrato que Plutarco faz de Teseu ou de Péricles, embora humano - porque ambos revelam virtudes e defeitos - apresenta-nos dois Atenienses que pautam a sua vida por uma conduta em geral distinta. No caso do Alcmeónida, podemos até afirmar que Plutarco a considera superior à média, mesmo excecional. No que concerne a Alcibíades, o tratamento que o Queroneu dá à figura parece sugerir que é impossível chegar a um julgamento moral satisfatório a seu respeito ou, pelo menos, que o biógrafo não se atreve a fazer um julgamento explícito do filho de Clínias. É que o Alcibíades de Plutarco desafia as classificações rotineiras nas categorias de vício e virtude e parece não se incluir em nenhum esquema moral. Ou, por outras palavras, como afirma Duff (1999: 240),

hard to define, harder to judge, it is impossible to draw simple moral lessons from this Life. And this is, perhaps, the great strength of Plutarch's Life; after all, how could Alkibiades, the individualist extraordinaire, be a paradigm for anything - except individuality itself?

Nesse sentido, resta-nos colocar uma questão: Alcibíades deve ser considerado um bom ou mau exemplo? Parece-nos que este Alcmeónida é, simplesmente um exemplo inacabado. Teve o seu tempo de mau; no entanto, quando tentou ser bom (qualquer mortal tem o direito de errar e de se regenerar), não lhe foi dada essa oportunidade. Fica, assim, a ideia de que Alcibíades, «o cheio de potencialidades», foi vítima do sistema social. O povo e os aduladores fizeram vir ao de cima o pior da sua personalidade. Em um misto de admiração e inveja, de amor e ódio, aguentaram as suas criancices até ao momento em que a dimensão do poder e da fama do Alcmeónida atingiram um nível supostamente incomportável para a segurança da ordem vigente. Nessa altura, o Alcmeónida foi escorraçado e teve a reação própria de quem, consciente do seu valor, se vê desprezado pelos que antes o exaltavam. Vingou-se, fez mal aos seus, contudo, quando os viu em apuros e estes, interesseiros, lhe pediram que regressasse, ele não hesitou. Voltou mais maduro, aparentemente disposto a enveredar pelo caminho do Bem. No entanto, a sociedade, que antes o corrompera, apesar de ter voltado acolhê-lo e de lhe ter entregado o exército, negou-lhe o voto de confiança. Ao mínimo deslize, que nem foi diretamente consequência do seu comportamento ou leviandade, voltou-lhe as costas. Fê-lo não porque pusesse em causa a sua lealdade, mas porque ninguém sabia do que ele era capaz quando movido pela ambição excessiva que o caracterizava. Ironicamente, Alcibíades foi afastado quando estava mais apto a conduzir os 


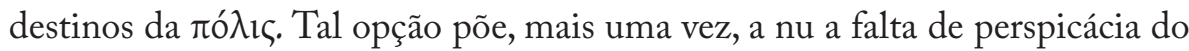
povo, que o acolheu de braços abertos quando era excessivamente jovem para abraçar a carreira política e o afastou no momento em que as suas capacidades eram mais necessárias, pois delas dependia a salvação de Atenas. A queda de Alcibíades, que antecede a de Atenas e a do regime democrático, mais não é, por isso, do que o testemunho do falhanço do sistema.

Neste contexto, que, no fundo, é aquele que Plutarco recria em uma biografia que prima pela omissão de pormenores relativamente à atuação política e militar do Alcmeónida, sobressai a imagem de um jovem prematuramente órfão, ao qual a sociedade do apogeu (representado pela figura do seu tutor Péricles) não conseguiu dar educação nem o apoio necessários. Por isso, apesar do seu comportamento criticável, Alcibíades parece ser desculpabilizado por Plutarco, do mesmo modo que hoje se desculpabilizam os jovens que se transformam em marginais com o argumento de que foram abandonados pela sociedade. $\mathrm{O}$ certo é que a culpa da degradação dos costumes, da moral e do sistema vigente deve ser atribuída àqueles que são os agentes atuais dessa degradação; mas quem assistiu passivamente e com paliativos ao despoletar dessa situação, deve ser tanto ou mais responsabilizado, porque foi a sua fraca conduta enquanto pais, governantes e concidadãos que deu origem ao aparecimento de uma geração que, apesar dos dons inatos, se tornou ignóbil.

A leitura cruzada das biografias dos Alcmeónidas permite-nos uma conclusão paradoxal: se pusermos lado a lado um texto e outro, Péricles sobressai como protótipo do político ideal; Alcibíades surge como uma frustração, um engodo: parece ser mais promissor, mais dotado do que o tutor (Péricles), embora, na prática, se revele uma fraude, pois a sua ação não corresponde às expectativas. Podemos compará-los a dois alunos: um, com mais capacidades, que não se aplica nas suas tarefas (Alcibíades); outro que, menos inteligente, trabalha com afinco, acabando por ultrapassar os feitos alcançados pelo mais dotado (Péricles).

Por outro lado, apesar do aparato elogioso com que Plutarco descreve a atuação de Péricles e da ambiguidade com que retrata Alcibíades, fica em nós a sensação de que a crítica a Alcibíades deve ser atenuada, porquanto a sua conduta resulta de uma conjuntura que é, em muito, da responsabilidade de Péricles. Assim sendo, fica a ideia de que, se calhar, o filho de Xantipo não mereceria estar em um pedestal tão elevado quanto aquele em que Plutarco o coloca. Podemos, por isso, indo ao encontro do objetivo do biógrafo (que pretendia que, perante os dados por ele fornecidos nós disséssemos de nossa justiça em relação aos seus heróis), concluir que, como seres humanos, ninguém é totalmente bom ou mau; as ações e opções de cada um não resultam apenas do caráter inato, mas também da influência da sociedade e do contexto em que se vive. E que apenas o Misantropo (Alc. 16.9) soube avaliar com justiça as 
capacidades de Alcibíades: haveria de se transformar em um grande mal para os Atenienses.

Ressalta, portanto, destas últimas páginas, toda a atualidade da obra de Plutarco que, como dissemos no princípio, foi um dos motivos que nos levou a escolher este autor para tema do nosso estudo. 


\section{Bibliografia}

\section{Considerações gerais}

Para os autores e títulos gregos, seguimos as abreviaturas utilizadas por $\mathrm{H}$. G. Liddell e R. Scott ( $\left.{ }^{9} 1996\right)$ em Greek English Lexicon, Oxford, pp. xvi-xliii; para os autores e títulos latinos, as de P. G. Glare (1982: reimpr. 1984), Oxford Latin Dictionary, Oxford, pp. ix-xx.

As abreviaturas usadas para os periódicos são as de L'Année Philologique.

Para os testemunhos iconográficos, seguimos o Lexicon iconographicum mythologiae classicae - 8 vols., Zurich, Artemis, 1981-1997. No que aos textos de Plutarco diz respeito, além das obras especificadas, consultámos as traduções publicadas pela Editorial Gredos, por Les Belles Lettres e pela Fondazione Lorenzo Valla.

Aalders, G. J. D. (1982), Plutarch's Political Thought, Amsterdam.

Adrins, A. W. H. (1960), Merit and Responsibility: a Study in Greek Values, Oxford.

(1963), «Friendship and self-sufficiency in Homer and Aristotle», CQ 13. $1,30-45$.

(1970), From the Many to the One: A Study of Personality and the Vierws of Human Nature in the Context of Ancient Greek Society, Values and Believes, London.

(1971), Polygramosyne and «Minding One's Own Business»»: A Study in Greek Social and Political Values», CP 71, 301-327.

(1972), Moral Values and Political Behaviour in Ancient Greece: from Homer to the End of the Fifth Century, New York.

AÉlion, R. (1986), Quelques Grands Mythes Hérö̈ques dans l'oeuvre d'Euripide, Paris.

Aguilar, R. M. (1997), «Plutarco y la Comedia Ateniense», in Plutarco y Historia, 3-27.

Albini, F. (1996), Vita di Coriolano, Vita di Alcibiade, introduzione e note di..., prefazione di C. B. R. Pelling, Milano.

- (1997), «Family and the formation of character: aspects of Plutarch thought», in Mossman, J. (ed.), Plutarch and his intellectual world: Essays on Plutarch, London, 59-71.

Alesse, F. (2004), «Fonti socratiche e stoiche nella Vita Alcibiadis», Statesman II, 187-198. 
Alexandre Júnior, M., Farmhouse Alberto, P., Nascimento Pena, A. (2005), Aristóteles, Retórica, Lisboa.

Allen, T. W., Halliday, W. R., Sines, E. E. (21936), The Homeric Hymns, Oxford.

Allison, J. W. (1979), «Thucidides and polugramosuvnb», AJAH 4, 10-22.

(1983), «Pericles' policy and the plague», Historia 32, 14-23.

Alsino Clota, J. (1957), «Helena de Troya. Historia de un mito», Helmantica 8, 373-394.

(1987), «Un modelo literario de la descripcíon de la peste de Atenas?», Emérita 55, 1-13.

Amaral, A. C., Gomes, C. C. (1998), Aristóteles. Política, Lisboa.

Ampolo, C., Manfredini, M. (1988), Plutarco. Le Vite di Teseo e de Romolo, Milano. Anderson, M. (1972), «The Imagery of the Persians», GE'R 19. 2, 166-174. Anderson, W. (1966), Ethos and Education in Greek Music, Harvard. (1998), Ovidius. Metamorphoses.

Andrewes, A. (1978), «The Opposition to Pericles», JHS 98, 1-8.

Ameling, W. (1985), «Plutarch, Perikles 12-14», Historia 34, 47-63.

Asheri, D. (1988), Erodoto, Storie - Libro I. La Lidia e La Persia.

—_, Medaglia, S. M. (1990), Erodoto, Storie - Libro III. La Persia.

—_, Corcella, A. (2003) Erodoto, Storie - Libro VIII. La Vitoria di Temmistocle,

—_, (2006), Erodoto, Storie - Libro IX. La battaglia di Platea.

Austin, M., Vidal-Naquet, P. (1986), Economias e Sociedades na Grécia Antiga, Lisboa.

Avery, H. C. (1972), «Herodotus' picture of Cyrus», AJPb 93, 529-546.

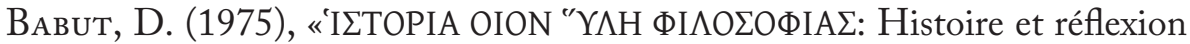
morale dans l'oeuvre de Plutarque», REG 88, 206-219.

Balcer, J. M. (1983), «The Greeks and the Persians: The Processes of Acculturation», Historia 32. 3, 257-267

Balot, R. (2001), «Pericles' anatomy of democratic courage», AJPh 122. 4, 505-525.

Banfi, A. (1999), «I processi contro Anassagora, Pericle, Fidia ed Aspasia e la questione del «circolo di Pericle»: note di cronologia e di storia», AIIS $16,3-85$. 
Barbu, A. N. (1933), Les Procédés de la Peinture des Caractères et la Verité Historique dans les Biographies de Plutarque, Roma.

Barnes, J. ed. (1995), The Cambridge Companion to Aristotle, Cambridge.

Barron, J. (1981), An Introduction to Greek Sculpture, London.

Barron, R. (1971), «New Light on Old Walls. The Murals of the Theseion», JHS 91, 141-143. (1976), Greek and Roman Education, Bristol.

Barthes, R. (1988), Mitologias (trad. port.), Lisboa, Edições 70.

Bearzot, C. (1988), «Strategia autocratica e aspirazioni tiranniche. Il caso di Alcibiade», Prometheus 14, 39-57.

Beck, F. A. G. (1964), Greek Education 450-350 B. C., London. (1975), Album of Greek education: the Greeks at school and at play, Sydney, Cheiron Press.

Beck, M. (2000), «Anecdote and the representation of Plutarch's ethos», in Rhetorical Theory and Praxis, 15-29.

Bellido, A. M. (1997), «Mito y Política en la comedia de Cratino», in A. L. Eire (ed.), Sociedad, Politica y Literatura Comedia Griega Antigua - Actas del I Congreso Internacional, Salamanca, 117-131.

Bertelli, G. (1987), «Teseo tra Mito e Storia Politica: un'Atene immaginaria?», Aufidus 1, 35-58.

Bertelli, L. (2001), «Hecataeus: from Genealogy to Historiography», in N. Luraghi (ed.), The Historian's Craft in the Age of Herodotus, Oxford University Press.

Bertinelli, M. G. A. et alii (1997), Plutarco. Le Vite di Lisandro e de Silla, Milano.

Bettalli, M. (2003), Plutarco Vite parallele. Teseo, introduzione, traduzione e note di...; Romolo, introduzione, traduzione e note di G. Vanotti, Milano.

Bicknell, P. (1972), Studies in Athenian Politics and Genealogy, Munich. (1975), «Alkibiades and Kleinias. A study in Athenian genealogy», $M P h L$ 1, 51-64.

Bloedow, E. F. (1973), Alcibiades re-examined (Historia Einzelchriften 21), Wiesbaden.

(1987), «Pericles' powers in the counter-strategy of 431», Historia 36, 9-27.

(1990), «Not the son of Achilles, but Achilles himself»: Alcibiades' entry on the political stage at Athens, II, Historia 39, 1-19. 
(1991), «An Alexander in the wrong place: Alcibiades, the ablest of all the sons of Athens»?», SCO 41, 191-216.

(1991b), «On nurturing lions in the state: Alcibiades' entry on the political stage in Athens», Klio 73, 49-65.

(1991c), «Phrynichus the «intelligent» Athenian», AHB 5, 89-100.

(1992), «Alcibiades «brilliant» or «intelligent» ?», Historia 41, 139157.

(1994), «Pericles and Athens' alliance with Corcyra», CEM 45, 5169.

(2000), «The implications of a major contradiction in Pericles' career», Hermes 128. 3, 295-319.

Blois, L. de et alii (2004), The Statesman in Plutarch's Works. Proceedings of the $6^{\text {th }}$ international conference of the International Plutarch Society, Nijmegen/Castle Hernen, May 1-5, 2002. Vol. I: Plutarch's Statesman and his aftermath: political, philosophical and literacy aspects, Leiden. [Statesman I]

- (2004b), «Classical and contemporary statesmen in Plutarch's Praecepta», Statesman I, 57-66.

(2005), The Statesman in Plutarch's Works. Proceedings of the $6^{\text {th }}$ international conference of the International Plutarch Society, Nijmegen/Castle Hernen, May 1-5, 2002. Vol. II: The Statesman in Plutarch's Greek and Roman Lives, Leiden. [Statesman II]

BLok, J. H. (1994), The Early Amazons - Modern and Ancient Perspectives on a Persistent Myth, Leiden.

Blomevist, K. (1997), «From Olympias to Aretaphila: women in politics in Plutarch», in J. M. Mossman, Plutarch and his Intellectual World: Essays on Plutarch. London.

Blundell, S. (1995), Women in ancient Greece, London, Harvard University Press.

(1998), Women in classical Athens, Bristol.

Blundell, M. W. (1991), Helping Friends and Harming Enemies - A study in Sophocles and Greek Ethics, Cambridge.

, (1993), "The ideal of Athens in Oedipus at Colonus», in Tragedy, Comedy and the Polis, Bari, 287-306.

Boardman, J. (1982), «Herakles, Theseus and Amazons», in D. Kurtz, B. A. Sparkes, The Eye of Greece: Studies in the Art of Athens, Cambridge, $1-28$. 
(21988), Cambridge Ancient History, Vol. IV-Persia, Greece and the Western Mediterranean, c. 525 to 479 BC.

Boer, W. (1969), "Theseus - the growth of a myth in history», GEंR 16, $1-13$.

Boeuffle, A. Le (1983), Hygin. L'Astronomie, Paris

Bois, P. du (1982), Centaurs and Amazons. Women and the pre-bistory of the great chain of being.

(1979), «On Horse/man, Amazons and Endogamy», Arethusa 12, 35-49.

Bonnachère, P. (1994), «Le Sacrifice Humain en Grèce Ancienne», Kernos supplément 3 , Liège.

(1998), «La notion d'«acte collectif» dans le sacrifice humain grec», Phoenix 52. 3-4, 191-215.

Bonner, R. J., Smith, G. (1938), The Administration of Justice from Homer to Aristotle, Chicago.

Boriaud, J.-Y. (2003), Hygin. Fables, Paris.

Bornecque, H. (2002), L'Art d'aimer, Paris.

Boulogne, J. (2000), «Les synkriseis de Plutarque: une rhétorique de la synkrisis», in Rhetorical Theory and Praxis, 33-44.

___ (2004), «L'imaginaire politique de Plutarque», Statesman I, 211-226.

Bowman, A., Garney, P., Rathbone, D. (ed.) (2000), The Cambridge Ancient History, vol. XI, The High Empire, AD 70-192.

Breebart, A. B. (1971), «Plutarch and the Political Development of Pericles», Mnemosyne ser. 4 24, 260-272.

Brelich, A. (1956), «Theseus e i suoi avversari», SMSR 27, 136-141.

(1969), «Aristofane come fonte per la storia dell'educazione ateniese», Dioniso 43, 385-398.

Bremmer, J. N. (1996), «Why did Medea kill her brother Apsyrtus?», in J. J. Clauss, S. I. Johnston (ed.), Medea - Essays on Medea in Myth. Literature, Philosophy and Art, Princeton, 1996, 83-100.

Brenk, F. (1975), «The Dreams of Plutarch's Lives», Latonus 34. 2, 336-349.

—_, E., Gallo, I. (eds.) (1986), Miscellanea Plutarchea. International Plutarch Society. Sezione Italiana. Atti del I Convegno di Studi su Plutarco (Roma, 23 novembre 1985), Quaderni del Giornale Filologico Ferrara 8. [Miscellanea Plutarchea]

Brillante, C. (1991), «Crescita e apprendimento: l'educazione del giovane eroe», QUCC 37. 1, 7-28. 
Brisson, L. (1975), «Le mythe de Protagoras. Essai d'analyse structurale», QUCC 20, 7-37.

Brommer, F. (1972), Herakles: die zwölfTaten des Helden in antiker Kunst und Literatur , Köln, Böhlau.

(1982), Theseus, Darmstadt.

Brunel, P. (ed.) (1993), Companion to Literary Myths, Heroes and Archetypes, Routledge.

Brunt, P. A. (1993), «Thucydides and Alcibiades», in P. A. Brunt, Studies in Greek History and Thought, Oxford, 17-46.

Bulsot, G. (1895), Grieschische Geschichte II 2, Gotha.

Burian, P. (1985), «Logos and Pathos: The politics in the Suppliant Women», in P. Burian, (ed.) Directions in Euripidean criticism, A collection of essays, Duckworth, 129-155.

Burkert, W. (2001), Mito e Mitologia (trad. port.), Lisboa, Edições 70.

Burn, A. R. (1984), Persia and the Greeks: the Defense of the West c. 546-478 B. $C$, Stanford.

Burnet, J. (1903), Platonis Opera, Oxford.

Bury, J. B. (1 958), The Ancient Greek Historians, New York.

Butcher, S. H. (1949), Demosthenis Orationes, Scriptorum Classicorum Bibliotheca Oxoniensis.

Buxton, R. G. A. (1980), «Blindness and Limits. Sophokles and the Logic of Myth», JHS 100, 22-37.

Bywater, I. (1963), Aristotelis. Ethica Nicomachea, Oxford.

Cabral, D. C. (2009), Plutarco. Como tirar partido dos seus inimigos; seguido de Como distinguir um bajulador de um amigo, Mem Martins, EuropaAmérica.

Caeiro, A. C. (2004), Aristóteles. Ética a Nicómaco, Lisboa.

Calame, C. (1988), «Mythe, récit épique et histoire: le récit hérodotéen de la fondation de Cyrène», C. Calame (ed.), Métamorphoses du Mythe en Grèce Antique, Genève, 105-125. (1989), «Narrating the foundation of a city: the symbolic birth of Cyrene», in L. Edmunds (ed.), Approaches to Greek myth, Baltimore, 277-341.

(1990), Thésée et l'imaginaire athénien: Légende et culte en Grèce Antique, Lausanne.

- (2000), Le récit en Grèce ancienne, Belin. 
Campos, D. J., López Cruces, J. L. (1990), «ALKIBIA/DHS POLU/ TROPOS: consideraciones en torno a la valorización y la caracterización de los personajes en la historiografía del siglo IV», Myrtia 5, 93-105.

Candau, J. M. (1995), «Los silencios de Plutarco: consideraciones sobre la composición de las Vidas Paralelas a propósito de un libro reciente», Habis 26, 133-143.

(1991), «Plutarco y la escenografía histórica. El moralismo plutarquiano frente a la historiografía trágica», in Paisaje y naturaleza, 21-26.

Canfora, L. (1982), «L'apologie d'Alcibiade», REG 95, 140-144. (1993), Demagogia, Palermo.

(1995), «Il Pericle di Plutarco: Forme del Potere Personale», in Teoría e Prasi, 83-90.

Cantarella, R. (1969), «Aspetti sociali e politici della commedia greca antica», Dioniso 43, 313-352.

Cantarelli, F. (1974), «Il personnagio di Menesteo nel mito e nelle ideologie politiche greche», Rendiconti 108, 459-505.

Carcopino, J. (1935), Lostracisme Athénien, Paris, Librairie Félix Alcan.

Carey, C. (2007), Lysiae Orationes cum Fragmentis, Oxford.

Carlier, J. (1979), «Voyage en Amazonie Grecque», AAntHung 27, 381-405.

Carrière, J. C. (1997), «Les métamorphoses des mythes et la crise de la cité dans la Comédie Ancienne', in P. Thiercy, M. Menu (ed.), Aristophane: la langue, la scène, la cité, Bari, Levante, 413-442.

Cassola, F. (1957), La Ionia nel mondo miceneo, Napoli.

Cawnwell, G. L. (1975), «Thucydides judgment of Periclean strategy», YClS 24, 53-70.

Cerezo, M. (1996), Plutarco. Virtudes y Vicios de Sus Héroes Biográficos, Ediciones de La Universidad de Lleida.

Cesa, M. (1994), Plutarco Vite parallele. Coriolano, introduzione e note di..., traduzione e note di L. M. Rafaelli; Alcibiade, introduzione e note di L. Prandi, traduzione e note di L. M. Rafaelli, Milano.

Chadwick, J. (1987), Linear B and related Scripts, University of California Press.

Chambers, M. (1986), Aristotelis Athenaion Politeia, Leipzig.

Chatelet, F. (1962), La Naissance de l'Histoire, Paris, Ed. Minuit.

Cherniss, H., Hembold, H. (1957), Plutarch's Moralia, London. 
Chevalier, J., Gheerbrandt, A. (1994), Dicionário dos Simbolos, Lisboa.

Chiasson, C. C. (1986), «Herodotus on Kings and Tyrants», JNES 45, 170195.

Chroust, A. H. (1954), «Treason and patriotism in Ancient Greece», JHI 15. 2, 280-288.

Cizek, A. (1975), «From the historical truth to the literary convention: the life of Cyrus the great viewed by Herodotus, Ctesias and Xenophon», $A C$ 44, 531-552.

Clark, G. (1988), Women in Classical Athens, Bristol.

(1989), Women in the ancient World. Greece and Rome - New surveys in the Classics 21, Oxford.

Clausen, W. V. (1992), Persius and Juvenal Saturae, Oxford.

Clauss, J. J., Johnston S. I. (1997), Medea: Essays on Medea in myth, literature, philosophy and art, Princeton University Press.

Clerc, M. (1893), Les Métèques athéniens, Paris.

Cobet, J. (1983), «Herodotus and Thucydides on War», in I. S. Moxon, J. D. Smart, A. J. Woodman (ed.), Past Perspectives - Studies in Greek and Roman Historical Writing, Cambridge University Press.

Cohen, B. (1991), «Perikles Portrait and the riace bronzes new evidence for «schinocephaly»", Hesperia 60. 4, 465-502.

Conen, E. E. (2003), The Athenian Nation, Princeton University Press.

Cole, P. R. (1931), A History of Greek Educational Thought, Oxford University Press.

Cole, T. (1993), «Le metamorfosi della saggezza: sofiva fra oralità e scritura», in Tradizione e innovazione nella cultura greca da Omero all'età ellensitica. Scritti in onnore di Bruno Gentili, Rome, Ed. R. Pretagostini, 753-763.

Collard, C. (1975), «Formal Debates in Euripides' Drama», GERR 22. 1, 58-71.

Collingwood, R. G. (1961), The Idea of History, Oxford University Press.

Comamala Malo, A. (1995), «La exculpación de Pericles por Tucídides: comentario de cinco discursos», EClás 108, 7-20.

Сомвѐs, R. (1995-1997), Faits et dits mémorables, Paris.

Conacher, D. J. (1981), «Rhetoric and Relevance in Euripidean Drama», AJP 102, 3-25

Connor, W. R. (1968), Theopompus and Fifth-Century Athens, CambridgeMass. 
(1970), «Theseus in Classical Athens», in A. G. Ward (ed.), The quest for Theseus, London, Pall Mall Press, 143-174.

(1971), The New Politicians of the Fifth Century Athens, Princeton.

Corbetta, C. (1977), «La fallita spedizione di Pericle a Cipro del 440-439», RIL 111, 156-166.

Corcella, A. (1993) Erodoto, Storie - Libro IV. La Scizia e la Libia.

Cornell, T. J. (1995), The beginnings of Rome, London.

Cornet, G. (2000), «Les aventures de Thésée lors de son voyage de Trézène à Athènes: transfiguration d'un jeune aventurier en héros national», $B A G B$ 1, 42-43.

Coulon, V., Daele, H. van ( $\left.{ }^{4} 1972\right)$, Aristophane, 5 vols., Paris.

Cromey, R. D. (1982), «Pericles' Wife: Chronological Calculations», GRBS 23, 203-212.

Cropp, M., Fantham, E., Scully, S. (1986), Greek Tragedy and its Legacy: Essays presented to D. J. Conacher, University of Calgary Press. [Greek Tragedy and its Legacy]

Dalmeyda, G. (2002), Andocide. Discours, Paris.

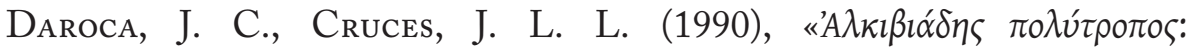
Consideraciones en torno a la valoración y la caracterización de los personajes en la historiografía del siglo IV», Myrtia 5, 77-92.

Daux, G. (1937), «Alcibiade proxène de Lacédémone», in Mélanges offerts à A.-M. Desrousseaux par ses amis et ses élèves en l'honneur de sa cinquantième année d'enseignement supérieur (1887-1937), Paris.

Davie, J. N. (1982), «Theseus the King in fifth-century Athens», GE'R, 25-34.

Davies, J. K. (1971), Athenian Propertied Families, 600-300 B. C., Oxford. $[A P F]$

Davison, J. A. (1958), «Notes on the Panathenaea», JHS 78, 23-42.

De Sanctis, G. ( $\left.{ }^{3} 1975\right)$, Atthis: Storia della reppublica Ateniese dalle origini alle riforme di Clistene, Roma.

Deвот , I. (2009), Plutarco. Conselhos aos políticos para bem governar; seguido de A um dirigente sem educação, Mem Martins, EuropaAmérica.

Deвut, J. (1986), «Contribution de la tradition indirecte à notre connaissance de l'éducation grecque», Euphrosyne 14 37-52.

Demand, N. (1987), «Herodotus' encomium of Athens: science or rhetoric?», AJPh 108. 4, 746-758. 
Desideri, P. (1992), «La formazione delle coppie nelle Vitte plutarchee», ANRW II 33. 6, 4470-4486.

Diamant, S. (1982), «Theseus and the unification of Attica», in Studies in Attic Epigraphy History and Topography - Hesperia: Supplement 19, 3847.

Dienl, E. ed. (1952), Die Fragmente der Vorsokratiker, Berlin.

Dienl, E. (31964), Anthologia Lyrica Graeca, Leipzig.

Dienl, E., Diggle, J. (1984), Euripides. Fabulae, vol. I - III, Scriptorum Classicorum Bibliotheca Oxoniensis.

Diels, H. ( ${ }^{31964), ~ T h e o p h r a s t i ~ C a r a c t e r e s, ~ O x f o r d . ~}$

Dodns, E. R. (1973), The Ancient Concept of Progress, Oxford.

Donnay, G. (1968), «La date du procès de Phidias», $A C$ 37. 1, 19-36.

Dopico Caínzos, M. D. (1997), «La utilización política de la xenía: algunos ejemplos», Hant 21, 525-543.

Dover, K. J. (1950), «The chronology of Antiphon Speeches», CQ 44 44-60. (1957), «The political aspect of Aeschylus Eumenides», JHS, 230-237. (1974), Greek popular morality in the time of Plato and Aristotle, Berkeley, University of California Press.

- (1978), Greek Homosexuality, Vintage Books.

Dowden, K. (1997), «The Amazons: Development and Functions», RbM 140. 2, 97-128.

Duchemin, J. (21968), L”Aүúv dans la tragédie grecque, Paris.

(1970), «Le thème du héros au labyrinthe dans la Vie de Thésée», KorkaloV 16, 30-52.

Duff, T. E. (1996), «The structure of Alcibiades-Coriolanus pair», in Aspectos Formales, 333-350.

(1999a), Plutarch's Lives: Exploring Virtue and Vice, Oxford. [Virtue and Vice]

(1999b), «Plutarch, Plato and the Great Natures», in Plutarco, Platón y Aristóteles, 313-332.

(2003), «Plutarch on the childhood of Alkibiades (Alk. 2-3)», PCPhS 49, 89-117.

- (2004), "The first Five anecdotes of Plutarch's Life of Alkibiades», in Statesman II, 157-166.

Dugas, C. (1943), «L'évolution de la légende de Thésée», REG 56, 1-24. 
—_, Flacelière, R. (1958) Thésée images E̋ récits, Paris, Ed. E. de Boccard. Dunkle, J. R. (1969), «The Aegeus Episode and the Theme of Euripides' Medea», TAPhA 100, 97-107.

Durán López, M. A. (1991), «Alcibíades según Platón», Habis 22, 113-128. , Martínez, J. L. C. (2004), «Oratoria y biografía. El retrato de Alcibíades en Lisias e Isócrates, in A. Pérez Jiménez, J. Ribeiro Ferreira, Maria do Céu Fialho (eds.), O retrato literário e a biografia como estratégia de teorização politica, Coimbra-Málaga, 37-48.

Durand, G. (1982), Mito, Símbolo e Mitodologia (tradução portuguesa), Lisboa, Presença.

Edelstein, L. (1967), The Idea of Progress in Classical Antiquity, Baltimore.

Edmunds, L. (1975), Chance and Intelligence in Thucydides, Cambridge MA.

Edwards, M. J., Swain, S. (ed.) (1997), Portraits: Biographical Representation in the Greek and Latin Literature of the Roman Empire, Oxford, Clarendon Press.

Eliade, M. (1977), Aspects du mythe, Paris, Flammarion.

Elias Pinheiro, A. P. (1999), Platão. Protágoras, Lisboa.

Ehrenberg, V. (1947), «Polypragmosyne: a study in Greek politics», JHS 67, 46-67.

Evans, J. A. S. (1979), «Herodotus and Athens: the evidence of the encomium», Ant. Class. 48. 1, 112-118. (1991), Herodotus, explorer of the past, Princeton.

Eyben, E. (1996), «Children in Plutarch», in Plutarchea Lovaniensia, 79-112.

Faure, D. (1960), L'éducation selon Plutarque d'après les «Oeuvres Morales». Tomes I e II, Série: Travaux et Mémoires no 13, Aix-en-Provence, Publications des Annales de la Faculté des Lettres.

Ferguson, J. (1958), Moral Values in the Ancient World, London, Methuen.

Ferguson, W. S. (1904), «The Historical Value of the Twelfth Chapter of Plutarch's Live of Pericles», TAPhA 35, 5-20.

Fernández Delgado, J. A., Pordomingo Pardo, F. (eds) (1996), Estudios sobre Plutarco: Aspectos Formales. Actas Del IV Simposio Español Sobre Plutarco (Salamanca, 26 a 28 de Mayo de 1994), Salamanca. [Aspectos Formales]

-, Scardigli, B. (1995), Teoría e Prassi Politica nelle Opere di Plutarco, Atti del $V$ Convegno Plutarcheo (Certosa di Pontignano, 7-9 giugno 1993), Napoli. [Teoría e Prassi] 
,(2000), I Generi Letterari in Plutarco. Atti de VIII Convegno plutarcheo

(Pisa, 2-4 giugno 1999), Napoli. [Generi Letterari]

Ferrari, G. R. F. (1987), Listening to the Cicadas - a Study of Plato's Phaedrus, Cambridge, University Press.

Ferreira, A., Rodrigues, A. (2010), Plutarco. Vidas Paralelas - Péricles e Fábio Máximo. Tradução do Grego, introdução e notas, Coimbra, Centro de Estudos Clássicos e Humanísticos.

Fialho, M. C. (1991), Sófocles. Rei Édipo, Lisboa, Edições 70.

, (1992), Luz e trevas no teatro de Sófocles, Coimbra: Instituto Nacional de Investigação Científica, Centro de Estudos Clássicos e Humanísticos da Universidade de Coimbra.

Fialho, M. C. (2002), "Teseu em Plutarco à luz da tradição», in Actas do Congresso «Plutarco Educador da Europa», Porto, 67-79.

__ LeÃo, D. F. (2008), Plutarco. Vidas Paralelas - Teseu e Rómulo. Tradução do Grego, introdução e notas, Coimbra, Centro de Estudos Clássicos e Humanísticos.

——, Rodrigues, N. S. (2010), Plutarco. Vidas Paralelas: Alcibiades e Coriolano, Coimbra, Centro de Estudos Clássicos e Humanísticos.

Finley, M. I. (1947), Thucydides, Cambridge, Massachusetts.

- (1962), «Athenian demagogues», PEंP 21, 3-24.

(1965), «Myth, memory and history», HET 4, 281-302.

(1988), O Mundo de Ulisses, Lisboa, Presença.

(1989), Uso e Abuso da História, São Paulo, Martins Fontes.

Flacelière, R. (1948), «Sur quelques passages des Vies de Plutarque», REG 61, 67-103. [Passages]

——, R., Снамвry, E. (1964), Plutarque: Vies I: Thésée-Romulus, LicurgueNuma, Paris.

___ (1968), Plutarque: Vies II: Solon-Publicola, Thémistocle-Camille, Paris.

—_- Снамbry, E. (1969), Plutarque: Vies III: Périclès-Fabius Maximus, Alcibiade-Coriolan, Paris.

Fohlen, G. (1931), Cicéron, Tusculanes, Paris.

Foley, H. P. (1996), «Tragedy and Politics in Aristophanes' Acharnians», in Readings in Aristophanes, 117-142.

Fornara, C. W. (1971), Herodotus. An interpretative essay, Oxford. (1975), «Plutarch and the Megarian Decree», YCLS 24, 213-228. 
(1991), L. J. Samons II, Athens from Cleisthenes to Pericles, Berkeley, University of California Press.

Fornis Vanquero, C. A. (1994), «Tucídides y Plutarco sobre la política argiva de Alcibíades», in Ideas Religiosas, 499-508.

Fortenbaugh, W. W. et alii (1992), Theophrastus of Eresus (Sources for his Life, Writings, Thoughy E' Influence), Leiden, New York, Köln.

Francotte, A. H. (1976), L'organisation de la cité athénienne et la réforme de Clisthènes, Roma, L'Erma di Bretscthneider.

Frazer, J. G. (1954-1956), Apollodorus. The Library, Harvard.

Frazier, F. (1988), «A propos de la philotimia dans les Vies. Quelques jalons dans l'histoire d'une notion», $R P h$ 62, 109-127.

(1989), «Remarques à propos de l'usage des citations en matière de chronologie dans les Vies», ICS 13. 2, 297-309.

(1992), «Contribution à l'étude de la composition des Vies de Plutarque: l'élaboration des grandes scènes», $A N R W 33.6$, 4487-4535.

(1995), «Principes et décisions dans le domaine politique d'après les Vies de Plutarque, in Teoria e Prassi, 147-171.

(1996), Histoire et Morale dans les Vies Parallèles de Plutarque, Paris, Les Belles Lettres.

- (2001), «Prestige et autorité de l'homme d'État chez Thucydide», Ktèma 26, 237-256.

French, A. (1994), «Pericles'citizenship law», $A H B$ 8, 71-75.

Freyburger, G., Scheid, J. (1992), Cicéron, De la divination, Paris.

Frost, F. J. (1964), «Pericles and Dracontides», JHS 84, 69-72.

(1984), «Plutarch and Theseus», CB 60. 4, 65-73.

Fuhrman, F. (1964), Les images de Plutarque, Paris.

Fuqua, C. (1965), «Possible implications of the ostracism of Hyperbolus», TAPhA 96, 65-179.

Furley, W. (1989), «Andokides IV (« Against Alkibiades »). Fact or fiction. What Alcibiades did or what happened to him», Hermes 97, 138-156.

Fuscagni, S. (2000), «Le Vite parallele come genere letterario, ovvero Plutarco: uno storico e il suo genero", in Generi Letterari, 19-28.

Gaвва, E. (1981), «True History and False History in Classical Antiquity», JRS 71, 50-52.

Gagarin, M. (1989), Early Greek Law, University of California Press. 
- ed. (1997), Antiphon: The Speeches, Cambridge.

Galinsky, G. K. (1972), The Herakles theme: the adaptations of the hero in literature from Homer to the twentieth century, Oxford, Blackwell.

García, A. B. (1973), «El pensamiento de Plutarco acerca de la paz y de la guerra», $C F C$ 5, 141-191.

(1988), «Nepos and Plutarch: From Latin to Greek biography», ICS 13, 245-256.

(1989), «Nepos and Plutarch: From Latin to Greek Political Biography», ICS 13. 2, 245-256.

- (2002), «Felicitas temporum and Plutarch's choice of heroes», in Sage and Emperor, 93-102.

Gauthier, Ph. (1972), Symbola. L'étranger et la justice dans les cités grecques, Nancy.

Gelder, K. van (1991), «The Iron-Age Hiatus in Attica and the Synoikismos of Theseus», MedArch 4, 55-64.

Genep, A. (1902), Les rites de passage, Paris, Edition Nourry.

Gentili, B., Reni, G. (1970), «L'Idea di Biografia nel Pensiero Greco», QUCC 27, 1-27.

Gentili, B., Prato, C. (1988), Poetarum elegiacorum testimonia et fragmenta.

Ghali-Kahil, L. B. (1955), Les Enlèvements et le retour d'Hélène dans les textes et les documents figurés, Paris, Boccard.

Giannantonini, G. ed. ( 1990), Socratis et Socraticorum Reliquiae, 4 vol. Nápoles.

Gill, C. (1983), «The Question of Character Development: Plutarch and Tacitus», CQ 33, 469-487.

Gleason, M. W. (1990), «The Semiotics of Gender: Phisognomy and SelfFashioning in the Second Century», in D. M. Halperin, J. J. Winkler, F. Zeitlin (ed .), Before Sexuality, Princeton.

Goldstream, J. (1976), «Hero-cult in the Age of Homer», JHS 96, 8-17.

Gomme, A. W. (1945-1956), A Historical Commentary on Thucydides, Oxford. (1996), «Aristophanes and Politics», in Readings in Aristophanes, 2941.

Goossens, R. (1932), «Périclès et Thésée», BAGB 35, 9-40.

Gould, J. (1980), «Law, custom and myth: aspects of the social position of women in classical Athens», JHS 100, 38-59. 
Gouschin, V. (1999), «Athenian synoikism of the fifth century B. C., or two stories of Theseus», GE'R 46. 2, 168-187.

Graves, R. (32004), Os Mitos Gregos, trad. port., Lisboa, D. Quixote.

Grayeff, F. (1974), Aristotle and his School, London, Duckworth.

Green, A. (1973), «Thésée et Oedipe: interpretation psycoanalytique», in Il Mito Greco - Atti del Convegno Internazionale, Urbino 7-12 Maggio 1973, a cura di B. Gentili e Giuseppe Paione, 137-191.

Green, P. (1996), The Greco-Persian Wars, University of California Press.

Gribble, D. (1997), «Rhetoric and history in [Andocides] 4, Against Alcibiades», CQ 47. 2, 367-391.

(1999), Alcibiades and Athens: A Study in Literary Presentation, Oxford Clarendon Press.

Griffith, G. T. (1978), «A note on Plutarch Pericles 17», Historia 27, 218219.

Griffith, M. (2001), «Public and private in early Greek institutions of education», in Y. Lee Too (ed.), Education in Greek and Roman Antiquity, Boston, Brill.

Grimal, P. (21992), Dicionário de Mitologia Grega e Romana, trad. port., Linda-a-Velha, Difel.

Groten, Jr., F. J. (1963), «Herodotus use of variant versions», Phoenix 17, 79-87.

Gual, C. G. (1990), «La modération Attique de Thésée», in F. Jouan, André Motte, Actes du Colloque de Liège [14-16 septembre 1989], organisé par le Centre de Recherches Mythologiques de l'Université de Paris X et le Centre d'Histoire des religions de l'Université de Liège], Bibliothèque de la Faculté de Philosophie et Lettres de l'Université de Liège - Fasc. 227, Paris, Les Belles Lettres, 139-154.

-_(2001), Mitos, viajes, héroes, Madrid.

Guillemin, M., Jal, P. (2003), Oeuvres, Paris.

Gutglueck, J. (1988), «From pleonexiva to polugramosurnh: a conflation of possession and action in Plato's Republic», AJPh 109. 1, 21-39.

Guthrie, W. K. (1969), A History of Greek Philosophy, Cambridge, University Press.

(1971), The Sophists, Cambridge University Press.

HaLl, E. (1991), Inventing the barbarian: Greek self-definition through tragedy, Oxford Clarendon Press. 
Hall, J. M. (1995), «Beyond the Polis: the Multilocality of heroes», in R. Hagg (ed.), Ancient Greek hero cult: proceedings of the Fifth International Seminar on Ancient Greek Cult, organized by the Department of Classical Archaeology E' Ancient History, Goteborg University, 21-23 April 1995, 49-59.

Hammond, N. G. L. (1969), «Strategia and hegemonia in fifth century Athens», CQ 19, 111-144.

Scullard, H. H. (ed.) (21992), Oxford Classical Dictionary, Oxford Clarendon Press.

Hardwick, L. (1990), «Ancient Amazons - heroes, outsiders or women?», GERR 37. 1, 14-36.

Harlow, M. (1998), «In the name of the father: procreation, paternity, and patriarchy», in L. Foxhall, J. Salmon (ed.), Thinking men: masculinity and its self-representation in the classical tradition, London, Routledge, 155-169.

Harris, E. M. (1992), «Pericles' Praise of Athenian Democracy: Thucydides 2. 37. 1», HSCP 94, 157-167

Harris, H. A. (1964), Greek Athletes and Athletics, London, 102-109

Harrison, A. R. W. (1968-71), The Law of Athens, Oxford University Press.

Hart, J. (1982), Herodotus and Greek history, New York.

Hartog, F. (1980), Le miroir d'Hérodote. Essai sur la représentation de l'autre, Paris.

Hatzfeld, J. (1940), Alcibiades, Paris.

Havelock, E. A. (1957), The Liberal Temper in Greek Politics, London.

Heath, M. (1990), «Aristophanes and his Rivals», GERR 37, 143-158.

Henderson,J.J. (1975), The Maculate Muse: Obscene Language in Attic Comedy, New Haven.

Henry, M. (1995), Prisoner of history. Aspasia of Miletus and her biographical tradition, Oxford University Press.

Herman, G. (1987), Ritualised Friendship and the Greek City, Cambridge University Press.

Herter, H. (1936), «Theseus der Athener», RbM 85, 177-191. (1939), «Theseus der Jonier», RhM 88, 244-326. (1973), «Theseus», in Pauly Wissowa, RE, Suppl. VII, cols. 1045-1238.

Hignett, C. (1952), A History of the Athenian Constitution to the End of the Fifth Century BC, Oxford, Clarendon Press. 
Holladay, A. J. (1978), "Athenian strategy in the Archidamian war», Historia 27, 399-427.

Ноок, R. van (1931), «The praise of Athens in Greek tragedy», $T A P h A$ 62, 26 sqq.

Hornblower, S. (1982), «Thucydides, the Panionian Festival and the Ephesia (iii.104)», Historia 31, 241-245

(1987), Thucydides, London, Duckworth.

(1991), A Commentary in Thucydides, Vol. I, Books I-III, Oxford.

ed. (1994), Greek Historiography, Oxford Clarendon Press.

Huart, P. (1968), Le vocabulaire d'analyse psychologique dans l'oeuvre de Thucydides, Paris.

Hubbard, T. K. (2003), Homosexuality in Greece and Rome, University of California Press

Hude, C. (1913-1925), Thucydidis Historiae, Leipzig.

- [repr. 1951], Herodoti Historiae 2 vols, Bibliotheca Scriptorum Classicorum Bibliotheca Oxoniensis.

Hughes, D. D. (1991), Human Sacrifice in Ancient Greece, London, Routledge.

Humpreys, S. C. (1983), The Family, Women and Death, London.

Hunter, V. (1982), Past and Process in Herodotus and Thucydides, Princeton University Press.

Huxley, G. L. (1969), Greek Epic Poetry. From Eumelos to Panyassis, Faber. (1972), «On Aristotles's Historical Methods», GRBS 13, 157-169.

Immerwahr, H. R. (1954), «Historical Action in Herodotus», TAPhA 85, 16-45.

(1956), «Aspects of historical causation in Herodotus», $T A P h A$ 87, 241-280.

(1966), Form and Thought in Herodotus, Atlanta, Scholars Press.

Ingenkamp, H. G. (2004), «How to present a Statesman?», Statesman I, 87-104.

Jabouille, V. (1994), Iniciação à Ciência dos Mitos, Lisboa, Editorial Inquérito. Jaсову, F. (1949), Attis. The local chronicles of Ancient Athens, Oxford Clarendon Press.

(1961-1968), Die Fragmente der Griechischen Historiker, Leiden.

Jeanmaire, H. (1939), Couroi et Courètes. Essai sur l'éducation spartiate et 
les rites d'adolescence dans l'antiquité hellénique, Lille, Bibliothèque de l'Université.

JouAnnA, J. (1978), «Le médecin modèle du legislateur dans les Lois de Platon», Ktema 3, 77-91.

Johansen, K. F. (1945), Thésée et la danse à Delos, Kobenhavn.

Johnson, C. N. (1989), «Socrates encounter with Polus in Plato's Gorgias», Phoenix 43. 3 196-216.

Jones, C. P. (1971), Plutarch and Rome, Oxford.

Jones, L. A. (1987), «The Role of Ephialtes in the Rise of Athenian Democracy», Classical Antiquity 6, 53-76.

Kadletz, E. (1980), «The race and procession of the Athenian Oschophoroi», GRBS 21, 363-371.

Kagan, D. (1981), The Peace of Nicias and the Sicilian Expedition, Ithaca, Cornell University Press.

- (1987), The fall of the Athenian Empire, Ithaca, Cornell University Press. (1990), Pericles of Athens and the Birth of Democracy, London, Secker \& Warburg.

Karageorghis, J. (1977), La Grande Déesse de Chypre et son culte, Lyon-Paris, Maison de l'Orient - De Boccard.

Karsai, G. (1982), «La question du nomadisme: les Scythes d'Hérodote», AAntHung 30, 113-127.

Kassel, R., Austin, C. (1983-1995), Poetae Comici Graeci, Berolini Novi Eboraci.

Kastely, J. (1993), «Violence and Rhetoric in Euripides's Hecuba», PMLA 108. 5, 1036-1049

Kearns, E. (1989), The Heroes of Attica, BICS Suppl. 57.

Keaveney, A. (1996) «Persian Behaviour and Misbehaviour - some Herodotean Examples», Athenaeum 84 (1) 23-48

Kerényi, C. (1963), Gli dei e gli eroi della Grecia II. Gli eroi, Il Saggiatore, Milano.

Kerferd, G. B. (1976), «The image of the wise man in Greece in the period before Plato", in Images of man in ancient and medieval thought, Louvain, $17-28$

- (1981), The sophistic movement, Cambridge University Press.

Kiтto, H. D. F. (1966), «Aeschylus. How intelligent were the Athenians», in Poiesis, structure and thought, Berkeley, 74-115. 
KLosкo, G. (1984), «The refutation of Callicles in Plato's Gorgias», GERR 31. 2, 126-139.

Knight, D. W. (1970), «Thucydides and the war strategy of Perikles», Mnemosyne 23, 150-161.

Knox, B. M. W. (1952), «The Hippolytus of Euripides», YClS 13, 3-31.

Knox, B. M. W. (1964), The heroic temper: studies in sophoclean tragedy, Berkeley, University of California Press.

(1985), «So Mischievous a Beast? The Athenian «Demos» and Its Treatment of Its Politicians», GE'R 32. 2, 132-161.

- (1957), Oedipus at Thebes, New Haven and London, Yale University Press.

Komornicka, A. M. (1991), «Hélène de Troie et son «double» dans la littérature grecque (Homère et Euripide)», Euphrosyne 19, 9-26.

(1997), «Le pouvoir en question dans les comédies d'Aristophane», in P. Thiercy, M. Menu (ed.), Aristophane: la langue, la scène, la cité, Bari, Levante, 397-411.

Konstan, D. (1997), Friendship in Classical World, Cambridge University Press.

Kraay, C. (1970), Archaic and Classical Greek Coins, London.

Krappe, A. H. (1930), «Le mythe de la naissance de Cyrus«, REG 43, 153159.

Krentz, P. (1984), «The ostracism of Thoukydides, son of Melesias», Historia 33, 499-504.

Kron, U. (1971), «Patriotic heroes», in D. G. Mitten (ed.), Studies presented to G. M. A. Hanfmann, Cambridge, Fogg Art Museum, 61-83. (1976), Die zehn attischen Phylenheroen, Berlin.

Kurke, L. (1993), «The Economy of Kudos», in C. Dougherty, L. Kurke (ed.), Cultural Poetics in Archaic Greece: Cult, Performance, Politics, (Cambridge University Press), pp. 131-63

(1999), Coins, Bodies, Games and Gold: The Politics of Meaning in Archaic Greece, Princeton University Press.

Lacey, W. K. (1968), The Family in classical Greece, London, Thames \& Hudson.

LANG, M. L. (1972),«Cleon as the anti-Pericles», CPh 67, 159-169.

(1996), «Alcibiades vs. Phrynichus», CQ 46. 1, 289-295.

Larmour, D. H. J. (1988), «Plutarch's compositional methods in the Theseus 
and Romulus», TAPhA 118, 361-375.

(2004), «Statesman and Self in the Parallel Lives», Statesman II, 43-52.

Lateiner, D. (1976), «Tissaphernes and the Phoenician Fleet (Thucydides 8. 87)», TAPhA 106, 267- 290.

(1989), The Historical Method of Herodotus, Toronto.

Lawler, L. B. (1946), «The Geranos Dance - a new interpretation», TAPhA 77, 112-30.

Lazenby, J. F. (1993), The Defence of Greece, Warminster, Aris and Phillips.

Leal Soares, C., Ribeiro Ferreira, J. (2001), Heródoto. Livro 8. o, Lisboa.

LeÃo, D. F. (1999), Plutarco. Vida de Sólon. Introdução, tradução e notas, Lisboa. (2001), Sólon. Ética e politica, Lisboa.

Lee Too, Y. (ed.) (2001), Education in Greek and Roman Antiquity, Boston, Brill.

Legras, B. (1998), Éducation et culture dans le monde grec - VIII-I av. J. C., Sedes.

Lenardon, R. J. (1978), The Saga of Themistocles, London, Thames and Hudson.

Lesky, A. (1983), Greek Tragic Poetry, New Haven.

(1995), História da Literatura Grega, trad. port., Lisboa, Fundação Calouste Gulbenkian.

Lever, K. (1956), The Art of Greek Comedy, London, Methuen.

Levi, M. (1980), Pericle. Un uomo, un regime, una cultura, Milano, Rusconi.

LÉvi-Strauss, C. (1981), Mito e Significado (trad. port.) Lisboa, Edições 70.

Lewis, D. M. (1958), «The Phoenician Fleet in 411», Historia 7. 4, 392-397.

(1963), «Cleisthenes and Attica», Historia 12, 22-40.

(et alii) (21992), The Cambridge Ancient History, Vol. V - The Fifth Century B. C, Cambridge, University Press.

Liddell, H. G., Scott, R. ( $\left.{ }^{30} 1996\right)$, Greek-English Lexicon, Oxford University Press.

Lindsay, J. (1974), Helen of Troy - Woman and Goddess, London, Constable.

Littman, R. J. (1968), «The Strategy of the Battle of Cyzicus», TAPhA 99, 265-272.

(1970), Plutarch's use of Thucydides in the Life of Nicias, Life of Alcibiades and Life of Themistocles, Columbia Univ. New York. 
(1970), «The Loves of Alcibiades», TAPhA 101, 263-276.

Lloyd, M. (1992), The Agon in Euripides, Oxford.

Llopis, J. L. S. (1997), "Platón el cómico y la evolución de la comedia grega», in A. López Eire, (ed.), Sociedad, Politica y Literatura: Comédia Griega Antigua - Actas del I Congreso Internacional, Salamanca, 329337.

Lombardi, M. (1997), «Questioni di etica e ritratto biografico nelle Vite di Plutarco: la metabole del carattere», Orpheus 18, 375-95.

Long, H. S. (1964), Diogenes Laertius. Vitae philosophorum, Scriptorum Classicorum Bibliotheca Oxoniensis.

Long, T. (1987), Repetition and variation in the short stories of Herodotus, Frankfurt.

López, A, Pociña, A. (eds.) (2002), Medeas. Versiones de um mito desde Grecia hasta hoy, Granada.

López, J. G., Calderón, E. (eds.) (1991), Estudios sobre Plutarco: paisaje y naturaleza. Actas del II Simposio Español sobre Plutarco, Madrid. [Paisaje y Naturaleza]

Loraux, N. (1979), «L'autochthonie: une topique athénienne. Le mythe dans l'espace civique», Annales 34, 1-26.

-_ (1981a), Les Enfants d'Athéna, Paris.

(1981b), L'invention d'Athènes. Histoire de l'oraison funèbre dans la «cité classique», Paris, Mouton Éditeur.

(1990), Les expériences de Tiresias: le féminin et l'homme grec, Paris, Gallimard.

- (1996), Né de la terre: Mythe et politique à Athènes, Paris.

Louis, P. (1945), Les Métaphores de Platon, Paris, Les Belles Lettres.

Lourenço, F. (2006), Poesia Grega de Álcman a Teócrito, Lisboa.

Luce, J. M. (1998), «Thésée, le synoecisme et l'Agora d'Athènes», RA 1, 3-31

Luce, T. J. (1997), The Greek Historians, Routledge.

Luginbillm, R. D. (1999), Thucydides on War and National Character, Westview Press.

Luraghi, N. (ed.) (2001), The Historian's Craft in the age of Herodotus, Oxford University Press.

Macdowell, D. M. (1976), «Bastards as Athenian citizens», CQ 26, 88-91. (1983), «The Nature of Aristophanes Akbarnians», GERR 30, 143-161. 
MagÁn, M. C. (I 996), «Algunas observaciones en torno a la originalidad de la técnica biográfica plutarquea», in Aspectos Formales, 267-279.

Magueijo, C. (1984), Aristófanes. As Nuvens, Lisboa.

Mansfeld, J. (1980), «The Chronology of Anaxagoras' Athenian Period and the Date of his Trial II: the plot against Pericles and his associates», Mnemosyne 33. 1-2, 17-95.

Marchant, E. C. (1949), Xenophontis Opera Omnia, Oxford.

Marr, J. L. (1970), «Who said what about Alcibiades? Frogs 1422-34», CQ 20, 53-55.

Marrou, H. I. (1965), Histoire de l'éducation dans l'antiquité, Paris, Editions Seuil.

Marsh, F B. (1932), «Alcibiades and the Persian Alliance », CJ 28. 1, 12-21.

Marshall, M. (1990), "Pericles and the Plague», in E. M. Craik, Owls to Athens: Essays on Classical Subjects Presented to Sir Kenneth Dover, Oxford, Clarendon Press, 163-170.

Martin Jr., H., (1960)«The Concept of Praotes in Plutarch's Lives», GRBS $3,65-73$.

Mastronarde, D. J. (1986), «The optimistic rationalist in Euripides: Theseus, Jocasta, Tiresias», in Greek Tragedy and its Legacy, 149-165.

Mathieu, G., Brémond, E. (2003), Isocrate. Discours. Tomes I-IV, Paris.

Mathieu, H. (1995), «L'enfant, point de départ ou aboutissement du héros», in D. Auger (ed.), Enfants et enfances dans les mythologies, Paris, Les Belles Lettres, 13-30.

Mazon, P. (1951), Hésiode, Théogonie. Les Travaux et les Jours. Le Bouclier, Paris.

__ et alii (1955-1957), Homère. Iliade, Paris.

McCauley, B. (1971), «Heroes and power: the politics of bone transferral», in D. G. Mitten (ed.), Studies presented to G. M.A. Hanfmann, Cambridge, Fogg Art Museum, 87-98.

MacDonald, B. (1982), «The Autenticity of the Congress Decree», Historia 31, 120-123.

Macdowell, D. M. (1962), Andokides: On the Mysteries, Oxford. (1976), «Bastards as Athenian citizens», CQ 26, 88-91. - (1978), The Law in Classical Athens, Ithaca, New York. (1983), «The Nature of Aristophanes Akharnians», GE'R 30, 143161. 
McKinnon, J. (1984), Music in early Christian literature, Cambridge University Press, 1984.

Mayor, D. (1952), «Ideología de Eurípides», Humanidades 4, 18-43.

McGregor, M. F. (1965), «The genius of Alkibiades», Phoenix 19. 1, 27-50.

McNellen, B. (1997), «Herodotean Symbolism: Pericles as Lion Cub», ICS 22, 11-23.

Meier, C. (1987), «Historical answers to historical questions: the origins of history in ancient Greece», Arethusa 20, 41-58.

Meinhardt, E. (1957), Perikles bei Plutarch, Frankfurt.

Meritt, B. D. (1930), «The departure of Alcibiades for Sicily», AJA 34. 2, $125-152$.

Merkelbach, R., West, M. L. (1999), Fragmenta Hesiodea, Oxford.

Mikalson, J. D. (1975), The Sacred and Civil Calendar of the Athenian Year, Princeton.

Mills, S. (1997), Theseus, Tragedy and the Athenian Empire, Oxford, Clarendon Press.

Milman Parry, A. (1981), Logos and Ergon in Thucydides, Salem, Ayer.

Modrzejewski, J. (1979), «La structure juridique du mariage grec», in P. Dimakis (ed.), Symposion, Wien, 39-71.

Moggi, M. (1976), I sinecismi interstatali greci I, Pisa.

Momigliano, A. (1969), Studies in historiography, London, Weidenfeld and Nicholson.

(1972), «Tradition and the classical historian», HET 11, 279-293. - (1992), Les Fondations du Savoir Historique, Paris, Les Belles Lettres. - (1993), The Development of Greek Biography, Harvard, University Press.

Mommsen, A. (1898), Feste der Stadt Athen im Altertum, Leipzig, 1898.

Montuori, M. (1981), «Di Aspasia Milesia», in G. Giangrande, Corolla Londiniensis I, 87-109.

Moorton, R. F. (1988), «Aristophanes on Alcibiades», GRBS 29, 345-359.

Moreau, A. (1990), «Le retour des cendres: Oreste et Thésée, deux cadavres (ou deux mythes) au service de la propagande politique», in F. Jouan, A. Motte, Actes du Colloque de Liège [14-16 septembre 1989], organisé par le Centre de Recherches Mythologiques de l'Université de Paris X et le Centre d'Histoire des religions de l'Université de Liège], Bibliothèque 
de la Faculté de Philosophie et Lettres de l'Université de Liège - Fasc. 227, Paris, Les Belles Lettres, 1990, 209-217.

Morgan, T. (1999), «Literate education in classical Athens», CQ 49.1, 46-61. Morrison, J. S., Gomme, A. W. (1950), «Pericles Monarchos», JHS 70, 7677.

Morley, N. (1999), Writing Ancient History, London, Duckworth.

Mossé, C. (1962), La fin de la démocratie athénienne, Paris, Presses Universitaires.

(1971), Histoire d'une démocratie: Athènes: des origines à la conquête macédonienne, Paris, Editions du Seuil.

(1979), «Comment s'élabore un mythe politique: Solon, «père fondateur» de la démocratie athénienne», Annales 54, 425-437.

—_, Schnapp-Gourbeillon, A. (1994), Sintese de História Grega (trad. port.), Porto, Edições Asa.

Mossman, J. (ed.) (1997), Plutarch and his Intelectual World, London, Duckworth.

Mühll, P. von der (1946), Homeri Odyssea, Basileia.

Murray, G. [repr. 1947], Aeschyli Septem quae supersunt tragoediae, Scriptorum Classicorum Bibliotheca Oxoniensis.

Myres, J. L. (1953), Herodotus, father of History, Oxford.

Mynors, R. (1958), Catulli, Carmina, Bibliotheca Scriptorum Classicorum Bibliotheca Oxoniensis.

(1969), P. Vergili Maronis Opera, Bibliotheca Scriptorum Classicorum Bibliotheca Oxoniensis.

NAGY, B. (1994), «Alcibiades' second «profanation»», Historia 43. 3, 275-285.

Nauck, A. ed. (1926), Tragicorum Graecorum Fragmenta, Leipzig.

Nikolaidis, A. G. (1978), «Aristotle's treatment of the concept of ПРАОТН $\Sigma$ », Hermes 106, 415-422.

(1997), «Plutarch's criteria for judging his historical material», in Historia, 329-341.

(1995), «Plutarch's heroes in action: does the end justify the means?», in Teoria e Prassi, 301-312.

, A. G. (2008), The unity of Plutarch's work: "Moralia" themes in the "Lives", features of the "Lives" in the "Moralia", Berlin - New York, Walter de Gruyter. 
Nilsson, M. P. (1953), «Political Propaganda in Sixth Century Athens», in G. E. Mylonas, D. Raymond, Studies Presented to David Moore Robinson, Saint Louis, Washington University Press, 743-748.

Nilsson, M. P. (1970), Geschichte der Griechischen Religion, I, Munich, 136-8. (1972), Cults, Myths, Oracles, and Politics in Ancient Greece, New York, Cooper Square Publishers, Inc.

Oliveira, F., Sousa e Silva, M. F. (1991), O Teatro de Aristófanes, Coimbra, Gabinete de Publicações da FLUC.

Oliver, J. H. (1955), «Praise of Periclean Athens as a Mixed Constitution», RhM 98, 37-40.

Orban, M. (1981), «Hippolyte»: Palinodie ou Revanche», LEC 49, 3-17.

Palerm, V. R. (1991), «Sobre Tradición y Originalidad en el Modelo Biográfico de Plutarco», in Paisaje y Naturaleza, 107-113.

Parke, H. W., Wormell, D. E. W. (1956), The Delphic Oracle, Basil, Blackwell. Parke, H. W. (1977), Festivals of the Athenians, London, Thames and Hudson.

Pauly,A.,Wissowa, G., Kroll,W. (1894-1978), Realencyclopädie der Classischen Altertumswissenschaft, Stuttgart. [RE]

Patterson, C. (1991), Married woman in Athenian Law», in S. B. Pomeroy (ed.) (1991), Women's History and Ancient History, Chapel Hill, University of Carolina Press, 48-72.

(1998), The family in Greek history, Harvard University Press.

Pearson, A. C. (repr. 1951), Sophoclis Fabulae 2 vols., Bibliotheca Scriptorum Classicorum Bibliotheca Oxoniensis.

PéLékidis, C. (1962), Histoire de l'éphébie attique, Paris, Editions E. de Boccard.

Pelling, C. (1980), «Plutarch's adaptation of his source-material», JHS 100 (1980), 127-140.

(1986), «Synkrisis in Plutarch's Lives», in Miscellanea Plutarchea, Ferrara, 83-96.

(1989), «Aspects of Plutarch characterization», ICS 13. 2, 257-273.

(1990), «Truth and Fiction in Plutarch's Lives», in D. A. Russell (ed.), Antonine Literature, Oxford Clarendon Press.

(1990b), "Childhood and Personality in Greek Biography», in C. Pelling (ed.), Characterisation and Individuality in Greek Literature, Oxford University Press, , 213-244.

(1997), (ed.), Greek Tragedy and the historian, Oxford Clarendon Press. 
(1999), «'Making myth look like History’: Plato in Plutarch’s TheseusRomulus», in Plutarco, Platón y Aristóteles, 432.

(2000), «Rhetoric, Paideia, and Psychology in Plutarch's Lives», in Rhetorical Theory and Praxis, 331-339.

- (2002), Plutarch and History, Classical Press of Wales.

(2004), «Do Plutarch's politicians never learn?», Statesman I, 105-114.

Percy, W. A. (1996), Pederasty and Pedagogy in Archaic Greece, University of Illinois Press, Urbana and Chicago.

Pérez Jiménez, A. (1988), «El ideal de buen rey según Plutarco», in J. M. Candau, F. Gascó, A. Ramírez de Verger (ed.), La Imagen de la Realeza en la Antigüedad, Madrid, 89-113.

(1994), «Plutarch: the irresponsabilities of Aegeus», $A n c W$ 25, 223231.

(1994b), «Precisiones a la doctrina de Plutarco sobre el carácter», in Ideas Religiosas, 331-340.

(1995), «Proairesis: las formas de acceso a la vida pública y el pensamiento político de Plutarco», in Teoría e Prassi, 363-381.

(1996), «La Asociación de Ideas como Criterio Formal en las Vidas Paralelas», in Aspectos Formales, 257-265.

(1996), Plutarco. Vidas Paralelas II - Sólon - Publicola; Temistocles Camilo; Pericles - Fabio Máximo, Madrid.

(1997), «Conciencia Lingüística del Modelo y Proceso de Creación Literaria: a Propósito de Plutarco Pericles 35. 3», in Plutarco y la Historia, pp. 379-384.

Pérez Jiménez, A. (ed.) (1999), Plutarco, Platón y Aristóteles. Actas del V Congreso Internacional de la I.P.S. (Madrid-Cuenca, 4-7 de mayo de 1999), Madrid. [Plutarco, Platón y Aristóteles]

(2000a), «Plutarco y su imagen de Teseo», in V. Pirenne-Delforge, E. S. de la Torre (ed.), Héros et héroïnes dans les mythes et les cultes grecs, Kernos Supplément 10, Liège, 229-240.

(2000b), «Perfiles humanos de un héroe: Plutarco y su imagen de Teseo», ibidem, 229-240.

(2000c), Plutarco. Vidas Paralelas I-Teseo-Rómulo; Numa-Licurgo, Madrid.

- Casadesús Bordoy, F. (eds.) (2001), Estudios Sobre Plutarco Misticismo y Religiones Mistéricas en la Obra de Plutarco. Actas del VII Simposio Español sobre Plutarco (Palma de Mallorca, 2-4 de noviembre 
de 2000), Madrid. [Misticismo]

(2002a), «Exemplum: the paradigmatic education of the ruler in the Lives of Plutarch», in Sage and Emperor, 105-114.

(2002b), «La elocuencia como instrumento político en las Vidas Paralelas de Plutarco», CFC 12, 253-270.

(2004), «Los héroes de Plutarco y su elección entre la justicia y la utilidad», Statesman I, 127-136.

, Titchener, F. (eds.) (2005), Historical Values of Plutarch's Works. Studies Devoted to Professor P. A. Stadter by the International Plutarch Society, Málaga-Logan. [Historical Values of Plutarch's Works]

, P. Ortiz (2006), Plutarco. Vidas Paralelas III - Coriolano-Alcibiades; Paulo Emilio - Timoleón; Pelópidas - Marcelo, Madrid.

Perrin, B. (1906), «The death of Alcibiades», TAPhA 37, 25-37.

(1907), Plutarch's Lives III. Pericles and Fabius Maximus, Nicias and Crassus, with an English Translation by..., London.

(1916), Plutarch's Lives IV. Alcibiades and Coriolanus, Lysander and Sulla, with an English Translation by..., London.

Pfeiffer, R. (1968), History of Classical Scholarship: From the Beginnings to the End of Hellenistic Age, Oxford Clarendon Press.

Piatкowski, A. (1972), «Les concepts de «civilisateur» et de «civilisation» dans la pensée des grecs anciens», StudClas 14, 27-39.

Picard, O. (1986), La Grèce ancienne, Paris, Editions du Seuil.

Piccirilli, L. (1975), Megariká: Testimonianze e Frammenti, Pisa.

(1989), «La tradizione «nera» biografie plutarchee degli Ateniesi del sesto e quinto secolo», in A.Cereza-Gastaldo, Gerolamo e la biografia letteraria, Publ. Dipartimento di Archeologia, filologia clássica e loro tradizioni, nuova série 125, Genova, 5-21.

Pinheiro, A. E., Ribeiro Ferreira, J. (2005), Hesiodo: Teogonia. Trabalhos e Dias, Lisboa.

Pinheiro, J. (2008), Plutarco. Obras morais: Da educação das crianças, Coimbra, Centro de Estudos Clássicos e Humanísticos.

Plácido, D. (1983), «De la muerte de Pericles a la stasis de Corcira», Gerion $1,131-143$.

Plinval, G. de (1959), Cicéron, Traité des Lois, Paris.

Podlecki, A. J. (1971), «Cimon, Skyros and Theseus' Bones», JHS 91, 141143. 
(1975), «Theseus and Themistocles», RSA 5, 1-20.

(1976), «A Pericles Prosôpon in Attic Tragedy», Euphrosyne 7, 7-27.

(1987), Plutarch Life of Pericles, Bristol.

(1989), «Plutarch and Athens», ICS 13. 2, 231-243.

Poliakoff, M. B. (1982), «Studies in the Terminology of Greek Combat Sports» Beiträge für klassischen Philologie 146.

(1987), Combat and Sports in the Ancient world: Competition, Violence and Culture, London, 23-63.

Polman, G. H. (1974), «Chronological Biography and Akmē in Plutarch», CPh 69, 169-177.

Poole, R. S. (et alii) (1873-1927), Catalogue of the greek coins in the British Museum, vol. 11 - Catalogue of the Greek coins: Attica, Megaris, Aegina, British Museum Trustees.

Portela, J. A. (2002), As Amazonas no mundo grego, Coimbra, (texto policopiado).

Powell, B. (2002), Writing and the Origins of Greek Literature, Cambridge University Press.

Prado, A. L. A. A. (1993), Tucídides - História da Guerra do Peloponeso. Livro I, São Paulo.

Prandi, L. (1977), «Processi contro Fidia, Aspasia, Anassagora, el'opposizione a Pericle», Aeuum 51, 10-26.

(2005), «Singolare e plurale nelle Vite greche di Plutarco», Statesman II, 141-156.

Price, T. H. (1973), «Hero-cult and Homer», Historia 22, 129-144.

Pritchett, W. K. (1969), «The transfer of the Delian Treasury», Historia 18, 17-21.

(1974), The Greek State at War, vol. II, Berkeley.

Proctor, D. (1980), The Experience of Thucydides, Warminter, Aris \& Phillips.

Pulquério, M. O. (1997), Platão. Górgias, Lisboa.

RaAflaub, K. (1987), «Herodotus, political thought, and the meaning of History», Arethusa 20, $221-248$.

- (1989), "Contemporary perception of democracy in fifth-century Athens», CङंM 40, 33-70.

Ramón Palerm, V. (1992), Plutarco y Nepote. Fuentes e interpretación del modelo biográfico plutarqueo, Zaragoza. 
Raubitscheк, A. E. (1966), «The peace policy of Perikles, AJA 70, 37-41.

Reinhardt, K. (1976), Sófocles, Barcelona, Ediciones Destino.

Reynolds, L. D. (1998), M. Tulli Ciceronis De Finibus bonorum et malorum: libri quinque, Bibliotheca Scriptorum Classicorum Bibliotheca Oxoniensis.

Reverdin, O., Nenci, G. (ed.) (1990), «Hérodote et les peuples non grecs», Entretiens Hardt 35, Genève.

Revermann, M. (1997), «Cratinus' Dionusalexandros and the head of Pericles», JHS 117, 197-200.

Rhodes, P. J. (1981), A Commentary on the Athenaion Politeia, Oxford, 74.

Ribeiro Ferreira, J. (1986), «Aspectos Políticos nas Suplicantes de Eurípides», Humanitas 37-38 87-121.

- (1990a), A Democracia Ateniense, Coimbra, Livraria Minerva.

(1990b), A Democracia na Grécia Antiga, Coimbra, Livraria Minerva.

(1990c), «Péricles e a democracia ateniense», Euphrosyne 18, 23-38.

-, Silva, M. F. (1994), Heródoto. Histórias. Livro 1. o, Lisboa.

(1997), Platão. Fedro, Lisboa.

——, Leão, D. F. (2000) Heródoto. Livro 6. ${ }^{\circ}$, Lisboa.

(coord.) (2002), Actas do congresso Plutarco, educador da Europa, Coimbra.

—_ LEÃo, D. F. (coords.) (2003): Os fragmentos de Plutarco e a recep̧̧ão da sua obra Coimbra.

—_ van der Stockt, L., Fialho, M. C. (ed.) (2008), Philosophy in society virtues and values in Plutarch, Leuven-Coimbra, Katholieke Universiteit Leuven-Imprensa da Universidade de Coimbra.

Ricotтi, E. S. P. (1995), «Giochi e giogattoli», Studi e Materiali del Museo della Civilità Romana 18, 47-48

Rовв, K. (1994), Literacy and Paideia in Ancient Greece, Oxford University Press.

Robertson, N. (1986), «Solon's axons and kyrbeis, and the $6^{\text {th }}$ century background», Historia 35, 147-176.

Rов кіn, A. L. H. (1979), «The Odeion of Perikles. The date of its construction and the Periklean building program», $A n c W 2,3-12$.

Rocha Pereira, M. H. (1989-1990), Pausaniae Graeciae Descriptio 3 vols., Bibliotheca Scriptorum Graecorum et Romanorum Teubneriana, 


\section{Leipsig.}

(1998a), Estudos de História da Cultura Clássica, volume I - Cultura Grega, Lisboa, Fundação Calouste Gulbenkian.

(1998b), Hélade, Coimbra.

- (2001), Platão. A República, Lisboa.

—_ Ribeiro Ferreira, J., Fialho, M. C. (2003), Sófocles. Tragédias, Coimbra.

Rocha, R., Soares, C. (2010), Obras Morais - Sobre o Afecto aos Filhos, Sobre a Música, Coimbra, Centro de Estudos Clássicos e Humanísticos.

Roscher, W. H. (1965), Ausfübrliches Lexicon der griechischen und römischen Mythologie, Hildesheim, Georg Olms Verlagsbuchhandlung.

Rodhes, P. J. (1981), A Commentary on the Aristotelian Athenaion Politeia, Oxford.

Rodrigues, A. C., Ferreira, A. (2010), Plutarco. Vidas Paralelas - Péricles e Fábio Máximo, Coimbra, Centro de Estudos Clássicos e Humanísticos.

Rodríguez Adrados, F. (1962), "Pericles y la democracia de su época», EClás 6, 333-403.

Rodríguez, M. T. A. (1997), «Crítica y Elogio en los fragmentos de Cratino: algunos aspectos», in A. López Eire, (ed.), Sociedad, Politica y Literatura Comedia Griega Antigua: Actas del I Congreso Internacional, Salamanca, 233-242.

Rodríguez Somolinos, H. (), Plutarco, Obras Morales y de Costumbres X Madrid, Gredos.

Roisman, J. (1984-6) «The image of the political exile in archaic Greece», AncSoc 17, 23-32.

Romilly, J. (1961), Thucydide et l'impérialisme athénien : la pensée de l'historien et la genèse de l'oeuvre, Les Belles Lettres.

(1962), Thucydide. La Guerre du Péloponnèse, Paris.

(1965), «L'optimisme de Thucydide et le jugement de l'historien sur Périclès (Thuc. ii, 65)», REG 78, 557-575.

(1979), La douceur dans la pensée grecque, Paris, 1979,

(1988a), Les grands sophistes dans l'Athènes de Périclès, Paris, Editions de Fallois.

(1988b), «Plutarch and Thucydides or the free use of quotations», Phoenix 42, 22-34.

(1989), «Rencontres avec Plutarque», ICS 13. 2, 219 -229. 
(1995), Alcibiade, Paris.

Rose, V. (1886), Aristotelis Qui Ferebantur Librorum Fragmenta, Leipzig.

Rosenbloom, D. (2004), «Ponêroi vs. Chrêstoi: The Ostracism of Hyperbolos and the Struggle for Hegemony in Athens after the Death of Perikles, Part I», TAPhA 134, 55-105.

Rosenmeyer, T. G. (1951), «The wrath of Oedipus», Phoenix 5. 1, 92-112. (1957), «Hesiod and Historiography», Hermes 85, 257-285.

Ros кAm, G. (2002), «A Paideia for the ruler. Plutarch's dream of collaboration between philosopher and ruler», Sage and Emperor, 175-189.

Ross, W. D. (1957), Ars Rhetorica, Scriptorum Classicorum Bibliotheca Oxoniensis.

(1959), Aristotelis Politica, Scriptorum Classicorum Bibliotheca Oxoniensis.

Roussel, D. (1973), Les Historiens grecs, Presse Universitaire de France.

Rosivach, V. J. (1987), «Autochthony and the Athenians», CQ 37. 2, 294306;

Russell, D. A. (1966a), «On Reading Plutarch's Lives», GERR 13. 2, 139154.

(1966b), «Plutarch, Alcibiades 1-16», PCPhS 12, 37-47.

(1973), Plutarch, London, Duckworth.

(1983), Greek Declamation, Cambridge, University Press.

Rusten, J. S. (1985), «Two lives or three? Pericles on the Athenian character (Thucydides 2. 40.1-2)», CQ 35, 14-19.

Saddington, D. B. (1970), «The education of an ideal man - the views of Plato, Cicero and Augustine», Akroterion, 15.1, 5-16.

SAÏD, S. (2005), «Plutarch and the People in the Parallel Lives», in Statesman II, 7-26.

Sainte Croix, G. E. M. (1972), The Origins of Peloponesian War, London, Duckworth.

___ «The Political outlook of Aristophanes», in Readings in Aristophanes, 42-64.

Salcedo Parrondo, M. (2001), «Alcibiades 34. ¿Un incumplimiento religioso, un conflicto social?», in Misticismo, 223-258.

(2005), «Retórica visual y carácter político, Alc. 10: un modelo negativo de enargeia», Statesman II, 179-186. 
Samons, L. J. (1998-1999), «Aeschylus, the Alkmeonids and the reform of the Areopagos», CJ 94. 3, 221-233.

Santoni, A. (1991), Plutarco. Vite Parallele. Pericle (Introduzione di P. A. Stadter). Pericle (Introduzione di Roberto Guerrini), Milano.

SAnsone, D. (1989), «Notes on Plutarch: Pericles and Fabius», ICS 13. 2, 311-318.

Saxonhouse, A. W. (1986), «Myths and the origins of the cities: reflections of the autochthony theme in Euripides' Ion», in J. P. Euben, Greek tragedy and Political Theory, University of California Press, 252-273.

Scarpi, P. (1997), I Miti Greci. Bibliotheca, Milano.

Schefold, K. (1946), «Kleisthenes», Museum Helveticum 3, 59-93.

Schmidt, T. S. (2004), «Barbarians in Plutarch's political thought», Statesman I, 227-236.

Schrader, C., Ramón, V., Vela, J. (ed.) (1997), Plutarco y la Historia. Actas del V Simposio Español sobre Plutarco, Zaragoza. [Plutarco y Historia]

Scodel, R. (1999-2000), «Verbal Performance and Euripidean Rhetoric», ICS 24. 5, 129-44.

Scotт, D. (2000), «Socrates and Alcibiades in the Symposium», Hermathena $168,25-37$.

Scott-Kilvert, I. (1960), The Rise and Fall of Athens: nine Greek lives by Plutarch, London.

Seager, R. (1967), «Alcibiades and the charge of aiming at tyranny», Historia 16, 6-18.

SÉchan, L. (1942), «Plutaruqe au miroir du Thésés», REG 56, 83-106.

SEgal, C. (1979), «The myth of Bacchylides 17: Heroic Quest and Heroic identity», Eranos 77. 1, 43-51. (2000), Oedipus Tyrannus - Tragic heroism and the limits of knowledge, Oxford University Press.

Segal, E. (1996), Oxford Readings in Aristophanes, Oxford University Press.

Serra, J. P. (1986), «Pedagogia e exemplo na Historiografia Grega», Euphrosyne 14, 53-76.

Shackleton Bailey, D. R. (1985), Q. Horati Flacci Opera, Stuttgardiae.

Shapiro, H. A. (1983), «The Marriage of Theseus and Helen», in Festivals of Attica, 232-236. (1990), «Myths in Images: Theseus and Medea as a Case study», in L. Edmunds, Approaches to Greek Myth, The Johns Hopkins University Press, Baltimore and London, 395-445. 
Shaw, B. D. (1991)«The paradoxes of people power», Helios 18. 2, 194-214.

Shaw, M. H. (1982), «The $\ddot{\eta} \theta$ o of Theseus in The Suppliant Women», Hermes 110, 3-19.

Sicking, C. M. (1995), «The general purport of Pericles' funeral oration and last speech», Hermes 123.4, 404-424.

Sikes, E. E. (1931), The Greek View of Poetry, London, Methuen \& Co. Ltd.

Snell, B. (1949), Bacchylidis Carmina cum Fragmentis post Fr. Blss et Guil, Leipzig.

Silva, C. R. (2000), C. Eurípides. Os Heraclidas., Lisboa, Edições 70.

Snell, B. (1953), Pindari Carmina cum Fragmentis, Bibliotheca Scriptorum Graecorum et Romanorum Teubneriana, Leipsig.

Silva, M. F. S. (1980), Aristófanes. Os Acarnenses, Coimbra, Centro de Estudos Clássicos e Humanísticos da FLUC.

(1997), CCratino - a Sombra de um Grande Poeta», Humanitas 49, 3-23.

(1999), Teofrasto. Os Caracteres, Lisboa.

- (2001), Heródoto. Livro 4. ${ }^{\circ}$, Lisboa.

(2004), «Os Cavaleiros de Aristófanes: um padrão de caricatura na biografia do político», in A. Pérez Jiménez, J. Ribeiro Ferreira, M. C. Fialho (coord.), O Retrato e a Biografia como estratégia de teorização politica, Imprensa da Univ. de Coimbra / Univ. de Málaga, 23-36.

_-_(2005), «Sacrifício voluntário. Teatralidade de um motivo euripidiano», in Ensaios Sobre Euripides, Lisboa, Cotovia, 125-165.

—__ed. (2006), Aristófanes. Comédias I, Lisboa. (2007), «Ser Ateniense: uma honra em risco? O testemunho de Acarnenses de Aristófanes», in Ensaios sobre Aristófanes, Lisboa, Cotovia, 137-151.

Silva, M. F. S., Abranches, C. (1997), Heródoto. Livro 3. ', Lisboa.

Silva, M. F. S., Leal Soares, C. (2007), Heródoto. Livro 5. o, Lisboa.

Simon, A. (1983), Festivals of Attica: an archaeological commentary, University of Wisconsim Press. [Festivals of Attica]

Simon, E. (1985), Die Götter der Griechen, München.

Slater, P. E. (1974), «The Greek family in history and myth», Arethusa 7, 9-44.

Soares, C. L, J. Ribeiro Ferreira, Fialho, M. C. (2008), Ética e paideia em 
Plutarco, Coimbra, Centro de Estudos Clássicos e Humanísticos.

Sommerstein, A. H. (1997), «Platón, Éupolis y la comedia de demagogo», in A. López Eire (ed.), Sociedad, Politica y Literatura: Comedía Griega Antigua-Actas del I Congreso Internacional, Salamanca, Logo, 183-195.

Sourvinou-Inwood, C. (1971), «Theseus lifting the rock and a cup near the Pithos painter (plate XII)», JHS 91, 94-109.

(1979), Theseus as Son and Stepson. A tentative illustration of the Greek mythological mentality, Institute of Classical Studies, University of London.

- (1987), «A series of erotic pursuits: images and meanings», JHS 107, 131-153.

Spence, I. G. (1990), «Perikles and the Defence of Attika during the Peloponnesian War», JHS 110, 91-109.

Sprague, R. K. (1976), Plato's Philosopher-King, Columbia-South Carolina, University of South Carolina Press.

Stadter, P. A. (1965), Plutarch's Historical Methods - An Analysis of the Mulierum Virtutes, Harvard University Press, 125-140.

(1973), The Speeches in Thucydides, Chapel Hill, University of North Carolina Press.

(1975),«Plutarch’s Comparison of Pericles and Fabius Maximus», GRBS 16, 77-85.

(1983), «The motives for Athens' alliance with Corcyra (Thuc. 1. 44)», GRBS 24, 131-136.

(1987), «The rhetoric of Plutarch's Pericles», Anc.Soc. 18 251-269.

(1988), «The proems of Plutarch's Lives», ICS 13. 2, 275 - 295.

(1989), A Commentary on Plutarch's Pericles, Chapel Hill and London, The University of North Carolina Press.

(1992), Plutarch's and the Historical Tradition, London, Routledge.

(1996), «Anecdotes and the Thematic Structure of Plutarchean Biography», in Aspectos Formales, 291-303.

(1997), «Plutarch's Lives: The Statesman as a Moral Actor», in Historia, 65-81.

(2000), «The Rhethoric of Virtue in Plutarch's Lives», in Rhetorical Theory and Praxis, 493-510.

——, Sтоскт, L. van der (2002), Sage and Emperor: Plutarch, Greek Intellectuals, and Roman Power in the Time of Trajan (98-117 A.D.), 


\section{Leuven. [Sage and Emperor]}

Stanford, W. B. (1963), The Ulysses Theme. A Study in the Adaptability of a Traditional Hero, Oxford.

Stanley, P. V. (1986), «The family connection of Alcibiades and Axiochus», GRBS 27. 2, 173-181.

Stevens, P. T. (1956), «Euripides and the Athenians», JHS 76, 87-94.

Sтоскт, L. van der (ed.) (1996), Plutarchea Lovaniensia. A Miscellany of Essays on Plutarch. Studia Hellenistica 32, Leuven. [Plutarchea Lovaniensia] (ed.) (2000), Rhetorical Theory and Praxis in Plutarch. Acta of the IVth International Congress of the IPS (Leuven, July 3-6, 1996), Louvain. [Rhetorical Theory and Praxis]

Stroud, R. (1979), The Axones and Kyrbeis of Dracon and Solon, London.

Swain, S. (1989), «Character Change in Plutarch», Phoenix 43, 62-68.

TArkow, T. A. (1984), «Tragedy and transformation. Parent and child in Euripides' Hecuba», Maia 36, 123-136

Tatum, J. W. (1996), «The Regal Image in Plutarch's Lives», JHS 116, 135-151.

TAylor, A. E. (1917), «On the date of the trial of Anaxagoras», CQ 11, 8187.

Taylor, M. W. (1981), The Tyrant Slayers. The Heroic Image in Fifth Century B. C., Athenian Art and Politics, New York, Arno Press.

Teixeira, E. (1991), «Poesie et education dans le De Audiendis Poetis de Plutarque», CEA 25, 223-236.

Teodorson, S. T. (2000), «Plutarch's use of synonyms: a typical feature of his style», in Rhetorical Theory and Praxis, 511-518.

Thomas, R. (1989), Oral Tradition and Written Record in Classical Athens, Cambridge.

Thompson, W. E. (1970), «The kinship of Perikles and Alcibiades», GRBS $11,27-33$.

Titchener, F. B. (2003), «Cornelius Nepos and the Biographical Tradition», $G \mathcal{E}^{2} R$ 50. 1, 85-99.

Todd, S. C. (1993), The Shape of Athenian Law, Oxford Clarendon Press.

Toepffer, J. (1889), Attische Genealogie, Berlin, 226-28.

Tracy, S. ( 1 987), «Helen, her name and nature», JHS ıо7, г 88-ı 93.

Trail, J. S. (1975), The Political Organization of Attica, Hesp. Suppl. 14.

Trapp, M. (2004), «Statesmanship in a minor key?», Statesman I, 189-200. 
Tricot, J. (1967), Aristote. Ethique à Nicomaque, Paris.

Tyrrell, W. B. (1984), Amazons: a Study in Athenian Mythmaking, Baltimore, The John Hopkins University Press.

—_, Brown, F. S. (1991), Athenian Myths and Institutions, Oxford University Press.

Untersteiner, M. (1993), Les Sophistes, Paris, Librairie Philosophique J. Vbrin.

Unz, R. K. (1986), «The Chronology of the Pentekontaetia», CQ 36, 68-85.

VALdÉs, M. G. (1984), «Análisis Formal de la Biografia en Plutarco», in P. Bádenas de la Peña et alii (ed.), Athlon - Satura Grammatica in honorem Francisci R. Adrados, vol II, Madrid, Gredos, 323-334.

- (ed.) (1994), Estudios sobre Plutarco: ideas religiosas. Actas del III Simposio Español sobre Plutarco (Oviedo, 30 de abril a 2 de mayo), Madrid. [Ideas Religiosas]

__ (2001), «El proceso del sinecismo del Ática: cultos, mitos y rituales en la «primera polis» de Atenas», Gerion 19, 127-197.

VAlgiglio, E. (1987), «ISTORIA E BIOS in Plutarco», Orpheus 8, 50-70. (1992), «Dagli «Ethica» ai «Bioi» in Plutarco», ANRW 33. 6, 39634051.

Valverde Sánchez, M., Somolinos, H. R., Martín, C. A. (2003), Plutarco, Obras Morales y de Costumbres X, Madrid.

Van RaAlte, M. (2004), «More philosophico: political virtue and philosophy in Plutarch's Lives, Statesman II, 75-112.

Vandiver, E. (1990), Heroes in Herodotus. The Interaction of Myth and History, Frankfurt, Peter Lang.

Várzeas, M. (2010), Plutarco. Vidas Paralelas: Demóstenes e Cicero, Coimbra, Centro de Estudos Clássicos e Humanísticos.

Vega, J. L. de la (2003), Sófocles, Madrid, Ediciones Clásicas.

Verdegem, S. (2001), «On the road again: Alcibiades' restoration of the Eleusinian pomptv in Plu. Alc. 34.3-7», in Misticismo, 451-459.

(2004/2005), «Plotting Alcibiades Downfall. Plutarch's use of his Historical Sources in Alc. 35.1 - 36. 5», Ploutarchos, n.s. 2, 141-150

(2004), «De gloria Alcibiadis. Alcibiades' military value and its relation to his doxa in Plutarch's Alcibiades», Statesman II, 167-178.

(2005), «An intriging begining. the proemial functions of Plu. Alc. 1», Historical Values of Plutarch's Works, 479-486. 
Vergetti, M. (1966), «La medicina in Platone», Rivista Critica di Storia della Filosofia 21, 3-39.

- (1967), «La medicina in Platone», Rivista Critica di Storia della Filosofia 22, 251-270.

(1968), «La medicina in Platone», Rivista Critica di Storia della Filosofia 23, 251-267.

(1969), «La medicina in Platone», Rivista Critica di Storia della Filosofia 24, 3-22.

Vergnières, S. (1995), Éthique et politique chez Aristote: physis, êthos, nomos, Paris, P.U.F.

Vernière, Y. (1983), «Masques et Visages du destin dans les Vies de Plutarque», in F. Jouan, Les Visages du destin dans les Mythologies, Mélanges Jacqueline Duchemin, Centre de Rech. Mythol. de l'Université. de Paris X (Travaux \& Mémoires. Actes du Colloque de Chantilly 1- 2 Mai 1980), Paris, Les Belles Lettres.

Vickers, M. J. (1989), «Alcibiades on stage: Aristophanes Birds», Historia 38. 3, 267-299.

(1994), «Alcibiades and Critias in the Gorgias: Plato's «fine satire»», DHA 20.2, 85-112.

(1995), «Alcibiades at Sparta: Aristophanes Birds», CQ 45. 2, 339-354.

(2000), «Alcibiades and Aspasia: notes on the Hippolytus », DHA 26. 2, 7-17.

Visser, M. (1986), «Medea: daughter, sister, wife and mother. Natal family versus conjugal family in Greek and Roman world», in Greek Tragedy and its Legacy, 149-65.

VRIEs, G. J. (1975), «Pericles tonans», Mnemosyne 28, 65-66.

(1975b), «Theophrastus on Pericles' last illness», Mnemosyne 28, 193.

Wade, H. T. (1938), «Two notes on Theopompus' Philippika 10», AJPh 59, 129-134.

Walbank, F. W. (1960), «History and Tragedy», Historia 9, 216-239.

Walcot, P. (1977), «Odysseus and the art of lying», AncSoc. 8, 1-19,

Walker, H. J. (1989), Myth and politics: the role of Theseus in Athenian ideology, Cornell University.

- (1995a), Theseus \& Athens, Oxford University Press.

(1995b), «The Early Development of the Theseus Myth», RhM 138. $1,1-33$. 
Walsh, G. B. (1978), «The Rhetoric of birthright and race in Euripides' Ion», Hermes 106. 2, 301-315.

Walz, C. (1835), Rhetores Graeci, vol. II, Stuttgart.

Vanderpool, E. (1970), Ostracism at Athens, University of Cincinnati.

Ward, A. G. ed. (1970), The quest for Theseus, London.

Wardman, A. E. (1960), «Myth in Greek Historiography», Historia 9, 403413.

(1971), «Plutarch Methods in the Lives», CQ 21, 254-261.

Waters, K. H. (1985), Herodotus the historian: his problems, methods and originality, London.

Waterfield, R. (1998), Plutarch Greek Lives. A new translation by.... With Introduction and Notes by P. A. Stadter, Oxford-New York. (1998), Plutarch Roman Lives. A new translation by.... With Introduction and Notes by P. A. Stadter, Oxford-New York.

Webster, T. B. L. (1966), «The Myth of Ariadne from Homer to Catullus», GछR 13. 1, 22-31. (1973), Athenian Culture and Society, London.

Wees, H. Van (1996), «Growing up in early Greece: Heroic and aristocratic educations", in A. H. Sommerstein and C. Atherton, Education in Greek Fiction, Bari, 1-25.

Wenrli, F. (1969), Die Schule des Aristoteles, Texte und Kommentar, vol. III Herakleides Pontikos, Basel.

West, A. B. (1924), «Pericles' Political Heirs. I», CPb 19. 2, 124-146.

West, S. R. (1998), «The Scythian Ultimatum (Herodotus IV. 131,132)», JHS 108, 207-211.

West, W. C. (1970), «Saviors of Greece», GRBS 11.4, 271-282.

Westlake, H. D. (1938), «Alcibiades, Agis and Spartan Policy», JHS 58. 1, 31-40.

(1945), «Seaborne raids in periclean strategy», CQ 39, 75-84.

(1968), Individuals in Thucydides, Cambridge.

(1987), «Diodorus and the expedition of Cyrus», Phoenix 61, 241254.

Wickersham, J. M. (1991), «Myth and Identity in the Archaic Polis», in D. C. Pozzi, J. M. Wickersham (ed.), Myth and the Polis, 16-31.

(1990), «The state and the individual: Euripides' plays of voluntary 
self-sacrifice», in A. Powell (ed.), Euripides, women and sexuality, London, 117-194.

Wilkins, J. (1990), «The young of Athens: religion and society in the Herakleidai of Euripides», CQ 40, 329-339.

WiLl, E. (1954), «De l'aspect éthiquedes origines de la monnaie», RH 212, 209-231.

(1955), «Réflexions et hypothèses sur les origines dela monnaie», $R N$ 17, 5-23.

Williams, G. W. (1951) «The Curse of Alkmaionidai - I», Hermathena 78, 32-49.

(1952), «The Curse of Alkmaionidai - II», Hermathena 79, 3-21.

Willis, J. (1963-1970), Saturnalia, Lipsiae.

Wilson, P. (1999), «The aulos in Athens», in S. Goldhill, R. Osborne (ed.), Performance Culture and Athenian Democracy, Cambridge, 58-95.

Woнl, V. (1999), «The eros of Alcibiades», ClAnt 18. 2, 349-385.

Woodford, S. (1971), "Cults of Heracles in Attica», in D. G. Mitten, J. G. Pedley, J. A. Scott (ed.), Studies presented to G. M. A. Harfmann, Cambridge, Fogg Art Museum, 211-225.

(1974), «More Lights is old walls: the Theseus of the Centauromachy in the Theseion», JHS 114, 158-165.

(1982), Cambridge Introduction to the History of Art in Greece and Rome, Cambridge University Press.

(1989), «Herakles' attributes and their appropriation by Eros», JHS 109, 200-203.

Woodward, R. (1997), Greek Writing from Knossos to Homer, Oxford.

Zanetto, G. (2000), «Plutarco e la commedia», in Generi Letterari, 319-334.

Ziegler, K. (1951), «Plutarchos von Chaeroneia», in RE 31.1, col. 805.

(1959-1971), Plutarchi Vitae Parallelae, Leipzig.

(1969), M. Tulli Ciceronis De Republica, Lipsiae.

Ziolkowski, J. E. (1981), Thucydides and the Tradition of Funeral Speeches at Athens, New York. 


\section{ÍNDICE DE NOMES}

Aca Larência: 31

Academia: 87, 104, 150, 187, 219, 220, $223,225,227,303$

Academo: 87

Acamante: 86, 160

Actéon: 77

Adrasto: 78, 81, 117

Afidnas: 86,87

Afidno: 87

Agamémnon: 107, 135, 193, 274, 286

Agátocles: 175

Alba: 44

Alcátoo: 84

Alcibíades: passim

Alcmena: 54-55, 78, 90, 101

Alcmeónidas: 8, 159-161, 167, 170, 175, 183, 191, 194, 197, 207-208, 210-211, 213, 217-218, 234, 243, 248-249, 259, 261, 263-264, 269, 271, 283, 288, 293, 294, 303, 304, 307,311 ,

Acrópole: 75, 91, 166, 238, 257

Ágora: 147, 170, 185, 239, 289

Álope: 84, 160, 203, 210, 222

Ájax: 78, 84, 160

Amazonas: 62, 71-77, 83, 99, 102, 104, $118,160,231,238$

Amazónion: 75-76, 104
Amúlio: 32, 35, 38, 40-42, 44

Anaxo: 78, 84

Anaxágoras: 140, 165, 178-181, 184, 200, 203, 221, 238, 247-249, 252253, 265, 282, 293

Andrógeo: 67-69

Anfitrião: 53, 197, 232, 268

Anteia: 51

Anteu: 57, 62

Antíoco: 197, 234, 255, 271, 273, 295, 300

Antíope: 70-76, 80, 83, 104

António: 84, 161

Apatúrias: 100, 102

Apolo: 52, 69-70, 100, 102, 177, 281

Apolo Delfínio: 67, 96, 102

Apsirto: 59

Aquiles: 16, 74, 77, 135-136, 176-177, 265, 267, 286

Arcádia: 84, 251

Ardeto: 75

Areópago: 72, 75, 104, 201-202, 219, 222, 224, 236, 248

Ares: 75, 256

Argonautas: 78

Ariadne: 61, 70, 78-85, 88-90, 99-100, 104, 189

Aristeu: 77 
Índice de nomes

Artaxerxes: 302

Ártemis:72

Artemísio: 161, 227

Asclépio: 77, 227

Ásia: 34-35, 262, 292

Aspásia: 165, 200, 238, 241, 243-247, $249,271-272,288,303,312$

Assírios: 35

Astíages: 34-36, 38-40, 42-44

Astíoco: 289

Atena: 53, 55, 73, 81, 101, 104, 115, $118,136,170,177,258,262,299$

Atena Higia: 253

Atena Pártenos: 72, 238-239

Atenas: 5, 7-8, 15, 22, 26, 31-32, 46, 49, 51-62, 64- 69, 71-74, 76-88, 90-91, 93-106, 109-111, 113, 115131, 135, 137, 139-143, 145, 147, $149,151,153,155,157,160-161$, 163-164, 166, 169-171, 177-178, 186, 191-192, 194, 196-198, 202, 204-205, 207-208, 210, 213-214, 216-221, 223-229, 231-235, 240, 243,-245, 247-248, 250, 252-259, 261-269, 271-278, 280-302, 305$307,311,313$

Ática: 32, 59, 66-67, 72-76, 78, 85, 8788, 96, 98-99, 101, 103, 107, 115, $117,160,214,225,227,239,251$, 257-258, 265, 271, 273, 275, 283, 286

Atenienses: 8, 55, 61, 63, 65-67, 69, 7275, 77, 80, 93-97, 99-100, 102-104, 107, 110, 115-131, 137, 141, 153, $170-171,177,182,192-193,195-$ 197, 202, 207, 214-221, 223, 225230, 232-235, 237, 248, 251, 254258, 260-263, 265-266, 268-278, 281-282, 284-298, 300-302, 305, $307,311-312,314$

Átis: 19

Atreu: 51

Báticles: 85

Bitínia: 173, 104, 295, 302

Briseida: 74

Cálcis: 76, 249

Calcodonte: 75

Cálicles: 63-63, 142, 169

Cambises: 35, 42

Cária: 79, 103

Cécrope: 51,78

Célere: 44

Centauro: 61-62, 76-77, 135, 164

Cércion: 62-63, 65, 78, 84

Cílon: 257

Címon: 55, 98, 110, 119-120, 125, 127, $161,182,185,190,198-199,202-$ 203, 206-207, 210, 218-220, 222, $224,231,233,240-243,245,252-$ $253,262,269,277,285$

Cino: $31,36,42$

Cinoscéfalas: 74

Cípselo: 35, 85, 169

Ciro (o assaltante): 62-63

Ciro da Pérsia: 34-44, 46, 51-52, 172, 199, 204, 302

Cites: 40, 46

Cítia: 40, 52

Clidemo: 73, 75, 80, 103

Clitemnestra: 86, 268

Clítias: 76

Clínias: 160-161, 184, 195, 201, 231, 235, 282, 295, 305, 312

Colina das Musas: 75

Colono: 91

Cónidas: 54, 102

Corcira: 249, 275-277

Corcireus: 276

Coríntios: 119-127, 129, 233, 276-277

Corinto: 37, 40, 58, 125, 153, 263, 275277

Creonte: 58, 68, 107

Creso: 19, 20, 44

Creúsa: 58, 148, 153 
Crisa (santuário de): 75

Crómion: 58, 62-64

Crono: 33, 125, 164-165, 212

David (rei): 40

Décelo: 87

Dédalo: 80

Deidamia: 76

Dejanira: 244

Déjoces: 39, 199

Delfos: 51, 68, 72, 96, 99, 102-103, 110, $257,276,278$

Demétrio: 25,84

Demofonte: 71, 80-81, 86, 116, 160

Deucalião: 80

Dido: 81

Diomedes: 17, 197, 258

Dioniso: 82-83, 100

Dioscuros: 76, 85-88, 96, 101, 107

Domiciano: 31

Doze Deuses: 170, 239

Édipo: 34, 37-46, 49, 51-52, 69-70, 73, $81,107,121-123,153,204$

Éfeso: 72, 197, 271, 295

Egeu: 34, 51-54, 58-59, 66-69, 72, 80, 90, 94-96, 100, 102-104, 106, 109, $116,169,191-192,204,273,311$

Egla: $78,81,84$

Eletra: 35, 268

Elêusis: 63, 217, 233, 270, 278, 286, 295, 299

Enaro: 82

Eneias: 41, 81

Enópion: 82

Epidauro: 62, 181, 227, 281, 282

Epígonos: 79

Erecteu: 51, 58, 87

Erétria: 70

Érino: 63

Esciro: 109-110

Ésciron: 87, 101
Escotussa : 74

Esculápio: 77

Esféria: 53

Esfinge: $37,43,47$

Esparta: 86-88, 98, 119-120, 123, 127$128,160,179,202,208,227,232$, $235,237-238,246,249,251,257-$ 258, 266, 271-272, 275-277, 283284, 286-288, 290, 292, 294, 305.

Espartanos: 124, 126, 202, 207, 216, $218,225,232,251,254,257,263$, 266, 268, 272, 275-277, 286-287, 290, 295, 305.

Estáfilo: 82

Etra: 52-53, 55, 85-87

Europa: 19, 262

Fábio Máximo: 26, 194, 225, 258

Faraó: 38

Farnábazo: 270,287,292-296,298,302, 306-307

Fáustulo: 32, 38-40, 44

Febo: 34

Fedra: 51, 74, 78, 80, 83, 148, 153, 160

Fenícios: 19-20, 262, 274, 290

Ferebeia: 78, 84

Fídias: 72, 200, 231, 234, 238-241, 248249

Folo: 77

Glauce: 70

Glauco: 17, 240, 249, 258

Gorpieu: 81, 100

Grécia/Hélade: 5, 8 11, 21, 31, 55-57, 61, 65, 73-74, 78, 93, 113, 115-119, 121, 123-127, 127, 129, 130-131, $135,141,142,144,160,198,210$, 213, 219, 222, 235, 241, 257-258, 262-264, 275, 278-279, 287, 311

Hades: 62, 70, 72, 82, 89-90, 99, 104, $164,166,214$

Hagnunte: 103

Hagnuso: 103

Hálico: 87 
Hárpago36, 39-40, 44

Hécala: 66, 102

Helena: 13, 17, 19, 49, 53, 61-62, 70, 78, $80,83,85-89,96,99,101,165,200$, 268,271

Helesponto: 268, 292, 294-295

Hemon: vide Termodonte

Hera: 212-213, 244

Heracleion: 55, 298

Héracles: 52, 57-58, 62-65, 71-73, 78, 80, 82, 84, 90, 91, 101, 104, 123, $136,169,192,246$

Hércules: 40-41, 49, 81, 102, 117, 128, 153,265

Heraclidas: 55, 68, 81, 103, 116-117, 122,160

Hipereia: 51

Hipodamia: 51, 76

Hipólita: 70, 71, 73, 75, 78, 104

Hipólito: 49, 51, 71, 83, 85, 128, 148

Hipótoo: 84

Horcomosion: 75, 104

Idas: 86

Íficles: 84

Ifigénia: 86

Io: 19

Iolau: 55

Íon: $52,58,153$

Iónia: 13, 98, 103, 267-269, 287, 300

Iónios: 274

Íope: 78

Ioxo: 79, 103-104

Ióxidas: 79, 103

Israel: 40

Istmo: 63, 101, 265

Jasão: 58-59, 65, 71, 77-78, 80, 83

Javalina de Crómion: 58, 62-64

Jocasta: 34,153

Labda: 35

Labdácida: 34
Lacedemónia: 119, 127, 202, 227, 232, 257, 267-268, 271, 283

Lacedemónios: 119, 123, 125-127, 129, 153, 172, 192, 200, 202, 206-208, 214, 217, 220, 225, 232, 235, 245, 254-255, 257, 259, 266, 273-280, 285-290, 292-294, 298, 301-302, 307

Laio: 34, 37, 45, 67

Lâmprocles: 175

Lápitas: 62, 76

Lemnos: 82, 250

Leucípides: 86

Liceu: 75, 251

Linceu: 86

Licurgo: 31, 111, 154, 267

Lisídice: 55

Macária: 68

Mandane: 34-36, 42

Maratona: 55, 59, 62, 67, 72, 96, 99, 102, 109, 140, 192, 198, 308

Meandro: 271

Medeia: 19, 58-59, 66, 71, 80, 83

Média: 35, 44, 59

Medo, filho de Medeia: 59

Megabizo: 269

Mégara: 62-63, 74, 84, 87-88, 98, 201, 254, 257, 262, 271-272, 277-279, 281

Melanipe: 70

Melanipo: 79, 103

Menão: 245

Meneceu: 68

Menécrates: 73

Menesteu: 86, 106-107, 109, 241, 311

Menipo: 246

Mérope: 37

Mícon: 72

Milcíades: 55, 161, 218, 247, 262, 265

Mileto: 247, 267, 271-272, 274

Minos: 67-68, 72, 82, 84 
Minotauro: 52, 58, 62, 66-68, 79, 85, 93, $100,102,192$

Mitra: 36

Mitradates: 36, 39-40

Moisés: 37-38

Molpadia: 76

Nausícaa: 79

Naxos: 82-83, 221

Nícias: 122, 124, 172, 200, 205-208, 215, 219, 222, 225-226, 230, 233, 235, 248-249, 251-252, 255, 257, $259,263,266,273,282-285,287$

Numa: 31

Numitor: 32, 35, 41, 44

Ônfale: 57,244

Orestes: 77, 136

Paládio: 75

Palanteu: 51, 103

Palântidas: 51, 53, 62, 67, 95, 99, 103, 204

Palene: 103

Panateneias: 67, 97, 101, 170, 197

Pandíon: 51

Parrásio: 54

Pasífae: 67, 68

Pátroclo: 77

Píndaro: 111, 71-72, 116, 138, 320

Peleu: 70

Pélias: 58-59

Peloponeso: 17, 21-22, 24, 32, 56-57, $85,87,98,115,147,165,194,200$, 213-214, 228-229, 235, 237, 241, $243,256,257,259,266,270,271-$ 272, 275-277, 279-285, 289, 291, $299,305,311$

Pélops: 51, 90

Peribeia / Eribeia / Ferebeia: 37, 84

Péricles: passim

Perifetes: 56, 62-64

Periguna: 65, 78, 79, 85, 99, 103

Persas/Medos: 18-20, 35, 39, 42, 59,
$72-73,77,93,115,124,126,128$, 161, 198, 215, 232, 262, 267, 270, 275, 288-289, 291-292, 302, 305

Perséfone: 61-62, 70, 88-89, 233

Pianépsion: 54, 100-102, 111

Pílades: 77

Pireu: 75, 91, 254, 299

Pirítodas: 77

Pirítoo: 71, 75-77, 87, 89-90

Pisíanax: 55

Piteu: 51-53, 55, 58

Pítia: 19, 51-52, 104, 110

Pitópolis: 73, 104

Plistóanax: 251, 265, 273, 275-276

Pnix: 75

Pólibo: 37, 40

Pórtico Pintado: 55, 110

Poséidon: 31, 53-55, 83-84, 101-102, 111,245

Priene: 271

Procrustes: 62-64

Prosopítis, ilha de: 269

Psaménito: 44

Queroneia: 74

Quíron: 77, 135, 164, 176, 212, 244

Rinon: 247

Remo: 31-32, 35, 38-42, 44, 83, 95

Roma: 26, 31, 44, 236, 253, 266, 281

Romanos: 26, 254

Rómulo: 24, 31-33, 35, 38-42, 44, 46, $52,66,83,88,97,204$

Sabinas: 84,89

Sabinos: 44

Sâmios: 236, 250, 265, 268, 271, 273274, 288-292

Sícion: 37

Silânio: 54

Sileu: 57,81

Sínis: 62-63, 65, 78, 84, 101

Siracusa: 121, 124, 226, 233, 245, 263, 
Índice de nomes

284-286

Sócrates: 137, 141, 145, 155, 160, 171, 174-179, 184,-189, 195-196, 198, 215, 244, 247, 261, 296

Solunte: 73, 104

Sóssio Senecião: 31

Tácito: 23

Tauro: 68,80

Tebanos: 43, 45, 121

Tebas: 39, 42-43, 45, 67, 78, 81

Télamon: 84

Telauges: 247

Telémaco: 65, 136

Temístocles: 55, 98, 100, 115, 121, 124, 126,-127, 153, 187, 193, 198, 201, 207, 211, 218-219, 231, 251, 265, 291

Temiscira: 72-73

Terra Olímpica: 75-76, 104

Termodonte: 74

Teseias: 74, 99-103

Teseu: 5, 7-8, 15, 24, 31-33, 41-42, 4647, 49-112, 116, 121, 123, 128, 131, $136,160,169,185-186,189,191-$ 194, 204-205, 207, 223, 235, 238, 241, 248, 252, 259, 261, 263, 265, $270,286,303,306-308,311-312$

Tesmofórias: 100

Tessália: 74

Tétis: 70

Teseion: 65, 72, 75-76, 104

Tiestes: 44, 51

Tíndaro: 53, 86

Tissafernes: 232, 266, 268, 287-290, 292-293, 305

Titaco: 87

Troianos:

Toas: 82

Touro de Creta: 67

Touro de Maratona: 62, 66-67, 96, 99, 102,192
Trácia: 68, 166, 300

Trajano: 31

Trézen: 51

Trezena: 51, 53-53, 56, 58, 62, 72-73, 78,84

Tucídides de Alópece: 160, 167, 179, 197,202-204, 207, 210, 222, 224, 255

Ulisses: 17, 65, 136, 168, 193, 258, 269

Urano: 33

Zeus: 33-34, 53-55, 66, 84, 86, 88, 90, 101-102, 138, 143, 145, 164-167, 170, 200, 212-213, 238-239, 244, 251

Zeus Hecálio: 66

Zeuxipa: 51

Xantipo, pai de Péricles: 161,

Xantipo, filho de Péricles: 188, 214, 226, 243, 245, 253

Xerxes: 118

Xuto: 52, 59, 153 


\section{ÍNDICE DE AUTORES ANTIGOS E CITAÇÕES}

Álcman, 317

frs. 21 e 22 Page, 85

Anacreonte, 170

Andócides, 235, 240, 317, 334

1. 38,235

2. 14,232

4. 17,183

4. 19,231

4. $20-21,186$

4. 21,215

4. 22-23, 232

4. 24,216

4. 26,197

4. 29,198

4. $29-30,198$

4. 33,220

13,246

Anthologia Palatina

6. 278,102

Antigo Testamento

Ex. 2, 38

Sam.1. 16. 1-13, 40

Antíoco Histórico

FGrHist 555 F 11, 251

Antístenes Socrático, 241

FGrHist 1004 F 5a-b, 185, 243

fr. V A 141 Giannantonini, 268 fr. V A 199 Giannantoni, 267

Apolodoro, 66, 70, 317

Bibl.1. 9. 16, 78, 82

Bibl. 1. 9. 23-24, 59

Bibl.1.9.27, 59

Bibl.1.9.28, 59

Bibl.2. 5. 9, 71

Bibl.2.6.3, 57

Bibl.2.7.8, 78

Bibl. 3. 5, 7, 34

Bibl. 3. 5-7, 37

Bibl.3. 6. 4, 82

Bibl. 3. 10. 3, 77

Bibl.3. 12. 7, 84

Bibl.3. 15. 6, 51

Bibl.3. 15. 7, 53, 67

Epit. 1. 1, 58

Epit. 1. 5, 58, 66

Epit. 1. 8, 79

Epit. 1. 9, 82

Epit.1.9.17, 82

Epit. 1. 10, 70

Epit.1. 11, 95, 204

Epit.1. 16, 70, 72, 104

Epit.1.17, 71, 80

Epit.1.21, 76

Epit.1.23, 85 
Índice de autores antigos e citações

Epit. 1.24, 86

Epit. 5. 2, 70

Aristodemo, 276

FGrHist 104, 17, 276

FGrHist 104. 16, 272

FGrHist 104 F 16, 188, 250

Aristófanes, 116, 124, 137, 143-144, $146,148,154,163,171,186,216$, 219, 222, 233, 248, 251, 259, 260, 271-272, 278-279, 284, 317, 341, 347

Ach. 270, 284

Ach. 515-539, 272

Ach. 524-52, 200, 271

Ach. 530-532, 213

Ach. 532, 278

Ach. 630-631, 121

Ach. 634-640, 116

Av. 521, 222

Av. 987-988, 222

Ec. 964-5, 171

Ec. 612-650, 148

Ec. 614, 154

Eq. 41-42, 233

Eq. 188-189, 137

Eq. 537, 232

Eq. 739, 206

Eq. 870-911, 222

Eq. 1037, 169

Eq. 1085, 248

Eq. 1111-1114, 233

Eq. 1111-14, 119

Eq. 1130, 119

Eq. 1133, 119

Eq. 1235-9, 137

Eq. 1329, 116

Eq. 1377, 205

Lys. 387-397, 282

Lys. 678, 72

Nu. 46-68, 253

Nu. 98-99, 146

Nu. 211-213, 219

Nu. 331, 145

Nu. 332, 239

Nu. 540, 168

Nu. 551-558, 206

Nu. 858-859, 251

Nu. 959-960, 140

Nu. 961, 137

Nu. 985-986, 140

Nu. 1005-1019, 144

Nu.1041-1042, 146

Nu. 1065, 206

Nu.1399-1405, 146

Nu. 1357-1358, 140

Pax 304, 284

Pax 601-611, 275

Pax 606-7, 259

Pax 608-610, 279

Pax 690, 206

Pax 762-3, 171

Pax 896-8, 171

Plu. 911-915, 120

Ra. 496, 56

Ra. 538-541, 298

Ra. 1025, 171

Ra. 1425, 171

Ra. 1432-1433, 216

Ra. 1432-3, 171

$\Sigma$ Eq. 969, 241

$\Sigma$ Eq. 1085, 248

$\Sigma$ Eq. 1368, 104

Th. 841, 284

V. 44-46, 163

V. 243, 232

V. 380,248

V. 405, 260

V.620, 119 
Aristóteles, 36, 68, 71, 97, 103, 138-142, 144-145, 147-150, 152, 154-155, 167, 170, 176, 194, 203, 207, 210, $216,221,225,240,243,245,254$, 261, 270, 274, 317-318, 323, 331, 342

Ath.14. 3, 170

Ath. 25, 201, 236, 240

Ath. 25.1-2, 236

Ath. 25. 4, 240

Ath. 26. 4, 245

Ath. 27. 1, 203

Ath. 27. 4, 221

Ath. 41.2, 97

Ath. 61.2, 283

EE 1242a22-26, 210

EN 1095a2, 192

EN 1100b35, 225

EN1103a16, 153

EN1104a15, 157

EN1115a6-1116a10, 194

EN 1122b 6-10, 254

EN1125b26, 167

EN1129a5, 167

EN 1140b4, 194

EN 1140b7, 261

EN1142A10-15, 207

EN1142a15, 192

EN 116a10, 194

EN1180a23-24, 141

fr. 2. Sandys, 97

fr. 401 Rose, 171

fr. 443 Rose, 68

fr. 577 Rose, 274

Mu. 399b, 238

Po. $1454 \mathrm{~b}-1455 \mathrm{a}, 36$

Pol. 1253a, 210

Pol. 1257a31-40, 97

Pol. 1278a, 245

Pol. 1279a17, 216
Pol. 1284a15-20, 206

Pol. 1305b, 289

Pol. 1327b39, 243

Pol. 1333a14, 142

Pol. 1333b37-38, 142

Pol. 1334b29-1336a, 148

Pol. 1334b29-30, 142

Pol. 1334b6-7, 153

Pol. 1336a, 148

Pol. 1336a23-25, 139

Pol. 1336a30, 149

Pol. 1336b, 148

Pol. 1337a, 145, 148, 150

Pol. 1337a18, 140

Pol. 1338a, 149, 150

Pol. 1338b-1339a, 149

Pol. 1339a, 150, 157

Pol. 1339a-1342b, 149

Pol. 13411a16, 177

Pol. 1341b2-8, 177

Rh. 1373a25, 226

Top. 116b29-30793c-d, 207

Top. $128 \mathrm{~b} 15,210$

Arquíloco, 185, 318

fr. 105 West, 228

fr. 27 Diehl, 185

Arquipo, 163, 164, 181

fr. 48 K.-A, 163

Arriano

An. 7.13.6, 73

Ateneu, 177, 185, 240, 247, 297, 303, 307

184d, 177

220c, 243

220d, 188

534b-c, 177

$534 \mathrm{c}, 232$

534d-e, 215

$534 \mathrm{e}-\mathrm{f}, 183$ 
Índice de autores antigos e citações

$$
\begin{aligned}
& 535 \mathrm{~b}-\mathrm{c}, 246 \\
& 535 \mathrm{c}, 243,297 \\
& 535 \mathrm{c}-\mathrm{d}, 297 \\
& 557 \mathrm{a}-\mathrm{b}, 78 \\
& 574 \mathrm{e}, 303 \\
& 574 \mathrm{~d}, 246
\end{aligned}
$$$$
589 \mathrm{e}, 203,241,242,247
$$$$
688 \mathrm{e}, 185
$$

Baquílides, 19, 53, 62, 318

17. 24,58

$18,63,65$

18. 30,58

Bíon de Esmirna, 77 fr. 12,77

Bíon de Proconeso, 73 FGrHist 332, 73

Camões, 265, 306

Catulo, 321 44. $80-85,68$

Cícero, 18

Arch. 24, 265

Div. 2. 143, 307

Fin. 5. 5, 303

Leg. 1. 1.5, 18

Rep.1.16, 281

Tusc. 2. 13, 154

Cílax de Carianda, 16

Clidemo, 53, 75

FGrHist 323 F 2, 103

FGrHist 323 F 17, 80

FGrHist 323 F 18, 70

Cornélio Nepos, 24, 161, 290, 300, 305

Alc. 2, 161

Alc. 3, 233, 267

Alc. 3-5, 267

Alc. 4. 5, 259

Alc. 4. 6-7, 286

Alc. 5. 1-2, 287

Alc. 5. 6, 290
Alc. 6. 1, 297

Alc. 6. 1-2, 299

Alc. 6. 4, 298

Alc. 7. 1, 300

Alc. 7. 1-3, 300

Alc. 7. 7. 1-3, 300

Alc. 7. 8. 3, 301

Alc. 9, 302

Alc. 10. 1-2, 305

Alc. 10. 3-6, 307

Alc. 10. 6, 307

Alc. 10.12, 258

Thr. 1. 3, 290

Cratino, 163-166, 200, 212, 244, 254

fr. 66 K.-A, 222

fr. 326 K.-A, 254

Nemesis, 200

fr. 118 K.-A, 165, 212

Quirones, 164, 212, 244

fr. 258 K.-A, 164, 212, 244

fr. 259 K.-A, 244

Trácias, 166

fr. 73 K.-A, 166

Cratipo, 233

FGrHist 64 F 3, 233

Demóstenes, 124, 225, 316, 318

6. 24,229

60. 4,118

$60.29,86$

Dio Crisóstomo, 77

$57.28,77$

$62.1,80,82,231$

Diodoro Sículo, 161, 239, 248, 250, 277, 283, 295, 297, 300
4. $9.5,57$
4. 16. 4, 72
4. 17. 4, 57
4. $28.1,70$
4. $28.2,104$ 
4. $31.7,57$

4. $55.5,59$

4. $59.4,58$

4. $60.3,82$

4. $60.5,67$

4. $61.4,68,80$

4. $61.4-5,79$

4. $61.5,70$

4. $62.1,80$

4. $63.3,85$

4. $63.4,89$

5. $62.1,82$

5. $79.1,82$

5. $84.3,82$

10. $27.1,59$

11. $88.3,238$

12. $27.2,250$

12. $27.5,273$

12. $31.1,270$

12. $38.3,161$

12. 38. 3-4, 188, 250

12. $38.7,160$

12. 39,277

12.39. 1,239

12. $39.2,248$

12. $39.3,188$

12. 39. 3-4, 272

12. $45.1,281$

12. $45.4,283$

12. $45.5,260$

12. $80-81,283$

12. $83.5-84,284$

13. 2. 3, 233

13. 2. 4,235

13. 5,235

13. 5. 4, 286

13. $34.2,287$

13. 37. 4-5, 287

13. $45.6-46.3,292$
13. 46. 3, 292

13. 46. 4-5, 292

13. $49.3,293$

13. 50,294

13. 50. 1-4, 294

13. $50.5-51.7,294$

13. 64. 1, 295

13. 66. 1, 295, 297

13. 66. 2, 295, 298

13. $66.5-67.7,269$

13. $66.6,298$

13. 68,217

13. $68.2,296$

13. $68.5,163$

13. 69. 1,297, 298

13. $69.3,300$

13. $71.1,255$

13. $73.6,300$

13. 74,197

13. $105.3,301$

13. $105.4,301$

13. 106. 10, 251

14. 11,302

14. 11. 2, 302

21. $147,183,186$

39. 3, 188, 250,

Diógenes Laércio, 203, 318

2. 6-7, 178, 252

2. 20,240

2. 40,189

Dionísio de Halicarnasso 1. 77,42

Dionísio de Mileto, 16

Dúris de Samos, 177, 270-271, 297

FGrHist 76 F 6, 297

FGrHist 76 F 29, 177

Éforo, 21, 251, 270, 297

FGrHist $70 \mathrm{~F}$ 193, 251

FGrHist $70 \mathrm{~F}$ 196, 272 
Índice de autores antigos e citações

Eliano

VH 4. 14, 267

Eratóstenes, 276

FGrHist 241 F 38, 276

Ésquilo, 72, 77, 116, 123, 171, 182

$$
\begin{aligned}
& \text { Ch., } 77 \\
& \text { Eu., 72, 75, 116, 122-123 } \\
& \text { Pers., 233-234, } 118 \\
& \text { Pers., 241-242, } 95 \\
& \text { Th., 18, } 137 \\
& \text { Th., 654, } 228
\end{aligned}
$$

Ésquines Socrático, 199, 260, 261

Estesícoro, 13, 85-86

$$
\begin{aligned}
& \text { fr. } 11 \text { Diehl, } 13 \\
& \text { fr. } 191 \text { Page, } 85
\end{aligned}
$$

Estesímbroto, 119, 203, 243, 253, 273

FGrHist 107 F 5, 203

FGrHist 107 F 8, 273

FGrHist 107 F 11, 243

Êupolis, 163, 166, 214, 245, 318, 348

Demos, 166, 245

fr. 110 K.-A, 245

fr. 115 K.-A, 166

fr. 193 K.-A, 206

Eurípides, 34-35, 49, 51, 77-78, 81, 83, $85,110,116,119,121,123,135$, 144-145, 147-148, 159, 165, 171, 182, 193, 197, 201, 318, 329, 331, 337, 339-340, 344, 346-347, 349, 351

El. 34,35

El. 286-287, 139

El. 369,145

fr. 974 Nauck, 201

Hec. 123-129, 160

Hec. 379-381, 138

Hec. 592-600, 138, 145

Hec. 592-692, 159

Hec. 1186-1236, 147

Heracl. 207-212, 55
Heracl. 215-2, 72

Heracl. 224, 55

Heracl. 236, 80

Heracl. 329-332, 118

Heracl. 423-4, 130

HF 1261-1262, 153

HF 1328-33, 55

Hipp. 34, 66

Hipp. 307-310, 71

Hipp. 424, 153

Hipp. 431, 148

Hipp. 581-582,

Hipp. 887, 71

IA 337-342, 193

IA 385, 193

IA 527, 193

IA 708, 136,

IA 925-926, 135

IT, 77

Ion, 148, 153

Ion 535,52

Ion 1177,59

Med. 663-688, 51

Med. 679-681, 51

Med. 708-758, 58

Med. 791-817, 59

Med. 824-832, 127

Med. 1334, 59

Or. 129, 267

Pers. 242, 130

Ph. 13-22, 34

Ph. 991-1018, 68

$\Sigma$ Hipp. 35, 66

$\Sigma$ Med. 679-681, 51

Supp. 188-190, 127

Supp. 305-310, 123

Supp. 341, 122

Supp. 349-353, 130

Supp. 403-408, 130 
Supp. 404-405, 130

Supp. 426-455, 130

Supp. 714, 56

Supp. 914, 145

Eustátio

Od. 1688,81

Ferecides, 78

FGrHist. 3 F 148, 68

FGrHist. 3 F 151, 72

Filócoro, 68, 80

FGrHist 328 F 3, 99

FGrHist 328 F 13, 102

FGrHist 328 F 17, 58

FGrHist 328 F 18, 54

FGrHist 328 F 34, 276

FGrHist 328 F 94, 286

FGrHist 328 F 110, 72

FGrHist 328 F 121, 239, 240

FGrHist 328 F 133, 233

Frínico, 188, 233

fr. 17 Nauck, 188

Górgias, 124, 179

DK 82 B6, 124

Harpocrácion

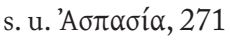

Hecateu de Mileto, 16, 20

FGrHist. 1 a, 14

Hégias de Trezena, 72, 73

comm. ad. FGrHist 606 F 1, 72

FGrHist 606 F 1, 73

Helânico, 88

FGrHist 323a F 15, 101

FGrHist 323a F 18, 86

FGrHist 323a F 19, 86

FGrHist 4 F $134=323$ a F 20, 89

FGrHist $4 \mathrm{~F} 164=323$ a F 14, 68

FGrHist 4 F 166, 72

FGrHist 4 F 167b, 73

Heraclidas de Lembo, 103
Héreas de Mégara, 84

FGrHist 486 F 2, 87

Hermógenes, 319

$\Sigma 7.165$ Walz, 241

Herodoro, 72, 76-77

FGrHist 31 F 25a-b, 72

Heródoto, 8, 11, 15, 17-21, 23, 27, 31, $34-43,73,87,110,115,169,173$

1. $1.4-5.1,19$

1. $5.3,19$

1. 5-6, 20

1. $38.1,19$

1. 55,19

1. 60,127

1. $67-68,110$

1. $98,39,51$

1. 99, 199

1. 107-113, 34

1. 111. 1,37

1.114-119, 38

1.118. 2,42

1. $120,43-44$

1.121. 1,42

1.122. 3 - 123. 1, 42

1. 123-124, 44

1.128. 2,44

1. 299,13

2. $91.3,110$

2. 99,20

3. 14,44

3. $80.1,130$

4. 5. 4, 40

4. 8-10, 40, 52

4. 10.2, 40

5. 56, 169

5. $62-73,160$

5. 66. 1, 166

5. 92,35

6. $108.1,55$ 
Índice de autores antigos e citações
6. $125-131,160$
6. 131,169
6. 137,128
7. 62,59
7. 96,13
7. $139,115,118$
7. $152.3,20$
7. $161,117,118$
8. 17,161
8. $57-63,126$
8. 75,139
9. $27,73,117$
9. 73,87

Hesíodo, 12, 14, 78, 81, 84, 166, 229, 319

fr. 280 Merkelbach-West, 89

fr. 298 Merkelbach-West, 84

Th. 155-211, 33

Th. 454-507, 33

Th. 992,77

Hesíquio, 50

Higino, 322

Astr. 2. 5, 84

Astr. 2. 34, 82

Fab. 15, 82

Fab. 27, 59

Fab. 37, 53

Fab. 38, 58

Fab. 42, 79, 80

Fab. 43, 81

Fab. 74, 82

Fab. 79, 85

Fab. 120, 82

Fab. 121, 82

Fab. 187, 84

Fab. 252, 84

Fab. 254, 82

Fab. 261, 82

Horácio, 322, 371

Ars 359, 17
Idomeneu de Lâmpsaco, 240

FGrHist 338 F 8, 240

Il. Parv. $23 \mathrm{~d}, 86$

Il. Pers. 4 e 11, 86

Íon de Quios, 82, 182, 274

FGrHist 392 F 15, 182

FGrHist 392 F 16, 274

fr. 7 Gentili-Prato, 82

Isócrates, 49, 57, 83, 88, 116, 145, 172 , 197, 216, 223, 252, 254, 287, 303, 320,331

2. 13,135

4. 20,119

4. $24-25,118$

4. 26,119

4. $26-40,125$

4. 33,122

4. $34-37,126$

4. 37,117

4. $52,118,122$

4. $52-53,122$

4. 54-57, 117

4. 68,118

4. $68-70,73$

4. 79-80, 129

4. 87,121

4. 94,126

4. 95,124

4. 100-101, 135

4. $102-103,128$

4. 103-105, 128

7. $66,223,254$

7. 75,73

8. $52,120,121$

8. 126,252

10. $18,53,85$

10. 20,89

10. 21,131

10. $23,55,57$ 
10. $24-25,5710.27,68$

10. 38,88

10. 46,85

12. $41-48,119$

12. 48,126

12. $124,117,122$

12. $193,70,73$

$15.15,283$

15. 166,116

15. $234,223,254$

15. 249,95

16. $5-7,270$

16. 9,235

16. 25-28, 194, 211

16. 28,184

16. 29,196

16. $31,244,246$

16. 34,197

16. 38,216

Istro, 78

FGrHist 334 F 10, 78 Juvenal, 322

10. 81,224

Leão de Nápoles, 265

Lísias, 116, 287, 320, 331

2. $4-6,118$

2. $10,117,128$

2. $11-16,117$

2. 18,130

2. $19,122,130$

2. $21-43,118$

2. 23,126

2. 24,126

2. 33,124

2. 43,118

2. 44,127

2. 47,127

2. 48,127

2. 56,126
2. 63,124

3. 1,290

14. $41-42,243$

Luciano, 170, 205

Demon. 49, 170

Macróbio, 322

1. 17,102

Novo Testamento

Mt.13. 3-23, 154

Mt. 25. 14-30, 154

Ovídio, 322, 371

Ars. 1. 509-510, 80

Met. 8. 180, 80

Parténio

Erot. 1, 82

Pausânias, 54, 62, 76, 87, 110, 127, 197, $251,303,320$

1. $2.1,70,72,73,76,189,295$

1.3. 1,62

1. 15,72

1.15.3, 55, 59, 110

1.17.2, 72,76

1.17. 4,89

1.18. 4,75

1.18. 7, 104

1.19.3, 54

1. $22.3,95,100$

1. $27.9,62$

1.27.9-10, 62

1.27. 10,67

1.28.2-3, 303

1.28. 10,66

1. $37.4,62$

1.38.5, 62

1.39.3, 84

1. $41.4,87$

1. $41.7,70$

1. $42.2,84$

1. $44.8,62$ 
1. $7.4,109$

1. $8.4,116$

1. $22.3,95,100$

2. $1.3,58,62$

2. 1. 3-4, 62

2. $10.1,54$

2. $11.8,54$

2. $22.7,86$

2. $23.7,100$

2. $3.8,59$

2. $30.8-9,51$

2. $31.12,34$

2. $33.1,53$

3. $3.5-8,110$

3. $8.9,246$

3. $15.3,54$

3. $18.15,86$

4. $23.10,54$

4. $30.1,54$

5. $19.2,86$

6. $21.3,54$

7. 5. 5, 54

8. $32.3,54$

8. $45.6,78$

8. 48. 3, 100

9. $11.4,54$

9. $11.6,54,57$

9. $24.3,54$

9. $26.1,54$

9. 27. 6-8, 54

9. $32.2,54$

9. $32.4,54$

9. $38.6,54$

10. $5.2,37$

Péon de Amato

FGrHist 757 F 2, 81

Píndaro, 11, 71, 72, 116, 138, 320

fr. 174 Snell, 72

fr. 175 Snell, 71 fr. 176 Snell, 71

fr. 243 Snell, 85

fr. 258 Snell, 85

fr. 76 Snell, 116

I. $2.20,116$

I. $4.87,57$

N. 3. $40,65,124,138$

N. 3. 43, 135

O. $1.29,11$

O. $2.86,138$

Pitoclides de Ceos, 176

Platão, 11, 63, 135, 138-141, 144-145, $147-152,154-155,162-163,169$, 174-176, 178-179, 181, 184-190, 192, 206, 212, 219-221, 223-224, 226-228, 241-244, 247, 260, 282283, 297, 320

Alc. 1. 104a-b, 160

Alc. 1. 104b, 161, 171

Alc. $1.104 \mathrm{~b}-\mathrm{c}, 171$

Alc. 1. 105a-b, 195

Alc. 1. 106e, 175, 176

Alc. $1.112 \mathrm{c}, 184$

Alc. 1. 113b, 163

Alc. $1.113 \mathrm{~b}-\mathrm{c}, 171$

Alc. 1. 113c, 175

Alc. $1.118 \mathrm{~b}-\mathrm{c}, 181$

Alc. 1. 118c, 175

Alc. $1.118 \mathrm{e}, 175$

Alc. 1. 119a, 178

Alc. 1. 119b, 175

Alc. 1. 121-2,160

Alc. 1. 122b, 174, 175

Ap. 24e, 141

Ap. 33a-b, 189

Ax. 365a, 76, 104

Clit. 407a, 155

Grg. 452e, 145

Grg. 456b, 225

Grg. 464b, 157 
Grg. 483a-484b, 63

Grg. 483e-484a, 169

Grg. 491e-492a, 63

Grg. 512b-d, 228

Grg. 512e-522a, 226, 227

Grg. 515e-516e, 222

Grg. 521e-522a, 226, 227

Hр. Ma. 281c, 178, 252

Hp. Ma. 283a, 178, 252

Hp. Mi. 364c-5b, 168

Hp. Mi. 368b-e, 144

La.197d, 175

Lg. 642 c, 131

Lg. 684c, 227

Lg. 747b, 149

Lg. 793e-794d, 149

Lg. 795a, 40

Lg. 795d-f, 150

Lg. 796, 149

Lg. 804, 149

Lg. 809c, 149

Lg. 809c-d, 150

Lg. 813, 149

Lg. 905e-906a, 225

Men. 94b, 188

Mx.235e, 244

Mx. 244e, 122

Phd. 91C, 260

Phlb. 56b-c, 150

Phdr. 243, 85

Phdr. 255d, 171

Phdr. 261a, 145

Phdr. 270a, 179

Phdr. 270b-d, 226

Prt. 309a, 163

Prt. 309a-c, 171

Prt. 312b, 137

Prt. 312c-d, 143

Prt. 314e, 188
Prt. 315, 245

Prt. 316a, 163

Prt.316e, 176

Prt. 317b, 143

Prt.319a, 143, 145

Prt.319e, 245

Prt. 320c, 11

Prt. 320d-322d, 145

Prt. 325d, 139

Prt.326b, 149

Prt.326c, 138

Prt. 326c-d, 141

Prt. 328b-c, 143

Prt. 328c, 245

Prt.336e, 171

R. 308-402, 150

R. 375 c, 243

R. 376,178

R. $376 \mathrm{e}, 178$

R. 377-398, 149

R. 399d-e, 177

R. 400b, 176

R. 401d, 149

R. 410d, 149

R. 412a, 149

R. $413 \mathrm{e}-414 \mathrm{a}, 151$

R. $415 \mathrm{a}-\mathrm{b}, 118$

R. 416e, 118

R. $424 \mathrm{a}-\mathrm{b}, 154$

R. $424 \mathrm{c}, 176$

R. $425 \mathrm{a}-426 \mathrm{~b}, 226$

R. 426b, 226, 304

R. $440 \mathrm{c}-\mathrm{d}, 148$

R. $458 \mathrm{c}-461 \mathrm{c}, 148$

R. 461d-e, 154

R. $488 \mathrm{a}-\mathrm{e}, 228$

R. 491b, 186

R. 491d-e, 154

R. 492a, 63, 154 
R. 493a-b, 64

R. $494 \mathrm{c}, 162$

R. 494d-495c, 189

R. $497 \mathrm{e}, 147$

R. $503 \mathrm{c}-\mathrm{e}, 150$

R. $522 \mathrm{c}-\mathrm{e}, 150$

R. 526b, 149, 150

R. 529-530, 150

R. $531 \mathrm{a}-\mathrm{b}, 150$

R. $535 \mathrm{a}-\mathrm{b}, 150$

R. 536d, 149

R. $537 \mathrm{a}, 150$

R. $537 \mathrm{a}-\mathrm{b}, 150$

R. 539b, 151

R. $539 \mathrm{e}-540 \mathrm{a}, 151$

R. $540 \mathrm{~b}, 151$

R. 562 c-d, 97

R. $562 \mathrm{c}-\mathrm{d}, 219$

R. $564 \mathrm{~b}-\mathrm{c}, 226,227$

R. 586,85

R. 606e-607a, 135

$\Sigma$ Alc. $118 \mathrm{c}, 176$

Smp. 215e, 189

Smp. 219e-221c, 196

Symp. 212c-d, 297

Symp. 212d-213a, 183

Symp. 217b-c, 171

Tht. 145 c, 172

Platão Cómico, 163, 176, 206, 320

fr. 187 K.-A, 206

fr. 207 K.-A, 176

Plínio

Nat 7. 194, 125

Plutarco, passim

Ages. 5. 5, 193

Agis. 3. 8-9, 246

Alc. 1. 1, 161, 184

Alc. 1. 2, 161

Alc. 1. 4, 161
Alc. 1. 4-8, 268

Alc. 1. 6-8, 163

Alc. 1. 7-8, 242

Alc. 1. 8, 246

Alc. 2. 1, 168, 173, 215

Alc. 2. 2-2. 7, 215

Alc. 2. 2-3, 169, 170, 185

Alc. 2.3 - 2. 4, 178

Alc. 2. 3-4, 172

Alc. 2. 5-7, 175

Alc. 3. 1, 184, 185, 215

Alc. 3. 2, 215

Alc. 4. 1, 178, 187

Alc. 4. 1-4, 178

Alc. 4. 3, 188

Alc. 4. 4, 171, 189

Alc. 4. 5, 183

Alc. 4. 7, 187

Alc. 5. 1, 183

Alc. 5. 1-5, 183

Alc. 5. 6, 215

Alc. 6 .1, 189

Alc. 6. 1-5, 178

Alc. 6. 2-3, 215

Alc. 6. 3, 171

Alc. 6. 4, 215, 266

Alc. 6. 4-5, 265

Alc. 7. 1, 186

Alc. 7. 1-2, 184, 260

Alc. 7. 3, 249

Alc. 7. 3-5, 195

Alc. 7. 4, 261

Alc. 7. 5, 195, 215

Alc. 7. 6, 195, 261, 296

Alc. 8. 1, 186, 231

Alc. 8. 3-4, 246

Alc. 8. 5, 186

Alc. 9. 1, 184

Alc. 10. 1, 196 
Alc. 11.2, 195, 215

Alc. 11-12, 172, 196

Alc. 12, 249

Alc. 12. 2, 215

Alc. 12. 2-3, 195

Alc. 13. 1, 205

Alc. 13. 3, 205, 221

Alc. 13. 4-9, 205, 206

Alc. 13. 7, 205

Alc. 13. 9, 206

Alc. 14, 172, 232, 284

Alc. 14. 1, 207, 257

Alc. 14. 1-2, 270

Alc. 14.3 - 15.1, 208

Alc. 15, 283

Alc. 15.2, 208

Alc. 15. 3, 217

Alc. 15.3-4, 273

Alc. 15. 4-5, 254

Alc. 15. 6, 254

Alc. 16, 178

Alc. 16. 1, 171

Alc. 16.1-7, 177

Alc. 16. 2, 217

Alc. 16. 2-3, 171

Alc. 16. 2-7, 215

Alc. 16. 4, 231

Alc. 16. 4-5, 195, 215

Alc. 16. 5, 183, 231, 232, 246

Alc. 16. 5-6, 186, 231

Alc. 16. 6, 186

Alc. 16. 7, 171, 217

Alc. 16. 9, 173, 263, 313

Alc. 17, 234, 264

Alc. 17. 1, 227, 263

Alc. 17. 2, 253, 284

Alc. 17. 3, 284

Alc. 17. 4, 284

Alc. 17. 6, 245
Alc. 18. 1, 284

Alc. 18. 1-2, 16. 4-5

Alc. 18. 2, 284

Alc. 18. 5, 282

Alc. 18. 6, 282

Alc. 19. 1, 233

Alc. 19. 3, 233, 234

Alc. 19. 4, 295

Alc. 19-20, 270

Alc. 20. 2, 285

Alc. 20. 3, 285

Alc. 20. 4-20.8, 234

Alc. 20. 6, 231, 233, 248

Alc. 21. 5, 240

Alc. 21. 7, 235

Alc. 22, 266

Alc. 22. 2, 235

Alc. 22. 3, 236, 305

Alc. 22. 4, 160, 259

Alc. 22. 5, 259

Alc. 23. 1, 286

Alc. 23. 2, 287

Alc. 23. 3, 267, 287

Alc. 23. 3-5, 266

Alc. 23. 5, 267

Alc. 23. 6, 176, 267

Alc. 23. 7-9, 232, 246

Alc. 23. 8, 246

Alc. 24, 266, 287

Alc. 24. 1, 287

Alc. 24. 1-2, 287

Alc. 24. 2, 287

Alc. 24. 3, 232

Alc. 24. 3-4, 232

Alc. 24. 4, 232, 305

Alc. 24. 5, 168, 266

Alc. 24. 7, 265

Alc. 25, 216, 232, 268

Alc. 25. 2, 260 
Alc. 25.3-26. 6, 236

Alc. 25. 6, 288

Alc. 25. 14, 289

Alc. 25-26, 273

Alc. 26, 216

Alc. 26. 2, 290

Alc. 26. 4, 290

Alc. 26. 5, 268

Alc. 26. 7, 287, 290

Alc. 27, 266

Alc. 27. 1, 291

Alc. 27.1-2, 260

Alc. 27. 2, 292

Alc. 27. 6, 264, 292

Alc. 28. 4, 293

Alc. 28. 9, 294

Alc. 28. 10, 294

Alc. 29. 5, 264

Alc. 29. 6, 269, 270

Alc. 30. 8, 296

Alc. 31, 290

Alc. 31. 1, 296

Alc. 31. 3-6, 298

Alc. 31.3-7, 269

Alc. 31. 6, 270

Alc. 31. 8, 218, 269

Alc. 32. 1, 299

Alc. 32. 2, 184, 297

Alc. 32. 3, 188, 195, 260, 299

Alc. 32. 4, 297, 299

Alc. 33. 1, 291

Alc. 33. 2, 298

Alc. 33. 3, 299

Alc. 34. 1, 299

Alc. 34. 1-2, 299

Alc. 34. 7, 217, 295

Alc. 35, 197, 232, 272

Alc. 35. 1, 300

Alc. 35. 2, 216
Alc. 35. 3, 300

Alc. 35. 5, 255

Alc. 35-36, 255

Alc. 36. 1, 300

Alc. 36. 3, 300

Alc. 36. 4, 234

Alc. 36. 6, 269, 301

Alc. 37. 2, 301, 302

Alc. 37. 2-3, 301

Alc. 37. 3, 301

Alc. 37. 4, 269

Alc. 37. 4-5, 301

Alc. 38. 1, 234, 301

Alc. 38. 1-2, 306

Alc. 38. 3, 258, 264, 302

Alc. 38. 5, 305

Alc. 38. 6, 258, 305

Alc. 39. 2, 307

Alc. 39. 4-7, 307

Alc. 39. 7, 307

Alc. 39. 9, 306

Alex. (1-)2, 22

Alex. 1. 2, 173

Alex. 4. 8-10. 4, 173

Ant. 1, 161

Ant. 70. 1-2, 263

Arist. 1. 2, 194

Arist. 3. 4, 201, 251

Arist. 4, 115

Arist. 4. 3, 251

Arist. 5, 251

Arist. 5.1, 118

Arist. 5. 6, 251

Arist. 7. 1, 211, 231

Arist. 7. 2, 206

Arist. 7. 3-4, 205

Arist. 10. 7, 123

Arist. 23, 127

Arist. 23. 7, 127 
Arist. 24, 256

Arist. 25. 9, 223

Arist. 25. 10, 207

Arist. 26.1-2, 240

Arist. 26. 5, 232

Brut. 1.2, 161

Ca. Mi. 1.3 - 3.10, 173

Ca. Mi. 24. 1, 173

Ca. Mi.26. 1, 224

Ca. Mi. 37. 10, 173

Ca.Mi.47. 2, 227

Caes. 31. 7, 227

Caes. 32. 8, 172

Caes. 57.1, 172

Cam. 9. 3, 227

Cic. 2. 1-5, 173

Cic. 24.1-27. 6, 173

Cim. 2. 4-5, 25

Cim. 4, 161

Cim. 4. 4, 190

Cim. 4. 5, 130, 231

Cim. 4. 6, 185

Cim. 4. 6-10, 241

Cim. 6.2, 127

Cim. 8. 5-7, 110

Cim. 10, 252

Cim. 10. 5-6, 220

Cim. 10. 6, 125

Cim. 11. 3, 125

Cim. 13. 1, 115, 126, 240

Cim. 14. 3-5, 203

Cim. 14. 4, 202

Cim. 14. 5, 203

Cim. 15. 2, 219, 236

Cim. 15. 4, 231

Cim. 16. 1, 202

Cim. 16. 2-3, 127

Cim. 16. 4, 119

Cim. 17. 9, 207
Cim. 18. 1, 120, 203

Cim. 18. 5-6, 270

Cim. 19. 3, 262

Comp. Cor.-Alc. 4. 1, 261

Comp. Cor.-Alc. 2. 6-9, 287

Comp. Num.-Lyc. 4. 10-12,

Comp. Per.-Fab. 3. 5, 252

Comp. Sol. Publ. 3.4, 106

Comp. Thes.-Rom. 6, 88

Comp. Thes.-Rom. 6. 5, 88

Cor. 1. 2, 174

Cor. 1. 3-5, 174

Cor. 2, 171

Cor. 3. 1, 172

Cor. 10. 8, 252

Cor. 12. 5, 227

Cor. 29. 1, 287

Cor. 31. 1-3, 232

Dem. 5. 5, 229

Dem. 14. 3, 225

Demetr. 3. 1-4. 5, 173

Fab. 3. 7, 225

Fab. 5. 3,194

Fab. 5. 5, 225

Fab. 7. 4, 258

Fab. 7. 7, 252

Fab. 8, 252

Fab. 10. 1, 225

Fab. 10. 2, 185

Fab. 17. 1, 281

Fab. 20. 4, 226, 229

Galba 2. 5, 22

Lis. 16. 2-17, 251

Lyc 15. 6, 153

Lyc. 30. 6-7, 111

Lys. 8. 4-5, 172

Lys. 18. 4-19. 6, 173

Lys. 22. 6-8, 246

Mar. 2. 2-4, 175 
Índice de autores antigos e citações

Moralia 1C, 153

Moralia 1C-D, 153

Moralia 2A, 153

Moralia 2B, 154

Moralia 3A-B, 154

Moralia 3B-D, 154

Moralia 3D-E, 139

Moralia 4A-5A, 155

Moralia 4A-B, 139

Moralia 4B-C, 154

Moralia 5A-F, 152

Moralia 6A, 135

Moralia 7F-8A, 151

Moralia 8D-E, 152

Moralia 9B, 156

Moralia 9D, 155

Moralia 11C-12A, 187

Moralia 12C-D, 155

Moralia 13A-C, 156

Moralia 38A, 155

Moralia 38D-E, 155

Moralia 52E, 266

Moralia 84B, 55

Moralia 92C, 55

Moralia 93E, 77

Moralia 96C, 90

Moralia 112D, 66, 204

Moralia 158F, 170

Moralia 164E-171F, 282

Moralia 184F, 55

Moralia 186D, 169, 170, 186, 236, 236

Moralia 186E, 188

Moralia 225F, 154

Moralia 234D, 169

Moralia 243B-C, 7

Moralia 275D, 259

Moralia 345F, 125

Moralia 349E, 290
Moralia 350E, 275

Moralia 351A, 254

Moralia 351B, 283

Moralia 439F, 152

Moralia 439F-440A, 139, 155

Moralia 440D-452D, 174

Moralia 450F, 157

Moralia 452C-D, 152, 174

Moralia 459A, 139

Moralia 496C, 155

Moralia 497E, 162

Moralia 529C, 139

Moralia 539D, 304

Moralia 552B, 55, 187

Moralia 561D-563A, 162

Moralia 562B, 162

Moralia 563A, 153

Moralia 607A, 66, 204

Moralia 621C, 270

Moralia 672F, 139

Moralia 724A, 100

Moralia 728A, 175

Moralia 752B-C, 171

Moralia 759D, 222

Moralia 762E, 188

Moralia 776F-777A,

Moralia 779D, 178

Moralia 780B-C, 231

Moralia 780D, 189

Moralia 781, 266

Moralia 783A-797F, 218

Moralia 784C, 192

Moralia 784E, 192, 222

Moralia 785D, 278

Moralia 785D-F, 224

Moralia 786E, 304

Moralia 787C, 231

Moralia 788C, 192, 260

Moralia 788E, 168, 224 
Moralia 789C, 222

Moralia 790A, 192

Moralia 790C, 224

Moralia 790D-E, 192

Moralia 791C, 210

Moralia 798C, 194

Moralia 798C-E, 194

Moralia 799A, 194

Moralia 799B, 218

Moralia 799B-800A, 218

Moralia 799B-C, 227

Moralia 799C, 116, 121, 232, 237

Moralia 799D, 196, 233

Moralia 800A, 224, 227

Moralia 800B, 55

Moralia 800B-D, 200

Moralia 800C, 222, 229

Moralia 800C-801B, 252

Moralia 800D, 231

Moralia 800E, 231

Moralia 800F-801A, 201

Moralia 801C, 229

Moralia 802C, 179, 222, 225

Moralia 802C-D, 225

Moralia 802D, 219, 226, 229

Moralia 802D-E, 224

Moralia 804D, 194

Moralia 804E, 283

Moralia 805C, 231

Moralia 805C, 236

Moralia 807-808, 238

Moralia 809B, 207

Moralia 809E, 224

Moralia 810A, 207

Moralia 810C-E, 186

Moralia 811D, 201

Moralia 811F, 260

Moralia 812A, 172

Moralia 812C-D, 201
Moralia 812E, 203

Moralia 813A, 229, 256

Moralia 813C, 236, 260

Moralia 814C, 229

Moralia 815B-C, 226

Moralia 815D, 266

Moralia 818A, 226

Moralia 818C, 221

Moralia 818D, 221

Moralia 818D-E, 226

Moralia 818F-819A, 265

Moralia 820A, 118

Moralia 820B-821C, 230

Moralia 821A, 229

Moralia 821B, 229

Moralia 821C, 230

Moralia 821D, 229

Moralia 821F, 229

Moralia 822A, 219

Moralia 822B, 221

Moralia 822C, 224

Moralia 823, 200

Moralia 823C, 210

Moralia 823E-F, 229

Moralia 823F, 237

Moralia 823F-825F, 236

Moralia 824A, 226

Moralia 824C, 237

Moralia 826D, 222

Moralia 827A, 226

Moralia 827A-B, 224

Moralia 920B, 304

Moralia 1008F, 139

Nic. 1. 2, 282

Nic. 2. 1, 226

Nic. 2. 4, 230

Nic. 3, 222

Nic. 3. 1, 252

Nic. 4, 282 
Nic. 5, 200

Nic. 5. 4, 253

Nic. 9, 206

Nic. 9. 1, 187

Nic. 9. 6, 257

Nic. 10. 4-9, 208

Nic. 10. 9, 283

Nic. 11, 205, 206

Nic. 11. 2, 200, 225, 226

Nic. 11.3-4, 205

Nic. 11.10, 205

Nic. 12, 284

Nic. 12. 1, 253

Nic. 12. 2, 284

Nic. 12.3-6, 284

Nic. 12. 4, 255

Nic. 12. 5, 285

Nic. 13, 282

Nic. 13. 1, 253, 284

Nic. 13. 11, 282

Nic. 14. 1, 284

Nic. 17. 4, 285

Nic. 21. 10, 280

Nic. 22. 2-3, 233

Nic. 23, 282

Nic. 23. 1, 282

Nic. 23. 4, 248

Nic. 24. 3-5, 256

Nic. 28. 4, 251

Num. 8. 2, 227

Num. 8. 3, 229

Num. 23. 6, 224

Pel. 29. 6, 188

Per. 1-2, 65

Per. 1. 4 -2. 1, 54

Per. 1. 5-6, 175

Per. 2. 2-4, 25

Per. 2. 5, 167, 225

Per. 3. 1-3, 161
Per. 3. 3, 162

Per. 3. 4, 162, 167, 244

Per. 3. 3-4, 169

Per. 3. 4-7, 163

Per. 3. 5, 212

Per. 3. 6, 166, 241

Per. 4. 1-4, 175, 221

Per. 4. 2, 176

Per. 4. 4, 176, 178

Per. 4. 5, 179

Per. 4.5 - 6. 5, 178

Per. 4. 6, 140, 180

Per. 5. 1, 180

Per. 5. 2, 185

Per. 5. 3, 182

Per. 6. 1, 181

Per. 6. 2, 222

Per. 6. 2-3, 201

Per. 7. 1, 194, 208

Per. 7. 2, 261, 264

Per. 7. 4, 198

Per. 7. 5, 199

Per. 7. 6, 199

Per. 7. 7, 201

Per. 7. 8, 97, 219, 236, 285

Per. 8. 1-4, 212

Per. 8. 3, 213

Per. 8. 4, 165

Per. 8. 5, 179

Per. 9. 1, 212

Per. 9. 1-2, 199

Per. 9. 1-3, 220

Per. 9. 2, 220

Per. 9. 3, 222, 224, 236

Per. 9. 5, 201, 236

Per. 10. 5, 203

Per. 10. 5-6, 241

Per. 10. 6, 242

Per. 10. 7, 205, 219, 240, 248 
Per. 10. 7-8, 236

Per. 10. 8, 203, 219, 240

Per. 11, 223

Per. 11. 1, 210

Per. 11. 3, 197

Per. 11. 3-4, 224

Per. 11. 4, 221, 222, 294

Per. 11. 5, 201

Per. 11. 6, 223

Per. 12, 22

Per. 12. 1, 254

Per. 12. 2, 256

Per. 12. 3-4, 256

Per. 12. 4, 223

Per. 12. 5, 223, 253

Per. 12. 6, 223

Per. 12-14, 223

Per. 13, 22

Per. 13.1,

Per. 13. 3, 121

Per. 13. 6, 238

Per. 13. 7,

Per. 13. 9, 166

Per. 13. 11, 197

Per. 13. 13, 253

Per. 13. 14, 238

Per. 13. 15, 201, 242, 246

Per. 13. 16, 242

Per. 14. 1-2, 256

Per. 14. 3, 167, 204, 224

Per. 15, 225

Per. 15. 1, 224, 225, 227, 228, 230

Per. 15. 2, 227, 228

Per. 15. 2-3, 229

Per. 15. 3, 231

Per. 16, 250

Per. 16. 1, 176, 194, 213, 242

Per. 16. 2, 229

Per. 16. 3, 200, 204, 252
Per. 16. 7, 247, 252

Per. 16. 7-8, 253

Per. 17, 275

Per. 17. 2-3, 275

Per. 18. 1, 264

Per. 18. 2-3, 226, 228

Per. 18. 3, 184, 264

Per. 19. 1, 262

Per. 19. 2, 264

Per. 19. 2-3, 270

Per. 19. 3, 264

Per. 20. 1, 270, 284

Per. 20. 3, 225, 270

Per. 20. 4, 227, 263, 269

Per. 20. 4-21.1, 264

Per. 21, 275

Per. 21. 1, 226, 227, 262, 275

Per. 22, 275

Per. 22. 1, 262

Per. 22. 1-2, 273

Per. 22. 2, 250, 265

Per. 22. 3, 251

Per. 22. 4, 251

Per. 23. 1, 230, 251

Per. 23. 1-2, 251, 280

Per. 23. 4, 270

Per. 24, 303

Per. 24. 5, 244, 271

Per. 24. 5-7, 245

Per. 24. 7, 244

Per. 24. 8, 243

Per. 24. 8-9, 246

Per. 24. 9, 244

Per. 24. 10, 244, 245

Per. 25. 1-3, 274

Per. 25. 2, 273

Per. 25. 2-3, 250

Per. 25. 4, 274

Per. 25. 5, 274 
Índice de autores antigos e citações

Per. 25-28, 270

Per. 26. 2, 274

Per. 26. 3, 274

Per. 27. 1, 265

Per. 27. 3, 122

Per. 28. 2, 270

Per. 28. 2-3, 297

Per. 28. 4, 262

Per. 28. 7, 182

Per. 29. 1-2, 202, 277

Per. 29. 4, 277

Per. 29. 5, 276

Per. 29. 6, 195, 276

Per. 29. 8, 277

Per. 30, 63

Per. 30. 1, 277

Per. 30. 2, 278

Per. 30. 2-4,

Per. 30. 3, 201, 278

Per. 30. 4, 278

Per. 31, 238

Per. 31. 1, 277, 279

Per. 31. 2, 234, 238, 279

Per. 31. 3, 231, 239

Per. 31-32, 200, 231

Per. 32, 303

Per. 32. 2, 248

Per. 32. 3, 231, 249

Per. 32. 3-5, 165

Per. 32. 5, 247

Per. 32. 6, 230, 238, 279, 280

Per. 33,

Per. 33. 1, 257

Per. 33. 2, 258

Per. 33. 3, 258

Per. 33. 4, 192

Per. 33. 5, 280

Per. 33. 6, 214, 225, 228, 281

Per. 33. 7, 194

Per. 33. 8, 237, 241

Per. 34. 1, 237, 281

Per. 34. 2, 220, 237, 281

Per. 34. 4, 272, 281, 285

Per. 34. 5, 226, 228, 281, 304

Per. 35. 2, 181

Per. 35. 3, 227, 237

Per. 35. 4, 237, 259, 260

Per. 35. 5, 231

Per. 36, 245, 303

Per. 36. 1, 260

Per. 36. 2-6, 188

Per. 36. 3, 253

Per. 36. 5, 253

Per. 36. 6, 253

Per. 36. 6-7, 257

Per. 36. 9, 247

Per. 37. 2-6, 245

Per. 38, 181, 303

Per. 38. 2, 181

Per. 38. 3, 264, 308

Per. 38. 4, 266

Per. 39, 303

Per. 39. 3, 229, 309

Per. 39. 3-4, 215

Phoc. 2. 7-8, 226

Phoc. 2. 7-9, 224

Phoc. 3. 1, 224

Phoc. 7. 5-6, 203

Publ. 1. 2, 252

Rom. 2.2-8, 35

Rom. 3, 38

Rom. 3-8, 35

Rom. 3. 4-5, 38

Rom. 3. 5, 38

Rom. 3-8, 35

Rom. 4. 1, 23, 32

Rom. 4. 2-3, 42

Rom. 4. 3-5, 31 
Rom. 6. 1, 32

Rom. 6.2, 32

Rom. 6. 3-5, 40

Rom. 7. 5, 41

Rom. 8. 1-6, 40

Rom. 8. 2-3, 39

Rom. 8.7 - 9.1, 44

Rom. 9. 2-3, 44

Rom. 9.4 - 10.2, 44

Rom. 14-19, 44

Rom. 30. 6-7, 189

Rom. 31, 97

Sol.1-2, 161

Sol.2. 1, 252

Sol.2. 5, 252

Sol. 22. 1, 115, 137

Sol.22. 3, 223

Them. 2. 1-3, 173

Them. 2. 7, 185, 187

Them. 3. 4, 55, 265

Them. 5. 7, 211

Them. 7. 4, 121

Them. 7-19, 115

Them. 8-2, 115

Them. 11. 4-5, 124

Them. 11. 5, 123

Them. 17.3, 126

Them. 18.1-9, 173

Them. 21, 251

Them. 22, 231

Them. 22. 4-5, 206

Them. 28. 6, 126

Them. 31. 4-5, 291

Thes. 1. 2, 24

Thes. 1. 4, 32

Thes. 1. 5, 31, 32

Thes. 2. 2, 32

Thes. 3-5, 34, 51

Thes. 3. 5, 34, 51
Thes. 4, 54

Thes. 4. 1, 52, 202

Thes. 5. 1, 102

Thes. 6-23, 49

Thes. 6. 2, 52

Thes. 6. 3, 63

Thes. 6. 4, 63

Thes. 6. 7, 56

Thes. 6. 9, 55, 265

Thes. 7.2, 56

Thes. 7. 3, 56

Thes. 8. 1, 56

Thes. 8. 3-6, 78, 79

Thes. 8. 6, 103

Thes. 8. 11, 54, 62

Thes. 8. 12, 58

Thes. 9.2, 63, 64

Thes. 11. 2, 56

Thes. 12. 1, 96

Thes. 12. 5, 94

Thes. 13, 62

Thes. 13. 4, 103

Thes. 14, 62

Thes. 14. 1, 67, 96

Thes. 14. 2, 102

Thes. 15, 67

Thes. 15-23, 62, 64

Thes. 16. 1, 58, 68

Thes. 16. 2, 68

Thes. 17.2, 68

Thes. 17. 7, 99, 100

Thes. 18, 69

Thes. 18. 3, 100

Thes. 18. 4-7, 68

Thes. 20. 1, 82, 84

Thes. 20. 6-7, 81, 99, 100

Thes. 20. 8-9, 82

Thes. 21. 2, 100

Thes. 22. 2, 96 
Índice de autores antigos e citações

Thes. 22. 4, 100, 102

Thes. 22. 4-7, 100

Thes. 23. 2, 100

Thes. 23. 3-6, 105

Thes. 23. 5, 104

Thes. 24. 2, 66, 95204

Thes. 24. 2-3, 96

Thes. 24. 3, 101

Thes. 24. 4, 101

Thes. 24. 5-6, 51

Thes. 24-25, 49

Thes. 25.1, 103

Thes. 25. 3, 97, 103, 106

Thes. 25. 6, 101

Thes. 26. 1, 72, 74

Thes. 26. 1-2, 72

Thes. 26. 2, 73

Thes. 26-28, 62, 70, 96, 238

Thes. 26-34, 59

Thes. 27. 2, 73, 75

Thes. 27. 3, 102, 104

Thes. 27. 5, 73, 74

Thes. 27. 6, 104

Thes. 27. 7, 104

Thes. 27. 8-9, 74

Thes. 28, 83

Thes. 28. 1, 74

Thes. 29.1-2, 83

Thes. 29. 2, 78, 79

Thes. 29. 3-5, 77

Thes. 30, 62

Thes. 30.2, 76

Thes. 30. 3, 76

Thes. 31, 62, 85

Thes. 31-34, 96

Thes. 32. 1, 106

Thes. 32.2, 107

Thes. 32. 5, 104

Thes. 32. 6, 87

Thes. 35. 3, 55, 248

Thes. 35. 4, 107

Thes. 35. 4-5, 260

Thes. 35. 5, 248

Thes. 35. 7, 109

Thes. 35. 7-8, 498

Thes. 35. 8, 59, 110

Thes. 35-36, 49

Thes. 36. 1, 308

Thes. 36. 2, 110

Thes. 36. 4, 102

Thes. 36. 4-5, 101

Poemas Homéricos,

Il. 1. 33-52, 281

Il. 1. 181-192, 74

Il. $1.262-272,110$

Il. $1.265,76$

Il. 1. 488-492, 286

Il. 1. 511, 164

Il. 2. 536, 102

Il. 2. 551-2, 107

Il. $2.742,76$

Il. 2. 742-744, 76

Il. $3.125-8,17$

Il. $3.144,85$

Il. 4. 464, 102

Il. 5. 638-9, 169

Il. 6. 119-129, 103

Il. $6.123-8,17$

Il. $6.208,136$

Il. 9. 182-192, 177

Il. 9. 189-194, 17

Il. 9. 432-605, 135, 136

Il. $9.443,11$

Il. $11.830-832,135$

Il. $11.832,77$

Il. 14,34

Il. $21.198,165$

Il. $23.87-8,172$ 
Od. $1.1,168$

Od. $1.358,11$

Od. 2. 267,136

Od. 2. 399, 136

Od. $3.13,136$

Od. 3. 94,11

Od. 4. 214,11

Od. 4. 230,187

Od. 7,258

Od. 10.330, 168

Od. 11.321, 80

Od. $11.631,53,89$

Od. 21. 255-304, 76

Polieno

1. 4,102

2. 10,251

2. $10.1,251$

2. 20.3, 251

3. 6,289

Pródico 145, 175

frg. 6 Diels, 143

Sátiro

FHG III 1 60, 267

Simónides, 170

fr. 53 Diehl, 141

Sófocles, 34, 37, 43, 140, 182

El., 77

$O C, 49,81,110,116,123$,

OC 260-62, 122

OC 897,123

OC 904,123

OC 1125,122

OC 1593, 75

OT 35-36, 43

OT 44-48, 45

OT 507-511, 45

OT 690-695, 45

OT 711-714, 33

OT 718-720, 37
OT 800-813, 45

OT 1022-1024, 37

OT 1036, 37

OT 1062-1063, 153

OT 1086-1109, 42

Tr. 351-369, 78

Tr. 459-460, 78

Sólon, 96, 97, 106, 161, 164, 223

fr. 19 Diels, 150

Suda

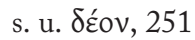

s. u. है $\varphi \circ \rho \circ, 251$

s. u. $\lambda$ íotol, 104

Teleclides, 163, 166, 229

fr. 45 K.-A, 229

fr. 47 K.-A, 166

Teofrasto, 26, 102, 181, 196, 200, 205, 251, 253, 271, 280, 304

Char. 16, 181

Char. 21, 102

Char. 22. 3, 196

Char. 24, 200

Char. 26. 6, 109

fr. 131 Wimmer, 109

fr. 463 Fortenbaugh, 181

Teopompo de Quios 18, 297 FGrHist 115 F 156, 276

Tucídides, 16, 17, 18, 21, 22, 24, 25, 27, 33, 57, 94, 97, 101, 116, 119, 120, 129, 165, 171, 212, 213, 214, 216, 218, 229, 233, 237, 238, 239, 250, 251, 258, 259-260, 263, 270, 274, 276, 277, 281, 282, 283, 286, 287, 297, 298

1. 1,277

1. 2. 2,97

1. $2.5,115,117$

1. 20,19

1. 21,16

1. $44.2,126$ 
Índice de autores antigos e citações

1. $55.2,276$

1. $56-66,276$

1. 57,121

1. $58.1,123$

1. $59.3-5,124$

1. 67,277

1. $67.2,277$

1. $68.2,125$

1. $68.3,125$

1. $68-71,129$

1. $69.1,123$

1. $69.3,127$

1. $69.5,123$

1. 70,115

1. $70.1-4,120$

1. $70.2,115,124$

1. $70.3,93$

1. $70.4,123$

1. $71.1,123$

1. $71.3,122$

1. $71.4,119$

1. $73.2,126$

1. $73.3,125$

1. $74.1,126,127$

1. $74.2,124,126$

1. $74.2-3,123$

1. $74.3,119,126$

1. $74.3-4,126$

1. $74.4,124,129$

1. $75.1,127$

1. $75.2,127$

1. $75.3,128$

1. $76.1,128$

1. $76.2,125,128$

1. $76.3,128$

1. $77.1,128,129$

1. $77.2,128$

1. $77.5-6,128$

1. $78.4,126$
1. $80.3,129$

1. $82.1,129$

1. 86,129

1. $86.5,119,130$

1. $89-117,120$

1. 90.3 - $93.8,115$

1. 93,121

1. $95.1,127$

1. $95.7,127$

1. $101.1-2,123$

1. 104,269

1. 107,216

1. 107. 2 - 108. 1, 202

1. $107-113,34$

1. $109-110,269$

1. $112.3-4,270$

1. $112.5,276$

1. 114,123

1. $115.2,271$

1. $115.2-1.117 .3,273$

1. $116.2,273$

1. $116.3,273$

1. 117,249

1. $117.2,273$

1. $126-127,257$

1. 130.1 - 132. 2, 197

1. $138,124,127$

1. $139.1,277$

1. $140.5,279$

1. $142.5,122$

1. 144,126

1. $144.4,124$

2. $8.4,119$

2. $10-12,257$

2. 11. 2,119

2. 13,216

2. $13.1,258$

2. 13. 5, 239

2. $14.2,101$ 
2. 15,52

2. $15.2,33,94,96$

2. $18-20,257$

2. 21. 1,251

2. 21. 3,237

2. 21-22, 192

2. $22.1,214,237$

2. $27.1,220$

2. 28,281

2. 34,298

2. $35-46,119$

2. 37,130

2. 38,118

2. 39,124

2. $40,120,131$

2. $40.3,121,123$

2. $40.4,122$

2. $40.5,122$

2. $41,116,141$

2. $41.4,66$

2. $42.2,124$

2. 47,281

2. 55,44

2. 58,249

2. 59,237

2. $59.3,237$

2. 59-60, 259

2. 60,124

2. $60.1,237$

2. $60.5,251$

2. 62,127

2. 63,130

2. $64,124,206$

2. $64.1,281$

2. 65,237

2. $65.1,237$

2. $65.3,237$

2. $65.4,260$

2. $65.7,281$
2. $65.8,251$

2. $65.8-9,229$

2. $65.9,176,212,225,228$

2. 65-66, 229

2. $68-71,119$

2. $73-79,119$

2. 89,122

2. $95.3,249$

3. $13.7,119$

3. $36,121,233$

3. 37,130

3. $37.1,119$

3. 86,263

3. 88,263

3. 90,263

3. 99,263

3. 103,263

3. 104. 3-5, 100, 263

4. 1-2, 263

4. 10,124

4. 25,263

4. $48.6,263$

4. 65,263

4. $102-103,128$

4. 102. 3, 249

4. 121. 1, 196

5. 11. 1, 249

5. 16. 1-3, 251

5. 16. 3, 251

5. 19. 2, 249

5. 24. 1, 249

5. 43,283

5. 43. 1-3, 172

5. 43-44, 207

5. 4-5, 205

5. 52. 2, 254, 283

5. 81-82, 283

5. $82.2-6,254$

5. $105.2,125$ 

6. 2. 4,195
8. $45.2-46-1,287$
6. 3,57
6. 6,57
6. $8.4,284$
6. 9,263
6. $15,215,285$
6. $15.2,284$
6. 15. 3-4, 171
6. 16. 2, 196, 197
6. 16-18, 197
6. $18,121,122,123$
6. 27. 1-3, 233
6. 28,233
6. $29.3,234$
6. 44,285
6. $53.3-6.60 .1,216$
6. 53-60, 216
6. $60,216,233,240$
6. $61.5,234$
6. 61. 6-7, 235
6. 61-64, 235
6. 74. 1, 235
8. 46,287
8. 47, 287, 288
8. 48. 1-4, 288
8. 50-51, 289
8. 61-62, 292
8. 65,234
8. $67.3,289$
8. $70.2,290$
8. 76. 4, 274
8. 86. 4, 268
8. 88,290
8. 89-97, 260
8. $90.1,289$
8. $92.2,289$
Tzetes
ad Lyc 143, 86
Valério Máximo
1. 7 ext. 9,307
3. $1,188,250$
8. 11 , ext. 1, 281
8. 14. 6, 238

6. $82-83,126$

6. 85,130

6. $88.9,235$

6. 88.10 - 93. 2, 286

6. 89. 2, 207, 257,

6. $90.2-3,284$

6. $91.4-6,286$

6. $93.2,251$

6. 98,121

7. 28,121

7. 48,233

7. 77,124

7. 77. 7, 124, 218

8. 6. 1-3, 287

8. 45,232

8. $45.1,287$

8. $45.2,287$

Virgílio

A. 4,81

Xanto da Lídia, 16

Xenófanes de Cólofon

fr. 10 Diels, 135

fr. 11 Diels, 13

fr. 14 Diels, 14

fr. 15 Diels, 14

fr. 3W, 198

Xenofonte, 295, 297

Cyn. 1. 2, 135

$H G$ 1. 1. 5, 292

$H G$ 1. 1. 6, 292

$H G$ 1. 1. 9, 293

$H G$ 1. 1. 11, 293

$H G$ 1. 1. 14-18, 294

HG 1. 1. 15, 295 
HG 1. 1. 16, 293

$H G$ 1. 1. 18, 294

$H G$ 1. 1. 23, 294

$H G$ 1. 2. 7-10, 295

$H G$ 1. 2. 15-17, 295

$H G$ 1. 3, 269

$H G$ 1. 3. 2-3, 295

$H G$ 1. 3. 6, 298

$H G$ 1. 3. 7, 298

$H G$ 1. 3. 10, 295, 296

$H G$ 1. 3. 14-22, 269

$H G$ 1. 3. 17, 298

$H G$ 1. 3. 19, 269

HG 1. 4. 12, 299

HG 1. 4. 13, 297

$H G$ 1. 4. 13-16, 299

$H G$ 1. 4. 13-17, 171

$H G$ 1. 4. 13-19, 299

$H G$ 1. 4. 17, 299

HG 1. 4. 18-19, 297

$H G$ 1. 4. 20, 298, 299

$H G$ 1. 4. 22, 300

$H G$ 1. 5. 11, 255

$H G$ 1. 5. 11-15, 255

$H G$ 1. 5. 8-9, 287

$H G$ 1. 6. 28, 245

$H G$ 1. 7. 35, 233

HG 2. 1. 24-25, 301

HG 2. 1. 26, 301

$H G$ 2. 1. 29, 301

$H G$ 2. 1. 30-32, 301

$H G$ 3. 3. 2-3, 246

Mem.1.1.1, 189

Mem. 1. 2. 12-16, 189

Mem. 2. 1. 31, 304

Smp. 8. 31, 77 


\section{ÍNDICE DE AUTORES MODERNOS}

Adkins, W. H. 77, 120, 123

Alberto, P. F. 117

Albini, F. 152, 159, 160

Alexandre Júnior, M. 117

Allison, J. W. 120

Alsino Clota, J. 85, 89

Amaral, A. C. 140

Ampolo, C. 73, 74, 90, 101

Anderson, M. 215

Anderson, W. 149

Andrewes, A. 238

Asheri, D. 26

Austin, M. 122

Balcer, J. M. 215

Barron, J. 98, 238

Barron, J. P. 98

Barrow, R. 140

Barthes, R. 12

Bearzot, C. 215

Beck, F. A. G. 137, 139, 140, 172

Bertelli, G. 96

Bertelli, L. 16

Bicknell, P. 161, 243

Blois, L. de 236, 252

Blomqvist, K. 272

Blundell, M. W. 116

Blundell, S. 74
Boardman, J. 70, 72, 73, 160, 161, 170, 263

Boer, W. 56, 111

Bois, P. du 77

Bonnechère, P. 68

Bonner, R. J. 122

Boulogne, J. 230

Breebart, A. B. 228

Bremmer, J. N. 59

Brisson, L. 145

Brommer, F. 57, 62, 66, 70, 76, 79, 85, 89,95

Brown, F. S. 74

Bulsot, G. 102

Burian, P. 78

Burkert, W. 12

Buxton, R. G. A. 43

Calame, C. 65, 67, 76, 77, 83, 84, 89, 96, 100, 109

Canfora, L. 106

Cantarelli, F. 106

Carcopino, J. 205

Cassola, F. 103

Chadwick, J. 11

Chatelet, F. 123

Clark, G. 74

Clerc, M. 122 
Índice de autores modernos

Cohen, B. 117, 167

Cole, P. R. 135

Cole, T. 143

Collard, C. 147

Comamala Malo, A. 238

Conacher, D. J. 147

Connor, W. R. 200, 206, 278

Corcella, A. 40

Cornet, G. 65

Cromey, R. D. 243

Daux, G. 207

Davies, J. K., 160, 184, 197

Demand, N. 115

Deubner, L. 99, 101, 102

Diamant, S. 94

Dodds, E. R. 145

Donnay, G. 188, 249

Dover, K. J. 77, 139, 159, 171, 184, 187, 193

Dowden, K. 75

Duchemin, J. 147

Duff, T. 164, 177, 180, 195, 198, 225, $249,294,319,332,338,340,344$

Dugas, C. 49

Dunkle, J. R. 58

Durand, G. 12

Edelstein, L. 145

Edmunds, L. 225

Ehrenberg, V. 120

Eliade, M. 12

Elias Pinheiro, A. P. 137

Euben, P. 141

Evans, J. A. S. 115

Eyben, E. 152

Faure, D. 151, 152

Ferguson, J. 123

Fialho, M. C. 37, 42, 43

Finley, M. 12, 7, 127

Flacelière, R. 31, 51, 52, 58, 63, 82, 102, 111, 165, 189, 297
Fornara, C. 160

Francotte, H. 96

Frazier, F. 54, 13

Frost, F. J. 188, 249

Fuhrmann, F. 226

Gagarin, M. 122, 184

Galinsky, G. K. 57

Gauthier, P. 122

Gelder, K. van 94

Genep, A. 69

Ghali-Kahil, L. B. 85

Gill, C. 182

Gleason, M.W. 267

Gomes, C. C. 140

Gomme, A. W. 120, 122, 124, 127, 128, $129,130,188,212,241,249$

Goossens, R. 98

Graves, R. 49, 56, 79, 160

Green, P. 115

Gribble, D. 196, 197, 198, 215, 216, 233, 257, 258, 285, 286, 287, 300, 307, 308

Griffith, M. 142

Grimal, P. 49, 79, 160

Gual, C. G. 53, 61, 80, 86, 89

Gutglueck, J. 120

Guthrie, W. K. 144, 176, 178, 182, 247, 252, 274

Hall, E. 77

Harris, E. M. 130

Harris, H. A. 169

Harrison, A. R. W. 122, 244, 245

Hatzfeld, J. 207, 232, 234, 235, 291, 294, 295, 307

Havelock, E. A. 77

Henderson, J. J. 171

Herman, G. 77, 257

Herter, H. 63, 67, 71, 95, 98, 102

Hignett, C. 94

Hook, R. van 116 
Hornblower, S. 17, 18, 120, 122, 124, $127,128,129,271$

Huart, P. 237

Hubbard, T. K. 187

Humpreys, S. C. 200

Hunter, V. 20

Huxley, G. L. 71

Immerwahr, H. R. 34, 35, 37

Jabouille, V. 12

Jacoby, F. 72, 80, 98, 99, 102, 103, 239, 245

Jeanmaire, H. 65

Jones, C. P. 31

Jones, L. A. 236

Jouanna, J. 226

Kadletz, E. 100

Kagan, D. 106, 263

Karageorghis, J. 81

Karsai, G. 83

Kastely, J. 147

Keaveney, A. 215

Kerferd, G. B. 142, 143, 144

Kitto, F. 116

Klosko, G. 63

Knox, B. M. W. 43, 83, 121, 131, 232

Komornicka, A. M. 86

Konstan, D. 77

Kraay, C. 103

Krappe, A. H. 34

Kron, U. 103

Kurke, L. 172, 196

Lacey, W. K. 59

Larmour, D. H. J. 66, 79, 83, 97

Lazenby, J. F. 115

Lee Too, Y. 141, 147

Legras, B. 142, 143

Lenardon, R. J. 115

Lesky, A. 16, 34, 159, 182

Lévi-Strauss, C. 12
Lewis, D. M. 66, 195, 198, 202, 204, 214, 221, 223, 234, 236, 238, 245, 251, 254-255, 258, 262-263, 270271, 275, 276, 277, 281, 283, 286, 287

Lindsay, J. 85, 89

Littman, R. J. 187, 244, 307

Lloyd, M. 147

López, A. 52

Loraux, N. 87, 116, 117, 124, 267

Louis, P. 189

Lourenço, F. 138

Luce, J.-M. 94

Luce, T. 26

Luginbill, R. D. 119

MacDonald, B. 303

MacDowell, D. 234, 241

Magueijo, C. 140

Manfredini, M. 73, 74, 91

Marrou, H. I. 65, 135, 139, 140, 143

Mayor, D. 159

McKinnon, J. 177

McNellen, B. 169

Meineke, A. 165

Meinhardt, E. 249, 253

Mikalson, J. D. 102

Mills, S. 56, 61, 62, 74, 78, 83, 85, 90, 104, 116, 119, 123,

Milman Parry, A. 120, 127

Modrzejewski, J. 244

Moggi, M. 94, 101

Mommsen, A. 102

Montuori, M. 241, 247

Moreau, A. 110

Morgan, T. 140

Morley, N. 12, 19

Morrison, J. S. 212

Mossé, C. 94, 106, 221, 236, 238, 241

Nagy, B. 299

Nikolaidis, A. 170, 184 
Índice de autores modernos

Nikolaidis, A. G. 170, 184

Nilsson, M. P. 58, 61, 98, 102

Oliver, J. H. 130

Orban, M. 83

Parke, H.W. 54, 96, 100, 101, 102, 276

Patterson, C. B. 59, 244

Pauly-Wissowa, 103

Pélékidis, C. 65

Pelling, C. 35, 104, 160, 168, 171, 173, 184,307

Pena, A. 117

Percy, W. A. 171, 187

Pérez Jiménez, A. 31, 51-54, 56, 89, $107,182,239,248,269,303$

Pfeiffer, R. 135

Picard, O. 97

Piccirilli, L. 171, 278

Pirenne-Delforge, V. 81

Pociña, A. 52

Podlecki, A. J. 98, 100, 110

Poliakoff, M. B. 169, 171

Polman, G. H. 173

Portela, J. A. 70, 71, 72, 77

Prado, A. L. A. A. 120

Prandi, L. 214, 238

Pritchett, W. K. 196, 256

Raalte, M. van 252

Rhodes, P. J. 103, 221

Ribeiro Ferreira, J. 4, 18, 20, 42, 78, 130, $179,219,221,236,238$

Ricotti, E. 172

Robb, K. 140

Robertson, N. 103, 141

Rocha Pereira, M. H. 14, 135

Rodríguez Somolinos, H. 210

Roisman, J. 168

Romilly, J. 128, 144, 227, 228, 254

Roscher, W. H. 103

Rose, H. J. 12, 68, 176, 274

Rosenmeyer, T. G. 12
Rosivach, V. J. 117

Roskam, G. 152

Russell, D. A. 26, 180

Rusten, J. S. 116

Said, S. 218, 220

Salcedo Parrondo, M. 196, 218, 241, 297, 299

Samons, L. J. 160

Sanctis, G. de 103

Schefold, K. 96, 98

Schnapp-Gourbeillon, A. 236

Scodel, R. 147

Scott, D. 177

Seager, R.J. 215

Segal, C. 37, 43, 45

Shapiro, H. A. 86

Sikes, E. E. 143

Silva, C. R. C. 118

Silva, M. F. S. 18, 20, 42, 69, 116, 137, 213, 233, 271

Simon, A. 54

Simon, E. 100

Smith, G. 122

Somerstein, A. H. 348

Sourvinou-Inwood, C. 53, 66, 70, 71

Stadter, P. A. 25, 188, 199, 202, 220, 221, 224, 241, 245, 248, 249, 251, 254, 270, 278, 281, 303

Stanford, W. B. 168

Stroud, R. 141

Swain, S. 182

Tatum, J. W. 38

Taylor, M. W. 62, 66

Teixeira, E. 151

Thomas, R. 211

Thompson, W. E 161

Todd, S. C. 122

Toepffer, J. 54, 160

Trail, J. S. 94

Trapp, M. 224 
Tyrrell, W. B. 73, 74

Untersteiner, M. 144

Valdés Guia, M. 94

Valgiglio, E. 23

Vanderpool, E. 205

Vandiver, E. 34, 36, 38

Vega, J. L. de la 43

Verdegem, S. 161, 217, 232, 255, 287, 291, 297, 299

Vergetti, M. 226

Vergnières, S. 77

Vickers, M. 169

Vidal-Naquet, P. 122

Visser, M. 59

Walcot, P. 168

Walker, H. J. 53, 55, 56, 61, 65, 78, 85, 89, 93, 96, 98, 116

Webster, T. B. L. 79

Wees, H. van 136

Westlake, D. 234, 289

Wickersham, J. M. 63

Wilkins, J. 55, 69

Will, E. 97

Wilson, P. 175, 177

Woodford, S. 55, 76, 98, 238

Wormell, D. E. W. 96, 276

Ziegler, K. 152, 165

Ziolkowski, J. E. 116 


\section{Volumes publicados na Colecção Humanitas SuPPLEMENTUM}

1. Francisco de Oliveira, Cláudia Teixeira e Paula Barata Dias: Espaços e Paisagens. Antiguidade Clássica e Heranças Contemporâneas. Vol. 1 - Linguas e Literaturas. Grécia e Roma (Coimbra, Classica Digitalia/CECH, 2009).

2. Francisco de Oliveira, Cláudia Teixeira e Paula Barata Dias: Espaços e Paisagens. Antiguidade Clássica e Heranças Contemporâneas. Vol. 2 - Linguas e Literaturas. Idade Média. Renascimento. Recepşão (Coimbra, Classica Digitalia/CECH, 2009).

3. Francisco de Oliveira, Jorge de Oliveira e Manuel Patrício: Espaços e Paisagens. Antiguidade Clássica e Heranças Contemporâneas. Vol. 3 - História, Arqueologia e Arte (Coimbra, Classica Digitalia/CECH, 2010).

4. Maria Helena da Rocha Pereira, José Ribeiro Ferreira e Francisco de Oliveira (Coords.): Horácio e a sua perenidade (Coimbra, Classica Digitalia/CECH, 2009).

5. José Luís Lopes Brandão: Máscaras dos Césares. Teatro e moralidade nas Vidas suetonianas (Coimbra, Classica Digitalia/CECH, 2009).

6. José Ribeiro Ferreira, Delfim Leão, Manuel Tröster and Paula Barata Dias (eds): Symposion and Philanthropia in Plutarch (Coimbra, Classica Digitalia/CECH, 2009).

7. Gabriele Cornelli (Org.): Representaçôes da Cidade Antiga. Categorias históricas e discursos filosóficos (Coimbra, Classica Digitalia/CECH/Grupo Archai, 2010).

8. Maria Cristina de Sousa Pimentel e Nuno Simões Rodrigues (Coords.): Sociedade, poder e cultura no tempo de Ovidio (Coimbra, Classica Digitalia/ $\mathrm{CECH} / \mathrm{CEC} / \mathrm{CH}, 2010)$.

9. Françoise Frazier et Delfim F. Leão (eds.): Tychè et pronoia. La marche du monde selon Plutarque (Coimbra, Classica Digitalia/CECH, École Doctorale 395, ArScAn-THEMAM, 2010).

10. Juan Carlos Iglesias-Zoido, El legado de Tucidides en la cultura occidental (Coimbra, Classica Digitalia/CECH, ARENGA, 2011).

11. Gabriele Cornelli, O pitagorismo como categoria historiográfica (Coimbra, Classica Digitalia/CECH, 2011).

12. Frederico Lourenço, The Lyric Metres of Euripidean Drama (Coimbra, Classica Digitalia/CECH, 2011). 
13. José Augusto Ramos, Maria Cristina de Sousa Pimentel, Maria do Céu Fialho, Nuno Simões Rodrigues (coords.), Paulo de Tarso: Grego e Romano, Judeu e Cristão (Coimbra, Classica Digitalia/CECH, 2012).

14. Carmen Soares \& Paula Barata Dias (coords.), Contributos para a história da alimentação na antiguidade (Coimbra, Classica Digitalia/CECH, 2012).

15. Carlos A. Martins de Jesus, Claudio Castro Filho, José Ribeiro Ferreira (coords.), Hipólito e Fedra - nos caminhos de um mito (Coimbra, Classica Digitalia/CECH, 2012).

16. José Ribeiro Ferreira, Delfim F. Leão, \& Carlos A. Martins de Jesus (eds.): Nomos, Kosmos E Dike in Plutarch (Coimbra, Classica Digitalia/CECH, 2012).

17. José Augusto Ramos \& Nuno Simões Rodrigues (coords.), Mnemosyne kai Sophia (Coimbra, Classica Digitalia/CECH, 2012).

18. Ana Maria Guedes Ferreira, O homem de Estado ateniense em Plutarco: o caso dos Alcmeónidas (Coimbra, Classica Digitalia/CECH, 2012). 

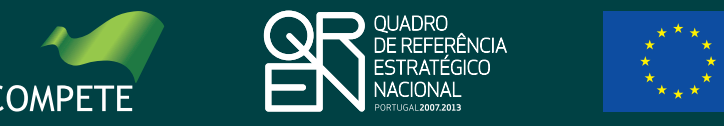